Министерство образования и науки

Российской Федерации

Федеральная служба

государственной статистики

(I) В НОШАЯ ШКОАА ЭКОНОМИКИ

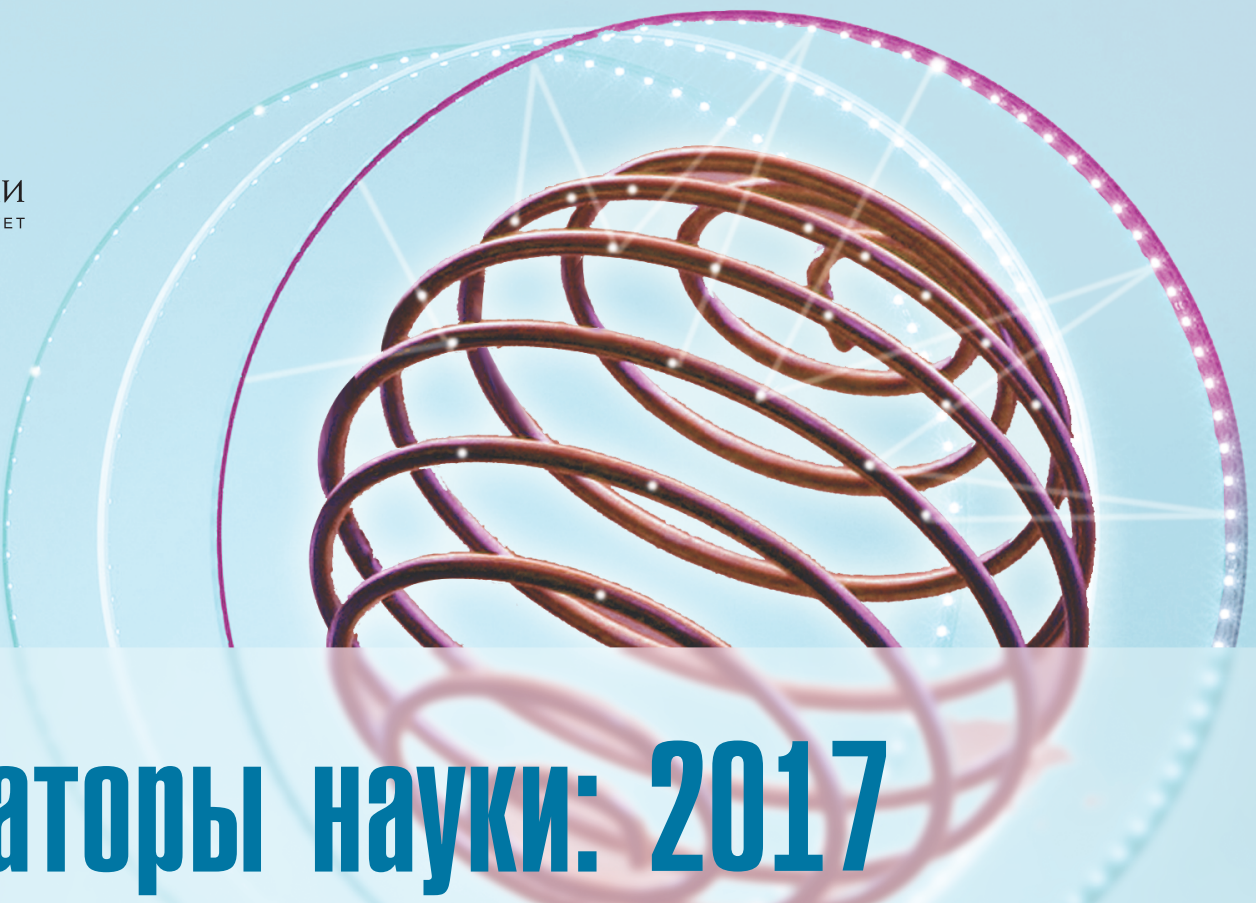

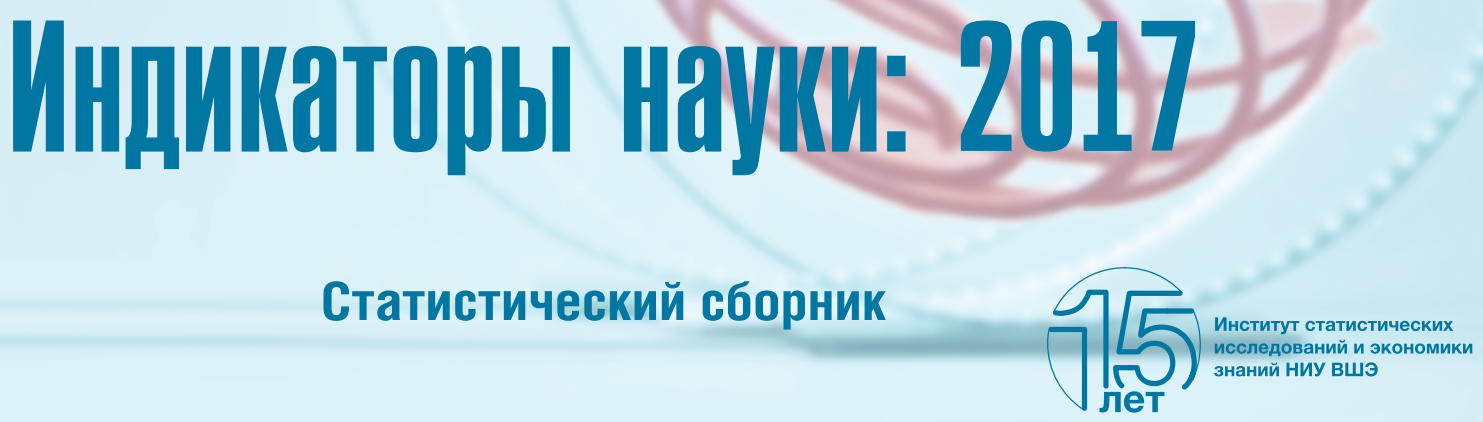


Министерство образования и науки

Российской Федерации

Федеральная служба

государственной статистики

(P В ЫСШАЯ ШКОАА ЭКОНОМИКИ НАЦИОНАЛЬНЫЙ ИССЛЕДОВАТЕЛЬСКИЙ УНИВЕРСИТЕТ

\section{ИндИкаторы науки: 2017}

\section{Статистический сборник}

Москва 2017 
УДК $001(470+571)(083.41)$

ББК $72(2 \mathrm{Poc})$ я2

И60

Редакционная коллегия: Л.М. Гохберг, Я.И. Кузьминов, К.Э. Лайкам, С.Ю. Матвеев

Авторы: Ю.Л. Войнилов, Н.В. Городникова, Л.М. Гохберг, К.А. Дитковский, М.Н. Коцемир, И.А. Кузнецова, Е.И. Лукинова, С.В. Мартынова,

Т.В. Ратай, Л.А. Росовецкая, Г.С. Сагиева, Е.А. Стрельцова, А.Б. Суслов, С.Ю. Фридлянова, К.С. Фурсов

В подготовке отдельных материалов принимали участие И.О. Варзановцева, И.И. Тарасенко

Индикаторы науки: 2017 : статистический сборник / Ю.Л. Войнилов, Н.В. Городникова, Л.М. Гохберг и др.; Нац. исслед. ун-т «Высшая школа И60 экономики». - М.: НИУ ВШЭ, 2017. - 304 с. - 350 экз. - ISBN 978-5-7598-1555-6 (в обл.).

Предлагаемый статистический сборник продолжает серию публикаций, посвященных различным аспектам развития науки в Российской Федерации. 0ткрывают сборник таблицы, в которых наряду с основными показателями науки и технологий представлены сведения об основных показателях инновационной деятельности. Приводятся статистические данные о составе организаций, выполняющих исследования и разработки, кадрах и финансировании науки, ее материально-технической базе. В отдельных разделах содержатся сведения об интеллектуальной собственности, коммерциализации и использовании технологий, данные международных сопоставлений.

В сборнике использованы сведения Федеральной службы государственной статистики, Министерства образования и науки Российской Федерации, Федеральной службы по интеллектуальной собственности, Межгосударственного статистического комитета СНГ, Организации экономического сотрудничества и развития, Европейской комиссии, Евростата, ЮНЕСКО, Всемирной организации интеллектуальной собственности, а также методологические и аналитические разработки Института статистических исследований и экономики знаний Национального исследовательского университета «Высшая школа экономики».

В ряде случаев данные по отдельным показателям уточняют ранее опубликованные. ББК 72(2Рос)я2

Публикация подготовлена по итогам работы в рамках Программы фундаментальных исследований Национального исследовательского университета «Высшая школа экономики» (НИУ ВШЭ) и с использованием средств субсидии в рамках государственной поддержки ведущих университетов Российской Федерации «5-100».

Editors: Leonid Gokhberg, Yaroslav Kuzminov, Konstantin Laykam, and Sergey Matveev

Authors: Yury Voynilov, Natalia Gorodnikova, Leonid Gokhberg, Kirill Ditkovskiy, Maxim Kotsemir, Irina Kuznetsova, Evgeniya Lukinova, Svetlana Martynova, Tatyana Ratay, Larisa Rosovetskaya, Galina Sagieva, Ekaterina Streltsova, Anton Suslov, Svetlana Fridlyanova, and Konstantin Fursov

With the contributions by Irina Varzanovtseva and Irina Tarasenko

Science and Technology Indicators: 2017 : Data Book / Y. Voynilov, N. Gorodnikova, L. Gokhberg et al.; National Research University Higher School of Economics. - Moscow: HSE, 2017.

The publication was prepared within the framework of the Basic Research Programme at the National Research University Higher School of Economics (HSE) and supported within the framework of a subsidy by the Russian Academic Excellence Project '5-100'.

ISBN 978-5-7598-1555-6

( ) Национальный исследовательский университет «Высшая школа экономики», 2017 При перепечатке ссылка обязательна 


\section{СОДЕРЖАНИЕ}

Основные показатели науки и технологий

Основные показатели инновационной деятельности .19

1. Организации 23

1.1. Организации, выполнявшие исследования и разработки

1.2. Динамика числа организаций, выполнявших исследования и разработки

1.3. Структура организаций, выполнявших исследования и разработки

1.4. Организации, выполнявшие исследования и разработки, по формам собственности

1.5. Структура организаций, выполнявших исследования и разработки, по организационно-правовым формам: 2015

1.6. Организации, выполнявшие исследования и разработки, по видам экономической деятельности.

2. Кадры науки 31

2.1. Персонал, занятый исследованиями и разработками

2.2. Персонал, занятый исследованиями и разработками, по категориям

2.3. Структура персонала, занятого исследованиями и разработками, по категориям
2.4. Персонал, занятый исследованиями и разработками, по формам собственности организаций .

2.5. Структура персонала, занятого исследованиями и разработками, по организационно-правовым формам организаций: 2015

2.6. Персонал, занятый исследованиями и разработками, по видам экономической деятельности

2.7. Персонал, занятый исследованиями и разработками, по уровню образования

2.8. Исследователи по полу и возрастным группам 39

2.9. Структура исследователей по возрастным группам 41

2.10. Средний возраст исследователей ............................42

2.11. Исследователи с учеными степенями.

2.12. Удельный вес исследователей с учеными степенями в их общей численности

2.13. Исследователи по областям науки

2.14. Распределение исследователей по областям науки: 2015

2.15. Движение персонала, занятого исследованиями и разработками

2.16. Прием выпускников образовательных организаций высшего образования на работу в организации, выполнявшие исследования и разработки

2.17. Показатели оборота персонала, занятого исследованиями и разработками 


\section{Подготовка научных кадров.}

48

2.18. Основные показатели деятельности аспирантуры

2.19. Прием в аспирантуру лиц, окончивших образовательные организации высшего образования в отчетном году, по формам обучения.

2.20. Удельный вес лиц, окончивших образовательные организации высшего образования в отчетном году, в общем приеме аспирантов

2.21. Численность аспирантов по полу и возрастным группам: 2015

2.22. Прием в аспирантуру и численность аспирантов по направлениям подготовки.

2.23. Численность аспирантов и выпуск из аспирантуры по отраслям наук. .56

2.24. Основные показатели деятельности докторантуры .........57

2.25. Численность докторантов по полу и возрастным группам: 2015

2.26. Численность, прием докторантов и выпуск из докторантуры по отраслям наук

2.27. Удельный вес лиц, защитивших диссертации в период подготовки, в общем выпуске из аспирантуры и докторантуры по отраслям наук: 2015

3. Финансирование исследований и разработок

3.1. Внутренние затраты на исследования и разработки .64

3.2. Динамика внутренних затрат на исследования и разработки
3.3. Ассигнования на гражданскую науку из средств федерального бюджета в действующих ценах

3.4. Ассигнования на гражданскую науку из средств федерального бюджета в постоянных ценах 1991 г.

3.5. Ассигнования на гражданскую науку из средств федерального бюджета в процентах к валовому внутреннему продукту

3.6. Ассигнования на гражданскую науку из средств федерального бюджета в процентах к расходам федерального бюджета

3.7. Распределение ассигнований на гражданскую науку из средств федерального бюджета по разделам классификации расходов и видам работ

3.8. Внутренние затраты на исследования и разработки по источникам финансирования

3.9. Динамика внутренних затрат на исследования и разработки по источникам финансирования

3.10. Гранты, субсидии, конкурсное финансирование исследований и разработок: 2015

3.11. Внутренние затраты на исследования и разработки из средств иностранных источников (зарубежных организаций)

3.12. Распределение финансирования исследований и разработок по секторам науки: 2015

3.13. Внутренние затраты на исследования и разработки по формам собственности организаций ..... 
3.14. Структура внутренних затрат на исследования и разработки по организационно-правовым формам организаций: 2015

3.15. Внутренние затраты на исследования

и разработки по видам экономической деятельности

3.16. Внутренние затраты на исследования и разработки по видам затрат

3.17. Внутренние затраты на исследования и разработки по приоритетным направлениям развития науки, технологий и техники и источникам финансирования: 2015 .

3.18. Структура внутренних затрат на исследования и разработки по приоритетным направлениям развития науки, технологий и техники и источникам финансирования: 2015

3.19. Внутренние затраты на исследования и разработки по социально-экономическим целям

3.20. Структура внутренних затрат на исследования и разработки по социально-экономическим целям

3.21. Внутренние текущие затраты на исследования и разработки по видам работ и областям науки

3.22. Структура внутренних текущих затрат на исследования и разработки по видам работ
3.23. Внутренние текущие затраты на исследования и разработки по видам работ в процентах к валовому внутреннему продукту

3.24. Среднемесячная заработная плата персонала, занятого исследованиями и разработками

4. Материально-техническая база науки...................... 93

4.1. Основные средства исследований и разработок. 94

4.2. Динамика стоимости основных средств исследований и разработок

4.3. Удельный вес машин и оборудования в общей стоимости основных средств исследований и разработок

4.4. Основные средства исследований и разработок по формам собственности организаций

4.5. Структура основных средств исследований и разработок по формам собственности организаций

4.6. Основные средства исследований и разработок по видам экономической деятельности

5. Секторы науки

5.1. Сводные показатели

5.1.1. Организации, выполнявшие исследования и разработки, по секторам науки 102 
5.1.2. Структура организаций, выполнявших исследования и разработки, по секторам науки.

5.1.3. Персонал, занятый исследованиями и разработками, по секторам науки и категориям

5.1.4. Персонал, занятый исследованиями и разработками, по секторам науки и уровню образования

5.1.5. Исследователи с учеными степенями по секторам науки. 106

5.1.6. Структура исследователей с учеными степенями по секторам науки

5.1.7. Исследователи, направленные на работу (стажировку) в зарубежные научные организации, по секторам науки: 2015

5.1.8. Структура исследователей, направленных на работу (стажировку) в зарубежные научные организации, по секторам науки: 2015.

5.1.9. Внутренние затраты на исследования и разработки по секторам науки

5.1.10. Структура внутренних затрат на исследования и разработки по секторам науки

5.1.11. Внутренние затраты на исследования и разработки по секторам науки в процентах к валовому внутреннему продукту

5.1.12. Внутренние затраты на исследования и разработки по секторам науки и источникам финансирования
5.1.13. Внутренние затраты, направленные на выполнение исследований и разработок, за счет грантов, субсидий, конкурсного финансирования: 2015

5.1.14. Внутренние затраты на исследования и разработки по приоритетным направлениям развития науки, технологий и техники и секторам науки: 2015.

5.1.15. Структура внутренних затрат на исследования и разработки по приоритетным направлениям развития науки, технологий и техники и секторам науки: 2015

5.1.16. Источники финансирования внутренних затрат на исследования и разработки по приоритетным направлениям развития науки, технологий и техники и секторам науки: 2015

5.1.17. Структура внутренних затрат на исследования и разработки по приоритетным направлениям развития науки, технологий и техники и источникам финансирования: 2015

5.1.18. Внутренние затраты на исследования и разработки по секторам науки и социально-экономическим целям.

5.1.19. Распределение внутренних затрат на исследования и разработки по секторам науки и социально-экономическим целям: 2015

5.1.20. Внутренние текущие затраты на исследования и разработки по секторам науки и видам работ 123 
5.1.21. Среднемесячная заработная плата персонала, занятого исследованиями и разработками,

по секторам науки.

\section{2. Государственный сектор}

5.2.1. Организации, выполнявшие исследования и разработки в государственном секторе, по типам

5.2.2. Персонал, занятый исследованиями

и разработками в государственном секторе,

по типам организаций

5.2.3. Персонал, занятый исследованиями

и разработками в государственном секторе, по категориям

5.2.4. Структура персонала, занятого исследованиями и разработками в государственном секторе, по категориям

5.2.5. Удельный вес государственного сектора в общей численности персонала, занятого исследованиями и разработками, по категориям

5.2.6. Персонал, занятый исследованиями и разработками в государственном секторе, по уровню образования

5.2.7. Исследователи в государственном секторе по полу и возрастным группам 130

5.2.8. Структура исследователей в государственном секторе по возрастным группам....
5.2.9. Средний возраст исследователей

в государственном секторе.

5.2.10. Исследователи с учеными степенями

в государственном секторе.

5.2.11. Удельный вес исследователей с учеными степенями в численности исследователей в государственном секторе

5.2.12. Исследователи в государственном секторе по областям науки .

5.2.13. Движение персонала, занятого исследованиями и разработками в государственном секторе, по категориям

5.2.14. Прием и выбытие персонала, занятого исследованиями и разработками

в государственном секторе.

5.2.15. Прием выпускников образовательных организаций высшего образования на работу в организации государственного сектора

5.2.16. Внутренние затраты на исследования и разработки в государственном секторе по типам организаций

5.2.17. Внутренние затраты на исследования и разработки в государственном секторе

5.2.18. Внутренние затраты на исследования и разработки в государственном секторе по источникам финансирования 140 


\subsubsection{9. Удельный вес государственного сектора} в общем объеме внутренних затрат

на исследования и разработки

по видам затрат

5.2.20. Внутренние затраты на исследования

и разработки в государственном секторе

по видам затрат ...

5.2.21. Внутренние текущие затраты на исследования

и разработки в государственном секторе

по видам работ и областям науки

5.2.22. Удельный вес государственного сектора

в общем объеме внутренних текущих

затрат на исследования и разработки

по видам работ

5.2.23. Структура внутренних текущих затрат на исследования и разработки в государственном секторе по видам работ

5.2.24. Среднемесячная заработная плата персонала, занятого исследованиями и разработками в государственном секторе.

\section{3. Предпринимательский сектор}

5.3.1. Организации, выполнявшие исследования и разработки в предпринимательском секторе, по типам ....

5.3.2. Персонал, занятый исследованиями

и разработками в предпринимательском секторе, по типам организаций
5.3.3. Персонал, занятый исследованиями и разработками в предпринимательском секторе, по категориям

5.3.4. Структура персонала, занятого исследованиями и разработками в предпринимательском секторе, по категориям

5.3.5. Удельный вес предпринимательского сектора в общей численности персонала, занятого исследованиями и разработками, по категориям

5.3.6. Персонал, занятый исследованиями и разработками в предпринимательском секторе, по уровню образования.

5.3.7. Исследователи в предпринимательском секторе по полу и возрастным группам

5.3.8. Структура исследователей

в предпринимательском секторе

по возрастным группам

5.3.9. Средний возраст исследователей в предпринимательском секторе

5.3.10. Исследователи с учеными степенями в предпринимательском секторе

5.3.11. Удельный вес исследователей с учеными степенями в численности исследователей в предпринимательском секторе

5.3.12. Исследователи в предпринимательском секторе по областям науки 
5.3.13. Движение персонала, занятого исследованиями и разработками в предпринимательском секторе, по категориям

5.3.14. Прием и выбытие персонала, занятого исследованиями и разработками

в предпринимательском секторе

5.3.15. Прием выпускников образовательных организаций высшего образования на работу в организации предпринимательского сектора

5.3.16. Внутренние затраты на исследования и разработки в предпринимательском секторе по типам организаций.

5.3.17. Внутренние затраты на исследования и разработки в предпринимательском секторе

5.3.18. Внутренние затраты на исследования и разработки в предпринимательском секторе по источникам финансирования

5.3.19. Удельный вес предпринимательского сектора в общем объеме внутренних затрат на исследования и разработки по видам затрат

5.3.20. Внутренние затраты на исследования и разработки в предпринимательском секторе по видам затрат

5.3.21. Внутренние текущие затраты на исследования и разработки в предпринимательском секторе по видам работ и областям науки
5.3.22. Удельный вес предпринимательского сектора в общем объеме внутренних текущих затрат на исследования и разработки по видам работ

5.3.23. Структура внутренних текущих затрат на исследования и разработки в предпринимательском секторе по видам работ

5.3.24. Среднемесячная заработная плата персонала, занятого исследованиями и разработками в предпринимательском секторе 171

5.4. Сектор высшего образования

5.4.1. Организации, выполнявшие исследования

и разработки в секторе высшего образования, по типам

5.4.2. Персонал, занятый исследованиями и разработками в секторе высшего образования, по типам организаций

5.4.3. Персонал, занятый исследованиями и разработками в секторе высшего образования, по категориям

5.4.4. Структура персонала, занятого исследованиями и разработками в секторе высшего образования, по категориям

5.4.5. Удельный вес сектора высшего образования в общей численности персонала, занятого исследованиями и разработками, по категориям 


\subsection{6. Персонал, занятый исследованиями}

и разработками в секторе высшего образования, по уровню образования

5.4.7. Исследователи в секторе высшего образования по полу и возрастным группам

5.4.8. Структура исследователей в секторе высшего образования по возрастным группам

5.4.9. Средний возраст исследователей в секторе высшего образования 181

5.4.10. Исследователи с учеными степенями в секторе высшего образования.

5.4.11. Удельный вес исследователей с учеными степенями в численности исследователей в секторе высшего образования

5.4.12. Исследователи в секторе высшего образования по областям науки

5.4.13. Движение персонала, занятого исследованиями и разработками в секторе высшего образования, по категориям

5.4.14. Прием и выбытие персонала, занятого исследованиями и разработками в секторе высшего образования.

5.4.15. Прием выпускников образовательных организаций высшего образования на работу в организации сектора высшего образования
5.4.16. Внутренние затраты на исследования и разработки в секторе высшего образования по типам организаций

5.4.17. Внутренние затраты на исследования и разработки в секторе высшего образования

5.4.18. Внутренние затраты на исследования и разработки в секторе высшего образования по источникам финансирования

5.4.19. Удельный вес сектора высшего образования в общем объеме внутренних затрат на исследования и разработки по видам затрат

5.4.20. Внутренние затраты на исследования и разработки в секторе высшего образования по видам затрат

5.4.21. Внутренние текущие затраты на исследования и разработки в секторе высшего образования по видам работ и областям науки .

5.4.22. Удельный вес сектора высшего образования в общем объеме внутренних текущих затрат на исследования и разработки по видам работ

5.4.23. Структура внутренних текущих затрат на исследования и разработки в секторе высшего образования по видам работ

5.4.24. Среднемесячная заработная плата персонала, занятого исследованиями и разработками в секторе высшего образования. 
6. Результативность исследований и разработок

6.1. Публикации российских авторов

в научных журналах, индексируемых в Scopus,

по типам документа

6.2. Публикации российских авторов

в научных журналах, индексируемых

в Web of Science, по типам документа

6.3. Публикации российских авторов

в научных журналах, индексируемых в Scopus

6.4. Публикации российских авторов

в научных журналах, индексируемых

в Web of Science.

6.5. Статьи российских авторов

в научных журналах, индексируемых в Scopus

6.6. Статьи российских авторов

в научных журналах, индексируемых

в Web of Science.

6.7. Структура публикаций российских авторов

в научных журналах, индексируемых в Scopus,

по областям науки

6.8. Структура публикаций российских авторов

в научных журналах, индексируемых

в Web of Science, по областям науки

6.9. Индексы научной специализации России

по публикациям в научных журналах,

индексируемых в Scopus,

по областям науки
6.10. Индексы научной специализации России

по публикациям в научных журналах,

индексируемых в Web of Science,

по областям науки

6.11. Поступление патентных заявок

и выдача патентов на изобретения

6.12. Показатели патентной активности

6.13. Патенты Российской Федерации

на изобретения по разделам международной

патентной классификации.

6.14. Распределение выданных патентов

Российской Федерации на изобретения

по принадлежности заявителей

и разделам международной патентной

классификации: 2014

6.15. Поступление патентных заявок

и выдача патентов на полезные модели

6.16. Патенты Российской Федерации

на полезные модели по разделам международной

патентной классификации

6.17. Регистрация объектов интеллектуальной

собственности в сфере информатизации

6.18. Регистрация внутренних договоров

о торговле лицензиями и отчуждении прав

на патенты ...

6.19. Регистрация внутренних договоров

о торговле лицензиями и отчуждении прав

на патенты по областям техники 


\subsection{0. Распределение внутренних договоров}

о торговле лицензиями и отчуждении прав

на патенты по областям техники

6.21. Распределение внутренних договоров

о торговле лицензиями и отчуждении прав

на патенты по категориям хозяйствующих

субъектов

6.22. Баланс платежей за технологии

по категориям соглашений

6.23. Структура экспорта и импорта технологий по категориям соглашений

6.24. Баланс платежей за технологии по странам

6.25. Структура экспорта и импорта технологий по группам стран

6.26. Баланс платежей за технологии

по секторам деятельности

6.27. Баланс платежей за технологии

по видам экономической деятельности

6.28. Разработка передовых производственных технологий по видам

6.29. Разработка передовых производственных технологий по степени новизны и видам

6.30. Разработка передовых производственных технологий по степени новизны и видам экономической деятельности

6.31. Использование передовых производственных технологий по видам
6.32. Использование передовых

производственных технологий по видам

и продолжительности

6.33. Использование передовых

производственных технологий

по видам экономической деятельности

и продолжительности

6.34. Использование передовых производственных

технологий по видам и источнику

приобретения: 2015

6.35. Использование передовых производственных технологий

по видам экономической деятельности

и источнику приобретения: 2015

6.36. Использование передовых производственных технологий, разработанных

на основе запатентованных изобретений,

по видам.

7. Общественное мнение о науке

7.1. Обеспокоенность населения России различными социальными проблемами: 2015

7.2. Оценка населением роли науки, технологий и техники в обществе

7.3. Оценки населением России влияния развития науки, технологий, техники на уровень жизни, здоровье людей и состояние окружающей среды 
7.4. Оценки населением влияния развития науки, технологий, техники на различные

стороны жизни: 2015

7.5. Отношение населения России

к приобретению и использованию технических

новинок в повседневной жизни: 2015

8. Международные сопоставления

8.1. Внутренние затраты на исследования

и разработки

8.2. Внутренние затраты на исследования

и разработки в процентах к валовому

внутреннему продукту: 2015

8.3. Структура внутренних затрат

на исследования и разработки по секторам науки: 2015

8.4. Структура внутренних затрат на исследования

и разработки по источникам

финансирования: 2015 .

8.5. Структура внутренних затрат

на исследования и разработки по областям

науки: 2015

8.6. Структура внутренних текущих затрат

на исследования и разработки

по видам работ: 2015

8.7. Ассигнования на исследования

и разработки из средств государственного

бюджета ....
8.8. Персонал, занятый исследованиями

и разработками: 2015

8.9. Численность персонала, занятого исследованиями и разработками,

в расчете на 10000 занятых

в экономике: 2015

8.10. Распределение численности исследователей

по секторам науки: 2015

8.11. Удельный вес женщин в численности

исследователей: 2015

8.12. Число публикаций и число цитирований

в научных журналах, индексируемых

в Web of Science: 2011-2015.

8.13. Число публикаций и число цитирований

в научных журналах, индексируемых

в Scopus: 2011-2015

8.14. Удельный вес стран в общемировом числе публикаций в научных журналах, индексируемых в Web of Science: 2015

8.15. Удельный вес стран в общемировом числе публикаций в научных журналах, индексируемых в Scopus: 2015

8.16. Удельный вес публикаций

в соавторстве с зарубежными учеными

в общем числе публикаций страны

в научных журналах, индексируемых

в Web of Science: 2015 
8.17. Удельный вес публикаций в соавторстве с зарубежными учеными в общем числе публикаций страны в научных журналах, индексируемых в Scopus: 2015

8.18. Патентные заявки на изобретения, поданные национальными и иностранными заявителями в патентные ведомства страны. 289
8.19. Структура патентных заявок на изобретения по заявителям и странам: 2015

8.20. Число патентных заявок, поданных национальными заявителями в стране и за рубежом..... 293

8.21. Число «триадных» патентных семей 296

8.22. Поступления от экспорта технологий и выплаты по импорту технологий: 2015 .298

\section{УСЛОВНЫЕ ОБОЗНАЧЕНИЯ:}

... нет данных,

- явление отсутствует,

0.0 незначительная величина.

В отдельных случаях небольшое расхождение итогов

с суммой слагаемых объясняется округлением данных. 


\section{ОСНОВНЫЕ ПОКАЗАТЕЛИ НАУКИ И ТЕХНОЛОГИЙ}

\begin{tabular}{|c|c|c|c|c|c|c|c|c|c|c|c|}
\hline & 1995 & 2000 & 2005 & 2008 & 2009 & 2010 & 2011 & 2012 & 2013 & 2014 & 2015 \\
\hline \multicolumn{12}{|c|}{$\begin{array}{l}\text { Внутренние затраты на исследования } \\
\text { и разработки, млн руб., } 1995 \text { г. - млрд руб.: }\end{array}$} \\
\hline в действующих ценах & 12149.5 & 76697.1 & 230785.2 & 431073.2 & 485834.3 & 523377.2 & 610426.7 & 699869.8 & 749797.6 & 847527.0 & 914669.1 \\
\hline в постоянных ценах 1989 г. & 2.49 & 3.32 & 4.55 & 5.49 & 6.07 & 5.72 & 5.76 & 6.10 & 6.23 & 6.57 & 6.59 \\
\hline \multicolumn{12}{|c|}{$\begin{array}{l}\text { Внутренние затраты на исследования } \\
\text { и разработки: }\end{array}$} \\
\hline в процентах к ВВП & 0.85 & 1.05 & 1.07 & 1.04 & 1.25 & 1.13 & 1.09 & 1.05 & 1.06 & 1.09 & 1.13 \\
\hline $\begin{array}{l}\text { в процентах к предыдущему } \\
\text { в постоянных ценах } 1989 \text { г. }\end{array}$ & 84.9 & 116.0 & 98.7 & 98.4 & 110.6 & 94.3 & 100.6 & 105.9 & 102.1 & 105.5 & 100.2 \\
\hline \multicolumn{12}{|c|}{$\begin{array}{l}\text { Внутренние затраты на исследования } \\
\text { и разработки в расчете на одну организацию, } \\
\text { выполнявшую исследования и разработки, } \\
\text { тыс. руб., } 1995 \text { г. - млн руб.: }\end{array}$} \\
\hline в действующих ценах & 2993.2 & 18711.2 & 64718.2 & 117586.8 & 137396.6 & 149878.9 & 165786.7 & 196261.9 & 207988.2 & 235162.9 & 219082.4 \\
\hline
\end{tabular}


(продолжение)

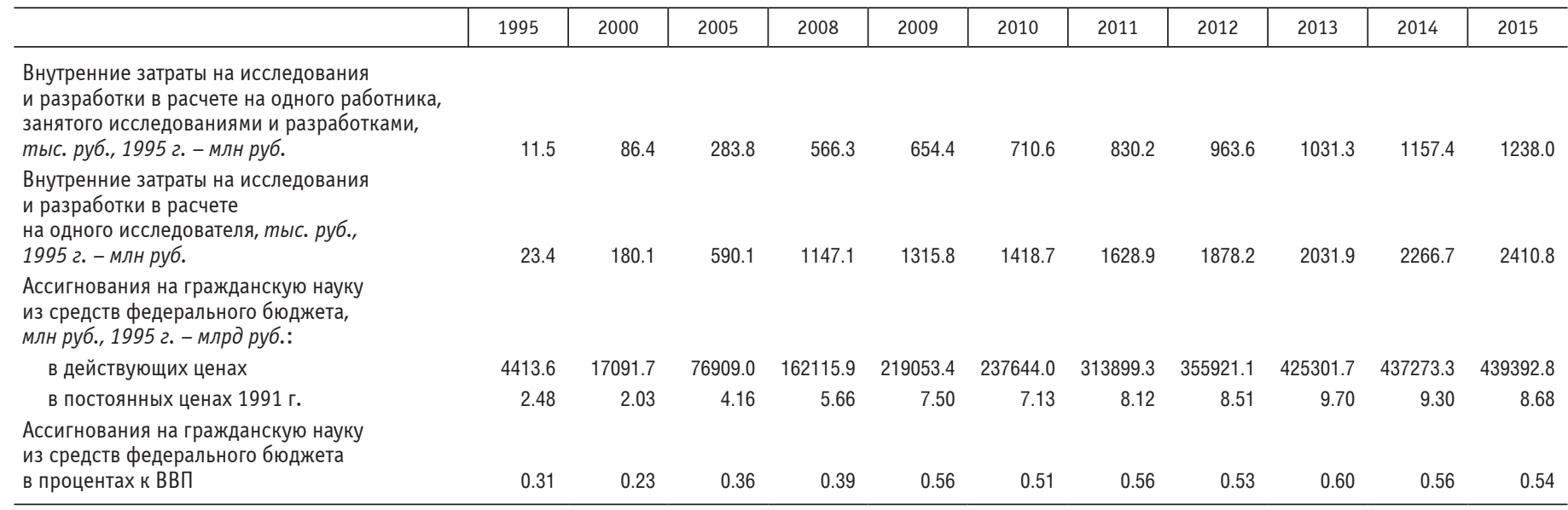


(продолжение)

\begin{tabular}{|c|c|c|c|c|c|c|c|c|c|c|c|}
\hline & 1995 & 2000 & 2005 & 2008 & 2009 & 2010 & 2011 & 2012 & 2013 & 2014 & 2015 \\
\hline \multicolumn{12}{|l|}{ Численность персонала, занятого } \\
\hline исследованиями и разработками, тыс. чел. & 1061.0 & 887.7 & 813.2 & 761.3 & 742.4 & 736.5 & 735.3 & 726.3 & 727.0 & 732.3 & 738.9 \\
\hline В процентах к предыдущему году & 95.9 & 101.8 & 96.9 & 95.0 & 97.5 & 99.2 & 99.8 & 98.8 & 100.1 & 100.7 & 100.9 \\
\hline $\begin{array}{l}\text { Численность персонала, занятого } \\
\text { исследованиями и разработками, в расчете } \\
\text { на одну организацию, выполнявшую исследо- } \\
\text { вания и разработки, чел. }\end{array}$ & 261 & 217 & 228 & 208 & 210 & 211 & 200 & 204 & 202 & 203 & 177 \\
\hline $\begin{array}{l}\text { Численность персонала, занятого } \\
\text { исследованиями и разработками, в расчете }\end{array}$ & & & & & & & & & & & \\
\hline на 10000 занятых в экономике, чел. & 160 & 138 & 122 & 111 & 110 & 109 & 109 & 107 & 107 & 108 & 108 \\
\hline Численность исследователей, тыс. чел. & 518.7 & 426.0 & 391.1 & 375.8 & 369.2 & 368.9 & 374.7 & 372.6 & 369.0 & 373.9 & 379.4 \\
\hline В процентах к предыдущему году & 98.7 & 101.4 & 97.4 & 95.7 & 98.3 & 99.9 & 101.6 & 99.4 & 99.0 & 101.3 & 101.5 \\
\hline
\end{tabular}


(окончание)

\begin{tabular}{|c|c|c|c|c|c|c|c|c|c|c|c|}
\hline & 1995 & 2000 & 2005 & 2008 & 2009 & 2010 & 2011 & 2012 & 2013 & 2014 & 2015 \\
\hline $\begin{array}{l}\text { Численность исследователей в расчете } \\
\text { на одну организацию, выполнявшую исследо- } \\
\text { вания и разработки, чел. }\end{array}$ & 128 & 104 & 110 & 103 & 104 & 106 & 102 & 104 & 102 & 104 & 91 \\
\hline Численность исследователей в расчете & & & & & & & & & & & \\
\hline на 10000 занятых в экономике, чел. & 78 & 66 & 59 & 55 & 55 & 55 & 55 & 55 & 54 & 55 & 55 \\
\hline $\begin{array}{l}\text { Подано патентных заявок на изобретения } \\
\text { в Российской Федерации }\end{array}$ & 22202 & 28688 & 32254 & 41849 & 38564 & 42500 & 41414 & 44211 & 44914 & 40308 & 45517 \\
\hline $\begin{array}{l}\text { Выдано патентов Российской Федерации } \\
\text { на изобретения }\end{array}$ & $31556^{\star}$ & 17592 & 23390 & 28808 & 34824 & 30322 & 29999 & 32880 & 31638 & 33950 & 34706 \\
\hline $\begin{array}{l}\text { Число разработанных передовых производ- } \\
\text { ственных технологий }\end{array}$ & $\ldots$ & 688 & 637 & 854 & 897 & 864 & 1138 & 1323 & 1429 & 1409 & 1398 \\
\hline $\begin{array}{l}\text { Число используемых передовых производ- } \\
\text { ственных технологий }\end{array}$ & $\ldots$ & 70069 & 140983 & 184568 & 201850 & 203330 & 191650 & 191372 & 193830 & 204546 & 218018 \\
\hline $\begin{array}{l}\text { Объем поступлений от экспорта технологий, } \\
\text { тыс. долл. США }\end{array}$ & $\ldots$ & 203493.5 & 389396.4 & 833164.4 & 618184.5 & 627887.5 & 584656.9 & 688469.9 & 770584.8 & 1279213.1 & 1654732.1 \\
\hline $\begin{array}{l}\text { Объем выплат по импорту технологий, } \\
\text { тыс. долл. США }\end{array}$ & $\cdots$ & 182908.0 & 954199.2 & 2087067.4 & 1619031.6 & 1425983.3 & 1862566.6 & 2043187.9 & 2463626.3 & 2455830.7 & 2205429.3 \\
\hline
\end{tabular}

* С учетом патентов, выданных в обмен на авторские свидетельства. 


\section{ОСНОВНЫЕ ПОКАЗАТЕЛИ ИННОВАЦИОННОЙ ДЕЯТЕЛЬНОСТИ}

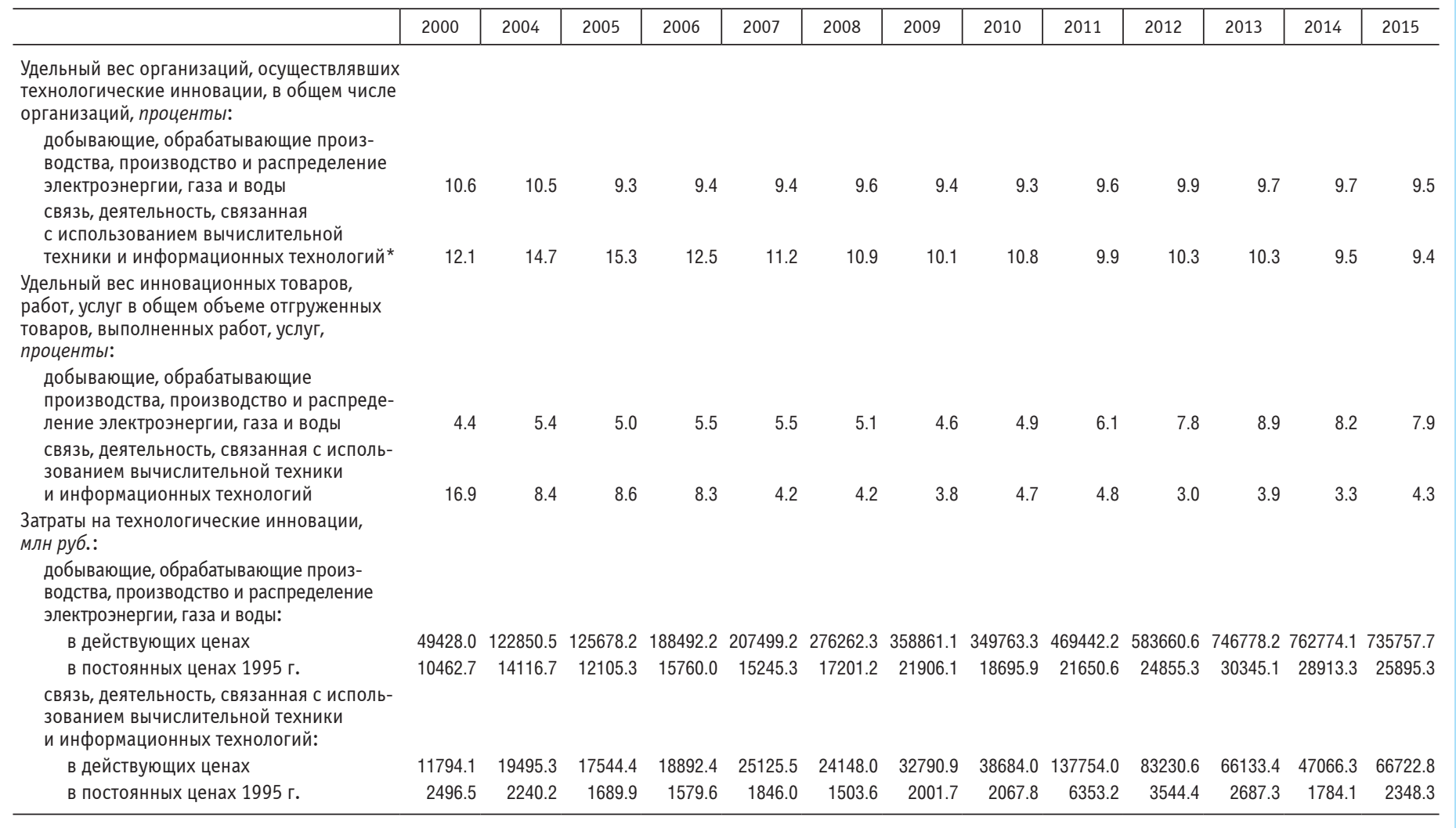


(продолжение)

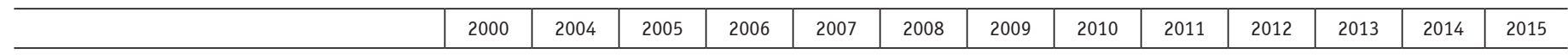

Удельный вес затрат на технологические инновации в общем объеме отгруженных

товаров, выполненных работ, услуг,

проценты:

добывающие, обрабатывающие производства, производство и распределение электроэнергии, газа и воды

связь, деятельность, связанная с использованием вычислительной техники и информационных технологий

Совокупный уровень инновационной активности (удельный вес организаций, осуществлявших технологические, маркетинговые, организационные инновации,

в общем числе организаций), проценты: добывающие, обрабатывающие производства, производство и распределение электроэнергии, газа и воды

связь, деятельность, связанная с использованием вычислительной техники и информационных технологий

Удельный вес организаций, осуществлявших маркетинговые инновации, в общем числе организаций, проценты:

добывающие, обрабатывающие произ-

водства, производство и распределение электроэнергии, газа и воды

1.5

1.2

1.4

1.2

1.4

1.9

1.5

1.5

1.8

2.2

связь, деятельность, связанная с исполь-

зованием вычислительной техники

и информационных технологий

$\begin{array}{lllllllllllll}\ldots & \ldots & \ldots & 10.6 & 10.8 & 11.0 & 11.0 & 10.8 & 11.1 & 11.1 & 10.9 & 10.9 & 10.6 \\ \ldots & \ldots & \ldots & 15.6 & 13.5 & 13.4 & 13.2 & 13.6 & 12.1 & 11.7 & 12.2 & 10.7 & 10.8\end{array}$

… 4.4


(продолжение)

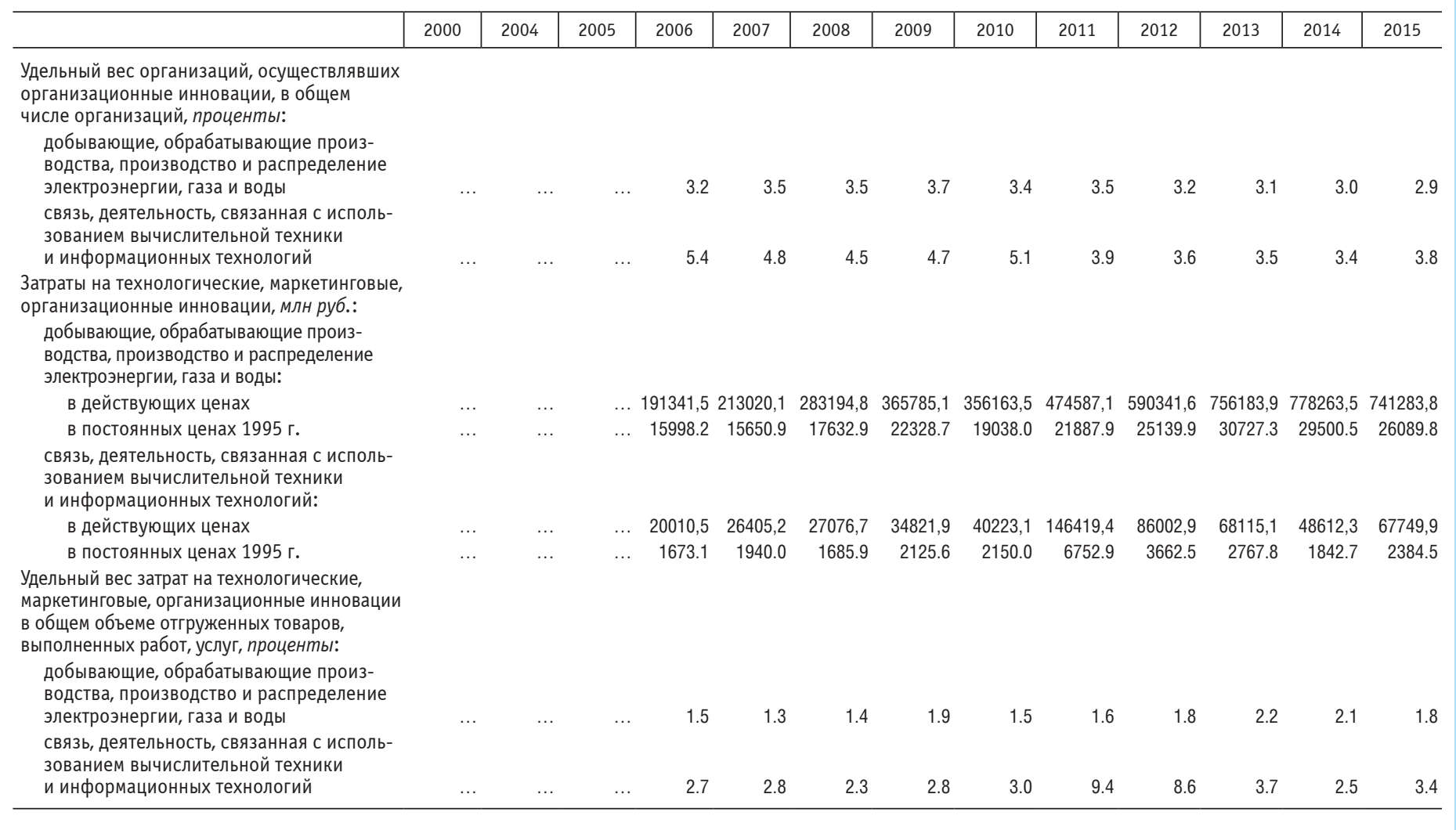


(окончание)

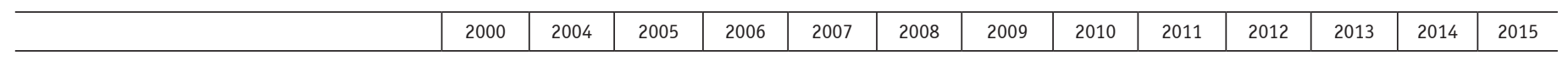

Удельный вес малых предприятий, осуществлявших технологические инновации,

в общем числе малых предприятий,

\section{проценты:}

добывающие, обрабатывающие произ-

водства, производство и распределение

электроэнергии, газа и воды

Удельный вес инновационных товаров,

работ, услуг в общем объеме отгруженных товаров, выполненных работ, услуг малых предприятий, проценты:

добывающие, обрабатывающие производства, производство и распределение электроэнергии, газа и воды

Затраты на технологические инновации малых предприятий, млн руб.:

добывающие, обрабатывающие производства, производство и распределение электроэнергии, газа и воды:

в действующих ценах

в постоянных ценах 1995 г.

Удельный вес затрат на технологические инновации в общем объеме отгруженных товаров, выполненных работ, услуг малых предприятий, проценты:

добывающие, обрабатывающие производства, производство и распределение электроэнергии, газа и воды

* В отличие от организаций других отраслей сферы услуг организации связи и организации, осуществлявшие деятельность, связанную с использованием вычислительной техники и информационных технологий, являлись целевыми объектами статистического наблюдения за инновационной деятельностью сферы услуг на протяжении всего рассматриваемого периода. 


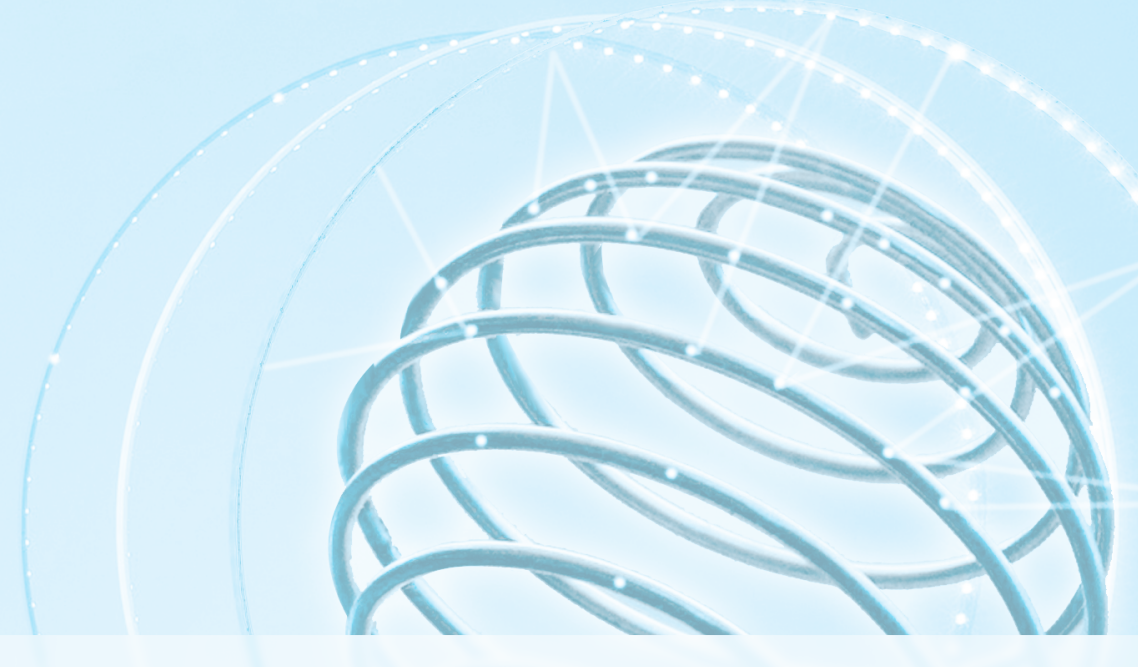

1. Организации 
1.1. ОРГАНИЗАЦИИ, ВЫПОЛНЯВШИЕ ИССЛЕДОВАНИЯ И РАЗРАБОТКИ

\begin{tabular}{|c|c|c|c|c|c|c|c|c|c|c|c|c|c|}
\hline & 1995 & 2000 & 2004 & $2005^{*}$ & $2007^{*}$ & $2008^{*}$ & $2009^{*}$ & $2010^{*}$ & $2011^{*}$ & $2012^{*}$ & $2013^{*}$ & $2014^{*}$ & $2015^{*}$ \\
\hline Всего & 4059 & 4099 & 3656 & 3566 & 3957 & 3666 & 3536 & 3492 & 3682 & 3566 & 3605 & 3604 & 4175 \\
\hline Научно-исследовательские & & & & & & & & & & & & & \\
\hline организации & 2284 & 2686 & 2464 & 2115 & 2036 & 1926 & 1878 & 1840 & 1782 & 1744 & 1719 & 1689 & 1708 \\
\hline Конструкторские организации & 548 & 318 & 194 & 489 & 497 & 418 & 377 & 362 & 364 & 338 & 331 & 317 & 322 \\
\hline Проектные и проектно- & & & & & & & & & & & & & \\
\hline изыскательские организации & 207 & 85 & 63 & 61 & 49 & 42 & 36 & 36 & 38 & 33 & 33 & 32 & 29 \\
\hline Опытные заводы & 23 & 33 & 31 & 30 & 60 & 58 & 57 & 47 & 49 & 60 & 53 & 53 & 61 \\
\hline $\begin{array}{l}\text { Образовательные организации } \\
\text { высшего образования }\end{array}$ & 395 & 390 & 402 & 406 & 500 & 503 & 506 & 517 & 581 & 562 & 673 & 702 & 1040 \\
\hline $\begin{array}{l}\text { Организации промышленного } \\
\text { производства }\end{array}$ & 325 & 284 & 244 & 231 & 265 & 239 & 228 & 238 & 280 & 274 & 266 & 275 & 371 \\
\hline Прочие организации & 277 & 303 & 258 & 234 & 550 & 480 & 454 & 452 & 588 & 555 & 530 & 536 & 644 \\
\hline
\end{tabular}

* С 2005 г. в связи с отменой 0бщероссийского классификатора отраслей народного хозяйства (ОКОНХ) изменена классификация типов организаций, выполнявших исследования и разработки. 
1.2. ДИНАМИКА ЧИСЛА ОРГАНИЗАЦИЙ, ВЫПОЛНЯВШИХ ИССЛЕДОВАНИЯ И РАЗРАБОТКИ

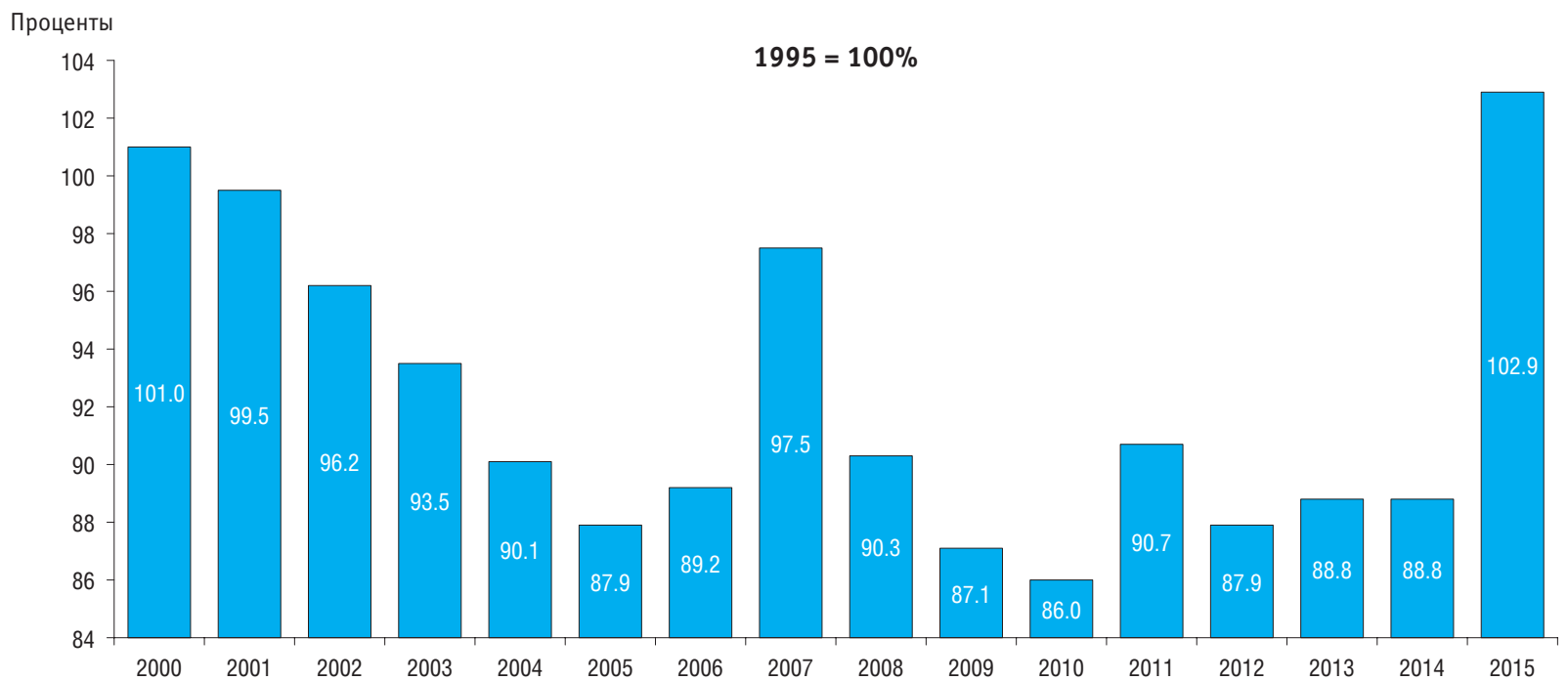


1.3. СТРУКТУРА ОРГАНИЗАЦИЙ, ВЫПОЛНЯВШИХ ИССЛЕДОВАНИЯ И РАЗРАБОТКИ (проценты)

2014

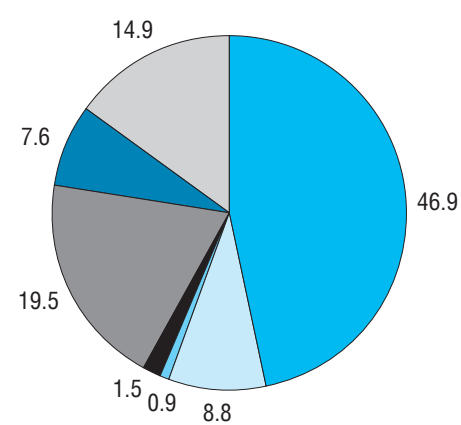

2015

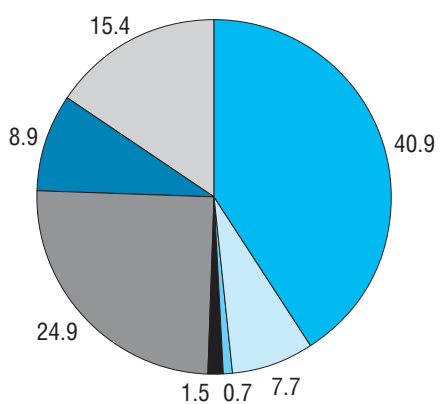

$\square$ Научно-исследовательские организации

$\square$ Конструкторские организации

$\square$ Проектные и проектно-изыскательские организации

- Опытные заводы

$\square$ Образовательные организации высшего образования

Организации промышленного производства

$\square$ Прочие организации 
1.4. ОРГАНИЗАЦИИ, ВЫПОЛНЯВШИЕ ИССЛЕДОВАНИЯ И РАЗРАБОТКИ, ПО ФОРМАМ СОБСТВЕННОСТИ

\begin{tabular}{|c|c|c|c|c|c|c|c|c|c|c|c|c|c|}
\hline & 1995 & 2000 & 2004 & 2005 & 2007 & 2008 & 2009 & 2010 & 2011 & 2012 & 2013 & 2014 & 2015 \\
\hline Всего & 4059 & 4099 & 3656 & 3566 & 3957 & 3666 & 3536 & 3492 & 3682 & 3566 & 3605 & 3604 & 4175 \\
\hline Российская собственность & 4034 & 4035 & 3599 & 3513 & 3895 & 3613 & 3483 & 3436 & 3614 & 3506 & 3542 & 3538 & 4077 \\
\hline Государственная & 2979 & $2938^{*}$ & 2675 & 2632 & 2821 & 2716 & 2655 & 2610 & 2670 & 2561 & 2526 & 2520 & 2684 \\
\hline Федеральная & 2783 & 2755 & 2524 & 2483 & 2650 & 2562 & 2503 & 2467 & 2493 & 2390 & 2363 & 2351 & 2494 \\
\hline Субъектов Российской Федерации & 196 & 181 & 151 & 149 & 166 & 148 & 146 & 140 & 176 & 170 & 163 & 169 & 190 \\
\hline Муниципальная & 9 & 11 & 7 & 6 & 13 & 13 & 14 & 14 & 18 & 14 & 14 & 13 & 15 \\
\hline Общественных организаций & 16 & 60 & 25 & 27 & 36 & 30 & 26 & 28 & 27 & 25 & 27 & 28 & 43 \\
\hline Частная & 198 & 388 & 420 & 422 & 638 & 508 & 475 & 470 & 532 & 545 & 607 & 614 & 881 \\
\hline \multicolumn{14}{|l|}{$\begin{array}{l}\text { Собственность российских } \\
\text { граждан, постоянно проживающих }\end{array}$} \\
\hline за границей & $\ldots$ & $\ldots$ & $\ldots$ & $\ldots$ & $\ldots$ & $\ldots$ & $\ldots$ & $\ldots$ & 1 & 1 & 1 & $\ldots{ }^{\star \star \star}$ & $\ldots^{\star \star \star \star}$ \\
\hline Потребительской кооперации ** & $\ldots$ & 3 & 4 & 4 & 3 & 2 & 3 & 4 & 4 & 2 & 2 & $\ldots{ }^{* \star *}$ & 5 \\
\hline Смешанная & 832 & 635 & 468 & 422 & 384 & 344 & 310 & 304 & 337 & 298 & 300 & 296 & 358 \\
\hline Иная смешанная & $\ldots$ & $\ldots$ & $\ldots$ & $\ldots$ & $\ldots$ & $\ldots$ & $\ldots$ & $\ldots$ & 41 & 51 & 64 & 65 & 83 \\
\hline Государственных корпораций & $\ldots$ & $\ldots$ & $\ldots$ & $\ldots$ & $\ldots$ & $\ldots$ & $\ldots$ & 6 & 25 & 60 & 65 & 64 & 90 \\
\hline Иностранная собственность & 1 & 6 & 6 & 7 & 11 & 13 & 14 & 16 & 21 & 16 & 16 & 17 & 36 \\
\hline Совместная российская & & & & & & & & & & & & & \\
\hline и иностранная собственность & 24 & 58 & 51 & 46 & 51 & 40 & 39 & 40 & 47 & 44 & 47 & 49 & 62 \\
\hline
\end{tabular}


(окончание)

\begin{tabular}{|c|c|c|c|c|c|c|c|c|c|c|c|c|c|}
\hline & 1995 & 2000 & 2004 & 2005 & 2007 & 2008 & 2009 & 2010 & 2011 & 2012 & 2013 & 2014 & 2015 \\
\hline Всего, проценты & 100 & 100 & 100 & 100 & 100 & 100 & 100 & 100 & 100 & 100 & 100 & 100 & 100 \\
\hline Российская собственность & 99.4 & 98.4 & 98.4 & 98.5 & 98.4 & 98.6 & 98.5 & 98.4 & 98.2 & 98.3 & 98.3 & 98.2 & 97.7 \\
\hline Государственная & 73.4 & 71.7 & 73.2 & 73.8 & 71.3 & 74.1 & 75.1 & 74.7 & 72.5 & 71.8 & 70.1 & 69.9 & 64.3 \\
\hline Федеральная & 68.6 & 67.2 & 69.0 & 69.6 & 67.0 & 69.9 & 70.8 & 70.6 & 67.7 & 67.0 & 65.5 & 65.2 & 59.7 \\
\hline Субъектов Российской Федерации & 4.8 & 4.4 & 4.1 & 4.2 & 4.2 & 4.0 & 4.1 & 4.0 & 4.8 & 4.8 & 4.5 & 4.7 & 4.6 \\
\hline Муниципальная & 0.2 & 0.3 & 0.2 & 0.2 & 0.3 & 0.4 & 0.4 & 0.4 & 0.5 & 0.4 & 0.4 & 0.4 & 0.4 \\
\hline Общественных организаций & 0.4 & 1.5 & 0.7 & 0.8 & 0.9 & 0.8 & 0.7 & 0.8 & 0.7 & 0.7 & 0.7 & 0.8 & 1.0 \\
\hline Частная & 4.9 & 9.5 & 11.5 & 11.8 & 16.1 & 13.9 & 13.4 & 13.5 & 14.4 & 15.3 & 16.8 & 17.0 & 21.1 \\
\hline \multicolumn{14}{|l|}{$\begin{array}{l}\text { Собственность российских } \\
\text { граждан, постоянно проживающих }\end{array}$} \\
\hline за границей & $\ldots$ & $\ldots$ & $\ldots$ & $\ldots$ & $\ldots$ & $\ldots$ & $\ldots$ & $\ldots$ & 0.03 & 0.03 & 0.03 & $\ldots{ }^{* \star *}$ & $\ldots{ }^{\star \star \star}$ \\
\hline Потребительской кооперации ** & $\ldots$ & 0.07 & 0.1 & 0.1 & 0.1 & 0.1 & 0.1 & 0.1 & 0.1 & 0.1 & 0.06 & $\ldots{ }^{* \star *}$ & 0.1 \\
\hline Смешанная & 20.5 & 15.5 & 12.8 & 11.8 & 9.7 & 9.4 & 8.8 & 8.7 & 9.2 & 8.4 & 8.3 & 8.2 & 8.6 \\
\hline \multicolumn{14}{|l|}{$\begin{array}{l}\text { Смешанная с долей } \\
\text { государственной }\end{array}$} \\
\hline собственности & $\ldots$ & $\ldots$ & $\cdots$ & $\cdots$ & $\ldots$ & $\ldots$ & $\ldots$ & 7.7 & 8.0 & 6.9 & 6.5 & 6.4 & 6.6 \\
\hline Иная смешанная & $\ldots$ & $\ldots$ & $\ldots$ & $\ldots$ & $\ldots$ & $\ldots$ & $\ldots$ & $\ldots$ & 1.1 & 1.4 & 1.8 & 1.8 & 2.0 \\
\hline Государственных корпораций & $\ldots$ & $\ldots$ & $\ldots$ & $\ldots$ & $\ldots$ & $\ldots$ & $\ldots$ & 0.2 & 0.7 & 1.7 & 1.8 & 1.8 & 2.2 \\
\hline Иностранная собственность & 0.02 & 0.1 & 0.2 & 0.2 & 0.3 & 0.4 & 0.4 & 0.5 & 0.6 & 0.4 & 0.4 & 0.5 & 0.9 \\
\hline $\begin{array}{l}\text { Совместная российская } \\
\text { и иностранная собственность }\end{array}$ & 0.6 & 1.4 & 1.4 & 1.3 & 1.3 & 1.1 & 1.1 & 1.1 & 1.3 & 1.2 & 1.3 & 1.4 & 1.5 \\
\hline
\end{tabular}

* Расхождение итогов с суммой слагаемых объясняется наличием у ряда организаций долевой собственности.

** До 2000 г. учитывалась в составе организаций частной и смешанной российской собственности.

*** Данные не публикуются в целях обеспечения конфиденциальности первичных статистических данных, полученных от организаций, в соответствии с Федеральным законом от 29.11.2007 № 282-Ф3 «0б официальном статистическом учете и системе государственной статистики в Российской Федерации» (ст. 4, п. 5; ст. 9, п. 1). 


\section{5. СТРУКТУРА ОРГАНИЗАЦИЙ, ВЫПОЛНЯВШИХ ИССЛЕДОВАНИЯ И РАЗРАБОТКИ, \\ ПО ОРГАНИЗАЦИОННО-ПРАВОВЫМ ФОРМАМ: 2015}

(проченты)

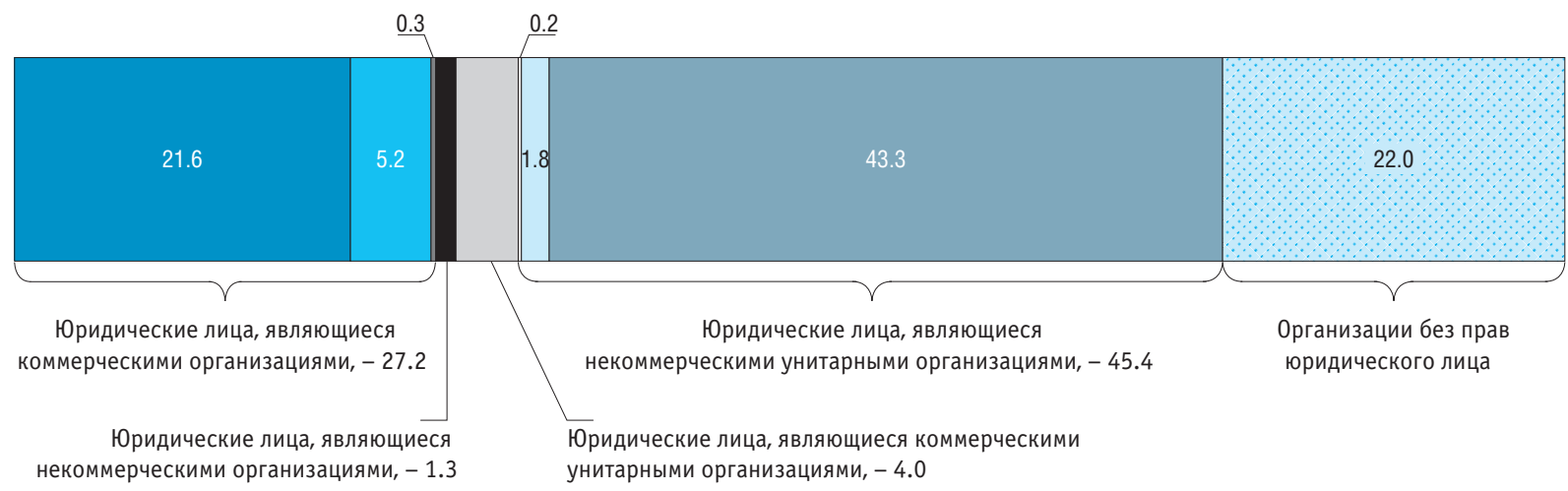

Акционерные общества

Общества с ограниченной ответственностью

Прочие коммерческие организации

\section{Фонды}

Автономные некоммерческие организации

Учреждения 


\section{6. ОРГАНИЗАЦИИ, ВЫПОЛНЯВШИЕ ИССЛЕДОВАНИЯ И РАЗРАБОТКИ, ПО ВИДАМ ЭКОНОМИЧЕСКОЙ ДЕЯТЕЛЬНОСТИ}

\begin{tabular}{|c|c|c|c|c|c|c|c|c|}
\hline & 2005 & 2009 & 2010 & 2011 & 2012 & 2013 & 2014 & 2015 \\
\hline Bcero & 3566 & 3536 & 3492 & 3682 & 3566 & 3605 & 3604 & 4175 \\
\hline Сельское хозяйство, охота и лесное хозяйство & 24 & 39 & 35 & 34 & 31 & 31 & 30 & 35 \\
\hline Рыбоводство, рыболовство и предоставление услуг в этих областях & 1 & 1 & 1 & - & - & - & - & - \\
\hline Добыча полезных ископаемых & 8 & 1 & 1 & 2 & 4 & 3 & 2 & 4 \\
\hline Обрабатывающие производства & 241 & 268 & 276 & 317 & 323 & 314 & 320 & 456 \\
\hline Производство и распределение электроэнергии, газа и воды & - & 1 & 1 & 1 & 1 & 1 & 1 & 5 \\
\hline Строительство & - & - & - & - & 1 & 1 & 1 & $\ldots{ }^{*}$ \\
\hline Гостиницы и рестораны & - & - & - & - & 1 & 1 & - & $\ldots{ }^{*}$ \\
\hline $\begin{array}{l}\text { Оптовая и розничная торговля, ремонт автотранспортных средств, } \\
\text { мотоциклов, бытовых изделий и предметов личного пользования }\end{array}$ & - & - & - & 2 & - & - & - & $\ldots{ }^{*}$ \\
\hline Транспорт и связь & 1 & 3 & 3 & 4 & 7 & 4 & 4 & 4 \\
\hline $\begin{array}{l}\text { Операции с недвижимым имуществом, аренда и предоставление услуг } \\
\text { Из них: }\end{array}$ & 2757 & 2517 & 2456 & 2526 & 2389 & 2344 & 2307 & 2321 \\
\hline научные исследования и разработки & 2628 & 2395 & 2331 & 2398 & 2257 & 2213 & 2193 & 2175 \\
\hline предоставление прочих видов услуг & 117 & 93 & 95 & 93 & 88 & 87 & 76 & 91 \\
\hline Образование & 428 & 541 & 549 & 620 & 632 & 732 & 768 & 1152 \\
\hline Из него высшее образование & 425 & 532 & 543 & 611 & 619 & 716 & 752 & 1129 \\
\hline Здравоохранение и предоставление социальных услуг & 11 & 21 & 24 & 26 & 29 & 32 & 33 & 42 \\
\hline $\begin{array}{l}\text { Предоставление прочих коммунальных, социальных } \\
\text { и персональных услуг }\end{array}$ & 95 & 144 & 146 & 150 & 148 & 142 & 138 & 148 \\
\hline $\begin{array}{l}\text { Из них деятельность по организации отдыха и развлечений, } \\
\text { культуры и спорта }\end{array}$ & 90 & 137 & 140 & 143 & 139 & 135 & 132 & 139 \\
\hline
\end{tabular}

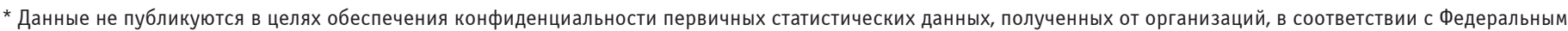

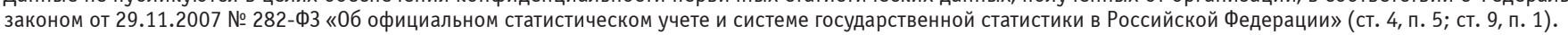




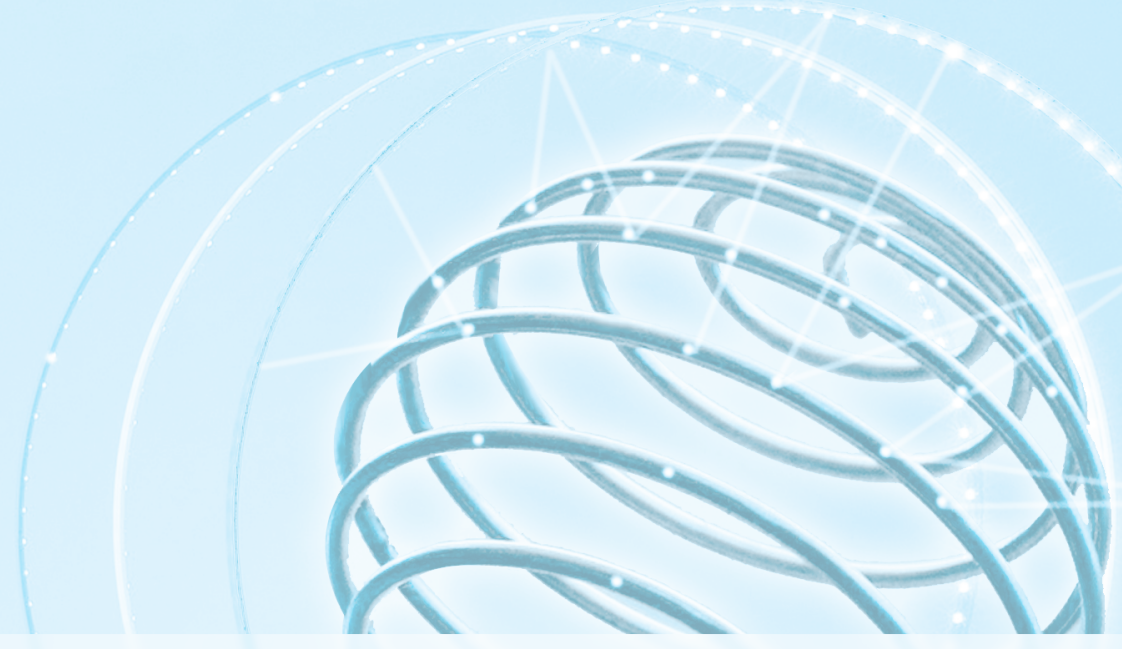

2. Кадры науки 


\section{1. ПЕРСОНАЛ, ЗАНЯТЫЙ ИССЛЕДОВАНИЯМИ И РАЗРАБОТКАМИ (человек)}

\begin{tabular}{|c|c|c|c|c|c|c|c|c|c|c|c|c|c|}
\hline & 1995 & 2000 & 2004 & $2005^{*}$ & $2007^{*}$ & $2008^{*}$ & $2009^{*}$ & $2010^{*}$ & $2011^{*}$ & $2012^{*}$ & $2013^{*}$ & $2014^{*}$ & $2015^{*}$ \\
\hline Всего & 1061044 & 887729 & 839338 & 813207 & 801135 & 761252 & 742433 & 736540 & 735273 & 726318 & 727029 & 732274 & 738857 \\
\hline Научно-исследовательские организации & 753253 & 718434 & 700308 & 510523 & 474985 & 454938 & 443702 & 435304 & 420031 & 430677 & 434243 & 435129 & 435502 \\
\hline Конструкторские организации & 129689 & 56488 & 41713 & 184785 & 179862 & 167517 & 163764 & 157146 & 159620 & 138295 & 137098 & 139608 & 136263 \\
\hline $\begin{array}{l}\text { Проектные и проектно-изыскательские } \\
\text { организации }\end{array}$ & 20870 & 6811 & 6261 & 5443 & 8406 & 7446 & 6738 & 6324 & 6466 & 6772 & 4907 & 4776 & 2849 \\
\hline Опытные заводы & 13640 & 6145 & 4605 & 1232 & 3528 & 1544 & 1588 & 1558 & 1817 & 2330 & 2383 & 2653 & 3023 \\
\hline $\begin{array}{l}\text { Образовательные организации высшего } \\
\text { образования }\end{array}$ & 40015 & 31110 & 32105 & 33942 & 40440 & 40003 & 41767 & 46776 & 53944 & 53699 & 54092 & 58573 & 60151 \\
\hline Организации промышленного производства & 89030 & 54721 & 42192 & 43524 & 56759 & 52042 & 49042 & 51807 & 52004 & 52071 & 52232 & 49358 & 53868 \\
\hline Прочие организации & 14547 & 14020 & 12154 & 33758 & 37155 & 37762 & 35832 & 37625 & 41391 & 42474 & 42074 & 42177 & 47201 \\
\hline
\end{tabular}

* С 2005 г. в связи с отменой Общероссийского классификатора отраслей народного хозяйства (ОКОНХ) изменена классификация типов организаций, выполнявших исследования и разработки.

\section{2. ПЕРСОНАЛ, ЗАНЯТЫЙ ИССЛЕДОВАНИЯМИ И РАЗРАБОТКАМИ, ПО КАТЕГОРИЯМ}

(человек)

\begin{tabular}{|c|c|c|c|c|c|c|c|c|c|c|c|c|c|}
\hline & 1995 & 2000 & 2004 & 2005 & 2007 & 2008 & 2009 & 2010 & 2011 & 2012 & 2013 & 2014 & 2015 \\
\hline Всего & 1061044 & 887729 & 839338 & 813207 & 801135 & 761252 & 742433 & 736540 & 735273 & 726318 & 727029 & 732274 & 738857 \\
\hline Исследователи & 518690 & 425954 & 401425 & 391121 & 392849 & 375804 & 369237 & 368915 & 374746 & 372620 & 369015 & 373905 & 379411 \\
\hline Техники & 101371 & 75184 & 69963 & 65982 & 64569 & 60218 & 60045 & 59276 & 61562 & 58905 & 61401 & 63168 & 62805 \\
\hline Вспомогательный персонал & 274925 & 240506 & 223356 & 215555 & 208052 & 194769 & 186995 & 183713 & 178494 & 175790 & 175365 & 173554 & 174056 \\
\hline Прочие & 166058 & 146085 & 144594 & 140549 & 135665 & 130461 & 126156 & 124636 & 120471 & 119003 & 121248 & 121647 & 122585 \\
\hline
\end{tabular}




\section{3. СТРУКТУРА ПЕРСОНАЛА, ЗАНЯТОГО ИССЛЕДОВАНИЯМИ И РАЗРАБОТКАМИ, ПО КАТЕГОРИЯМ}

Проценты

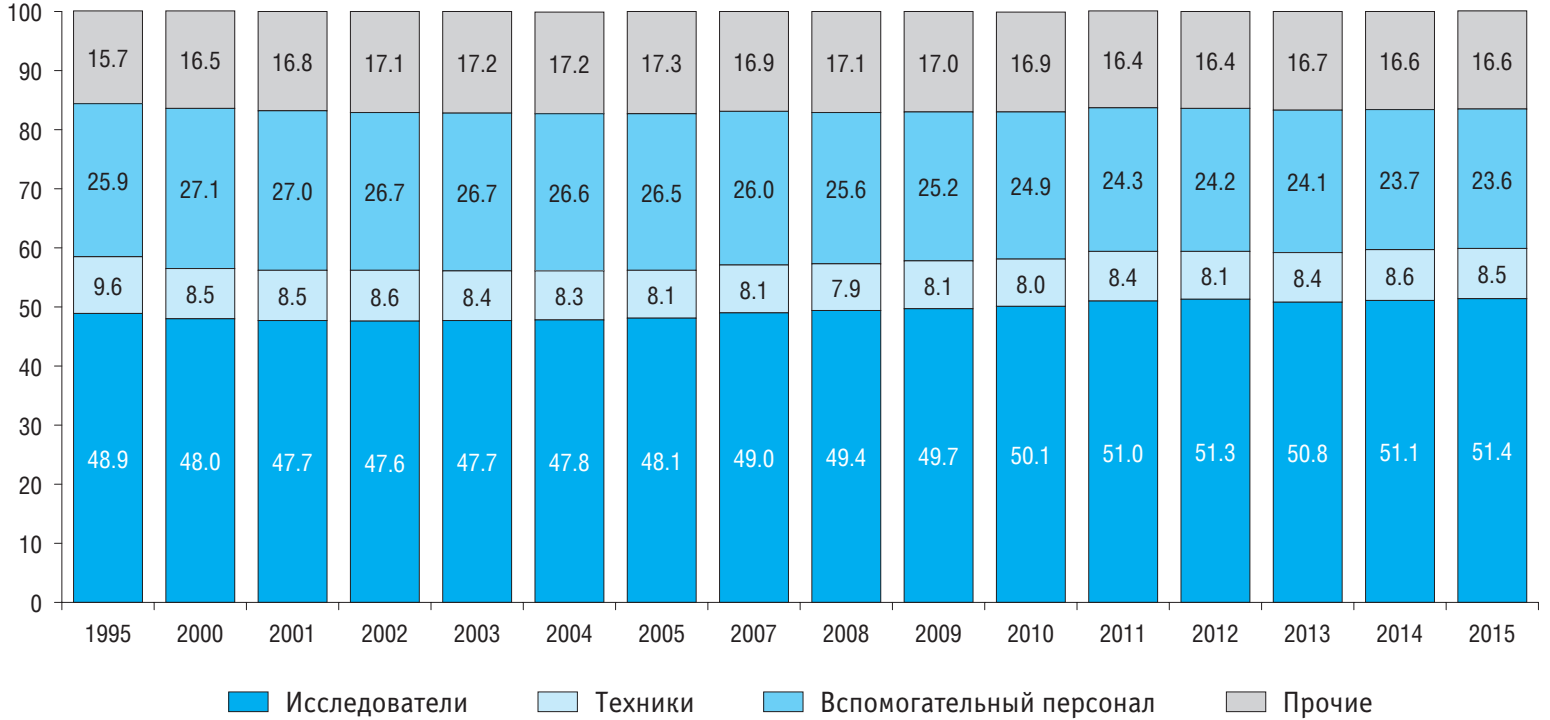




\section{4. ПЕРСОНАЛ, ЗАНЯТЫЙ ИССЛЕДОВАНИЯМИ И РАЗРАБОТКАМИ, ПО ФОРМАМ СОБСТВЕННОСТИ ОРГАНИЗАЦИЙ}

\begin{tabular}{|c|c|c|c|c|c|c|c|c|c|c|c|c|c|}
\hline & 1995 & 2000 & 2004 & 2005 & 2007 & 2008 & 2009 & 2010 & 2011 & 2012 & 2013 & 2014 & 2015 \\
\hline \multicolumn{14}{|c|}{ Человек } \\
\hline Всего & 1061044 & 887729 & 839338 & 813207 & 801135 & 761252 & 742433 & 736540 & 735273 & 726318 & 727029 & 732274 & 738857 \\
\hline Российская собственность & 1060480 & 866386 & 822749 & 797394 & 785560 & 746412 & 734405 & 726234 & 723642 & 715691 & 710336 & 723101 & 729121 \\
\hline Государственная & 816799 & $673658^{*}$ & 646727 & 641310 & 622602 & 595458 & 585675 & 575035 & 559339 & 536212 & 518460 & 522994 & 485424 \\
\hline Федеральная & 795299 & 657696 & 635449 & 629207 & 610145 & 584117 & 574697 & 564238 & 547922 & 525200 & 508083 & 508938 & 472548 \\
\hline Субъектов Российской Федерации & 21500 & 15957 & 11278 & 12103 & 11979 & 10861 & 10503 & 10450 & 11355 & 10947 & 10377 & 14056 & 12876 \\
\hline Муниципальная & 738 & 725 & 85 & 77 & 207 & 186 & 180 & 170 & 229 & 142 & 208 & 155 & 141 \\
\hline Общественных организаций & 1036 & 1207 & 208 & 231 & 376 & 460 & 474 & 512 & 531 & 600 & 740 & 821 & 1010 \\
\hline Частная & 26238 & 53408 & 62862 & 58480 & 79876 & 73509 & 69167 & 66906 & 74795 & 73260 & 77830 & 76920 & 85798 \\
\hline \multicolumn{14}{|l|}{$\begin{array}{l}\text { Собственность российских } \\
\text { граждан, постоянно проживающих }\end{array}$} \\
\hline за границей & $\ldots$ & $\ldots$ & $\ldots$ & $\ldots$ & $\ldots$ & $\ldots$ & $\ldots$ & $\ldots$ & 23 & 25 & $\ldots{ }^{* \star *}$ & $\ldots^{* \star *}$ & $\ldots^{* * *}$ \\
\hline Потребительской кооперации ** & $\ldots$ & 16 & 27 & 27 & 10 & 10 & 253 & 268 & 308 & 2 & $\ldots{ }^{* * *}$ & $\ldots{ }^{* * *}$ & 20 \\
\hline Смешанная & 215669 & 137372 & 112840 & 97269 & 82489 & 76789 & 78656 & 78464 & 78756 & 82862 & 87532 & 95863 & 124661 \\
\hline $\begin{array}{l}\text { Смешанная с долей государствен- } \\
\text { ной собственности }\end{array}$ & $\cdots$ & $\ldots$ & $\ldots$ & $\ldots$ & $\ldots$ & $\ldots$ & $\ldots$ & 66574 & 65362 & 59406 & 67452 & 75024 & 90907 \\
\hline Иная смешанная & $\ldots$ & $\ldots$ & $\ldots$ & $\ldots$ & $\ldots$ & $\ldots$ & $\ldots$ & $\ldots$ & 13394 & 23456 & 20080 & 20839 & 33754 \\
\hline Государственных корпораций & $\ldots$ & $\ldots$ & $\ldots$ & $\ldots$ & $\ldots$ & $\ldots$ & $\ldots$ & 4879 & 9661 & 22588 & 25560 & 26324 & 32063 \\
\hline Иностранная собственность & - & 146 & 337 & 1145 & 835 & 699 & 553 & 1130 & 1358 & 1233 & 1955 & 2344 & 2898 \\
\hline $\begin{array}{l}\text { Совместная российская и иностранная } \\
\text { собственность }\end{array}$ & 564 & 21197 & 16252 & 14668 & 14740 & 14141 & 7475 & 9176 & 10273 & 9394 & 14738 & 6829 & 6838 \\
\hline
\end{tabular}


(окончание)

\begin{tabular}{|c|c|c|c|c|c|c|c|c|c|c|c|c|c|}
\hline & 1995 & 2000 & 2004 & 2005 & 2007 & 2008 & 2009 & 2010 & 2011 & 2012 & 2013 & 2014 & 2015 \\
\hline \multicolumn{14}{|c|}{ Проценты } \\
\hline Bcero & 100 & 100 & 100 & 100 & 100 & 100 & 100 & 100 & 100 & 100 & 100 & 100 & 100 \\
\hline Российская собственность & 99.9 & 97.6 & 98.0 & 98.1 & 98.1 & 98.1 & 98.9 & 98.6 & 98.4 & 98.5 & 97.7 & 98.7 & 98.7 \\
\hline Государственная & 77.0 & 75.9 & 77.1 & 78.9 & 77.7 & 78.2 & 78.9 & 78.1 & 76.1 & 73.8 & 71.3 & 71.4 & 65.7 \\
\hline Федеральная & 75.0 & 74.1 & 75.7 & 77.4 & 76.2 & 76.7 & 77.4 & 76.6 & 74.5 & 72.3 & 69.9 & 69.5 & 64.0 \\
\hline Субъектов Российской Федерации & 2.0 & 1.8 & 1.3 & 1.49 & 1.5 & 1.4 & 1.4 & 1.4 & 1.5 & 1.5 & 1.4 & 1.9 & 1.7 \\
\hline Муниципальная & 0.07 & 0.08 & 0.01 & 0.01 & 0.03 & 0.02 & 0.02 & 0.02 & 0.03 & 0.02 & 0.03 & 0.02 & 0.02 \\
\hline Общественных организаций & 0.1 & 0.1 & 0.02 & 0.028 & 0.05 & 0.1 & 0.1 & 0.1 & 0.1 & 0.1 & 0.1 & 0.1 & 0.1 \\
\hline Частная & 2.5 & 6.0 & 7.5 & 7.19 & 10.0 & 9.7 & 9.3 & 9.1 & 10.2 & 10.1 & 10.7 & 10.5 & 11.6 \\
\hline \multicolumn{14}{|l|}{$\begin{array}{l}\text { Собственность российских } \\
\text { граждан, постоянно проживающих }\end{array}$} \\
\hline Потребительской кооперации ** & $\begin{array}{l}\cdots \\
\ldots\end{array}$ & 0.002 & $\begin{array}{r}\cdots \\
0.003\end{array}$ & $\begin{array}{r}\cdots \\
0.003\end{array}$ & $\begin{array}{r}\cdots \\
0.001\end{array}$ & $\begin{array}{r}\cdots \\
0.001\end{array}$ & $\begin{array}{r}\cdots \\
0.03\end{array}$ & $\begin{array}{r}\cdots \\
0.04\end{array}$ & $\begin{array}{r}0.003 \\
0.04\end{array}$ & $\begin{array}{r}0.003 \\
0.0\end{array}$ & $\ldots^{\cdots * \star *}$ & $\begin{array}{l}\cdots \\
\ldots^{* * *}\end{array}$ & $\begin{array}{l}\ldots \\
0.003\end{array}$ \\
\hline Смешанная & 20.3 & 15.5 & 13.4 & 11.96 & 10.3 & 10.1 & 10.6 & 10.7 & 10.7 & 11.4 & 12.0 & 13.1 & 16.9 \\
\hline $\begin{array}{l}\text { Смешанная с долей государ- } \\
\text { ственной собственности }\end{array}$ & $\ldots$ & $\ldots$ & $\ldots$ & $\ldots$ & $\ldots$ & $\ldots$ & $\ldots$ & 9.0 & 8.9 & 8.2 & 9.3 & 10.2 & 12.3 \\
\hline Иная смешанная & $\ldots$ & $\ldots$ & $\ldots$ & $\ldots$ & $\ldots$ & $\ldots$ & $\ldots$ & $\ldots$ & 1.8 & 3.2 & 2.8 & 2.8 & 4.6 \\
\hline Государственных корпораций & $\ldots$ & $\ldots$ & 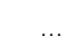 & $\ldots$ & $\ldots$ & $\ldots$ & $\ldots$ & 0.7 & 1.3 & 3.1 & 3.5 & 3.6 & 4.3 \\
\hline Иностранная собственность & - & 0.02 & 0.04 & 0.14 & 0.1 & 0.1 & 0.1 & 0.2 & 0.2 & 0.2 & 0.3 & 0.3 & 0.4 \\
\hline $\begin{array}{l}\text { Совместная российская и иностранная } \\
\text { собственность }\end{array}$ & 0.05 & 2.4 & 1.9 & 1.8 & 1.8 & 1.9 & 1.0 & 1.2 & 1.4 & 1.3 & 2.0 & 0.9 & 0.9 \\
\hline
\end{tabular}

* Расхождение итогов с суммой слагаемых объясняется наличием у ряда организаций долевой собственности.

** До 2000 г. учитывалась в составе организаций частной и смешанной российской собственности.

*** Данные не публикуются в целях обеспечения конфиденциальности первичных статистических данных, полученных от организаций, в соответствии с Федеральным законом от 29.11.2007 г. № 282-Ф3 «06 официальном статистическом учете и системе государственной статистики в Российской Федерации» (ст. 4, п. 5; ст. 9, п. 1). 


\section{5. СТРУКТУРА ПЕРСОНАЛА, ЗАНЯТОГО ИССЛЕДОВАНИЯМИ И РАЗРАБОТКАМИ, ПО ОРГАНИЗАЦИОННО-ПРАВОВЫМ ФОРМАМ ОРГАНИЗАЦИЙ: 2015 \\ (проченты)}

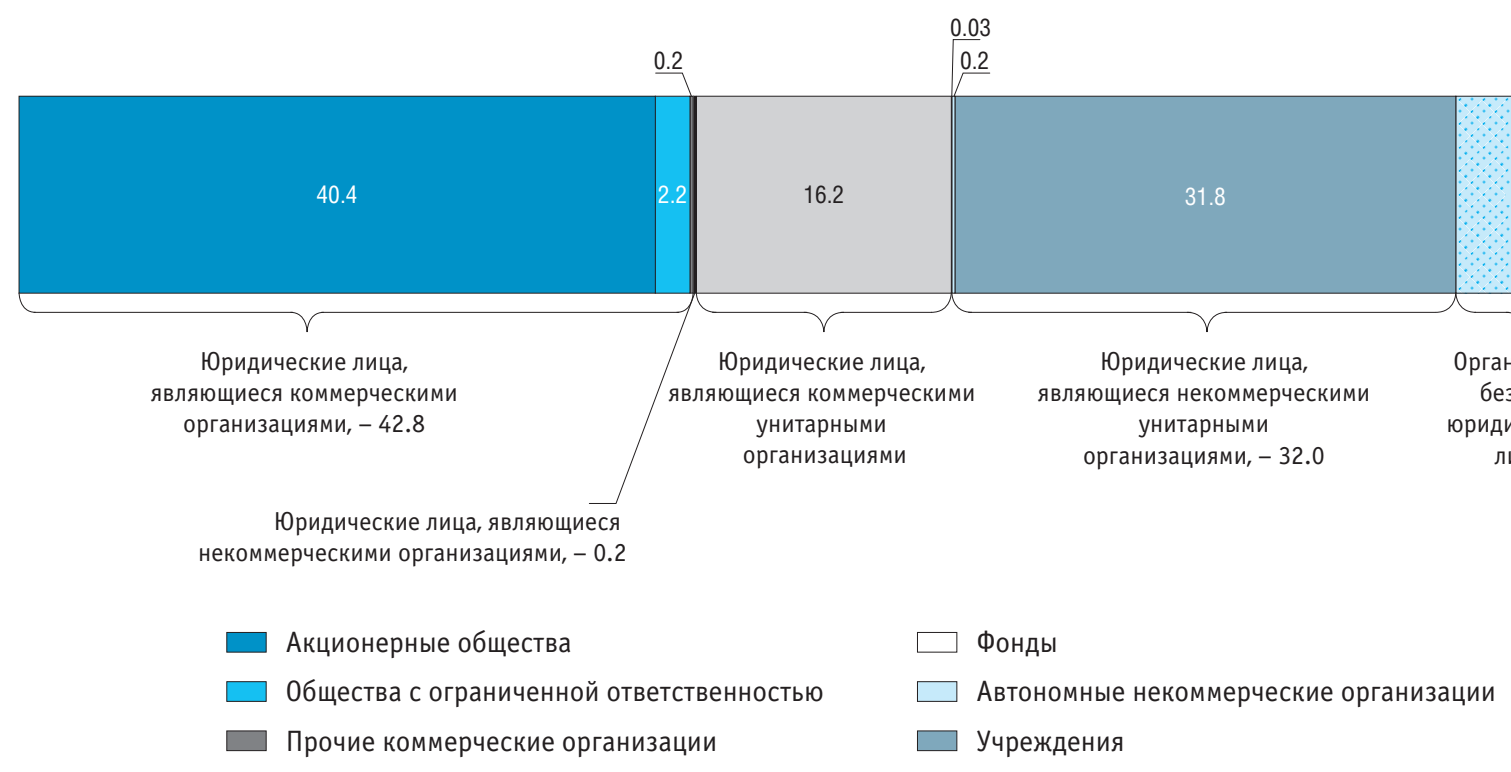




\section{6. ПЕРСОНАЛ, ЗАНЯТЫЙ ИССЛЕДОВАНИЯМИ И РАЗРАБОТКАМИ, ПО ВИДАМ ЭКОНОМИЧЕСКОЙ ДЕЯТЕЛЬНОСТИ}

(человек)

\begin{tabular}{|c|c|c|c|c|c|c|}
\hline & \multicolumn{3}{|c|}{$\begin{array}{c}\text { Персонал, занятый исследованиями } \\
\text { и разработками }\end{array}$} & \multicolumn{3}{|c|}{ Исследователи } \\
\hline & 2013 & 2014 & 2015 & 2013 & 2014 & 2015 \\
\hline Bcero & 727029 & 732274 & 738857 & 369015 & 373905 & 379411 \\
\hline Сельское хозяйство, охота и лесное хозяйство & 1141 & 1101 & 1054 & 357 & 350 & 296 \\
\hline Рыбоводство, рыболовство и предоставление услуг в этих областях & - & - & - & - & - & - \\
\hline Добыча полезных ископаемых & 19 & $\ldots{ }^{*}$ & 73 & 16 & $\ldots{ }^{*}$ & 71 \\
\hline Обрабатывающие производства & 43621 & 42758 & 80980 & 25031 & 25251 & 41085 \\
\hline Производство и распределение электроэнергии, газа и воды & - & $\ldots{ }^{*}$ & 166 & - &.$^{*}$ & 120 \\
\hline Строительство & $\ldots{ }^{*}$ & $\ldots{ }^{*}$ & $\ldots{ }^{*}$ & $\ldots{ }^{*}$ & $\ldots{ }^{*}$ & $\ldots{ }^{*}$ \\
\hline Гостиницы и рестораны & $\ldots{ }^{*}$ & - & $\ldots{ }^{*}$ & $\ldots{ }^{*}$ & - & $\ldots^{*}$ \\
\hline $\begin{array}{l}\text { Оптовая и розничная торговля, ремонт автотранспортных средств, мотоциклов, } \\
\text { бытовых изделий и предметов личного пользования }\end{array}$ & - & - & $\ldots^{*}$ & - & - & $\ldots^{*}$ \\
\hline Транспорт и связь & 1006 & 1098 & 325 & 599 & 574 & 221 \\
\hline $\begin{array}{l}\text { Операции с недвижимым имуществом, аренда и предоставление услуг } \\
\text { Из них: }\end{array}$ & 615419 & 618029 & 583084 & 297393 & 299881 & 286012 \\
\hline научные исследования и разработки & 603911 & 607491 & 572632 & 290055 & 292849 & 278805 \\
\hline предоставление прочих видов услуг & 7808 & 6608 & 6069 & 5082 & 4509 & 4135 \\
\hline Образование & 56142 & 60908 & 65065 & 40858 & 44001 & 47397 \\
\hline Из него высшее образование & 55816 & 60587 & 64834 & 40584 & 43742 & 47220 \\
\hline Здравоохранение и предоставление социальных услуг & 3260 & 3147 & 3723 & 1764 & 1680 & 1826 \\
\hline Предоставление прочих коммунальных, социальных и персональных услуг & 5581 & 5118 & 3968 & 2345 & 2098 & 2042 \\
\hline Из них деятельность по организации отдыха и развлечений, культуры и спорта & 5569 & 5109 & 3875 & 2333 & 2089 & 1963 \\
\hline
\end{tabular}

* Данные не публикуются в целях обеспечения конфиденциальности первичных статистических данных, полученных от организаций, в соответствии с Федеральным законом от 29.11.2007 № 282-Ф3 «0б официальном статистическом учете и системе государственной статистики в Российской Федерации» (ст. 4, п. 5; ст. 9, п. 1). 
2.7. ПЕРСОНАЛ, ЗАНЯТЫЙ ИССЛЕДОВАНИЯМИ И РАЗРАБОТКАМИ, ПО УРОВНЮ ОБРАЗОВАНИЯ (человек)

\begin{tabular}{|c|c|c|c|c|}
\hline & Всего & $\begin{array}{c}\text { Высшее } \\
\text { образование }\end{array}$ & $\begin{array}{c}\text { Среднее профессиональное } \\
\text { образование }\end{array}$ & $\begin{array}{c}\text { Прочее } \\
\text { образование }\end{array}$ \\
\hline 1995 & 1061044 & 626979 & 168999 & 265066 \\
\hline 2000 & 887729 & 530649 & 144503 & 212577 \\
\hline 2001 & 885568 & 529905 & 147604 & 208059 \\
\hline 2002 & 870878 & 525145 & 146052 & 199681 \\
\hline 2003 & 858470 & 521137 & 144197 & 193136 \\
\hline 2004 & 839338 & 511778 & 141682 & 185878 \\
\hline 2005 & 813207 & 501718 & 134222 & 177267 \\
\hline 2006 & 807066 & 502657 & 133454 & 170955 \\
\hline 2007 & 801135 & 513099 & 129360 & 158676 \\
\hline 2008 & 761252 & 495255 & 121508 & 144489 \\
\hline 2009 & 742433 & 489076 & 115042 & 138315 \\
\hline 2010 & 736540 & 493852 & 109158 & 133530 \\
\hline 2011 & 735273 & 506330 & 103873 & 125070 \\
\hline 2012 & 726318 & 508057 & 99503 & 118758 \\
\hline 2013 & 727029 & 512017 & 97867 & 117145 \\
\hline 2014 & 732274 & 522726 & 95564 & 113984 \\
\hline 2015 & 738857 & 537118 & 95640 & 106099 \\
\hline
\end{tabular}


2.8. ИССЛЕДОВАТЕЛИ ПО ПОЛУ И ВОЗРАСТНЫМ ГРУППАМ

(человек)

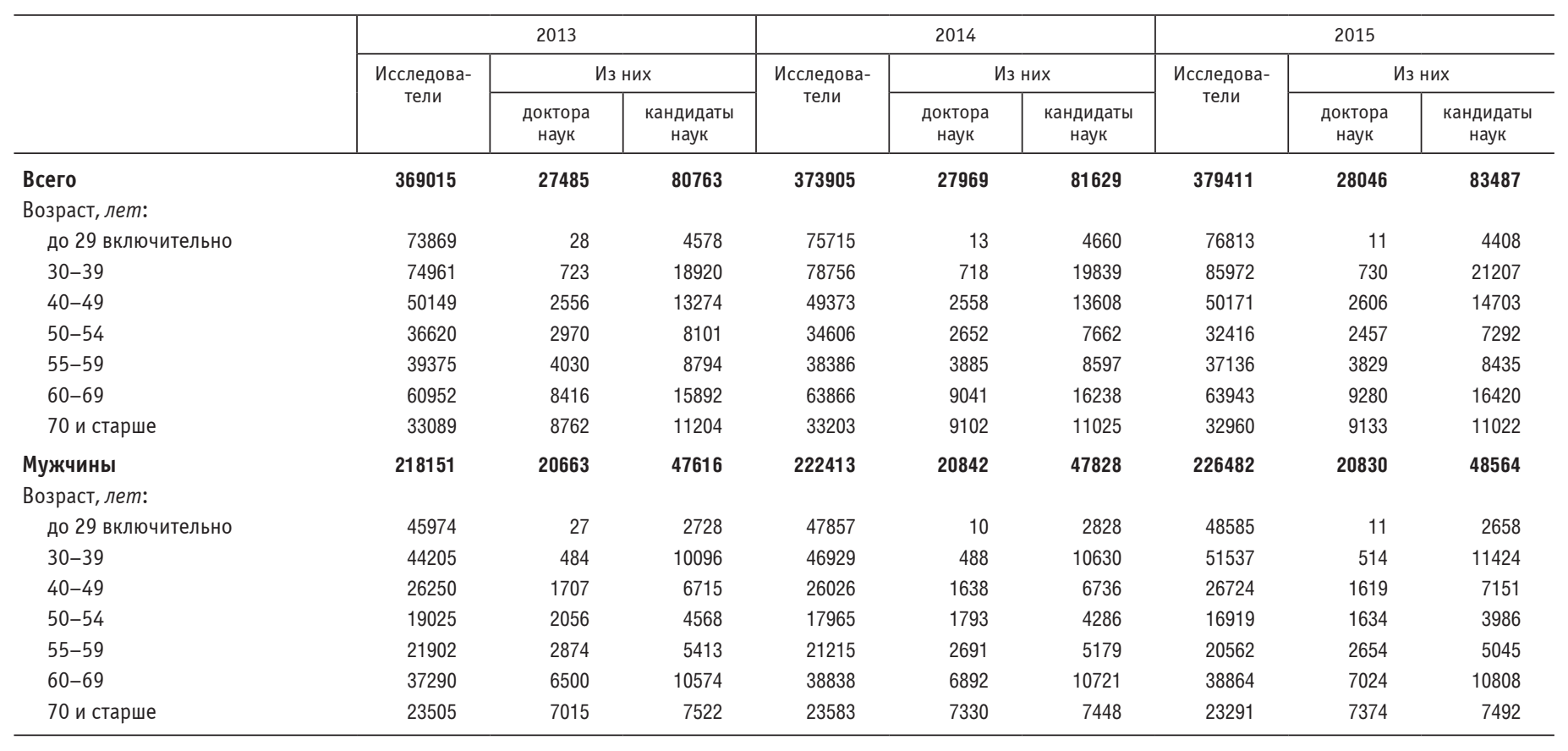


(окончание)

\begin{tabular}{|c|c|c|c|c|c|c|c|c|c|}
\hline & \multicolumn{3}{|c|}{2013} & \multicolumn{3}{|c|}{2014} & \multicolumn{3}{|c|}{2015} \\
\hline & \multirow{2}{*}{$\begin{array}{l}\text { Исследова- } \\
\text { тели }\end{array}$} & \multicolumn{2}{|c|}{ Из них } & \multirow{2}{*}{$\begin{array}{c}\text { Исследова- } \\
\text { тели }\end{array}$} & \multicolumn{2}{|c|}{ Из них } & \multirow{2}{*}{$\begin{array}{c}\text { Исследова- } \\
\text { тели }\end{array}$} & \multicolumn{2}{|c|}{ Из них } \\
\hline & & $\begin{array}{c}\text { доктора } \\
\text { наук }\end{array}$ & $\begin{array}{c}\text { кандидаты } \\
\text { наук }\end{array}$ & & $\begin{array}{c}\text { доктора } \\
\text { наук }\end{array}$ & $\begin{array}{c}\text { кандидаты } \\
\text { наук }\end{array}$ & & $\begin{array}{c}\text { доктора } \\
\text { наук }\end{array}$ & $\begin{array}{c}\text { кандидаты } \\
\text { наук }\end{array}$ \\
\hline Женщины & 150864 & 6822 & 33147 & 151492 & 7127 & 33801 & 152929 & 7216 & 34923 \\
\hline \multicolumn{10}{|l|}{ Возраст, лет: } \\
\hline до 29 включительно & 27895 & 1 & 1850 & 27858 & 3 & 1832 & 28228 & - & 1750 \\
\hline $30-39$ & 30756 & 239 & 8824 & 31827 & 230 & 9209 & 34435 & 216 & 9783 \\
\hline $40-49$ & 23899 & 849 & 6559 & 23347 & 920 & 6872 & 23447 & 987 & 7552 \\
\hline $50-54$ & 17595 & 914 & 3533 & 16641 & 859 & 3376 & 15497 & 823 & 3306 \\
\hline $55-59$ & 17473 & 1156 & 3381 & 17171 & 1194 & 3418 & 16574 & 1175 & 3390 \\
\hline $60-69$ & 23662 & 1916 & 5318 & 25028 & 2149 & 5517 & 25079 & 2256 & 5612 \\
\hline 70 и старше & 9584 & 1747 & 3682 & 9620 & 1772 & 3577 & 9669 & 1759 & 3530 \\
\hline
\end{tabular}




\section{9. СТРУКТУРА ИССЛЕДОВАТЕЛЕЙ ПО ВОЗРАСТНЫМ ГРУППАМ}
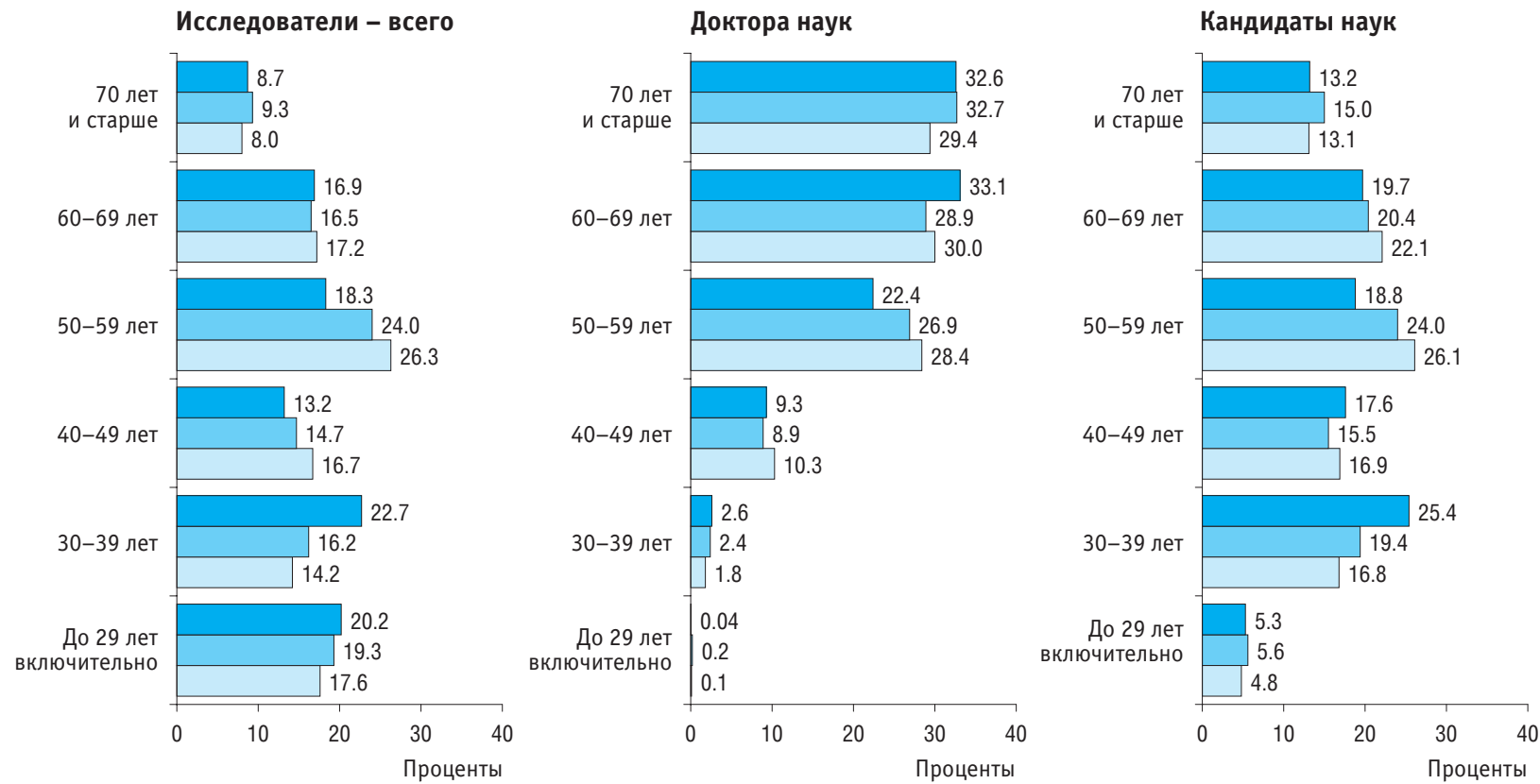

$\square 2008$

$\square 2010$

2015 


\subsection{0. СРЕДНИЙ ВОЗРАСТ ИССЛЕДОВАТЕЛЕЙ}

Возраст, лет

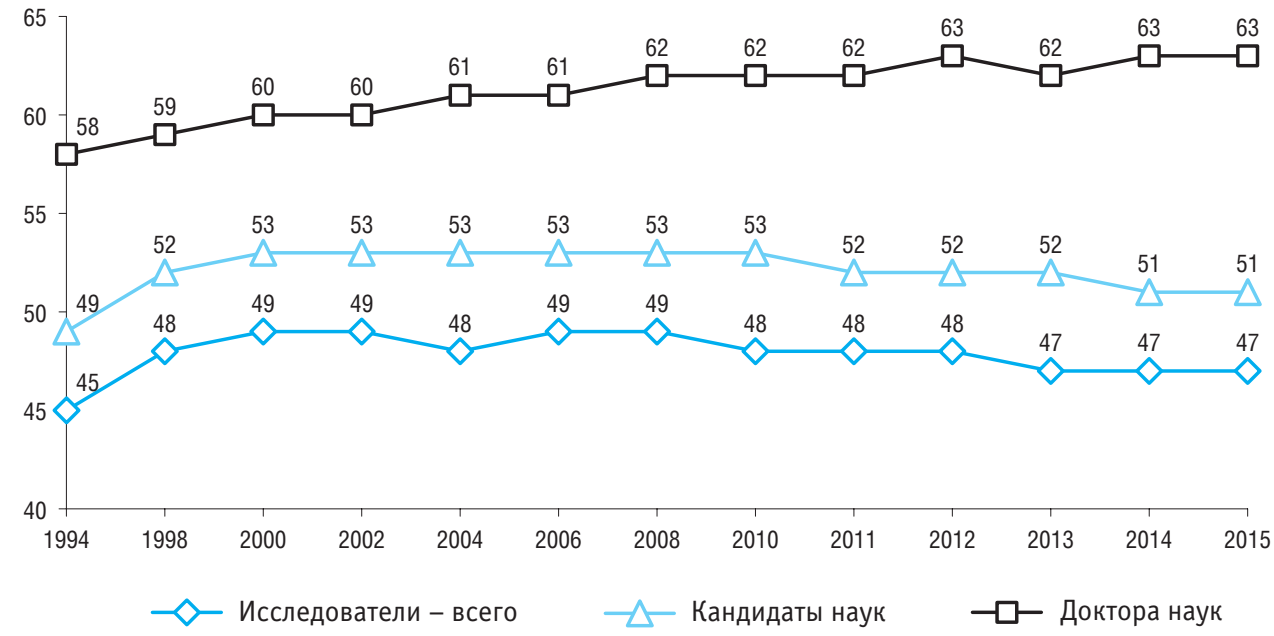




\subsection{1. ИССЛЕДОВАТЕЛИ С УЧЕНЫМИ СТЕПЕНЯМИ}

(человек)

\begin{tabular}{|c|c|c|c|c|c|c|c|c|c|c|c|c|c|}
\hline & 1995 & 2000 & 2004 & 2005 & 2007 & 2008 & 2009 & 2010 & 2011 & 2012 & 2013 & 2014 & 2015 \\
\hline Исследователи с учеными степенями & 116465 & 105911 & 99910 & 99428 & 103725 & 101049 & 101275 & 105114 & 109493 & 109330 & 108248 & 109598 & 111533 \\
\hline Доктора наук & 19330 & 21949 & 23102 & 23410 & 25213 & 25140 & 25295 & 26789 & 27675 & 27784 & 27485 & 27969 & 28046 \\
\hline Кандидаты наук & 97135 & 83962 & 76808 & 76018 & 78512 & 75909 & 75980 & 78325 & 81818 & 81546 & 80763 & 81629 & 83487 \\
\hline
\end{tabular}

\subsection{2. УДЕЛЬНЫЙ ВЕС ИССЛЕДОВАТЕЛЕЙ С УЧЕНЫМИ СТЕПЕНЯМИ В ИХ ОБЩЕЙ ЧИСЛЕННОСТИ}

\section{Проценты}

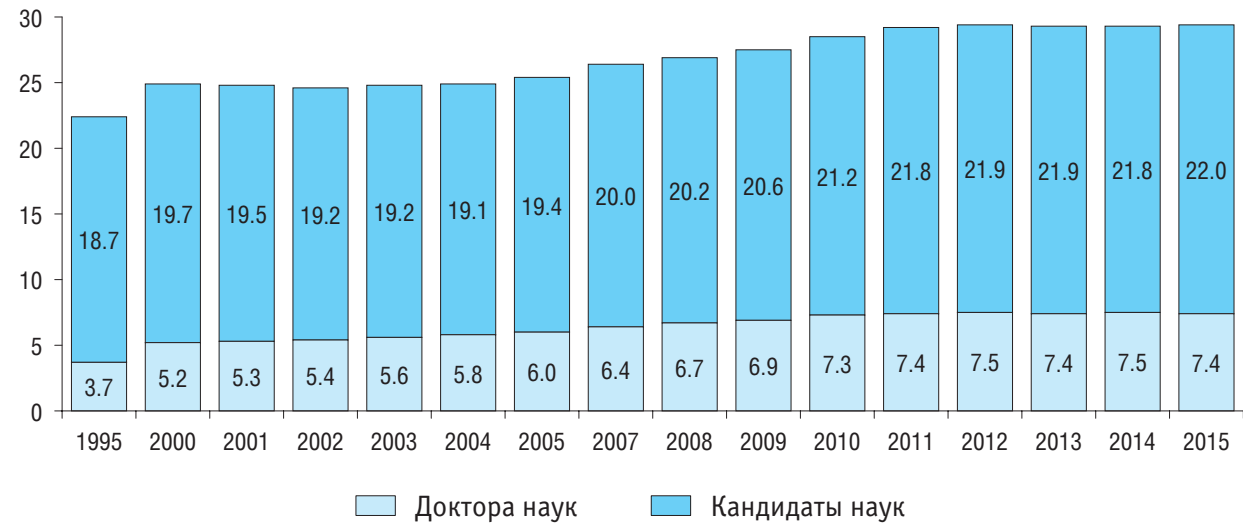




\subsection{3. ИССЛЕДОВАТЕЛИ ПО ОБЛАСТЯМ НАУКИ}

(человек)

\begin{tabular}{|c|c|c|c|c|c|c|c|c|c|c|c|c|c|c|c|}
\hline & \multicolumn{3}{|c|}{2005} & \multicolumn{3}{|c|}{2012} & \multicolumn{3}{|c|}{2013} & \multicolumn{3}{|c|}{2014} & \multicolumn{3}{|c|}{2015} \\
\hline & \multirow{2}{*}{$\begin{array}{c}\text { Исследо- } \\
\text { ватели }\end{array}$} & \multicolumn{2}{|c|}{ Из них } & \multirow{2}{*}{$\begin{array}{c}\text { Исследо- } \\
\text { ватели }\end{array}$} & \multicolumn{2}{|c|}{ Из них } & \multirow{2}{*}{$\begin{array}{c}\text { Исследо- } \\
\text { - ватели }\end{array}$} & \multicolumn{2}{|c|}{ Из них } & \multirow{2}{*}{$\begin{array}{c}\text { Исследо- } \\
\text { ватели }\end{array}$} & \multicolumn{2}{|c|}{ Из них } & \multirow{2}{*}{$\begin{array}{l}\text { Исследо- } \\
\text { ватели }\end{array}$} & \multicolumn{2}{|c|}{ Из них } \\
\hline & & $\begin{array}{c}\text { доктора } \\
\text { наук }\end{array}$ & $\begin{array}{c}\text { кандида- } \\
\text { ты наук }\end{array}$ & & $\begin{array}{c}\text { доктора } \\
\text { наук }\end{array}$ & $\begin{array}{c}\text { кандида- } \\
\text { ты наук }\end{array}$ & & $\begin{array}{c}\text { доктора } \\
\text { наук }\end{array}$ & $\begin{array}{c}\text { кандида- } \\
\text { ты наук }\end{array}$ & & $\begin{array}{c}\text { доктора } \\
\text { наук }\end{array}$ & $\begin{array}{c}\text { кандида- } \\
\text { ты наук }\end{array}$ & & $\begin{array}{c}\text { доктора } \\
\text { наук }\end{array}$ & $\begin{array}{l}\text { кандида- } \\
\text { ты наук }\end{array}$ \\
\hline $\begin{array}{l}\text { Всего } \\
\text { Области науки: }\end{array}$ & 391121 & 23410 & 76018 & 372620 & 27784 & 81546 & 369015 & 27485 & 80763 & 373905 & 27969 & 81629 & 379411 & 28046 & 83487 \\
\hline естественные & 91570 & 10738 & 32969 & 88704 & 12397 & 34068 & 85588 & 12163 & 33266 & 88370 & 12312 & 33943 & 86722 & 12233 & 33725 \\
\hline технические & 249358 & 4495 & 23677 & 225118 & 4757 & 21325 & 225082 & 4777 & 21514 & 226682 & 4874 & 21248 & 231809 & 4928 & 21861 \\
\hline медицинские & 15672 & 3715 & 6791 & 16595 & 4001 & 7200 & 16352 & 4053 & 7363 & 15714 & 3907 & 6961 & 15819 & 3899 & 6808 \\
\hline сельскохозяйственные & 13724 & 1356 & 4922 & 12288 & 1688 & 5038 & 11869 & 1565 & 4707 & 11869 & 1570 & 4763 & 11296 & 1551 & 4592 \\
\hline общественные & 12497 & 1336 & 4158 & 17284 & 2501 & 7941 & 18384 & 2638 & 8435 & 18705 & 2875 & 8775 & 20874 & 2951 & 10357 \\
\hline гуманитарные & 8300 & 1770 & 3501 & 12631 & 2440 & 5974 & 11740 & 2289 & 5478 & 12565 & 2431 & 5939 & 12891 & 2484 & 6144 \\
\hline
\end{tabular}

\subsection{4. РАСПРЕДЕЛЕНИЕ ИССЛЕДОВАТЕЛЕЙ ПО ОБЛАСТЯМ НАУКИ: 2015}

Проценты

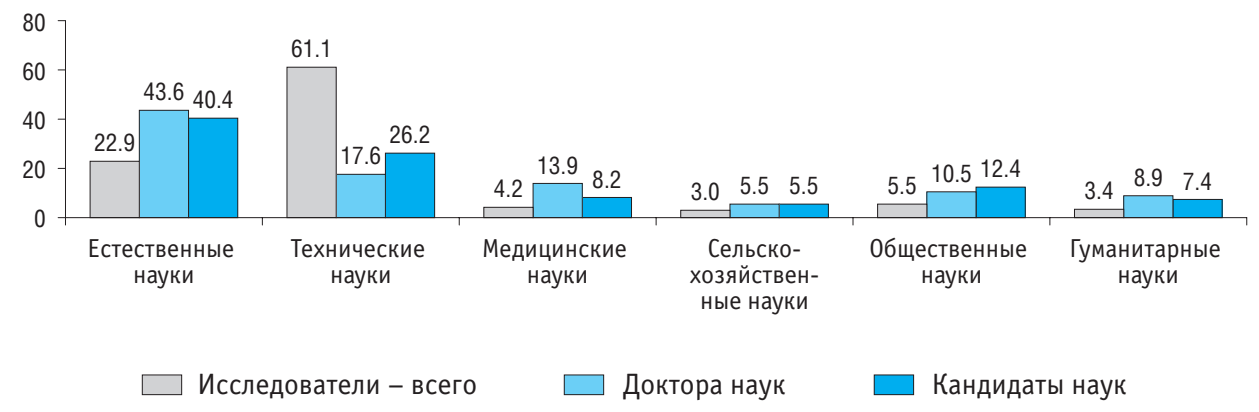




\subsection{5. ДВИЖЕНИЕ ПЕРСОНАЛА, ЗАНЯТОГО ИССЛЕДОВАНИЯМИ И РАЗРАБОТКАМИ}

(человек)

\begin{tabular}{|c|c|c|c|c|c|c|c|c|c|c|}
\hline & \multirow{3}{*}{$\begin{array}{c}\text { Наличие } \\
\text { на начало } \\
\text { отчетного } \\
\text { года }\end{array}$} & \multicolumn{4}{|c|}{ Принято } & \multicolumn{4}{|c|}{ Выбыло } & \multirow{3}{*}{$\begin{array}{c}\text { Наличие } \\
\text { на конец } \\
\text { отчетного } \\
\text { года }\end{array}$} \\
\hline & & \multirow[t]{2}{*}{ Всего } & \multicolumn{3}{|c|}{ В том числе } & \multirow[t]{2}{*}{ Всего } & \multicolumn{3}{|c|}{ В том числе } & \\
\hline & & & $\begin{array}{c}\text { после } \\
\text { окончания } \\
\text { вуза }\end{array}$ & $\left|\begin{array}{c}\text { из других } \\
\text { научных } \\
\text { организаций }\end{array}\right|$ & прочие & & $\begin{array}{l}\text { по соб- } \\
\text { ственному } \\
\text { желанию }\end{array}$ & $\begin{array}{c}\text { в связи } \\
\text { с сокраще- } \\
\text { нием штатов }\end{array}$ & $\begin{array}{c}\text { по прочим } \\
\text { причинам }\end{array}$ & \\
\hline 1995 & 1179294 & 108335 & 6498 & 23402 & 78435 & 226585 & 141776 & 29747 & 55062 & 1061044 \\
\hline 2001 & 890718 & 132757 & 14122 & 21549 & 97086 & 137932 & 93587 & 3542 & 40803 & 885568 \\
\hline 2003 & 867456 & 120298 & 13777 & 20702 & 85819 & 129284 & 89513 & 5917 & 33854 & 858470 \\
\hline 2005 & 826007 & 109973 & 13495 & 15618 & 80860 & 122773 & 81623 & 6598 & 34552 & 813207 \\
\hline 2007 & 814329 & 105758 & 14150 & 19778 & 71830 & 118952 & 80536 & 4617 & 33799 & 801135 \\
\hline 2009 & 745978 & 93526 & 13235 & 13529 & 66762 & 97071 & 58295 & 5776 & 33000 & 742433 \\
\hline 2011 & 741183 & 94939 & 13725 & 11881 & 69333 & 100849 & 62848 & 2973 & 35028 & 735273 \\
\hline 2013 & 725591 & 94550 & 11075 & 13210 & 70265 & 93112 & 59214 & 2015 & 31883 & 727029 \\
\hline 2015 & 737210 & 100290 & 11662 & 14026 & 74602 & 98643 & 58285 & 4238 & 36120 & 738857 \\
\hline
\end{tabular}




\subsection{6. ПРИЕМ ВЫПУСКНИКОВ ОБРАЗОВАТЕЛЬНЫХ ОРГАНИЗАЦИЙ ВЫСШЕГО ОБРАЗОВАНИЯ НА РАБОТУ В ОРГАНИЗАЦИИ, ВЫПОЛНЯВШИЕ ИССЛЕДОВАНИЯ И РАЗРАБОТКИ}

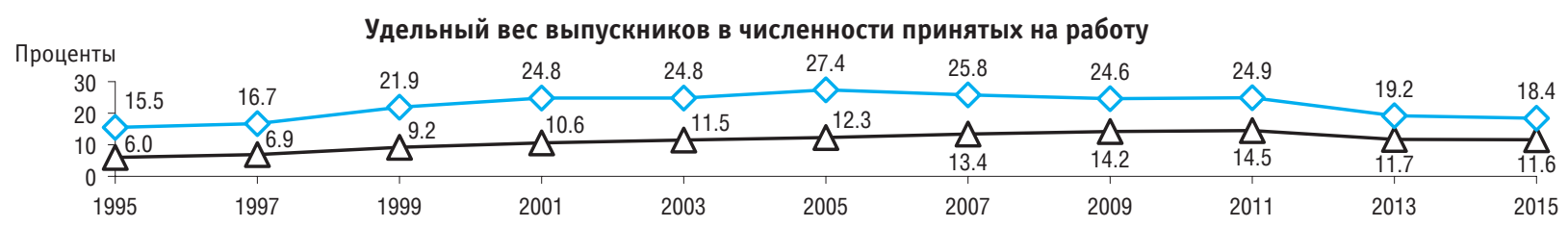

Удельный вес выпускников в численности персонала,

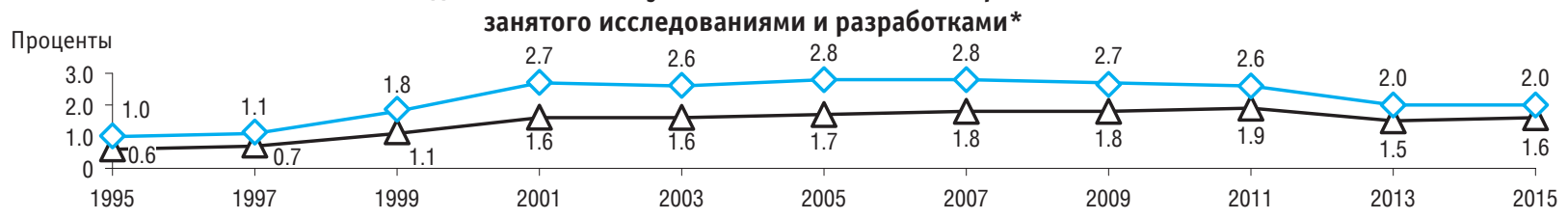

Удельный вес выпускников, принятых на работу в организации, выполнявшие исследования и разработки, в общей численности выпускников образовательных организаций высшего образования * *

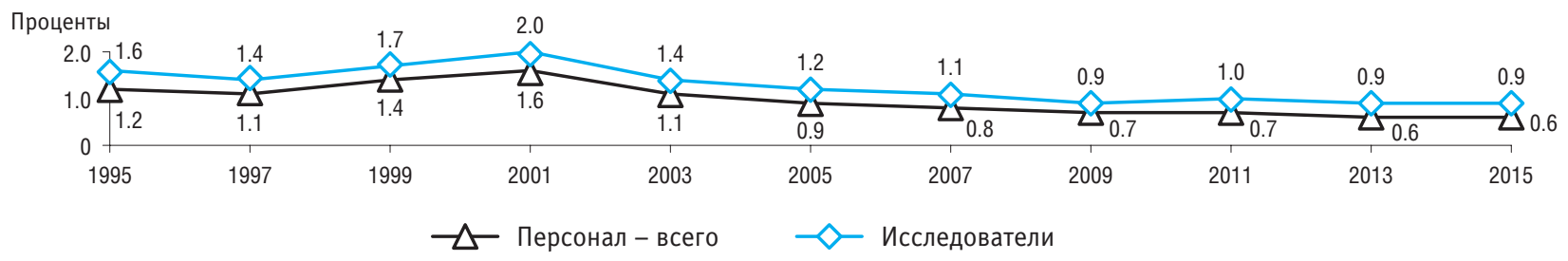

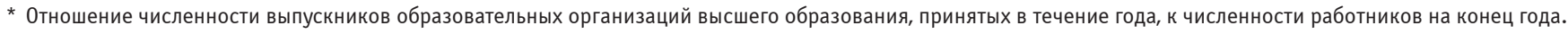

** Включая частные. 


\subsection{7. ПОКАЗАТЕЛИ ОБОРОТА ПЕРСОНАЛА, ЗАНЯТОГО ИССЛЕДОВАНИЯМИ И РАЗРАБОТКАМИ}

\begin{tabular}{|c|c|c|c|c|c|c|c|c|}
\hline & 1995 & 2001 & 2005 & 2007 & 2009 & 2011 & 2013 & 2015 \\
\hline Коэффициент оборота персонала, занятого & & & & & & & & \\
\hline исследованиями и разработками, по приему* & 0.099 & 0.152 & 0.138 & 0.135 & 0.131 & 0.135 & 0.138 & 0.144 \\
\hline $\begin{array}{l}\text { Коэффициент оборота персонала, занятого } \\
\text { исследованиями и разработками, по выбытию* }\end{array}$ & 0.207 & 0.158 & 0.154 & 0.152 & 0.136 & 0.144 & 0.136 & 0.142 \\
\hline $\begin{array}{l}\text { Коэффициент замещения рабочей силы } \\
\text { (восполнения работников)*** }\end{array}$ & 0.478 & 0.962 & 0.896 & 0.889 & 0.963 & 0.941 & 1.015 & 1.017 \\
\hline
\end{tabular}

* Отношение численности лиц, принятых в течение года на работу в организацию, к среднесписочной численности работников.

** Отношение численности лиц, выбывших в течение года из организации, к среднесписочной численности работников.

*** Отношение численности лиц, принятых в течение года на работу в организацию, к численности лиц, выбывших из организации за этот же период. 


\section{Подготовка научных кадров}

\subsection{8. ОСНОВНЫЕ ПОКАЗАТЕЛИ ДЕЯТЕЛЬНОСТИ АСПИРАНТУРЫ}

\begin{tabular}{|c|c|c|c|c|c|}
\hline & $\begin{array}{c}\text { Число организаций } \\
\text { (на конец года) }\end{array}$ & $\begin{array}{c}\text { Численность аспирантов, } \\
\text { чел. (на конец года) }\end{array}$ & $\begin{array}{c}\text { Прием } \\
\text { в аспирантуру, чел. }\end{array}$ & $\begin{array}{c}\text { Выпуск } \\
\text { из аспирантуры, чел. }\end{array}$ & $\begin{array}{c}\text { Из него } \\
\text { с защитой диссертации, чел. }\end{array}$ \\
\hline \multicolumn{6}{|c|}{ Всего } \\
\hline 1995 & 1334 & 62317 & 24025 & 11369 & 2609 \\
\hline 2000 & 1362 & 117714 & 43100 & 24828 & 7503 \\
\hline 2001 & 1393 & 128420 & 45241 & 25696 & 6172 \\
\hline 2002 & 1416 & 136242 & 46935 & 28101 & 7411 \\
\hline 2003 & 1441 & 140741 & 47803 & 30799 & 8378 \\
\hline 2004 & 1452 & 142662 & 47687 & 32595 & 10256 \\
\hline 2005 & 1473 & 142899 & 46896 & 33561 & 10650 \\
\hline 2006 & 1493 & 146111 & 50462 & 35530 & 11893 \\
\hline 2007 & 1490 & 147719 & 51633 & 35747 & 10970 \\
\hline 2008 & 1529 & 147674 & 49638 & 33670 & 8831 \\
\hline 2009 & 1547 & 154470 & 55540 & 34235 & 10770 \\
\hline 2010 & 1568 & 157437 & 54558 & 33763 & 9611 \\
\hline 2011 & 1570 & 156279 & 50582 & 33082 & 9635 \\
\hline 2012 & 1575 & 146754 & 45556 & 35162 & 9195 \\
\hline 2013 & 1557 & 132002 & 38971 & 34733 & 8979 \\
\hline 2014 & 1519 & 119868 & 32981 & 28273 & 5189 \\
\hline 2015 & 1446 & 109936 & 31647 & 25826 & 4651 \\
\hline
\end{tabular}


(продолжение)

\begin{tabular}{|c|c|c|c|c|c|}
\hline & $\begin{array}{c}\text { Число организаций } \\
\text { (на конец года) }\end{array}$ & $\begin{array}{c}\text { Численность аспирантов, } \\
\text { чел. (на конец года) }\end{array}$ & $\begin{array}{c}\text { Прием } \\
\text { в аспирантуру, чел. }\end{array}$ & $\begin{array}{c}\text { Выпуск } \\
\text { из аспирантуры, чел. }\end{array}$ & $\begin{array}{c}\text { Из него } \\
\text { с защитой диссертации, чел. }\end{array}$ \\
\hline \multicolumn{6}{|c|}{ Научно-исследовательские институты } \\
\hline 1995 & 828 & 11488 & 4024 & 2814 & 596 \\
\hline 2000 & 797 & 17502 & 6075 & 3813 & 873 \\
\hline 2001 & 806 & 17784 & 6092 & 3859 & 685 \\
\hline 2002 & 818 & 18323 & 6026 & 4205 & 851 \\
\hline 2003 & 827 & 18959 & 6335 & 4336 & 841 \\
\hline 2004 & 831 & 19654 & 6620 & 4656 & 1002 \\
\hline 2005 & 833 & 19986 & 6577 & 4806 & 1009 \\
\hline 2006 & 820 & 19542 & 6330 & 4865 & 852 \\
\hline 2007 & 799 & 18346 & 6072 & 4847 & 895 \\
\hline 2008 & 811 & 17397 & 5381 & 4781 & 715 \\
\hline 2009 & 800 & 16549 & 5549 & 4359 & 734 \\
\hline 2010 & 809 & 16936 & 5655 & 4335 & 729 \\
\hline 2011 & 805 & 15865 & 4784 & 4028 & 693 \\
\hline 2012 & 820 & 14823 & 4555 & 4101 & 655 \\
\hline 2013 & 818 & 13593 & 4166 & 3943 & 674 \\
\hline 2014 & 805 & 12175 & 3126 & 3331 & 397 \\
\hline 2015 & 771 & 11528 & 3189 & 2728 & 313 \\
\hline
\end{tabular}


(окончание)

\begin{tabular}{|c|c|c|c|c|c|}
\hline & $\begin{array}{c}\text { Число организаций } \\
\text { (на конец года) }\end{array}$ & $\begin{array}{c}\text { Численность аспирантов, } \\
\text { чел. (на конец года) }\end{array}$ & $\begin{array}{c}\text { Прием } \\
\text { в аспирантуру, чел. }\end{array}$ & $\begin{array}{c}\text { Выпуск } \\
\text { из аспирантуры, чел. }\end{array}$ & $\begin{array}{c}\text { Из него } \\
\text { с защитой диссертации, чел. }\end{array}$ \\
\hline \multicolumn{6}{|c|}{ Образовательные организации высшего образования } \\
\hline 1995 & 506 & 50829 & 20001 & 8555 & 2013 \\
\hline 2000 & 565 & 100212 & 37025 & 21015 & 6630 \\
\hline 2001 & 587 & 110636 & 39149 & 21837 & 5487 \\
\hline 2002 & 598 & 117919 & 40909 & 23896 & 6560 \\
\hline 2003 & 614 & 121782 & 41468 & 26463 & 7537 \\
\hline 2004 & 621 & 123008 & 41067 & 27939 & 9254 \\
\hline 2005 & 640 & 122913 & 40319 & 28755 & 9641 \\
\hline 2006 & 673 & 126569 & 44132 & 30665 & 11041 \\
\hline 2007 & 691 & 129373 & 45561 & 30900 & 10075 \\
\hline 2008 & 718 & 130277 & 44257 & 28889 & 8116 \\
\hline 2009 & 730 & 137068 & 49736 & 29678 & 9996 \\
\hline 2010 & 748 & 139908 & 48748 & 29268 & 8854 \\
\hline 2011 & 750 & 139542 & 45561 & 28847 & 8869 \\
\hline 2012 & 740 & 131226 & 40802 & 30885 & 8480 \\
\hline 2013 & 724 & 117790 & 34643 & 30639 & 8257 \\
\hline 2014 & 698 & 107083 & 29700 & 24836 & 4770 \\
\hline 2015 & 661 & 97847 & 28285 & 22971 & 4318 \\
\hline \multicolumn{6}{|c|}{ Организации дополнительного профессионального образования } \\
\hline 2009 & 17 & 853 & 255 & 198 & 40 \\
\hline 2010 & 11 & 593 & 155 & 160 & 28 \\
\hline 2011 & 15 & 872 & 237 & 207 & 73 \\
\hline 2012 & 15 & 705 & 199 & 176 & 60 \\
\hline 2013 & 15 & 619 & 162 & 151 & 48 \\
\hline 2014 & 16 & 610 & 155 & 106 & 22 \\
\hline 2015 & 14 & 561 & 173 & 127 & 20 \\
\hline
\end{tabular}




\subsection{9. ПРИЕМ В АСПИРАНТУРУ ЛИЦ, ОКОНЧИВШИХ ОБРАЗОВАТЕЛЬНЫЕ ОРГАНИЗАЦИИ ВЫСШЕГО ОБРАЗОВАНИЯ \\ В ОТЧЕТНОМ ГОДУ, ПО ФОРМАМ ОБУЧЕНИЯ \\ (человек)}

\begin{tabular}{|c|c|c|c|c|c|c|c|c|c|c|c|c|c|}
\hline & 1995 & 2000 & 2005 & 2006 & 2007 & 2008 & 2009 & 2010 & 2011 & 2012 & 2013 & 2014 & 2015 \\
\hline Всего & 13673 & 26926 & 31211 & 32232 & 33341 & 31756 & 35855 & 37528 & 34326 & 28411 & 23736 & 21720 & 20585 \\
\hline \multicolumn{14}{|l|}{ Принято на обучение: } \\
\hline по очной форме & 11215 & 22076 & 25535 & 26022 & 27210 & 24827 & 28487 & 28507 & 24754 & 21528 & 19432 & 18180 & 17544 \\
\hline по заочной форме & 2458 & 4850 & 5676 & 6210 & 6131 & 6929 & 7368 & 9021 & 9572 & 6883 & 4304 & 3540 & 3041 \\
\hline Научно-исследовательские институты & 1777 & 3370 & 4328 & 4124 & 3918 & 3391 & 3595 & 3569 & 2933 & 2718 & 2326 & 1965 & 2005 \\
\hline \multicolumn{14}{|l|}{ Принято на обучение: } \\
\hline по очной форме & 1340 & 2677 & 3439 & 3262 & 3167 & 2723 & 2896 & 2877 & 2379 & 2226 & 1852 & 1652 & 1772 \\
\hline по заочной форме & 437 & 693 & 889 & 862 & 751 & 668 & 699 & 692 & 554 & 492 & 474 & 313 & 233 \\
\hline $\begin{array}{l}\text { Образовательные организации } \\
\text { высшего образования }\end{array}$ & 11896 & 23556 & 26883 & 28108 & 29423 & 28365 & 32223 & 33955 & 31356 & 25671 & 21398 & 19746 & 18572 \\
\hline \multicolumn{14}{|l|}{ Принято на обучение: } \\
\hline по очной форме & 9875 & 19399 & 22096 & 22760 & 24043 & 22104 & 25564 & 25628 & 22347 & 19298 & 17578 & 16525 & 15770 \\
\hline по заочной форме & 2021 & 4157 & 4787 & 5348 & 5380 & 6261 & 6659 & 8327 & 9009 & 6373 & 3820 & 3221 & 2802 \\
\hline $\begin{array}{l}\text { Организации дополнительного } \\
\text { профессионального образования }\end{array}$ & - & - & - & - & - & - & 37 & 4 & 37 & 22 & 12 & 9 & 8 \\
\hline \multicolumn{14}{|l|}{ Принято на обучение: } \\
\hline по очной форме & - & - & - & - & - & - & 27 & 2 & 28 & 4 & 2 & 3 & 2 \\
\hline по заочной форме & - & - & - & - & - & - & 10 & 2 & 9 & 18 & 10 & 6 & 6 \\
\hline
\end{tabular}




\subsection{0. УДЕЛЬНЫЙ ВЕС ЛИЦ, ОКОНЧИВШИХ ОБРАЗОВАТЕЛЬНЫЕ ОРГАНИЗАЦИИ ВЫСШЕГО ОБРАЗОВАНИЯ} В ОТЧЕТНОМ ГОДУ, В ОБЩЕМ ПРИЕМЕ АСПИРАНТОВ*

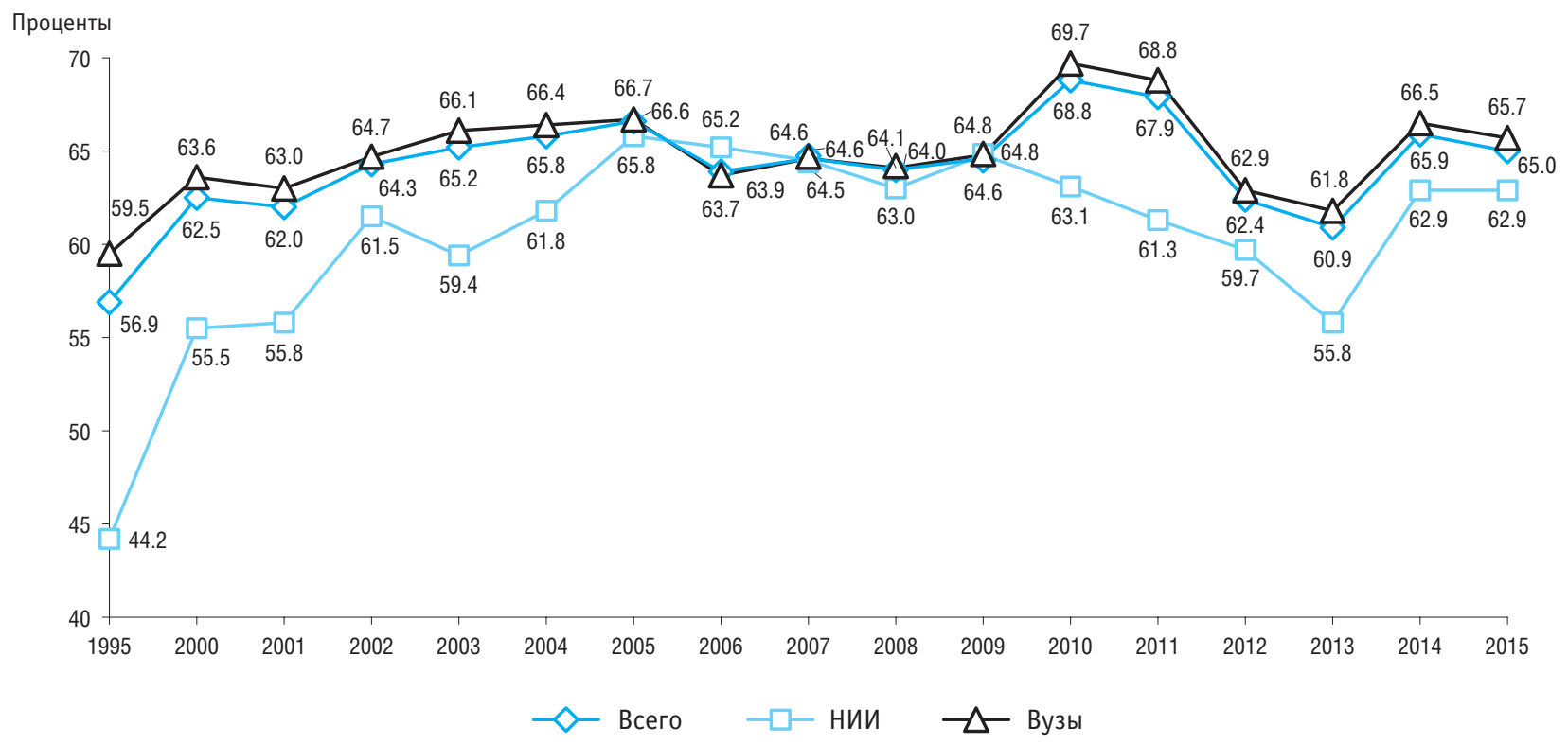

* Организации дополнительного профессионального образования: 2009 г. - 14.5\%, 2010 г. - 2.6\%, 2011 г. - 15.6\%, 2012 г. - $11.1 \%, 2013$ г. - $7.4 \%$, 2014 г. - 5.8\%, 2015 г. $-4.6 \%$. 
2.21. ЧИСЛЕННОСТЬ АСПИРАНТОВ ПО ПОЛУ И ВОЗРАСТНЫМ ГРУППАМ: 2015

(на конец года)

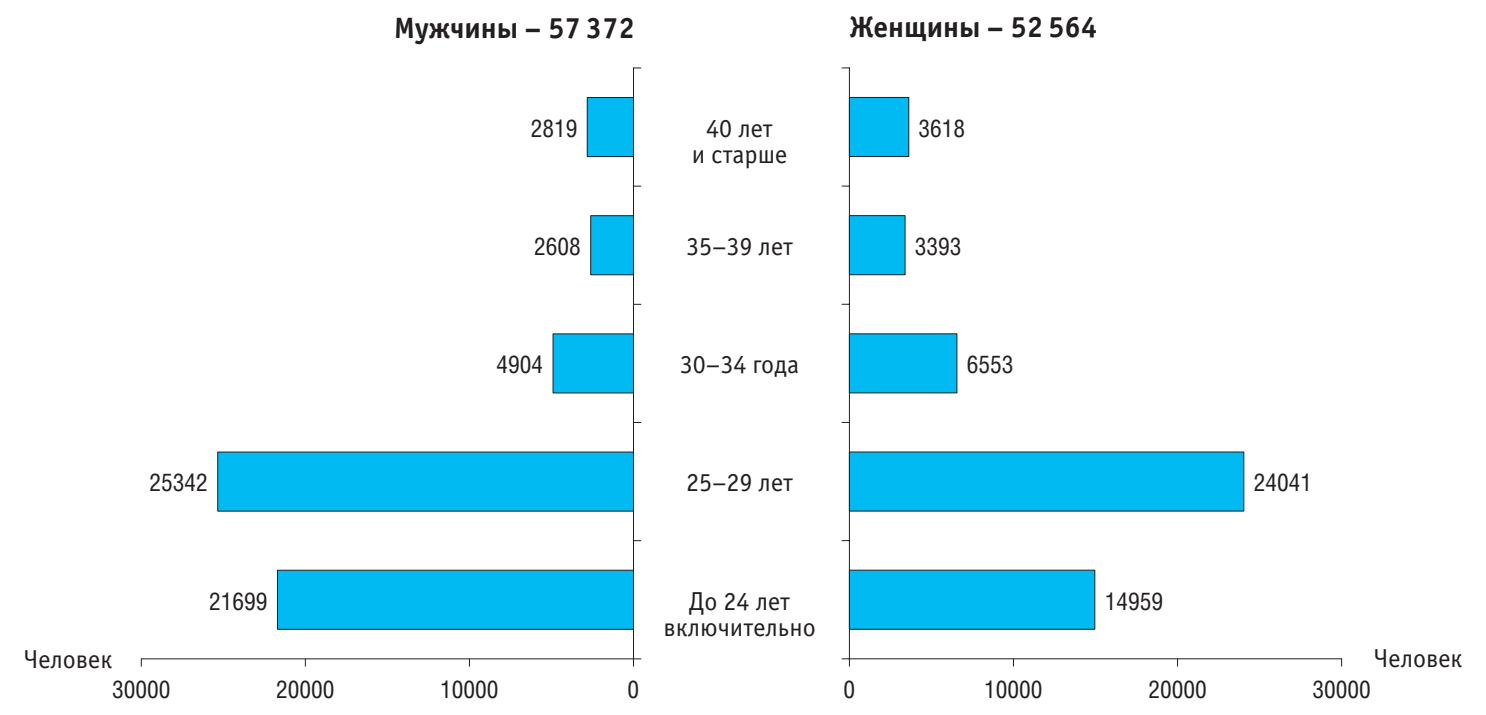




\subsection{2. ПРИЕМ В АСПИРАНТУРУ И ЧИСЛЕННОСТЬ АСПИРАНТОВ ПО НАПРАВЛЕНИЯМ ПОДГОТОВКИ} (человек)

\begin{tabular}{|c|c|c|c|c|}
\hline & \multicolumn{2}{|c|}{ Численность аспирантов } & \multicolumn{2}{|c|}{ Прием в аспирантуру } \\
\hline & $2014^{*}$ & $2015^{\star}$ & 2014 & 2015 \\
\hline Всего & 32859 & 60449 & 32981 & 31647 \\
\hline \multicolumn{5}{|l|}{ Направления подготовки: } \\
\hline математика и механика & 771 & 1459 & 782 & 752 \\
\hline компьютерные и информационные науки & 119 & 211 & 120 & 148 \\
\hline физика и астрономия & 1288 & 2358 & 1301 & 1214 \\
\hline химия & 856 & 1584 & 861 & 799 \\
\hline науки о земле & 1249 & 2097 & 1271 & 1065 \\
\hline биологические науки & 1276 & 2563 & 1258 & 1352 \\
\hline архитектура & 180 & 323 & 184 & 158 \\
\hline техника и технологии строительства & 721 & 1239 & 726 & 663 \\
\hline информатика и вычислительная техника & 2655 & 4802 & 2667 & 2556 \\
\hline информационная безопасность & 142 & 307 & 143 & 158 \\
\hline электроника, радиотехника и системы связи & 567 & 1115 & 569 & 558 \\
\hline фотоника, приборостроение, оптические и биотехнические системы и технологии & 287 & 577 & 289 & 300 \\
\hline электро- и теплоэнергетика & 577 & 1065 & 573 & 528 \\
\hline ядерная энергетика и технологии & 98 & 160 & 100 & 88 \\
\hline машиностроение & 722 & 1366 & 726 & 731 \\
\hline физико-технические науки и технологии & 29 & 52 & 18 & 32 \\
\hline оружие и системы вооружения & - & 4 & - & 3 \\
\hline химические технологии & 370 & 743 & 368 & 399 \\
\hline промышленная экология и биотехнологии & 349 & 562 & 348 & 262 \\
\hline техносферная безопасность и природообустройство & 162 & 270 & 160 & 130 \\
\hline прикладная геология, горное дело, нефтегазовое дело и геодезия & 335 & 601 & 337 & 310 \\
\hline технологии материалов & 286 & 558 & 289 & 289 \\
\hline техника и технологии наземного транспорта & 245 & 436 & 243 & 232 \\
\hline авиационная и ракетно-космическая техника & 236 & 471 & 237 & 247 \\
\hline
\end{tabular}


(окончание)

\begin{tabular}{|c|c|c|c|c|}
\hline & \multicolumn{2}{|c|}{ Численность аспирантов } & \multicolumn{2}{|c|}{ Прием в аспирантуру } \\
\hline & $2014^{*}$ & $2015^{*}$ & 2014 & 2015 \\
\hline аэронавигация и эксплуатация авиационной и ракетно-космической техники & 34 & 75 & 34 & 43 \\
\hline техника и технологии кораблестроения и водного транспорта & 136 & 268 & 135 & 148 \\
\hline управление в технических системах & 276 & 541 & 278 & 280 \\
\hline нанотехнологии и наноматериалы & 13 & 22 & 13 & 11 \\
\hline технологии легкой промышленности & 80 & 145 & 80 & 74 \\
\hline фундаментальная медицина & 221 & 530 & 220 & 288 \\
\hline клиническая медицина & 1940 & 4124 & 1932 & 2096 \\
\hline науки о здоровье и профилактическая медицина & 201 & 389 & 203 & 205 \\
\hline фармация & 113 & 224 & 114 & 125 \\
\hline сельское, лесное и рыбное хозяйство & 1074 & 1976 & 1067 & 1053 \\
\hline ветеринария и зоотехния & 554 & 979 & 546 & 490 \\
\hline психологические науки & 771 & 1433 & 777 & 804 \\
\hline экономика и управление & 4493 & 7808 & 4543 & 4056 \\
\hline социология и социальная работа & 513 & 931 & 513 & 507 \\
\hline юриспруденция & 2371 & 4040 & 2396 & 2191 \\
\hline политические науки и регионоведение & 580 & 1047 & 583 & 559 \\
\hline средства массовой информации и информационно-библиотечное дело & 142 & 284 & 141 & 151 \\
\hline образование и педагогические науки & 1830 & 3512 & 1852 & 1917 \\
\hline языкознание и литературоведение & 1470 & 2684 & 1468 & 1387 \\
\hline история и археология & 1048 & 1903 & 1046 & 967 \\
\hline философия, этика и религиоведение & 633 & 1156 & 631 & 599 \\
\hline теология & - & 5 & - & 5 \\
\hline физическая культура и спорт & 234 & 390 & 234 & 194 \\
\hline искусствознание & 341 & 613 & 333 & 296 \\
\hline культуроведение и социокультурные проекты & 271 & 447 & 272 & 227 \\
\hline
\end{tabular}

* В соответствии с Федеральным законом от 29.12.2012 № 273-Ф3 «0б образовании в Российской Федерации» прием в аспирантуру с 01.01.2014 осуществляется по направлениям подготовки, утвержденным приказом Министерства образования и науки Российской Федерации от 12.09 .2013 № 1061 «06 утверждении перечней специальностей и направлений подготовки высшего образования». Представлены данные о численности аспирантов: за 2014 г. - первого года обучения; за 2015 г. первого и второго годов обучения. 


\subsection{3. ЧИСЛЕННОСТЬ АСПИРАНТОВ И ВЫПУСК ИЗ АСПИРАНТУРЫ ПО ОТРАСЛЯМ НАУК} (человек)

\begin{tabular}{|c|c|c|c|c|c|c|}
\hline & \multicolumn{2}{|c|}{$\begin{array}{c}\text { Численность аспирантов } \\
\text { (на конец года) }\end{array}$} & \multicolumn{2}{|c|}{$\begin{array}{c}\text { Выпуск } \\
\text { из аспирантуры }\end{array}$} & \multicolumn{2}{|c|}{$\begin{array}{c}\text { Из него } \\
\text { с защитой диссертации }\end{array}$} \\
\hline & $2014^{*}$ & $2015^{*}$ & 2014 & 2015 & 2014 & 2015 \\
\hline Всего & 87009 & 49487 & 28273 & 25826 & 5189 & 4651 \\
\hline Физико-математические науки & 4991 & 3299 & 1669 & 1230 & 311 & 272 \\
\hline Химические науки & 2012 & 1346 & 694 & 497 & 158 & 146 \\
\hline Биологические науки & 4563 & 2889 & 1371 & 1235 & 241 & 232 \\
\hline Технические науки * & 23644 & 14011 & 7282 & 6723 & 1246 & 1093 \\
\hline Сельскохозяйственные науки *** & 3039 & 1684 & 1024 & 1006 & 245 & 254 \\
\hline Исторические науки и археология & 2545 & 1362 & 932 & 855 & 143 & 127 \\
\hline Экономические науки & 11945 & 6082 & 4040 & 3839 & 703 & 582 \\
\hline Философские науки & 1592 & 845 & 555 & 492 & 81 & 77 \\
\hline Филологические науки & 3900 & 2212 & 1323 & 1248 & 271 & 272 \\
\hline Юридические науки & 5544 & 2808 & 1737 & 1461 & 226 & 205 \\
\hline Педагогические науки & 5024 & 2762 & 1800 & 1580 & 358 & 286 \\
\hline Медицинские науки **** & 8297 & 4781 & 2429 & 2611 & 761 & 722 \\
\hline Искусствоведение & 927 & 529 & 549 & 304 & 26 & 12 \\
\hline Психологические науки & 1924 & 1040 & 621 & 544 & 103 & 69 \\
\hline Социологические науки & 1396 & 725 & 460 & 423 & 78 & 68 \\
\hline Политология & 1269 & 674 & 393 & 392 & 52 & 48 \\
\hline Науки о Земле $\mathrm{e}^{* * * * *}$ & 3393 & 1883 & 1103 & 1104 & 149 & 154 \\
\hline Прочие науки & 1004 & 555 & 291 & 282 & 37 & 32 \\
\hline
\end{tabular}

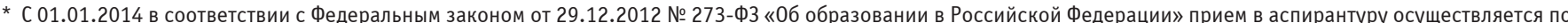

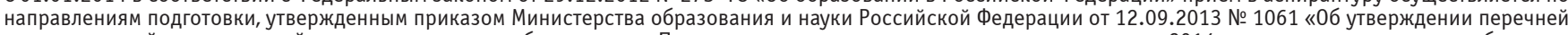

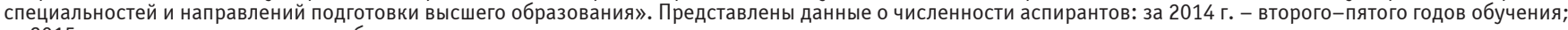
за 2015 г. - третьего-пятого годов обучения.

** Включая архитектуру.

*** Включая ветеринарные науки.

**** Включая фармацевтические науки.

***** Включая геолого-минералогические и географические науки. 


\subsection{4. ОСНОВНЫЕ ПОКАЗАТЕЛИ ДЕЯТЕЛЬНОСТИ ДОКТОРАНТУРЫ}

\begin{tabular}{|c|c|c|c|c|c|}
\hline & $\begin{array}{c}\text { Число организаций } \\
\text { (на конец года) }\end{array}$ & $\begin{array}{c}\text { Численность докторантов, } \\
\text { чел. (на конец года) }\end{array}$ & $\begin{array}{c}\text { Прием } \\
\text { в докторантуру, чел. }\end{array}$ & $\begin{array}{c}\text { Выпуск } \\
\text { из докторантуры, чел. }\end{array}$ & $\begin{array}{l}\text { Из него с защитой } \\
\text { диссертации, чел. }\end{array}$ \\
\hline \multicolumn{6}{|c|}{ Всего } \\
\hline 1995 & 384 & 2190 & 904 & 464 & 137 \\
\hline 1998 & 452 & 3684 & 1473 & 821 & 312 \\
\hline 1999 & 476 & 3993 & 1466 & 1033 & 356 \\
\hline 2000 & 492 & 4213 & 1637 & 1251 & 486 \\
\hline 2001 & 510 & 4462 & 1630 & 1257 & 397 \\
\hline 2002 & 531 & 4546 & 1579 & 1267 & 411 \\
\hline 2003 & 543 & 4567 & 1611 & 1385 & 414 \\
\hline 2004 & 533 & 4466 & 1567 & 1451 & 505 \\
\hline 2005 & 535 & 4282 & 1457 & 1417 & 516 \\
\hline 2006 & 548 & 4189 & 1499 & 1383 & 450 \\
\hline 2007 & 579 & 4109 & 1520 & 1320 & 429 \\
\hline 2008 & 593 & 4242 & 1517 & 1216 & 297 \\
\hline 2009 & 598 & 4294 & 1569 & 1302 & 435 \\
\hline 2010 & 602 & 4418 & 1650 & 1259 & 336 \\
\hline 2011 & 608 & 4562 & 1696 & 1321 & 382 \\
\hline 2012 & 597 & 4554 & 1632 & 1371 & 394 \\
\hline 2013 & 585 & 4572 & 1582 & 1356 & 323 \\
\hline 2014 & 478 & 3204 & 166 & 1359 & 231 \\
\hline 2015 & 437 & 2007 & 419 & 1386 & 181 \\
\hline
\end{tabular}


(продолжение)

\begin{tabular}{|c|c|c|c|c|c|}
\hline & $\begin{array}{l}\text { Число организаций } \\
\text { (на конец года) }\end{array}$ & $\begin{array}{c}\text { Численность докторантов, } \\
\text { чел. (на конец года) }\end{array}$ & $\begin{array}{c}\text { Прием } \\
\text { в докторантуру, чел. }\end{array}$ & $\begin{array}{c}\text { Выпуск } \\
\text { из докторантуры, чел. }\end{array}$ & $\begin{array}{l}\text { Из него с защитой } \\
\text { диссертации, чел. }\end{array}$ \\
\hline \multicolumn{6}{|c|}{ Научно-исследовательские институты } \\
\hline 1995 & 167 & 483 & 197 & 128 & 41 \\
\hline 1998 & 170 & 446 & 161 & 159 & 55 \\
\hline 1999 & 173 & 447 & 182 & 146 & 54 \\
\hline 2000 & 178 & 505 & 192 & 151 & 63 \\
\hline 2001 & 181 & 485 & 183 & 138 & 38 \\
\hline 2002 & 189 & 517 & 194 & 140 & 35 \\
\hline 2003 & 195 & 515 & 184 & 154 & 47 \\
\hline 2004 & 179 & 481 & 156 & 155 & 52 \\
\hline 2005 & 173 & 445 & 147 & 148 & 48 \\
\hline 2006 & 178 & 426 & 142 & 139 & 35 \\
\hline 2007 & 201 & 358 & 118 & 116 & 33 \\
\hline 2008 & 205 & 336 & 111 & 123 & 23 \\
\hline 2009 & 204 & 327 & 114 & 107 & 23 \\
\hline 2010 & 192 & 299 & 100 & 95 & 20 \\
\hline 2011 & 192 & 303 & 106 & 100 & 17 \\
\hline 2012 & 183 & 254 & 87 & 99 & 16 \\
\hline 2013 & 184 & 262 & 110 & 73 & 9 \\
\hline 2014 & 105 & 194 & 23 & 78 & 14 \\
\hline 2015 & 91 & 153 & 46 & 67 & 8 \\
\hline
\end{tabular}


(окончание)

\begin{tabular}{|c|c|c|c|c|c|}
\hline & $\begin{array}{l}\text { Число организаций } \\
\text { (на конец года) }\end{array}$ & $\begin{array}{c}\text { Численность докторантов, } \\
\text { чел. (на конец года) }\end{array}$ & $\begin{array}{c}\text { Прием } \\
\text { в докторантуру, чел. }\end{array}$ & $\begin{array}{c}\text { Выпуск } \\
\text { из докторантуры, чел. }\end{array}$ & $\begin{array}{l}\text { Из него с защитой } \\
\text { диссертации, чел. }\end{array}$ \\
\hline \multicolumn{6}{|c|}{ Образовательные организации высшего образования } \\
\hline 1995 & 217 & 1707 & 707 & 336 & 96 \\
\hline 1998 & 282 & 3238 & 1312 & 662 & 257 \\
\hline 1999 & 303 & 3546 & 1284 & 887 & 302 \\
\hline 2000 & 314 & 3708 & 1445 & 1100 & 423 \\
\hline 2001 & 329 & 3977 & 1447 & 1119 & 359 \\
\hline 2002 & 342 & 4029 & 1385 & 1127 & 376 \\
\hline 2003 & 348 & 4052 & 1427 & 1231 & 367 \\
\hline 2004 & 354 & 3985 & 1411 & 1296 & 453 \\
\hline 2005 & 362 & 3837 & 1310 & 1269 & 468 \\
\hline 2006 & 370 & 3763 & 1357 & 1244 & 415 \\
\hline 2007 & 378 & 3751 & 1402 & 1204 & 396 \\
\hline 2008 & 388 & 3906 & 1406 & 1093 & 274 \\
\hline 2009 & 391 & 3962 & 1454 & 1193 & 412 \\
\hline 2010 & 407 & 4116 & 1548 & 1162 & 316 \\
\hline 2011 & 412 & 4256 & 1589 & 1220 & 365 \\
\hline 2012 & 410 & 4296 & 1543 & 1271 & 378 \\
\hline 2013 & 398 & 4307 & 1471 & 1281 & 314 \\
\hline 2014 & 372 & 3009 & 143 & 1281 & 217 \\
\hline 2015 & 345 & 1853 & 373 & 1319 & 173 \\
\hline \multicolumn{6}{|c|}{ Организации дополнительного профессионального образования } \\
\hline 2009 & 3 & 5 & 1 & 2 & - \\
\hline 2010 & 3 & 3 & 2 & 2 & - \\
\hline 2011 & 4 & 3 & 1 & 1 & - \\
\hline 2012 & 4 & 4 & 2 & 1 & - \\
\hline 2013 & 3 & 3 & 1 & 2 & - \\
\hline 2014 & 1 & 1 & - & - & - \\
\hline 2015 & 1 & 1 & - & - & - \\
\hline
\end{tabular}


2.25. ЧИСЛЕННОСТЬ ДОКТОРАНТОВ ПО ПОЛУ И ВОЗРАСТНЫМ ГРУППАМ: 2015 (на конец года)

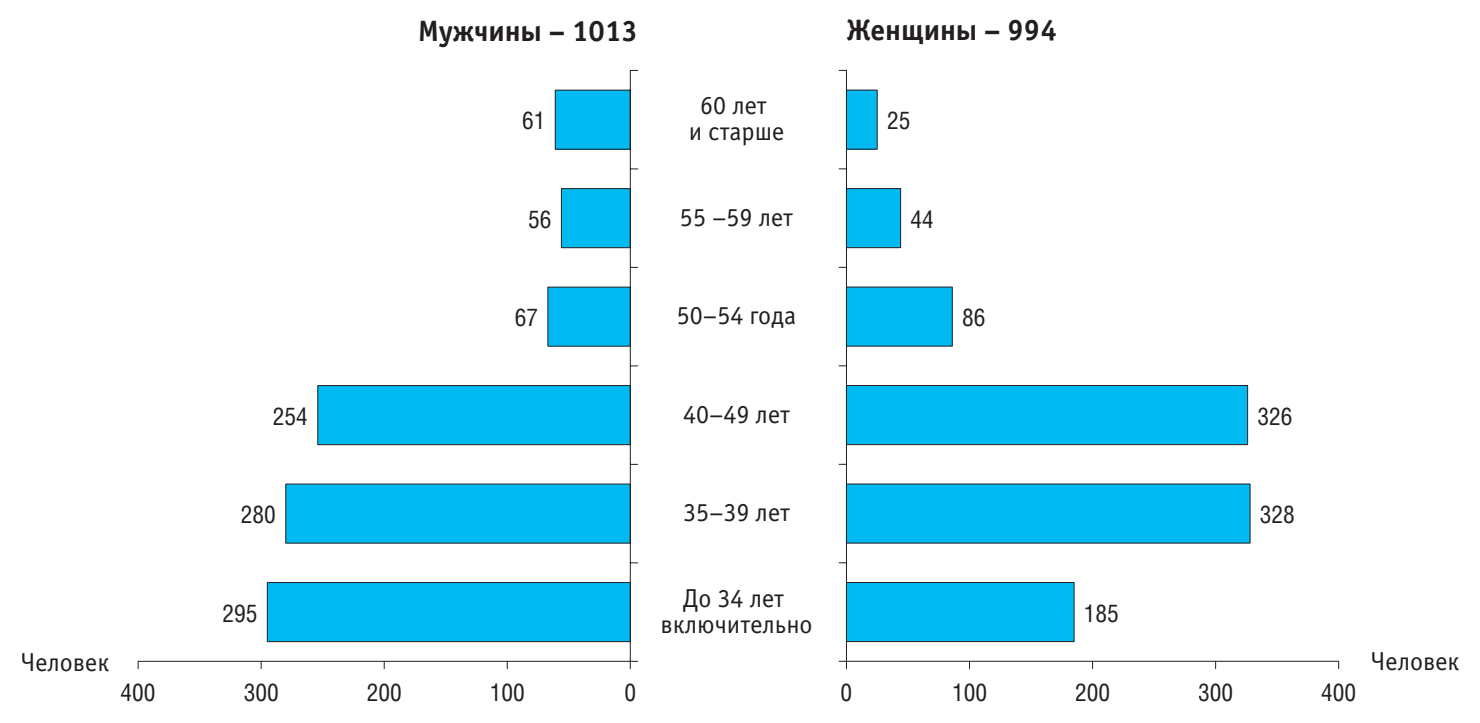


2.26. ЧИСЛЕННОСТЬ, ПРИЕМ ДОКТОРАНТОВ И ВЫПУСК ИЗ ДОКТОРАНТУРЫ ПО ОТРАСЛЯМ НАУК (человек)

\begin{tabular}{|c|c|c|c|c|c|c|c|c|}
\hline & \multicolumn{2}{|c|}{$\begin{array}{c}\text { Численность докторантов } \\
\text { (на конец года) }\end{array}$} & \multicolumn{2}{|c|}{$\begin{array}{c}\text { Прием } \\
\text { в докторантуру }\end{array}$} & \multicolumn{2}{|c|}{$\begin{array}{c}\text { Выпуск } \\
\text { из докторантуры }\end{array}$} & \multicolumn{2}{|c|}{$\begin{array}{c}\text { Из него } \\
\text { с защитой диссертации }\end{array}$} \\
\hline & 2014 & 2015 & 2014 & 2015 & 2014 & 2015 & 2014 & 2015 \\
\hline Bcero & 3204 & 2007 & 166 & 419 & 1359 & 1386 & 231 & 181 \\
\hline Физико-математические науки & 232 & 147 & 12 & 28 & 99 & 105 & 16 & 11 \\
\hline Химические науки & 99 & 61 & 3 & 6 & 41 & 40 & 4 & 4 \\
\hline Биологические науки & 89 & 59 & 6 & 10 & 47 & 35 & 4 & 4 \\
\hline Технические науки * & 868 & 517 & 34 & 99 & 377 & 409 & 62 & 56 \\
\hline Сельскохозяйственные науки * & 78 & 54 & 3 & 5 & 40 & 30 & 8 & 4 \\
\hline Исторические науки и археология & 158 & 101 & 7 & 20 & 66 & 67 & 14 & 11 \\
\hline Экономические науки & 389 & 286 & 36 & 103 & 150 & 158 & 24 & 29 \\
\hline Философские науки & 102 & 58 & 7 & 8 & 55 & 44 & 5 & 5 \\
\hline Филологические науки & 215 & 119 & 11 & 12 & 95 & 95 & 18 & 6 \\
\hline Юридические науки & 82 & 63 & 16 & 28 & 26 & 25 & 2 & 6 \\
\hline Медицинские науки*** & 188 & 99 & 14 & 11 & 89 & 82 & 24 & 14 \\
\hline Искусствоведение & 37 & 25 & 1 & 1 & 9 & 12 & 3 & 1 \\
\hline Психологические науки & 81 & 56 & 1 & 12 & 37 & 35 & 3 & 2 \\
\hline Социологические науки & 75 & 42 & 4 & 4 & 30 & 26 & 6 & 3 \\
\hline Политология & 85 & 33 & 1 & 6 & 11 & 27 & 1 & 2 \\
\hline Науки о Земле **** & 102 & 61 & - & 12 & 40 & 47 & 7 & 4 \\
\hline Прочие науки & 54 & 41 & 2 & 16 & 20 & 22 & 3 & 3 \\
\hline
\end{tabular}

* Включая архитектуру.

** Включая ветеринарные науки.

*** Включая фармацевтические науки.

**** Включая геолого-минералогические и географические науки. 


\subsection{7. УДЕЛЬНЫЙ ВЕС ЛИЦ, ЗАЩИТИВШИХ ДИССЕРТАЦИИ В ПЕРИОД ПОДГОТОВКИ, В ОБЩЕМ ВЫПУСКЕ ИЗ АСПИРАНТУРЫ И ДОКТОРАНТУРЫ ПО ОТРАСЛЯМ НАУК: 2015}

Проценты

\section{Аспирантура}

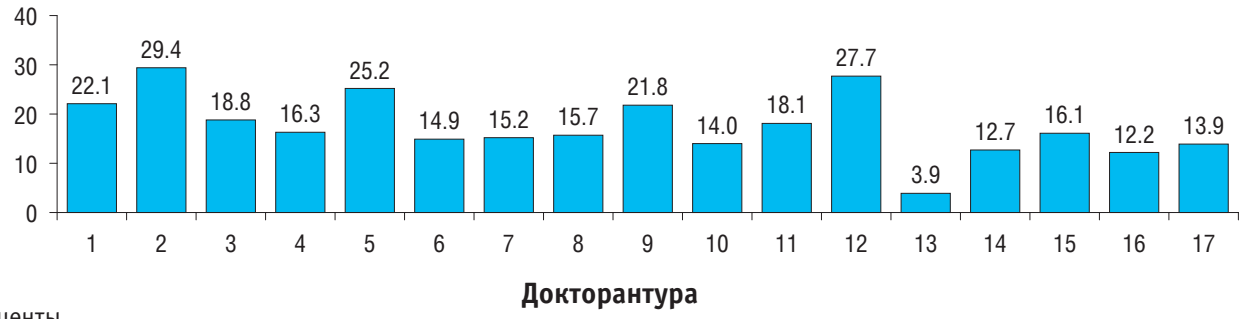

Проценты

Докторантура

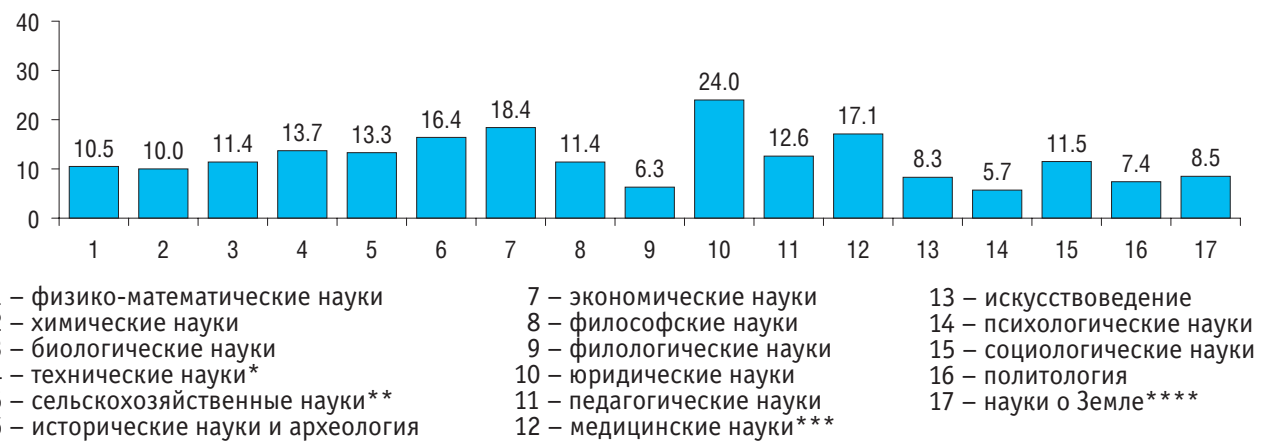

* Включая архитектуру.

** Включая ветеринарные науки.

*** Включая фармацевтические науки.

**** Включая геолого-минералогические и географические науки. 


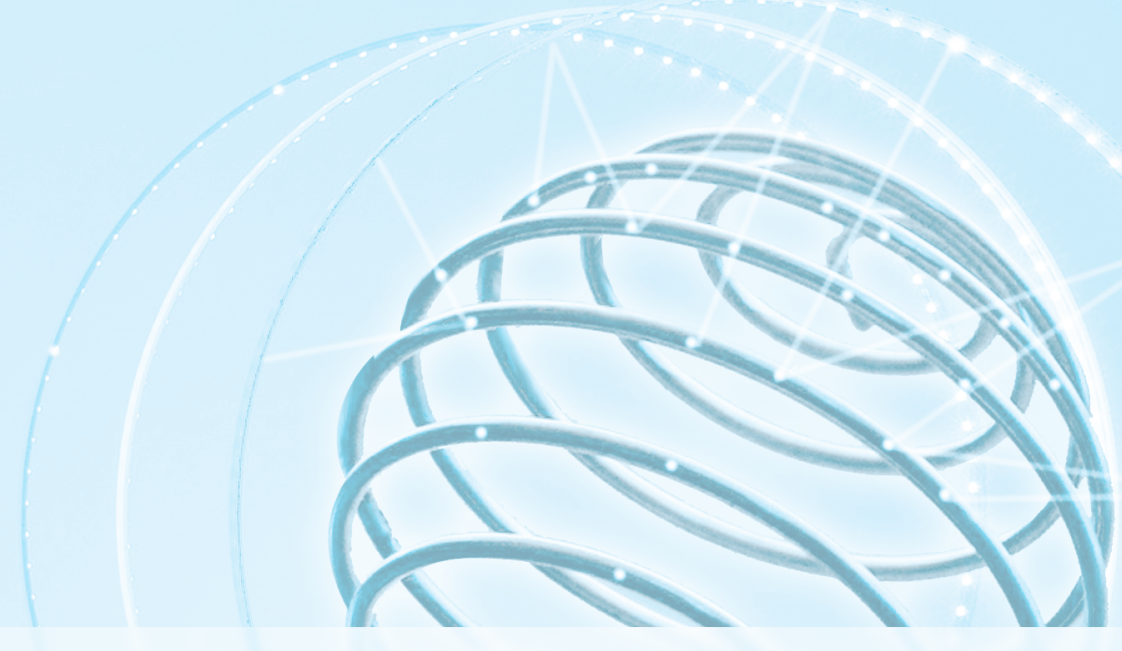

3. Финансирование исследований и разработок 


\section{1. ВНУТРЕННИЕ ЗАТРАТЫ НА ИССЛЕДОВАНИЯ И РАЗРАБОТКИ}

(тысячи рублей, 1995 г. - миллионы рублей)

\begin{tabular}{l|l|l|l|l|l|l|l|l|l|l|l|l}
\hline & 1995 & 2000 & 2005 & 2007 & 2008 & 2009 & 2010 & 2011 & 2012 & 2013 & 2014 & 2015 \\
\hline
\end{tabular}

\section{Внутренние}

затраты

на исследования

и разработки:

в действующих

ценах

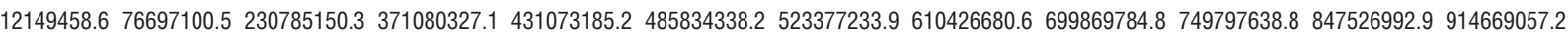

в постоянных

ценах 1989 г.

2485.4

3321.2

4547.5

5577.5

5490.8

6067.0

5723.2

5759.3

6097.2

6232.9

6572.2

6585.7

\section{Внутренние затраты на исследования и разработки}

в процентах к валовому внутреннему продукту

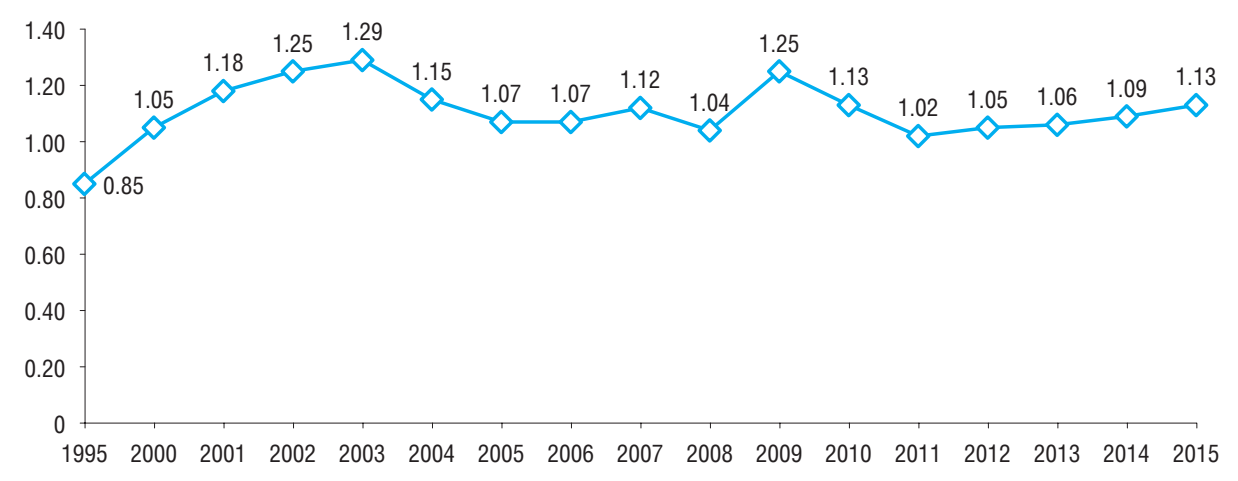




\section{2. ДИНАМИКА ВНУТРЕННИХ ЗАТРАТ НА ИССЛЕДОВАНИЯ И РАЗРАБОТКИ}

(в постоянных ценах 1989 г.)

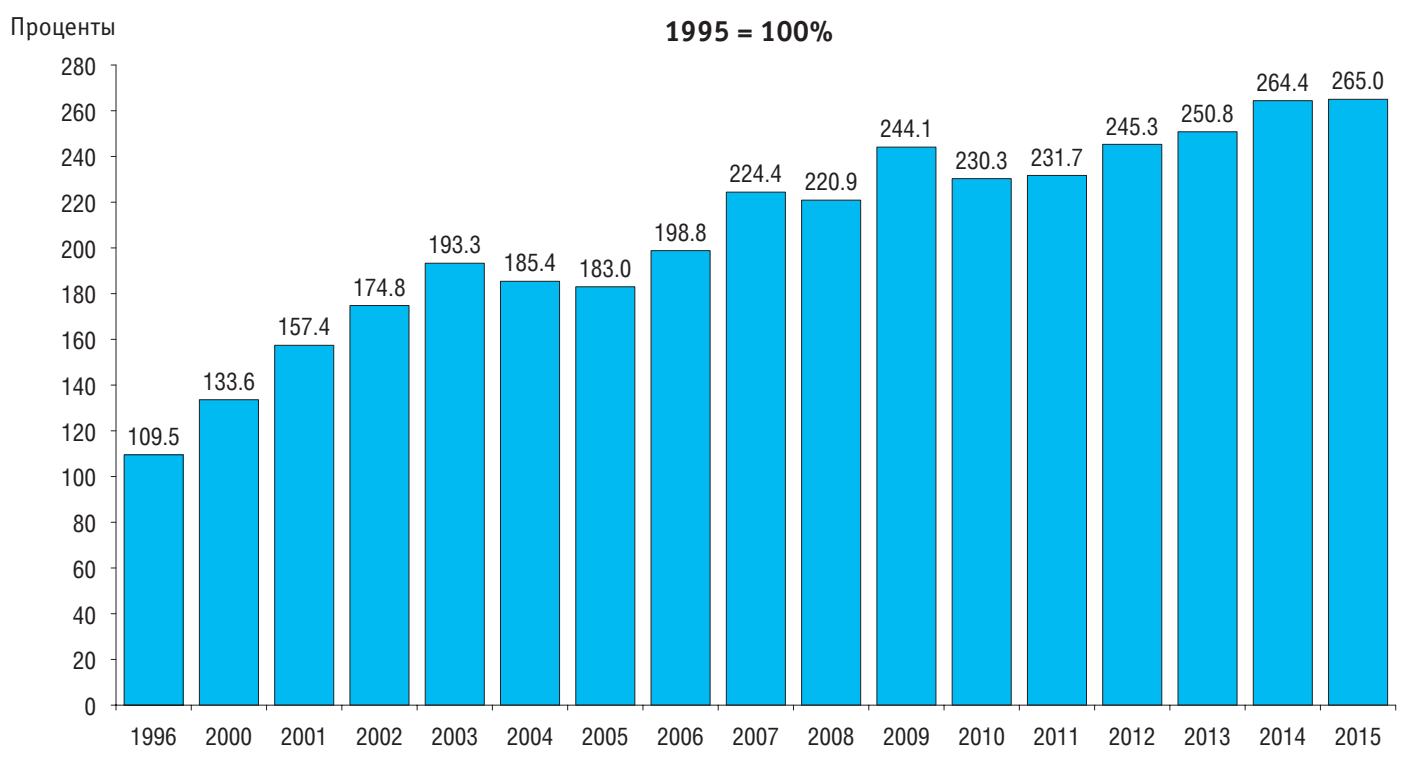




\section{3. АССИГНОВАНИЯ НА ГРАЖДАНСКУЮ НАУКУ ИЗ СРЕДСТВ ФЕДЕРАЛЬНОГО БЮДЖЕТА В ДЕЙСТВУЮЩИХ ЦЕНАХ*}

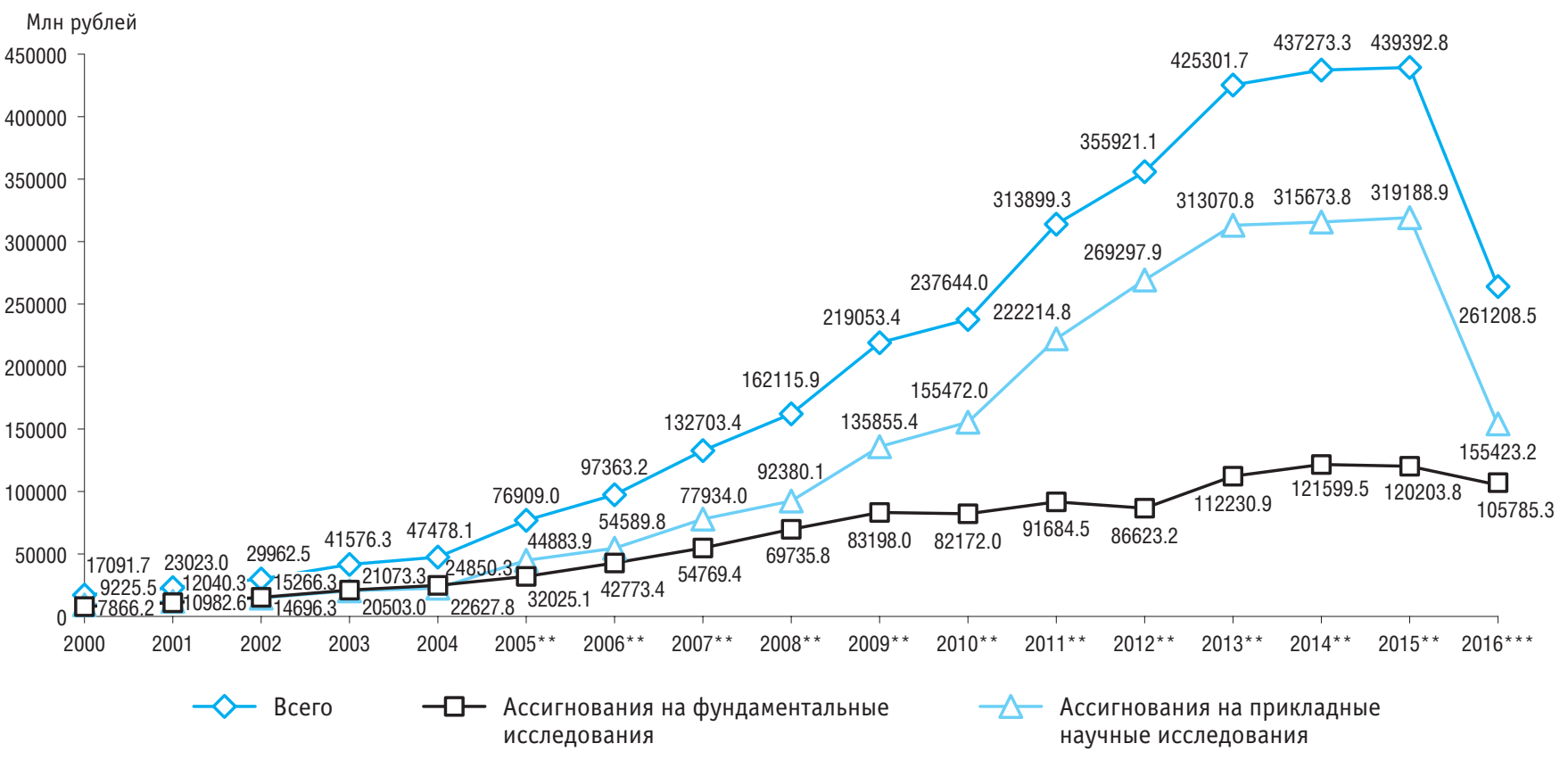

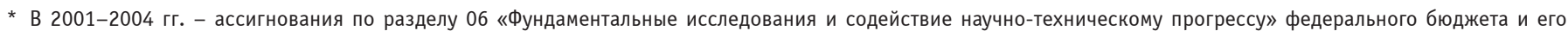
соответствующим подразделам.

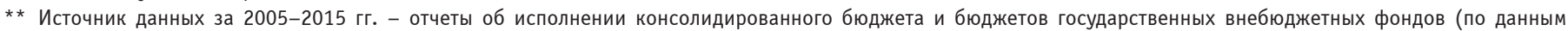
Федерального казначейства).

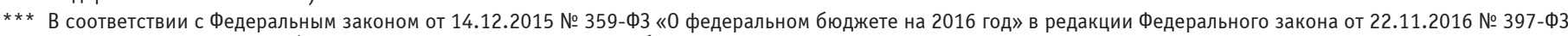
«0 внесении изменений в Федеральный закон «0 федеральном бюджете на 2016 год». 


\section{4. АССИГНОВАНИЯ НА ГРАЖДАНСКУЮ НАУКУ ИЗ СРЕДСТВ ФЕДЕРАЛЬНОГО БЮДЖЕТА В ПОСТОЯННЫХ ЦЕНАХ 1991 Г.*}

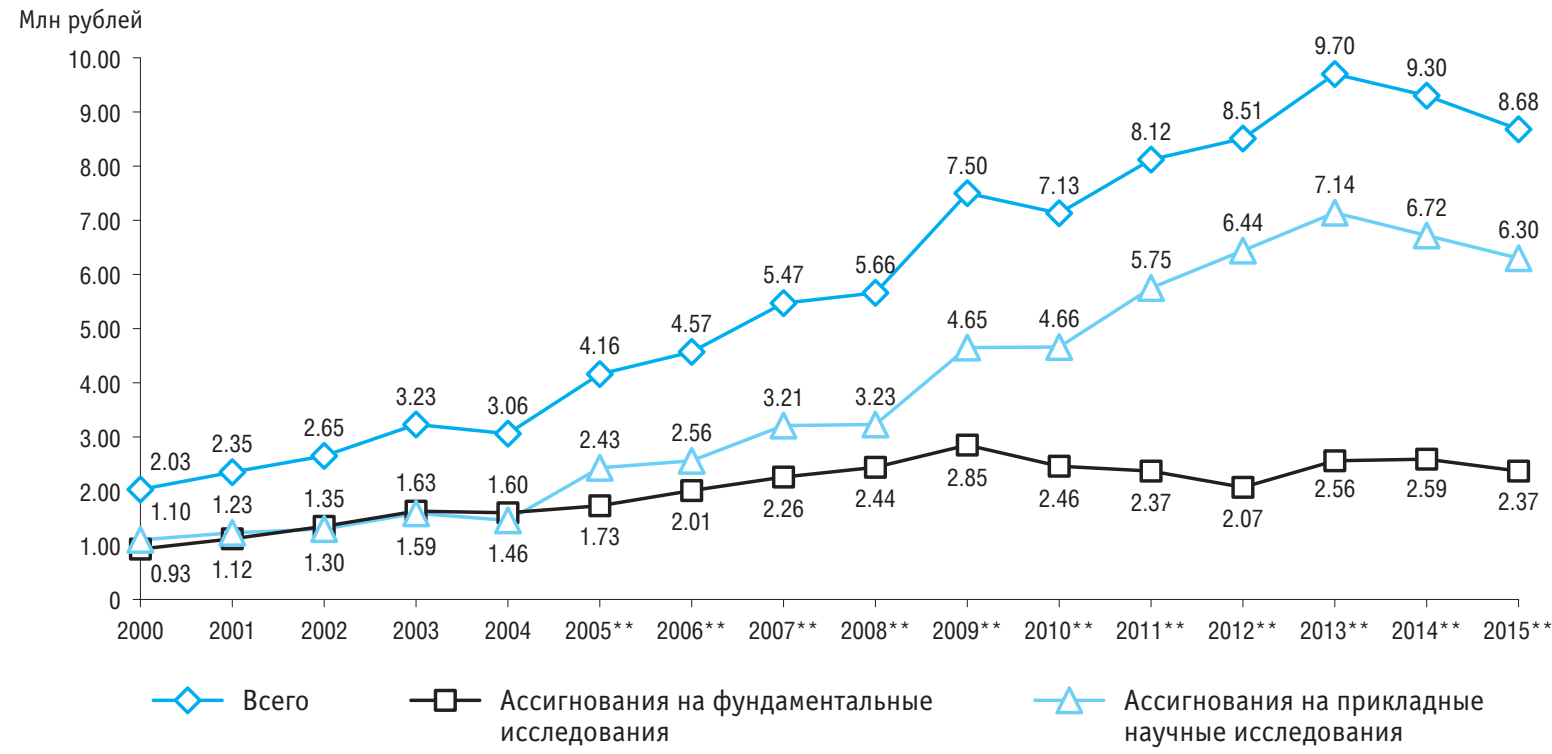

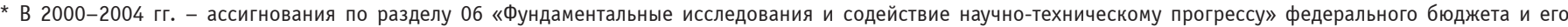
соответствующим подразделам.

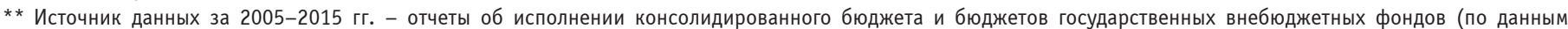
Федерального казначейства). 


\section{5. АССИГНОВАНИЯ НА ГРАЖДАНСКУЮ НАУКУ ИЗ СРЕДСТВ ФЕДЕРАЛЬНОГО БЮДЖЕТА В ПРОЦЕНТАХ К ВАЛОВОМУ ВНУТРЕННЕМУ ПРОДУКТУ*}

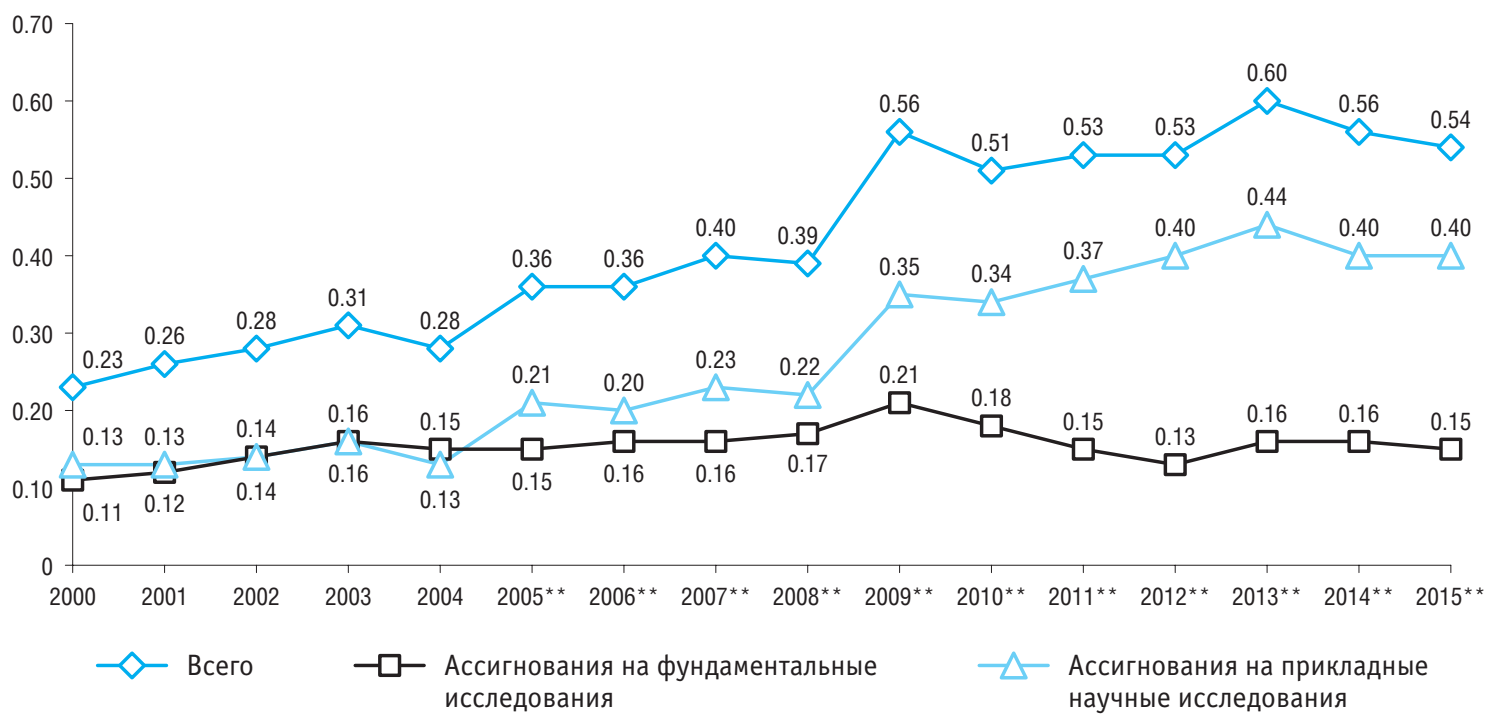

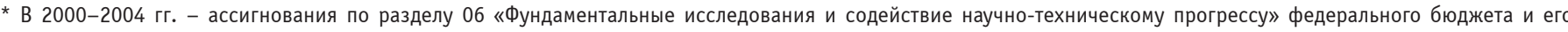
соответствующим подразделам.

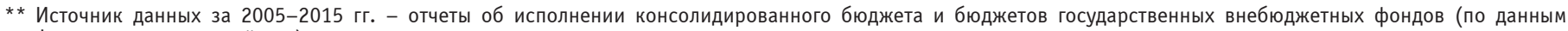
Федерального казначейства). 


\section{6. АССИГНОВАНИЯ НА ГРАЖДАНСКУЮ НАУКУ ИЗ СРЕДСТВ ФЕДЕРАЛЬНОГО БЮДЖЕТА \\ В ПРОЦЕНТАХ К РАСХОДАМ ФЕДЕРАЛЬНОГО БЮДЖЕТА*}

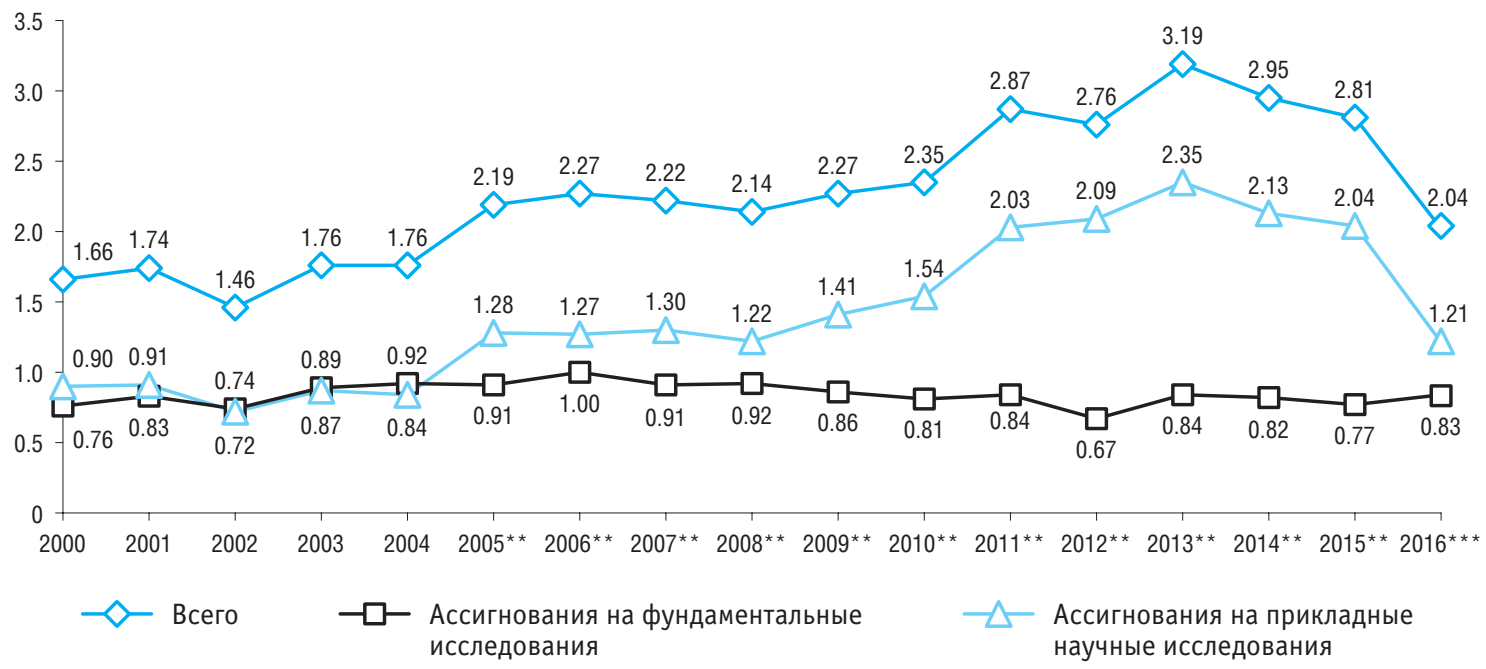

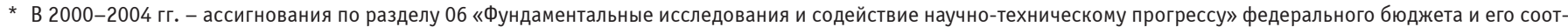
ветствующим подразделам.

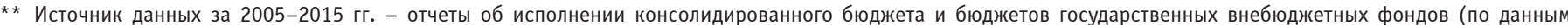
Федерального казначейства).

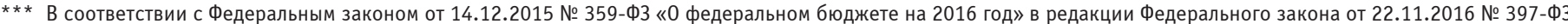
«0 внесении изменений в Федеральный закон «0 федеральном бюджете на 2016 год». 


\section{7. РАСПРЕДЕЛЕНИЕ АССИГНОВАНИЙ НА ГРАЖДАНСКУЮ НАУКУ ИЗ СРЕДСТВ ФЕДЕРАЛЬНОГО БЮДЖЕТА ПО РАЗДЕЛАМ КЛАССИФИКАЦИИ РАСХОДОВ И ВИДАМ РАБОТ}

(проченты)

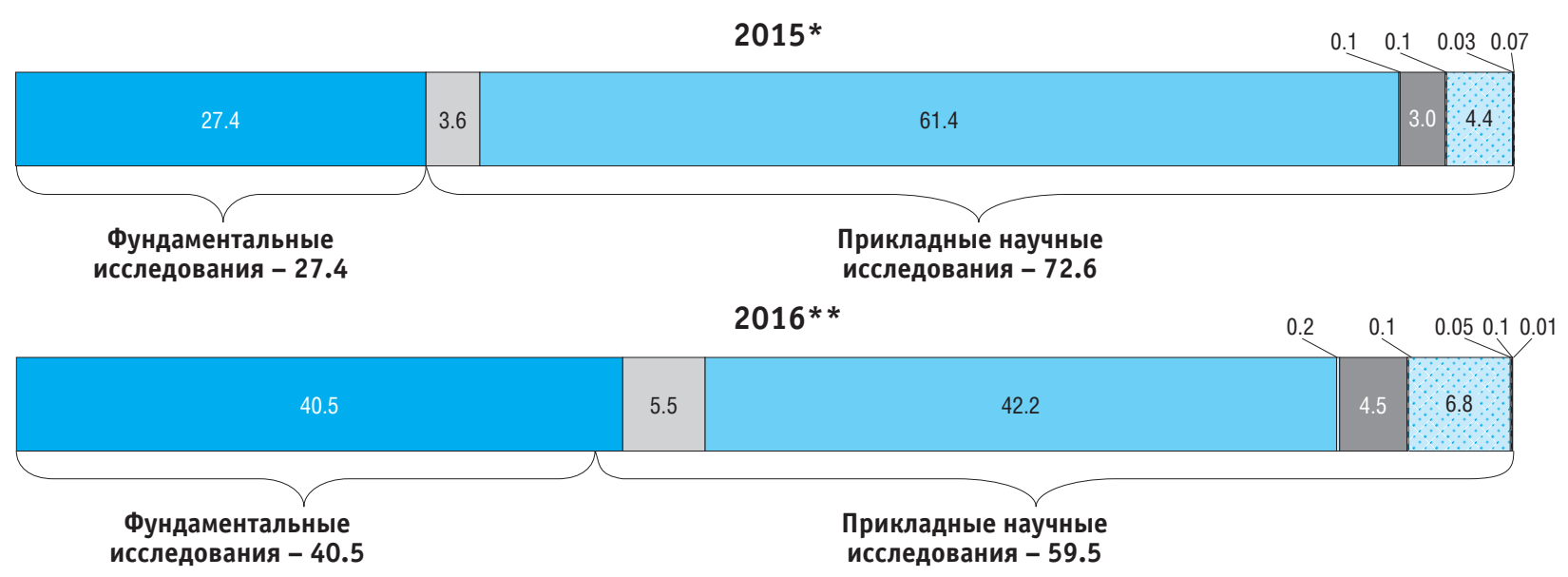

Общегосударственные вопросы

$\square$ Национальная экономика

$\square$ Охрана окружающей среды

$\square$ Образование
К. Культура, кинематография

$\therefore$ Здравоохранение

$\square$ Социальная политика

Фи Физиеская культура и спорт

$\because$ Средства массовой информации

* Источник данных за 2015 г. - отчет об исполнении консолидированного бюджета и бюджетов государственных внебюджетных фондов (по данным Федерального казначейства).

** В соответствии с Федеральным законом от 14.12.2015 № 359-Ф3 «0 федеральном бюджете на 2016 год» в редакции Федерального закона от 22.11.2016 № 397-Ф3 «0 внесении изменений в Федеральный закон «0 федеральном бюджете на 2016 год». 
3.8. ВНУТРЕННИЕ ЗАТРАТЫ НА ИССЛЕДОВАНИЯ И РАЗРАБОТКИ ПО ИСТОЧНИКАМ ФИНАНСИРОВАНИЯ

\begin{tabular}{|c|c|c|c|c|c|c|}
\hline & \begin{tabular}{|c|} 
Внутренние затраты \\
на исследования \\
и разработки
\end{tabular} & $\begin{array}{c}\text { Средства } \\
\text { государства* }\end{array}$ & $\begin{array}{c}\text { Средства } \\
\text { предприниматель- } \\
\text { ского сектора }\end{array}$ & $\begin{array}{c}\text { Средства } \\
\text { образовательных } \\
\text { организаций выс- } \\
\text { шего образования }\end{array}$ & $\begin{array}{c}\text { Средства частных } \\
\text { некоммерческих } \\
\text { организаций }\end{array}$ & $\begin{array}{c}\text { Средства } \\
\text { иностранных } \\
\text { источников }\end{array}$ \\
\hline \multicolumn{7}{|c|}{ В действующих ценах, тыс. рублей, 1995 г. - млн рублей } \\
\hline 1995 & 12149458.6 & 7476767.6 & 4076707.0 & 30543.0 & 3672.1 & 561768.9 \\
\hline 2000 & 76697100.5 & 42035655.1 & 25208436.5 & 212990.3 & 67641.5 & 9172377.1 \\
\hline 2001 & 105260731.6 & 60228854.3 & 35394269.5 & 359916.1 & 205512.5 & 9072179.2 \\
\hline 2002 & 135004491.9 & 78883876.7 & 44699518.7 & 426216.0 & 134353.6 & 10860526.9 \\
\hline 2003 & 169862369.1 & 101252097.2 & 52256884.6 & 807293.0 & 277916.5 & 15268177.8 \\
\hline 2004 & 196039870.2 & 118867302.8 & 61528028.1 & 692412.1 & 98631.6 & 14853495.6 \\
\hline 2005 & 230785150.3 & 142960799.1 & 69244740.5 & 983242.0 & 68412.2 & 17527956.5 \\
\hline 2006 & 288805211.5 & 176457427.8 & 83197909.8 & 1652533.1 & 296869.8 & 27200471.0 \\
\hline 2007 & 371080327.1 & 232364775.8 & 109265410.0 & 2276881.0 & 377417.8 & 26795842.5 \\
\hline 2008 & 431073185.2 & 278992303.3 & 123695707.2 & 1993888.9 & 768479.1 & 25622806.7 \\
\hline 2009 & 485834338.2 & 322889237.6 & 129170972.3 & 1896167.0 & 471799.6 & 31406161.7 \\
\hline 2010 & 523377233.9 & 368191779.8 & 133498976.0 & 2436564.1 & 682378.0 & 18567536.0 \\
\hline 2011 & 610426680.6 & 409449448.8 & 168957596.6 & 4664465.3 & 1209661.5 & 26145508.4 \\
\hline 2012 & 699869784.8 & 474789779.0 & 190545904.2 & 5905489.1 & 877937.6 & 27750674.9 \\
\hline 2013 & 749797638.8 & 507197614.5 & 211135955.9 & 7820677.9 & 896366.0 & 22747024.5 \\
\hline 2014 & 847526992.9 & 586658713.4 & 229444656.4 & 9069176.1 & 1372014.1 & 20982432.9 \\
\hline 2015 & 914669057.2 & 635859865.4 & 242155382.4 & 10875090.0 & 1566750.2 & 24211969.2 \\
\hline
\end{tabular}


(окончание)

\begin{tabular}{|c|c|c|c|c|c|c|}
\hline & $\begin{array}{c}\text { Внутренние затраты } \\
\text { на исследования } \\
\text { и разработки }\end{array}$ & $\begin{array}{c}\text { Средства } \\
\text { государства* }\end{array}$ & $\begin{array}{c}\text { Средства } \\
\text { предприниматель- } \\
\text { ского сектора }\end{array}$ & $\begin{array}{c}\text { Средства } \\
\text { образовательных } \\
\text { организаций выс- } \\
\text { шего образования }\end{array}$ & $\begin{array}{c}\text { Средства частных } \\
\text { некоммерческих } \\
\text { организаций }\end{array}$ & $\begin{array}{c}\text { Средства } \\
\text { иностранных } \\
\text { источников }\end{array}$ \\
\hline \multicolumn{7}{|c|}{ Проценты } \\
\hline 1995 & 100 & 61.5 & 33.6 & 0.3 & 0.03 & 4.6 \\
\hline 2000 & 100 & 54.8 & 32.9 & 0.3 & 0.09 & 12.0 \\
\hline 2001 & 100 & 57.2 & 33.6 & 0.3 & 0.2 & 8.6 \\
\hline 2002 & 100 & 58.4 & 33.1 & 0.3 & 0.1 & 8.0 \\
\hline 2003 & 100 & 59.6 & 30.8 & 0.5 & 0.2 & 9.0 \\
\hline 2004 & 100 & 60.6 & 31.4 & 0.4 & 0.05 & 7.6 \\
\hline 2005 & 100 & 61.9 & 30.0 & 0.4 & 0.03 & 7.6 \\
\hline 2006 & 100 & 61.1 & 28.8 & 0.6 & 0.1 & 9.4 \\
\hline 2007 & 100 & 62.6 & 29.4 & 0.6 & 0.1 & 7.2 \\
\hline 2008 & 100 & 64.7 & 28.7 & 0.5 & 0.2 & 5.9 \\
\hline 2009 & 100 & 66.5 & 26.6 & 0.4 & 0.1 & 6.5 \\
\hline 2010 & 100 & 70.3 & 25.5 & 0.5 & 0.1 & 3.5 \\
\hline 2011 & 100 & 67.1 & 27.7 & 0.8 & 0.2 & 4.3 \\
\hline 2012 & 100 & 67.8 & 27.2 & 0.8 & 0.1 & 4.0 \\
\hline 2013 & 100 & 67.6 & 28.2 & 1.0 & 0.1 & 3.0 \\
\hline 2014 & 100 & 69.2 & 27.1 & 1.1 & 0.2 & 2.5 \\
\hline 2015 & 100 & 69.5 & 26.5 & 1.2 & 0.2 & 2.6 \\
\hline
\end{tabular}

* Включая средства бюджета, бюджетные ассигнования на содержание образовательных организаций высшего образования, средства организаций государственного сектора (в том числе собственные). 


\section{9. ДИНАМИКА ВНУТРЕННИХ ЗАТРАТ НА ИССЛЕДОВАНИЯ И РАЗРАБОТКИ ПО ИСТОЧНИКАМ ФИНАНСИРОВАНИЯ}

(в постоянных ценах 1989 г.)

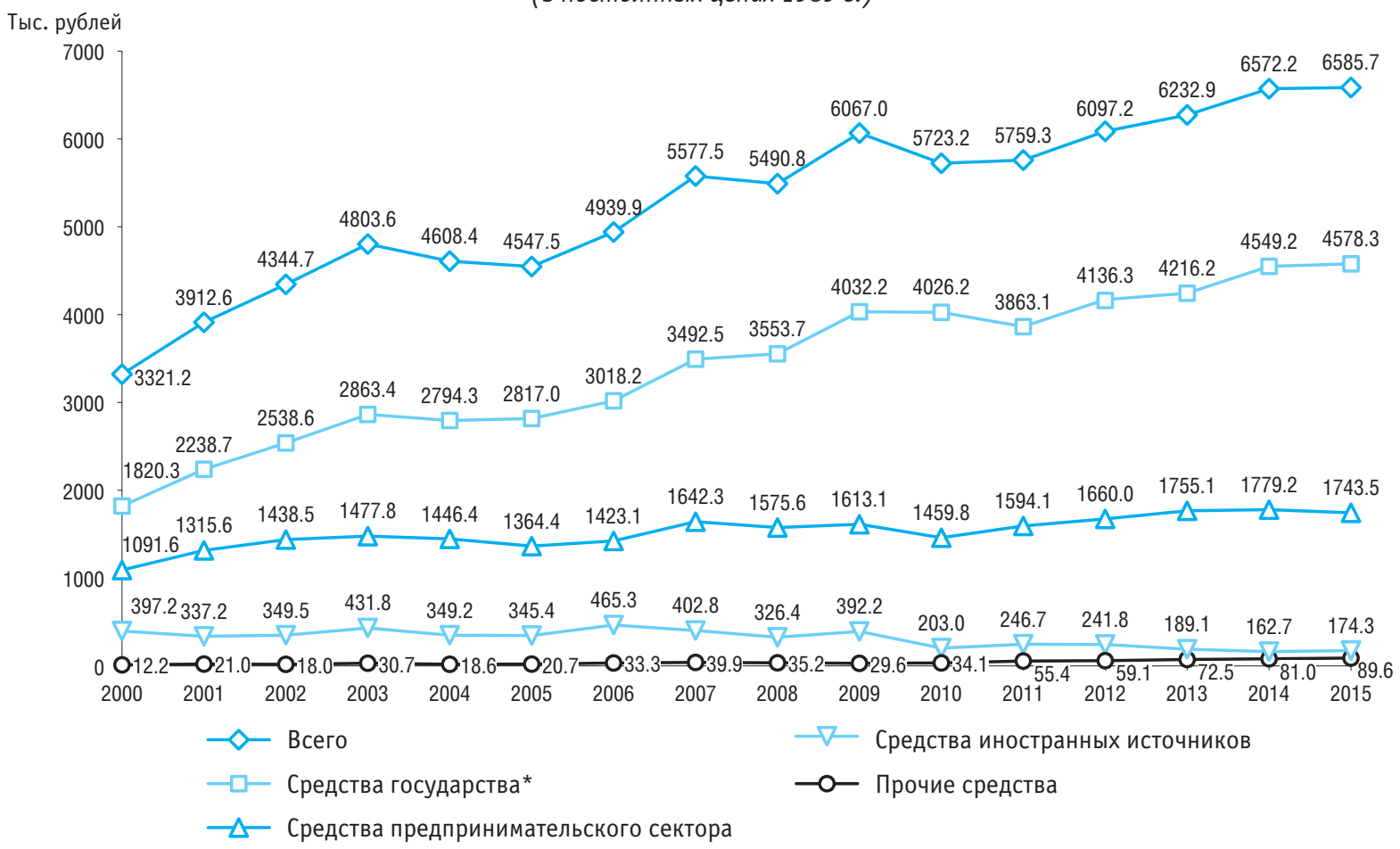

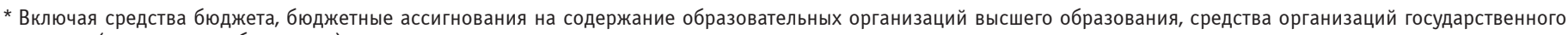
сектора (в том числе собственные). 


\subsection{0. ГРАНТЫ, СУБСИДИИ, КОНКУРСНОЕ ФИНАНСИРОВАНИЕ ИССЛЕДОВАНИЙ И РАЗРАБОТОК: 2015}

\begin{tabular}{|c|c|c|}
\hline & $\begin{array}{l}\text { Всего, } \\
\text { тыс. руб. }\end{array}$ & $\begin{array}{c}\text { В процентах к объему } \\
\text { внутренних затрат } \\
\text { на исследования } \\
\text { и разработки }\end{array}$ \\
\hline Внутренние затраты на исследования и разработки, всего & 914669057.2 & 100.0 \\
\hline \multicolumn{3}{|l|}{ Из них: } \\
\hline $\begin{array}{l}\text { субсидии бюджета на финансовое обеспечение выполнения государственного задания в сфере науч } \\
\text { (научно-исследовательской) деятельности }\end{array}$ & 92260622.5 & 10.1 \\
\hline субсидии бюджета на выполнение научно-исследовательских и/или опытно-конструкторских работ & 34143669.8 & 3.7 \\
\hline гранты фондов поддержки научной, научно-технической и инновационной деятельности & 22725394.7 & 2.5 \\
\hline другие виды конкурсного финансирования & 79479326.3 & 8.7 \\
\hline
\end{tabular}

\subsection{1. ВНУТРЕННИЕ ЗАТРАТЫ НА ИССЛЕДОВАНИЯ И РАЗРАБОТКИ ИЗ СРЕДСТВ ИНОСТРАННЫХ ИСТОЧНИКОВ (ЗАРУБЕЖНЫХ ОРГАНИЗАЦИЙ)}

\begin{tabular}{|c|c|c|c|c|c|c|}
\hline & \multicolumn{2}{|c|}{2013} & \multicolumn{2}{|c|}{2014} & \multicolumn{2}{|c|}{2015} \\
\hline & Всего, тыс. руб. & Проценты & Всего, тыс. руб. & Проценты & Всего, тыс. руб. & Проценты \\
\hline \multicolumn{7}{|l|}{ Внутренние затраты на исследования и разработки } \\
\hline из средств иностранных источников & 22747024.5 & 100.0 & 20982432.9 & 100.0 & 24211969.2 & 100.0 \\
\hline \multicolumn{7}{|l|}{ В том числе: } \\
\hline международных организаций & 1424149.2 & 6.3 & 3104558.8 & 14.8 & 1287164.2 & 5.3 \\
\hline государственных организаций зарубежных стран & 4582879.4 & 20.1 & 4769488.7 & 22.7 & 7221887.0 & 29.8 \\
\hline организаций предпринимательского сектора & & & & & & \\
\hline зарубежных стран & 15525544.5 & 68.3 & 12082110.8 & 57.6 & 14209467.4 & 58.7 \\
\hline прочих зарубежных организаций (организаций & & & & & & \\
\hline образования, фондов, некоммерческих организаций) & 1214451.4 & 5.3 & 1026274.6 & 4.9 & 1493450.6 & 6.2 \\
\hline
\end{tabular}




\subsection{2. РАСПРЕДЕЛЕНИЕ ФИНАНСИРОВАНИЯ ИССЛЕДОВАНИЙ И РАЗРАБОТОК ПО СЕКТОРАМ НАУКИ: 2015}

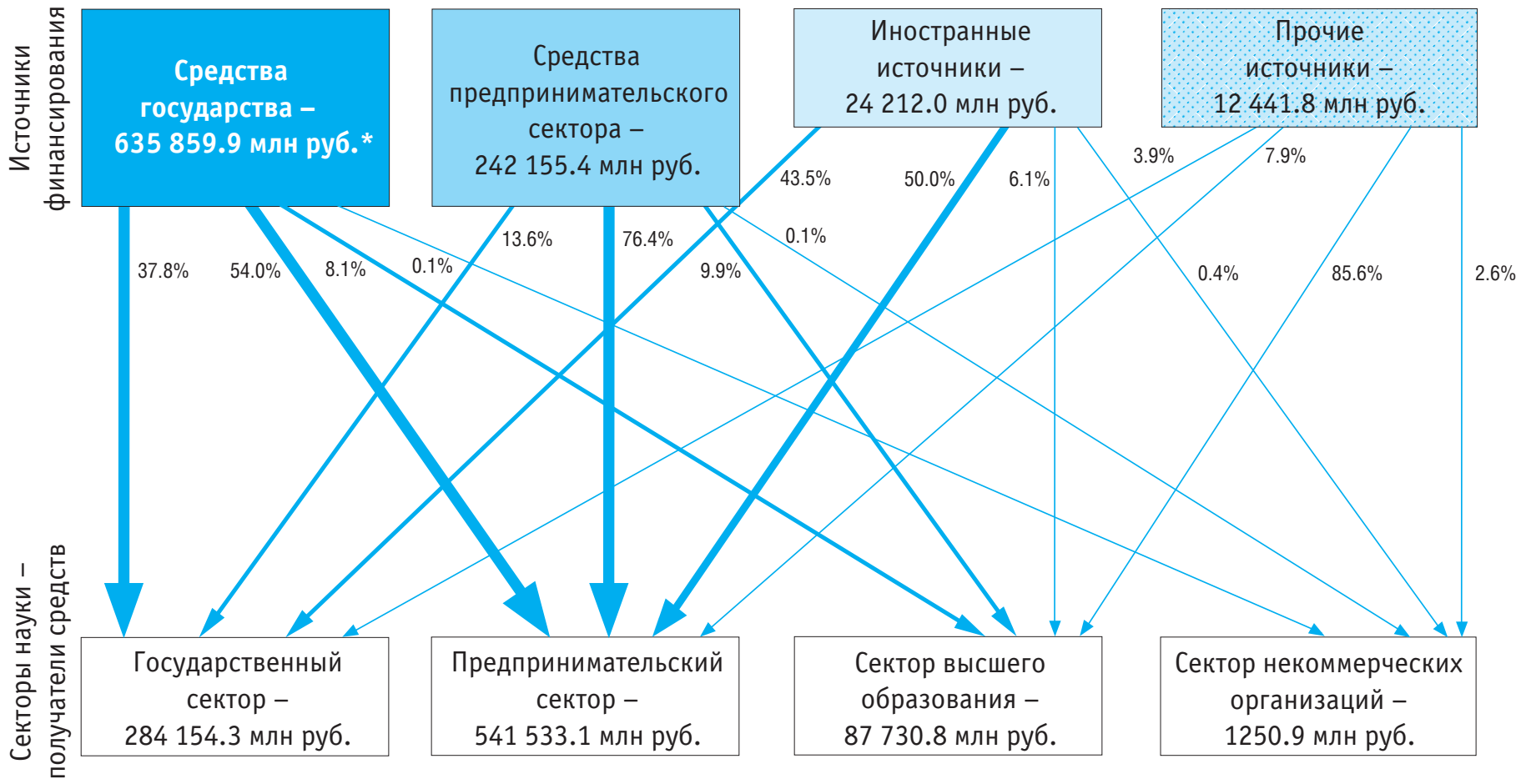

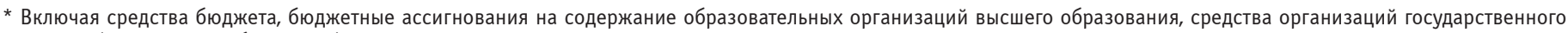
сектора (в том числе собственные). 


\subsection{3. ВНУТРЕННИЕ ЗАТРАТЫ НА ИССЛЕДОВАНИЯ И РАЗРАБОТКИ ПО ФОРМАМ СОБСТВЕННОСТИ ОРГАНИЗАЦИЙ}

\begin{tabular}{|c|c|c|c|c|c|c|c|c|c|c|c|}
\hline & 1995 & 2000 & 2007 & 2008 & 2009 & 2010 & 2011 & 2012 & 2013 & 2014 & 2015 \\
\hline \multicolumn{12}{|c|}{ В действующих ценах, тыс. рублей, 1995 г. - млн рублей } \\
\hline Всего & 12149458.6 & 76697100.5 & 371080327.1 & 431073185.2 & 485834338.2 & 523377233.9 & 610426680.6 & 699869784.8 & 749797638.8 & 847526992.9 & 914669057.2 \\
\hline Российская собственность & 12137095.6 & 74254897.9 & 362788255.0 & 422024862.3 & 478787821.5 & 514058161.4 & 598027432.9 & 685495275.4 & 725512775.4 & 831700355.3 & 3897702466.4 \\
\hline Государственная & 9303329.4 & 56254567.1 & 268054481.0 & 315468440.4 & 362864344.6 & 394615118.0 & 448854863.1 & 495689326.0 & 510811584.2 & 588219503.3 & 3570759794.5 \\
\hline Федеральная & 9047499.6 & 55150426.2 & 263267216.7 & 310681404.3 & 358511516.2 & 389105256.8 & 441676795.3 & 487535217.5 & 502816626.9 & 577892310.2 & 2559987658.5 \\
\hline $\begin{array}{l}\text { Субъектов Российской } \\
\text { Федерации }\end{array}$ & 5829.8 & 1099762.3 & 4674078.0 & 4675955.0 & 4181193.6 & 5396479.0 & 7152191.4 & 8124552.8 & 994957.3 & 10327193.1 & 10772136.0 \\
\hline Муниципальная & 15214.6 & 50381.9 & 38024.6 & 58426.2 & 52807.3 & 50304.2 & 74152.5 & 65889.2 & 93873.2 & 78104.2 & 93960.3 \\
\hline $\begin{array}{l}\text { Общественных } \\
\text { организаций }\end{array}$ & 35640.0 & 209229.3 & 589456.4 & 610938.9 & 525257.1 & 525085.2 & 711349.2 & 915629.8 & 1246181.6 & 1181906.2 & 2010818.4 \\
\hline Частная & 265827.3 & 4948266.7 & 51427162.7 & 63511011.8 & 66857001.6 & 60263592.5 & 69577239.4 & 80608901.3 & 394280978.5 & 100226515.2 & 2. 116626956.5 \\
\hline $\begin{array}{l}\text { Собственность российских } \\
\text { граждан, постоянно про- } \\
\text { живающих за границей }\end{array}$ & $\cdots$ & .. & 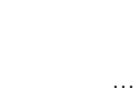 & .. & $\ldots$ & 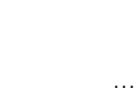 & 21631.3 & 6949.0 & ** & ** & $\ldots{ }^{\star *}$ \\
\hline $\begin{array}{l}\text { Потребительской } \\
\text { кооперации* }\end{array}$ & & 1095.2 & 2635.3 & 2515.4 & 35877.1 & 36590.0 & 39286.2 & 2468.5 &.$^{* *}$ & - & 20664.7 \\
\hline Смешанная & 2517084.3 & 12791357.7 & 42676495.0 & 42373529.6 & 48452533.8 & 55954325.1 & 69203059.8 & 83947440.0 & 89367594.5 & 114333241.0 & 168031713.1 \\
\hline $\begin{array}{l}\text { Смешанная с долей } \\
\text { государственной }\end{array}$ & & & & & & & & & & & \\
\hline собственности & $\ldots$ & $\ldots$ & $\ldots$ & .. & $\ldots$ & 49557690.9 & 62421583.0 & 62059799.4 & $4 \quad 73525307.2$ & 97555613.4 & 4129154411.8 \\
\hline Иная смешанная & $\cdots$ & $\ldots$ & $\cdots$ & $\ldots$ & $\ldots$ & $\cdots$ & 6781476.8 & 21887640.6 & 15842287.3 & 16777627.6 & 38877301.3 \\
\hline Государственных & & & & & & & & & & & \\
\hline корпор & & $\ldots$ & & $\cdots$ & $\ldots$ & 2613146.4 & 9545851.4 & 24258671.6 & 29695934.9 & 27615092.9 & 40134256.9 \\
\hline Иностранная собственность & 336.7 & 117265.0 & 675533.7 & 711942.6 & 778685.9 & 1390905.3 & 1780045.0 & 2683049.2 & 7059984.4 & 7945428.4 & 5684831.2 \\
\hline $\begin{array}{l}\text { Совместная российская } \\
\text { и иностранная собственность }\end{array}$ & 12026.3 & 2324937.6 & 7616538.4 & 8336380.3 & 6267830.8 & 7928167.2 & 10619202.7 & 11691460.2 & 2 17224879.0 & 7881209.2 & 211281759.6 \\
\hline
\end{tabular}


(окончание)

\begin{tabular}{|c|c|c|c|c|c|c|c|c|c|c|c|}
\hline & 1995 & 2000 & 2007 & 2008 & 2009 & 2010 & 2011 & 2012 & 2013 & 2014 & 2015 \\
\hline \multicolumn{12}{|c|}{ Проценты } \\
\hline Всего & 100 & 100 & 100 & 100 & 100 & 100 & 100 & 100 & 100 & 100 & 100 \\
\hline Российская собственность & 99.9 & 96.8 & 97.8 & 97.9 & 98.5 & 98.2 & 98.0 & 97.9 & 96.8 & 98.1 & 98.1 \\
\hline Государственная & 76.6 & 73.3 & 72.2 & 73.2 & 74.7 & 75.4 & 73.5 & 70.8 & 68.1 & 69.4 & 62.4 \\
\hline Федеральная & 74.5 & 71.9 & 70.9 & 72.1 & 73.8 & 74.3 & 72.4 & 69.7 & 67.1 & 68.2 & 61.2 \\
\hline $\begin{array}{l}\text { Субъектов Российской } \\
\text { Федерации }\end{array}$ & & 11 & 12 & 11 & 00 & 10 & 10 & 10 & 11 & 12 & \\
\hline Муниципальная & 0.1 & 0.07 & 0.01 & 0.01 & $\begin{array}{r}0.9 \\
0.01\end{array}$ & $\begin{array}{r}1.0 \\
0.01\end{array}$ & $\begin{array}{r}1.2 \\
0.01\end{array}$ & $\begin{array}{l}1.2 \\
0.01\end{array}$ & $\begin{array}{r}1.1 \\
0.01\end{array}$ & $\begin{array}{r}1.2 \\
0.01\end{array}$ & $\begin{array}{l}1.2 \\
0.01\end{array}$ \\
\hline \multicolumn{12}{|l|}{ Общественных } \\
\hline организаций & 0.3 & 0.3 & 0.2 & 0.1 & 0.1 & 0.1 & 0.1 & 0.1 & 0.2 & 0.1 & 0.2 \\
\hline Частная & 2.2 & 6.5 & 13.9 & 14.7 & 13.8 & 11.5 & 11.4 & 11.5 & 12.6 & 11.8 & 12.8 \\
\hline \multicolumn{12}{|l|}{$\begin{array}{l}\text { Собственность российских } \\
\text { граждан, постоянно про- }\end{array}$} \\
\hline живающих за границей & $\ldots$ & $\ldots$ & $\ldots$ & $\ldots$ & $\ldots$ & $\ldots$ & 0.004 & 0.001 & $\ldots{ }^{\star \star}$ & $\ldots{ }^{* *}$ & $\ldots{ }^{* *}$ \\
\hline \multicolumn{12}{|l|}{ Потребительской } \\
\hline кооперации* & $\ldots$ & 0.0 & 0.0 & 0.0 & 0.0 & 0.0 & 0.006 & 0.0 & $\ldots{ }^{* *}$ & - & 0.002 \\
\hline Смешанная & 20.7 & 16.7 & 11.5 & 9.8 & 10.0 & 10.7 & 11.3 & 12.0 & 11.9 & 13.5 & 18.4 \\
\hline \multicolumn{12}{|l|}{$\begin{array}{l}\text { Смешанная с долей } \\
\text { государственной }\end{array}$} \\
\hline собственности & $\ldots$ & $\ldots$ & $\ldots$ & $\ldots$ & $\ldots$ & 9.5 & 10.2 & 8.9 & 9.8 & 11.5 & 14.1 \\
\hline Иная смешанная & $\ldots$ & $\ldots$ & $\ldots$ & $\ldots$ & $\ldots$ & $\ldots$ & 1.1 & 3.1 & 2.1 & 2.0 & 4.3 \\
\hline \multicolumn{12}{|l|}{ Государственных } \\
\hline корпораций & & $\ldots$ & $\ldots$ & $\ldots$ & $\ldots$ & 0.5 & 1.6 & 3.5 & 4.0 & 3.3 & 4.4 \\
\hline Иностранная собственность & 0.002 & 0.2 & 0.2 & 0.2 & 0.2 & 0.3 & 0.3 & 0.4 & 0.9 & 0.9 & 0.6 \\
\hline \multicolumn{12}{|l|}{ Совместная российская } \\
\hline и иностранная собственность & 0.1 & 3.0 & 2.1 & 1.9 & 1.3 & 1.5 & 1.7 & 1.7 & 2.3 & 0.9 & 1.2 \\
\hline
\end{tabular}

* До 2000 г. учитывалась в составе организаций частной и смешанной российской собственности.

** Данные не публикуются в целях обеспечения конфиденциальности первичных статистических данных, полученных от организаций, в соответствии с Федеральным законом от 29.11.2007 № 282-Ф3 «0б официальном статистическом учете и системе государственной статистики в Российской Федерации» (ст. 4, п. 5; ст. 9, п. 1). 


\subsection{4. СТРУКТУРА ВНУТРЕННИХ ЗАТРАТ НА ИССЛЕДОВАНИЯ И РАЗРАБОТКИ \\ ПО ОРГАНИЗАЦИОННО-ПРАВОВЫМ ФОРМАМ ОРГАНИЗАЦИЙ: 2015 \\ (проченты)}

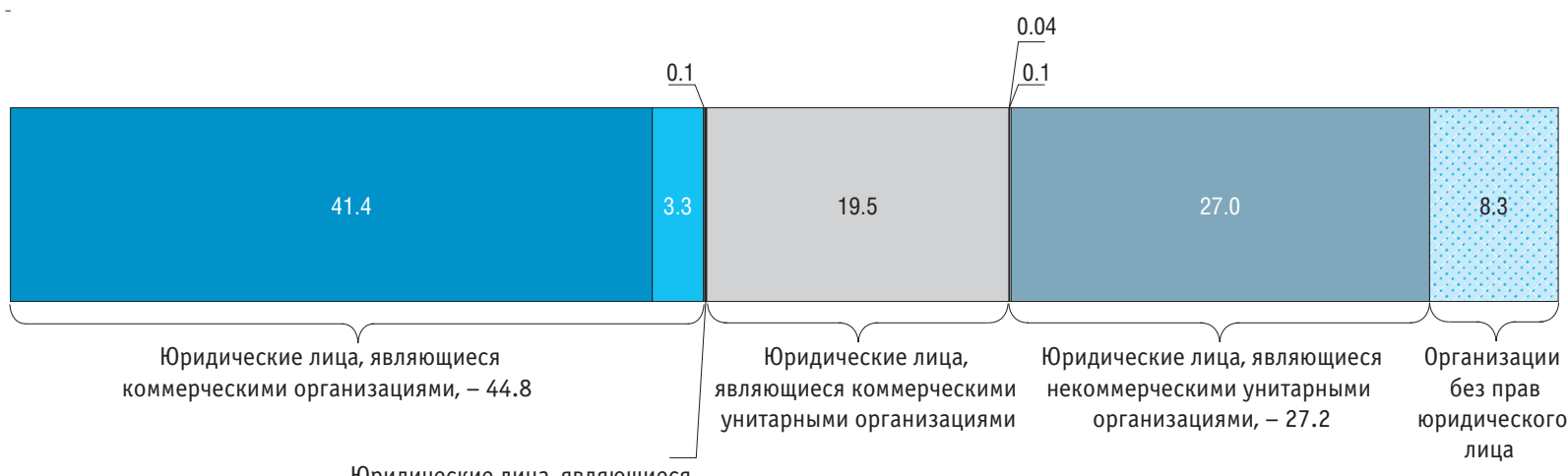

Юридические лица, являющиеся некоммерческими организациями, - 0.1

Акционерные общества

$\square$ 0бщества с ограниченной ответственностью

$\square$ Прочие коммерческие организации

\section{Фонды}

$\square$ Автономные некоммерческие организации

Учреждения 


\subsection{5. ВНУТРЕННИЕ ЗАТРАТЫ НА ИССЛЕДОВАНИЯ И РАЗРАБОТКИ ПО ВИДАМ ЭКОНОМИЧЕСКОЙ ДЕЯТЕЛЬНОСТИ}

(тысячи рублей)

\begin{tabular}{|c|c|c|c|c|c|c|c|c|}
\hline & 2005 & 2009 & 2010 & 2011 & 2012 & 2013 & 2014 & 2015 \\
\hline Всего & 230785150.3 & 485834338.2 & 523377233.9 & 610426680.6 & 699869784.8 & 749797638.8 & 847526992.9 & 914669057.2 \\
\hline Сельское хозяйство, охота и лесное хозяйство & 146783.8 & 247724.7 & 253871.9 & 289856.1 & 286476.4 & 392683.9 & 430205.2 & 583798.7 \\
\hline \multicolumn{9}{|l|}{ Рыбоводство, рыболовство и предоставление } \\
\hline услуг в этих областях & 5559.6 & 2890.8 & 485.2 & - & - & - & - & - \\
\hline Добыча полезных ископаемых & 584953.6 & 79238.0 & 55728.0 & 54729.0 & 42282.0 & 23211.4 & $\ldots$ * & 53955.0 \\
\hline 0брабатывающие производства & 10631526.1 & 17009365.1 & 21372426.7 & 23051252.7 & 33489559.2 & 41036284.6 & 41125116.8 & 96197060.7 \\
\hline \multicolumn{9}{|l|}{ Производство, передача и распределение } \\
\hline электроэнергии, газа и воды & - & 10085.0 & 8234.0 & 8654.0 & - & $\ldots{ }^{*}$ & $\ldots^{*}$ & 33170.1 \\
\hline Строительство & - & - & - & - & 35200.7 & $\ldots{ }^{*}$ & $\ldots{ }^{*}$ & $\ldots$ * \\
\hline Гостиницы и рестораны & - & - & - & - & 1074534.1 & $\ldots{ }^{*}$ & - & $\ldots{ }^{*}$ \\
\hline \multicolumn{9}{|l|}{$\begin{array}{l}\text { Оптовая и розничная торговля; ремонт автотран- } \\
\text { спортных средств, мотоциклов, бытовых изделий }\end{array}$} \\
\hline и предметов личного пользования & - & - & - & 5468.0 & - & - & - & $\ldots{ }^{*}$ \\
\hline \multicolumn{9}{|l|}{ Операции с недвижимым имуществом, аренда } \\
\hline и предоставление услуг & 207643389.9 & 433962004.3 & 455185374.4 & 530882724.2 & 591315932.3 & 634954769.4 & 713774604.4 & 724449636.6 \\
\hline \multicolumn{9}{|l|}{ Из них: } \\
\hline научные исследования и разработки & 204907680.4 & 425872251.2 & 447596655.1 & 520913787.4 & 576874368.1 & 621911256.0 & 702052200.0 & 711713170.0 \\
\hline предоставление прочих видов услуг & 2469504.1 & 6434826.7 & 5464671.8 & 7513061.1 & 9712021.4 & 8582367.7 & 8147046.4 & 7558585.6 \\
\hline
\end{tabular}


(окончание)

\begin{tabular}{|c|c|c|c|c|c|c|c|c|}
\hline & 2005 & 2009 & 2010 & 2011 & 2012 & 2013 & 2014 & 2015 \\
\hline Образование & 11076460.7 & 31254495.1 & 39254089.2 & 50880815.2 & 61985553.1 & 64847625.7 & 80366333.4 & 85381308.6 \\
\hline Из него высшее образование & 11071971.7 & 31224588.5 & 39220988.4 & 50849957.2 & 61929787.4 & 64705330.3 & 80220750.8 & 85025299.0 \\
\hline $\begin{array}{l}\text { Здравоохранение и предоставление социальных } \\
\text { услуг }\end{array}$ & 71943.4 & 1080303.2 & 4758071.7 & 2082060.2 & 1961525.5 & 2372871.1 & 2401072.1 & 2927519.4 \\
\hline $\begin{array}{l}\text { Предоставление прочих коммунальных, социальных } \\
\text { и персональных услуг }\end{array}$ & 594782.9 & 2070238.5 & 2345175.2 & 2980322.5 & 2974343.8 & 2908651.8 & 3200835.2 & 3513767.1 \\
\hline $\begin{array}{l}\text { Из них деятельность по организации отдыха } \\
\text { и развлечений, культуры и спорта }\end{array}$ & 574352.3 & 2032341.9 & 2331388.6 & 2930451.3 & 2963837.0 & 2901432.2 & 3196933.0 & 3418087.3 \\
\hline
\end{tabular}

* Данные не публикуются в целях обеспечения конфиденциальности первичных статистических данных, полученных от организаций, в соответствии с Федеральным законом от 29.11.2007 № 282-Ф3 «0б официальном статистическом учете и системе государственной статистики в Российской Федерации» (ст. 4, п. 5; ст. 9, п. 1). 
3.16. ВНУТРЕННИЕ ЗАТРАТЫ НА ИССЛЕДОВАНИЯ И РАЗРАБОТКИ ПО ВИДАМ ЗАТРАТ

\begin{tabular}{|c|c|c|c|c|c|c|c|c|c|c|}
\hline & 2000 & 2007 & 2008 & 2009 & 2010 & 2011 & 2012 & 2013 & 2014 & 2015 \\
\hline \multicolumn{11}{|c|}{ В действующих ценах, тыс. рублей } \\
\hline $\begin{array}{l}\text { Внутренние затраты на исследования } \\
\text { и разработки }\end{array}$ & 76697100.5 & 371080327.1 & 431073185.2 & 485834338.2 & 523377233.9 & 610426680.6 & 699869784.8 & 749797638.8 & 847526992.9 & 914669057.2 \\
\hline Внутренние текущие затраты & 73873345.0 & 352917701.2 & 410864983.6 & 461006216.2 & 489450798.7 & 568386749.7 & 655061743.4 & 699948879.0 & 795407850.6 & 854288043.8 \\
\hline Затраты на оплату труда & 27762734.2 & 157514386.8 & 193344895.7 & 217897038.1 & 241472234.1 & 275925134.3 & 307881674.7 & 334769102.6 & 372215515.4 & 398143690.1 \\
\hline $\begin{array}{l}\text { Из них работникам, выполнявшим } \\
\text { исследования и разработки* }\end{array}$ & 24452200.6 & 137956617.2 & 170633861.4 & 189457703.8 & 211660690.5 & 239162179.8 & 268058587.8 & 293118611.5 & 325421624.4 & 346425420.7 \\
\hline $\begin{array}{l}\text { Страховые взносы в Пенсионный } \\
\text { фонд, ФСС, ФФОМС }\end{array}$ & 10419152.6 & 34565859.1 & 40020294.9 & 43723470.6 & 47904606.9 & 68647474.6 & 75417597.8 & 82806275.3 & 92645219.2 & 104167630.5 \\
\hline Затраты на оборудование & 3433380.7 & 14027427.5 & 14604195.2 & 16144658.7 & 18067655.4 & 20065178.2 & 25365780.5 & 23529482.7 & 26062433.8 & 28480160.0 \\
\hline Другие материальные затраты & 17470855.0 & 83426976.6 & 72945529.7 & 89861803.2 & 89279048.7 & 101591855.4 & 123689963.6 & 134096570.4 & 158082737.1 & 157810431.8 \\
\hline Прочие текущие затраты & 14787222.5 & 63383051.2 & 89950068.1 & 93379245.6 & 92727253.6 & 102157107.2 & 122706726.8 & 124747448.0 & 146401945.1 & 165686131.4 \\
\hline Капитальные затраты & 2823755.5 & 18162625.9 & 20208201.6 & 24828122.0 & 33926435.2 & 42039930.9 & 44808041.4 & 49848759.8 & 52119142.3 & 60381013.4 \\
\hline Земельные участки и здания & 496202.4 & 3577647.3 & 5474654.9 & 4298550.9 & 8077521.7 & 8421252.7 & 11692714.0 & 8721163.4 & 9987854.6 & 10029243.3 \\
\hline Оборудование & 1448665.0 & 11689028.2 & 10775180.6 & 15438763.7 & 19887596.3 & 23968272.7 & 25459703.1 & 27306873.6 & 29421964.1 & 33807469.6 \\
\hline Прочие капитальные затраты & 878888.1 & 2895950.4 & 3958366.1 & 5090807.4 & 5961317.2 & 9650405.5 & 7655624.3 & 13820722.8 & 12709323.6 & 16544300.5 \\
\hline
\end{tabular}


(окончание)

\begin{tabular}{|c|c|c|c|c|c|c|c|c|c|c|}
\hline & 2000 & 2007 & 2008 & 2009 & 2010 & 2011 & 2012 & 2013 & 2014 & 2015 \\
\hline \multicolumn{11}{|c|}{ Проценты } \\
\hline $\begin{array}{l}\text { Внутренние затраты на исследования } \\
\text { и разработки }\end{array}$ & 100 & 100 & 100 & 100 & 100 & 100 & 100 & 100 & 100 & 100.0 \\
\hline Внутренние текущие затраты & 96.3 & 95.1 & 95.3 & 94.9 & 93.5 & 93.1 & 93.6 & 93.4 & 93.9 & 93.4 \\
\hline Затраты на оплату труда & 36.2 & 42.4 & 44.9 & 44.9 & 46.1 & 45.2 & 44.0 & 44.6 & 43.9 & 43.5 \\
\hline $\begin{array}{l}\text { Из них работникам, выполнявшим } \\
\text { исследования и разработки* }\end{array}$ & 31.9 & 37.2 & 39.6 & 39.0 & 40.4 & 39.2 & 38.3 & 39.1 & 38.4 & 37.9 \\
\hline $\begin{array}{l}\text { Страховые взносы в Пенсионный } \\
\text { фонд, ФСС, ФФОМС }\end{array}$ & 13.6 & 9.3 & 9.3 & 9.0 & 9.2 & 11.2 & 10.8 & 11.0 & 10.9 & 11.4 \\
\hline Затраты на оборудование & 4.5 & 3.8 & 3.4 & 3.3 & 3.5 & 3.3 & 3.6 & 3.1 & 3.1 & 3.1 \\
\hline Другие материальные затраты & 22.8 & 22.5 & 16.9 & 18.5 & 17.1 & 16.6 & 17.7 & 17.9 & 18.7 & 17.3 \\
\hline Прочие текущие затраты & 19.3 & 17.1 & 20.9 & 19.2 & 17.7 & 16.7 & 17.5 & 16.6 & 17.3 & 18.1 \\
\hline Капитальные затраты & 3.7 & 4.9 & 4.7 & 5.1 & 6.5 & 6.9 & 6.4 & 6.6 & 6.1 & 6.6 \\
\hline Земельные участки и здания & 0.6 & 1.0 & 1.3 & 0.9 & 1.5 & 1.4 & 1.7 & 1.2 & 1.2 & 1.1 \\
\hline Оборудование & 1.9 & 3.1 & 2.5 & 3.2 & 3.8 & 3.9 & 3.6 & 3.6 & 3.5 & 3.7 \\
\hline Прочие капитальные затраты & 1.1 & 0.8 & 0.9 & 1.0 & 1.1 & 1.6 & 1.1 & 1.8 & 1.5 & 1.8 \\
\hline
\end{tabular}

* Без совместителей и работавших по договорам гражданско-правового характера. 


\subsection{7. ВНУТРЕННИЕ ЗАТРАТЫ НА ИССЛЕДОВАНИЯ И РАЗРАБОТКИ ПО ПРИОРИТЕТНЫМ НАПРАВЛЕНИЯМ РАЗВИТИЯ НАУКИ, ТЕХНОЛОГИЙ И ТЕХНИКИ И ИСТОЧНИКАМ ФИНАНСИРОВАНИЯ: 2015}

(тысячи рублей)

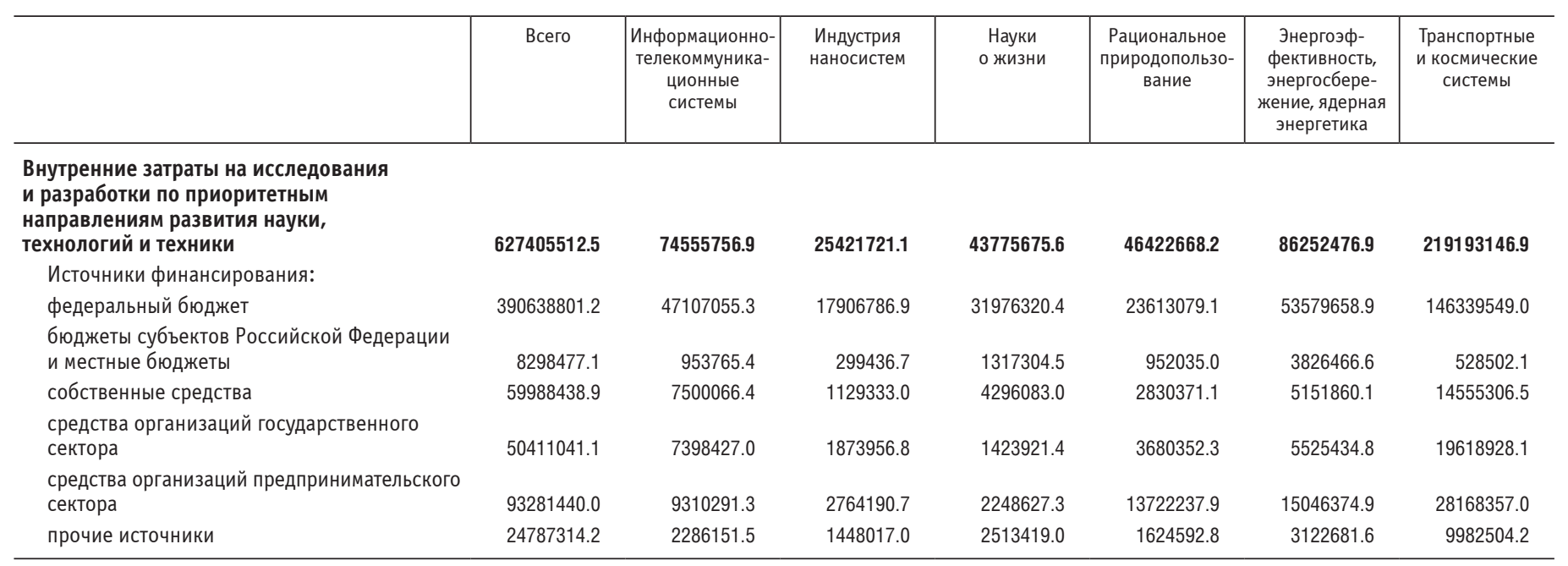


3.18. СТРУКТУРА ВНУТРЕННИХ ЗАТРАТ НА ИССЛЕДОВАНИЯ И РАЗРАБОТКИ ПО ПРИОРИТЕТНЫМ НАПРАВЛЕНИЯМ РАЗВИТИЯ НАУКИ, ТЕХНОЛОГИЙ И ТЕХНИКИ И ИСТОЧНИКАМ ФИНАНСИРОВАНИЯ: 2015

\section{Транспортные и космические системы}

Энергоэффективность, энергосбережение, ядерная энергетика

Рациональное природопользование

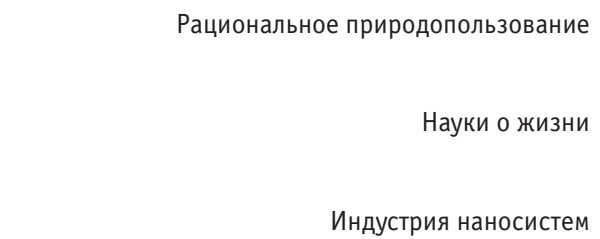

Информационно-телекоммуникационные системы

федеральный бюджет

бюджеты субъектов Российской Федерации и местные бюджеты

$\square$ собственные средства

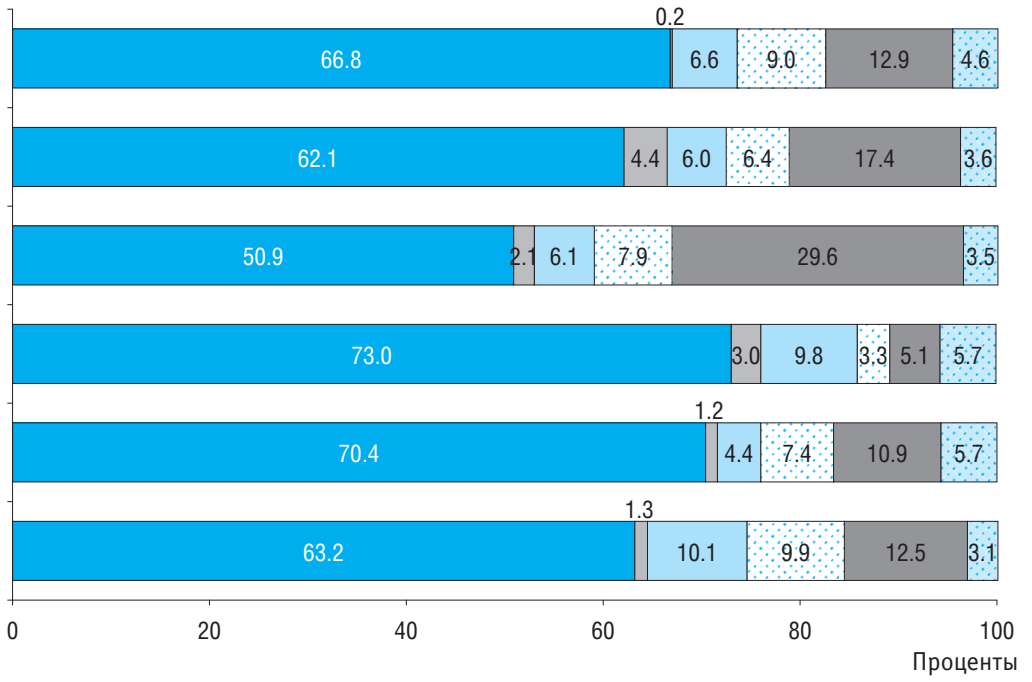

Источники финансирования:

средства организаций государственного сектора

$\square$ средства организаций предпринимательского сектора

прочие средства 


\subsection{9. ВНУТРЕННИЕ ЗАТРАТЫ НА ИССЛЕДОВАНИЯ И РАЗРАБОТКИ ПО СОЦИАЛЬНО-ЭКОНОМИЧЕСКИМ ЦЕЛЯМ}

(тысячи рублей)

\begin{tabular}{|c|c|c|c|c|c|c|c|}
\hline & 2006 & 2010 & 2011 & 2012 & 2013 & 2014 & 2015 \\
\hline Внутренние затраты на исследования и разработки & 288805211.5 & 523377233.9 & 610426680.6 & 699869784.8 & 749797638.8 & 847526992.9 & 914669057.2 \\
\hline Развитие экономики & 103033497.6 & 183113782.3 & 231941668.2 & 295901906.0 & 303849005.2 & 319943400.5 & 335508245.3 \\
\hline Сельское хозяйство, лесоводство и рыболовство & 7248977.0 & 12090814.9 & 15011619.7 & 16151602.6 & 18162639.9 & 19356066.3 & 20507885.2 \\
\hline \multicolumn{8}{|l|}{ Производство, распределение и рациональное использование } \\
\hline энергии & 10267046.6 & 19174764.6 & 19913673.7 & 30798200.6 & 32391136.1 & 30009786.7 & 28233810.5 \\
\hline Промышленное производство & 71319151.3 & 126029410.7 & 156695798.9 & 200459644.4 & 211581275.8 & 225973823.4 & 247190324.1 \\
\hline $\begin{array}{l}\text { Повышение экономической эффективности и технологическо- } \\
\text { го уровня промышленного производства }\end{array}$ & 8331516.8 & 14916168.9 & 19904782.4 & 22472542.8 & 23766954.4 & 26183678.7 & 27970190.2 \\
\hline Добыча и переработка неэнергетических минералов & 628547.3 & 1279265.4 & 1359844.0 & 1863605.2 & 2857681.5 & 1893285.1 & 2979762.1 \\
\hline Химическое производство & 4194564.2 & 5839135.5 & 6835610.4 & 9155732.6 & 9253596.1 & 12102652.2 & 18046159.1 \\
\hline Производство автомобилей и прочих транспортных средств & 14450931.1 & 21495410.4 & 25640612.6 & 32391176.2 & 43571684.0 & 37432847.4 & 38496344.6 \\
\hline \multicolumn{8}{|l|}{$\begin{array}{l}\text { Производство электронного оборудования, его компонентов, } \\
\text { аппаратуры для радио, телевидения и связи, офисного }\end{array}$} \\
\hline оборудования & 9281563.7 & 13389386.0 & 17546855.7 & 26449997.0 & 30121503.4 & 30917362.1 & 34152557.2 \\
\hline Разработка средств программного обеспечения & 3355339.6 & 6740442.6 & 7701782.0 & 8932282.7 & 10343013.7 & 8906139.6 & 10935776.1 \\
\hline Производство электрических машин и электрооборудования & 1292927.0 & 2879253.1 & 3179319.1 & 5235647.6 & 10666259.5 & 6852593.2 & 6855694.7 \\
\hline Производство приборов & 6600437.6 & 13466912.8 & 20205983.0 & 29563984.4 & 26441262.5 & 25964146.5 & 24545740.1 \\
\hline Производство других машин и оборудования & 6965389.1 & 13654259.2 & 15485756.9 & 15781575.2 & 14251449.9 & 21053098.6 & 19618563.5 \\
\hline Производство одежды, текстильных и кожаных изделий & 54077.2 & 97483.3 & 106648.1 & 254582.3 & 116171.9 & 125925.2 & 152999.3 \\
\hline Производство пищевых продуктов и напитков & 296729.6 & 565348.2 & 565873.8 & 758191.9 & 1043282.0 & 777287.7 & 883049.0 \\
\hline Прочие производства & 15867128.1 & 31706345.3 & 38162730.9 & 47600326.5 & 39148416.9 & 53764807.1 & 62553488.2 \\
\hline
\end{tabular}


(окончание)

\begin{tabular}{|c|c|c|c|c|c|c|c|}
\hline & 2006 & 2010 & 2011 & 2012 & 2013 & 2014 & 2015 \\
\hline Строительство & 2697184.2 & 5513681.4 & 7294997.0 & 8504203.4 & 5514071.6 & 7302858.5 & 4100727.2 \\
\hline Транспорт & 9011178.7 & 12686004.3 & 22041615.8 & 23986235.6 & 26950369.3 & 25052775.9 & 28936996.8 \\
\hline Связь & 1709581.2 & 6704734.7 & 9211899.0 & 14147246.2 & 7577748.3 & 10809004.6 & 5137035.8 \\
\hline $\begin{array}{l}\text { Инфраструктура и планировка городских и сельских населенных } \\
\text { пунктов }\end{array}$ & 430140.7 & 354546.0 & 916966.4 & 912451.2 & 702102.6 & 754005.3 & 720423.3 \\
\hline Сфера услуг & 350237.9 & 559825.7 & 855097.7 & 942322.0 & 969661.6 & 685079.8 & 681042.4 \\
\hline Социальные цели & 11954593.3 & 24966176.4 & 29640390.9 & 33070785.7 & 39876895.8 & 45328439.6 & 47512609.4 \\
\hline 0храна окружающей среды & 2595076.2 & 5950018.6 & 6638173.2 & 6972125.5 & 6139294.7 & 7690689.6 & 7698790.1 \\
\hline Охрана здоровья населения & 5897030.0 & 14373675.7 & 17100379,3 & 19694713.1 & 22382779.3 & 27197492.2 & 27779185.8 \\
\hline Социальное развитие и общественные структуры & 3462487.1 & 4642482.1 & 5901838.4 & 6403947.1 & 11354821.8 & 10440257.8 & 12034633.5 \\
\hline Общее развитие науки & 60629124.4 & 104294714.1 & 111947458.3 & 117873370.5 & 130695141.4 & 136414580.0 & 145154435.8 \\
\hline Исследование и использование Земли и атмосферы & 7577493.4 & 19821817.2 & 20390660.8 & 25474648.5 & 32889936.2 & 39068691.1 & 43206894.0 \\
\hline Использование космоса в мирных целях & 14018574.9 & 27503697.9 & 35752455.2 & 37558965.0 & 51558366.4 & 48996185.8 & 57441295.9 \\
\hline Прочие затраты & 91591927.9 & 163677046.0 & 180754047.2 & 189990109.1 & 190928293.8 & 257775695.9 & 285845576.8 \\
\hline
\end{tabular}



(проценты)

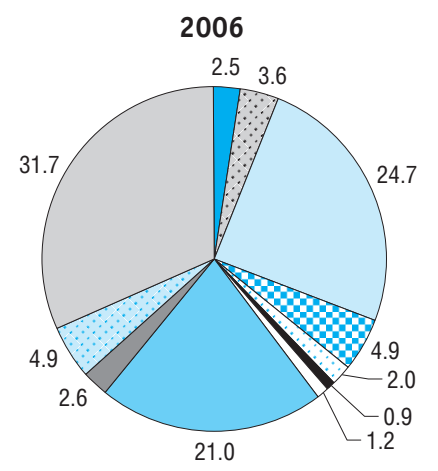

Сельское хозяйство

$\because$ Энергетика

$\square$ Развитие промышленного производства

Прочие экономические цели

Здоровье населения

— Охрана окружающей среды

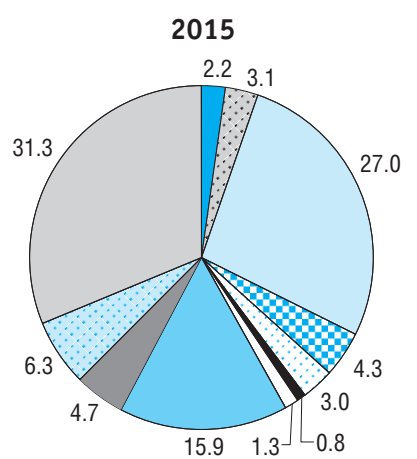

Социальное развитие

Общее развитие науки

Исследование и использование Земли и атмосферы

$\therefore$ Использование космоса в мирных целях

Прочие затраты 


\subsection{1. ВНУТРЕННИЕ ТЕКУЩИЕ ЗАТРАТЫ НА ИССЛЕДОВАНИЯ И РАЗРАБОТКИ ПО ВИДАМ РАБОТ И ОБЛАСТЯМ НАУКИ} (тысячи рублей)

\begin{tabular}{|c|c|c|c|c|c|c|c|}
\hline & Всего & $\begin{array}{c}\text { Естественные } \\
\text { науки }\end{array}$ & $\begin{array}{c}\text { Технические } \\
\text { науки }\end{array}$ & $\begin{array}{c}\text { Медицинские } \\
\text { науки }\end{array}$ & $\begin{array}{c}\text { Сельскохозяйст- } \\
\text { венные науки }\end{array}$ & $\begin{array}{c}\text { Общественные } \\
\text { науки }\end{array}$ & $\begin{array}{c}\text { Гуманитарные } \\
\text { науки }\end{array}$ \\
\hline \multicolumn{8}{|c|}{2005} \\
\hline \multicolumn{8}{|l|}{ Внутренние текущие затраты } \\
\hline на исследования и разработки & 221119537.6 & 34579040.8 & 171109626.3 & 4571313.8 & 4159368.3 & 4628535.6 & 2071652.8 \\
\hline Фундаментальные исследования & 31022855.8 & 19345182.8 & 4579039.5 & 1865239.8 & 1947227.1 & 1723405.3 & 1562761.3 \\
\hline Прикладные исследования & 36360266.9 & 8860755.5 & 21725918.2 & 2051910.3 & 1409317.9 & 1957292.2 & 355072.8 \\
\hline Разработки & 153736414.9 & 6373102.5 & 144804668.6 & 654163.7 & 802823.3 & 947838.1 & 153818.7 \\
\hline & & & 2010 & & & & \\
\hline \multicolumn{8}{|l|}{ Внутренние текущие затраты } \\
\hline на исследования и разработки & 489450798.7 & 96010015.2 & 348621966.4 & 15462300.4 & 8887624.5 & 13752461.7 & 6716430.5 \\
\hline Фундаментальные исследования & 95881364.3 & 50550000.6 & 22866475.2 & 6378644.4 & 4766037.6 & 6074153.0 & 5246053.5 \\
\hline Прикладные исследования & 92010677.2 & 27202686.8 & 46841680.2 & 7900476.3 & 2582521.1 & 6199410.7 & 1283902.1 \\
\hline Разработки & 301558757.2 & 18257327.8 & 278913811.0 & 1183179.7 & 1539065.8 & 1478898.0 & 186474.9 \\
\hline & & & 2012 & & & & \\
\hline \multicolumn{7}{|l|}{ Внутренние текущие затраты } & 9808263.0 \\
\hline Фундаментальные исследования & 108160904.7 & 62038278.0 & 20496211.5 & 7623680.5 & 4587407.0 & 6563320.3 & 6852007.4 \\
\hline Прикладные исследования & 129304402.1 & 32656475.6 & 69302228.8 & 10852676.9 & 4503917.6 & 9824213.5 & 2164889.7 \\
\hline Разработки & 417596436.6 & 24249337.4 & 386679933.6 & 1766419.3 & 1764134.1 & 2345246.3 & 791365.9 \\
\hline
\end{tabular}


(окончание)

\begin{tabular}{|c|c|c|c|c|c|c|c|}
\hline & Всего & $\begin{array}{c}\text { Естественные } \\
\text { науки }\end{array}$ & $\begin{array}{l}\text { Технические } \\
\text { науки }\end{array}$ & $\begin{array}{l}\text { Медицинские } \\
\text { науки }\end{array}$ & $\begin{array}{c}\text { Сельскохозяйст- } \\
\text { венные науки }\end{array}$ & $\begin{array}{l}\text { Общественные } \\
\text { науки }\end{array}$ & $\begin{array}{c}\text { Гуманитарные } \\
\text { науки }\end{array}$ \\
\hline \multicolumn{8}{|c|}{2013} \\
\hline \multicolumn{8}{|l|}{ Внутренние текущие затраты } \\
\hline на исследования и разработки & 699948879.0 & 124384149.8 & 511559101.0 & 21833262.2 & 11504657.6 & 20769449.3 & 9898259.1 \\
\hline Фундаментальные исследования & 114829117.8 & 62710077.9 & 22645513.3 & 9046385.0 & 4845910.5 & 8500037.6 & 7081193.5 \\
\hline Прикладные исследования & 133787976.7 & 36709680.9 & 69787265.9 & 10611446.9 & 4651482.5 & 9865521.3 & 2162579.2 \\
\hline Разработки & 451331784.5 & 24964391.0 & 419126321.8 & 2175430.3 & 2007264.6 & 2403890.4 & 654486.4 \\
\hline \multicolumn{8}{|c|}{2014} \\
\hline \multicolumn{8}{|l|}{ Внутренние текущие затраты } \\
\hline на исследования и разработки & 795407850.6 & 144536189.4 & 578160024.6 & 25016451.2 & 13156185.8 & 22959524.1 & 11579475.5 \\
\hline Фундаментальные исследования & 130618045.6 & 72493481.3 & 22849372.1 & 10263113.4 & 7535996.1 & 9379368.0 & 8096714.7 \\
\hline Прикладные исследования & 155231401.5 & 41403579.4 & 84622052.5 & 12393369.8 & 3703331.5 & 10613069.7 & 2495998.6 \\
\hline Разработки & 509558403.5 & 30639128.7 & 470688600.0 & 2359968.0 & 1916858.2 & 2967086.4 & 986762.2 \\
\hline \multicolumn{8}{|c|}{2015} \\
\hline $\begin{array}{l}\text { Внутренние текущие затраты } \\
\text { на исследования и разработки }\end{array}$ & 854288043.8 & 148980051.6 & 624144576.7 & 29945902.1 & 13664068.9 & 23961543.0 & 13591901.5 \\
\hline Фундаментальные исследования & 132064934.3 & 75057491.5 & 20557380.6 & 9996433.7 & 8047617.4 & 9160226.3 & 9245784.8 \\
\hline Прикладные исследования & 169654641.2 & 43503918.7 & 90396242.3 & 16630952.5 & 3699011.9 & 12207246.2 & 3217269.6 \\
\hline Разработки & 552568468.3 & 30418641.4 & 513190953.8 & 3318515.9 & 1917439.6 & 2594070.5 & 1128847.1 \\
\hline
\end{tabular}




\subsection{2. СТРУКТУРА ВНУТРЕННИХ ТЕКУЩИХ ЗАТРАТ НА ИССЛЕДОВАНИЯ И РАЗРАБОТКИ ПО ВИДАМ РАБОТ}

\section{Проценты}

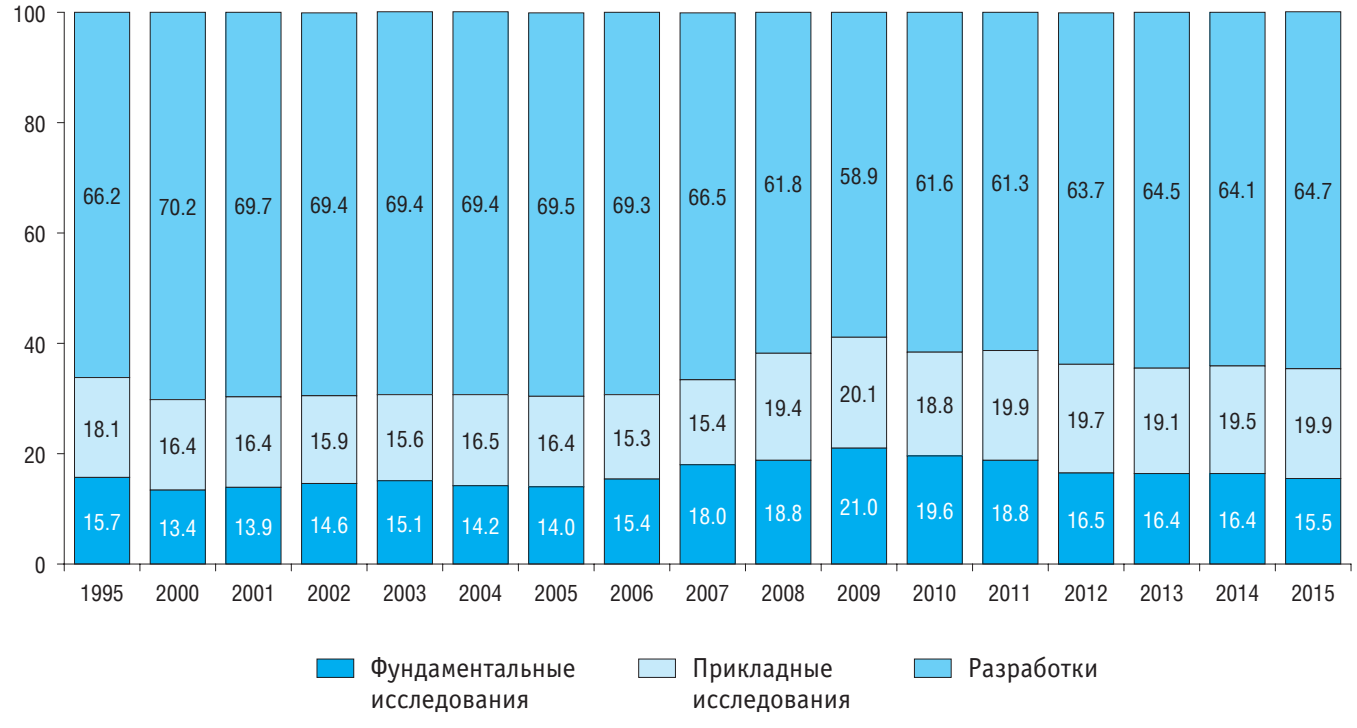




\subsection{3. ВНУТРЕННИЕ ТЕКУЩИЕ ЗАТРАТЫ НА ИССЛЕДОВАНИЯ И РАЗРАБОТКИ ПО ВИДАМ РАБОТ}

В ПРОЦЕНТАХ К ВАЛОВОМУ ВНУТРЕННЕМУ ПРОДУКТУ

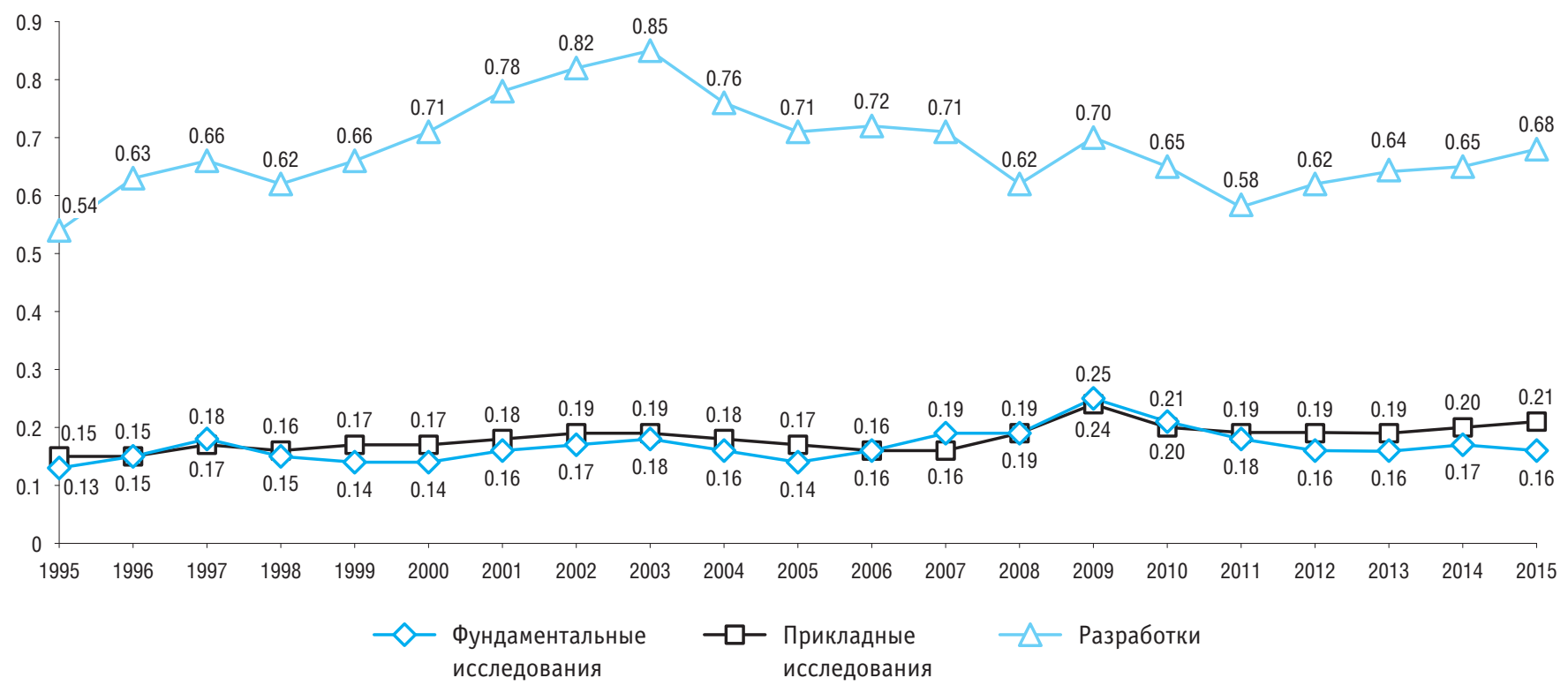




\subsection{4. СРЕДНЕМЕСЯЧНАЯ ЗАРАБОТНАЯ ПЛАТА ПЕРСОНАЛА, ЗАНЯТОГО ИССЛЕДОВАНИЯМИ И РАЗРАБОТКАМИ}

\begin{tabular}{|c|c|c|c|c|c|c|c|c|c|c|c|c|}
\hline & 1995 & 2004 & 2005 & 2007 & 2008 & 2009 & 2010 & 2011 & 2012 & 2013 & 2014 & 2015 \\
\hline $\begin{array}{l}\text { Среднемесячная заработная плата, } \\
\text { руб., } 1995 \text { г. - тыс. руб. } \\
\text { В процентах к заработной плате: }\end{array}$ & 305.3 & 6918.4 & 8672.0 & 14683.4 & 19263.3 & 22104.3 & 25043.5 & 28387.5 & 32539.9 & 35618.8 & 39549.3 & 41511.8 \\
\hline в экономике в целом (=100\%) & 64.6 & 102.7 & 101.4 & 108.0 & 111.4 & 118.6 & 119.5 & 121.5 & 122.2 & 119.6 & 121.7 & 122.2 \\
\hline $\begin{array}{l}\text { в обрабатывающих производствах } \\
(=100 \%)\end{array}$ & 67.3 & 101.0 & 103.0 & 114.0 & 120.0 & 133.3 & 131.3 & 130.3 & 132.8 & 131.7 & 134.0 & 130.4 \\
\hline в строительстве $(=100 \%)$ & 52.0 & 94.7 & 95.9 & 102.4 & 103.7 & 122.0 & 118.3 & 119.9 & 125.4 & 128.6 & 134.7 & 138.9 \\
\hline
\end{tabular}




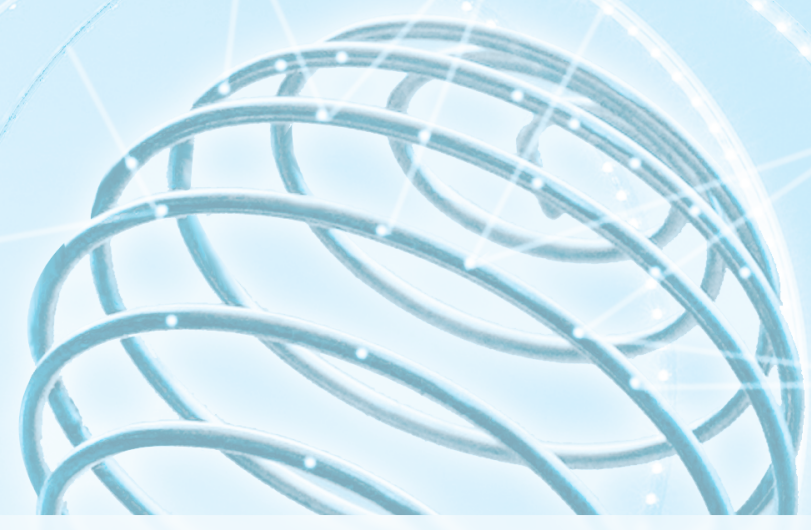

4. Материально-техническая

база науки 


\section{1. ОСНОВНЫЕ СРЕДСТВА ИССЛЕДОВАНИЙ И РАЗРАБОТОК}

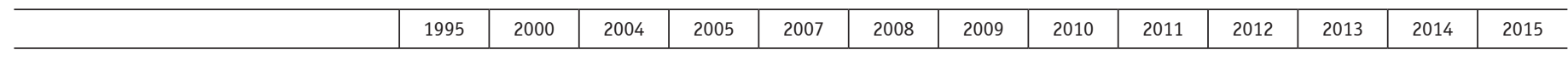

\section{В действующих ценах}

Основные средства - всего, млн руб., 1995 г. - млрд руб.

Фондовооруженность персонала, занятого исследованиями и разработками:

стоимость основных средств

исследований и разработок

в расчете на одного работника,

тыс. руб., 1995 г. - млн руб.

стоимость основных средств

исследований и разработок

в расчете на одного исследователя,

тыс. руб., 1995 г. - млн руб.

Машины и оборудование, млн руб.,

1995 г. - млрд руб.

Техновооруженность персонала, заня-

того исследованиями и разработками:

стоимость машин и оборудования

в расчете на одного работника,

тыс. руб., 1995 г. - млн руб.

стоимость машин и оборудования

в расчете на одного исследователя,

тыс. руб., 1995 2. - млн руб.

\section{Машины и оборудование в возрасте} до пяти лет, млн руб.

В процентах от общей стоимости машин и оборудования

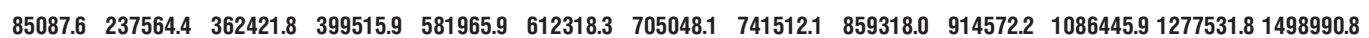

\begin{tabular}{|c|c|c|c|c|c|c|c|c|c|c|c|}
\hline 267.6 & 431.8 & 491.3 & 726.4 & 804.4 & 949.6 & 1006.8 & 1168.7 & 1259.2 & 1494.4 & 1744.6 & 2028.8 \\
\hline 557.7 & 902.8 & 1021.5 & 1481.4 & 1629.4 & 1909.5 & 2010.0 & 2292.8 & 2454.4 & 2944.2 & 3416.7 & 3950.8 \\
\hline 66938.3 & 120533.3 & 142154.7 & 196844.6 & 226391.7 & 288345.5 & 300165.9 & 348511.4 & 398562.4 & 466609.0 & 562860.4 & 676194.6 \\
\hline
\end{tabular}

\begin{tabular}{|c|c|c|c|c|c|c|c|c|c|c|c|c|}
\hline 25.0 & 75.4 & 143.6 & 174.8 & 245.7 & 297.4 & 388.4 & 407.5 & 474.0 & 548.7 & 641.8 & 768.6 & 915.2 \\
\hline 51.1 & 157.1 & 300.3 & 363.5 & 501.1 & 602.4 & 780.9 & 813.6 & 929.9 & 1069.6 & 1264.5 & 1505.4 & 1782.2 \\
\hline$\ldots$ & $\ldots$ & $\ldots$ & $\ldots$ & $\ldots$ & $\ldots$ & $\ldots$ & $\ldots$ & $\ldots$ & 169757.0 & 205062.6 & 257269.1 & 320676.7 \\
\hline$\ldots$ & $\ldots$ & $\ldots$ & $\ldots$ & $\ldots$ & $\ldots$ & $\ldots$ & $\ldots$ & $\ldots$ & 42.6 & 43.9 & 47.5 & 47.4 \\
\hline
\end{tabular}


(окончание)

\begin{tabular}{|c|c|c|c|c|c|c|c|c|c|c|c|c|c|}
\hline & 1995 & 2000 & 2004 & 2005 & 2007 & 2008 & 2009 & 2010 & 2011 & 2012 & 2013 & 2014 & 2015 \\
\hline \multicolumn{14}{|c|}{ В постоянных ценах 1995 г.* } \\
\hline $\begin{array}{l}\text { Основные средства - всего, } \\
\text { млн руб., } 1995 \text { г. - млрд руб. } \\
\text { Фондовооруженность персонала, заня- } \\
\text { того исследованиями и разработками: }\end{array}$ & 85087.6 & 46336.0 & 40589.3 & 40383.7 & 46184.1 & 40766.9 & 43302.3 & 41103.8 & 43540.6 & 43348.8 & 48950.0 & 55453.2 & 56627.7 \\
\hline $\begin{array}{l}\text { стоимость основных средств } \\
\text { исследований и разработок } \\
\text { в расчете на одного работника, } \\
\text { тыс. руб., } 1995 \text { г. - млн руб. }\end{array}$ & 80.2 & 52.2 & 48.4 & 49.7 & 57.6 & 53.6 & 58.3 & 55.8 & 59.2 & 59.7 & 67.3 & 73.3 & 76.6 \\
\hline $\begin{array}{l}\text { стоимость основных средств } \\
\text { исследований и разработок } \\
\text { в расчете на одного исследователя, } \\
\text { тыс. руб., } 1995 \text { г. - млн руб. }\end{array}$ & 164.0 & 108.8 & 101.1 & 103.3 & 117.6 & 108.6 & 117.3 & 111.4 & 116.2 & 116.3 & 132.7 & 143.5 & 149.3 \\
\hline $\begin{array}{l}\text { Машины и оборудование, млн руб., } \\
1995 \text { г. - млрд руб. }\end{array}$ & 26505.8 & 13056.0 & 13499.1 & 14369.2 & 15621.3 & 15072.7 & 17709.5 & 16638.9 & 17658.7 & 18891.0 & 21023.2 & 24431.8 & 25544.7 \\
\hline $\begin{array}{l}\text { Техновооруженность персонала, заня- } \\
\text { того исследованиями и разработками: }\end{array}$ & & & & & & & & & & & & & \\
\hline $\begin{array}{l}\text { стоимость машин и оборудования } \\
\text { в расчете на одного работника, } \\
\text { тыс. руб., } 1995 \text { г. - млн руб. }\end{array}$ & 25.0 & 14.7 & 16.1 & 17.7 & 19.5 & 19.8 & 23.9 & 22.6 & 24.0 & 26.0 & 28.9 & 33.4 & 34.6 \\
\hline $\begin{array}{l}\text { стоимость машин и оборудования } \\
\text { в расчете на одного исследователя, } \\
\text { тыс. руб., } 1995 \text { г. - млн руб. }\end{array}$ & 51.1 & 30.7 & 33.6 & 36.7 & 39.8 & 40.1 & 48.0 & 45.1 & 47.1 & 50.7 & 57.0 & 65.3 & 67.3 \\
\hline $\begin{array}{l}\text { Машины и оборудование в возрасте } \\
\text { до пяти лет, млн руб. }\end{array}$ & $\ldots$ & $\ldots$ & $\ldots$ & $\ldots$ & $\ldots$ & $\ldots$ & $\ldots$ & $\ldots$ & $\ldots$ & 8046.1 & 9239.1 & 11167.2 & 12114.3 \\
\hline
\end{tabular}

* Рассчитано по дефлятору валового накопления основного капитала. 


\section{2. ДИНАМИКА СТОИМОСТИ ОСНОВНЫХ СРЕДСТВ ИССЛЕДОВАНИЙ И РАЗРАБОТОК*}

(в постоянных ценах 1995 г.)

Проценты

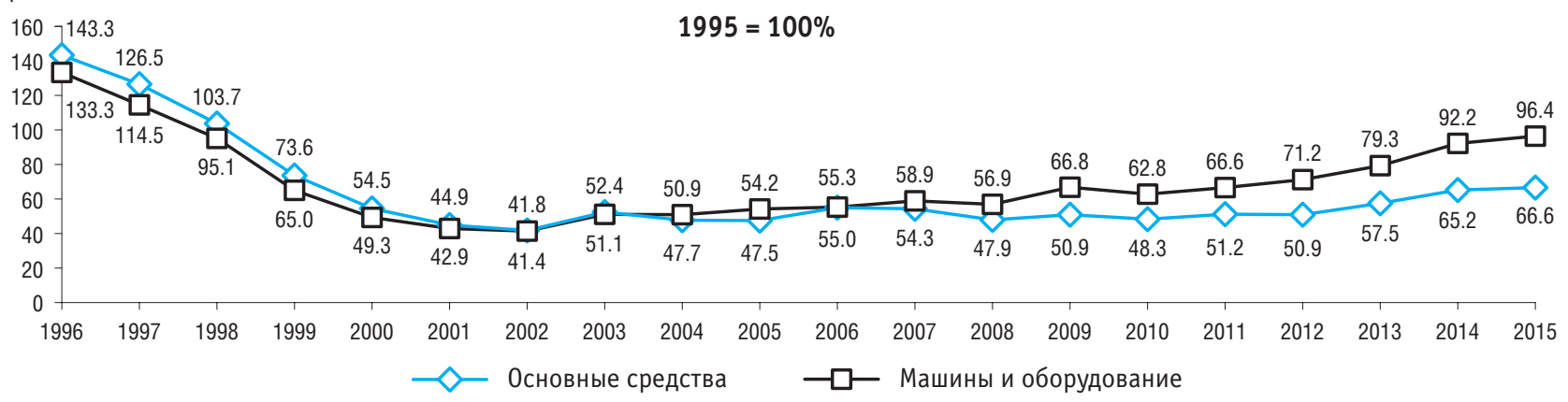

* Рассчитано по дефлятору валового накопления основного капитала.

\section{3. УДЕЛЬНЫЙ ВЕС МАШИН И ОБОРУДОВАНИЯ В ОБЩЕЙ СТОИМОСТИ ОСНОВНЫХ СРЕДСТВ ИССЛЕДОВАНИЙ И РАЗРАБОТОК}

Проценты

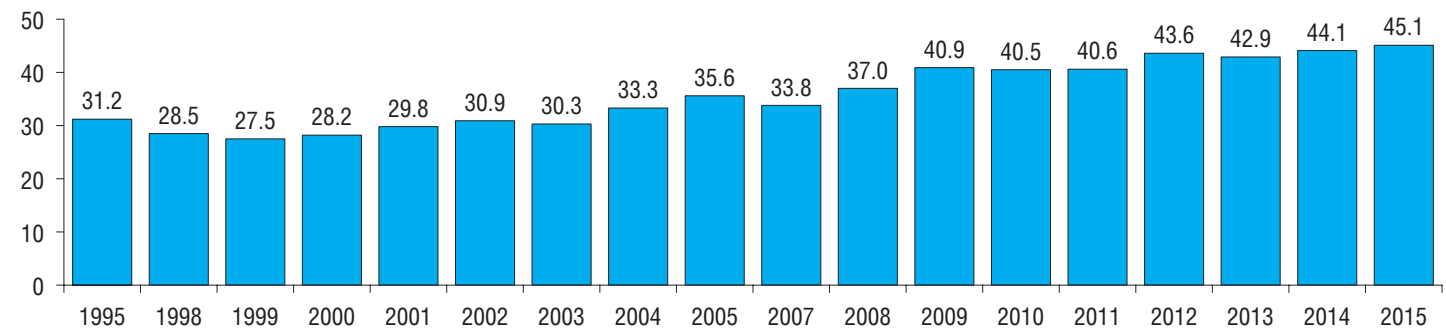




\section{4. ОСНОВНЫЕ СРЕДСТВА ИССЛЕДОВАНИЙ И РАЗРАБОТОК ПО ФОРМАМ СОБСТВЕННОСТИ ОРГАНИЗАЦИЙ \\ (миллионы рублей, 1995 г. - миллиарды рублей)}

\begin{tabular}{|c|c|c|c|c|c|c|c|c|c|c|c|c|c|}
\hline & 1995 & 2000 & 2004 & 2005 & 2007 & 2008 & 2009 & 2010 & 2011 & 2012 & 2013 & 2014 & 2015 \\
\hline \multicolumn{14}{|c|}{ Основные средства } \\
\hline Всего & 85087.6 & 237564.4 & 362421.8 & 399515.9 & 581965.9 & 612318.3 & 705048.1 & 741512.1 & 859318.0 & 914572.2 & 1086445.9 & 1235780.3 & 1498990.8 \\
\hline Российская собственность & 85081.2 & 232793.0 & 356206.2 & 393181.0 & 570760.1 & 600596.0 & 696133.5 & 725165.1 & 847942.2 & 897838.2 & 1052994.8 & 1218842.6 & 1469213.6 \\
\hline Государственная & 71686.4 & $194659.0^{*}$ & 311757.9 & 344693.4 & 504967.3 & 537366.1 & 619151.2 & 635491.6 & 736631.7 & 757157.9 & 886578.4 & 1005741.7 & 1126242.5 \\
\hline Федеральная & 70561.9 & 191972.3 & 304821.5 & 336223.9 & 486643.7 & 518920.0 & 574713.9 & 617118.2 & 712172.1 & 733671.7 & 861801.5 & 960098.3 & 1090290.3 \\
\hline $\begin{array}{l}\text { Субъектов Российской } \\
\text { Федерации }\end{array}$ & 1124.5 & 2686.3 & 6936.4 & 8469.5 & 17526.8 & 17479.4 & 43454.1 & 18110.1 & 24452.1 & 23477.9 & 24776.9 & 45643.4 & 35952.3 \\
\hline Муниципальная & 190.0 & 541.7 & 3.9 & 28.2 & 32.9 & 34.7 & 40.7 & 35.9 & 74.7 & 17.3 & 53.0 & 38.0 & 104.4 \\
\hline Общественных организаций & 77.5 & 221.8 & 34.1 & 38.9 & 90.0 & 85.4 & 82.4 & 82.1 & 98.7 & 164.4 & 372.6 & 495.7 & 832.5 \\
\hline Частная & 1306.4 & 10499.1 & 10468.3 & 17478.8 & 25338.8 & 26957.6 & 30709.8 & 43615.5 & 49833.4 & 56938.0 & 64420.2 & 80213.8 & 107275.4 \\
\hline \multicolumn{14}{|l|}{$\begin{array}{l}\text { Собственность российских } \\
\text { граждан, постоянно проживающих }\end{array}$} \\
\hline 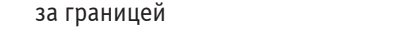 & $\ldots$ & $\ldots$ & $\ldots$ & $\ldots$ & $\ldots$ & $\ldots$ & $\ldots$ & $\ldots$ & 18.1 & 17.0 & $\ldots{ }^{* \star *}$ & $\ldots{ }^{\star \star *}$ & $\ldots{ }^{* * *}$ \\
\hline Потребительской кооперации ** & & 0.09 & 1.0 & 0.9 & 0.9 & 0.9 & 1.6 & 1.7 & 5.5 & - & - & $\ldots * * *$ & 28.9 \\
\hline Смешанная & 11820.9 & 26871.3 & 33941.0 & 30940.7 & 40330.3 & 36151.4 & 46147.9 & 42862.9 & 52606.5 & 59170.5 & 68104.5 & 93511.6 & 157314.6 \\
\hline $\begin{array}{l}\text { Смешанная с долей государ- } \\
\text { ственной собственности }\end{array}$ & $\ldots$ & $\ldots$ & $\ldots$ & $\ldots$ & $\ldots$ & $\ldots$ & $\ldots$ & 38571.0 & 47524.3 & 47722.7 & 56261.7 & 72454.4 & 117386.6 \\
\hline Иная смешанная & $\ldots$ & $\ldots$ & $\ldots$ & $\ldots$ & $\ldots$ & $\ldots$ & $\ldots$ & $\ldots$ & 5082.1 & 11447.8 & 11842.7 & 21057.3 & 39928.0 \\
\hline Государственных корпораций & $\ldots$ & $\ldots$ & $\ldots$ & $\ldots$ & $\ldots$ & $\ldots$ & $\ldots$ & 3075.4 & 8673.7 & 24373.1 & 33451.8 & 38817.0 & 77404.6 \\
\hline Иностранная собственность & 0.04 & 49.0 & 75.5 & 114.9 & 225.1 & 216.2 & 124.3 & 1131.5 & 1063.7 & 1177.8 & 3064.9 & 2571.1 & 6198.6 \\
\hline $\begin{array}{l}\text { Совместная российская и иностран- } \\
\text { ная собственность }\end{array}$ & 6.4 & 4722.4 & 6140.1 & 6220.1 & 10980.6 & 11506.0 & 8790.3 & 15215.5 & 10312.1 & 15556.2 & 30386.2 & 14366.6 & 23578.6 \\
\hline
\end{tabular}


(окончание)

\begin{tabular}{|c|c|c|c|c|c|c|c|c|c|c|c|c|c|}
\hline & 1995 & 2000 & 2004 & 2005 & 2007 & 2008 & 2009 & 2010 & 2011 & 2012 & 2013 & 2014 & 2015 \\
\hline \multicolumn{14}{|c|}{ Машины и оборудование } \\
\hline Всего & 26505.8 & 66938.3 & 120533.3 & 142154.7 & 196844.6 & 226391.7 & 288345.5 & 300165.9 & 348511.4 & 398562.4 & 466609.0 & 541617.9 & 676194.6 \\
\hline Российская собственность & 26503.0 & 65631.5 & 118511.7 & 140294.5 & 191984.4 & 221221.1 & 283264.4 & 290440.4 & 341846.2 & 390464.6 & 457596.7 & 533892.2 & 659628.5 \\
\hline Государственная & 21632.0 & $53434.4^{*}$ & 102288.6 & 121662.2 & 164900.6 & 194059.9 & 250646.7 & 256172.4 & 293528.4 & 332053.6 & 382612.7 & 433814.9 & 503877.8 \\
\hline Федеральная & 21340.3 & 52750.5 & 98656.7 & 117529.4 & 156807.8 & 185556.4 & 215954.3 & 248766.8 & 284876.3 & 323644.7 & 371352.8 & 422330.3 & 487747.4 \\
\hline Субъектов Рос & & 835 & 9 & 8 & 80385 & 1 & & 9 & 6 & & 112 & & 30.4 \\
\hline $\begin{array}{c}\text { Федерации } \\
\text { Муниципальная }\end{array}$ & 113.0 & 176.0 & 2.8 & 4.7 & 7.6 & 11.3 & 25.5 & 6.2 & $\begin{array}{r}8040.0 \\
17.0\end{array}$ & $\begin{array}{r}8401.9 \\
4.4\end{array}$ & $\begin{array}{r}11259.9 \\
6.7\end{array}$ & $\begin{array}{r}34.6 \\
7.2\end{array}$ & $\begin{array}{l}30.4 \\
26.0\end{array}$ \\
\hline Общественных организаций & 32.3 & 41.6 & 20.2 & 20.4 & 61.7 & 56.2 & 47.0 & 49.5 & 69.9 & 62.6 & 98.2 & 134.7 & 209.1 \\
\hline Частная & 353.5 & 4235.7 & 4297.6 & 8094.0 & 10656.1 & 12278.4 & 15307.8 & 17150.5 & 22907.4 & 26610.2 & 30837.6 & 41712.6 & 50474.8 \\
\hline \multicolumn{14}{|l|}{$\begin{array}{l}\text { Собственность российских } \\
\text { граждан, постоянно проживающих } \\
\text { за гранищей }\end{array}$} \\
\hline Потребительской кооперации ** & $\ldots$ & 0.09 & 0.2 & 0.2 & 0.2 & 0.2 & 0.9 & 1.0 & 4.2 & - & - & $\ldots{ }^{* \star *}$ & 7.0 \\
\hline Смешанная & 4372.2 & 7743.7 & 11902.3 & 10513.1 & 16358.2 & 14815.2 & 17236.5 & 15944.0 & 21883.9 & 22090.9 & 30297.8 & 41440.4 & 70093.0 \\
\hline $\begin{array}{l}\text { Смешанная с долей государ- } \\
\text { ственной собственности }\end{array}$ & $\ldots$ & $\cdots$ & $\cdots$ & $\cdots$ & $\cdots$ & $\cdots$ & $\ldots$ & 13870.9 & 19476.7 & 16689.3 & 25209.2 & 31476.5 & 52907.6 \\
\hline Иная смешанная & $\ldots$ & $\ldots$ & $\ldots$ & $\ldots$ & $\ldots$ & $\ldots$ & $\ldots$ & $\ldots$ & 2407.1 & 5401.6 & 5088.6 & 9964.0 & 17185.5 \\
\hline Государственных корпораций & $\ldots$ & $\ldots$ & $\cdots$ & $\ldots$ & $\ldots$ & $\ldots$ & $\ldots$ & 1116.7 & 3418.5 & 9627.0 & 13730.4 & 16767.1 & 34931.1 \\
\hline Иностранная собственность & 0.03 & 48.2 & 57.2 & 61.0 & 128.3 & 119.6 & 83.7 & 630.0 & 611.0 & 438.0 & 668.9 & 975.0 & 2958.5 \\
\hline $\begin{array}{l}\text { Совместная российская и иностран- } \\
\text { ная собственность }\end{array}$ & 2.8 & 1258.6 & 1964.4 & 1792.2 & 4731.9 & 5050.9 & 4997.4 & 9095.5 & 6054.2 & 7659.8 & 8343.4 & 6750.7 & 13607.6 \\
\hline
\end{tabular}

* Расхождение итогов с суммой слагаемых объясняется наличием у ряда организаций долевой собственности.

** До 2000 г. учитывалась в составе организаций частной и смешанной российской собственности.

*** Данные не публикуются в целях обеспечения конфиденциальности первичных статистических данных, полученных от организаций, в соответствии с Федеральным законом от 29.11.2007 № 282-Ф3 «0б официальном статистическом учете и системе государственной статистики в Российской Федерации» (ст. 4, п. 5; ст. 9, п. 1). 
4.5. СТРУКТУРА ОСНОВНЫХ СРЕДСТВ ИССЛЕДОВАНИЙ И РАЗРАБОТОК ПО ФОРМАМ СОБСТВЕННОСТИ ОРГАНИЗАЦИЙ (проценты)
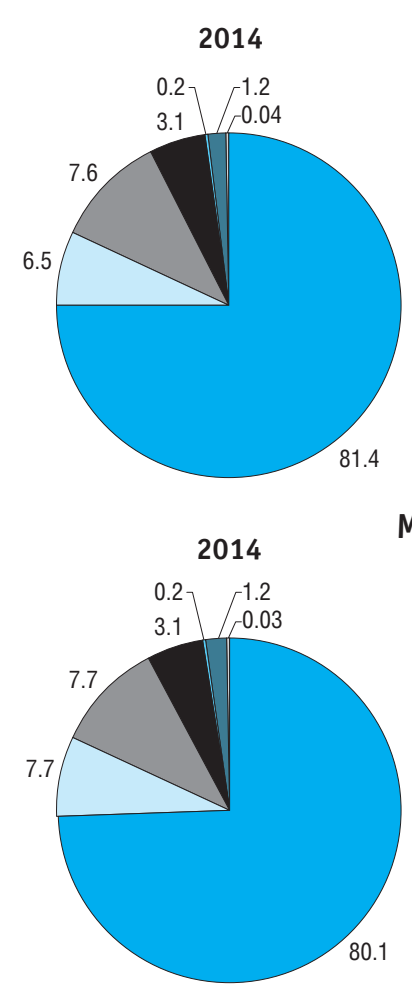

\section{Основные средства}

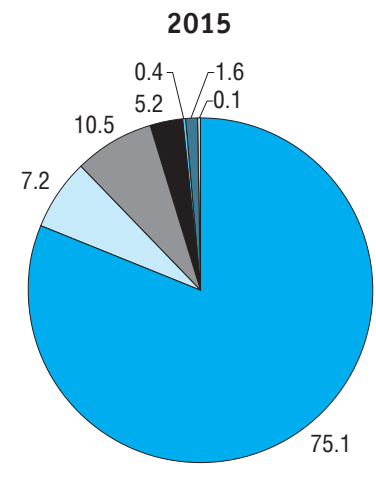

Машины и оборудование

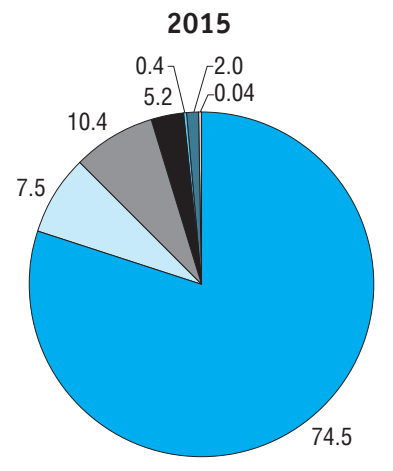

Формы собственности:

$\square$ государственная

$\square$ частная

$\square$ смешанная

— государственных корпораций

$\square$ иностранная

$\square$ совместная российская и иностранная

$\square$ прочие 


\section{6. ОСНОВНЫЕ СРЕДСТВА ИССЛЕДОВАНИЙ И РАЗРАБОТОК ПО ВИДАМ ЭКОНОМИЧЕСКОЙ ДЕЯТЕЛЬНОСТИ (миллионы рублей)}

\begin{tabular}{|c|c|c|c|c|c|c|}
\hline & \multicolumn{3}{|c|}{ Основные средства } & \multicolumn{3}{|c|}{ Машины и оборудование } \\
\hline & 2013 & 2014 & 2015 & 2013 & 2014 & 2015 \\
\hline Всего & 1086445.9 & 1235780.3 & 1498990.8 & 466609.0 & 541617.9 & 676194.6 \\
\hline Сельское хозяйство, охота и лесное хозяйство & 846.9 & 1389.8 & 1239.0 & 164.6 & 323.2 & 346.6 \\
\hline Рыбоводство, рыболовство и предоставление услуг в этих областях & - & - & - & - & - & - \\
\hline Добыча полезных ископаемых & 12.5 & - & 347.4 & 10.4 & - & 220.2 \\
\hline Обрабатывающие производства & 65763.2 & 82216.7 & 168166.4 & 31652.9 & 41598.8 & 83071.8 \\
\hline Производство и распределение электроэнергии, газа и воды & - & $\ldots{ }^{*}$ & 735.5 & - & $\ldots{ }^{*}$ & 98.8 \\
\hline Строительство &..${ }^{*}$ & $\ldots{ }^{*}$ & $\ldots{ }^{*}$ &..$^{*}$ &..$^{*}$ & ... $^{*}$ \\
\hline Гостиницы и рестораны & $\ldots^{*}$ & - & - & $\ldots{ }^{*}$ & - & - \\
\hline $\begin{array}{l}\text { Оптовая и розничная торговля, ремонт автотранспортных средств, мотоциклов, } \\
\text { бытовых изделий и предметов личного пользования }\end{array}$ & - & - & $\ldots^{*}$ & - & - & $\ldots{ }^{*}$ \\
\hline Транспорт и связь & 636.9 & 688.4 & 243.2 & 329.8 & 345.6 & 164.5 \\
\hline $\begin{array}{l}\text { Операции с недвижимым имуществом, аренда и предоставление услуг } \\
\text { Из них: }\end{array}$ & 849363.9 & 965527.1 & 1095270.3 & 364450.3 & 425416.3 & 494779.2 \\
\hline научные исследования и разработки & 830424.8 & 946522.9 & 1075073.9 & 357486.9 & 418474.8 & 483186.2 \\
\hline предоставление прочих видов услуг & 12077.8 & 11830.5 & 14757.6 & 4508.0 & 4258.4 & 8382.7 \\
\hline Образование & 142890.6 & 158770.1 & 205562.2 & 58534.9 & 62501.3 & 86336.6 \\
\hline Из него высшее образование & 142757.2 & 158691.5 & 205499.4 & 58514.6 & 62488.2 & 86319.6 \\
\hline Здравоохранение и предоставление социальных услуг & 22045.5 & 23652.8 & 23371.1 & 9594.6 & 10882.5 & 10340.0 \\
\hline Предоставление прочих коммунальных, социальных и персональных услуг & 3365.5 & 3483.6 & 3124.5 & 407.0 & 511.2 & 433.4 \\
\hline Из них деятельность по организации отдыха и развлечений, культуры и спорта & 3355.5 & 3481.2 & 3105.3 & 399.6 & 508.8 & 415.4 \\
\hline
\end{tabular}

* Данные не публикуются в целях обеспечения конфиденциальности первичных статистических данных, полученных от организаций, в соответствии с Федеральным законом от 29.11.2007 № 282-Ф3 «0б официальном статистическом учете и системе государственной статистики в Российской Федерации» (ст. 4, п. 5; ст. 9, п. 1). 


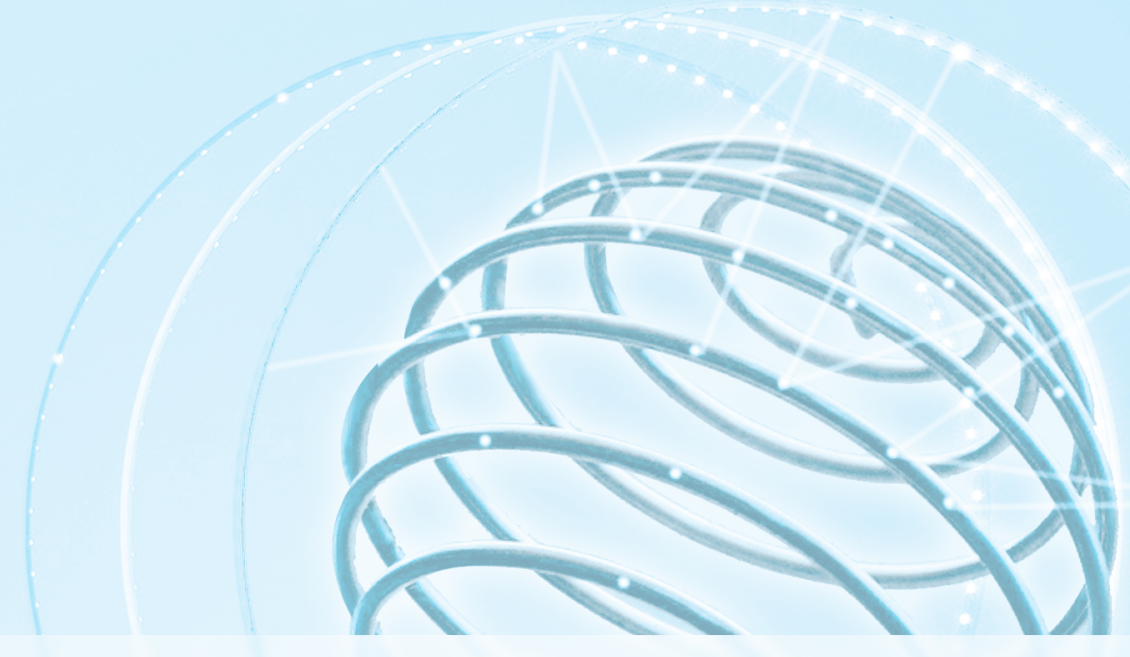

5. Секторы науки 


\section{1. Сводные показатели}

5.1.1. ОРГАНИЗАЦИИ, ВЫПОЛНЯВШИЕ ИССЛЕДОВАНИЯ И РАЗРАБОТКИ, ПО СЕКТОРАМ НАУКИ

\begin{tabular}{|c|c|c|c|c|c|}
\hline & Всего & $\begin{array}{c}\text { Государственный } \\
\text { сектор }\end{array}$ & $\begin{array}{c}\text { Предпринимательский } \\
\text { сектор }\end{array}$ & $\begin{array}{c}\text { Сектор высшего } \\
\text { образования }\end{array}$ & $\begin{array}{c}\text { Сектор некоммерческих } \\
\text { организаций }\end{array}$ \\
\hline 1995 & 4059 & 1193 & 2345 & 511 & 10 \\
\hline 2000 & 4099 & 1247 & 2278 & 526 & 48 \\
\hline 2002 & 3906 & 1218 & 2110 & 531 & 47 \\
\hline 2003 & 3797 & 1233 & 1990 & 526 & 48 \\
\hline 2004 & 3656 & 1230 & 1851 & 533 & 42 \\
\hline 2005 & 3566 & 1282 & 1703 & 539 & 42 \\
\hline 2006 & 3622 & 1341 & 1682 & 540 & 59 \\
\hline 2007 & 3957 & 1483 & 1742 & 616 & 116 \\
\hline 2008 & 3666 & 1429 & 1540 & 603 & 94 \\
\hline 2009 & 3536 & 1406 & 1446 & 603 & 81 \\
\hline 2010 & 3492 & 1400 & 1405 & 617 & 70 \\
\hline 2011 & 3682 & 1457 & 1450 & 696 & 79 \\
\hline 2012 & 3566 & 1465 & 1362 & 662 & 77 \\
\hline 2013 & 3605 & 1495 & 1269 & 762 & 79 \\
\hline 2014 & 3604 & 1491 & 1265 & 777 & 71 \\
\hline 2015 & 4175 & 1560 & 1400 & 1124 & 91 \\
\hline
\end{tabular}


5.1.2. СТРУКТУРА ОРГАНИЗАЦИЙ, ВЫПОЛНЯВШИХ ИССЛЕДОВАНИЯ И РАЗРАБОТКИ, ПО СЕКТОРАМ НАУКИ (проченты)
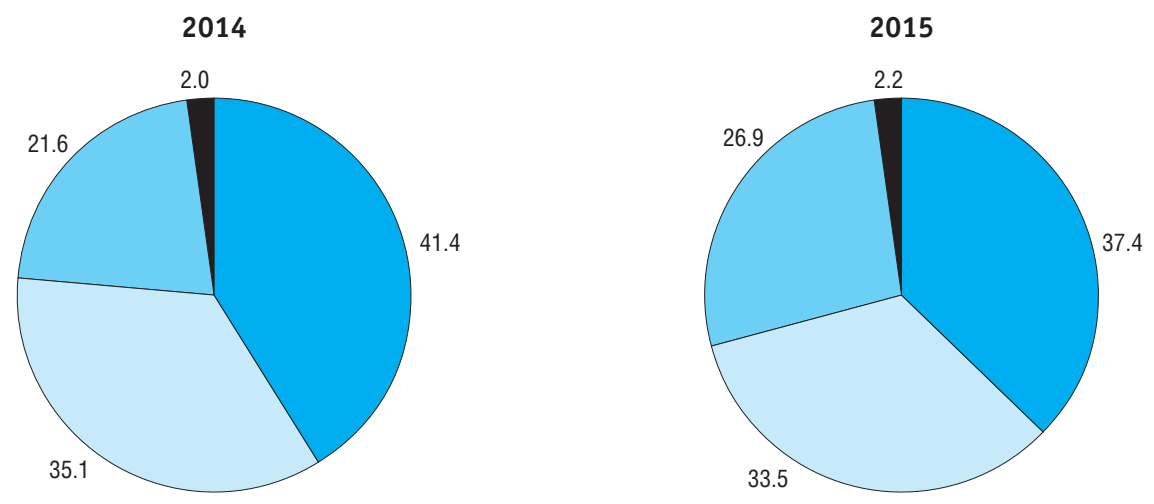

Секторы науки:

$\square$ государственный

$\square$ высшего образования

$\square$ предпринимательский

- некоммерческих организаций

\section{3}




\subsection{3. ПЕРСОНАЛ, ЗАНЯТЫЙ ИССЛЕДОВАНИЯМИ И РАЗРАБОТКАМИ, ПО СЕКТОРАМ НАУКИ И КАТЕГОРИЯМ} (человек)

\begin{tabular}{|c|c|c|c|c|c|c|c|c|c|c|c|c|c|}
\hline & 1995 & 2000 & 2005 & 2006 & 2007 & 2008 & 2009 & 2010 & 2011 & 2012 & 2013 & 2014 & 2015 \\
\hline Всего & 1061044 & 887729 & 813207 & 807066 & 801135 & 761252 & 742433 & 736540 & 735273 & 726318 & 727029 & 732274 & 738857 \\
\hline Исследователи & 518690 & 425954 & 391121 & 388939 & 392849 & 375804 & 369237 & 368915 & 374746 & 372620 & 369015 & 373905 & 379411 \\
\hline Техники & 101371 & 75184 & 65982 & 66031 & 64569 & 60218 & 60045 & 59276 & 61562 & 58905 & 61401 & 63168 & 62805 \\
\hline Вспомогательный персонал & 274925 & 240506 & 215555 & 213579 & 208052 & 194769 & 186995 & 183713 & 178494 & 175790 & 175365 & 173554 & 174056 \\
\hline Прочие & 166058 & 146085 & 140549 & 138517 & 135665 & 130461 & 126156 & 124636 & 120471 & 119003 & 121248 & 121647 & 122585 \\
\hline Государственный сектор & 282166 & 255850 & 272718 & 274802 & 272255 & 260854 & 260360 & 259007 & 254896 & 271466 & 261869 & 263712 & 265429 \\
\hline Исследователи & 146342 & 129725 & 139378 & 138728 & 138169 & 132261 & 132955 & 131734 & 128672 & 136442 & 132117 & 132701 & 134794 \\
\hline Техники & 27178 & 25085 & 25462 & 25667 & 26545 & 24531 & 24554 & 24009 & 26960 & 28094 & 27777 & 27761 & 27090 \\
\hline Вспомогательный персонал & 66226 & 59706 & 61448 & 62482 & 61031 & 58591 & 56846 & 56530 & 54176 & 60067 & 56795 & 56744 & 56552 \\
\hline Прочие & 42420 & 41334 & 46430 & 47925 & 46510 & 45471 & 46005 & 46734 & 45088 & 46863 & 45180 & 46506 & 46993 \\
\hline Предпринимательский сектор & 726568 & 590646 & 496706 & 486613 & 478401 & 451532 & 432415 & 423112 & 419752 & 394182 & 405268 & 405529 & 408802 \\
\hline Исследователи & 336671 & 267640 & 221445 & 218702 & 219632 & 209579 & 201668 & 197785 & 202185 & 192285 & 193736 & 196320 & 198123 \\
\hline Техники & 70180 & 46535 & 36837 & 36315 & 33340 & 31230 & 30613 & 30063 & 28235 & 26720 & 28920 & 29452 & 29850 \\
\hline Вспомогательный персонал & 201122 & 175261 & 147980 & 144966 & 140507 & 129496 & 123814 & 120485 & 116829 & 106306 & 109691 & 107215 & 108230 \\
\hline Прочие & 118595 & 101210 & 90444 & 86630 & 84922 & 81227 & 76320 & 74779 & 72503 & 68871 & 72921 & 72542 & 72599 \\
\hline Сектор высшего образования & 52065 & 40787 & 43500 & 44473 & 49059 & 47595 & 48498 & 53290 & 59454 & 59469 & 59247 & 62400 & 63870 \\
\hline Исследователи & 35508 & 28325 & 30111 & 30793 & 34162 & 33160 & 33847 & 38640 & 43121 & 43103 & 42692 & 44427 & 45967 \\
\hline Техники & 4010 & 3509 & 3658 & 3972 & 4606 & 4349 & 4778 & 5095 & 6256 & 3998 & 4670 & 5939 & 5836 \\
\hline Вспомогательный персонал & 7520 & 5463 & 6098 & 5945 & 6282 & 6520 & 6198 & 6564 & 7345 & 9264 & 8828 & 9538 & 9217 \\
\hline Прочие & 5027 & 3490 & 3633 & 3763 & 4009 & 3566 & 3675 & 2991 & 2732 & 3104 & 3057 & 2496 & 2850 \\
\hline Сектор некоммерческих организаций & 245 & 446 & 283 & 1178 & 1420 & 1271 & 1160 & 1131 & 1171 & 1201 & 645 & 633 & 756 \\
\hline Исследователи & 169 & 264 & 187 & 716 & 886 & 804 & 767 & 756 & 768 & 790 & 470 & 457 & 527 \\
\hline Техники & 3 & 55 & 25 & 77 & 78 & 108 & 100 & 109 & 111 & 93 & 34 & 16 & 29 \\
\hline Вспомогательный персонал & 57 & 76 & 29 & 186 & 232 & 162 & 137 & 134 & 144 & 153 & 51 & 57 & 57 \\
\hline Прочие & 16 & 51 & 42 & 199 & 224 & 197 & 156 & 132 & 148 & 165 & 90 & 103 & 143 \\
\hline
\end{tabular}




\subsection{4. ПЕРСОНАЛ, ЗАНЯТЫЙ ИССЛЕДОВАНИЯМИ И РАЗРАБОТКАМИ, ПО СЕКТОРАМ НАУКИ И УРОВНЮ ОБРАЗОВАНИЯ}

(человек)

\begin{tabular}{|c|c|c|c|c|c|}
\hline & Всего & $\begin{array}{l}\text { Государственный } \\
\text { сектор }\end{array}$ & $\begin{array}{l}\text { Предпринимательский } \\
\text { сектор }\end{array}$ & $\begin{array}{l}\text { Сектор высшего } \\
\text { образования }\end{array}$ & $\begin{array}{c}\text { Сектор некоммерческих } \\
\text { организаций }\end{array}$ \\
\hline \multicolumn{6}{|c|}{$\begin{array}{l}\text { Персонал, занятый исследованиями } \\
\text { и разработками }\end{array}$} \\
\hline 2005 & 813207 & 272718 & 496706 & 43500 & 283 \\
\hline 2012 & 726318 & 271466 & 394182 & 59469 & 1201 \\
\hline 2013 & 727029 & 261869 & 405268 & 59247 & 645 \\
\hline 2014 & 732274 & 263712 & 405529 & 62400 & 633 \\
\hline 2015 & 738857 & 265429 & 408802 & 63870 & 756 \\
\hline \multicolumn{6}{|c|}{ Высшее образование } \\
\hline 2005 & 501718 & 177676 & 288649 & 35159 & 234 \\
\hline 2012 & 508057 & 191193 & 263555 & 52334 & 975 \\
\hline 2013 & 512017 & 187058 & 271434 & 52927 & 598 \\
\hline 2014 & 522726 & 189447 & 276675 & 56009 & 595 \\
\hline 2015 & 537118 & 194608 & 283664 & 58144 & 702 \\
\hline \multicolumn{6}{|c|}{ Среднее профессиональное образование } \\
\hline 2005 & 134222 & 40495 & 89265 & 4430 & 32 \\
\hline 2012 & 99503 & 35958 & 60764 & 2673 & 108 \\
\hline 2013 & 97867 & 33629 & 61575 & 2625 & 38 \\
\hline 2014 & 95564 & 33699 & 59564 & 2274 & 27 \\
\hline 2015 & 95640 & 33163 & 60370 & 2071 & 36 \\
\hline \multicolumn{6}{|c|}{ Прочее образование } \\
\hline 2005 & 177267 & 54547 & 118792 & 3911 & 17 \\
\hline 2012 & 118758 & 44315 & 69863 & 4462 & 118 \\
\hline 2013 & 117145 & 41182 & 72259 & 3695 & 9 \\
\hline 2014 & 113984 & 40566 & 69290 & 4117 & 11 \\
\hline 2015 & 106099 & 37658 & 64768 & 3655 & 18 \\
\hline
\end{tabular}


5.1.5. ИССЛЕДОВАТЕЛИ С УЧЕНЫМИ СТЕПЕНЯМИ ПО СЕКТОРАМ НАУКИ (человек)

\begin{tabular}{|c|c|c|c|c|c|c|c|c|c|c|c|c|c|}
\hline & 1995 & 2000 & 2005 & 2006 & 2007 & 2008 & 2009 & 2010 & 2011 & 2012 & 2013 & 2014 & 2015 \\
\hline Исследователи с учеными степенями & 116465 & 105911 & 99428 & 99507 & 103725 & 101049 & 101275 & 105114 & 109493 & 109330 & 108248 & 109598 & 111533 \\
\hline Доктора наук & 19330 & 21949 & 23410 & 23880 & 25213 & 25140 & 25295 & 26789 & 27675 & 27784 & 27485 & 27969 & 28046 \\
\hline Кандидаты наук & 97135 & 83962 & 76018 & 75627 & 78512 & 75909 & 75980 & 78325 & 81818 & 81546 & 80763 & 81629 & 83487 \\
\hline Государственный сектор & 61062 & 58901 & 60066 & 60054 & 61707 & 60369 & 61309 & 61194 & 61605 & 63092 & 62837 & 62944 & 63906 \\
\hline Доктора наук & 13358 & 14987 & 16511 & 16766 & 17415 & 17326 & 17554 & 17646 & 17789 & 18181 & 18184 & 18198 & 18264 \\
\hline Кандидаты наук & 47704 & 43914 & 43555 & 43288 & 44292 & 43043 & 43755 & 43548 & 43816 & 44911 & 44653 & 44746 & 45642 \\
\hline Предпринимательский сектор & 41207 & 34775 & 26661 & 25958 & 26257 & 24844 & 23861 & 23169 & 23045 & 21758 & 20955 & 20595 & 20270 \\
\hline Доктора наук & 4348 & 4806 & 4222 & 4108 & 4446 & 4284 & 4093 & 3987 & 4018 & 3767 & 3622 & 3511 & 3413 \\
\hline Кандидаты наук & 36859 & 29969 & 22439 & 21850 & 21811 & 20560 & 19768 & 19182 & 19027 & 17991 & 17333 & 17084 & 16857 \\
\hline Сектор высшего образования & 14162 & 12113 & 12618 & 13153 & 15330 & 15479 & 15774 & 20423 & 24502 & 24144 & 24306 & 25899 & 27184 \\
\hline Доктора наук & 1617 & 2120 & 2654 & 2924 & 3252 & 3439 & 3568 & 5068 & 5774 & 5753 & 5638 & 6218 & 6318 \\
\hline Кандидаты наук & 12545 & 9993 & 9964 & 10229 & 12078 & 12040 & 12206 & 15355 & 18728 & 18391 & 18668 & 19681 & 20866 \\
\hline Сектор некоммерческих организаций & 34 & 122 & 83 & 342 & 431 & 357 & 331 & 328 & 341 & 336 & 150 & 160 & 173 \\
\hline Доктора наук & 7 & 36 & 23 & 82 & 100 & 91 & 80 & 88 & 94 & 83 & 41 & 42 & 51 \\
\hline Кандидаты наук & 27 & 86 & 60 & 260 & 331 & 266 & 251 & 240 & 247 & 253 & 109 & 118 & 122 \\
\hline
\end{tabular}




\subsection{6. СТРУКТУРА ИССЛЕДОВАТЕЛЕЙ С УЧЕНЫМИ СТЕПЕНЯМИ ПО СЕКТОРАМ НАУКИ}

(проценты)

\section{Доктора наук}

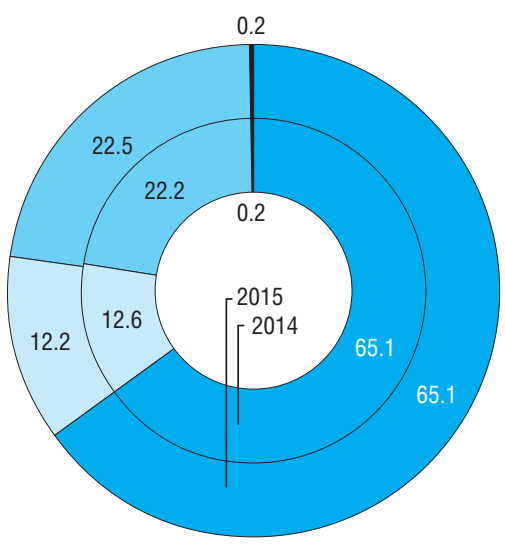

Кандидаты наук

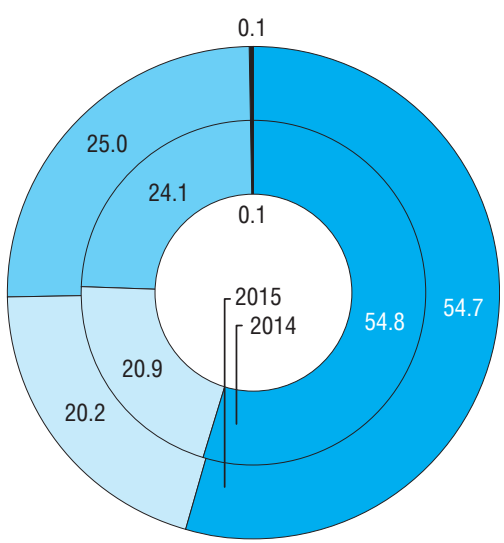

Секторы науки:

$\square$ государственный

$\square$ предпринимательский высшего образования

некоммерческих организаций 
5.1.7. ИССЛЕДОВАТЕЛИ, НАПРАВЛЕННЫЕ НА РАБОТУ (СТАЖИРОВКУ) В ЗАРУБЕЖНЫЕ НАУЧНЫЕ ОРГАНИЗАЦИИ, ПО СЕКТОРАМ НАУКИ: 2015

\begin{tabular}{|c|c|c|c|c|}
\hline & Всего & $\begin{array}{l}\text { Государственный } \\
\text { сектор }\end{array}$ & $\begin{array}{l}\text { Предпринимательский } \\
\text { сектор }\end{array}$ & $\begin{array}{c}\text { Сектор высшего } \\
\text { образования }\end{array}$ \\
\hline $\begin{array}{l}\text { Число организаций, направлявших исследователей на р } \\
\text { (стажировку) в зарубежные научные организации }\end{array}$ & 278 & 109 & 28 & 140 \\
\hline $\begin{array}{l}\text { Численность исследователей, направленных на работу } \\
\text { (стажировку) в зарубежные научные организации, чел. }\end{array}$ & 3515 & 987 & 138 & 2388 \\
\hline Из них в возрасте до 39 лет & 1667 & 450 & 93 & 1124 \\
\hline
\end{tabular}

5.1.8. СТРУКТУРА ИССЛЕДОВАТЕЛЕЙ, НАПРАВЛЕННЫХ НА РАБОТУ (СТАЖИРОВКУ) В ЗАРУБЕЖНЫЕ НАУЧНЫЕ ОРГАНИЗАЦИИ, ПО СЕКТОРАМ НАУКИ: 2015

(проченты)

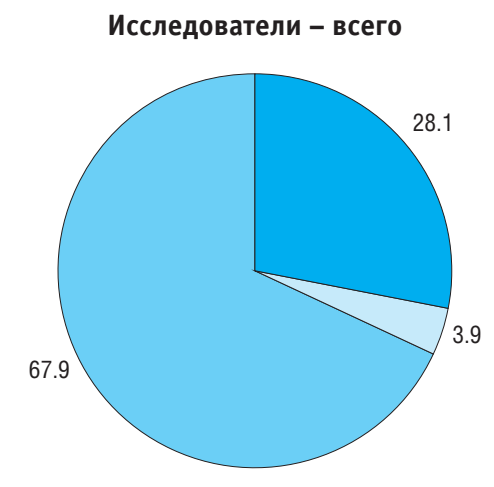

\section{Исследователи в возрасте до 39 лет}

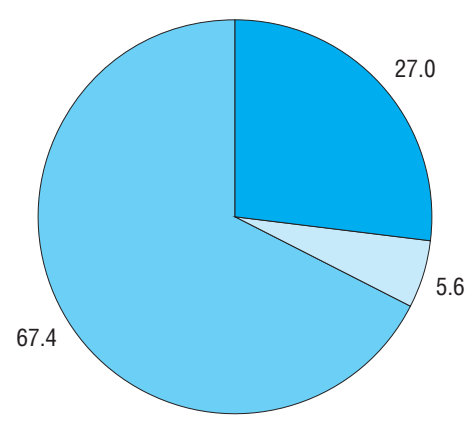

Секторы науки:

государственный

предпринимательский

$\square$ высшего образования 
5.1.9. ВНУТРЕННИЕ ЗАТРАТЫ НА ИССЛЕДОВАНИЯ И РАЗРАБОТКИ ПО СЕКТОРАМ НАУКИ

(тысячи рублей, 1995 г. - миллионы рублей)

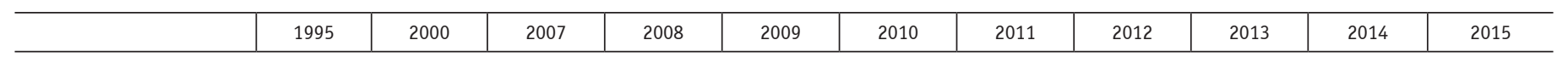

\section{В действующих ценах}

\section{Внутренние затраты} на исследования

и разработки

Секторы науки:

государственный

предпринимательский

высшего образования

некоммерческих

организаций

\section{Внутренние затраты}

\section{на исследования}

и разработки

Секторы науки:

государственный

предпринимательский

высшего образования

некоммерческих

организаций

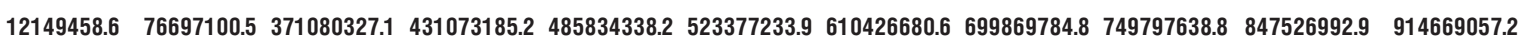

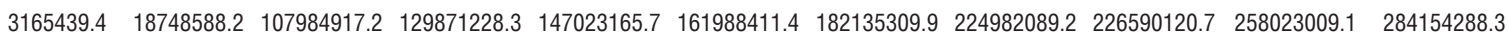

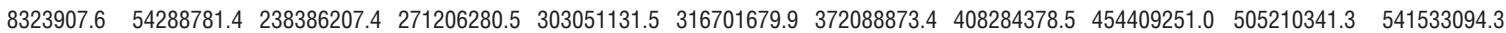

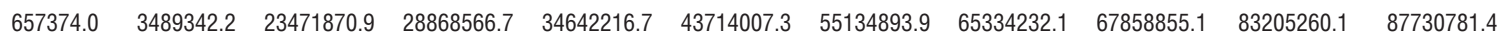

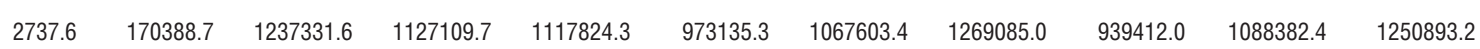

В постоянных ценах 1989 г.

\begin{tabular}{rrrrrrrrrrr}
$\mathbf{2 4 8 5 . 4}$ & $\mathbf{3 3 2 1 . 2}$ & $\mathbf{5 5 7 7 . 5}$ & $\mathbf{5 4 9 0 . 8}$ & $\mathbf{6 0 6 7 . 0}$ & $\mathbf{5 7 2 3 . 2}$ & $\mathbf{5 7 5 9 . 3}$ & $\mathbf{6 0 9 7 . 2}$ & $\mathbf{6 2 3 2 . 9}$ & $\mathbf{6 5 7 2 . 2}$ & $\mathbf{6 5 8 5 . 7}$ \\
$\mathbf{6 4 7 . 6}$ & 811.9 & 1623.1 & 1654.3 & 1836.0 & 1771.4 & 1718.4 & 1960.0 & 1883.6 & 2000.8 & 2045.9 \\
1702.8 & 2350.9 & 3583.0 & 3454.5 & 3784.5 & 3463.2 & 3510.6 & 3556.9 & 3777.4 & 3917.7 & 3899.1 \\
134.5 & 151.1 & 352.8 & 367.7 & 432.6 & 478.0 & 520.2 & 569.2 & 564.1 & 645.2 & 631.7 \\
0.6 & 7.4 & 18.6 & 14.4 & 14.0 & 10.6 & 10.1 & 11.1 & 7.8 & 8.4 \\
\hline
\end{tabular}


5.1.10. СТРУКТУРА ВНУТРЕННИХ ЗАТРАТ НА ИССЛЕДОВАНИЯ И РАЗРАБОТКИ ПО СЕКТОРАМ НАУКИ (проценты)

2014

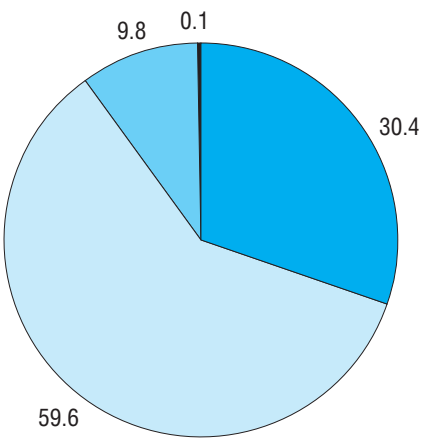

2015

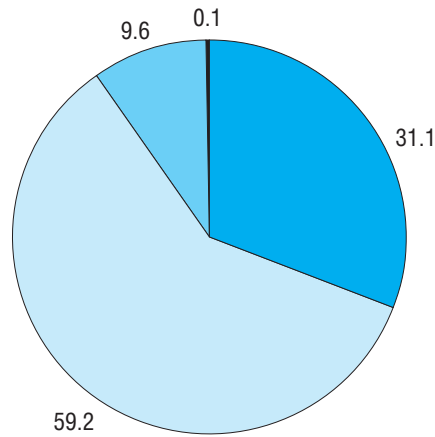

Секторы науки:

$\square$ государственный $\square$ высшего образования

предпринимательский некоммерческих организаций 
5.1.11. ВНУТРЕННИЕ ЗАТРАТЫ НА ИССЛЕДОВАНИЯ И РАЗРАБОТКИ ПО СЕКТОРАМ НАУКИ В ПРОЦЕНТАХ К ВАЛОВОМУ ВНУТРЕННЕМУ ПРОДУКТУ

\begin{tabular}{|c|c|c|c|c|}
\hline & Всего & $\begin{array}{l}\text { Государственный } \\
\text { сектор }\end{array}$ & $\begin{array}{c}\text { Предпринимательский } \\
\text { сектор }\end{array}$ & $\begin{array}{c}\text { Сектор } \\
\text { высшего образования }\end{array}$ \\
\hline 1995 & 0.85 & 0.22 & 0.58 & 0.05 \\
\hline 2000 & 1.05 & 0.26 & 0.74 & 0.05 \\
\hline 2002 & 1.25 & 0.31 & 0.87 & 0.07 \\
\hline 2003 & 1.29 & 0.33 & 0.88 & 0.08 \\
\hline 2004 & 1.15 & 0.29 & 0.80 & 0.06 \\
\hline 2005 & 1.07 & 0.28 & 0.73 & 0.06 \\
\hline 2006 & 1.07 & 0.29 & 0.72 & 0.07 \\
\hline 2007 & 1.12 & 0.32 & 0.72 & 0.07 \\
\hline 2008 & 1.04 & 0.31 & 0.66 & 0.07 \\
\hline 2009 & 1.25 & 0.38 & 0.78 & 0.09 \\
\hline 2010 & 1.13 & 0.35 & 0.68 & 0.09 \\
\hline 2011 & 1.02 & 0.31 & 0.62 & 0.09 \\
\hline 2012 & 1.05 & 0.34 & 0.61 & 0.10 \\
\hline 2013 & 1.06 & 0.32 & 0.64 & 0.10 \\
\hline 2014 & 1.09 & 0.33 & 0.65 & 0.11 \\
\hline 2015 & 1.13 & 0.35 & 0.67 & 0.11 \\
\hline
\end{tabular}




\subsubsection{2. ВНУТРЕННИЕ ЗАТРАТЫ НА ИССЛЕДОВАНИЯ И РАЗРАБОТКИ ПО СЕКТОРАМ НАУКИ \\ И ИСТОЧНИКАМ ФИНАНСИРОВАНИЯ \\ (тысячи рублей)}

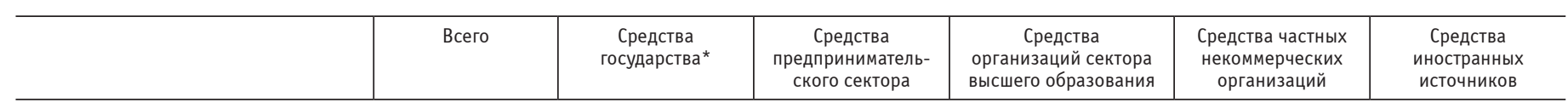

\section{Внутренние затраты}

\section{на исследования и разработки}

\section{8}

Секторы науки:

государственный

предпринимательский

высшего образования

некоммерческих организаций

226590120.7
454409251.0
67858855.1
939412.0

\section{9}

\section{на исследования и разработки}

Секторы науки:

государственный

предпринимательский

высшего образования

некоммерческих организаций

\section{3}

507197614.5

186930366.9

279358934.6

40378679.8

529633.2

\section{9}

31300159.7

161100909.7

18663427.9

71458.6

\section{4}

258023009.1

505210341.3

83205260.1

1088382.4
586658713.4

229444656.4

219020381.4

316622608.3

50496387.8

519335.9

29660844.5

60131.1

\section{9}

175890.2

515567.0

7080091.0

49129.7

9069176.1

357181.2

442911.7

8215233.9

53849.3

\section{0}

105228.8

88727.4

448892.7

253517.1
1372014.1

100284.6

359214.0

506189.0

406326.5
22747024.5

8078475.1

13345112.3

1287763.7

35673.4 
(окончание)

\begin{tabular}{|c|c|c|c|c|c|c|}
\hline & Всего & $\begin{array}{c}\text { Средства } \\
\text { государства* }\end{array}$ & $\begin{array}{c}\text { Средства } \\
\text { предприниматель- } \\
\text { ского сектора }\end{array}$ & $\begin{array}{c}\text { Средства } \\
\text { организаций сектора } \\
\text { высшего образования }\end{array}$ & $\begin{array}{c}\text { Средства частных } \\
\text { некоммерческих } \\
\text { организаций }\end{array}$ & $\begin{array}{c}\text { Средства } \\
\text { иностранных } \\
\text { источников }\end{array}$ \\
\hline \multicolumn{7}{|c|}{2015} \\
\hline \multicolumn{7}{|l|}{ Внутренние затраты } \\
\hline на исследования и разработки & 914669057.2 & 635859865.4 & 242155382.4 & 10875090.0 & 1566750.2 & 24211969.2 \\
\hline \multicolumn{7}{|l|}{ Секторы науки: } \\
\hline государственный & 284154288.3 & 240265758.8 & 32877099.7 & 321525.4 & 163335.5 & 10526568.9 \\
\hline предпринимательский & 541533094.3 & 343396867.3 & 185037359.3 & 561703.2 & 421868.8 & 12115295.7 \\
\hline высшего образования & 87730781.4 & 51570251.1 & 24028351.9 & 9979551.2 & 671465.0 & 1481162.2 \\
\hline некоммерческих организаций & 1250893.2 & 626988.2 & 212571.5 & 12310.2 & 310080.9 & 88942.4 \\
\hline
\end{tabular}

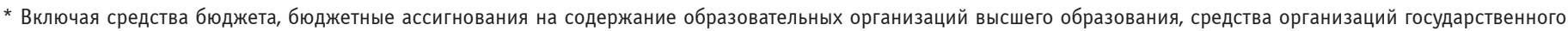
сектора (в том числе собственные). 


\subsubsection{3. ВНУТРЕННИЕ ЗАТРАТЫ, НАПРАВЛЕННЫЕ НА ВЫПОЛНЕНИЕ ИССЛЕДОВАНИЙ И РАЗРАБОТОК, ЗА СЧЕТ ГРАНТОВ, СУБСИДИЙ, КОНКУРСНОГО ФИНАНСИРОВАНИЯ: 2015} (тысяч рублей)

\begin{tabular}{|c|c|c|c|c|c|}
\hline & Всего & $\begin{array}{l}\text { Государственный } \\
\text { сектор }\end{array}$ & $\begin{array}{c}\text { Предпринимательский } \\
\text { сектор }\end{array}$ & $\begin{array}{c}\text { Сектор } \\
\text { высшего } \\
\text { образования }\end{array}$ & $\begin{array}{c}\text { Сектор } \\
\text { некоммерческих } \\
\text { организаций }\end{array}$ \\
\hline \multicolumn{6}{|l|}{$\begin{array}{l}\text { Субсидии бюджета на финансовое обеспечение } \\
\text { выполнения государственного задания в сфере }\end{array}$} \\
\hline научной (научно-исследовательской) деятельности & 92260622.5 & 67903553.2 & 8880016.5 & 15444778.5 & 32274.3 \\
\hline За счет средств бюджетов всех уровней & 92260622.5 & 67903553.2 & 8880016.5 & 15444778.5 & 32274.3 \\
\hline из них федерального & 89644529.2 & 65997940.3 & 8880016.5 & 14747756.1 & 18816.3 \\
\hline $\begin{array}{l}\text { Субсидии бюджета на выполнение научно-исследова } \\
\text { тельских и/или опытно-конструкторских работ }\end{array}$ & 34143669.8 & 9092707.3 & 14958709.5 & 10048718.0 & 43535.0 \\
\hline За счет средств бюджетов всех уровней & 34143669.8 & 9092707.3 & 14958709.5 & 10048718.0 & 43535.0 \\
\hline из них федерального & 32914108.4 & 8755861.2 & 14874108.5 & 9242927.7 & 41211.0 \\
\hline $\begin{array}{l}\text { Гранты фондов поддержки научной, научно-техниче- } \\
\text { ской и инновационной деятельности }\end{array}$ & 22725394.7 & 13933378.4 & 597706.6 & 8133416.5 & 60893.2 \\
\hline За счет средств бюджетов всех уровней & 21690080.7 & 13460002.0 & 475897.4 & 7734049.8 & 20131.5 \\
\hline из них федерального & 20237643.7 & 12637755.5 & 473897.4 & 7105859.3 & 20131.5 \\
\hline Другие виды конкурсного финансирования & 79479326.3 & 12853196.2 & 58324911.7 & 8266305.7 & 34912.7 \\
\hline За счет средств бюджетов всех уровней & 71170924.3 & 11258683.0 & 55739651.5 & 4163685.1 & 8904.7 \\
\hline из них федерального & 70161614.6 & 11039038.8 & 55587776.4 & 3531719.4 & 3080.0 \\
\hline
\end{tabular}


5.1.14. ВНУТРЕННИЕ ЗАТРАТЫ НА ИССЛЕДОВАНИЯ И РАЗРАБОТКИ ПО ПРИОРИТЕТНЫМ НАПРАВЛЕНИЯМ РАЗВИТИЯ

НАУКИ, ТЕХНОЛОГИЙ И ТЕХНИКИ И СЕКТОРАМ НАУКИ: 2015

(тысячи рублей)

\begin{tabular}{|c|c|c|c|c|c|}
\hline & Всего & $\begin{array}{l}\text { Государственный } \\
\text { сектор }\end{array}$ & $\begin{array}{l}\text { Предприниматель- } \\
\text { ский сектор }\end{array}$ & $\begin{array}{l}\text { Сектор высшего } \\
\text { образования }\end{array}$ & $\begin{array}{l}\text { Сектор некоммерче- } \\
\text { ских организаций }\end{array}$ \\
\hline \multicolumn{6}{|l|}{$\begin{array}{l}\text { Внутренние затраты на исследования и разработки } \\
\text { по приоритетным направлениям развития науки, }\end{array}$} \\
\hline технологий и техники & 627405512.5 & 193116547.6 & 372141244.0 & 61489317.8 & 658403.1 \\
\hline \multicolumn{6}{|l|}{ Из них: } \\
\hline информационно-телекоммуникационные системы & 74555756.9 & 11647729.4 & 52767415.3 & 10076776.7 & 63835.5 \\
\hline индустрия наносистем & 25421721.1 & 8102386.8 & 7757301.1 & 9560205.1 & 1828.1 \\
\hline науки о жизни & 43775675.6 & 28285531.2 & 5034188.0 & 10428171.8 & 27784.6 \\
\hline рациональное природопользование & 46422668.2 & 24665354.3 & 13156016.7 & 8571151.0 & 30146.2 \\
\hline \multicolumn{6}{|l|}{ энергоэффективность, энергосбережение, ядерная } \\
\hline энергетика & 86252476.9 & 52022507.3 & 26732275.0 & 7384338.1 & 113356.5 \\
\hline транспортные и космические системы & 219193146.9 & 34260391.7 & 175184635.9 & 9372079.1 & 376040.2 \\
\hline
\end{tabular}


5.1.15. СТРУКТУРА ВНУТРЕННИХ ЗАТРАТ НА ИССЛЕДОВАНИЯ И РАЗРАБОТКИ ПО ПРИОРИТЕТНЫМ НАПРАВЛЕНИЯМ РАЗВИТИЯ НАУКИ, ТЕХНОЛОГИЙ И ТЕХНИКИ И СЕКТОРАМ НАУКИ: 2015

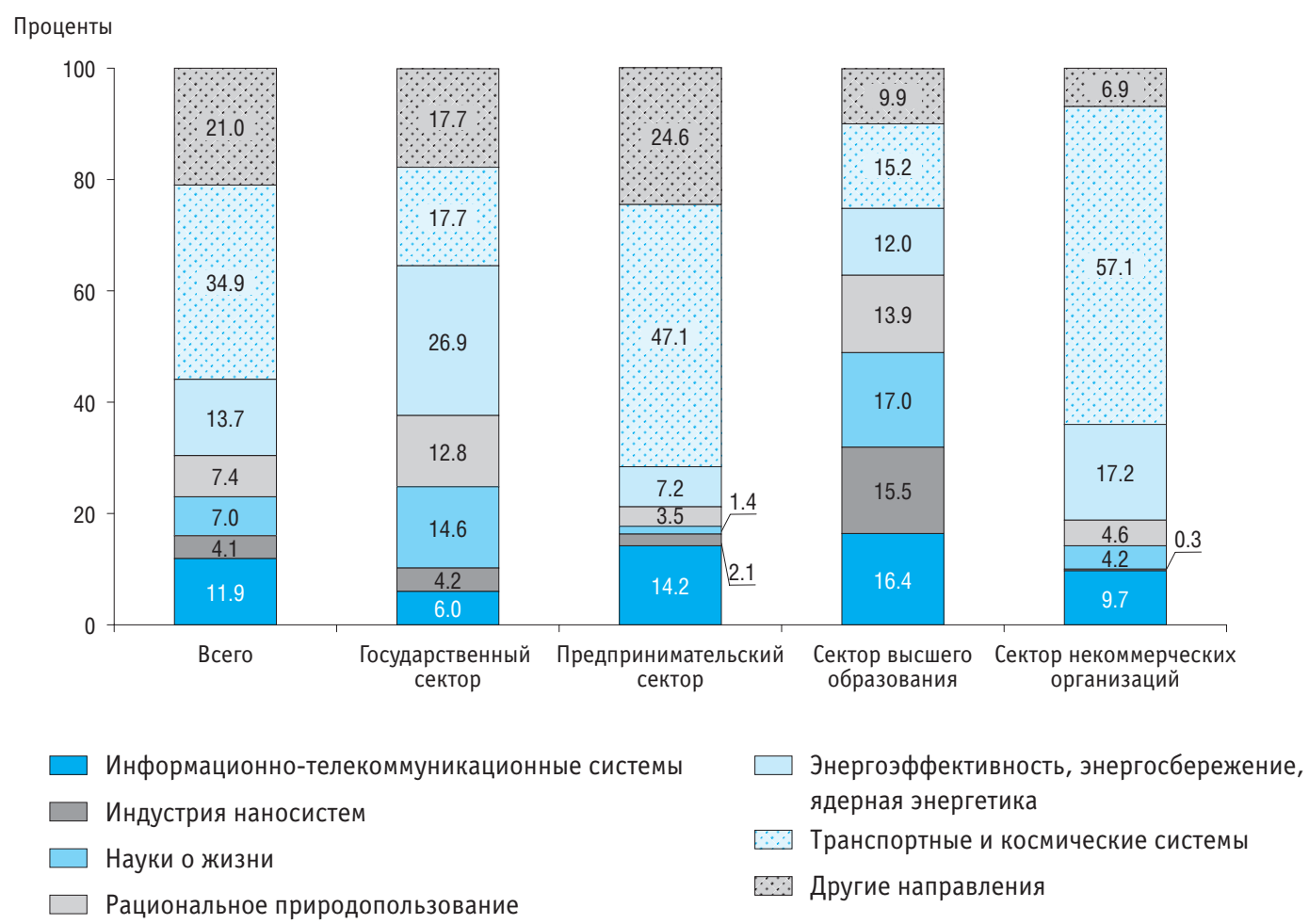


5.1.16. ИСТОЧНИКИ ФИНАНСИРОВАНИЯ ВНУТРЕННИХ ЗАТРАТ НА ИССЛЕДОВАНИЯ И РАЗРАБОТКИ ПО ПРИОРИТЕТНЫМ НАПРАВЛЕНИЯМ РАЗВИТИЯ НАУКИ, ТЕХНОЛОГИЙ И ТЕХНИКИ И СЕКТОРАМ НАУКИ: 2015

(тысячи рублей)

\begin{tabular}{|c|c|c|c|c|c|}
\hline & Всего & $\begin{array}{l}\text { Государственный } \\
\text { сектор }\end{array}$ & $\begin{array}{l}\text { Предприниматель- } \\
\text { ский сектор }\end{array}$ & $\begin{array}{l}\text { Сектор высшего } \\
\text { образования }\end{array}$ & $\begin{array}{l}\text { Сектор некоммерче- } \\
\text { ских организаций }\end{array}$ \\
\hline \multicolumn{6}{|l|}{$\begin{array}{l}\text { Внутренние затраты на исследования и разработки } \\
\text { по приоритетным направлениям развития науки, }\end{array}$} \\
\hline \multicolumn{6}{|l|}{ В том числе по источникам финансирования: } \\
\hline средства бюджетов всех уровней & 398937278.3 & 145239840.0 & 219027336.0 & 34299454.6 & 370647.7 \\
\hline из них федерального & 390638801.2 & 139185773.8 & 218074037.8 & 33033450.1 & 345539.5 \\
\hline собственные средства & 59988438.9 & 10320128.0 & 45063911.7 & 4478778.6 & 125620.6 \\
\hline средства организаций государственного сектора & 50411041.1 & 11253484.4 & 35831802.4 & 3265311.7 & 60442.6 \\
\hline средства организаций предпринимательского сектора & 93281440.0 & 18424691.0 & 59175131.6 & 15612243.9 & 69373.5 \\
\hline прочие источники & 24787314.2 & 7878404.2 & 13043062.3 & 3833529.0 & 32318.7 \\
\hline
\end{tabular}


5.1.17. СТРУКТУРА ВНУТРЕННИХ ЗАТРАТ НА ИССЛЕДОВАНИЯ И РАЗРАБОТКИ ПО ПРИОРИТЕТНЫМ НАПРАВЛЕНИЯМ РАЗВИТИЯ НАУКИ, ТЕХНОЛОГИЙ И ТЕХНИКИ И ИСТОЧНИКАМ ФИНАНСИРОВАНИЯ: 2015

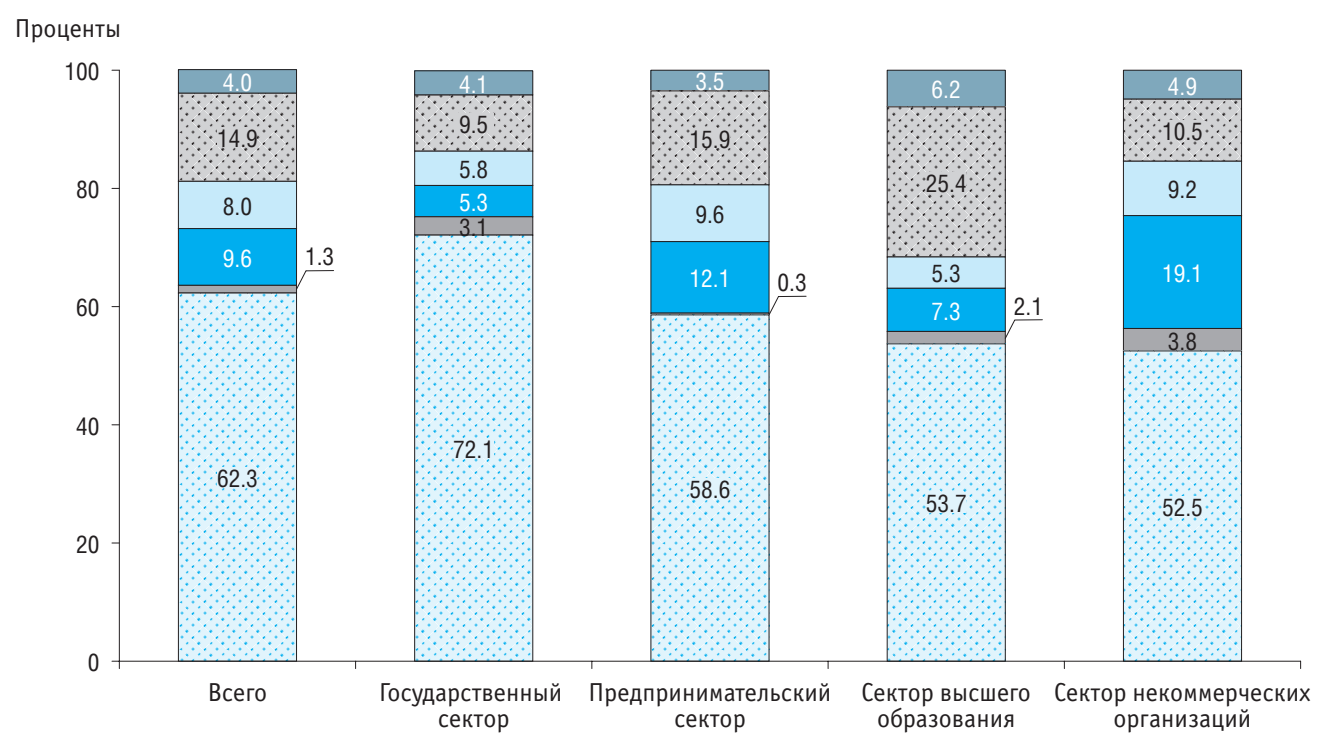

Источники финансирования:

$\therefore$ федеральный бюджет

$\square$ бюджеты субъектов Российской Федерации и местные бюджеты $\square$ собственные средства

средства организаций государственного сектора $\because$ средства организаций предпринимательского сектора

прочие источники 
5.1.18. ВНУТРЕННИЕ ЗАТРАТЫ НА ИССЛЕДОВАНИЯ И РАЗРАБОТКИ ПО СЕКТОРАМ НАУКИ И СОЦИАЛЬНО-ЭКОНОМИЧЕСКИМ ЦЕЛЯМ (тысячи рублей)

\begin{tabular}{|c|c|c|c|c|c|}
\hline & Всего & $\begin{array}{c}\text { Государственный } \\
\text { сектор }\end{array}$ & $\begin{array}{c}\text { Предпринимательский } \\
\text { сектор }\end{array}$ & $\begin{array}{c}\text { Сектор высшего } \\
\text { образования }\end{array}$ & $\begin{array}{c}\text { Сектор некоммерческих } \\
\text { организаций }\end{array}$ \\
\hline \multicolumn{6}{|c|}{2012} \\
\hline \multicolumn{6}{|l|}{ Внутренние затраты на исследования } \\
\hline и разработки & 699869784.8 & 224982089.2 & 408284378.5 & 65334232.1 & 1269085.0 \\
\hline Развитие экономики & 295901906.0 & 55032357.1 & 212179260.2 & 28615008.6 & 75280.1 \\
\hline Социальные цели & 33070785.7 & 19656464.9 & 5033592.1 & 8289720.7 & 91008.0 \\
\hline Общее развитие науки & 117873370.5 & 67230975.7 & 28688459.8 & 21318775.7 & 635159.3 \\
\hline \multicolumn{6}{|l|}{ Исследование и использование Земли } \\
\hline и атмосферы & 25474648.5 & 15629075.7 & 7772629.1 & 1957383.8 & 115559.9 \\
\hline Использование космоса в мирных целях & 37558965.0 & 10910796.0 & 25723269.3 & 901131.6 & 23768.1 \\
\hline Прочие затраты & 189990109.1 & 56522419.8 & 128887168.0 & 4252211.7 & 328309.6 \\
\hline \multicolumn{6}{|c|}{2013} \\
\hline \multicolumn{6}{|l|}{ Внутренние затраты на исследования } \\
\hline Развитие экономики & 303849005.2 & 57707206.0 & 215317955.6 & 30734547.3 & 89296.3 \\
\hline Социальные цели & 39876895.8 & 22956650.4 & 4021637.0 & 12783813.4 & 114795.0 \\
\hline Общее развитие науки & 130695141.4 & 69352465.7 & 42790745.8 & 18121418.8 & 430511.1 \\
\hline \multicolumn{6}{|l|}{ Исследование и использование Земли } \\
\hline и атмосферы & 32889936.2 & 17181592.3 & 13663338.5 & 2011482.9 & 33522.5 \\
\hline Использование космоса в мирных целях & 51558366.4 & 11237808.4 & 39084006.0 & 1207010.5 & 29541.5 \\
\hline Прочие затраты & 190928293.8 & 48154397.9 & 139531568.1 & 3000582.2 & 241745.6 \\
\hline
\end{tabular}


(окончание)

\section{Внутренние затраты на исследования}

\section{и разработки}

Развитие экономики

Социальные цели

Общее развитие науки

Исследование и использование Земли

и атмосферы

Использование космоса в мирных целях

Прочие затраты

\section{Внутренние затраты на исследования}

\section{и разработки}

Развитие экономики

Социальные цели

Общее развитие науки

Исследование и использование Земли

и атмосферы

Использование космоса в мирных целях

Прочие затраты

\section{9 \\ 319943400.5 \\ 45328439.6 \\ 136414580.0 \\ 39068691.1 \\ 48996185.8 \\ 257775695.9}

914669057.2

335508245.3

47512609.4

145154435.8

43206894.0

57441295.9

285845576.8
Государственный сектор

2014

\author{
258023009.1 \\ 58260041.0 \\ 24604406.8 \\ 75836748.8 \\ 19049241.1 \\ 10308768.0
}

69963803.4

2015

284154288.3
66498291.0
26204488.0
84086241.6

18496276.7
10919478.4
77949512.6

\section{3}

\section{3 \\ 224881936.8 \\ 4745913.8 \\ 36193754.2 \\ 17826089.6 \\ 37455033.6 \\ 184107613.3}

$\mathbf{5 4 1 5 3 3 0 9 4 . 3}$
229892147.1
3635210.6
37477260.5

22445320.5
45009580.3
203073575.3

83205260.1

36680335.6

15848699.1

23948358.6

2155683.5

1189438.9

3382744.4

87730781.4

38839549.5

17511474.7

23092224.3

1250893.2

2221571.2

1437968.4

4627993.3
278257.7

161436.1

498709.4

1088382.4

121087.1

129419.9

435718.4

37676.9

42945.3

321534.8

43725.6

74268.8

194495.6 
5.1.19. РАСПРЕДЕЛЕНИЕ ВНУТРЕННИХ ЗАТРАТ НА ИССЛЕДОВАНИЯ И РАЗРАБОТКИ ПО СЕКТОРАМ НАУКИ

И СОЦИАЛЬНО-ЭКОНОМИЧЕСКИМ ЦЕЛЯМ: 2015

(проценты)

Bcero -

914669.1 млн руб.

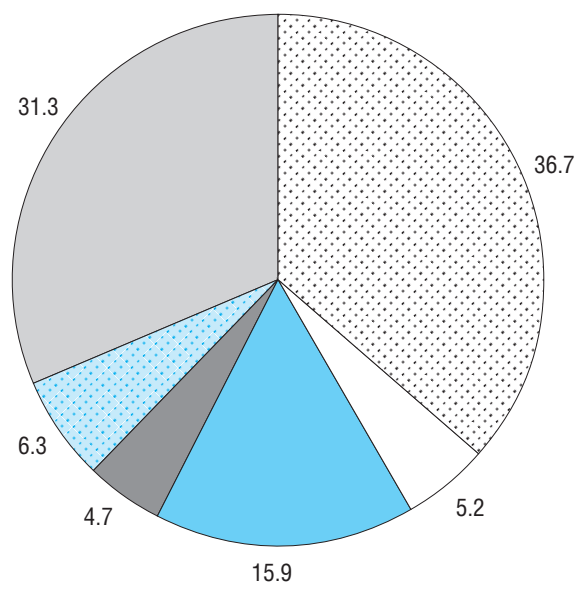

$\because$ Развитие экономики

$\square$ Социальные цели

$\square$ 0бщее развитие науки

\section{Предпринимательский сектор -} 541533.1 млн руб.

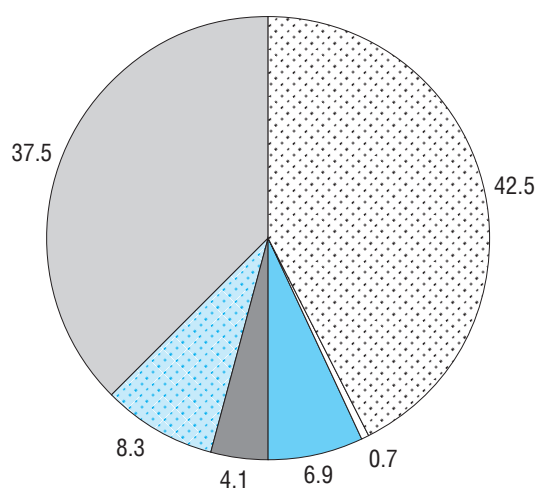

42.5

Исследование и использование Земли и атмосферы

$\because$ Использование космоса в мирных целях

Прочие затраты 
(окончание)

\section{Государственный сектор -} 284154.3 млн руб.

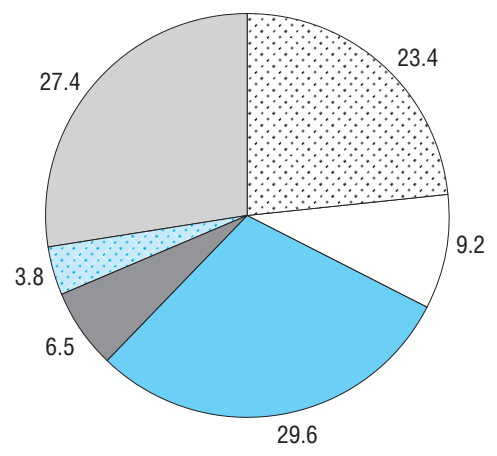

Сектор высшего образования 87730.8 млн руб.

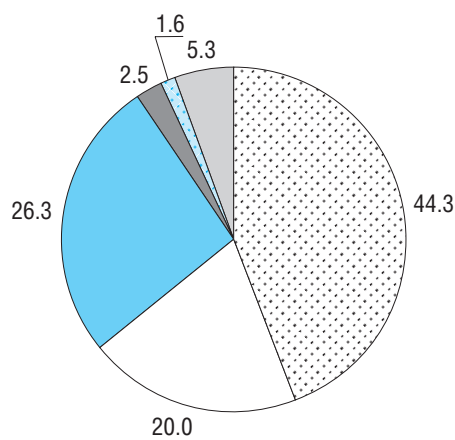

Сектор некоммерческих организаций 1250.9 млн руб.

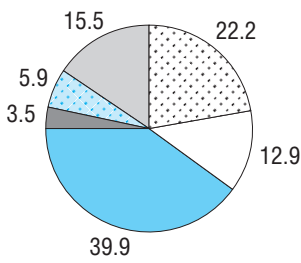

$\because$ Развитие экономики

Социальные цели

$\square$ 0бщее развитие науки $\square$ Исследование и использование Земли и атмосферы

$\therefore$ Использование космоса в мирных целях

$\square$ Прочие затраты 
5.1.20. ВНУТРЕННИЕ ТЕКУЩИЕ ЗАТРАТЫ НА ИССЛЕДОВАНИЯ И РАЗРАБОТКИ ПО СЕКТОРАМ НАУКИ И ВИДАМ РАБОТ (тысячи рублей)

\begin{tabular}{|c|c|c|c|c|c|}
\hline & Всего & $\begin{array}{l}\text { Государственный } \\
\text { сектор }\end{array}$ & $\begin{array}{l}\text { Предпринимательский } \\
\text { сектор }\end{array}$ & $\begin{array}{l}\text { Сектор высшего } \\
\text { образования }\end{array}$ & $\begin{array}{c}\text { Сектор некоммерческих } \\
\text { организаций }\end{array}$ \\
\hline \multicolumn{6}{|c|}{$\begin{array}{l}\text { Внутренние текущие затраты } \\
\text { на исследования и разработки }\end{array}$} \\
\hline 2005 & 221119537.6 & 56342327.7 & 151228693.6 & 13144292.5 & 404223.8 \\
\hline 2012 & 655061743.4 & 210559632.9 & 380968190.9 & 62268471.4 & 1265448.2 \\
\hline 2013 & 699948879.0 & 213468794.6 & 420438999.3 & 65103832.7 & 937252.4 \\
\hline 2014 & 795407850.6 & 244655172.5 & 470728154.3 & 78939146.3 & 1085377.5 \\
\hline 2015 & 854288043.8 & 265478556.9 & 503088818.5 & 84495233.0 & 1225435.4 \\
\hline \multicolumn{6}{|c|}{ Фундаментальные исследования } \\
\hline 2005 & 31022855.8 & 24586195.8 & 2591506.7 & 3841327.6 & 3825.7 \\
\hline 2012 & 108160904.7 & 78699812.7 & 11034975.2 & 18092897.7 & 333219.1 \\
\hline 2013 & 114829117.8 & 86128282.9 & 10319086.1 & 18292483.8 & 89265.0 \\
\hline 2014 & 130618045.6 & 97017979.4 & 11654667.9 & 21840738.8 & 104659.5 \\
\hline 2015 & 132064934.3 & 99987000.6 & 7122577.4 & 24839057.2 & 116299.1 \\
\hline \multicolumn{6}{|c|}{ Прикладные исследования } \\
\hline 2005 & 36360266.9 & 10603039.3 & 20026408.8 & 5405410.3 & 325408.5 \\
\hline 2012 & 129304402.1 & 50128152.6 & 50351025.6 & 28324950.6 & 500273.3 \\
\hline 2013 & 133787976.7 & 49843105.3 & 52414718.7 & 31034270.9 & 495881.8 \\
\hline 2014 & 155231401.5 & 53934451.4 & 62451087.5 & 38214808.7 & 631053.9 \\
\hline 2015 & 169654641.2 & 66248286.3 & 61520451.3 & 41098469.1 & 787434.5 \\
\hline \multicolumn{6}{|c|}{ Разработки } \\
\hline 2005 & 153736414.9 & 21153092.6 & 128610778.1 & 3897554.6 & 74989.6 \\
\hline 2012 & 417596436.6 & 81731667.6 & 319582190.1 & 15850623.1 & 431955.8 \\
\hline 2013 & 451331784.5 & 77497406.4 & 357705194.5 & 15777078.0 & 352105.6 \\
\hline 2014 & 509558403.5 & 93702741.7 & 396622398.9 & 18883598.8 & 349664.1 \\
\hline 2015 & 552568468.3 & 99243270.0 & 434445789.8 & 18557706.7 & 321701.8 \\
\hline
\end{tabular}


5.1.21. СРЕДНЕМЕСЯЧНАЯ ЗАРАБОТНАЯ ПЛАТА ПЕРСОНАЛА, ЗАНЯТОГО ИССЛЕДОВАНИЯМИ И РАЗРАБОТКАМИ, ПО СЕКТОРАМ НАУКИ (рубли, до 1998 г. - тысячи рублей)

\begin{tabular}{|c|c|c|c|c|c|}
\hline & Всего & $\begin{array}{l}\text { Государственный } \\
\text { сектор }\end{array}$ & $\begin{array}{l}\text { Предпринимательский } \\
\text { сектор }\end{array}$ & $\begin{array}{c}\text { Сектор высшего } \\
\text { образования }\end{array}$ & $\begin{array}{c}\text { Сектор некоммерческих } \\
\text { организаций }\end{array}$ \\
\hline 1995 & 305.3 & 330.5 & 297.6 & 280.1 & 164.2 \\
\hline 1996 & 550.9 & 555.5 & 557.1 & 441.4 & 587.5 \\
\hline 1997 & 746.5 & 790.1 & 740.8 & 575.2 & 572.8 \\
\hline 1998 & 836.0 & 814.2 & 861.3 & 624.9 & 581.0 \\
\hline 1999 & 1432.6 & 1355.2 & 1491.1 & 1098.7 & 930.2 \\
\hline 2000 & 2322.9 & 2015.6 & 2519.9 & 1400.3 & 1836.1 \\
\hline 2001 & 3348.9 & 2870.5 & 3630.1 & 2383.8 & 2619.8 \\
\hline 2002 & 4552.1 & 3970.4 & 4893.6 & 3476.9 & 4770.2 \\
\hline 2003 & 5712.8 & 4969.6 & 6124.3 & 4749.1 & 5654.7 \\
\hline 2004 & 6918.4 & 5958.7 & 7525.0 & 5088.8 & 6575.0 \\
\hline 2005 & 8672.0 & 7220.9 & 9599.6 & 7042.0 & 5767.4 \\
\hline 2007 & 14683.4 & 14208.3 & 15203.6 & 12233.1 & 13237.3 \\
\hline 2008 & 19263.3 & 19561.0 & 19345.3 & 16812.7 & 21161.2 \\
\hline 2009 & 22104.3 & 22979.7 & 21674.1 & 21191.5 & 24253.8 \\
\hline 2010 & 25043.5 & 24792.1 & 25359.7 & 23716.4 & 24438.5 \\
\hline 2011 & 28387.5 & 27869.4 & 29174.9 & 24963.9 & 25956.5 \\
\hline 2012 & 32539.9 & 31990.2 & 33165.2 & 30915.1 & 25983.7 \\
\hline 2013 & 35618.8 & 34532.8 & 36540.8 & 34101.0 & 27979.8 \\
\hline 2014 & 39549.3 & 38715.6 & 39855.8 & 41258.6 & 37197.0 \\
\hline 2015 & 41511.8 & 40513.5 & 42102.7 & 41850.5 & 41898.6 \\
\hline
\end{tabular}




\section{2. Государственный сектор}

\subsection{1. ОРГАНИЗАЦИИ, ВЫПОЛНЯВШИЕ ИССЛЕДОВАНИЯ И РАЗРАБОТКИ В ГОСУДАРСТВЕННОМ СЕКТОРЕ, ПО ТИПАМ}

\begin{tabular}{|c|c|c|c|c|c|c|c|c|}
\hline & 2005 & 2009 & 2010 & 2011 & 2012 & 2013 & 2014 & 2015 \\
\hline Всего & 1282 & 1406 & 1400 & 1457 & 1465 & 1495 & 1491 & 1560 \\
\hline Научно-исследовательские институты & 1145 & 1126 & 1124 & 1109 & 1114 & 1144 & 1139 & 1173 \\
\hline $\begin{array}{l}\text { Конструкторские, проектно-конструкторские, технологические } \\
\text { организации }\end{array}$ & 62 & 60 & 61 & 65 & 64 & 56 & 55 & 55 \\
\hline Проектные и проектно-изыскательские организации строительства & 6 & 5 & 5 & 6 & 6 & 7 & 6 & 8 \\
\hline Опытные базы & 14 & 35 & 30 & 33 & 37 & 43 & 42 & 48 \\
\hline Прочие организации & 55 & 180 & 180 & 244 & 244 & 245 & 249 & 276 \\
\hline
\end{tabular}

\subsection{2. ПЕРСОНАЛ, ЗАНЯТЫЙ ИССЛЕДОВАНИЯМИ И РАЗРАБОТКАМИ В ГОСУДАРСТВЕННОМ СЕКТОРЕ, ПО ТИПАМ ОРГАНИЗАЦИЙ}

(человек)

\begin{tabular}{|c|c|c|c|c|c|c|c|c|}
\hline & 2005 & 2008 & 2010 & 2011 & 2012 & 2013 & 2014 & 2015 \\
\hline Всего & 272718 & 260854 & 259007 & 254896 & 271466 & 261869 & 263712 & 265429 \\
\hline Научно-исследовательские институты & 248214 & 223190 & 222613 & 219220 & 232655 & 225798 & 228146 & 230893 \\
\hline $\begin{array}{l}\text { Конструкторские, проектно-конструкторские, технологические } \\
\text { организации }\end{array}$ & 21499 & 27021 & 26473 & 23290 & 26084 & 22979 & 23448 & 19459 \\
\hline Проектные и проектно-изыскательские организации строительства & 159 & 1442 & 1419 & 1390 & 1370 & 1156 & 1174 & 1220 \\
\hline Опытные базы & 367 & 694 & 631 & 957 & 1375 & 1762 & 1278 & 1519 \\
\hline Прочие организации & 2479 & 8507 & 7871 & 10039 & 9982 & 10174 & 9666 & 12338 \\
\hline
\end{tabular}


5.2.3. ПЕРСОНАЛ, ЗАНЯТЫЙ ИССЛЕДОВАНИЯМИ И РАЗРАБОТКАМИ В ГОСУДАРСТВЕННОМ СЕКТОРЕ, ПО КАТЕГОРИЯМ (человек)

\begin{tabular}{|c|c|c|c|c|c|c|c|c|c|c|c|c|c|}
\hline & 1995 & 2000 & 2005 & 2006 & 2007 & 2008 & 2009 & 2010 & 2011 & 2012 & 2013 & 2014 & 2015 \\
\hline Bcero & 282166 & 255850 & 272718 & 274802 & 272255 & 260854 & 260360 & 259007 & 254896 & 271466 & 261869 & 263712 & 265429 \\
\hline Исследователи & 146342 & 129725 & 139378 & 138728 & 138169 & 132261 & 132955 & 131734 & 128672 & 136442 & 132117 & 132701 & 134794 \\
\hline Техники & 27178 & 25085 & 25462 & 25667 & 26545 & 24531 & 24554 & 24009 & 26960 & 28094 & 27777 & 27761 & 27090 \\
\hline Вспомогательный персонал & 66226 & 59706 & 61448 & 62482 & 61031 & 58591 & 56846 & 56530 & 54176 & 60067 & 56795 & 56744 & 56552 \\
\hline Прочие & 42420 & 41334 & 46430 & 47925 & 46510 & 45471 & 46005 & 46734 & 45088 & 46863 & 45180 & 46506 & 46993 \\
\hline
\end{tabular}

\subsection{4. СТРУКТУРА ПЕРСОНАЛА, ЗАНЯТОГО ИССЛЕДОВАНИЯМИ И РАЗРАБОТКАМИ \\ В ГОСУДАРСТВЕННОМ СЕКТОРЕ, ПО КАТЕГОРИЯМ}

Проценты

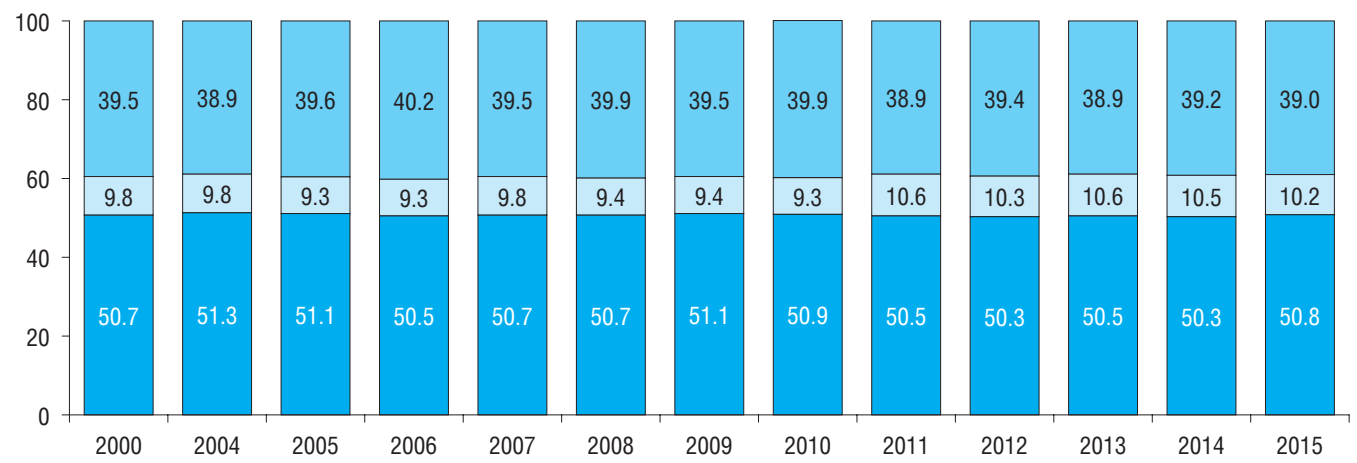

$\square$ Исследователи $\square$ Техники $\square$ Вспомогательный и прочий персонал 


\subsection{5. УДЕЛЬНЫЙ ВЕС ГОСУДАРСТВЕННОГО СЕКТОРА В ОБЩЕЙ ЧИСЛЕННОСТИ ПЕРСОНАЛА ЗАНЯТОГО ИССЛЕДОВАНИЯМИ И РАЗРАБОТКАМИ, ПО КАТЕГОРИЯМ}

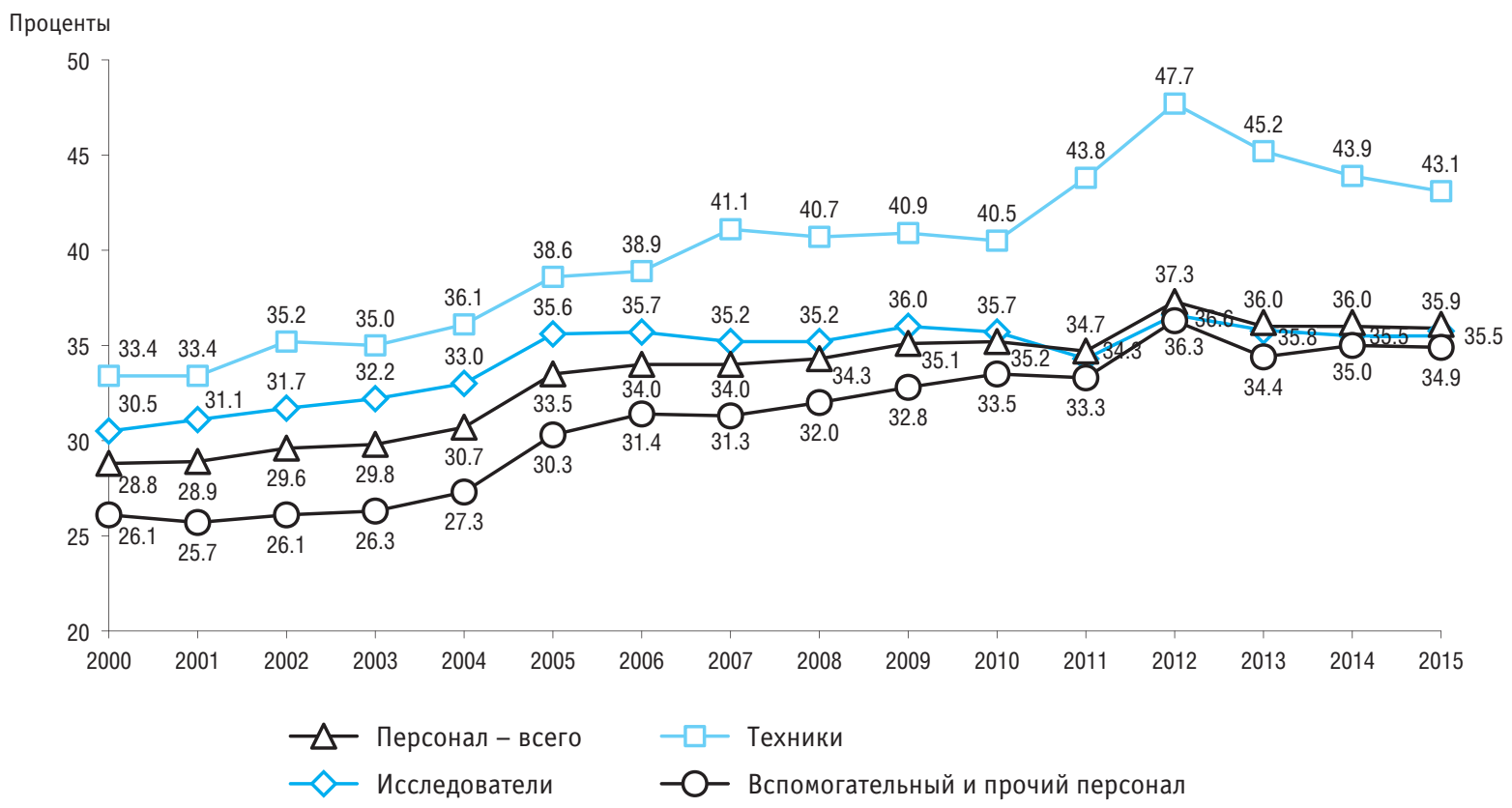


5.2.6. ПЕРСОНАЛ, ЗАНЯТЫЙ ИССЛЕДОВАНИЯМИ И РАЗРАБОТКАМИ В ГОСУДАРСТВЕННОМ СЕКТОРЕ,

ПО УРОВНЮ ОБРАЗОВАНИЯ

(человек)

\begin{tabular}{|c|c|c|c|c|}
\hline & Всего & $\begin{array}{c}\text { Высшее } \\
\text { образование }\end{array}$ & $\begin{array}{l}\text { Среднее профессиональное } \\
\text { образование }\end{array}$ & $\begin{array}{c}\text { Прочее } \\
\text { образование }\end{array}$ \\
\hline \multicolumn{5}{|c|}{$\begin{array}{l}\text { Персонал, занятый исследованиями } \\
\text { и разработками }\end{array}$} \\
\hline 2005 & 272718 & 177676 & 40495 & 54547 \\
\hline 2010 & 259007 & 178026 & 36091 & 44890 \\
\hline 2012 & 271466 & 191193 & 35958 & 44315 \\
\hline 2013 & 261869 & 187058 & 33629 & 41182 \\
\hline 2014 & 263712 & 189447 & 33699 & 40566 \\
\hline 2015 & 265429 & 194608 & 33163 & 37658 \\
\hline \multicolumn{5}{|c|}{ Исследователи } \\
\hline 2005 & 139378 & 139378 & - & - \\
\hline 2010 & 131734 & 131734 & - & - \\
\hline 2012 & 136442 & 136442 & - & - \\
\hline 2013 & 132117 & 132117 & - & - \\
\hline 2014 & 132701 & 132701 & - & - \\
\hline 2015 & 134794 & 134794 & - & - \\
\hline \multicolumn{5}{|l|}{ Техники } \\
\hline 2005 & 25462 & 7802 & 12177 & 5483 \\
\hline 2010 & 24009 & 9110 & 10155 & 4744 \\
\hline 2012 & 28094 & 11957 & 10841 & 5296 \\
\hline 2013 & 27777 & 12669 & 9747 & 5361 \\
\hline 2014 & 27761 & 13245 & 9310 & 5206 \\
\hline 2015 & 27090 & 13761 & 8609 & 4720 \\
\hline
\end{tabular}


(окончание)

\begin{tabular}{|c|c|c|c|c|}
\hline & Всего & $\begin{array}{c}\text { Высшее } \\
\text { образование }\end{array}$ & $\begin{array}{c}\text { Среднее профессиональное } \\
\text { образование }\end{array}$ & $\begin{array}{c}\text { Прочее } \\
\text { образование }\end{array}$ \\
\hline \multicolumn{5}{|c|}{ Вспомогательный персонал } \\
\hline 2005 & 61448 & 19119 & 15834 & 26495 \\
\hline 2010 & 56530 & 21762 & 14287 & 20481 \\
\hline 2012 & 60067 & 24637 & 13977 & 21453 \\
\hline 2013 & 56795 & 24082 & 13110 & 19603 \\
\hline 2014 & 56744 & 24586 & 13038 & 19120 \\
\hline 2015 & 56552 & 26144 & 13119 & 17289 \\
\hline \multicolumn{5}{|l|}{ Прочие } \\
\hline 2005 & 46430 & 11377 & 12484 & 22569 \\
\hline 2010 & 46734 & 15420 & 11649 & 19665 \\
\hline 2012 & 46863 & 18157 & 11140 & 17566 \\
\hline 2013 & 45180 & 18190 & 10772 & 16218 \\
\hline 2014 & 46506 & 18915 & 11351 & 16240 \\
\hline 2015 & 46993 & 19909 & 11435 & 15649 \\
\hline
\end{tabular}




\subsection{7. ИССЛЕДОВАТЕЛИ В ГОСУДАРСТВЕННОМ СЕКТОРЕ ПО ПОЛУ И ВОЗРАСТНЫМ ГРУППАМ}

(человек)

\begin{tabular}{|c|c|c|c|c|c|c|}
\hline & \multicolumn{3}{|c|}{2008} & \multicolumn{3}{|c|}{2015} \\
\hline & \multirow[t]{2}{*}{ Исследователи } & \multicolumn{2}{|c|}{ Изних } & \multirow[t]{2}{*}{ Исследователи } & \multicolumn{2}{|c|}{ Из них } \\
\hline & & доктора наук & кандидаты наук & & доктора наук & кандидаты наук \\
\hline Всего & 132261 & 17326 & 43043 & 134794 & 18264 & 45642 \\
\hline \multicolumn{7}{|l|}{ Возраст, лет: } \\
\hline до 29 включительно & 19971 & 5 & 2348 & 21144 & 1 & 2223 \\
\hline $30-39$ & 20242 & 289 & 8296 & 28769 & 362 & 11813 \\
\hline $40-49$ & 22644 & 1838 & 7969 & 18693 & 1609 & 8014 \\
\hline $50-54$ & 16357 & 2194 & 5445 & 11776 & 1552 & 4084 \\
\hline $55-59$ & 16849 & 2821 & 5492 & 13789 & 2506 & 4646 \\
\hline $60-69$ & 23031 & 5106 & 8553 & 25090 & 6104 & 8971 \\
\hline 70 и старше & 13167 & 5073 & 4940 & 15533 & 6130 & 5891 \\
\hline Мужчины & 72653 & 13078 & 23696 & 75500 & 13325 & 24652 \\
\hline \multicolumn{7}{|l|}{ Возраст, лет: } \\
\hline до 29 включительно & 11530 & 2 & 1354 & 12173 & 1 & 1266 \\
\hline $30-39$ & 9970 & 209 & 4091 & 15651 & 244 & 6102 \\
\hline $40-49$ & 10894 & 1307 & 3946 & 9199 & 1018 & 3657 \\
\hline $50-54$ & 8373 & 1583 & 2966 & 5934 & 1008 & 2102 \\
\hline $55-59$ & 9183 & 2073 & 3229 & 7344 & 1687 & 2549 \\
\hline $60-69$ & 13688 & 4001 & 4974 & 14778 & 4522 & 5392 \\
\hline 70 и старше & 9015 & 3903 & 3136 & 10421 & 4845 & 3584 \\
\hline Женщины & 59608 & 4248 & 19347 & 59294 & 4939 & 20990 \\
\hline \multicolumn{7}{|l|}{ Возраст, лет: } \\
\hline до 29 включительно & 8441 & 3 & 994 & 8971 & - & 957 \\
\hline $30-39$ & 10272 & 80 & 4205 & 13118 & 118 & 5711 \\
\hline $40-49$ & 11750 & 531 & 4023 & 9494 & 591 & 4357 \\
\hline $50-54$ & 7984 & 611 & 2479 & 5842 & 544 & 1982 \\
\hline $55-59$ & 7666 & 748 & 2263 & 6445 & 819 & 2097 \\
\hline $60-69$ & 9343 & 1105 & 3579 & 10312 & 1582 & 3579 \\
\hline 70 и старше & 4152 & 1170 & 1804 & 5112 & 1285 & 2307 \\
\hline
\end{tabular}




\subsection{8. СТРУКТУРА ИССЛЕДОВАТЕЛЕЙ В ГОСУДАРСТВЕННОМ СЕКТОРЕ ПО ВОЗРАСТНЫМ ГРУППАМ}
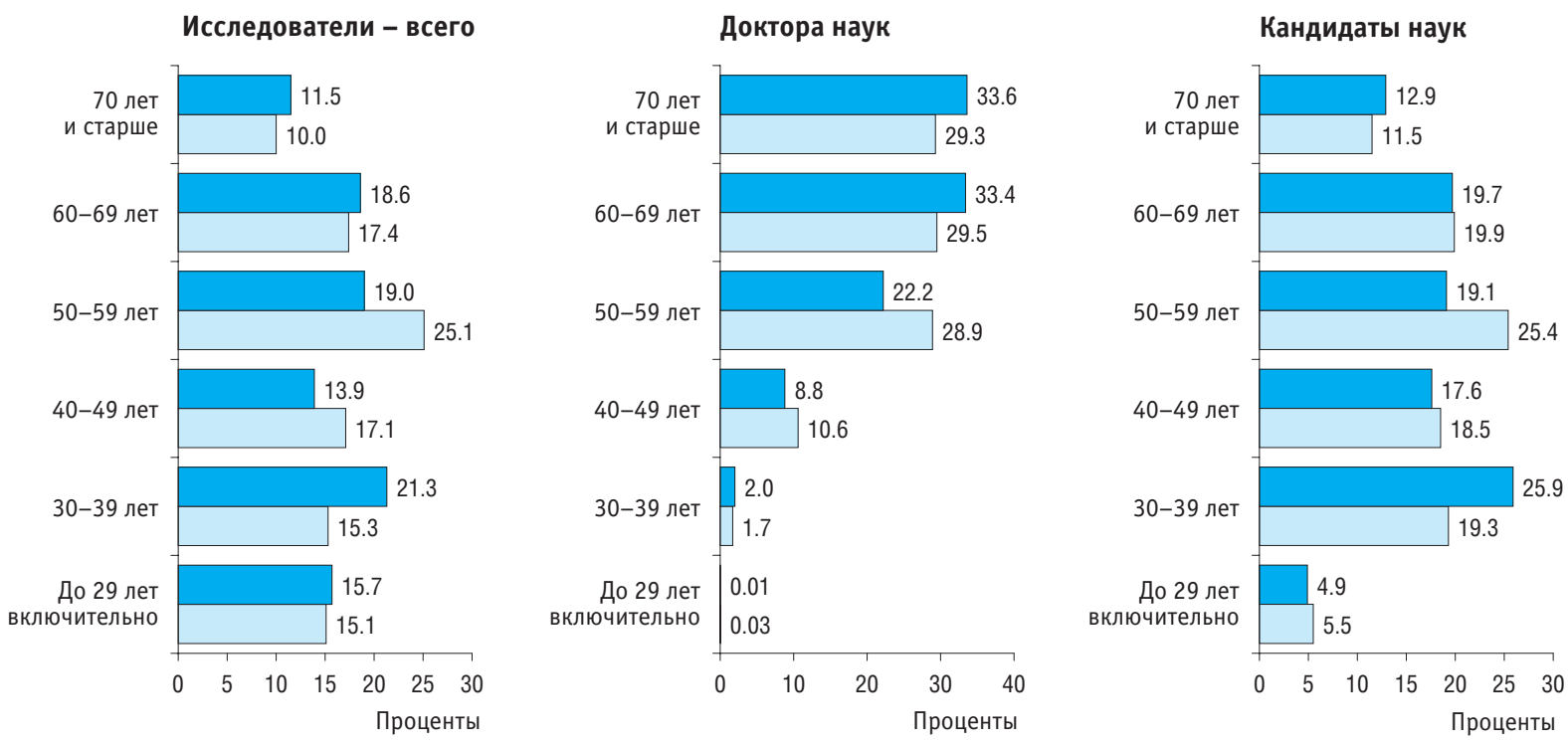


\subsection{9. СРЕДНИЙ ВОЗРАСТ ИССЛЕДОВАТЕЛЕЙ В ГОСУДАРСТВЕННОМ СЕКТОРЕ}

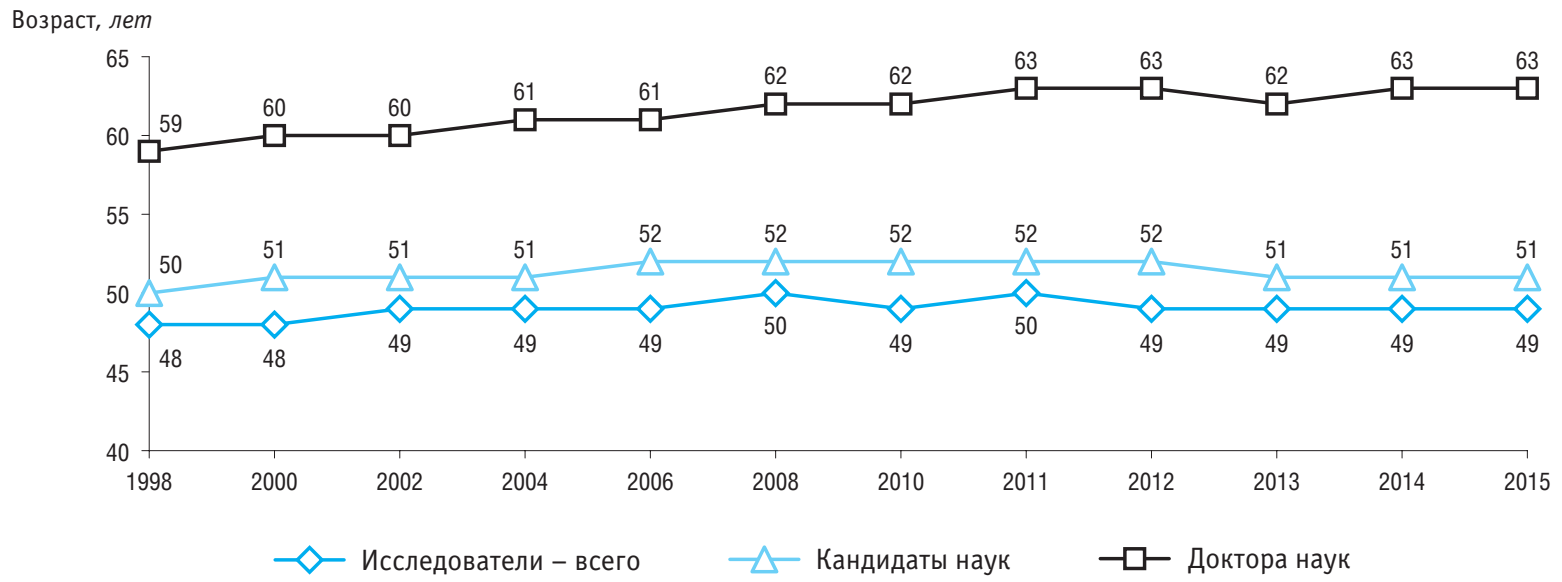

5.2.10. ИССЛЕДОВАТЕЛИ С УЧЕНЫМИ СТЕПЕНЯМИ В ГОСУДАРСТВЕННОМ СЕКТОРЕ

(человек)

\begin{tabular}{|c|c|c|c|c|c|c|c|c|c|c|c|c|c|}
\hline & 1995 & 2000 & 2005 & 2006 & 2007 & 2008 & 2009 & 2010 & 2011 & 2012 & 2013 & 2014 & 2015 \\
\hline Исследователи с учеными степенями & 61062 & 58901 & 60066 & 60054 & 61707 & 60369 & 61309 & 61194 & 61605 & 63092 & 62837 & 62944 & 63906 \\
\hline Доктора наук & 13358 & 14987 & 16511 & 16766 & 17415 & 17326 & 17554 & 17646 & 17789 & 18181 & 18184 & 18198 & 18264 \\
\hline Кандидаты наук & 47704 & 43914 & 43555 & 43288 & 44292 & 43043 & 43755 & 43548 & 43816 & 44911 & 44653 & 44746 & 45642 \\
\hline
\end{tabular}




\subsubsection{1. УДЕЛЬНЫЙ ВЕС ИССЛЕДОВАТЕЛЕЙ С УЧЕНЫМИ СТЕПЕНЯМИ В ЧИСЛЕННОСТИ ИССЛЕДОВАТЕЛЕЙ}

В ГОСУДАРСТВЕННОМ СЕКТОРЕ

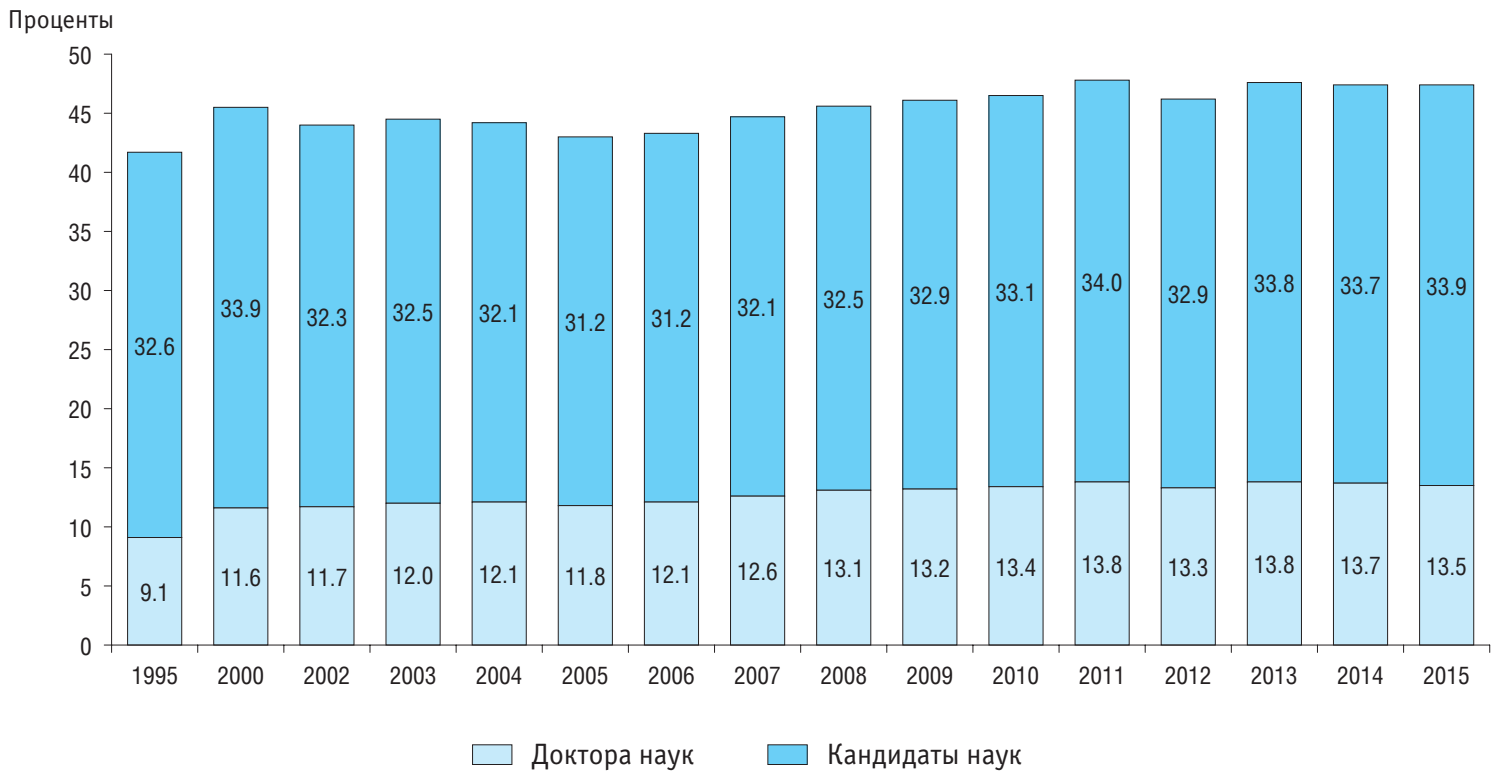




\subsubsection{2. ИССЛЕДОВАТЕЛИ В ГОСУДАРСТВЕННОМ СЕКТОРЕ ПО ОБЛАСТЯМ НАУКИ}

(человек)

\begin{tabular}{|c|c|c|c|c|c|c|c|c|c|c|c|c|}
\hline & \multicolumn{3}{|c|}{2008} & \multicolumn{3}{|c|}{2013} & \multicolumn{3}{|c|}{2014} & \multicolumn{3}{|c|}{2015} \\
\hline & \multirow{2}{*}{\begin{tabular}{|c|} 
Исследова- \\
тели
\end{tabular}} & \multicolumn{2}{|c|}{ Из них } & \multirow{2}{*}{$\begin{array}{c}\text { Исследова- } \\
\text { тели }\end{array}$} & \multicolumn{2}{|c|}{ Из них } & \multirow{2}{*}{$\begin{array}{c}\text { Исследова- } \\
\text { тели }\end{array}$} & \multicolumn{2}{|c|}{ Из них } & \multirow{2}{*}{$\begin{array}{c}\text { Исследова- } \\
\text { тели }\end{array}$} & \multicolumn{2}{|c|}{ Из них } \\
\hline & & $\begin{array}{c}\text { доктора } \\
\text { наук }\end{array}$ & $\begin{array}{c}\text { кандидаты } \\
\text { наук }\end{array}$ & & $\begin{array}{c}\text { доктора } \\
\text { наук }\end{array}$ & $\begin{array}{c}\text { кандидаты } \\
\text { наук }\end{array}$ & & $\begin{array}{c}\text { доктора } \\
\text { наук }\end{array}$ & $\begin{array}{c}\text { кандидаты } \\
\text { наук }\end{array}$ & & $\begin{array}{c}\text { доктора } \\
\text { наук }\end{array}$ & $\begin{array}{c}\text { кандидаты } \\
\text { наук }\end{array}$ \\
\hline Всего & 132261 & 17326 & 43043 & 132117 & 18184 & 44653 & 132701 & 18198 & 44746 & 134794 & 18264 & 45642 \\
\hline \multicolumn{13}{|l|}{ Области науки: } \\
\hline естественные & 52719 & 8525 & 21841 & 53195 & 8920 & 22899 & 54676 & 8950 & 23242 & 56349 & 9010 & 23705 \\
\hline технические & 44097 & 1740 & 6204 & 42914 & 1750 & 6084 & 42378 & 1765 & 5874 & 42326 & 1802 & 6044 \\
\hline медицинские & 12918 & 3320 & 5921 & 13363 & 3521 & 6163 & 12710 & 3407 & 5801 & 12643 & 3369 & 5628 \\
\hline сельскохозяйственные & 10285 & 1225 & 3930 & 9898 & 1292 & 3820 & 10093 & 1315 & 3979 & 10008 & 1344 & 4040 \\
\hline общественные & 5456 & 935 & 2251 & 6158 & 1188 & 2763 & 6174 & 1254 & 2859 & 6709 & 1213 & 3153 \\
\hline гуманитарные & 6786 & 1581 & 2896 & 6589 & 1513 & 2924 & 6670 & 1507 & 2991 & 6759 & 1526 & 3072 \\
\hline
\end{tabular}


5.2.13. ДВИЖЕНИЕ ПЕРСОНАЛА, ЗАНЯТОГО ИССЛЕДОВАНИЯМИ И РАЗРАБОТКАМИ В ГОСУДАРСТВЕННОМ СЕКТОРЕ, ПО КАТЕГОРИЯМ

(человек)

\begin{tabular}{|c|c|c|c|c|c|c|c|c|c|c|}
\hline & \multirow{3}{*}{$\begin{array}{c}\text { Наличие } \\
\text { на начало } \\
\text { отчетного } \\
\text { года }\end{array}$} & \multicolumn{4}{|c|}{ Принято } & \multicolumn{4}{|c|}{ Выбыло } & \multirow{3}{*}{$\begin{array}{c}\text { Наличие } \\
\text { на конец } \\
\text { отчетного } \\
\text { года }\end{array}$} \\
\hline & & \multirow[t]{2}{*}{ Всего } & \multicolumn{3}{|c|}{ В том числе } & \multirow[t]{2}{*}{ Bсего } & \multicolumn{3}{|c|}{ В том числе } & \\
\hline & & & $\begin{array}{c}\text { после окон- } \\
\text { чания вуза }\end{array}$ & $\begin{array}{c}\text { из других } \\
\text { научных ор- } \\
\text { ганизаций }\end{array}$ & прочие & & $\begin{array}{c}\text { по } \\
\text { собственно- } \\
\text { му желанию }\end{array}$ & $\begin{array}{c}\text { в связи с со- } \\
\text { кращением } \\
\text { штатов }\end{array}$ & $\begin{array}{l}\text { по прочим } \\
\text { причинам }\end{array}$ & \\
\hline \multicolumn{11}{|l|}{ Всего } \\
\hline 2005 & 275249 & 32634 & 3990 & 5456 & 23188 & 35165 & 24924 & 851 & 9390 & 272718 \\
\hline 2011 & 256637 & 29523 & 3152 & 4193 & 22178 & 31264 & 20567 & 1115 & 9582 & 254896 \\
\hline 2013 & 264121 & 28184 & 2650 & 3461 & 22073 & 30436 & 20179 & 642 & 9615 & 261869 \\
\hline 2015 & 268080 & 33169 & 3182 & 4136 & 25851 & 35820 & 20622 & 1319 & 13879 & 265429 \\
\hline \multicolumn{11}{|c|}{ Исследователи } \\
\hline 2005 & 139746 & 11715 & 3127 & 3121 & 5467 & 12087 & 8871 & 358 & 2858 & 139378 \\
\hline 2011 & 129871 & 10428 & 2192 & 2337 & 5899 & 10944 & 7072 & 335 & 3537 & 128717 \\
\hline 2013 & 133682 & 10035 & 1894 & 2211 & 5930 & 11819 & 8172 & 277 & 3370 & 132117 \\
\hline 2015 & 136237 & 11127 & 2147 & 2347 & 6633 & 12169 & 7725 & 505 & 3939 & 134794 \\
\hline \multicolumn{11}{|l|}{ Техники } \\
\hline 2005 & 25569 & 4128 & 336 & 630 & 3162 & 4227 & 2892 & 83 & 1252 & 25462 \\
\hline 2011 & 24540 & 4424 & 363 & 220 & 3841 & 4484 & 2717 & 146 & 1621 & 26960 \\
\hline 2013 & 28152 & 4034 & 349 & 292 & 3393 & 4371 & 2696 & 55 & 1620 & 27777 \\
\hline 2015 & 28250 & 4634 & 463 & 439 & 3732 & 5846 & 2689 & 138 & 3019 & 27090 \\
\hline \multicolumn{11}{|c|}{ Вспомогательный и прочий персонал } \\
\hline 2005 & 109934 & 16791 & 527 & 1705 & 14555 & 18851 & 13161 & 410 & 5280 & 107878 \\
\hline 2011 & 102226 & 14671 & 597 & 1636 & 12438 & 15836 & 10778 & 634 & 4424 & 99219 \\
\hline 2013 & 102287 & 14115 & 407 & 958 & 12750 & 14246 & 9311 & 310 & 4625 & 101975 \\
\hline 2015 & 103593 & 17408 & 572 & 1350 & 15486 & 17805 & 10208 & 676 & 6921 & 103545 \\
\hline
\end{tabular}




\section{6}

\subsubsection{4. ПРИЕМ И ВЫБЫТИЕ ПЕРСОНАЛА, ЗАНЯТОГО ИССЛЕДОВАНИЯМИ И РАЗРАБОТКАМИ В ГОСУДАРСТВЕННОМ СЕКТОРЕ}

Персонал, занятый исследованиями

$$
\text { и разработками }
$$

Проценты

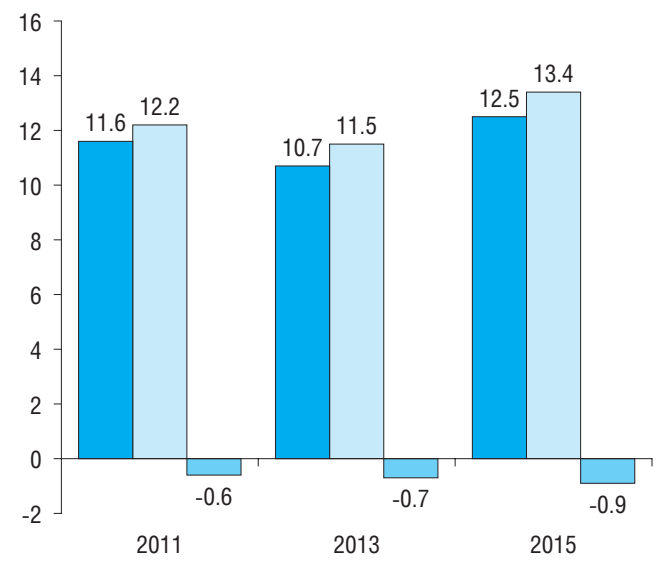

\section{Исследователи}

Проценты

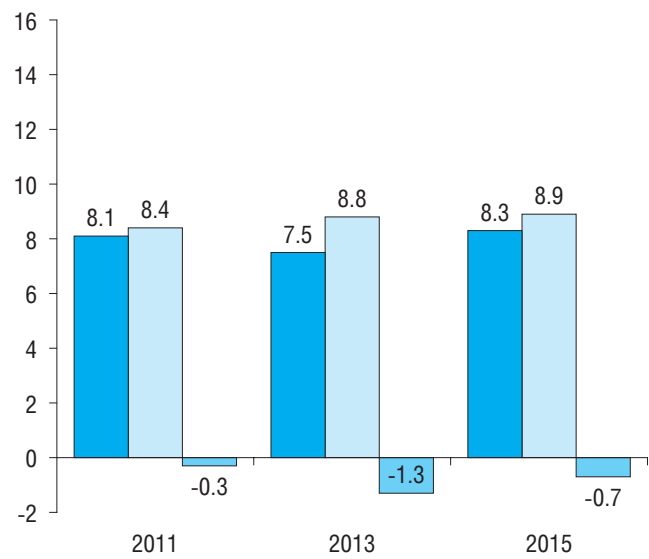

Принято*

Выбыло**

Сальдо

* Отношение численности принятых в течение года к численности работников на конец года.

** Отношение численности выбывших в течение года к численности работников на начало года. 


\subsubsection{5. ПРИЕМ ВЫПУСКНИКОВ ОБРАЗОВАТЕЛЬНЫХ ОРГАНИЗАЦИЙ ВЫСШЕГО ОБРАЗОВАНИЯ \\ НА РАБОТУ В ОРГАНИЗАЦИИ ГОСУДАРСТВЕННОГО СЕКТОРА}

Удельный вес выпускников

в численности принятых

на работу

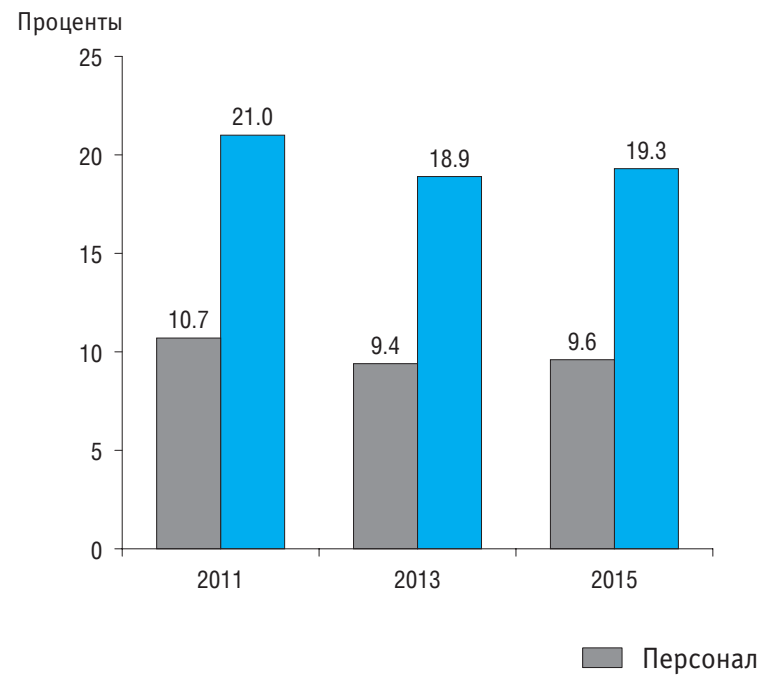

Удельный вес выпускников

в численности персонала, занятого исследованиями и разработками * Проценты

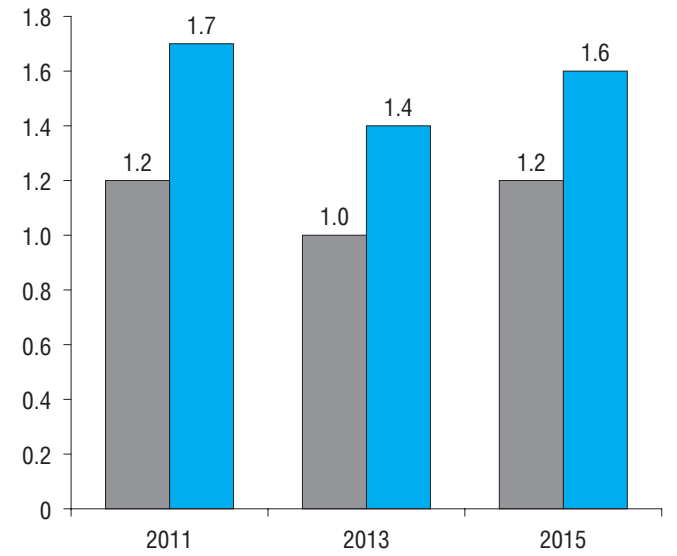

Исследователи

* Отношение численности выпускников образовательных организаций высшего образования, принятых на работу в течение года, к численности работников на конец года. 


\section{8}

5.2.16. ВНУТРЕННИЕ ЗАТРАТЫ НА ИССЛЕДОВАНИЯ И РАЗРАБОТКИ В ГОСУДАРСТВЕННОМ СЕКТОРЕ ПО ТИПАМ ОРГАНИЗАЦИЙ (тысячи рублей)

\begin{tabular}{|c|c|c|c|c|c|c|c|}
\hline & 2005 & 2010 & 2011 & 2012 & 2013 & 2014 & 2015 \\
\hline Всего & 60158166.6 & 161988411.4 & 182135309.9 & 224982089.2 & 226590120.7 & 258023009.1 & 284154288.3 \\
\hline Научно-исследовательские институты & 55762222.6 & 136870186.3 & 151261078.9 & 190774482.9 & 191023430.1 & 222183967.5 & 241159555.3 \\
\hline $\begin{array}{l}\text { Конструкторские, проектно-конструктор- } \\
\text { ские, технологические организации }\end{array}$ & 4007361.7 & 20163653.6 & 23348735.0 & 24722611.1 & 25707283.0 & 27081699.7 & 31243788.5 \\
\hline $\begin{array}{l}\text { Проектные и проектно-изыскательские } \\
\text { организации строительства }\end{array}$ & 21993.6 & 524208.6 & 551628.3 & 561026.1 & 433811.9 & 449560.6 & 384269.6 \\
\hline Опытные базы & 20300.0 & 139733.5 & 528561.1 & 970655.0 & 1076831.6 & 925741.2 & 998142.5 \\
\hline Прочие организации & 346288.7 & 4290629.4 & 6445306.6 & 7953314.1 & 8348764.1 & 7382040.1 & 10368532.4 \\
\hline
\end{tabular}




\subsubsection{7. ВНУТРЕННИЕ ЗАТРАТЫ НА ИССЛЕДОВАНИЯ И РАЗРАБОТКИ В ГОСУДАРСТВЕННОМ СЕКТОРЕ}

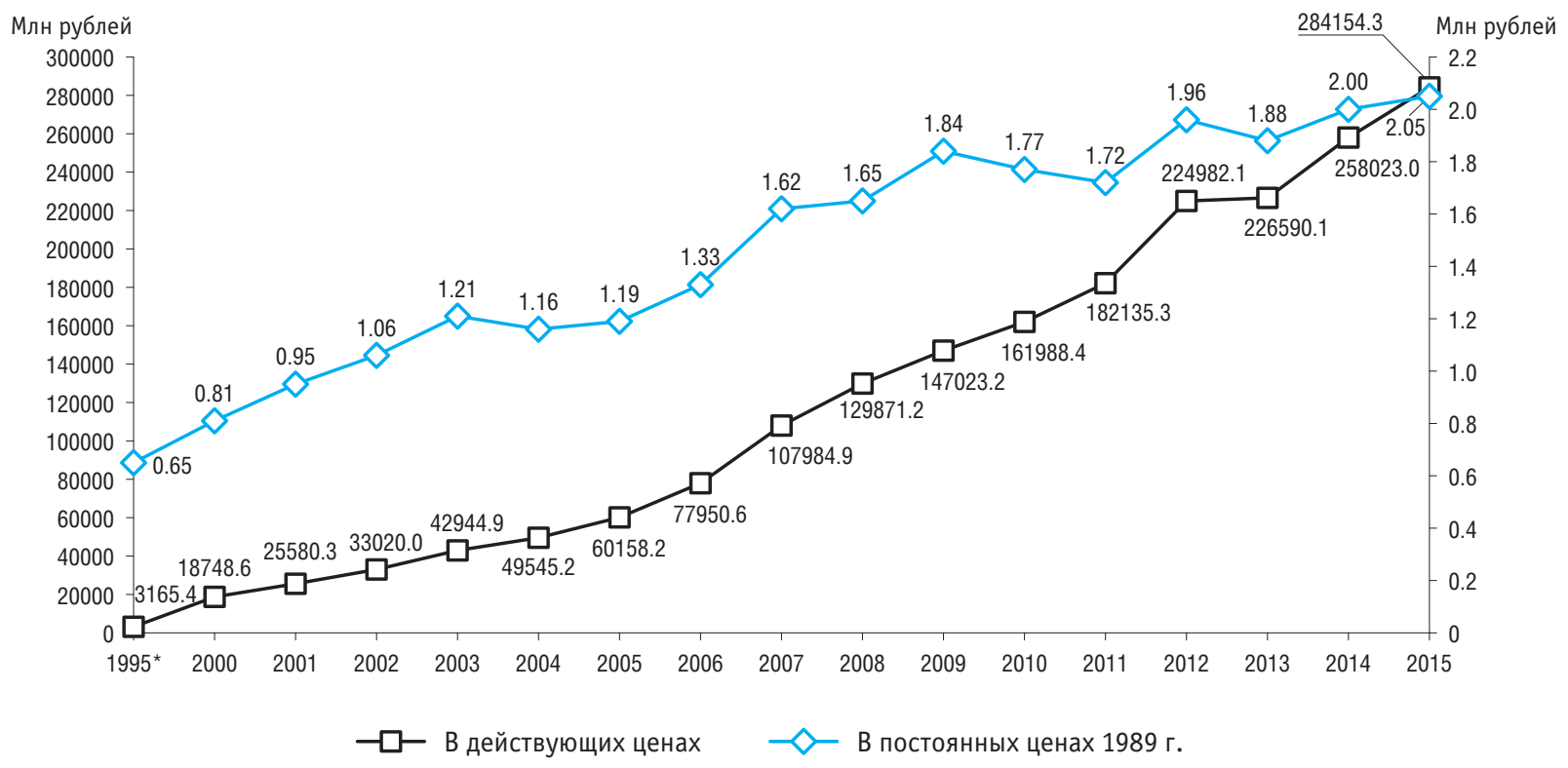

* Млрд рублей. 
5.2.18. ВНУТРЕННИЕ ЗАТРАТЫ НА ИССЛЕДОВАНИЯ И РАЗРАБОТКИ В ГОСУДАРСТВЕННОМ СЕКТОРЕ ПО ИСТОЧНИКАМ ФИНАНСИРОВАНИЯ

\begin{tabular}{|c|c|c|c|c|c|c|}
\hline & Bсего & $\begin{array}{c}\text { Средства } \\
\text { государства* }\end{array}$ & $\begin{array}{c}\text { Средства } \\
\text { предпринима- } \\
\text { тельского сектора }\end{array}$ & $\begin{array}{c}\text { Средства } \\
\text { организаций сектора } \\
\text { высшего образования }\end{array}$ & $\begin{array}{c}\text { Средства } \\
\text { некоммерческих } \\
\text { организаций }\end{array}$ & $\begin{array}{c}\text { Средства } \\
\text { иностранных } \\
\text { источников }\end{array}$ \\
\hline \multicolumn{7}{|c|}{ В действующих ценах, тыс. рублей, 1995 г. - млн рублей } \\
\hline 1995 & 3165439.4 & 2779222.3 & 255799.4 & 2313.0 & 821.0 & 127283.7 \\
\hline 2000 & 18748588.2 & 15060439.1 & 2028296.2 & 11323.4 & 3898.5 & 1644631.0 \\
\hline 2002 & 33020017.4 & 26539969.2 & 4019173.2 & 16110.2 & 49374.0 & 2395390.8 \\
\hline 2003 & 42944862.9 & 34808445.2 & 4925941.0 & 23854.9 & 22789.9 & 3163831.9 \\
\hline 2004 & 49545237.7 & 40562960.9 & 6491792.8 & 47839.9 & 10698.3 & 2431945.8 \\
\hline 2005 & 60158166.6 & 50589802.5 & 6845507.2 & 46912.8 & 21976.9 & 2653967.2 \\
\hline 2006 & 77950634.9 & 65449102.1 & 9136754.4 & 111817.6 & 52071.9 & 3200888.9 \\
\hline 2007 & 107984917.2 & 85896140.4 & 14355790.2 & 80481.6 & 12412.3 & 7640092.7 \\
\hline 2008 & 129871228.3 & 108231726.8 & 16119227.3 & 183124.2 & 120667.0 & 5216483.0 \\
\hline 2009 & 147023165.7 & 124027349.4 & 16292839.6 & 90578.1 & 38990.4 & 6573408.2 \\
\hline 2010 & 161988411.4 & 134275595.6 & 20873979.0 & 205154.5 & 73117.4 & 6560564.9 \\
\hline 2011 & 182135309.9 & 153529403.4 & 21528707.1 & 244802.6 & 61568.4 & 6770828.4 \\
\hline 2012 & 224982089.2 & 186513895.7 & 29459319.3 & 197336.7 & 75635.7 & 8735901.8 \\
\hline 2013 & 226590120.7 & 186895055,8 & 31300159.7 & 211201,3 & 105228.8 & 8078475.1 \\
\hline 2014 & 258023009.1 & 219020381.4 & 29660844.5 & 357181.2 & 100284.6 & 8884317.4 \\
\hline 2015 & 284154288.3 & 240265758.8 & 32877099.7 & 321525.4 & 163335.5 & 10526568.9 \\
\hline
\end{tabular}


(окончание)

\begin{tabular}{|c|c|c|c|c|c|c|}
\hline & Bсего & $\begin{array}{c}\text { Средства } \\
\text { государства* }\end{array}$ & $\begin{array}{c}\text { Средства } \\
\text { предпринима- } \\
\text { тельского сектора }\end{array}$ & $\begin{array}{c}\text { Средства } \\
\text { организаций сектора } \\
\text { высшего образования }\end{array}$ & $\begin{array}{c}\text { Средства } \\
\text { некоммерческих } \\
\text { организаций }\end{array}$ & $\begin{array}{c}\text { Средства } \\
\text { иностранных } \\
\text { источников }\end{array}$ \\
\hline \multicolumn{7}{|c|}{ Проценты } \\
\hline 1995 & 100 & 87.8 & 8.1 & 0.07 & 0.03 & 4.0 \\
\hline 2000 & 100 & 80.3 & 10.8 & 0.06 & 0.02 & 8.8 \\
\hline 2002 & 100 & 80.4 & 12.2 & 0.05 & 0.1 & 7.3 \\
\hline 2003 & 100 & 81.1 & 11.5 & 0.06 & 0.05 & 7.4 \\
\hline 2004 & 100 & 81.9 & 13.1 & 0.1 & 0.02 & 4.9 \\
\hline 2005 & 100 & 84.1 & 11.4 & 0.08 & 0.04 & 4.4 \\
\hline 2006 & 100 & 84.0 & 11.7 & 0.1 & 0.07 & 4.1 \\
\hline 2007 & 100 & 79.5 & 13.3 & 0.07 & 0.01 & 7.1 \\
\hline 2008 & 100 & 83.3 & 12.4 & 0.1 & 0.09 & 4.0 \\
\hline 2009 & 100 & 84.4 & 11.1 & 0.06 & 0.03 & 4.5 \\
\hline 2010 & 100 & 82.9 & 12.9 & 0.1 & 0.05 & 4.1 \\
\hline 2011 & 100 & 84.3 & 11.8 & 0.1 & 0.03 & 3.7 \\
\hline 2012 & 100 & 82.9 & 13.1 & 0.09 & 0.03 & 3.9 \\
\hline 2013 & 100 & 82.5 & 13.8 & 0.09 & 0.05 & 3.6 \\
\hline 2014 & 100 & 84.9 & 11.5 & 0.1 & 0.04 & 3.4 \\
\hline 2015 & 100 & 84.6 & 11.6 & 0.1 & 0.06 & 3.7 \\
\hline
\end{tabular}

\footnotetext{
* Включая средства бюджета, собственные средства и средства организаций государственного сектора.
} 


\subsubsection{9. УДЕЛЬНЫЙ ВЕС ГОСУДАРСТВЕННОГО СЕКТОРА В ОБЩЕМ ОБЪЕМЕ ВНУТРЕННИХ ЗАТРАТ}

НА ИССЛЕДОВАНИЯ И РАЗРАБОТКИ ПО ВИДАМ ЗАТРАТ

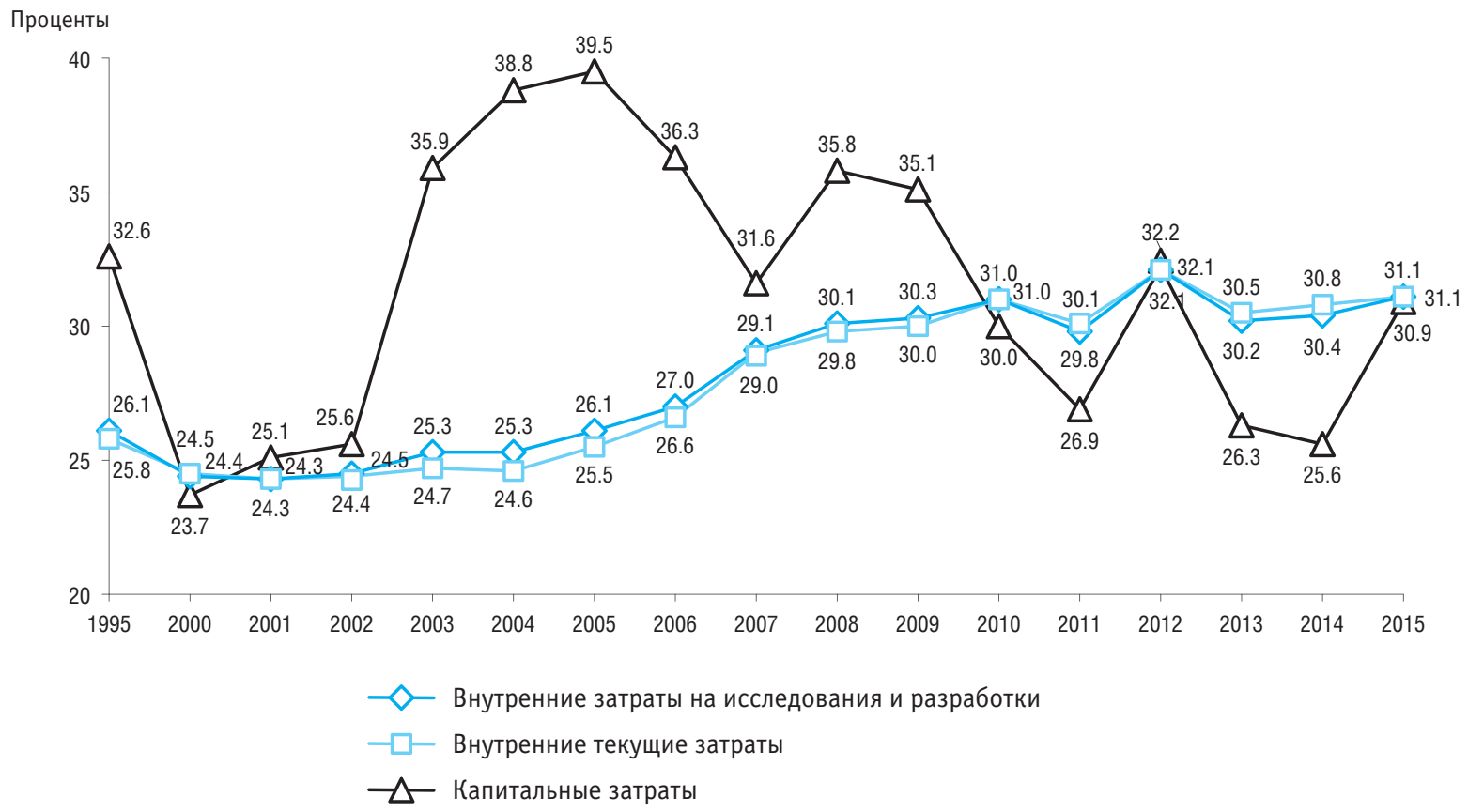




\subsubsection{0. ВНУТРЕННИЕ ЗАТРАТЫ НА ИССЛЕДОВАНИЯ И РАЗРАБОТКИ В ГОСУДАРСТВЕННОМ СЕКТОРЕ ПО ВИДАМ ЗАТРАТ}

(тысячи рублей)

\begin{tabular}{l|r|r|r|r|rrr}
\hline & \multicolumn{1}{|c|}{2005} & \multicolumn{1}{c|}{2010} & 2011 & 2012 & 2013 & 2014 & 2015 \\
\hline Внутренние затраты на исследования и разработки & $\mathbf{6 0 1 5 8 1 6 6 . 6}$ & $\mathbf{1 6 1 9 8 8 4 1 1 . 4}$ & $\mathbf{1 8 2 1 3 5 3 0 9 . 9}$ & $\mathbf{2 2 4 9 8 2 0 8 9 . 2}$ & $\mathbf{2 2 6 5 9 0 1 2 0 . 7}$ & $\mathbf{2 5 8 0 2 3 0 0 9 . 1}$ & $\mathbf{2 8 4 1 5 4 2 8 8 . 3}$ \\
Внутренние текущие затраты & 56342327.7 & 151825126.6 & 170811017.0 & 210559632.9 & 213468794.6 & 244655172.5 & 265478556.9 \\
Затраты на оплату труда & 25406848.5 & 80849201.5 & 89553195.8 & 108036774.5 & 112439789.3 & 126267663.6 & 134412102.1 \\
$\quad$ Из них работникам, выполнявшим исследования & & & & & & & \\
$\quad$ и разработки* & 23066423.6 & 73752076.2 & 81321475.8 & 98720480.9 & 102744281.9 & 114929478.2 & 121375793.9 \\
Страховые взносы в Пенсионный фонд, ФСС, ФФОМС & 6257309.9 & 16436614.4 & 23348352.4 & 27038528.7 & 2923058.9 & 32567448.4 & 36154760.9 \\
Затраты на оборудование & 3086873.3 & 5458681.5 & 5276489.5 & 8154615.9 & 6600021.2 & 7776357.0 & 7442689.6 \\
Другие материальные затраты & 9781232.9 & 22464861.8 & 25352173.1 & 33170617.4 & 32362326.9 & 39503365.7 & 42451174.6 \\
Прочие текущие затраты & 11810063.1 & 26615767.4 & 27280806.2 & 34159096.4 & 32836118.3 & 38540337.8 & 45017829.7 \\
Капитальные затраты & 3815838.9 & 10163284.8 & 11324292.9 & 14422456.3 & 13121326.1 & 13367836.6 & 18675731.4 \\
Земельные участки и здания & 399698.5 & 3113137.6 & 2285830.0 & 2579811.6 & 2467555.2 & 3248423.4 & 3903611.8 \\
Оборудование & 2485274.0 & 4647644.5 & 5963907.8 & 8948846.1 & 7352490.4 & 7037782.8 & 10358881.1 \\
Прочие капитальные затраты & 930866.4 & 2402502.7 & 3074555.1 & 2893798.6 & 3301280.5 & 3081630.4 & 4413238.5 \\
\hline
\end{tabular}

* Без совместителей и работавших по договорам гражданско-правового характера. 


\subsubsection{1. ВНУТРЕННИЕ ТЕКУЩИЕ ЗАТРАТЫ НА ИССЛЕДОВАНИЯ И РАЗРАБОТКИ В ГОСУДАРСТВЕННОМ СЕКТОРЕ} ПО ВИДАМ РАБОТ И ОБЛАСТЯМ НАУКИ

(тысячи рублей)

\begin{tabular}{|c|c|c|c|c|c|c|c|}
\hline & Bсего & $\begin{array}{c}\text { Естественные } \\
\text { науки }\end{array}$ & $\begin{array}{l}\text { Технические } \\
\text { науки }\end{array}$ & $\begin{array}{c}\text { Медицинские } \\
\text { науки }\end{array}$ & $\begin{array}{c}\text { Сельскохозяйст- } \\
\text { венные науки }\end{array}$ & $\begin{array}{c}\text { Общественные } \\
\text { науки }\end{array}$ & $\begin{array}{c}\text { Гуманитарныє } \\
\text { науки }\end{array}$ \\
\hline \multicolumn{8}{|c|}{2005} \\
\hline Внутренние текущие затраты & 56342327.7 & 20577533.0 & 25509704.3 & 3738833.2 & 2939051.4 & 1951167.1 & 1626038.7 \\
\hline Фундаментальные исследования & 24586195.8 & 15976354.8 & 2622298.0 & 1662238.3 & 1678543.7 & 1333808.2 & 1312952.8 \\
\hline Прикладные исследования & 10603039.3 & 2644812.7 & 4734050.4 & 1703960.2 & 840824.2 & 475142.3 & 204249.5 \\
\hline Разработки & 21153092.6 & 1956365.5 & 18153355.9 & 372634.7 & 419683.5 & 142216.6 & 108836.4 \\
\hline \multicolumn{8}{|c|}{2012} \\
\hline Внутренние текущие затраты & 210559632.9 & 74578391.3 & 99706257.2 & 15817690.9 & 8026764.3 & 5652165.9 & 677836.3 \\
\hline Фундаментальные исследования & 78699812.7 & 48982304.9 & 10692686.1 & 6227176.1 & 4157881.1 & 3442922.0 & 5196842.5 \\
\hline Прикладные исследования & 50128152.6 & 16568445.2 & 19005871.9 & 8523260.5 & 2915626.9 & 1908941.7 & 1206006.4 \\
\hline Разработки & 81731667.6 & 9027641.2 & 70007699.2 & 1067254.3 & 953256.3 & 300302.2 & 375514.4 \\
\hline \multicolumn{8}{|c|}{2013} \\
\hline Внутренние текущие затраты & 213468794.6 & 79572896.8 & 93847670.4 & 17128372.1 & 9466494.3 & 6624251.4 & 6829109.6 \\
\hline Фундаментальные исследования & 86128282.9 & 51133027.0 & 12746351.4 & 7571746.5 & 4660236.1 & 4449803.8 & 5567118.1 \\
\hline Прикладные исследования & 49843105.3 & 19084334.2 & 16571591.2 & 8104764.8 & 3455260.0 & 1661589.4 & 965565.7 \\
\hline Разработки & 77497406.4 & 9355535.6 & 64529727.8 & 1451860.8 & 1350998.2 & 512858.2 & 296425.8 \\
\hline \multicolumn{8}{|c|}{2014} \\
\hline Внутренние текущие затраты & 244655172.5 & 92732641.7 & 107607344.3 & 18464196.6 & 10908795.6 & 7106804.7 & 7835389.6 \\
\hline Фундаментальные исследования & 97017979.4 & 57696082.8 & 12355070.9 & 8397591.8 & 7316853.9 & 4853294.3 & 6399085.7 \\
\hline Прикладные исследования & 53934451.4 & 19852066.9 & 20568881.7 & 8767461.7 & 2429711.6 & 1501888.3 & 814441.2 \\
\hline Разработки & 93702741.7 & 15184492.0 & 74683391.7 & 1299143.1 & 1162230.1 & 751622.1 & 621862.7 \\
\hline \multicolumn{8}{|c|}{2015} \\
\hline Внутренние текущие затраты & 265478556.9 & 98742002.1 & 117329719.0 & 22341866.9 & 11448932.5 & 7440718.3 & 8175318.1 \\
\hline Фундаментальные исследования & 99987000.6 & 58183429.9 & 14273618.3 & 7951401.7 & 7804653.1 & 4972403.3 & 6801494.3 \\
\hline Прикладные исследования & 66248286.3 & 24349761.4 & 23686724.2 & 13081555.6 & 2396404.2 & 1982310.8 & 751530.1 \\
\hline Разработки & 99243270.0 & 16208810.8 & 79369376.5 & 1308909.6 & 1247875.2 & 486004.2 & 622293.7 \\
\hline
\end{tabular}




\subsubsection{2. УДЕЛЬНЫЙ ВЕС ГОСУДАРСТВЕННОГО СЕКТОРА В ОБЩЕМ ОБЪЕМЕ ВНУТРЕННИХ ТЕКУЩИХ ЗАТРАТ НА ИССЛЕДОВАНИЯ И РАЗРАБОТКИ ПО ВИДАМ РАБОТ}

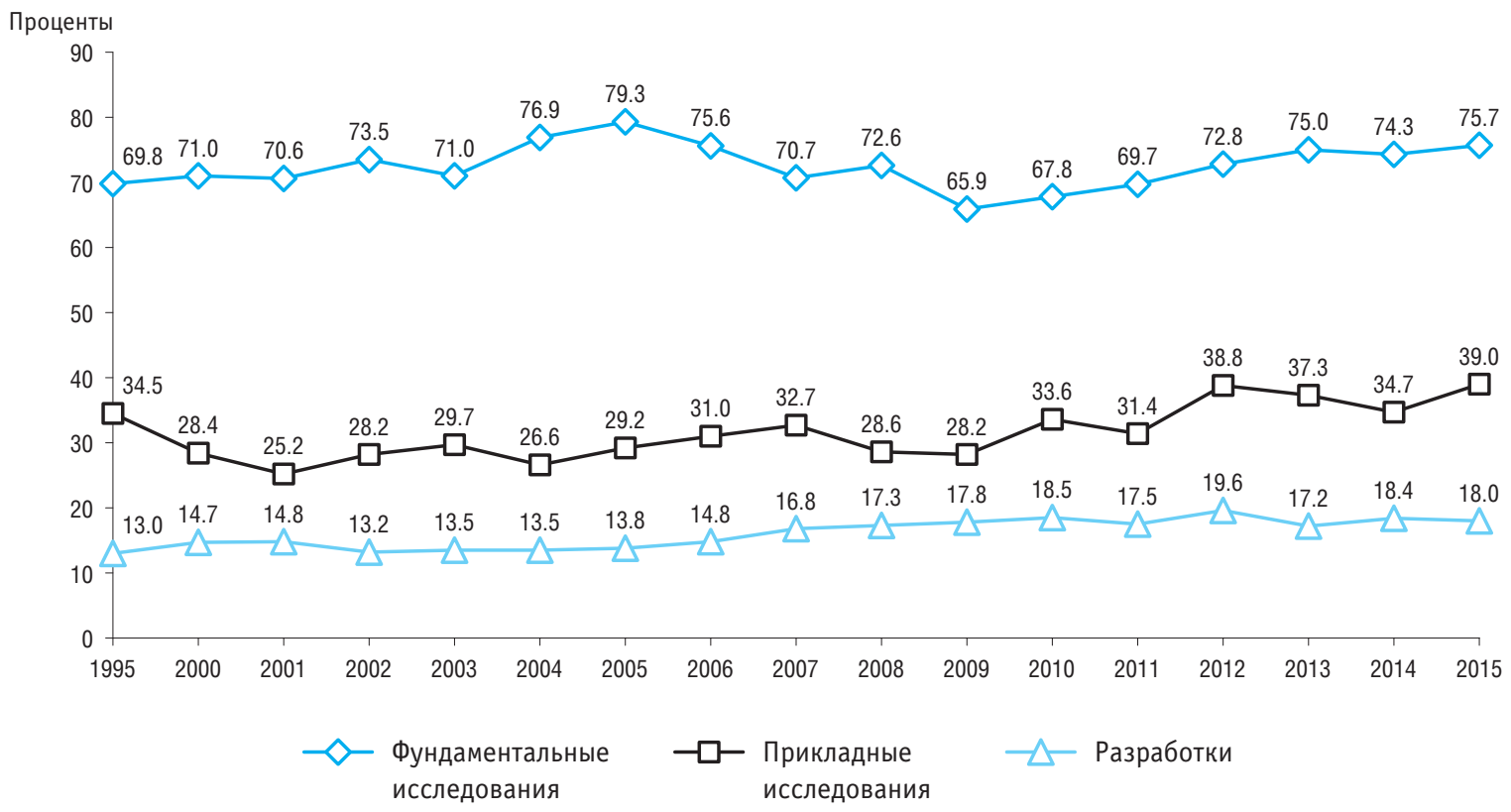




\subsubsection{3. СТРУКТУРА ВНУТРЕННИХ ТЕКУЩИХ ЗАТРАТ НА ИССЛЕДОВАНИЯ И РАЗРАБОТКИ} В ГОСУДАРСТВЕННОМ СЕКТОРЕ ПО ВИДАМ РАБОТ

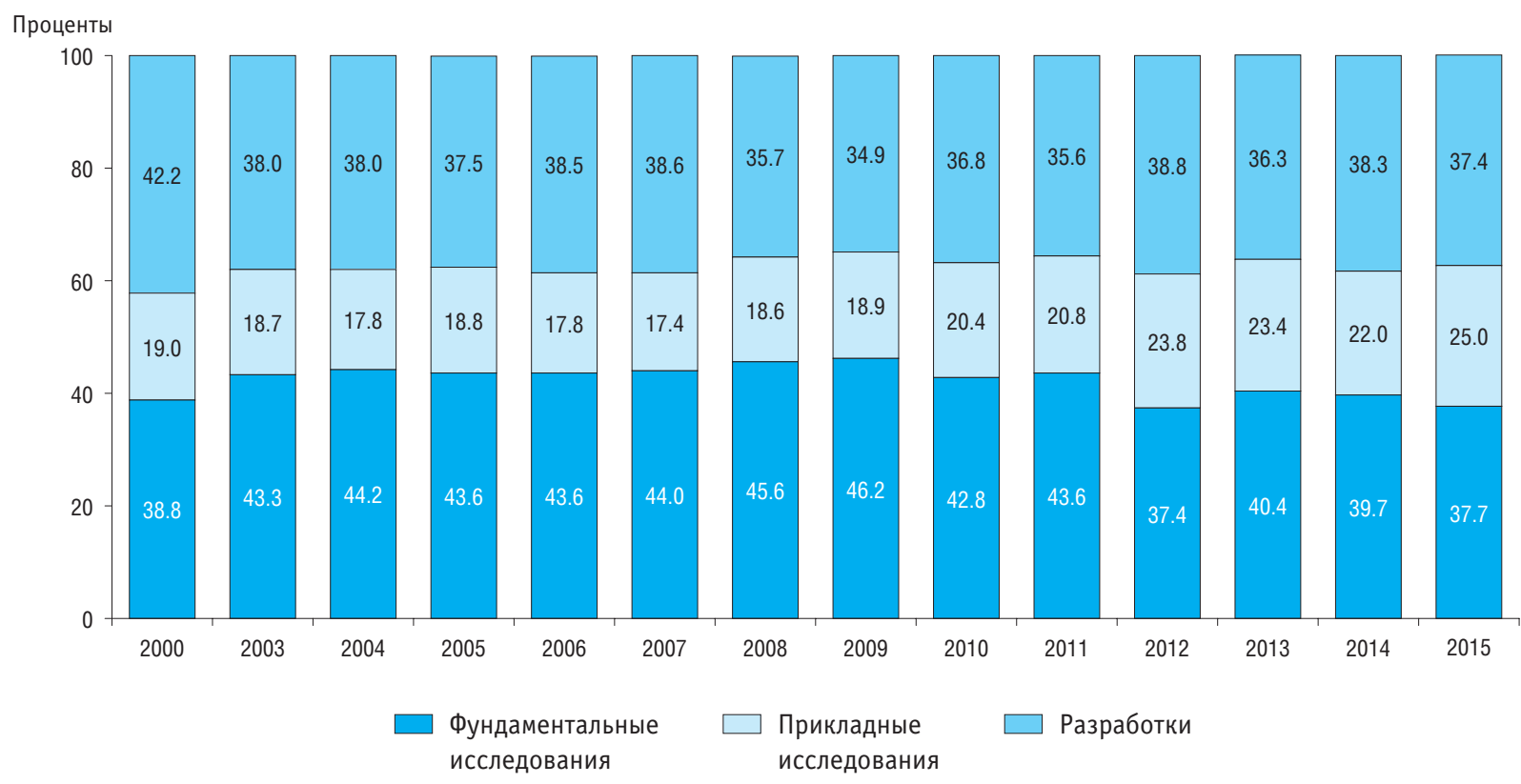


5.2.24. СРЕДНЕМЕСЯЧНАЯ ЗАРАБОТНАЯ ПЛАТА ПЕРСОНАЛА, ЗАНЯТОГО ИССЛЕДОВАНИЯМИ И РАЗРАБОТКАМИ В ГОСУДАРСТВЕННОМ СЕКТОРЕ

\begin{tabular}{|c|c|c|c|c|c|c|c|c|c|c|c|c|}
\hline & 1995 & 2000 & 2005 & 2007 & 2008 & 2009 & 2010 & 2011 & 2012 & 2013 & 2014 & 2015 \\
\hline $\begin{array}{l}\text { Среднемесячная заработная плата, } \\
\text { руб., } 1995 \text { г. - тыс. руб. } \\
\text { В процентах к заработной плате: }\end{array}$ & 330.5 & 2015.6 & 7220.9 & 14208.3 & 19561.0 & 22979.7 & 24792.1 & 27869.4 & 32031.0 & 34532.8 & 38715.6 & 40513.5 \\
\hline в экономике в целом (=100\%) & 70.0 & 90.7 & 84.4 & 104.5 & 113.1 & 123.3 & 118.3 & 119.3 & 120.3 & 115.9 & 119.1 & 119.2 \\
\hline в обрабатывающих производствах (=100\%) & 72.1 & 85.2 & 85.7 & 110.3 & 121.9 & 138.6 & 130.0 & 128.0 & 130.7 & 127.7 & 131.2 & 127.2 \\
\hline в строительстве (=100\%) & 56.2 & 76.4 & 79.9 & 99.1 & 105.3 & 126.8 & 117.1 & 117.7 & 123.4 & 124.7 & 131.9 & 135.6 \\
\hline
\end{tabular}




\section{3. Предпринимательский сектор}

5.3.1. ОРГАНИЗАЦИИ, ВЫПОЛНЯВШИЕ ИССЛЕДОВАНИЯ И РАЗРАБОТКИ

В ПРЕДПРИНИМАТЕЛЬСКОМ СЕКТОРЕ, ПО ТИПАМ

\begin{tabular}{|c|c|c|c|c|c|c|c|c|c|c|c|c|c|}
\hline & 1995 & 2000 & 2005 & 2006 & 2007 & 2008 & 2009 & 2010 & 2011 & 2012 & 2013 & 2014 & 2015 \\
\hline Всего & 2345 & 2278 & 1703 & 1682 & 1742 & 1540 & 1446 & 1405 & 1450 & 1362 & 1269 & 1265 & 1400 \\
\hline Научно-исследовательские институты & 1089 & 1062 & 855 & 805 & 765 & 699 & 659 & 634 & 598 & 567 & 514 & 504 & 482 \\
\hline $\begin{array}{l}\text { Конструкторские, проектно-конструктор- } \\
\text { ские, технологические организации }\end{array}$ & 615 & 564 & 410 & 398 & 391 & 334 & 306 & 290 & 287 & 262 & 265 & 254 & 260 \\
\hline $\begin{array}{l}\text { Проектные и проектно-изыскательские } \\
\text { организации строительства }\end{array}$ & 204 & 94 & 55 & 51 & 45 & 37 & 31 & 31 & 32 & 27 & 26 & 26 & 21 \\
\hline Организации промышленного производства & 286 & 276 & 231 & 255 & 265 & 239 & 228 & 238 & 280 & 274 & 266 & 275 & 371 \\
\hline Опытные базы & 31 & 32 & 16 & 15 & 19 & 20 & 21 & 16 & 14 & 19 & 9 & 10 & 11 \\
\hline Прочие организации & 120 & 250 & 136 & 158 & 257 & 211 & 201 & 196 & 239 & 213 & 189 & 196 & 255 \\
\hline
\end{tabular}


5.3.2. ПЕРСОНАЛ, ЗАНЯТЫЙ ИССЛЕДОВАНИЯМИ И РАЗРАБОТКАМИ В ПРЕДПРИНИМАТЕЛЬСКОМ СЕКТОРЕ, ПО ТИПАМ ОРГАНИЗАЦИЙ (человек)

\begin{tabular}{|c|c|c|c|c|c|c|c|c|c|c|c|c|c|}
\hline & 1995 & 2000 & 2005 & 2006 & 2007 & 2008 & 2009 & 2010 & 2011 & 2012 & 2013 & 2014 & 2015 \\
\hline Bcero & 726568 & 590646 & 496706 & 486613 & 478401 & 451532 & 432415 & 423112 & 419752 & 394182 & 405268 & 405529 & 408802 \\
\hline Научно-исследовательские институты & 438599 & 349242 & 255233 & 243004 & 234808 & 225430 & 214050 & 207166 & 196235 & 194274 & 205511 & 204860 & 202431 \\
\hline $\begin{array}{l}\text { Конструкторские, } \\
\text { проектно-конструкторские, }\end{array}$ & & & & & & & & & & & & & \\
\hline $\begin{array}{l}\text { технологические организации } \\
\text { Проектные } \\
\text { и проектно-изыскательские }\end{array}$ & $1 / 4523$ & $151 / 05$ & 161295 & 153259 & 148294 & $138 / 13$ & 135811 & 129281 & 135133 & 110381 & $11261 /$ & $114 / 52$ & 115683 \\
\hline организации строительства & 20844 & 8177 & 5284 & 5839 & 7001 & 6004 & 5320 & 4905 & 5076 & 5402 & 3751 & 3602 & 1629 \\
\hline $\begin{array}{l}\text { Организации промышленного произ- } \\
\text { водства }\end{array}$ & 73410 & 52598 & 43524 & 59856 & 56759 & 52042 & 49042 & 51807 & 52004 & 52071 & 52232 & 49358 & 53868 \\
\hline Опытные базы & 9998 & 3945 & 865 & 5736 & 2653 & 849 & 938 & 925 & 852 & 946 & 705 & 1374 & 1499 \\
\hline Прочие организации & 9194 & 24979 & 30505 & 18919 & 28886 & 28494 & 27254 & 29028 & 30452 & 31108 & 30536 & 31583 & 33692 \\
\hline
\end{tabular}

\subsection{3. ПЕРСОНАЛ, ЗАНЯТЫЙ ИССЛЕДОВАНИЯМИ И РАЗРАБОТКАМИ В ПРЕДПРИНИМАТЕЛЬСКОМ СЕКТОРЕ, ПО КАТЕГОРИЯМ (человек)}

\begin{tabular}{|c|c|c|c|c|c|c|c|c|c|c|c|c|c|}
\hline & 1995 & 2000 & 2005 & 2006 & 2007 & 2008 & 2009 & 2010 & 2011 & 2012 & 2013 & 2014 & 2015 \\
\hline Всего & 726568 & 590646 & 496706 & 486613 & 478401 & 451532 & 432415 & 423112 & 419752 & 394182 & 405268 & 405529 & 408802 \\
\hline Исследователи & 336671 & 267640 & 221445 & 218702 & 219632 & 209579 & 201668 & 197785 & 202185 & 192285 & 193736 & 196320 & 198123 \\
\hline Техники & 70180 & 46535 & 38837 & 36315 & 33340 & 31230 & 30613 & 30063 & 28235 & 26720 & 28920 & 29452 & 29850 \\
\hline Вспомогательный персонал & 201122 & 175261 & 147980 & 144966 & 140507 & 129496 & 123814 & 120485 & 116829 & 106306 & 109691 & 107215 & 108230 \\
\hline Прочие & 118595 & 101210 & 90444 & 86630 & 84922 & 81227 & 76320 & 74779 & 72503 & 68871 & 72921 & 72542 & 72599 \\
\hline
\end{tabular}




\subsection{4. СТРУКТУРА ПЕРСОНАЛА, ЗАНЯТОГО ИССЛЕДОВАНИЯМИ И РАЗРАБОТКАМИ}

В ПРЕДПРИНИМАТЕЛЬСКОМ СЕКТОРЕ, ПО КАТЕГОРИЯМ

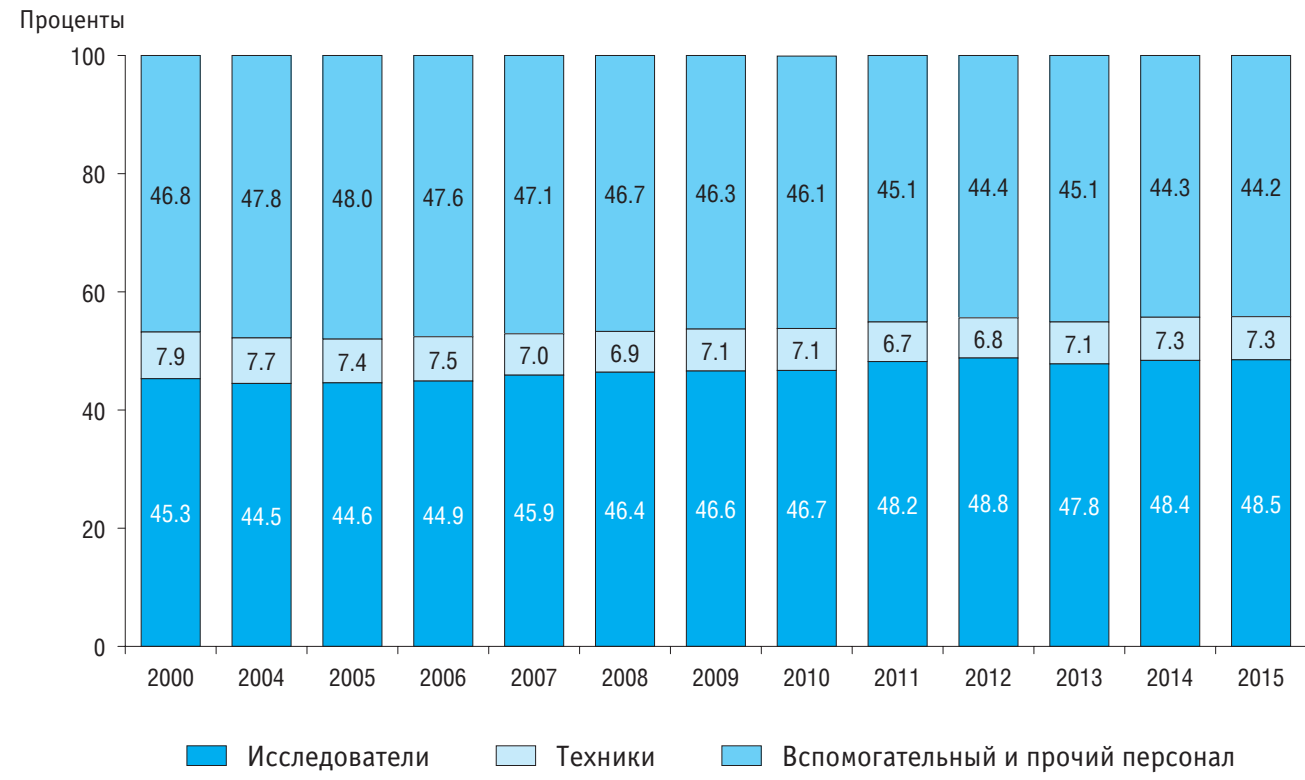




\subsection{5. УДЕЛЬНЫЙ ВЕС ПРЕДПРИНИМАТЕЛЬСКОГО СЕКТОРА В ОБЩЕЙ ЧИСЛЕННОСТИ ПЕРСОНАЛА,}

ЗАНЯТОГО ИССЛЕДОВАНИЯМИ И РАЗРАБОТКАМИ, ПО КАТЕГОРИЯМ

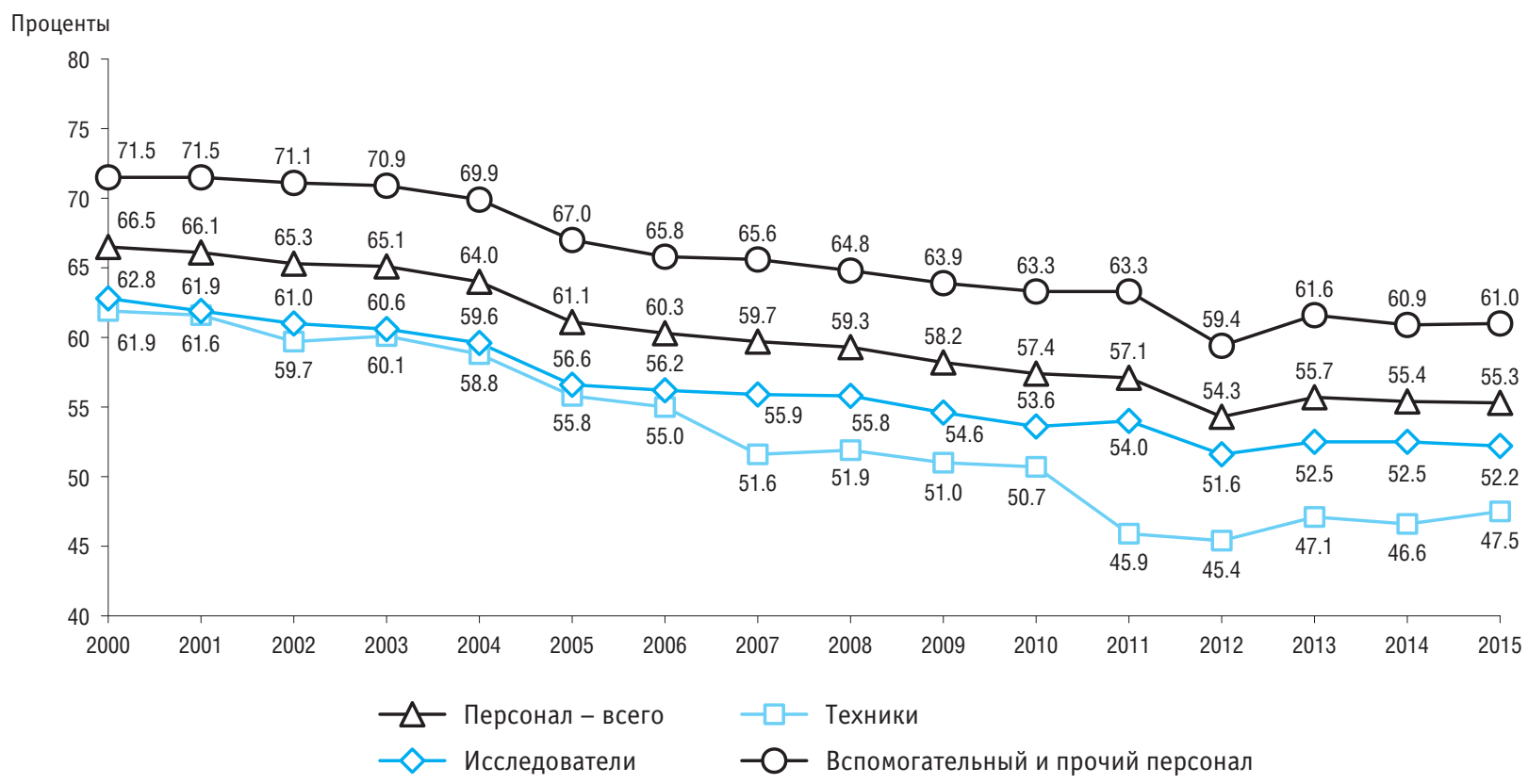


5.3.6. ПЕРСОНАЛ, ЗАНЯТЫЙ ИССЛЕДОВАНИЯМИ И РАЗРАБОТКАМИ В ПРЕДПРИНИМАТЕЛЬСКОМ СЕКТОРЕ, ПО УРОВНЮ ОБРАЗОВАНИЯ (человек)

\begin{tabular}{|c|c|c|c|c|}
\hline & Всего & $\begin{array}{c}\text { Высшее } \\
\text { образование }\end{array}$ & $\begin{array}{l}\text { Среднее профессиональное } \\
\text { образование }\end{array}$ & $\begin{array}{c}\text { Прочее } \\
\text { образование }\end{array}$ \\
\hline \multicolumn{5}{|c|}{$\begin{array}{l}\text { Персонал, занятый исследованиями } \\
\text { и разработками }\end{array}$} \\
\hline 2005 & 496706 & 288649 & 89265 & 118792 \\
\hline 2010 & 423112 & 268821 & 69552 & 84739 \\
\hline 2012 & 394182 & 263555 & 60764 & 69863 \\
\hline 2013 & 405268 & 271434 & 61575 & 72259 \\
\hline 2014 & 405529 & 276675 & 59564 & 69290 \\
\hline 2015 & 408802 & 283664 & 60370 & 64768 \\
\hline \multicolumn{5}{|c|}{ Исследователи } \\
\hline 2005 & 221445 & 221445 & - & - \\
\hline 2010 & 197785 & 197785 & - & - \\
\hline 2012 & 192285 & 192285 & - & - \\
\hline 2013 & 193736 & 193736 & - & - \\
\hline 2014 & 196320 & 196320 & - & - \\
\hline 2015 & 198123 & 198123 & - & - \\
\hline \multicolumn{5}{|l|}{ Техники } \\
\hline 2005 & 36837 & 6274 & 21435 & 9130 \\
\hline 2010 & 30063 & 7842 & 15051 & 7170 \\
\hline 2012 & 26720 & 7547 & 13096 & 6077 \\
\hline 2013 & 28920 & 9428 & 12887 & 6605 \\
\hline 2014 & 29452 & 10215 & 12503 & 6734 \\
\hline 2015 & 29850 & 11656 & 11794 & 6400 \\
\hline
\end{tabular}


(окончание)

\begin{tabular}{|c|c|c|c|c|}
\hline & Всего & $\begin{array}{c}\text { Высшее } \\
\text { образование }\end{array}$ & $\begin{array}{c}\text { Среднее профессиональное } \\
\text { образование }\end{array}$ & $\begin{array}{c}\text { Прочее } \\
\text { образование }\end{array}$ \\
\hline \multicolumn{5}{|c|}{ Вспомогательный персонал } \\
\hline 2005 & 147980 & 37101 & 42099 & 68780 \\
\hline 2010 & 120485 & 38988 & 33362 & 48135 \\
\hline 2012 & 106306 & 37181 & 29116 & 40009 \\
\hline 2013 & 109691 & 39124 & 29508 & 41059 \\
\hline 2014 & 107215 & 40615 & 28175 & 38425 \\
\hline 2015 & 108230 & 42934 & 30297 & 34999 \\
\hline \multicolumn{5}{|l|}{ Прочие } \\
\hline 2005 & 90444 & 23829 & 25733 & 40882 \\
\hline 2010 & 74779 & 24206 & 21139 & 29434 \\
\hline 2012 & 68871 & 26542 & 18552 & 23777 \\
\hline 2013 & 72921 & 29146 & 19180 & 24595 \\
\hline 2014 & 72542 & 29525 & 18886 & 24131 \\
\hline 2015 & 72599 & 30951 & 18279 & 23369 \\
\hline
\end{tabular}




\subsection{7. ИССЛЕДОВАТЕЛИ В ПРЕДПРИНИМАТЕЛЬСКОМ СЕКТОРЕ ПО ПОЛУ И ВОЗРАСТНЫМ ГРУППАМ}

(человек)

\begin{tabular}{|c|c|c|c|c|c|c|}
\hline & \multicolumn{3}{|c|}{2008} & \multicolumn{3}{|c|}{2015} \\
\hline & \multirow[t]{2}{*}{ Исследователи } & \multicolumn{2}{|c|}{ Из них } & \multirow[t]{2}{*}{ Исследователи } & \multicolumn{2}{|c|}{ Из них } \\
\hline & & доктора наук & кандидаты наук & & доктора наук & кандидаты наук \\
\hline Всего & 209579 & 4284 & 20560 & 198123 & 3413 & 16857 \\
\hline \multicolumn{7}{|l|}{ Возраст, лет: } \\
\hline до 29 включительно & 39743 & 8 & 522 & 46854 & 4 & 701 \\
\hline $30-39$ & 26840 & 21 & 1845 & 46046 & 78 & 3090 \\
\hline $40-49$ & 33992 & 250 & 2234 & 23651 & 156 & 2087 \\
\hline $50-54$ & 28373 & 369 & 2334 & 16763 & 214 & 1293 \\
\hline $55-59$ & 29208 & 572 & 3324 & 19333 & 392 & 1861 \\
\hline $60-69$ & 36400 & 1375 & 6113 & 31975 & 1147 & 4383 \\
\hline 70 и старше & 15023 & 1689 & 4188 & 13501 & 1422 & 3442 \\
\hline Мужчины & 125997 & 3905 & 16502 & 126019 & 3108 & 13546 \\
\hline \multicolumn{7}{|l|}{ Возраст, лет: } \\
\hline до 29 включительно & 25365 & 7 & 397 & 31232 & 4 & 538 \\
\hline $30-39$ & 16324 & 17 & 1303 & 30325 & 65 & 2295 \\
\hline $40-49$ & 17239 & 220 & 1676 & 13918 & 125 & 1520 \\
\hline $50-54$ & 15126 & 317 & 1817 & 9061 & 196 & 1020 \\
\hline $55-59$ & 16262 & 509 & 2667 & 11102 & 343 & 1542 \\
\hline $60-69$ & 23519 & 1276 & 5109 & 20028 & 1047 & 3694 \\
\hline 70 и старше & 12162 & 1559 & 3533 & 10353 & 1328 & 2937 \\
\hline Женщины & 83582 & 379 & 4058 & 72104 & 305 & 3311 \\
\hline \multicolumn{7}{|l|}{ Возраст, лет: } \\
\hline до 29 включительно & 14378 & 1 & 125 & 15622 & - & 163 \\
\hline $30-39$ & 10516 & 4 & 542 & 15721 & 13 & 795 \\
\hline $40-49$ & 16753 & 30 & 558 & 9733 & 31 & 567 \\
\hline $50-54$ & 13247 & 52 & 517 & 7702 & 18 & 273 \\
\hline $55-59$ & 12946 & 63 & 657 & 8231 & 49 & 319 \\
\hline $60-69$ & 12881 & 99 & 1004 & 11947 & 100 & 689 \\
\hline 70 и старше & 2861 & 130 & 655 & 3148 & 94 & 505 \\
\hline
\end{tabular}




\subsection{8. СТРУКТУРА ИССЛЕДОВАТЕЛЕЙ В ПРЕДПРИНИМАТЕЛЬСКОМ СЕКТОРЕ ПО ВОЗРАСТНЫМ ГРУППАМ}
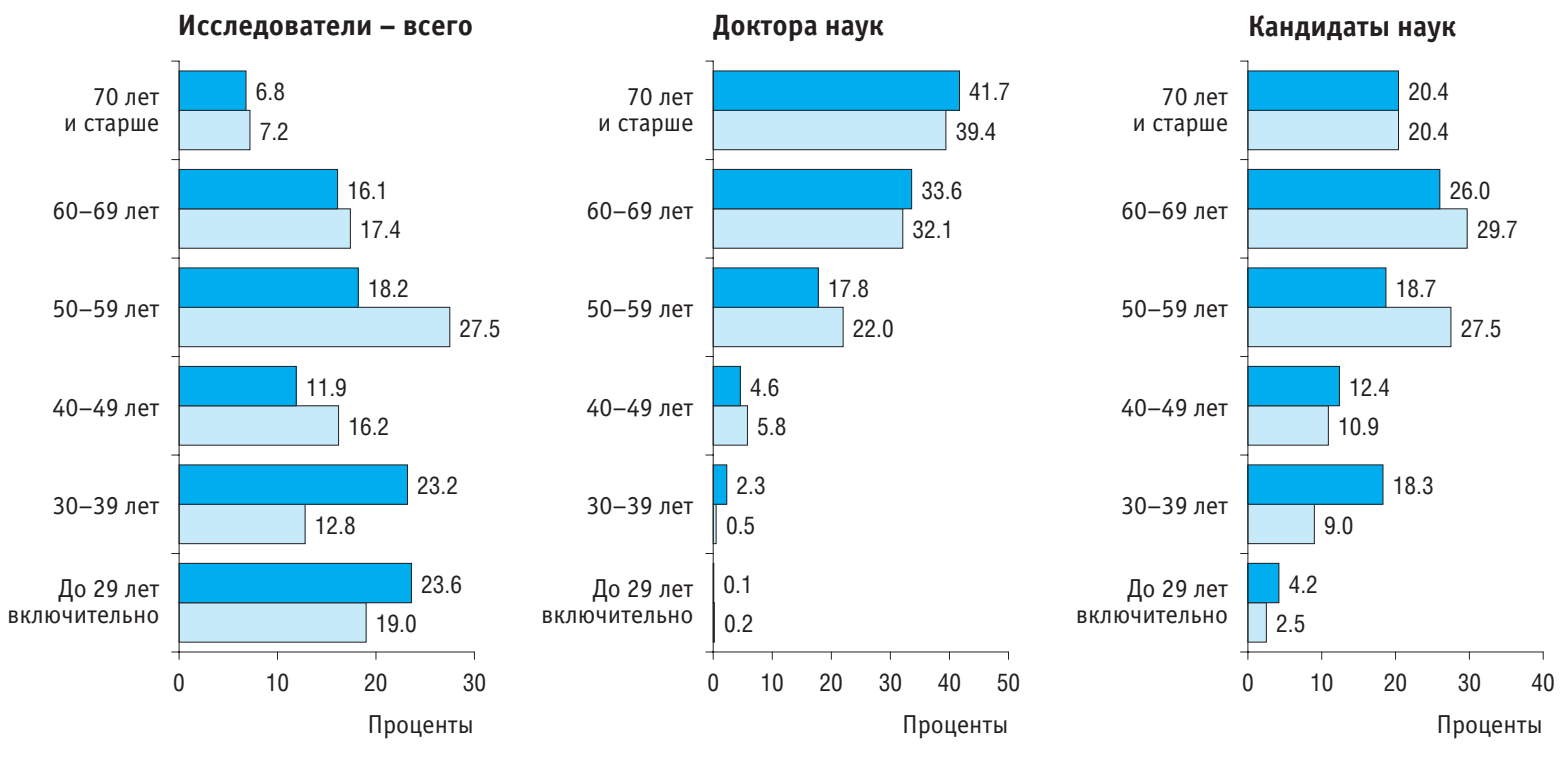

$\square 2008 \quad \square 2015$ 
5.3.9. СРЕДНИЙ ВОЗРАСТ ИССЛЕДОВАТЕЛЕЙ В ПРЕДПРИНИМАТЕЛЬСКОМ СЕКТОРЕ

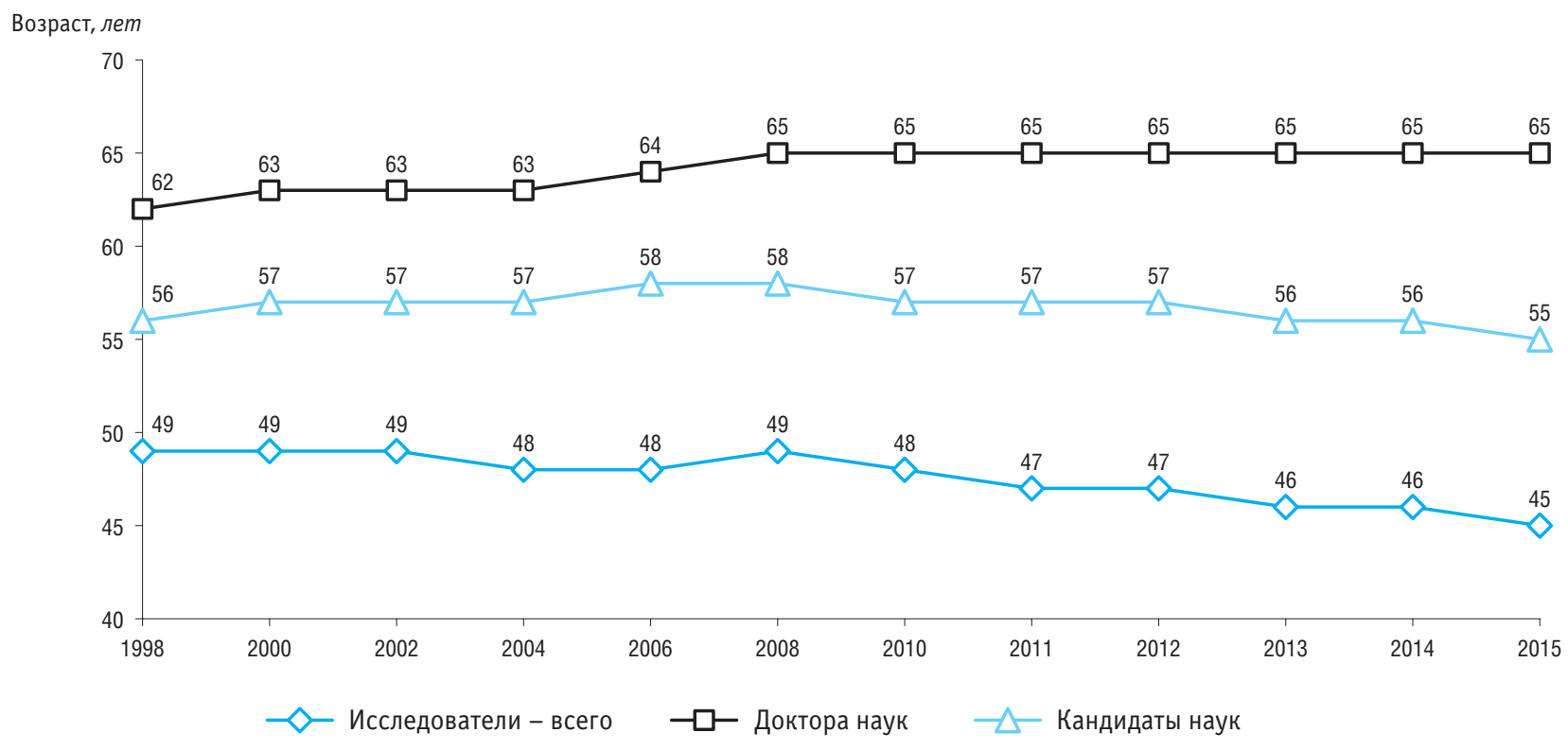




\subsubsection{0. ИССЛЕДОВАТЕЛИ С УЧЕНЫМИ СТЕПЕНЯМИ В ПРЕДПРИНИМАТЕЛЬСКОМ СЕКТОРЕ}

(человек)

\begin{tabular}{|c|c|c|c|c|c|c|c|c|c|c|c|c|c|}
\hline & 1995 & 2000 & 2005 & 2006 & 2007 & 2008 & 2009 & 2010 & 2011 & 2012 & 2013 & 2014 & 2015 \\
\hline Исследователи с учеными степенями & 41207 & 34775 & 26661 & 25958 & 26257 & 24844 & 23861 & 23169 & 23045 & 21758 & 20955 & 20595 & 20270 \\
\hline Доктора наук & 4348 & 4806 & 4222 & 4108 & 4446 & 4284 & 4093 & 3987 & 4018 & 3767 & 3622 & 3511 & 3413 \\
\hline Кандидаты наук & 36859 & 29969 & 22439 & 21850 & 21811 & 20560 & 19768 & 19182 & 19027 & 17991 & 17333 & 17084 & 16857 \\
\hline
\end{tabular}

\subsubsection{1. УДЕЛЬНЫЙ ВЕС ИССЛЕДОВАТЕЛЕЙ С УЧЕНЫМИ СТЕПЕНЯМИ В ЧИСЛЕННОСТИ ИССЛЕДОВАТЕЛЕЙ} В ПРЕДПРИНИМАТЕЛЬСКОМ СЕКТОРЕ

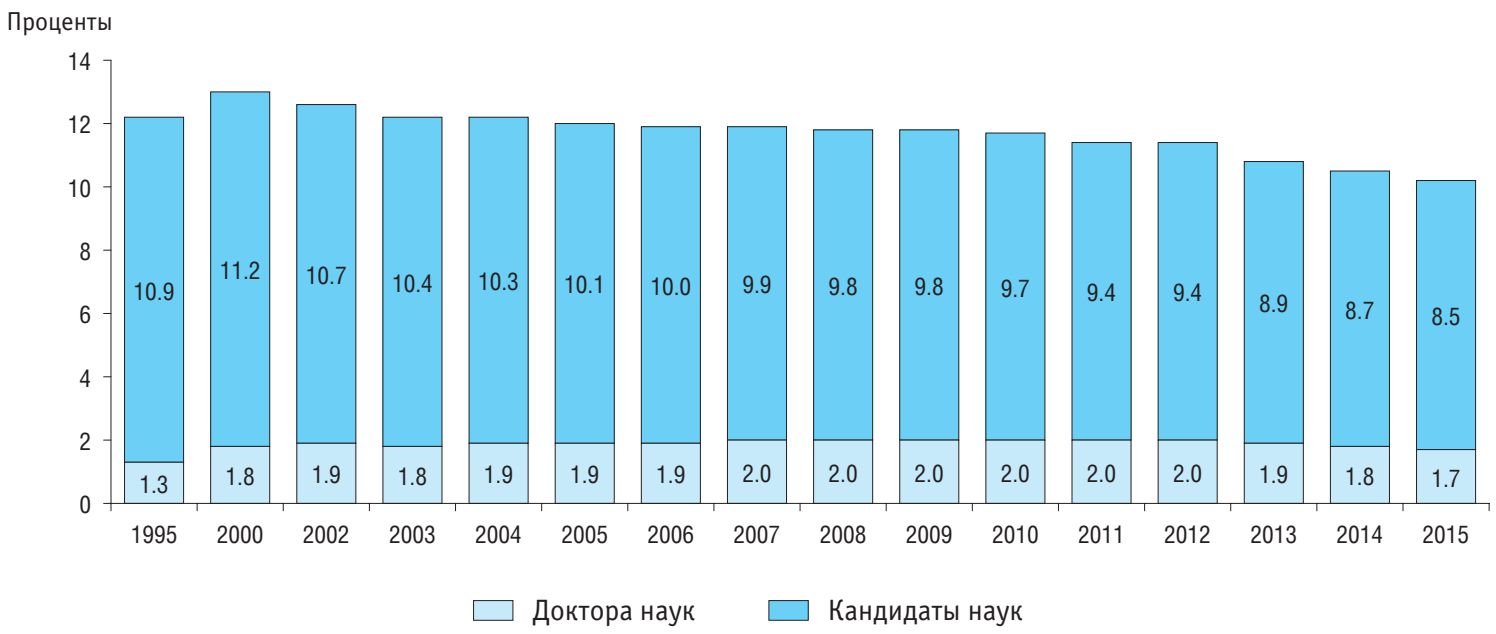




\section{8}

\subsubsection{2. ИССЛЕДОВАТЕЛИ В ПРЕДПРИНИМАТЕЛЬСКОМ СЕКТОРЕ ПО ОБЛАСТЯМ НАУКИ}

(человек)

\begin{tabular}{|c|c|c|c|c|c|c|c|c|c|c|c|c|}
\hline & \multicolumn{3}{|c|}{2008} & \multicolumn{3}{|c|}{2013} & \multicolumn{3}{|c|}{2014} & \multicolumn{3}{|c|}{2015} \\
\hline & \multirow{2}{*}{$\begin{array}{c}\text { Исследо- } \\
\text { ватели }\end{array}$} & \multicolumn{2}{|c|}{ Из них } & \multirow{2}{*}{$\begin{array}{c}\text { Исследо- } \\
\text { ватели }\end{array}$} & \multicolumn{2}{|c|}{ Из них } & \multirow{2}{*}{$\begin{array}{c}\text { Исследо- } \\
\text { ватели }\end{array}$} & \multicolumn{2}{|c|}{ Из них } & \multirow{2}{*}{$\begin{array}{c}\text { Исследо- } \\
\text { ватели }\end{array}$} & \multicolumn{2}{|c|}{ Из них } \\
\hline & & $\begin{array}{c}\text { доктора } \\
\text { наук }\end{array}$ & $\begin{array}{c}\text { кандидаты } \\
\text { наук }\end{array}$ & & $\begin{array}{c}\text { доктора } \\
\text { наук }\end{array}$ & $\begin{array}{c}\text { кандидаты } \\
\text { наук }\end{array}$ & & $\begin{array}{c}\text { доктора } \\
\text { наук }\end{array}$ & $\begin{array}{c}\text { кандидаты } \\
\text { наук }\end{array}$ & & $\begin{array}{c}\text { доктора } \\
\text { наук }\end{array}$ & $\begin{array}{c}\text { кандидаты } \\
\text { наук }\end{array}$ \\
\hline Всего & 209579 & 4284 & 20560 & 193736 & 3622 & 17333 & 196320 & 3511 & 17084 & 198123 & 3413 & 16857 \\
\hline \multicolumn{13}{|l|}{ Области науки: } \\
\hline естественные & 25014 & 1301 & 5106 & 19327 & 1059 & 4006 & 20007 & 1034 & 3963 & 17101 & 928 & 3480 \\
\hline технические & 177503 & 2478 & 13712 & 170013 & 2306 & 12311 & 171705 & 2177 & 12034 & 176440 & 2172 & 12325 \\
\hline медицинские & 1353 & 139 & 413 & 933 & 65 & 192 & 949 & 77 & 198 & 1116 & 64 & 179 \\
\hline сельскохозяйственные & 2401 & 185 & 685 & 690 & 38 & 234 & 587 & 46 & 159 & 437 & 44 & 131 \\
\hline общественные & 3109 & 161 & 587 & 2670 & 150 & 578 & 2747 & 156 & 620 & 2577 & 166 & 602 \\
\hline гуманитарные & 199 & 20 & 57 & 103 & 4 & 12 & 325 & 21 & 110 & 452 & 39 & 140 \\
\hline
\end{tabular}




\subsubsection{3. ДВИЖЕНИЕ ПЕРСОНАЛА, ЗАНЯТОГО ИССЛЕДОВАНИЯМИ И РАЗРАБОТКАМИ \\ В ПРЕДПРИНИМАТЕЛЬСКОМ СЕКТОРЕ, ПО КАТЕГОРИЯМ}

(человек)

\begin{tabular}{|c|c|c|c|c|c|c|c|c|c|c|}
\hline & \multirow{3}{*}{$\begin{array}{l}\text { Наличие } \\
\text { на начало } \\
\text { отчетного } \\
\text { года }\end{array}$} & \multicolumn{4}{|c|}{ Принято } & \multicolumn{4}{|c|}{ Выбыло } & \multirow{3}{*}{$\begin{array}{c}\text { Наличие } \\
\text { на конец } \\
\text { отчетного } \\
\text { года }\end{array}$} \\
\hline & & \multirow[t]{2}{*}{ Всего } & \multicolumn{3}{|c|}{ В том числе } & \multirow[t]{2}{*}{ Всего } & \multicolumn{3}{|c|}{ В том числе } & \\
\hline & & & $\begin{array}{c}\text { после } \\
\text { окончания } \\
\text { вуза }\end{array}$ & $\begin{array}{c}\text { из других } \\
\text { научных } \\
\text { организаций }\end{array}$ & прочие & & $\begin{array}{c}\text { по } \\
\text { собствен- } \\
\text { ному жела- } \\
\text { нию }\end{array}$ & $\begin{array}{c}\text { в связи } \\
\text { с сокраще- } \\
\text { нием } \\
\text { штатов }\end{array}$ & $\begin{array}{l}\text { по прочим } \\
\text { причинам }\end{array}$ & \\
\hline \multicolumn{11}{|l|}{ Всего } \\
\hline 2005 & 508840 & 68528 & 8027 & 8756 & 51745 & 80662 & 52534 & 5722 & 22406 & 496706 \\
\hline 2011 & 427274 & 50218 & 7976 & 6092 & 36150 & 57740 & 36033 & 1794 & 19913 & 419752 \\
\hline 2013 & 401809 & 52700 & 6758 & 7632 & 38310 & 49241 & 32584 & 1159 & 15498 & 405268 \\
\hline 2015 & 405181 & 52033 & 6175 & 7075 & 38783 & 48412 & 30324 & 2568 & 15520 & 408802 \\
\hline \multicolumn{11}{|c|}{ Исследователи } \\
\hline 2005 & 227397 & 22807 & 6529 & 5028 & 11250 & 28822 & 19496 & 2053 & 7273 & 221445 \\
\hline 2011 & 202213 & 21121 & 5890 & 3770 & 11461 & 21109 & 14428 & 696 & 5985 & 202185 \\
\hline 2015 & 197658 & 21426 & 4225 & 3730 & 13471 & 20954 & 13382 & 831 & 6741 & 198123 \\
\hline \multicolumn{11}{|l|}{ Техники } \\
\hline 2005 & 38078 & 5739 & 301 & 729 & 4709 & 6965 & 4347 & 388 & 2230 & 36837 \\
\hline 2011 & 29057 & 4500 & 358 & 524 & 3618 & 5365 & 3378 & 124 & 1863 & 28235 \\
\hline 2013 & 28318 & 5409 & 506 & 665 & 4238 & 4779 & 2829 & 75 & 1875 & 28920 \\
\hline 2015 & 30047 & 4897 & 546 & 574 & 3777 & 4977 & 2973 & 304 & 1700 & 29850 \\
\hline \multicolumn{11}{|c|}{ Вспомогательный и прочий персонал } \\
\hline 2005 & 243365 & 39982 & 1197 & 2999 & 35786 & 44875 & 28691 & 3281 & 12903 & 238424 \\
\hline 2011 & 196004 & 24597 & 1728 & 1798 & 21071 & 31266 & 18227 & 974 & 12065 & 189332 \\
\hline 2013 & 181185 & 25383 & 1549 & 2496 & 21338 & 23963 & 15986 & 704 & 7273 & 182612 \\
\hline 2015 & 177476 & 25710 & 1404 & 2771 & 21535 & 22481 & 13969 & 1433 & 7079 & 180829 \\
\hline
\end{tabular}


5.3.14. ПРИЕМ И ВЫБЫТИЕ ПЕРСОНАЛА, ЗАНЯТОГО ИССЛЕДОВАНИЯМИ И РАЗРАБОТКАМИ В ПРЕДПРИНИМАТЕЛЬСКОМ СЕКТОРЕ

Персонал, занятый исследованиями и разработками

Проценты

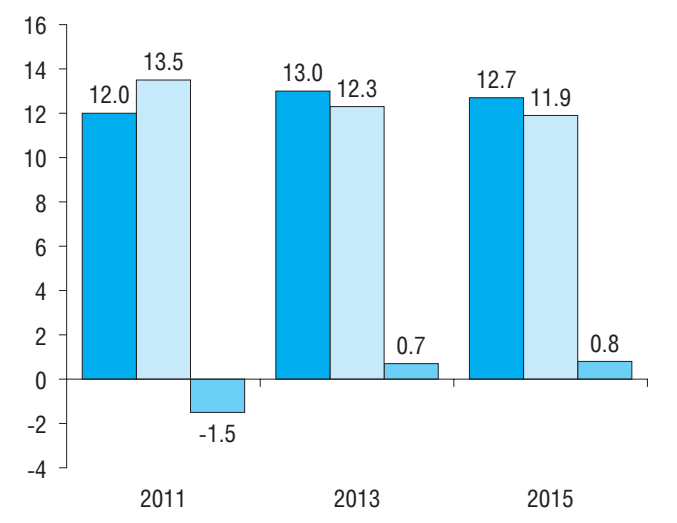

$\square$ Принято*

\section{Исследователи}

Проценты

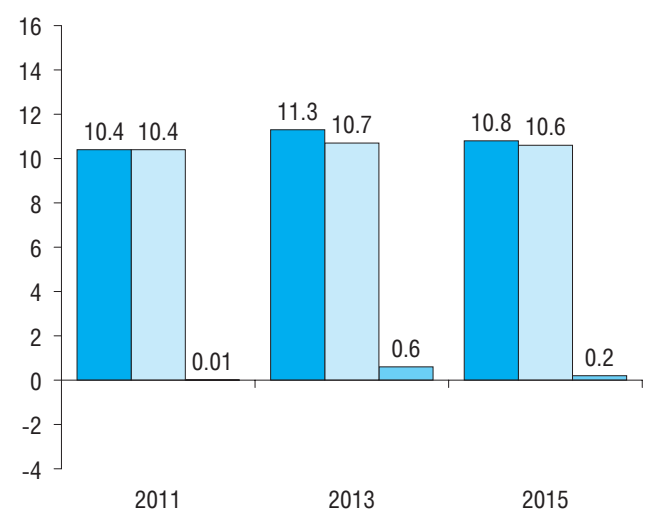

* Отношение численности принятых в течение года к численности работников на конец года.

** Отношение численности выбывших в течение года к численности работников на начало года. 


\subsubsection{5. ПРИЕМ ВЫПУСКНИКОВ ОБРАЗОВАТЕЛЬНЫХ ОРГАНИЗАЦИЙ ВЫСШЕГО ОБРАЗОВАНИЯ \\ НА РАБОТУ В ОРГАНИЗАЦИИ ПРЕДПРИНИМАТЕЛЬСКОГО СЕКТОРА}

\section{Удельный вес выпускников}

в численности принятых

на работу

Проценты

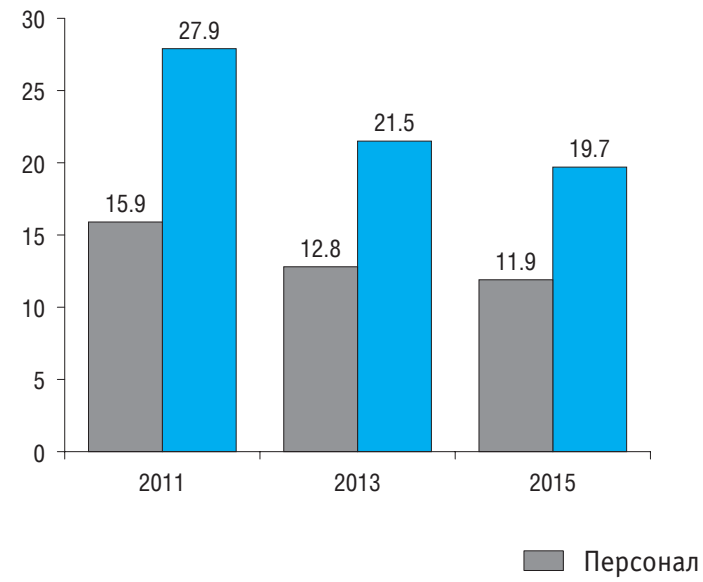

Удельный вес выпускников

в численности персонала, занятого исследованиями и разработками *

Проценты

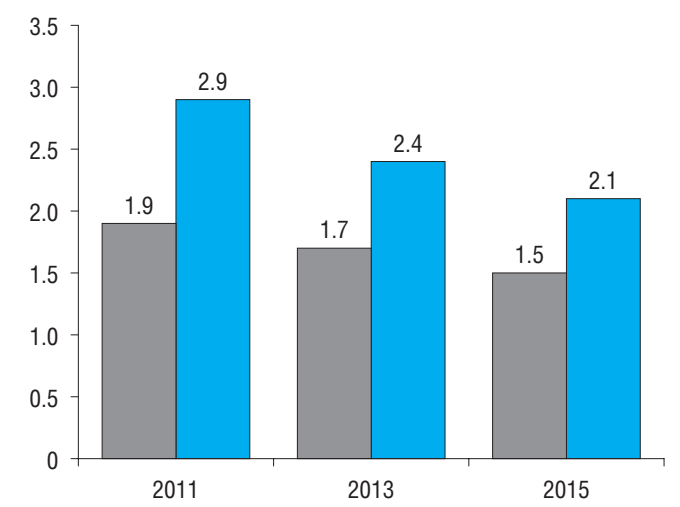

* Отношение численности выпускников образовательных организаций высшего образования, принятых на работу в течение года, к численности работников на конец года. 
5.3.16. ВНУТРЕННИЕ ЗАТРАТЫ НА ИССЛЕДОВАНИЯ И РАЗРАБОТКИ В ПРЕДПРИНИМАТЕЛЬСКОМ СЕКТОРЕ ПО ТИПАМ ОРГАНИЗАЦИЙ (тысячи рублей)

\begin{tabular}{|c|c|c|c|c|c|c|c|c|c|}
\hline & 2000 & 2005 & 2008 & 2010 & 2011 & 2012 & 2013 & 2014 & 2015 \\
\hline Всего & 54288781.4 & 156880029.0 & 271206280.5 & 316701679.9 & 372088873.4 & 408284378.5 & 454409251.0 & 505210341.3 & 541533094.3 \\
\hline \multicolumn{10}{|c|}{ Научно-исследовательские } \\
\hline институты & 31145022.1 & 79303185.8 & 126680440.5 & 149370680.2 & 169714137.6 & 200622676.3 & 223137546.4 & 246251822.0 & 264045184.4 \\
\hline \multicolumn{10}{|c|}{$\begin{array}{l}\text { Конструкторские, проектно- } \\
\text { конструкторские, технологиче- }\end{array}$} \\
\hline ские организации & 13115444.7 & 51857668.0 & 91233658.1 & 99778643.7 & 117208342.7 & 104269890.1 & 118708123.0 & 140108876.6 & 142841408.8 \\
\hline \multicolumn{10}{|c|}{$\begin{array}{l}\text { Проектные и проектно-изыска- } \\
\text { тельские организации строи- }\end{array}$} \\
\hline тельства & 539721.1 & 1604470.7 & 4511306.2 & 3690958.0 & 4688711.6 & 5827594.8 & 3579155.2 & 3567752.9 & 2380598.7 \\
\hline \multicolumn{10}{|c|}{ Организации промышленного } \\
\hline Опытные базы & 294581.2 & 150835.5 & 331824.8 & 398159.1 & 372177.7 & 746678.7 & 808351.2 & 1749042.3 & 2223362.2 \\
\hline Прочие организации & 4467929.9 & 11330433.1 & 24530435.9 & 30624458.0 & 38853792.9 & 46864775.8 & 48829217.2 & 52570676.1 & 55348641.0 \\
\hline
\end{tabular}




\subsubsection{7. ВНУТРЕННИЕ ЗАТРАТЫ НА ИССЛЕДОВАНИЯ И РАЗРАБОТКИ В ПРЕДПРИНИМАТЕЛЬСКОМ СЕКТОРЕ}

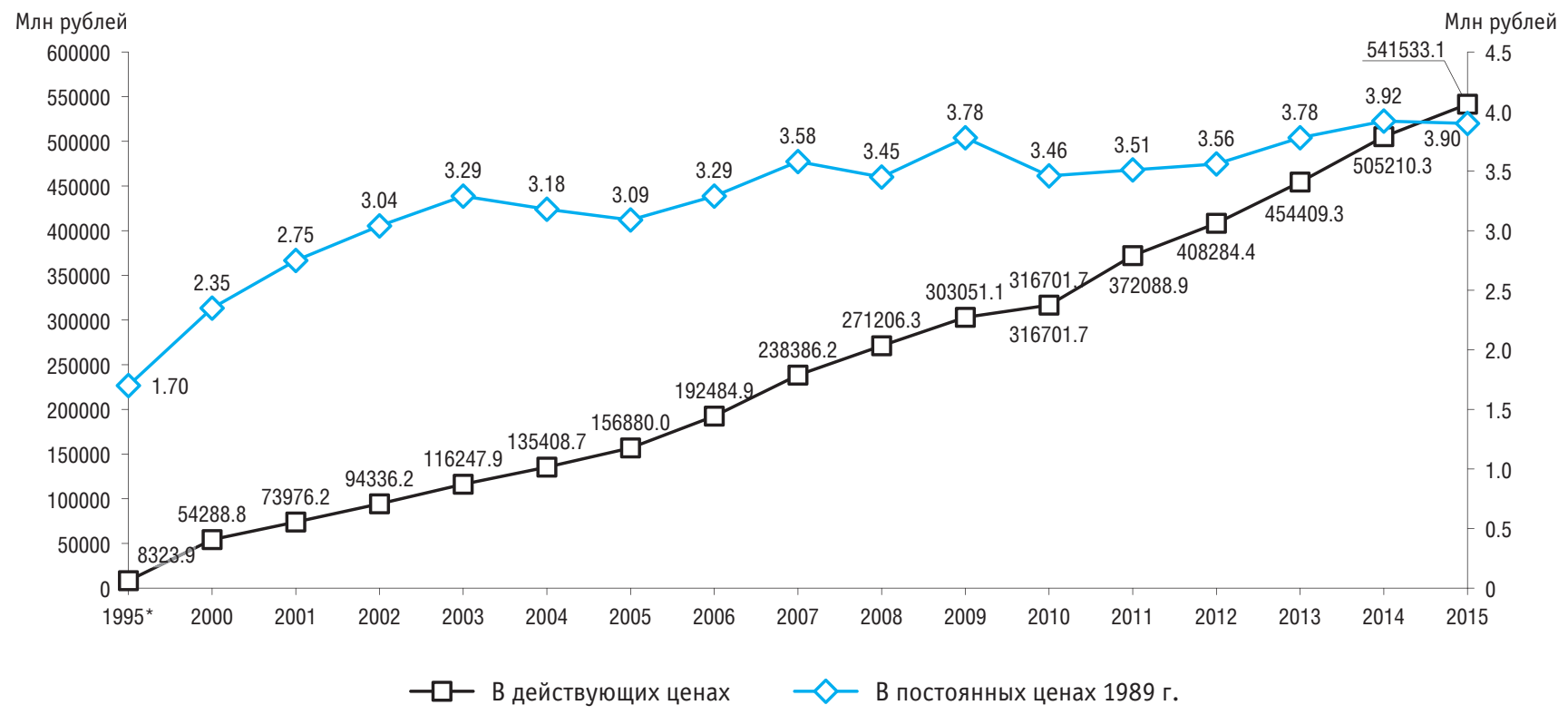

* Млрд рублей. 
5.3.18. ВНУТРЕННИЕ ЗАТРАТЫ НА ИССЛЕДОВАНИЯ И РАЗРАБОТКИ В ПРЕДПРИНИМАТЕЛЬСКОМ СЕКТОРЕ ПО ИСТОЧНИКАМ ФИНАНСИРОВАНИЯ

\begin{tabular}{|c|c|c|c|c|c|c|}
\hline & Bcero & $\begin{array}{c}\text { Средства } \\
\text { государства* }\end{array}$ & $\begin{array}{c}\text { Средства } \\
\text { предприниматель- } \\
\text { ского сектора }\end{array}$ & $\begin{array}{c}\text { Средства } \\
\text { организаций сектора } \\
\text { высшего образования }\end{array}$ & $\begin{array}{c}\text { Средства } \\
\text { некоммерческих } \\
\text { организаций }\end{array}$ & $\begin{array}{c}\text { Средства } \\
\text { иностранных } \\
\text { источников }\end{array}$ \\
\hline \multicolumn{7}{|c|}{ В действующих ценах, тыс. рублей, 1995 г. - млн рублей } \\
\hline 1995 & 8323907.6 & 4256825.1 & 3639140.1 & 822.4 & 486.8 & 426633.2 \\
\hline 2000 & 54288781.4 & 24674880.5 & 22199361.6 & 23662.7 & 18968.0 & 7371908.6 \\
\hline 2002 & 94336248.9 & 47710158.8 & 38602812.7 & 28047.5 & 63017.2 & 7932212.7 \\
\hline 2003 & 116247853.0 & 59896801.9 & 44401742.9 & 77901.7 & 204665.7 & 11666740.8 \\
\hline 2004 & 135408690.9 & 71716243.4 & 51502628.6 & 46246.5 & 71105.3 & 12072467.1 \\
\hline 2005 & 156880029.0 & 84032725.4 & 58460580.8 & 46809.5 & 14570.8 & 14325342.5 \\
\hline 2006 & 192484851.0 & 100122872.7 & 68769254.4 & 34681.0 & 160678.6 & 23397364.3 \\
\hline 2007 & 238386207.4 & 131768069.7 & 87352197.2 & 616853.5 & 163906.9 & 18485180.1 \\
\hline 2008 & 271206280.5 & 151975682.0 & 99123835.8 & 43931.1 & 468252.7 & 19594578.9 \\
\hline 2009 & 303051131.5 & 173872629.4 & 104955691.5 & 60958.8 & 238908.1 & 23922943.7 \\
\hline 2010 & 316701679.9 & 203267110.6 & 101760706.5 & 75409.3 & 427247.1 & 11171206.4 \\
\hline 2011 & 372088873.4 & 218291814.8 & 134043614.4 & 376915.9 & 806970.4 & 18569557.9 \\
\hline 2012 & 408284378.5 & 246761318.2 & 143181603.7 & 240986.2 & 152505.3 & 17947965.1 \\
\hline 2013 & 454409251.0 & 279358934.6 & 161100909.7 & 515567.0 & 88727.4 & 13345112.3 \\
\hline 2014 & 505210341.3 & 316622608.3 & 177116134.2 & 442911.7 & 359214.0 & 10669473.1 \\
\hline 2015 & 541533094.3 & 343396867.3 & 185037359.3 & 561703.2 & 421868.8 & 12115295.7 \\
\hline
\end{tabular}


(окончание)

\begin{tabular}{|c|c|c|c|c|c|c|}
\hline & Bcero & $\begin{array}{c}\text { Средства } \\
\text { государства* }\end{array}$ & $\begin{array}{c}\text { Средства } \\
\text { предприниматель- } \\
\text { ского сектора }\end{array}$ & $\begin{array}{c}\text { Средства } \\
\text { организаций сектора } \\
\text { высшего образования }\end{array}$ & $\begin{array}{c}\text { Средства } \\
\text { некоммерческих } \\
\text { организаций }\end{array}$ & $\begin{array}{c}\text { Средства } \\
\text { иностранных } \\
\text { источников }\end{array}$ \\
\hline \multicolumn{7}{|c|}{ Проценты } \\
\hline 1995 & 100 & 51.1 & 43.7 & 0.01 & 0.01 & 5.1 \\
\hline 2000 & 100 & 45.5 & 40.9 & 0.04 & 0.03 & 13.6 \\
\hline 2002 & 100 & 50.6 & 40.9 & 0.03 & 0.07 & 8.4 \\
\hline 2003 & 100 & 51.5 & 38.2 & 0.07 & 0.2 & 10.0 \\
\hline 2004 & 100 & 53.0 & 38.0 & 0.03 & 0.05 & 8.9 \\
\hline 2005 & 100 & 53.6 & 37.3 & 0.03 & 0.01 & 9.1 \\
\hline 2006 & 100 & 52.0 & 35.7 & 0.02 & 0.08 & 12.2 \\
\hline 2007 & 100 & 55.3 & 36.6 & 0.3 & 0.07 & 7.8 \\
\hline 2008 & 100 & 56.0 & 36.5 & 0.02 & 0.2 & 7.2 \\
\hline 2009 & 100 & 57.4 & 34.6 & 0.02 & 0.08 & 7.9 \\
\hline 2010 & 100 & 64.2 & 32.1 & 0.02 & 0.1 & 3.5 \\
\hline 2011 & 100 & 58.7 & 36.0 & 0.1 & 0.2 & 5.0 \\
\hline 2012 & 100 & 60.4 & 35.1 & 0.06 & 0.04 & 4.4 \\
\hline 2013 & 100 & 61.5 & 35.5 & 0.1 & 0.02 & 2.9 \\
\hline 2014 & 100 & 62.7 & 35.1 & 0.09 & 0.07 & 2.1 \\
\hline 2015 & 100 & 63.4 & 34.2 & 0.1 & 0.08 & 2.2 \\
\hline
\end{tabular}

\footnotetext{
* Включая средства бюджета и средства организаций государственного сектора.
} 


\subsubsection{9. УДЕЛЬНЫЙ ВЕС ПРЕДПРИНИМАТЕЛЬСКОГО СЕКТОРА В ОБЩЕМ ОБЪЕМЕ ВНУТРЕННИХ ЗАТРАТ} НА ИССЛЕДОВАНИЯ И РАЗРАБОТКИ ПО ВИДАМ ЗАТРАТ

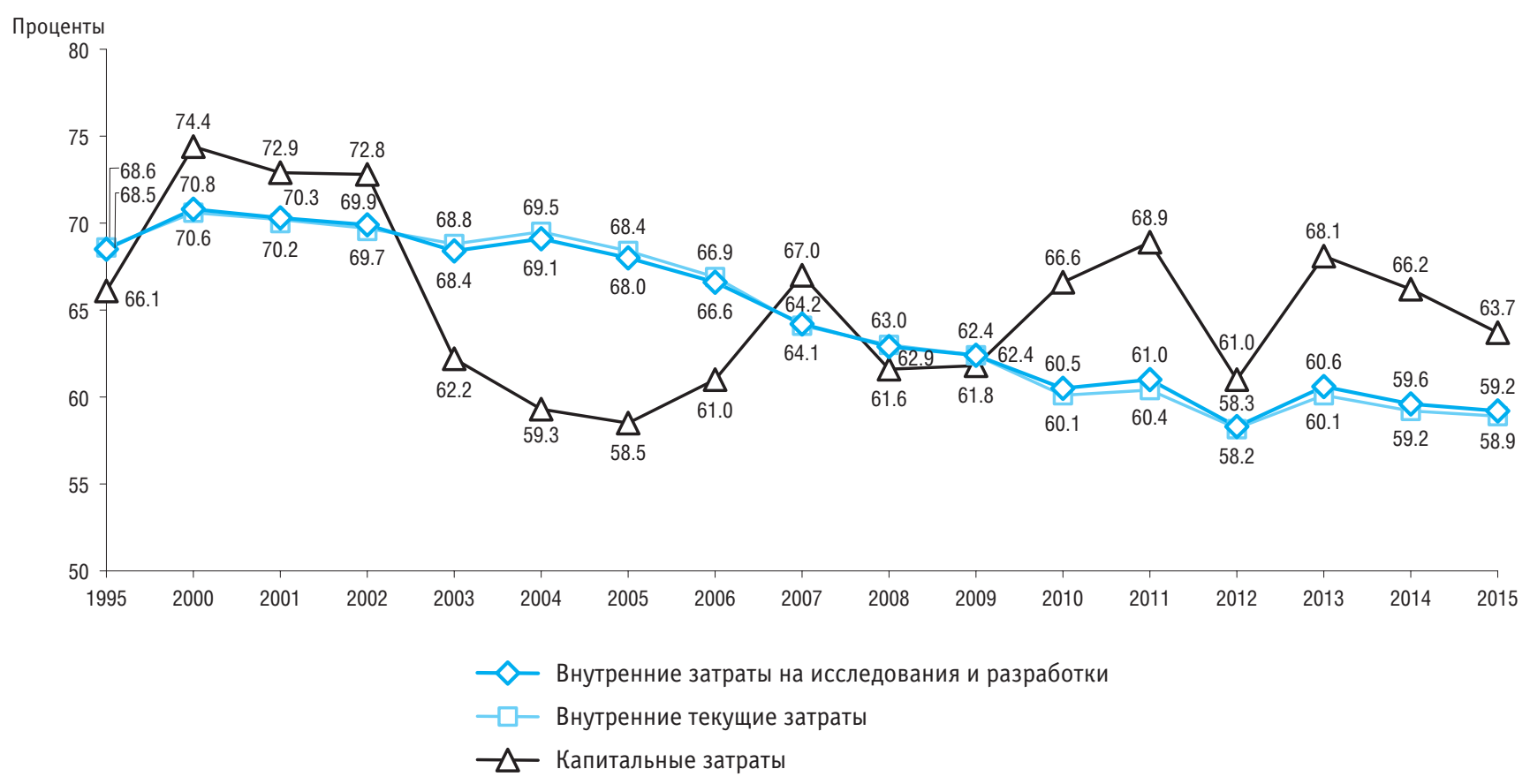




\subsubsection{0. ВНУТРЕННИЕ ЗАТРАТЫ НА ИССЛЕДОВАНИЯ И РАЗРАБОТКИ В ПРЕДПРИНИМАТЕЛЬСКОМ СЕКТОРЕ ПО ВИДАМ ЗАТРАТ}

(тысячи рублей)

\begin{tabular}{|c|c|c|c|c|c|c|c|}
\hline & 2005 & 2010 & 2011 & 2012 & 2013 & 2014 & 2015 \\
\hline Внутренние затраты на исследования и разработки & 156880029.0 & 316701679.9 & 372088873.4 & 408284378.5 & 454409251.0 & 505210341.3 & 541533094.3 \\
\hline Внутренние текущие затраты & 151228693.6 & 294103827.7 & 343121369.6 & 380968190.9 & 420438999.3 & 470728154.3 & 503088818.5 \\
\hline Затраты на оплату труда & 61762384.5 & 134771346.7 & 154670826.0 & 163680881.0 & 184301583.4 & 199981537.7 & 214055655.0 \\
\hline $\begin{array}{l}\text { Из них работникам, выполнявшим исследования } \\
\text { и разработки* }\end{array}$ & 56579998.4 & 123576290.3 & 141005622.8 & 149328527.6 & 168490249.3 & 184318111.2 & 196822214.9 \\
\hline Страховые взносы в Пенсионный фонд, ФСС, ФФОМС & 14652167.0 & 26089246.1 & 37534823.2 & 39738423.4 & 44519677.6 & 49274407.7 & 55348833.5 \\
\hline Затраты на оборудование & 5919453.8 & 9955224.5 & 11788168.9 & 13822393.6 & 13592306.5 & 13499794.4 & 17319573.0 \\
\hline Другие материальные затраты & 39963918.4 & 63367540.7 & 72417381.8 & 85310764.1 & 96060693.9 & 111940812.4 & 109075443.3 \\
\hline Прочие текущие затраты & 28930769.9 & 59920469.7 & 66710169.7 & 78415728.8 & 81964737.9 & 96031602.1 & 107289313.7 \\
\hline Капитальные затраты & 5651335.4 & 22597852.2 & 28967503.8 & 27316187.6 & 33970251.7 & 34482187.0 & 38444275.8 \\
\hline Земельные участки и здания & 1208092.5 & 4950198.0 & 6068422.7 & 9006103.9 & 6020259.0 & 6094066.5 & 5984058.2 \\
\hline Оборудование & 3228403.1 & 14167838.2 & 16379917.3 & 13818410.4 & 17818744.0 & 19820476.8 & 21054397.0 \\
\hline Прочие капитальные затраты & 1214839.8 & 3479816.0 & 6519163.8 & 4491673.3 & 10131248.7 & 8567643.7 & 11405820.6 \\
\hline
\end{tabular}

* Без совместителей и работавших по договорам гражданско-правового характера. 


\subsubsection{1. ВНУТРЕННИЕ ТЕКУЩИЕ ЗАТРАТЫ НА ИССЛЕДОВАНИЯ И РАЗРАБОТКИ В ПРЕДПРИНИМАТЕЛЬСКОМ СЕКТОРЕ ПО ВИДАМ РАБОТ И ОБЛАСТЯМ НАУКИ \\ (тысячи рублей)}

\begin{tabular}{|c|c|c|c|c|c|c|c|}
\hline & Bсего & $\begin{array}{c}\text { Естественные } \\
\text { науки }\end{array}$ & $\begin{array}{c}\text { Технические } \\
\text { науки }\end{array}$ & $\begin{array}{l}\text { Медицинские } \\
\text { науки }\end{array}$ & $\begin{array}{c}\text { Сельскохозяйст- } \\
\text { венные науки }\end{array}$ & $\begin{array}{c}\text { 0бщественные } \\
\text { науки }\end{array}$ & $\begin{array}{c}\text { Гуманитарныє } \\
\text { науки }\end{array}$ \\
\hline \multicolumn{8}{|c|}{2005} \\
\hline Внутренние текущие затраты & 151228693.6 & 10041430.0 & 138455122.3 & 450558.6 & 1020195.6 & 1212995.6 & 48391.5 \\
\hline Фундаментальные исследования & 2591506.7 & 1025517.8 & 1205156.9 & 53282.5 & 236864.8 & 47440.2 & 23244.5 \\
\hline Прикладные исследования & 20026408.8 & 5053993.0 & 13842212.4 & 184566.8 & 446665.3 & 489579.6 & 9391.7 \\
\hline Разработки & 128610778.1 & 3961919.2 & 123407753.0 & 212709.3 & 336665.5 & 675975.8 & 15755.3 \\
\hline \multicolumn{8}{|c|}{2012} \\
\hline Внутренние текущие затраты & 380968190.9 & 27243077.6 & 347059349.6 & 1992378.4 & 1492477.6 & 2959975.4 & 220932.3 \\
\hline Фундаментальные исследования & 11034975.2 & 2857779.7 & 6972175.3 & 601995.0 & 201513.8 & 371427.0 & 30084.4 \\
\hline Прикладные исследования & 50351025.6 & 10971542.8 & 35740717.8 & 1045163.7 & 684025.7 & 1855202.6 & 54373.0 \\
\hline Разработки & 319582190.1 & 13413755.1 & 304346456.5 & 345219.7 & 606938.1 & 733345.8 & 136474.9 \\
\hline \multicolumn{8}{|c|}{2013} \\
\hline Внутренние текущие затраты & 420438999.3 & 27242178.5 & 387371546.1 & 1725365.5 & 695005.3 & 3272145.6 & 132758.3 \\
\hline Фундаментальные исследования & 10319086.1 & 2228394.9 & 6697821.2 & 570043.5 & 214.9 & 817156.1 & 5455.5 \\
\hline Прикладные исследования & 52414718.7 & 11542963.9 & 37944237.8 & 910860.1 & 297745.9 & 1694730.7 & 24180.3 \\
\hline Разработки & 357705194.5 & 13470819.7 & 342729487.1 & 244461.9 & 397044.5 & 760258.8 & 103122.5 \\
\hline \multicolumn{8}{|c|}{2014} \\
\hline Внутренние текущие затраты & 470728154.3 & 28859233.5 & 435503592.5 & 2222531.9 & 727819.4 & 3252029.7 & 162947.3 \\
\hline Фундаментальные исследования & 11654667.9 & 2995756.1 & 7271091.0 & 705469.6 & 60395.0 & 600783.9 & 21172.3 \\
\hline Прикладные исследования & 62451087.5 & 13258425.5 & 46200081.4 & 938617.9 & 139398.7 & 1880216.0 & 34348.0 \\
\hline Разработки & 396622398.9 & 12605051.9 & 382032420.1 & 578444.4 & 528025.7 & 771029.8 & 107427.0 \\
\hline \multicolumn{8}{|c|}{2015} \\
\hline Внутренние текущие затраты & 503088818.5 & 25579412.6 & 470180938.1 & 3064111.9 & 695241.7 & 3421527.3 & 147586.9 \\
\hline Фундаментальные исследования & 7122577.4 & 3196716.9 & 2633478.4 & 696593.3 & 47856.6 & 494091.3 & 53840.9 \\
\hline Прикладные исследования & 61520451.3 & 10793921.5 & 47539713.2 & 949480.0 & 127789.3 & 2074879.6 & 34667.7 \\
\hline Разработки & 434445789.8 & 11588774.2 & 420007746.5 & 1418038.6 & 519595.8 & 852556.4 & 59078.3 \\
\hline
\end{tabular}




\subsubsection{2. УДЕЛЬНЫЙ ВЕС ПРЕДПРИНИМАТЕЛЬСКОГО СЕКТОРА В ОБЩЕМ ОБЪЕМЕ ВНУТРЕННИХ ТЕКУЩИХ ЗАТРАТ}

НА ИССЛЕДОВАНИЯ И РАЗРАБОТКИ ПО ВИДАМ РАБОТ

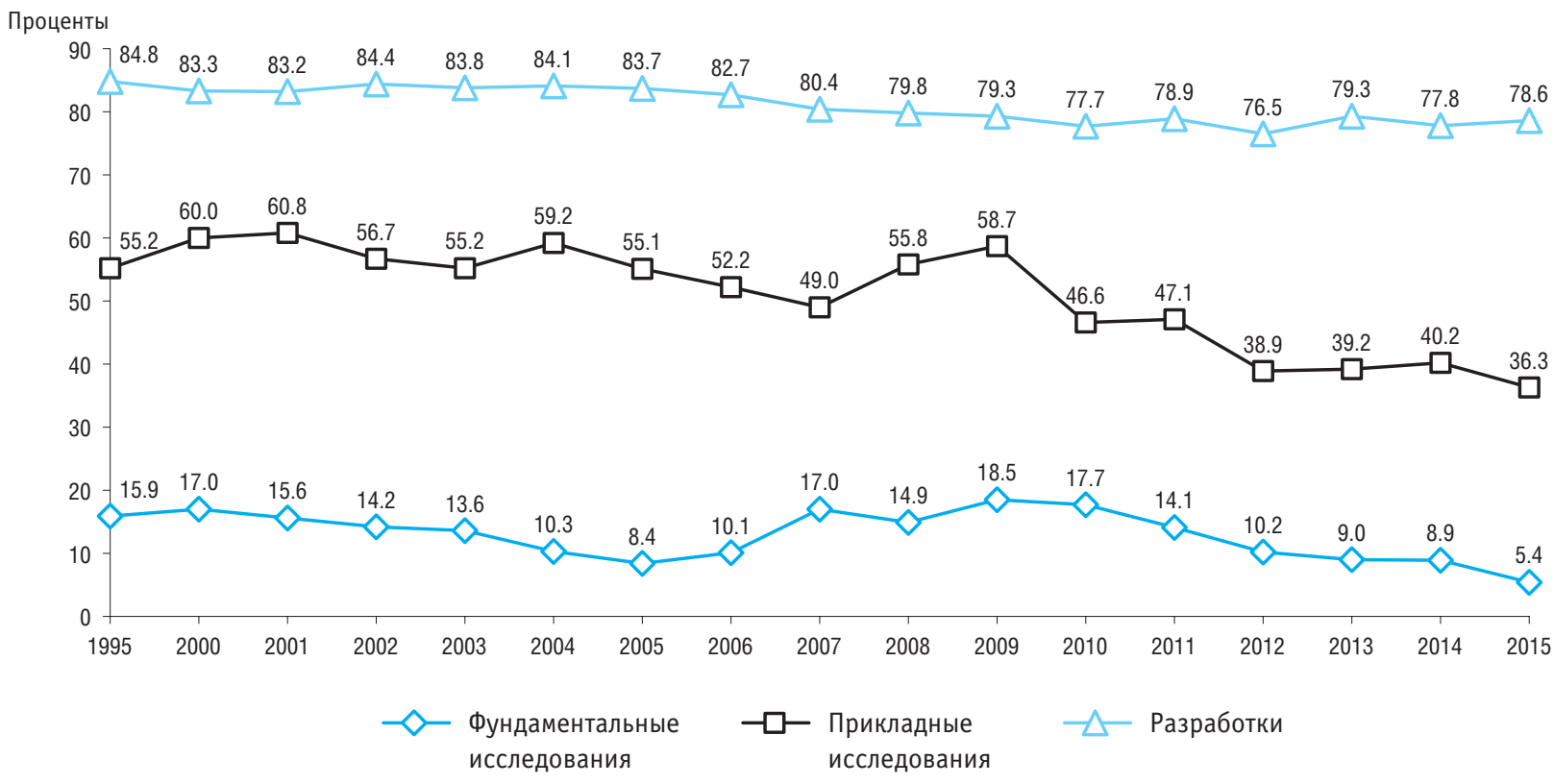


5.3.23. СТРУКТУРА ВНУТРЕННИХ ТЕКУЩИХ ЗАТРАТ НА ИССЛЕДОВАНИЯ И РАЗРАБОТКИ В ПРЕДПРИНИМАТЕЛЬСКОМ СЕКТОРЕ ПО ВИДАМ РАБОТ

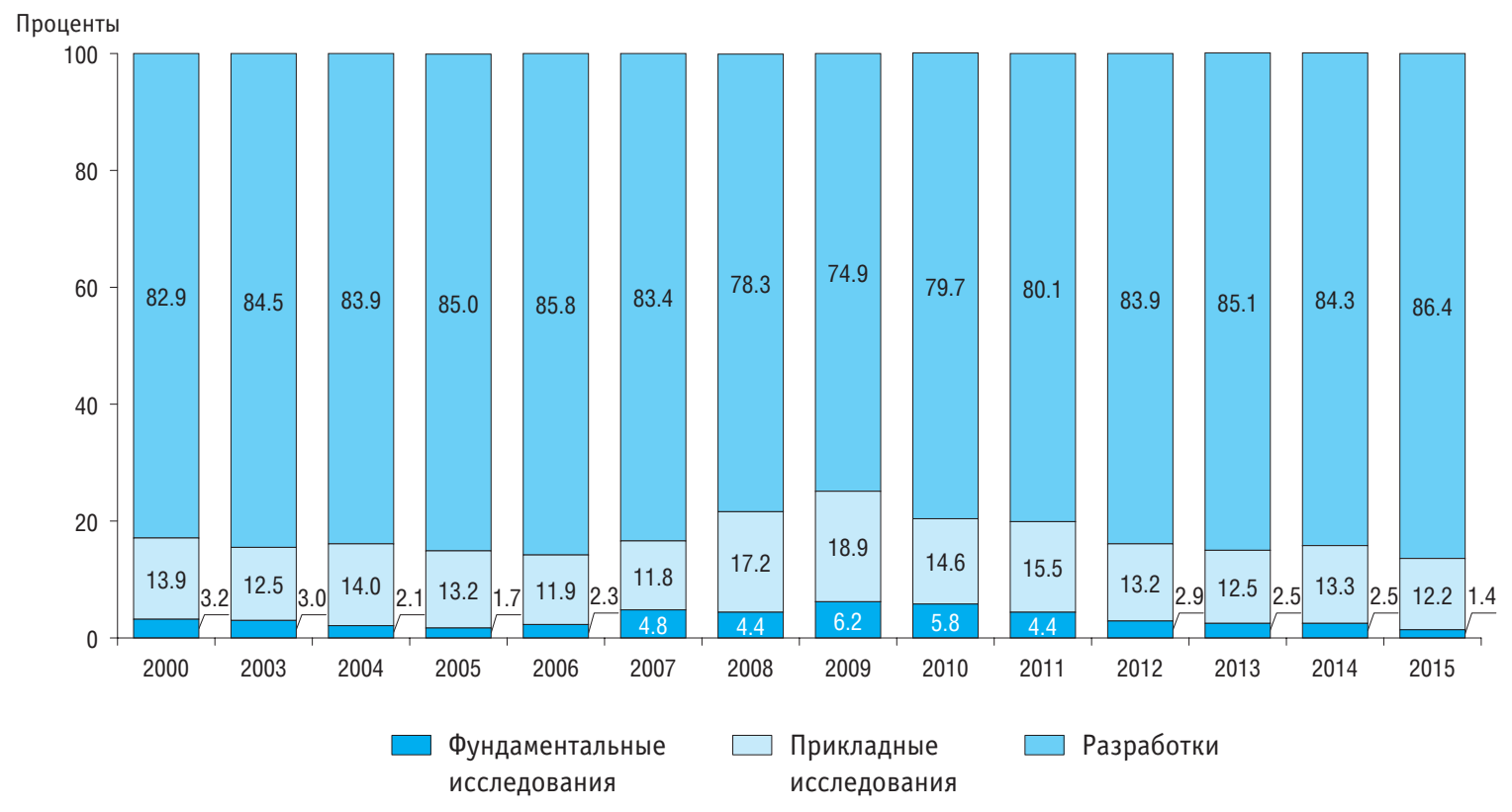


5.3.24. СРЕДНЕМЕСЯЧНАЯ ЗАРАБОТНАЯ ПЛАТА ПЕРСОНАЛА, ЗАНЯТОГО ИССЛЕДОВАНИЯМИ И РАЗРАБОТКАМИ В ПРЕДПРИНИМАТЕЛЬСКОМ СЕКТОРЕ

\begin{tabular}{|c|c|c|c|c|c|c|c|c|c|c|c|c|}
\hline & 1995 & 2000 & 2005 & 2007 & 2008 & 2009 & 2010 & 2011 & 2012 & 2013 & 2014 & 2015 \\
\hline $\begin{array}{l}\text { Среднемесячная заработная плата, } \\
\text { руб., } 1995 \text { г. - тыс. руб. }\end{array}$ & 297.6 & 2519.9 & 9599.6 & 15203.6 & 19345.3 & 21674.1 & 25359.7 & 29174.9 & 33165.2 & 36540.8 & 39855.8 & 42102.7 \\
\hline \multicolumn{13}{|l|}{ В процентах к заработной плате: } \\
\hline в экономике в целом (=100\%) & 63.0 & 113.3 & 112.2 & 111.8 & 111.9 & 116.3 & 121.0 & 124.8 & 124.5 & 122.7 & 122.7 & 123.9 \\
\hline в обрабатывающих производствах (=100\%) & 64.9 & 106.5 & 114.0 & 118.1 & 120.5 & 130.7 & 132.9 & 133.9 & 135.3 & 135.1 & 135.1 & 132.2 \\
\hline в строительстве (=100\%) & 50.6 & 95.5 & 106.2 & 106.1 & 104.2 & 119.6 & 119.8 & 123.2 & 127.8 & 131.9 & 135.8 & 140.9 \\
\hline
\end{tabular}


5.4. Сектор высшего образования

\subsection{1. ОРГАНИЗАЦИИ, ВЫПОЛНЯВШИЕ ИССЛЕДОВАНИЯ И РАЗРАБОТКИ В СЕКТОРЕ ВЫСШЕГО ОБРАЗОВАНИЯ, ПО ТИПАМ}

\begin{tabular}{|c|c|c|c|c|c|c|c|c|c|c|c|c|c|}
\hline & 1995 & 2000 & 2005 & 2006 & 2007 & 2008 & 2009 & 2010 & 2011 & 2012 & 2013 & 2014 & 2015 \\
\hline Всего & 511 & 526 & 539 & 540 & 616 & 603 & 603 & 617 & 696 & 662 & 762 & 777 & 1124 \\
\hline $\begin{array}{l}\text { Образовательные организации высшего } \\
\text { образования }\end{array}$ & 395 & 390 & 406 & 417 & 500 & 503 & 506 & 517 & 581 & 562 & 673 & 702 & 1040 \\
\hline $\begin{array}{l}\text { Научно-исследовательские институты } \\
\text { (центры) }\end{array}$ & 88 & 107 & 109 & 106 & 95 & 80 & 78 & 71 & 67 & 54 & 51 & 37 & 43 \\
\hline $\begin{array}{l}\text { Конструкторские, } \\
\text { проектно-конструкторские } \\
\text { организации }\end{array}$ & 18 & 19 & 17 & 14 & 12 & 11 & 11 & 11 & 12 & 12 & 10 & 8 & 7 \\
\hline $\begin{array}{l}\text { Опытные (экспериментальные) } \\
\text { предприятия }\end{array}$ & 1 & 2 & - & - & 1 & 1 & 1 & 1 & 2 & 4 & $\ldots{ }^{*}$ & $\ldots{ }^{*}$ & $\ldots{ }^{*}$ \\
\hline Прочие организации & 9 & 8 & 7 & 3 & 8 & 8 & 7 & 17 & 34 & 30 & 27 & 29 & 32 \\
\hline
\end{tabular}

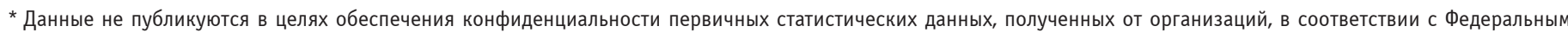

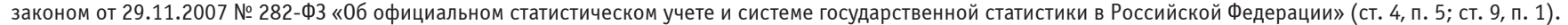




\subsection{2. ПЕРСОНАЛ, ЗАНЯТЫЙ ИССЛЕДОВАНИЯМИ И РАЗРАБОТКАМИ В СЕКТОРЕ ВЫСШЕГО ОБРАЗОВАНИЯ, ПО ТИПАМ ОРГАНИЗАЦИЙ \\ (человек)}

\begin{tabular}{|c|c|c|c|c|c|c|c|c|c|c|c|c|c|}
\hline & 1995 & 2000 & 2005 & 2006 & 2007 & 2008 & 2009 & 2010 & 2011 & 2012 & 2013 & 2014 & 2015 \\
\hline Bcero & 52065 & 40787 & 43500 & 44473 & 49059 & 47595 & 48498 & 53290 & 59454 & 59469 & 59247 & 62400 & 63870 \\
\hline \multicolumn{14}{|l|}{ 0бразовательные организации } \\
\hline высшего образования & 40015 & 31110 & 33942 & 35179 & 40440 & 40003 & 41767 & 46776 & 53944 & 53699 & 54092 & 58573 & 60151 \\
\hline \multicolumn{14}{|l|}{ Научно-исследовательские } \\
\hline институты (центры) & 9458 & 7254 & 7021 & 7294 & 6609 & 5522 & 4995 & 4796 & 3904 & 3070 & 2864 & 2049 & 2092 \\
\hline \multicolumn{14}{|l|}{ Конструкторские, проектно- } \\
\hline конструкторские организации & 2170 & 2198 & 1991 & 1878 & 1843 & 1783 & 1446 & 1392 & 1197 & 1830 & 1502 & 1408 & 1121 \\
\hline \multicolumn{14}{|l|}{ 0пытные (экспериментальные) } \\
\hline предприятия & 23 & 4 & - & - & 2 & 1 & 2 & 2 & 8 & 9 & $\ldots{ }^{\star}$ & $\ldots{ }^{*}$ & $\ldots{ }^{*}$ \\
\hline Прочие организации & 399 & 221 & 546 & 122 & 165 & 286 & 288 & 324 & 401 & 861 & 775 & 369 & 506 \\
\hline
\end{tabular}

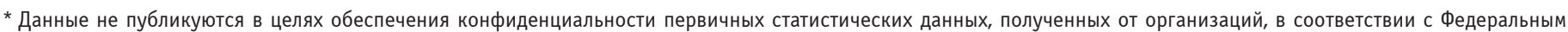

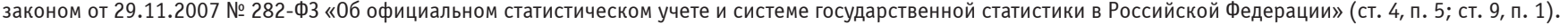


5.4.3. ПЕРСОНАЛ, ЗАНЯТЫЙ ИССЛЕДОВАНИЯМИ И РАЗРАБОТКАМИ В СЕКТОРЕ ВЫСШЕГО ОБРАЗОВАНИЯ, ПО КАТЕГОРИЯМ (человек)

\begin{tabular}{|c|c|c|c|c|c|c|c|c|c|c|c|c|c|}
\hline & 1995 & 2000 & 2005 & 2006 & 2007 & 2008 & 2009 & 2010 & 2011 & 2012 & 2013 & 2014 & 2015 \\
\hline Всего & 52065 & 40787 & 43500 & 44473 & 49059 & 47595 & 48498 & 53290 & 59454 & 59469 & 59247 & 62400 & 63870 \\
\hline Исследователи & 35508 & 28325 & 30111 & 30793 & 34162 & 33160 & 33847 & 38640 & 43121 & 43103 & 42692 & 44427 & 45967 \\
\hline Техники & 4010 & 3509 & 3658 & 3972 & 4606 & 4349 & 4778 & 5095 & 6256 & 3998 & 4670 & 5939 & 5836 \\
\hline Вспомогательный персонал & 7520 & 5463 & 6098 & 5945 & 6282 & 6520 & 6198 & 6564 & 7345 & 9264 & 8828 & 9538 & 9217 \\
\hline Прочие & 5027 & 3490 & 3633 & 3763 & 4009 & 3566 & 3675 & 2991 & 2732 & 3104 & 3057 & 2496 & 2850 \\
\hline
\end{tabular}




\subsection{4. СТРУКТУРА ПЕРСОНАЛА, ЗАНЯТОГО ИССЛЕДОВАНИЯМИ И РАЗРАБОТКАМИ}

В СЕКТОРЕ ВЫСШЕГО ОБРАЗОВАНИЯ, ПО КАТЕГОРИЯМ

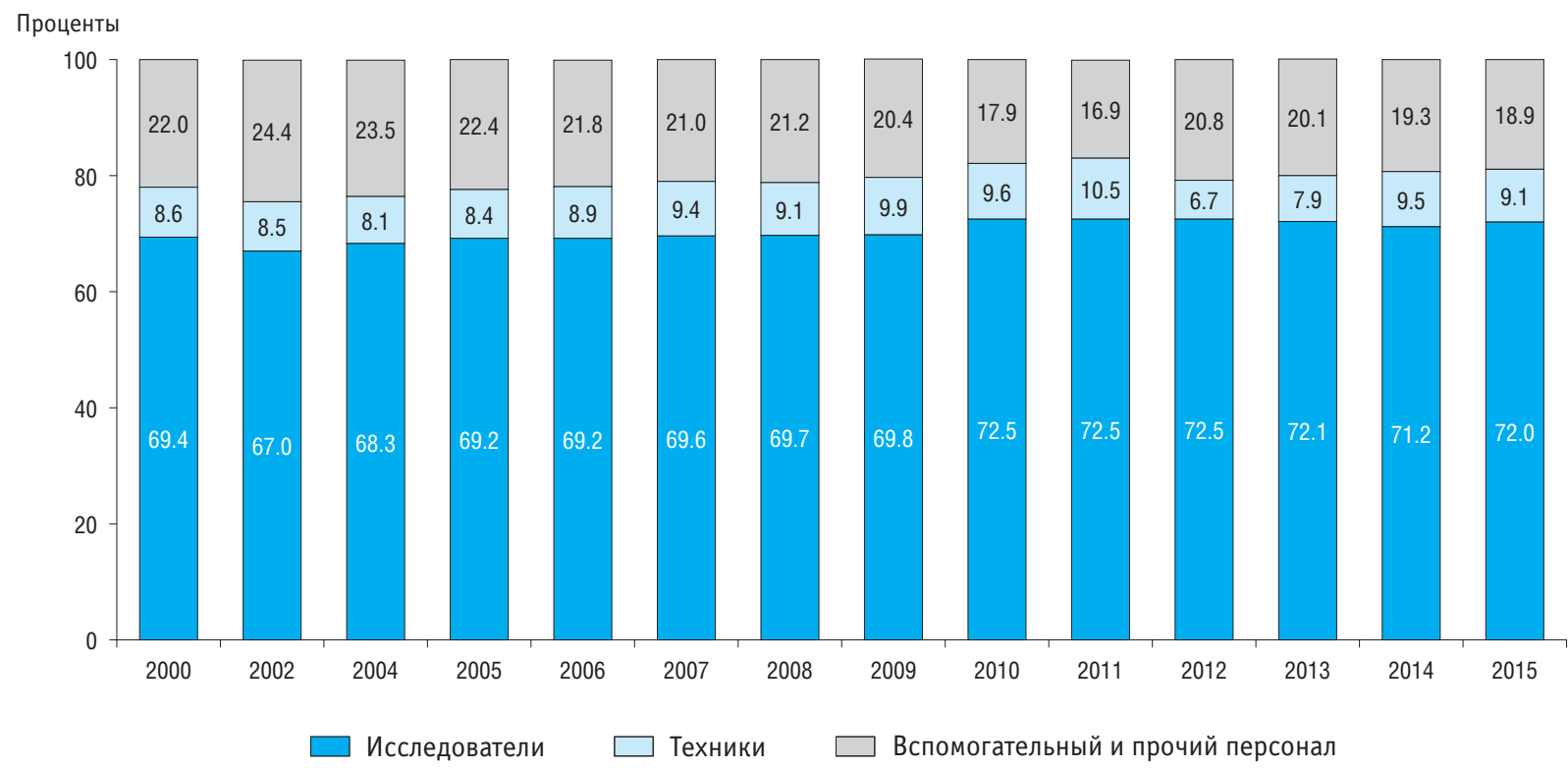


5.4.5. УДЕЛЬНЫЙ ВЕС СЕКТОРА ВЫСШЕГО ОБРАЗОВАНИЯ В ОБЩЕЙ ЧИСЛЕННОСТИ ПЕРСОНАЛА, ЗАНЯТОГО ИССЛЕДОВАНИЯМИ И РАЗРАБОТКАМИ, ПО КАТЕГОРИЯМ

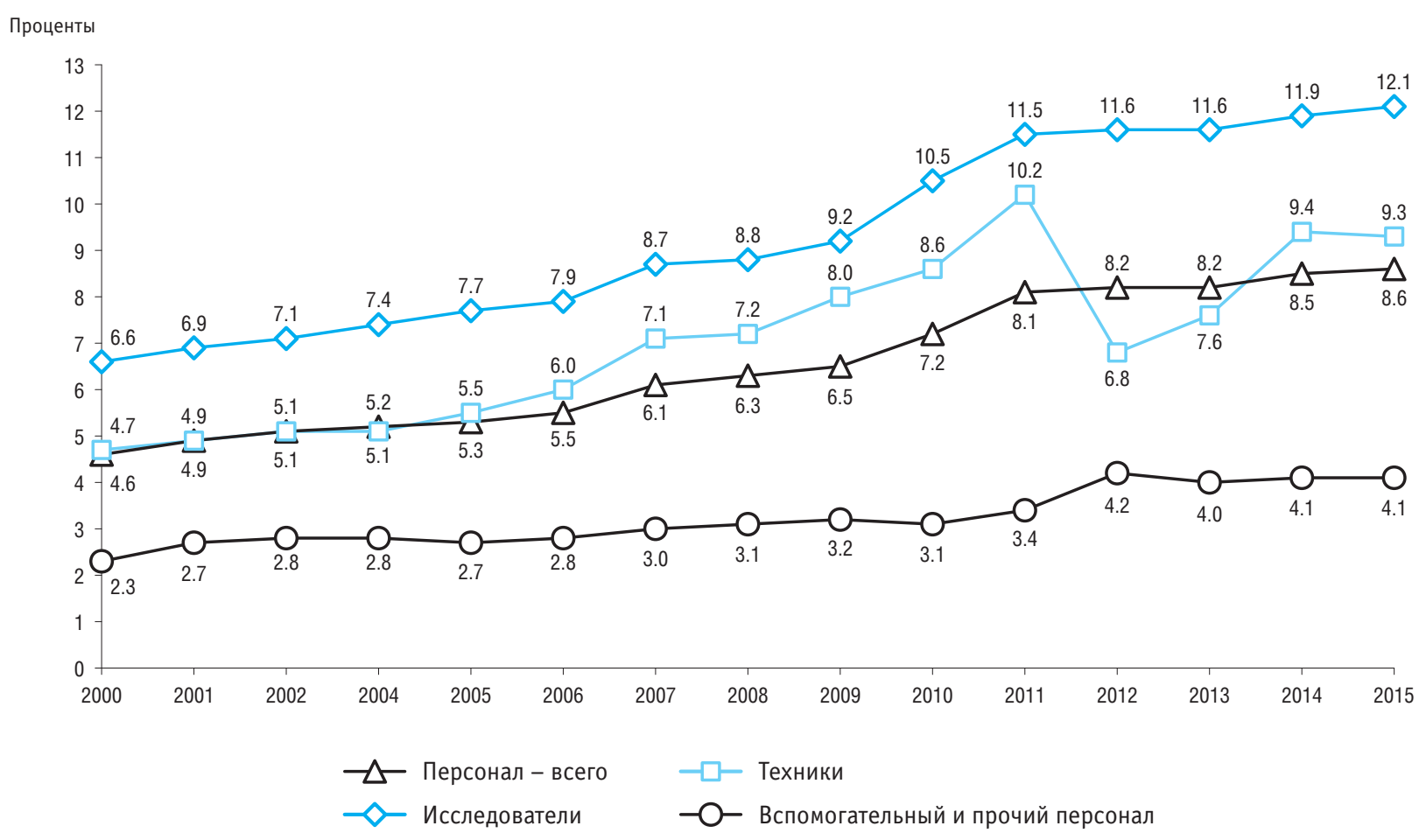


5.4.6. ПЕРСОНАЛ, ЗАНЯТЫЙ ИССЛЕДОВАНИЯМИ И РАЗРАБОТКАМИ В СЕКТОРЕ ВЫСШЕГО ОБРАЗОВАНИЯ, ПО УРОВНЮ ОБРАЗОВАНИЯ (человек)

\begin{tabular}{|c|c|c|c|c|}
\hline & Всего & $\begin{array}{c}\text { Высшее } \\
\text { образование }\end{array}$ & $\begin{array}{l}\text { Среднее профессиональное } \\
\text { образование }\end{array}$ & $\begin{array}{l}\text { Прочее } \\
\text { образование }\end{array}$ \\
\hline \multicolumn{5}{|c|}{$\begin{array}{l}\text { Персонал, занятый исследованиями } \\
\text { и разработками }\end{array}$} \\
\hline 2005 & 43500 & 35159 & 4430 & 3911 \\
\hline 2010 & 53290 & 46112 & 3394 & 3784 \\
\hline 2012 & 59469 & 52334 & 2673 & 4462 \\
\hline 2013 & 59247 & 52927 & 2625 & 3695 \\
\hline 2014 & 62400 & 56009 & 2274 & 4117 \\
\hline 2015 & 63870 & 58144 & 2071 & 3655 \\
\hline \multicolumn{5}{|c|}{ Исследователи } \\
\hline 2005 & 30111 & 30111 & - & - \\
\hline 2010 & 38640 & 38640 & - & - \\
\hline 2012 & 43103 & 43103 & - & - \\
\hline 2013 & 42692 & 42692 & - & - \\
\hline 2014 & 44427 & 44427 & - & - \\
\hline 2015 & 45967 & 45967 & - & - \\
\hline \multicolumn{5}{|l|}{ Техники } \\
\hline 2005 & 3658 & 1079 & 2082 & 497 \\
\hline 2010 & 5095 & 2460 & 1526 & 1109 \\
\hline 2012 & 3998 & 1755 & 987 & 1256 \\
\hline 2013 & 4670 & 2570 & 919 & 1181 \\
\hline 2014 & 5939 & 3835 & 816 & 1288 \\
\hline 2015 & 5836 & 4120 & 742 & 974 \\
\hline
\end{tabular}


(окончание)

\begin{tabular}{|c|c|c|c|c|}
\hline & Всего & $\begin{array}{c}\text { Высшее } \\
\text { образование }\end{array}$ & $\begin{array}{l}\text { Среднее профессиональное } \\
\text { образование }\end{array}$ & $\begin{array}{c}\text { Прочее } \\
\text { образование }\end{array}$ \\
\hline \multicolumn{5}{|c|}{ Вспомогательный персонал } \\
\hline 2005 & 6098 & 2758 & 1465 & 1875 \\
\hline 2010 & 6564 & 3695 & 1190 & 1679 \\
\hline 2012 & 9264 & 5950 & 1093 & 2221 \\
\hline 2013 & 8828 & 5917 & 1129 & 1782 \\
\hline 2014 & 9538 & 6404 & 976 & 2158 \\
\hline 2015 & 9217 & 6068 & 898 & 2251 \\
\hline \multicolumn{5}{|l|}{ Прочие } \\
\hline 2005 & 3633 & 1211 & 883 & 1539 \\
\hline 2010 & 2991 & 1317 & 678 & 996 \\
\hline 2012 & 3104 & 1526 & 593 & 985 \\
\hline 2013 & 3057 & 1748 & 577 & 732 \\
\hline 2014 & 2496 & 1343 & 482 & 671 \\
\hline 2015 & 2850 & 1989 & 431 & 430 \\
\hline
\end{tabular}


5.4.7. ИССЛЕДОВАТЕЛИ В СЕКТОРЕ ВЫСШЕГО ОБРАЗОВАНИЯ ПО ПОЛУ И ВОЗРАСТНЫМ ГРУППАМ

\begin{tabular}{|c|c|c|c|c|c|c|}
\hline & \multicolumn{3}{|c|}{2008} & \multicolumn{3}{|c|}{2015} \\
\hline & \multirow[t]{2}{*}{ Исследователи } & \multicolumn{2}{|c|}{ Из них } & \multirow[t]{2}{*}{ Исследователи } & \multicolumn{2}{|c|}{ Из них } \\
\hline & & доктора наук & кандидаты наук & & доктора наук & кандидаты наук \\
\hline Всего & 33160 & 3439 & 12040 & 45967 & 6318 & 20866 \\
\hline \multicolumn{7}{|l|}{ Возраст, лет: } \\
\hline до 29 включительно & 6379 & 4 & 792 & 8714 & 6 & 1480 \\
\hline $30-39$ & 6164 & 133 & 2606 & 11032 & 288 & 6275 \\
\hline $40-49$ & 5964 & 499 & 2619 & 7742 & 837 & 4578 \\
\hline $50-54$ & 3999 & 547 & 1603 & 3826 & 683 & 1907 \\
\hline $55-59$ & 3760 & 627 & 1544 & 3952 & 924 & 1905 \\
\hline $60-69$ & 4937 & 1029 & 2055 & 6807 & 2009 & 3047 \\
\hline 70 и старше & 1957 & 600 & 821 & 3894 & 1571 & 1674 \\
\hline Мужчины & 19506 & 2538 & 6770 & 24659 & 4357 & 10280 \\
\hline \multicolumn{7}{|l|}{ Возраст, лет: } \\
\hline до 29 включительно & 4055 & 3 & 448 & 5125 & 6 & 851 \\
\hline $30-39$ & 3284 & 94 & 1353 & 5502 & 203 & 3011 \\
\hline $40-49$ & 3298 & 349 & 1412 & 3562 & 473 & 1957 \\
\hline $50-54$ & 2951 & 384 & 909 & 1891 & 425 & 858 \\
\hline $55-59$ & 2224 & 450 & 928 & 2076 & 619 & 937 \\
\hline $60-69$ & 3063 & 791 & 1205 & 4013 & 1440 & 1708 \\
\hline 70 и старше & 1231 & 467 & 515 & 2490 & 1191 & 958 \\
\hline Женщины & 13654 & 901 & 5270 & 21308 & 1961 & 10586 \\
\hline \multicolumn{7}{|l|}{ Возраст, лет: } \\
\hline до 29 включительно & 2324 & 1 & 344 & 3589 & & 629 \\
\hline $30-39$ & 2880 & 39 & 1253 & 5530 & 85 & 3264 \\
\hline $40-49$ & 2666 & 150 & 1207 & 4180 & 364 & 2621 \\
\hline $50-54$ & 1648 & 163 & 694 & 1935 & 258 & 1049 \\
\hline $55-59$ & 1536 & 177 & 616 & 1876 & 305 & 968 \\
\hline $60-69$ & 1874 & 238 & 850 & 2794 & 569 & 1339 \\
\hline 70 и старше & 726 & 133 & 306 & 1404 & 380 & 716 \\
\hline
\end{tabular}




\section{0}

\subsection{8. СТРУКТУРА ИССЛЕДОВАТЕЛЕЙ В СЕКТОРЕ ВЫСШЕГО ОБРАЗОВАНИЯ ПО ВОЗРАСТНЫМ ГРУППАМ}
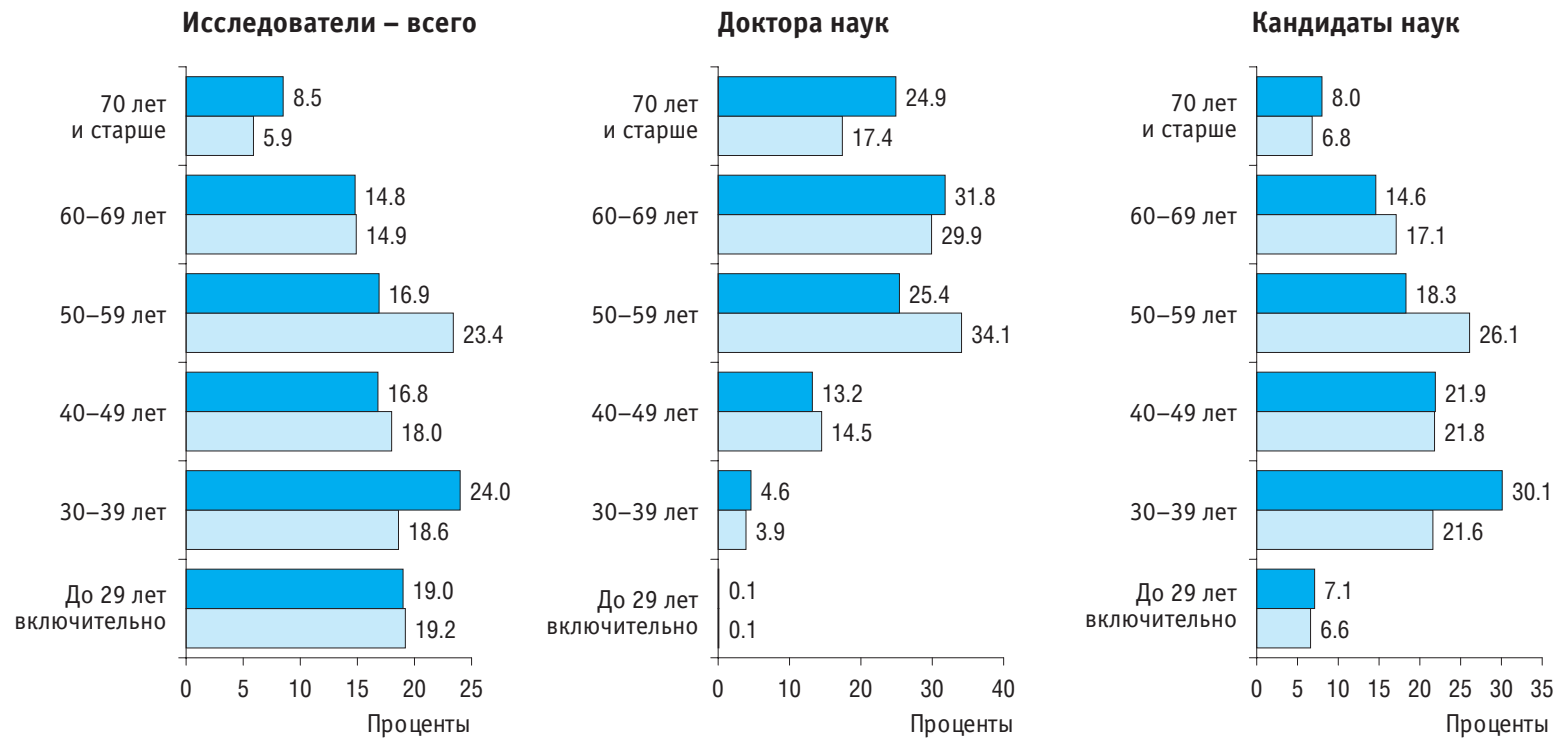


\subsection{9. СРЕДНИЙ ВОЗРАСТ ИССЛЕДОВАТЕЛЕЙ В СЕКТОРЕ ВЫСШЕГО ОБРАЗОВАНИЯ}

Возраст, лет

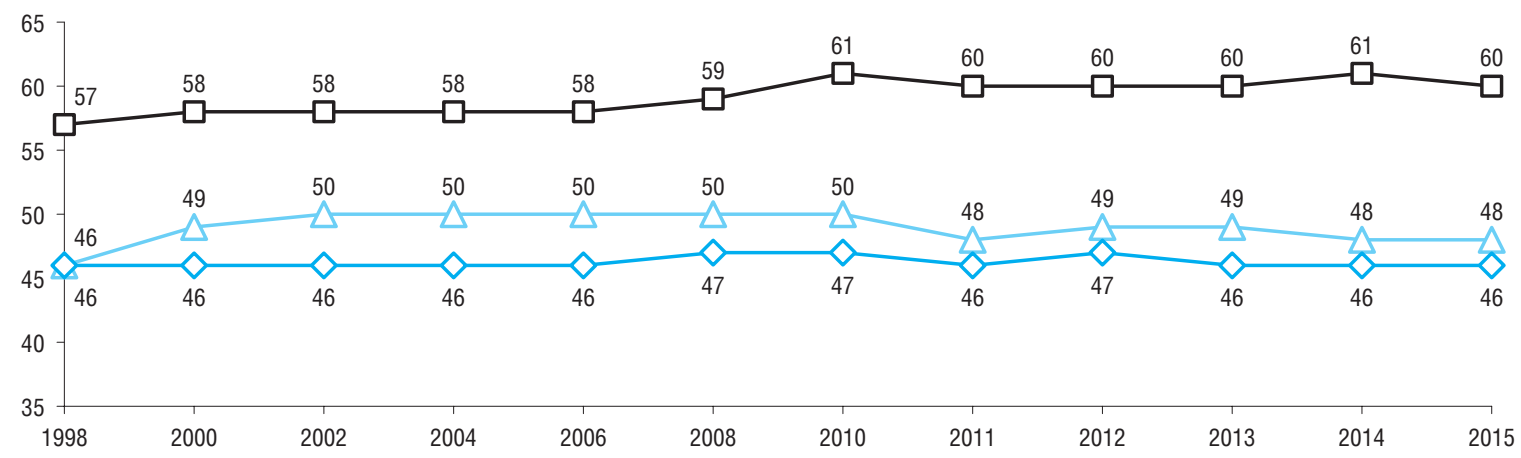

$$
\checkmark \text { Исследователи - всего } \quad \square \text { Доктора наук }
$$

\subsubsection{0. ИССЛЕДОВАТЕЛИ С УЧЕНЫМИ СТЕПЕНЯМИ В СЕКТОРЕ ВЫСШЕГО ОБРАЗОВАНИЯ}

(человек)

\begin{tabular}{|c|c|c|c|c|c|c|c|c|c|c|c|c|c|}
\hline & 1995 & 2000 & 2005 & 2006 & 2007 & 2008 & 2009 & 2010 & 2011 & 2012 & 2013 & 2014 & 2015 \\
\hline $\begin{array}{l}\text { Исследователи с учеными } \\
\text { степенями }\end{array}$ & 14162 & 12113 & 12618 & 13153 & 15330 & 15479 & 15774 & 20423 & 24502 & 24144 & 24306 & 25899 & 27184 \\
\hline Доктора наук & 1617 & 2120 & 2654 & 2924 & 3252 & 3439 & 3568 & 5068 & 5774 & 5753 & 5638 & 6218 & 6318 \\
\hline Кандидаты наук & 12545 & 9993 & 9964 & 10229 & 12078 & 12040 & 12206 & 15355 & 18728 & 18391 & 18668 & 19681 & 20866 \\
\hline
\end{tabular}


5.4.11. УДЕЛЬНЫЙ ВЕС ИССЛЕДОВАТЕЛЕЙ С УЧЕНЫМИ СТЕПЕНЯМИ В ЧИСЛЕННОСТИ ИССЛЕДОВАТЕЛЕЙ В СЕКТОРЕ ВЫСШЕГО ОБРАЗОВАНИЯ

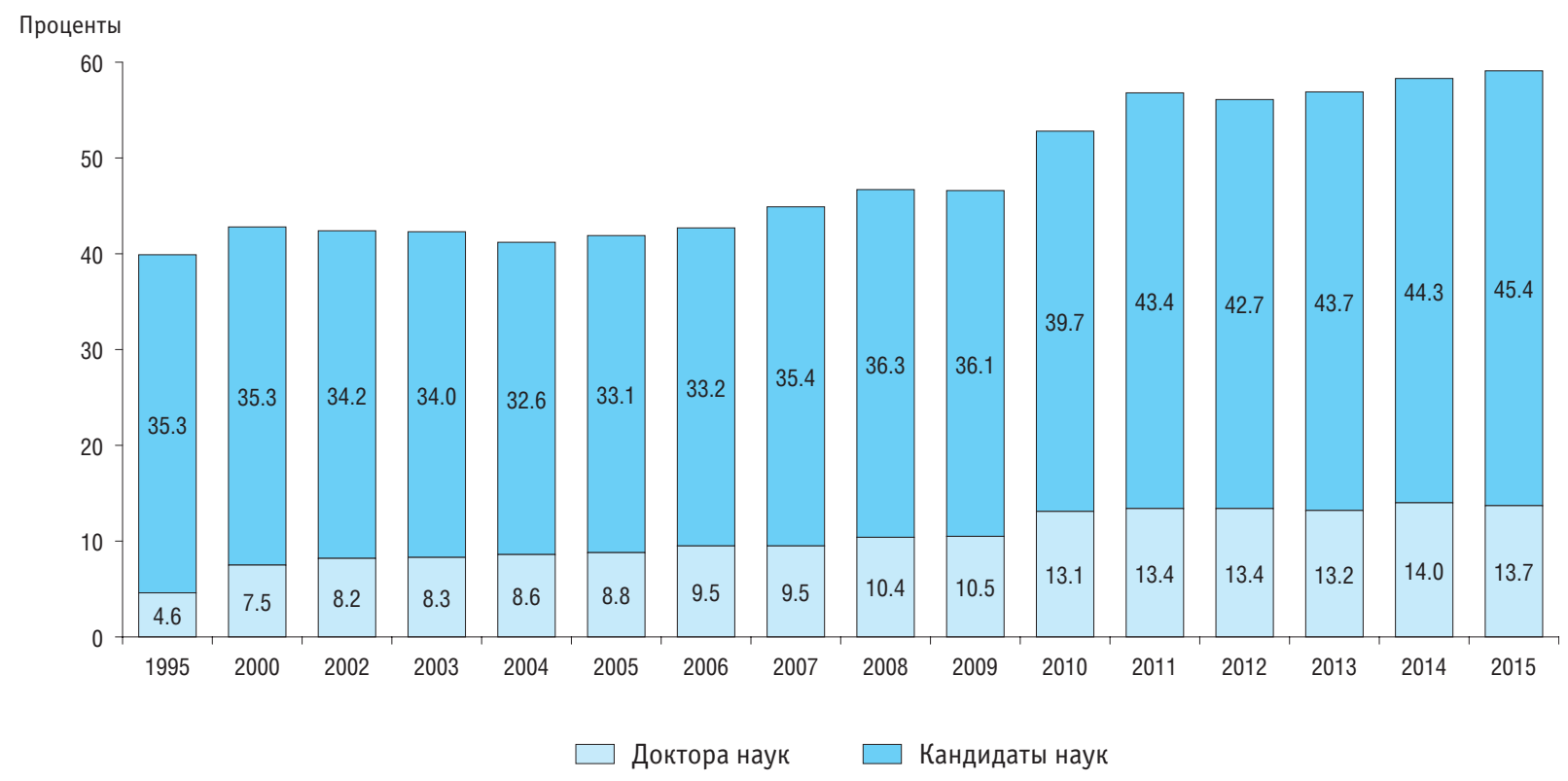




\subsubsection{2. ИССЛЕДОВАТЕЛИ В СЕКТОРЕ ВЫСШЕГО ОБРАЗОВАНИЯ ПО ОБЛАСТЯМ НАУКИ}

(человек)

\begin{tabular}{|c|c|c|c|c|c|c|c|c|c|c|c|c|}
\hline & \multicolumn{3}{|c|}{2008} & \multicolumn{3}{|c|}{2013} & \multicolumn{3}{|c|}{2014} & \multicolumn{3}{|c|}{2015} \\
\hline & \multirow{2}{*}{$\begin{array}{c}\text { Исследо- } \\
\text { ватели }\end{array}$} & \multicolumn{2}{|c|}{ Из них } & \multirow{2}{*}{$\begin{array}{c}\text { Исследо- } \\
\text { ватели }\end{array}$} & \multicolumn{2}{|c|}{ Из них } & \multirow{2}{*}{$\begin{array}{c}\text { Исследо- } \\
\text { ватели }\end{array}$} & \multicolumn{2}{|c|}{ Из них } & \multirow{2}{*}{$\begin{array}{c}\text { Исследо- } \\
\text { ватели }\end{array}$} & \multicolumn{2}{|c|}{ Из них } \\
\hline & & $\begin{array}{c}\text { доктора } \\
\text { наук }\end{array}$ & $\begin{array}{c}\text { кандидаты } \\
\text { наук }\end{array}$ & & $\begin{array}{c}\text { доктора } \\
\text { наук }\end{array}$ & $\begin{array}{c}\text { кандидаты } \\
\text { наук }\end{array}$ & & $\begin{array}{c}\text { доктора } \\
\text { наук }\end{array}$ & $\begin{array}{c}\text { кандидаты } \\
\text { наук }\end{array}$ & & $\begin{array}{c}\text { доктора } \\
\text { наук }\end{array}$ & $\begin{array}{c}\text { кандидаты } \\
\text { наук }\end{array}$ \\
\hline Всего & 33160 & 3439 & 12040 & 42692 & 5638 & 18668 & 44427 & 6218 & 19681 & 45967 & 6318 & 20866 \\
\hline \multicolumn{13}{|l|}{ Области науки: } \\
\hline технические & 10524 & 484 & 2352 & 11989 & 716 & 3088 & 12403 & 919 & 3283 & 12856 & 939 & 3444 \\
\hline медицинские & 2403 & 441 & 1142 & 2032 & 458 & 999 & 2035 & 413 & 956 & 2018 & 451 & 990 \\
\hline сельскохозяйственные & 933 & 116 & 416 & 1275 & 235 & 653 & 1188 & 209 & 625 & 851 & 163 & 421 \\
\hline общественные & 4309 & 512 & 1818 & 9367 & 1280 & 5052 & 9659 & 1460 & 5281 & 11420 & 1562 & 6571 \\
\hline гуманитарные & 1880 & 351 & 1068 & 5025 & 772 & 2535 & 5521 & 899 & 2818 & 5647 & 918 & 2925 \\
\hline
\end{tabular}




\subsubsection{3. ДВИЖЕНИЕ ПЕРСОНАЛА, ЗАНЯТОГО ИССЛЕДОВАНИЯМИ И РАЗРАБОТКАМИ В СЕКТОРЕ ВЫСШЕГО ОБРАЗОВАНИЯ, \\ ПО КАТЕГОРИЯМ \\ (человек)}

\begin{tabular}{|c|c|c|c|c|c|c|c|c|c|c|}
\hline & \multirow{3}{*}{$\begin{array}{c}\text { Наличие } \\
\text { на начало } \\
\text { отчетного года }\end{array}$} & \multicolumn{4}{|c|}{ Принято } & \multicolumn{4}{|c|}{ Выбыло } & \multirow{3}{*}{ 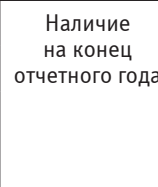 } \\
\hline & & \multirow[t]{2}{*}{ Bсего } & \multicolumn{3}{|c|}{ В том числе } & \multirow[t]{2}{*}{ Bcero } & \multicolumn{3}{|c|}{ В том числе } & \\
\hline & & & $\begin{array}{c}\text { после } \\
\text { окончания } \\
\text { вуза }\end{array}$ & $\begin{array}{c}\text { из других } \\
\text { научных } \\
\text { организаций }\end{array}$ & прочие & & \begin{tabular}{|c|} 
по \\
собственному \\
желанию
\end{tabular} & \begin{tabular}{|c|} 
в связи \\
с сокращением \\
штатов
\end{tabular} & \begin{tabular}{|c|} 
по прочим \\
причинам
\end{tabular} & \\
\hline \multicolumn{11}{|l|}{ Всего } \\
\hline 2005 & 41601 & 8770 & 1475 & 1388 & 5907 & 6871 & 4096 & 25 & 2750 & 43500 \\
\hline 2011 & 56117 & 15068 & 2579 & 1578 & 10911 & 11731 & 6151 & 64 & 5516 & 59454 \\
\hline 2013 & 59043 & 13561 & 1648 & 2104 & 9809 & 13357 & 6381 & 212 & 6764 & 59247 \\
\hline 2015 & 63192 & 14971 & 2293 & 2788 & 9890 & 14293 & 7256 & 350 & 6687 & 63870 \\
\hline \multicolumn{11}{|c|}{ Исследователи } \\
\hline 2005 & 28951 & 5219 & 1229 & 1058 & 2932 & 4062 & 2470 & 16 & 1576 & 30111 \\
\hline 2011 & 41648 & 7823 & 1707 & 1156 & 4960 & 6347 & 3639 & 42 & 2666 & 43121 \\
\hline 2013 & 42229 & 7140 & 903 & 1604 & 4633 & 6663 & 3584 & 134 & 2945 & 42692 \\
\hline 2015 & 45677 & 8141 & 1102 & 1934 & 5105 & 7854 & 4158 & 226 & 3470 & 45967 \\
\hline \multicolumn{11}{|l|}{ Техники } \\
\hline 2005 & 3451 & 1030 & 114 & 115 & 801 & 820 & 467 & 1 & 352 & 3658 \\
\hline 2011 & 4713 & 3267 & 398 & 136 & 2733 & 1723 & 924 & 8 & 791 & 6256 \\
\hline 2013 & 4490 & 2260 & 277 & 187 & 1796 & 2081 & 870 & 37 & 1174 & 4670 \\
\hline 2015 & 5443 & 2701 & 606 & 186 & 1909 & 2276 & 1318 & 28 & 930 & 5836 \\
\hline \multicolumn{11}{|c|}{$\begin{array}{l}\text { Вспомогательный } \\
\text { и прочий персонал }\end{array}$} \\
\hline 2005 & 9199 & 2521 & 132 & 215 & 2174 & 1989 & 1159 & 8 & 822 & 9731 \\
\hline 2011 & 9756 & 3978 & 474 & 286 & 3218 & 3661 & 1588 & 14 & 2059 & 10077 \\
\hline 2013 & 12324 & 4161 & 468 & 313 & 3380 & 4613 & 1927 & 41 & 2645 & 11885 \\
\hline 2015 & 12072 & 4129 & 585 & 668 & 2876 & 4163 & 1780 & 96 & 2287 & 12067 \\
\hline
\end{tabular}




\subsubsection{4. ПРИЕМ И ВЫБЫТИЕ ПЕРСОНАЛА, ЗАНЯТОГО ИССЛЕДОВАНИЯМИ И РАЗРАБОТКАМИ}

В СЕКТОРЕ ВЫСШЕГО ОБРАЗОВАНИЯ

\section{Персонал, занятый исследованиями}

\section{и разработками}

Проценть

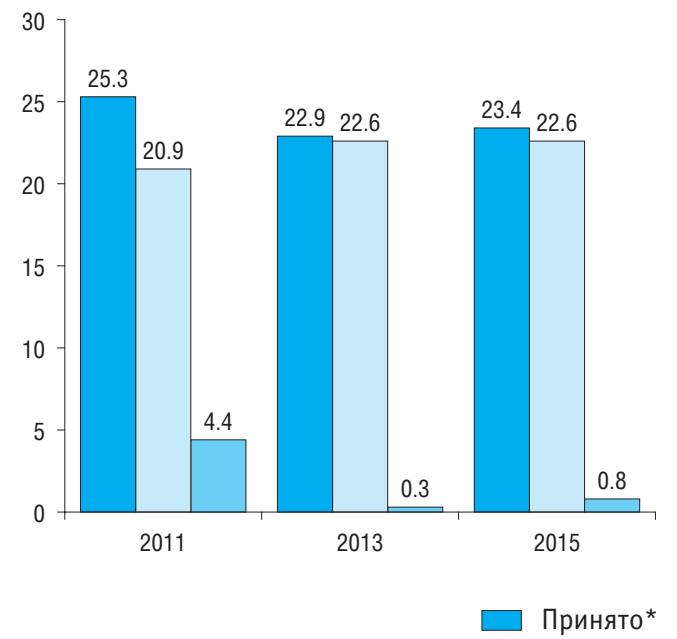

Проценты

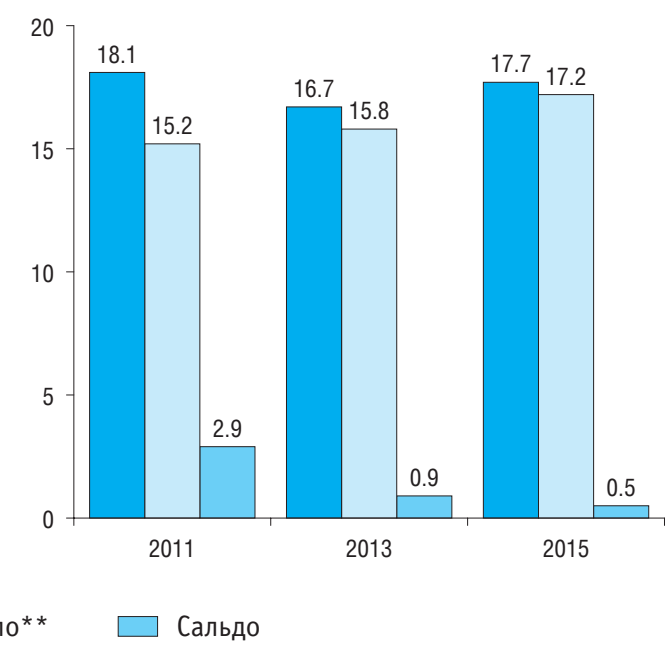

* Отношение численности принятых в течение года к численности работников на конец года.

** Отношение численности выбывших в течение года к численности работников на начало года.

\section{Исследователи}




\section{6}

\subsubsection{5. ПРИЕМ ВЫПУСКНИКОВ ОБРАЗОВАТЕЛЬНЫХ ОРГАНИЗАЦИЙ ВЫСШЕГО ОБРАЗОВАНИЯ НА РАБОТУ В ОРГАНИЗАЦИИ СЕКТОРА ВЫСШЕГО ОБРАЗОВАНИЯ}

Удельный вес выпускников

в численности принятых

на работу

Проценты

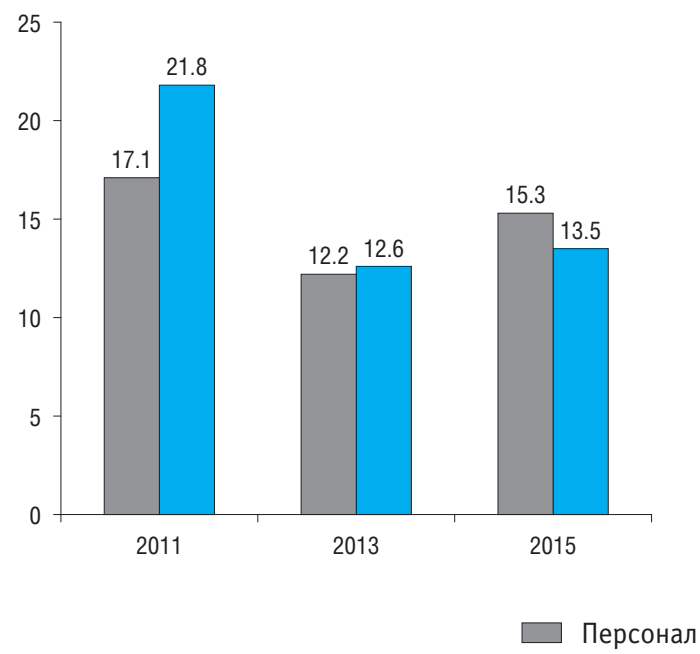

Удельный вес выпускников

в численности персонала, занятого исследованиями и разработками * Проценты

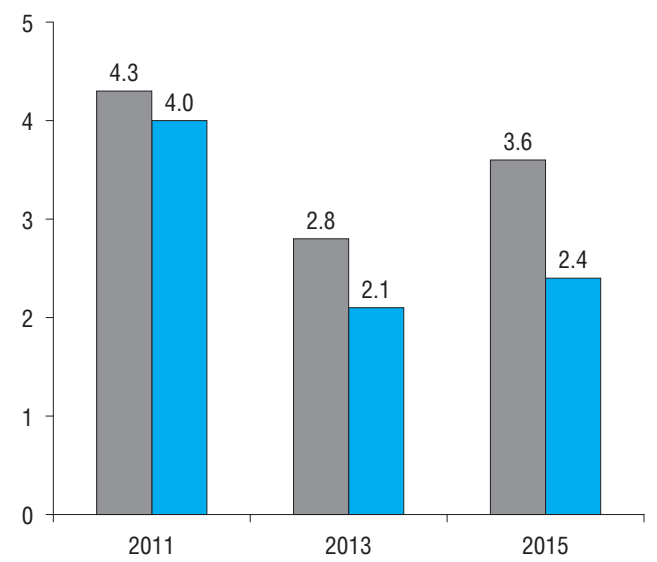

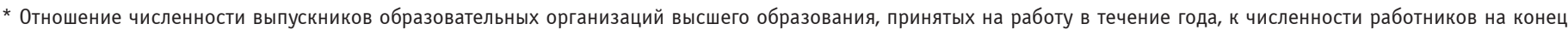
года. 


\subsubsection{6. ВНУТРЕННИЕ ЗАТРАТЫ НА ИССЛЕДОВАНИЯ И РАЗРАБОТКИ В СЕКТОРЕ ВЫСШЕГО ОБРАЗОВАНИЯ \\ ПО ТИПАМ ОРГАНИЗАЦИЙ \\ (тысячи рублей)}

\begin{tabular}{|c|c|c|c|c|c|c|c|c|c|c|}
\hline & 2000 & 2006 & 2007 & 2008 & 2010 & 2011 & 2012 & 2013 & 2014 & 2015 \\
\hline Bcero & 3489342.2 & 17639173.8 & 23471870.9 & 28868566.7 & 43714007.3 & 55134893.9 & 65334232.1 & 67858855.1 & 83205260.1 & 87730781.4 \\
\hline $\begin{array}{l}\text { Образовательные организации } \\
\text { высшего образования }\end{array}$ & 2777397.1 & 14672493.3 & 20110291.8 & 25254713.6 & 38787366.4 & 51055347.1 & 59717923.7 & 63138131.0 & 77975805.2 & 82972415.2 \\
\hline $\begin{array}{l}\text { Научно-исследовательские } \\
\text { институты (центры) }\end{array}$ & 528449.7 & 2362999.9 & 2444732.5 & 2552781.1 & 3429235.6 & 2935458.1 & 3571846.1 & 3022702.5 & 3616147.7 & 3382500.2 \\
\hline $\begin{array}{l}\text { Конструкторские, проектно- } \\
\text { конструкторские организации }\end{array}$ & 157818.5 & 600446.4 & 875313.6 & 869259.6 & 984428.5 & 809586.0 & 1344028.6 & 1090711.3 & 1092686.4 & 1114835.9 \\
\hline $\begin{array}{l}\text { Опытные (экспериментальные) } \\
\text { предприятия }\end{array}$ & 78.5 & - & 14145.0 & 24376.0 & 26584.0 & 12042.6 & 14652.7 & * &.$^{*}$ & $\ldots{ }^{*}$ \\
\hline Прочие & 25598.4 & 3234.2 & 27388.0 & 167436.4 & 486392.8 & 322460.1 & 685781.0 & 596309.4 & 515769.8 & 253618.1 \\
\hline
\end{tabular}

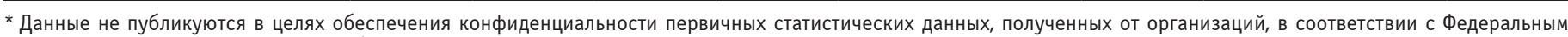

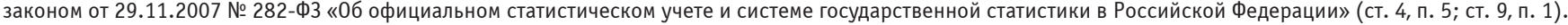




\section{8}

\subsubsection{7. ВНУТРЕННИЕ ЗАТРАТЫ НА ИССЛЕДОВАНИЯ И РАЗРАБОТКИ В СЕКТОРЕ ВЫСШЕГО ОБРАЗОВАНИЯ}

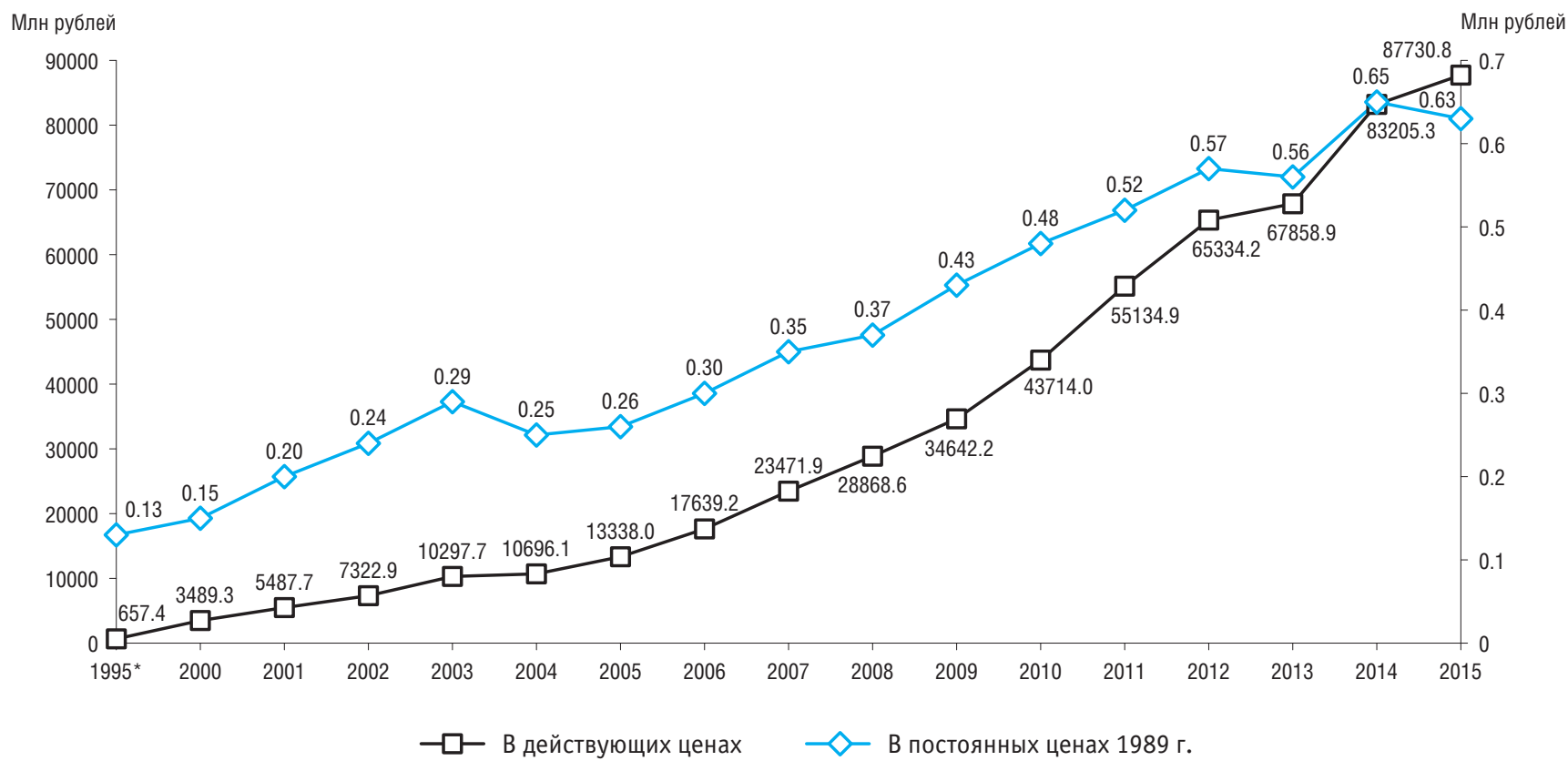

* Млрд рублей. 
5.4.18. ВНУТРЕННИЕ ЗАТРАТЫ НА ИССЛЕДОВАНИЯ И РАЗРАБОТКИ В СЕКТОРЕ ВЫСШЕГО ОБРАЗОВАНИЯ ПО ИСТОЧНИКАМ ФИНАНСИРОВАНИЯ

\begin{tabular}{|c|c|c|c|c|c|c|}
\hline & Bcero & $\begin{array}{c}\text { Средства } \\
\text { государства* }\end{array}$ & $\begin{array}{c}\text { Средства } \\
\text { предприниматель- } \\
\text { ского сектора }\end{array}$ & $\begin{array}{c}\text { Средства } \\
\text { организаций сектора } \\
\text { высшего образования }\end{array}$ & $\begin{array}{c}\text { Средства частных } \\
\text { некоммерческих } \\
\text { организаций }\end{array}$ & $\begin{array}{c}\text { Средства } \\
\text { иностранных } \\
\text { источников }\end{array}$ \\
\hline \multicolumn{7}{|c|}{ В действующих ценах, тыс. рублей, 1995 г. - млн рублей } \\
\hline 1995 & 657374.0 & 440429.9 & 181015.3 & 27407.6 & 1279.1 & 7242.1 \\
\hline 2000 & 3489342.2 & 2220574.3 & 951898.2 & 178004.2 & 6651.5 & 132214.0 \\
\hline 2001 & 5487653.7 & 3443940.3 & 1454005.4 & 297109.0 & 8069.0 & 284530.0 \\
\hline 2002 & 7322943.2 & 4458540.7 & 1989239.9 & 382058.3 & 12154.0 & 480950.3 \\
\hline 2003 & 10297745.0 & 6294220.6 & 2870119.3 & 704239.2 & 12759.1 & 416406.8 \\
\hline 2004 & 10696125.8 & 6269141.4 & 3488281.5 & 597899.1 & 8162.1 & 332641.7 \\
\hline 2005 & 13337987.1 & 7982229.6 & 3911201.8 & 889069.7 & 20503.0 & 534983.0 \\
\hline 2006 & 17639173.8 & 10350996.7 & 5169607.6 & 1505274.5 & 26181.7 & 587113.3 \\
\hline 2007 & 23471870.9 & 13931491.1 & 7267861.9 & 1573278.8 & 64898.0 & 634341.1 \\
\hline 2008 & 28868566.7 & 18003735.9 & 8244450.2 & 1758509.8 & 84419.2 & 777451.6 \\
\hline 2009 & 34642216.7 & 24181368.4 & 7769897.9 & 1741764.5 & 95595.8 & 853590.1 \\
\hline 2010 & 43714007.3 & 30017817.7 & 10724045.9 & 2154774.3 & 55055.8 & 762313.6 \\
\hline 2011 & 55134893.9 & 37047554.1 & 13224580.6 & 4030900.0 & 93584.3 & 738274.9 \\
\hline 2012 & 65334232.1 & 40803297.5 & 17709405.2 & 5441235.5 & 371292.2 & 1009001.7 \\
\hline 2013 & 67858855.1 & 40378679.8 & 18663427.9 & 7080091.0 & 448892.7 & 1287763.7 \\
\hline 2014 & 83205260.1 & 50496387.8 & 22607546.6 & 8215233.9 & 506189.0 & 1379902.8 \\
\hline 2015 & 87730781.4 & 51570251.1 & 24028351.9 & 9979551.2 & 671465.0 & 1481162.2 \\
\hline
\end{tabular}


(окончание)

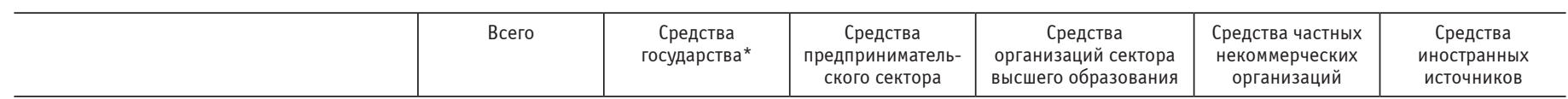

\begin{tabular}{|c|c|c|c|c|c|c|}
\hline \multicolumn{7}{|c|}{ Проценты } \\
\hline 1995 & 100 & 67.0 & 27.5 & 4.2 & 0.2 & 1.1 \\
\hline 2000 & 100 & 63.6 & 27.3 & 5.1 & 0.2 & 3.8 \\
\hline 2001 & 100 & 62.8 & 26.5 & 5.4 & 0.1 & 5.2 \\
\hline 2002 & 100 & 60.9 & 27.2 & 5.2 & 0.2 & 6.6 \\
\hline 2003 & 100 & 61.1 & 27.9 & 6.8 & 0.1 & 4.0 \\
\hline 2004 & 100 & 58.6 & 32.6 & 5.6 & 0.08 & 3.1 \\
\hline 2005 & 100 & 59.8 & 29.3 & 6.7 & 0.2 & 4.0 \\
\hline 2006 & 100 & 58.7 & 29.3 & 8.5 & 0.1 & 3.3 \\
\hline 2007 & 100 & 59.4 & 31.0 & 6.7 & 0.3 & 2.7 \\
\hline 2008 & 100 & 62.4 & 28.6 & 6.1 & 0.3 & 2.7 \\
\hline 2009 & 100 & 69.8 & 22.4 & 5.0 & 0.3 & 2.5 \\
\hline 2010 & 100 & 68.7 & 24.5 & 4.9 & 0.1 & 1.7 \\
\hline 2011 & 100 & 67.2 & 24.0 & 7.3 & 0.2 & 1.3 \\
\hline 2012 & 100 & 62.5 & 27.1 & 8.3 & 0.6 & 1.5 \\
\hline 2013 & 100 & 59.5 & 27.5 & 10.4 & 0.7 & 1.9 \\
\hline 2014 & 100 & 60.7 & 27.2 & 9.9 & 0.6 & 1.7 \\
\hline 2015 & 100 & 58.8 & 27.4 & 11.4 & 0.8 & 1.7 \\
\hline
\end{tabular}

* Включая средства бюджета, бюджетные ассигнования на содержание образовательных организаций высшего образования и средства организаций государственного сектора. 


\subsubsection{9. УДЕЛЬНЫЙ ВЕС СЕКТОРА ВЫСШЕГО ОБРАЗОВАНИЯ В ОБЩЕМ ОБЪЕМЕ ВНУТРЕННИХ ЗАТРАТ}

НА ИССЛЕДОВАНИЯ И РАЗРАБОТКИ ПО ВИДАМ ЗАТРАТ

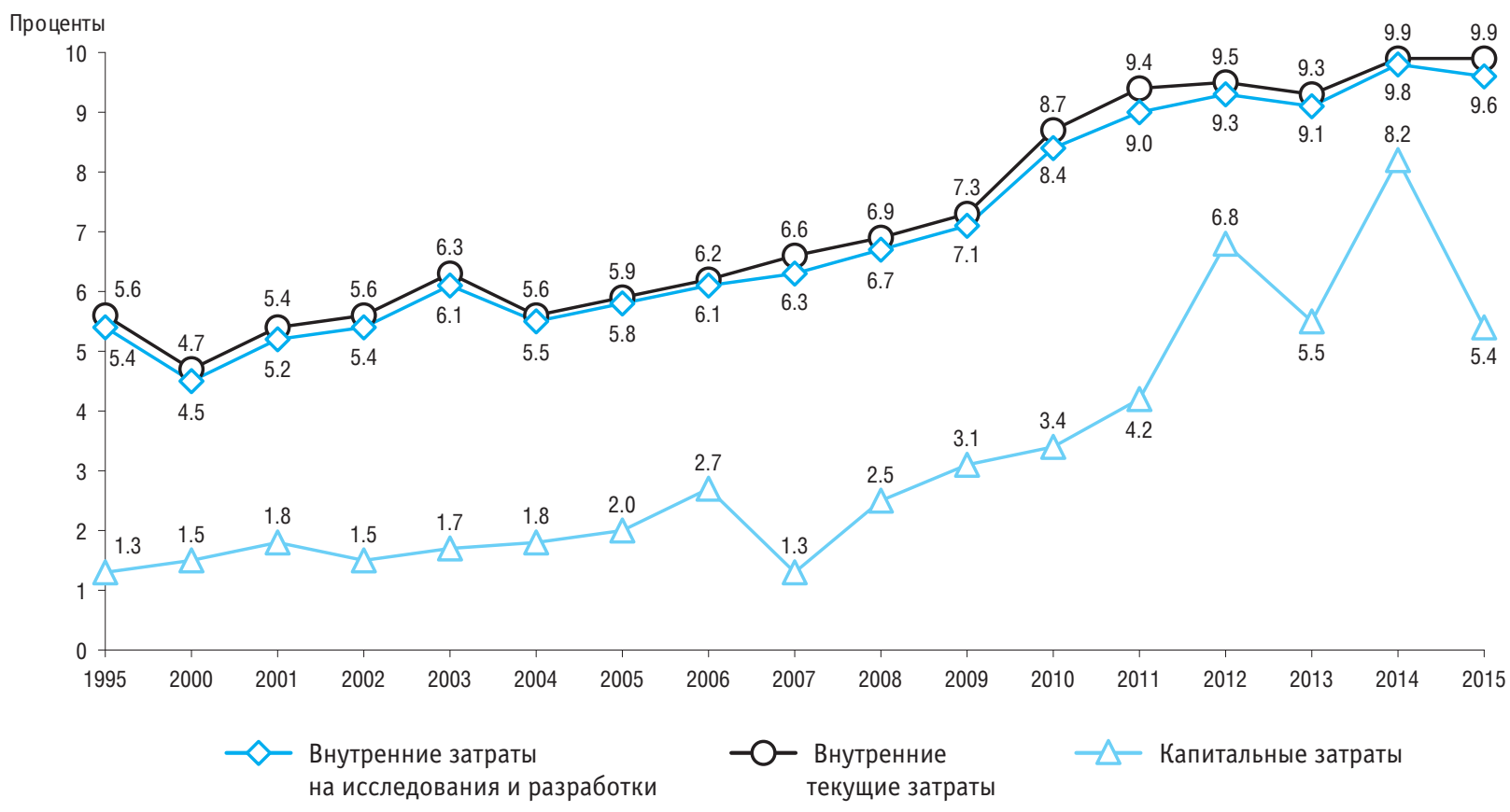




\subsubsection{0. ВНУТРЕННИЕ ЗАТРАТЫ НА ИССЛЕДОВАНИЯ И РАЗРАБОТКИ В СЕКТОРЕ ВЫСШЕГО ОБРАЗОВАНИЯ ПО ВИДАМ ЗАТРАТ} (тысячи рублей)

\begin{tabular}{|c|c|c|c|c|c|c|c|}
\hline & 2005 & 2010 & 2011 & 2012 & 2013 & 2014 & 2015 \\
\hline Внутренние затраты на исследования и разработки & 13337987.1 & 43714007.3 & 55134893.9 & 65334232.1 & 67858855.1 & 83205260.1 & 87730781.4 \\
\hline Внутренние текущие затраты & 13144292.5 & 42552245.4 & 53389079.3 & 62268471.4 & 65103832.7 & 78939146.3 & 84495233.0 \\
\hline Затраты на оплату труда & 6952057.5 & 25267352.4 & 31150804.4 & 35432527.8 & 37483889.6 & 45381722.2 & 48945642.1 \\
\hline Из них работникам, выполнявшим исследования и разработки* & 3552276.8 & 14033490.5 & 16496816.3 & 19671272.1 & 21683297.6 & 25919161.2 & 27878480.3 \\
\hline Страховые взносы в Пенсионный фонд, ФСС, ФФОМС & 1654258.7 & 5260709.4 & 7630274.5 & 8475705.7 & 8920077.8 & 10651630.2 & 12471272.2 \\
\hline Затраты на оборудование & 917350.6 & 2639343.7 & 2969583.7 & 3336796.8 & 3288338.4 & 4767932.9 & 3708006.7 \\
\hline Другие материальные затраты & 1501392.4 & 3344896.4 & 3695390.0 & 5072129.7 & 5585226.3 & 6487280.5 & 6193042.0 \\
\hline Прочие текущие затраты & 2119233.3 & 6039943.5 & 7943026.7 & 9951311.4 & 9826300.6 & 11650580.5 & 13177270.0 \\
\hline Капитальные затраты & 193694.6 & 1161761.9 & 1745814.6 & 3065760.7 & 2755022.4 & 4266113.8 & 3235548.4 \\
\hline Земельные участки и здания & 39711.4 & 14186.1 & 67000.0 & 106798.5 & 233349.2 & 645364.7 & 141573.3 \\
\hline Оборудование & 104359.6 & 1068873.2 & 1622614.3 & 2688993.0 & 2133749.9 & 2561153.5 & 2375951.4 \\
\hline Прочие капитальные затраты & 49623.6 & 78702.6 & 56200.3 & 269969.2 & 387923.3 & 1059595.6 & 718023.7 \\
\hline
\end{tabular}

* Без совместителей и работавших по договорам гражданско-правового характера. 


\subsubsection{1. ВНУТРЕННИЕ ТЕКУЩИЕ ЗАТРАТЫ НА ИССЛЕДОВАНИЯ И РАЗРАБОТКИ В СЕКТОРЕ ВЫСШЕГО ОБРАЗОВАНИЯ \\ ПО ВИДАМ РАБОТ И ОБЛАСТЯМ НАУКИ \\ (тысячи рублей)}

\begin{tabular}{|c|c|c|c|c|c|c|c|}
\hline & Bсего & $\begin{array}{c}\text { Естественные } \\
\text { науки }\end{array}$ & $\begin{array}{c}\text { Технические } \\
\text { науки }\end{array}$ & $\begin{array}{c}\text { Медицинские } \\
\text { науки }\end{array}$ & $\begin{array}{l}\text { Сельскохозяй- } \\
\text { ственные науки }\end{array}$ & $\begin{array}{c}\text { Общественные } \\
\text { науки }\end{array}$ & $\begin{array}{c}\text { Гуманитарные } \\
\text { науки }\end{array}$ \\
\hline \multicolumn{8}{|c|}{2005} \\
\hline Внутренние текущие затраты & 13144292.5 & 3896908.4 & 6853399.7 & 378448.2 & 200121.3 & 1419552.8 & 395862.1 \\
\hline Фундаментальные исследования & 3841327.6 & 2342791.4 & 751584.6 & 147772.6 & 31818.6 & 342156.9 & 225203.5 \\
\hline Прикладные исследования & 5405410.3 & 1112036.2 & 2918946.4 & 161855.9 & 121828.4 & 949311.8 & 141431.6 \\
\hline Разработки & 3897554.6 & 442080.8 & 3182868.7 & 68819.7 & 46474.3 & 128084.1 & 29227.0 \\
\hline \multicolumn{8}{|c|}{2012} \\
\hline Внутренние текущие затраты & 62268471.4 & 16680876.1 & 29103142.6 & 2423858.7 & 1335727.7 & 9954116.6 & 2770749.7 \\
\hline Фундаментальные исследования & 18092897.7 & 9987728.3 & 2764446.8 & 790365.8 & 228012.1 & 2720694.0 & 1601650.5 \\
\hline Прикладные исследования & 28324950.6 & 4983014.1 & 14319866.5 & 1283660.8 & 903775.9 & 5941367.0 & 8932666.3 \\
\hline Разработки & 15850623.1 & 1710133.7 & 12018829.3 & 349832.1 & 203939.7 & 1292055.4 & 275832.9 \\
\hline \multicolumn{8}{|c|}{2013} \\
\hline Внутренние текущие затраты & 65103832.7 & 17390347.8 & 29875049.0 & 2969687.3 & 1342285.6 & 10615711.4 & 2910751.6 \\
\hline Фундаментальные исследования & 18292483.8 & 9321872.1 & 3188442.9 & 899868.3 & 184993.8 & 3200249.8 & 1497056.9 \\
\hline Прикладные исследования & 31034270.9 & 6043026.6 & 15030689.6 & 1593736.0 & 898069.9 & 6307037.3 & 1161711.5 \\
\hline Разработки & 15777078.0 & 2025449.1 & 11655916.5 & 476083.0 & 259221.9 & 1108424.3 & 251983.2 \\
\hline
\end{tabular}


(окончание)

\begin{tabular}{|c|c|c|c|c|c|c|c|}
\hline & Всего & $\begin{array}{c}\text { Естественные } \\
\text { науки }\end{array}$ & $\begin{array}{l}\text { Технические } \\
\text { науки }\end{array}$ & $\begin{array}{l}\text { Медицинские } \\
\text { науки }\end{array}$ & $\begin{array}{l}\text { Сельскохозяй- } \\
\text { ственные науки }\end{array}$ & $\begin{array}{c}\text { Общественные } \\
\text { науки }\end{array}$ & $\begin{array}{c}\text { Гуманитарные } \\
\text { науки }\end{array}$ \\
\hline \multicolumn{8}{|c|}{2014} \\
\hline Внутренние текущие затраты & 78939146.3 & 22847258.1 & 34368948.3 & 4319356.6 & 1519234.5 & 12390936.4 & 3493412.4 \\
\hline Фундаментальные исследования & 21840738.8 & 11783175.6 & 3215755.1 & 1160052.0 & 158747.2 & 3908850.7 & 1614158.2 \\
\hline Прикладные исследования & 38214808.7 & 8240598.6 & 17468661.1 & 2682946.2 & 1133884.9 & 7048722.5 & 1639995.4 \\
\hline Разработки & 18883598.8 & 2823483.9 & 13684532.1 & 476358.4 & 226602.4 & 1433363.2 & 239258.8 \\
\hline \multicolumn{8}{|c|}{2015} \\
\hline Внутренние текущие затраты & 84495233.0 & 24471293.5 & 36048768.8 & 4478205.2 & 1515246.7 & 12800336.7 & 5181382.1 \\
\hline Фундаментальные исследования & 24839057.2 & 13659393.9 & 3644828.6 & 1348438.7 & 193512.2 & 3664822.7 & 2328061.1 \\
\hline Прикладные исследования & 41098469.1 & 8214107.1 & 18786848.4 & 2576517.7 & 1171765.9 & 7925797.8 & 2423432.2 \\
\hline Разработки & 18557706.7 & 2597792.5 & 13617091.8 & 553248.8 & 149968.6 & 1209716.2 & 429888.8 \\
\hline
\end{tabular}




\subsubsection{2. УДЕЛЬНЫЙ ВЕС СЕКТОРА ВЫСШЕГО ОБРАЗОВАНИЯ В ОБЩЕМ ОБЪЕМЕ ВНУТРЕННИХ ТЕКУЩИХ ЗАТРАТ}

НА ИССЛЕДОВАНИЯ И РАЗРАБОТКИ ПО ВИДАМ РАБОТ

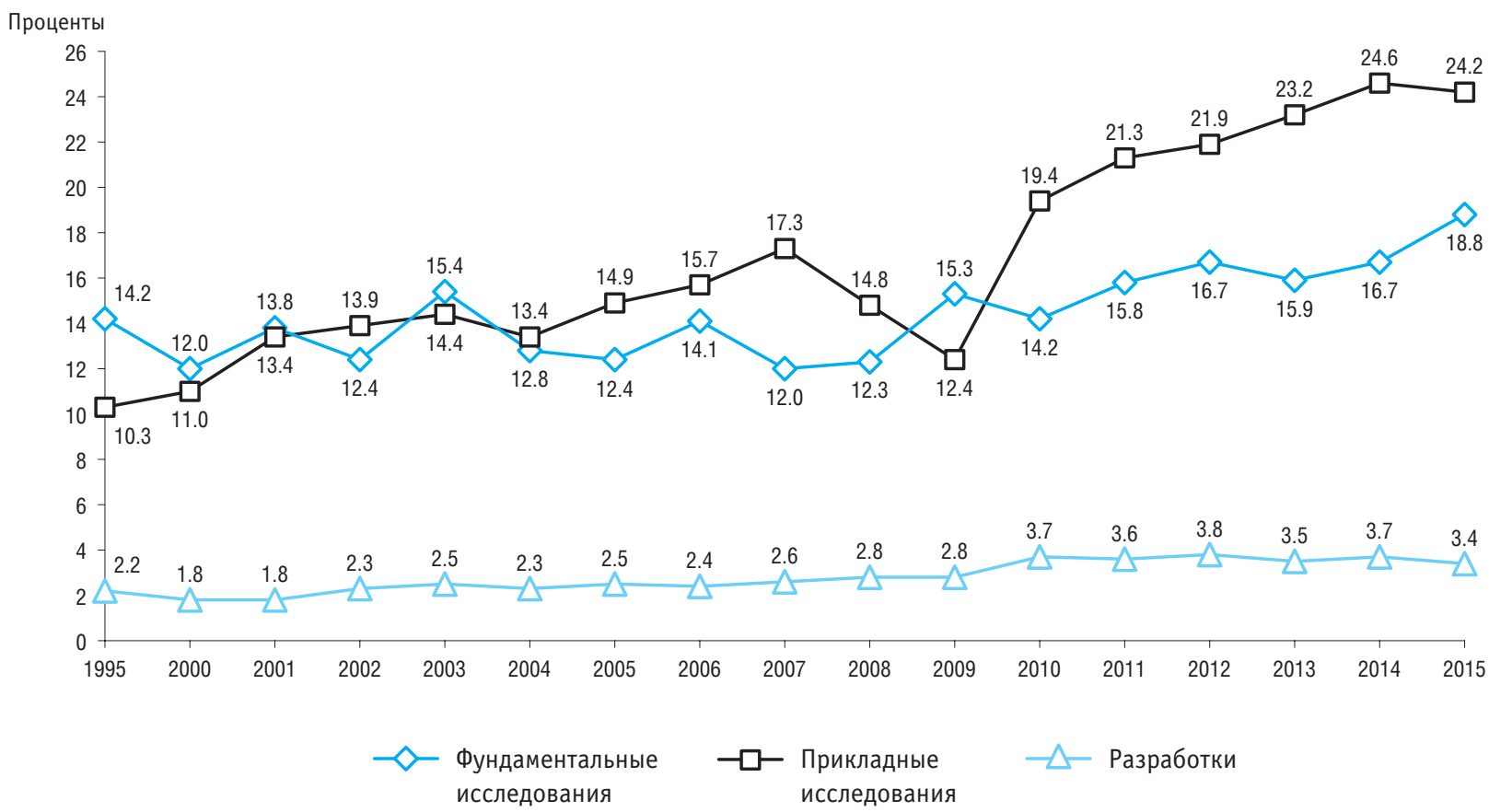




\subsubsection{3. СТРУКТУРА ВНУТРЕННИХ ТЕКУЩИХ ЗАТРАТ НА ИССЛЕДОВАНИЯ И РАЗРАБОТКИ В СЕКТОРЕ ВЫСШЕГО ОБРАЗОВАНИЯ} ПО ВИДАМ РАБОТ

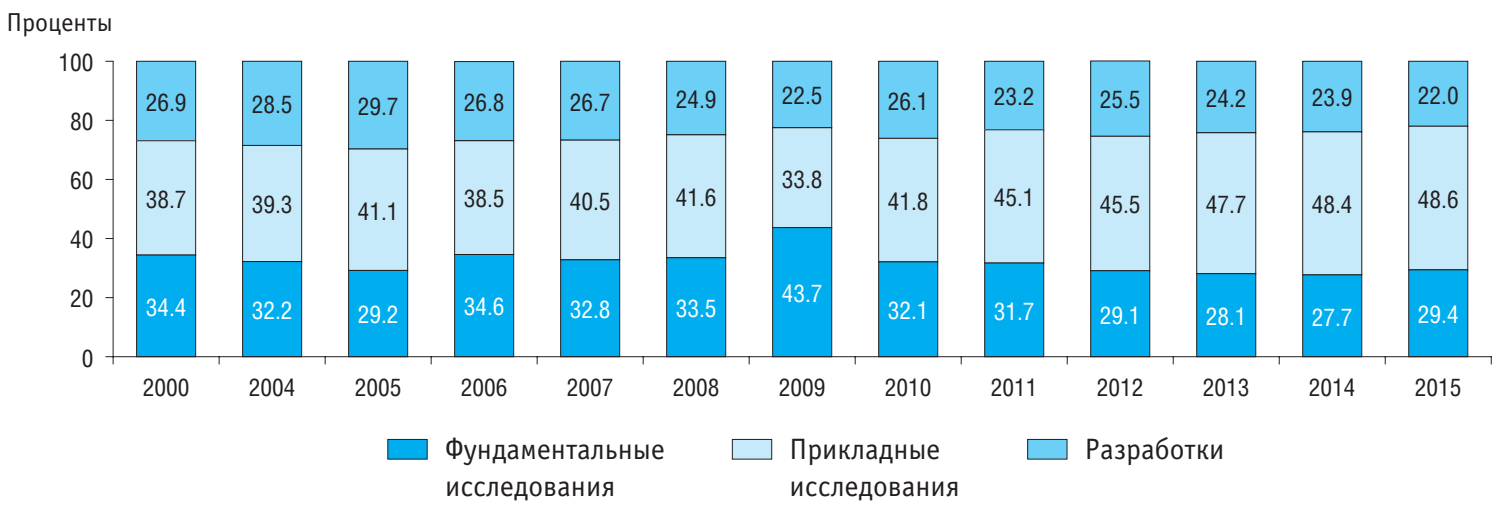

\subsubsection{4. СРЕДНЕМЕСЯЧНАЯ ЗАРАБОТНАЯ ПЛАТА ПЕРСОНАЛА, ЗАНЯТОГО ИССЛЕДОВАНИЯМИ}

И РАЗРАБОТКАМИ В СЕКТОРЕ ВЫСШЕГО ОБРАЗОВАНИЯ

\begin{tabular}{|c|c|c|c|c|c|c|c|c|c|c|c|c|}
\hline & 1995 & 2000 & 2005 & 2007 & 2008 & 2009 & 2010 & 2011 & 2012 & 2013 & 2014 & 2015 \\
\hline \multicolumn{13}{|l|}{$\begin{array}{l}\text { Среднемесячная заработная плата, руб., } \\
1995 \text { г. - тыс. руб. }\end{array}$} \\
\hline \multicolumn{13}{|l|}{ В процентах к заработной плате: } \\
\hline в экономике в целом (=100\%) & 59.3 & 63.0 & 82.3 & 90.0 & 97.2 & 113.7 & 113.2 & 106.8 & 116.1 & 114.5 & 127.0 & 123.2 \\
\hline в обрабатывающих производствах (=100\%) & 61.1 & 59.2 & 83.6 & 95.0 & 104.8 & 127.8 & 124.3 & 114.6 & 126.1 & 126.1 & 139.8 & 131.4 \\
\hline В строительстве $(=100 \%)$ & 47.7 & 53.0 & 77.9 & 85.3 & 90.5 & 116.9 & 112.0 & 105.4 & 119.1 & 123.1 & 140.6 & 140.0 \\
\hline
\end{tabular}




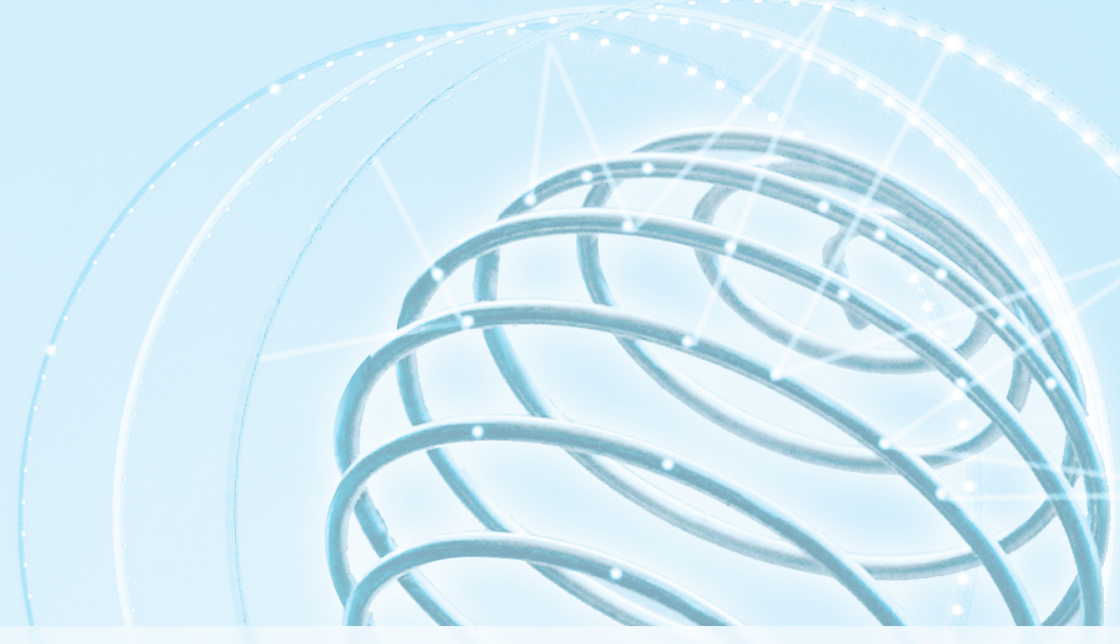

6. Результативность исследований и разработок 
6.1. ПУБЛИКАЦИИ РОССИЙСКИХ АВТОРОВ В НАУЧНЫХ ЖУРНАЛАХ, ИНДЕКСИРУЕМЫХ В SCOPUS, ПО ТИПАМ ДОКУМЕНТА

\begin{tabular}{|c|c|c|c|c|c|c|c|c|c|c|c|c|}
\hline & 2000 & 2005 & 2006 & 2007 & 2008 & 2009 & 2010 & 2011 & 2012 & 2013 & 2014 & 2015 \\
\hline Публикации - всего & 32253 & 39136 & 35055 & 35723 & 36832 & 38596 & 39899 & 43331 & 45089 & 48145 & 56446 & 64237 \\
\hline Статьи & 28589 & 28970 & 26346 & 27901 & 29632 & 31361 & 31578 & 33970 & 32853 & 38018 & 43004 & 48840 \\
\hline Доклады & 2858 & 8220 & 7088 & 6453 & 5698 & 5664 & 6489 & 6696 & 7749 & 7204 & 10416 & 11806 \\
\hline Обзоры & 641 & 1425 & 1038 & 699 & 683 & 692 & 799 & 1190 & 1412 & 1254 & 1431 & 1739 \\
\hline Прочие & 165 & 521 & 583 & 670 & 819 & 879 & 1033 & 1475 & 3075 & 1669 & 1595 & 1852 \\
\hline
\end{tabular}

6.2. ПУБЛИКАЦИИ РОССИЙСКИХ АВТОРОВ В НАУЧНЫХ ЖУРНАЛАХ, ИНДЕКСИРУЕМЫХ В WЕВ ОF SСIENCE, ПО ТИПАМ ДОКУМЕНТА*

\begin{tabular}{|c|c|c|c|c|c|c|c|c|c|c|c|c|}
\hline & 2000 & 2005 & 2006 & 2007 & 2008 & 2009 & 2010 & 2011 & 2012 & 2013 & 2014 & 2015 \\
\hline Публикации - всего & 32683 & 30543 & 29634 & 31212 & 33430 & 33685 & 32415 & 34050 & 34184 & 36816 & 41399 & 48891 \\
\hline Статьи & 27020 & 24383 & 23775 & 25081 & 26926 & 27605 & 26894 & 28501 & 27738 & 29034 & 30128 & 34166 \\
\hline Доклады & 7290 & 6443 & 5787 & 5900 & 5076 & 4568 & 3332 & 2957 & 3336 & 3711 & 7124 & 11388 \\
\hline Обзоры & 633 & 681 & 750 & 773 & 865 & 878 & 772 & 730 & 805 & 857 & 872 & 1046 \\
\hline Прочие & 1362 & 2120 & 2106 & 2220 & 2594 & 2469 & 2685 & 2752 & 2775 & 3674 & 3560 & 3417 \\
\hline
\end{tabular}

* Некоторые публикации могут быть классифицированы одновременно как статья и доклад. 


\section{3. ПУБЛИКАЦИИ РОССИЙСКИХ АВТОРОВ В НАУЧНЫХ ЖУРНАЛАХ, ИНДЕКСИРУЕМЫХ В SСОРUS*}

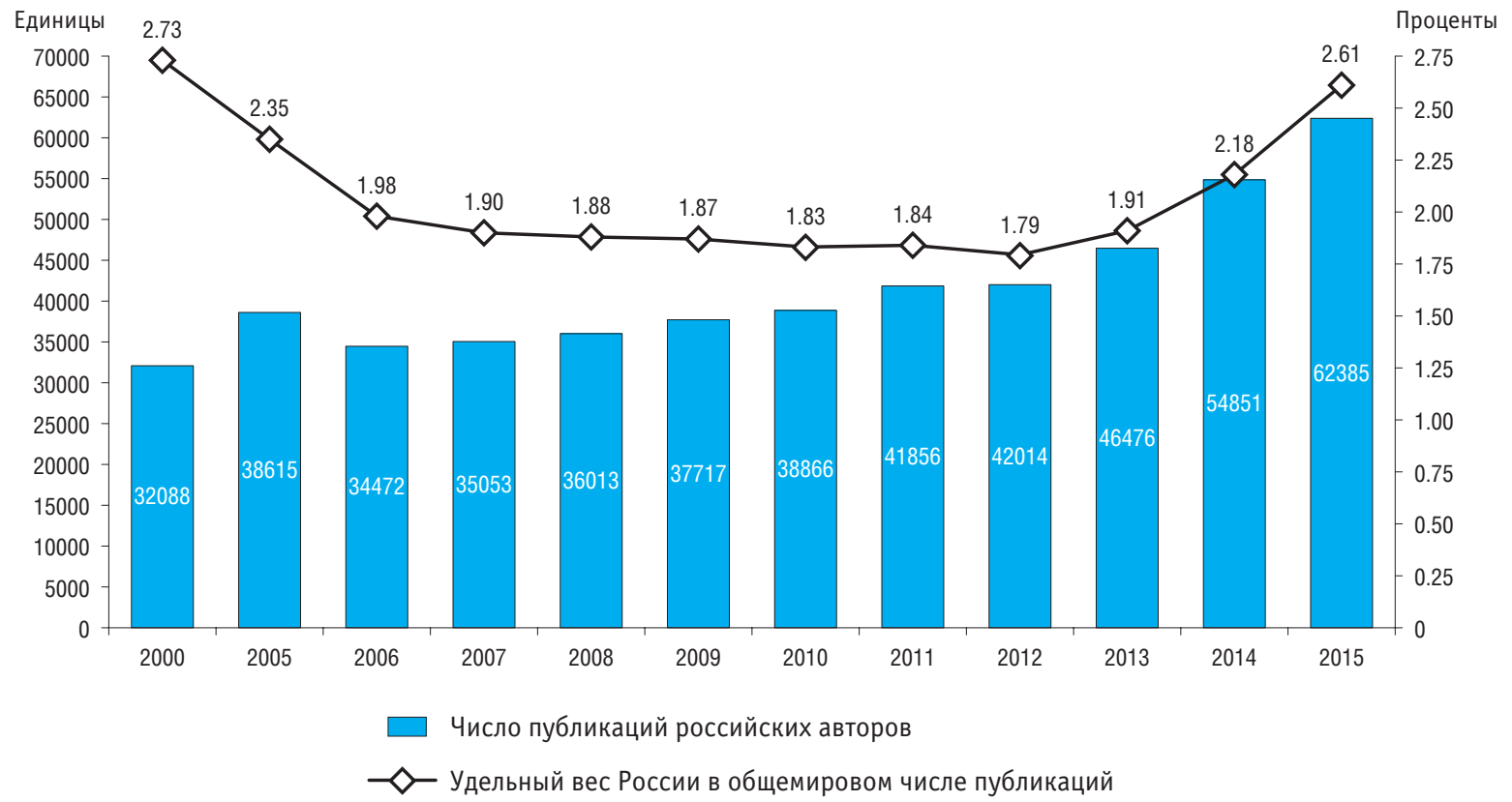

* В разделах 6.3-6.8, если не указано иное, под публикацией подразумеваются три типа документов (статья, обзор, доклад). 
6.4. ПУБЛИКАЦИИ РОССИЙСКИХ АВТОРОВ В НАУЧНЫХ ЖУРНАЛАХ, ИНДЕКСИРУЕМЫХ В WEВ ОF SCIENCE

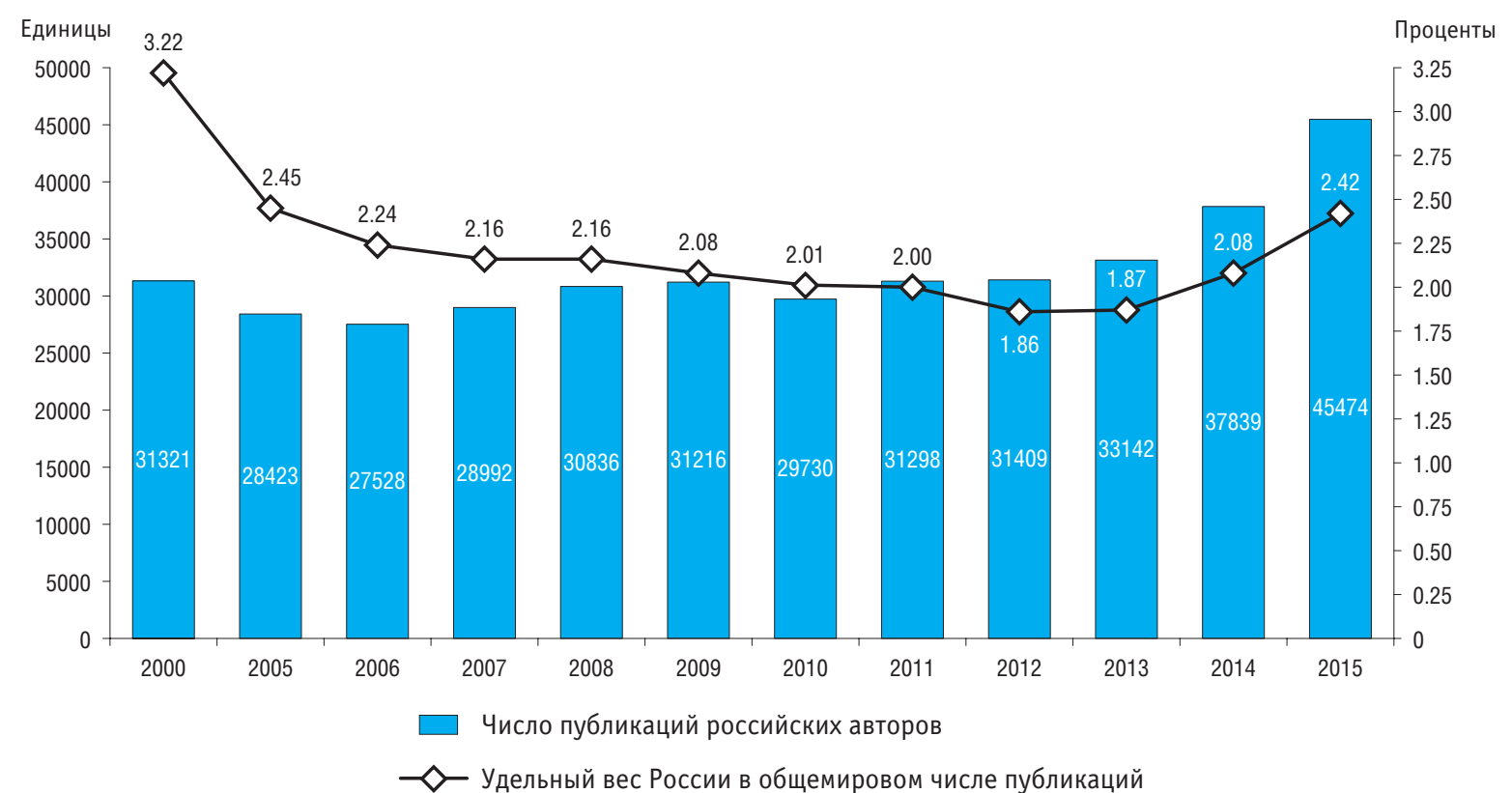




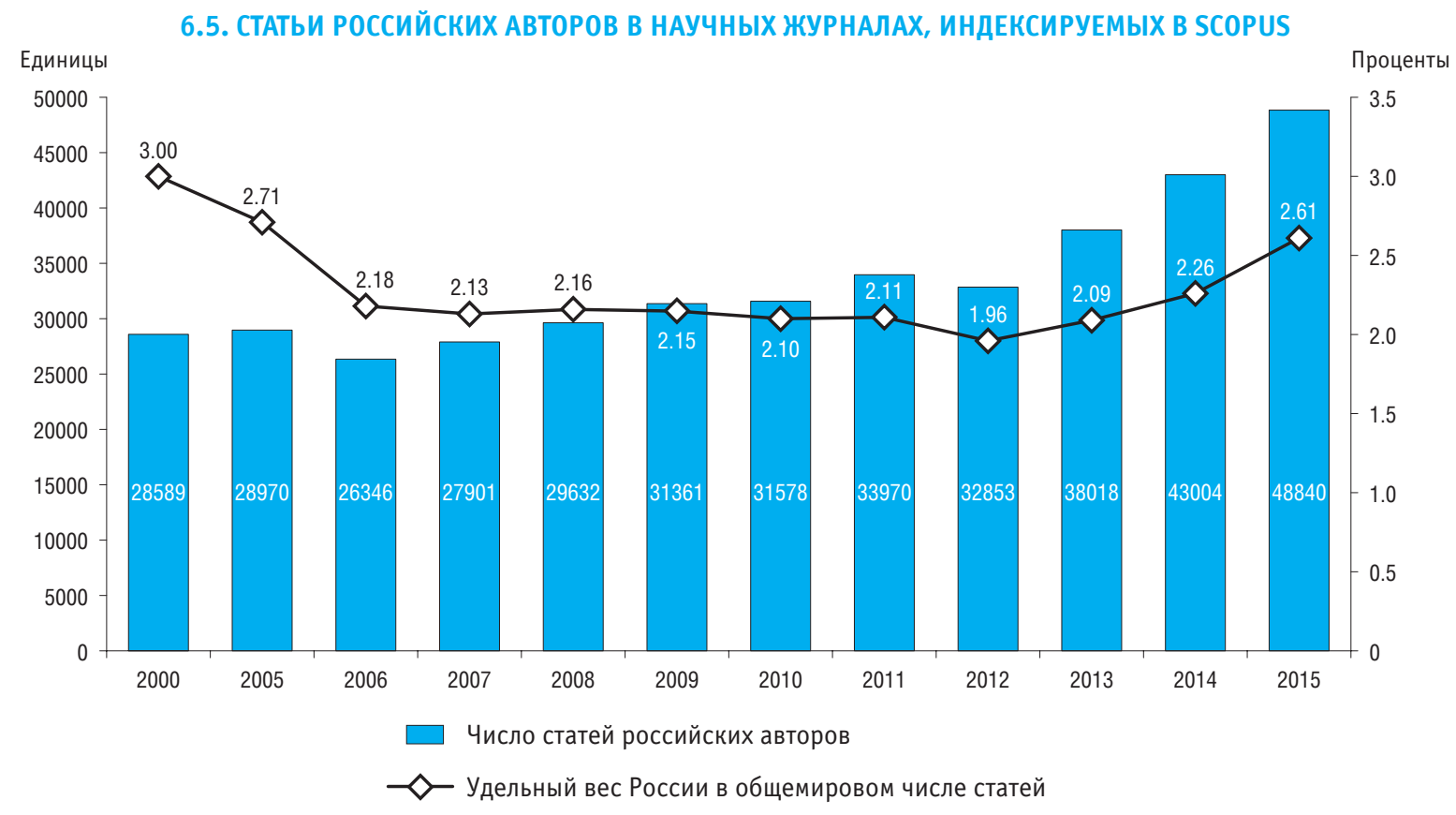


6.6. СТАТЬИ РОССИЙСКИХ АВТОРОВ В НАУЧНЫХ ЖУРНАЛАХ, ИНДЕКСИРУЕМЫХ В WЕВ ОF SCIENCE

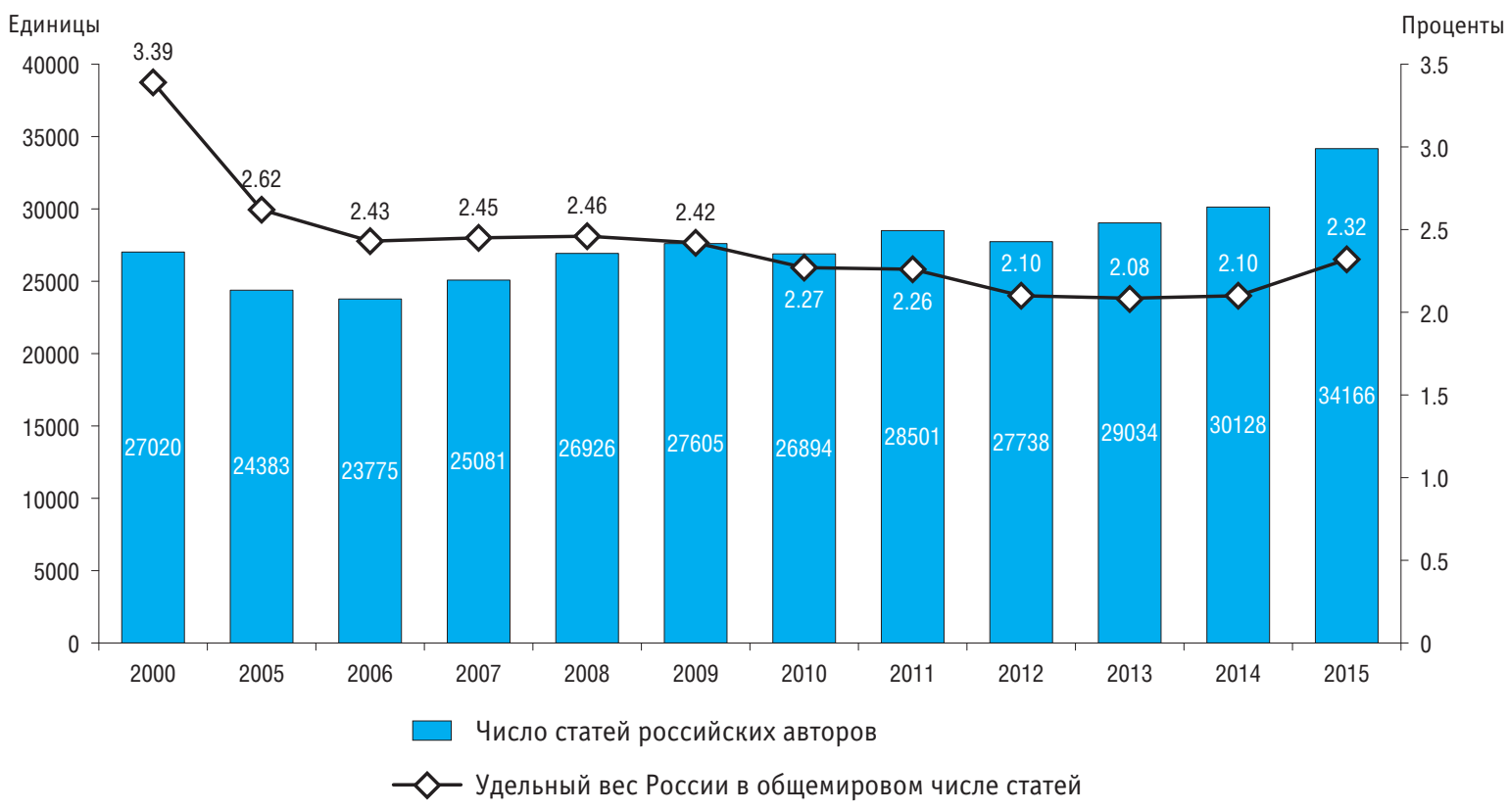




\section{7. СТРУКТУРА ПУБЛИКАЦИЙ РОССИЙСКИХ АВТОРОВ В НАУЧНЫХ ЖУРНАЛАХ, ИНДЕКСИРУЕМЫХ В SСОРUS, ПО ОБЛАСТЯМ НАУКИ* \\ (проценты)}

\begin{tabular}{|c|c|c|c|c|c|c|c|c|c|c|c|c|}
\hline & 2000 & 2005 & 2006 & 2007 & 2008 & 2009 & 2010 & 2011 & 2012 & 2013 & 2014 & 2015 \\
\hline \multicolumn{13}{|c|}{ Россия } \\
\hline $\begin{array}{l}\text { Естественные и точные } \\
\text { науки }\end{array}$ & 67.6 & 58.5 & 65.3 & 65.0 & 67.1 & 66.2 & 65.8 & 63.4 & 61.5 & 59.5 & 57.8 & 56.1 \\
\hline Технические науки & 27.2 & 27.5 & 25.8 & 28.1 & 28.2 & 29.7 & 29.1 & 29.0 & 29.0 & 29.1 & 29.3 & 29.4 \\
\hline Медицинские науки & 4.2 & 3.4 & 4.2 & 4.1 & 5.3 & 5.1 & 5.5 & 6.0 & 7.6 & 7.8 & 7.8 & 7.7 \\
\hline \multicolumn{13}{|l|}{ Сельскохозяйственные } \\
\hline Общественные науки & 1.1 & 1.5 & 1.8 & 2.2 & 2.2 & 2.7 & 2.4 & 2.8 & 4.2 & 3.8 & 4.6 & 6.1 \\
\hline Гуманитарные науки & 0.1 & 0.3 & 0.4 & 0.4 & 0.3 & 0.6 & 0.5 & 0.7 & 1.1 & 1.1 & 1.9 & 2.5 \\
\hline \multicolumn{13}{|c|}{ Мир в целом } \\
\hline \multicolumn{13}{|l|}{ Естественные и точные } \\
\hline Технические науки & 21.9 & 22.1 & 24.3 & 26.0 & 27.6 & 27.4 & 26.9 & 25.9 & 25.0 & 25.0 & 25.3 & 26.4 \\
\hline Медицинские науки & 26.3 & 22.1 & 22.6 & 22.3 & 23.2 & 23.9 & 23.7 & 23.4 & 23.5 & 23.2 & 23.0 & 23.6 \\
\hline \multicolumn{13}{|l|}{ Сельскохозяйственные } \\
\hline науки & 6.3 & 5.5 & 5.8 & 5.8 & 5.9 & 5.6 & 5.5 & 5.6 & 5.5 & 5.4 & 5.3 & 5.5 \\
\hline Общественные науки & 7.9 & 8.4 & 9.1 & 9.8 & 10.4 & 10.7 & 11.0 & 10.9 & 10.6 & 10.5 & 10.7 & 11.0 \\
\hline Гуманитарные науки & 1.1 & 2.2 & 2.2 & 2.3 & 2.3 & 2.4 & 2.6 & 3.1 & 3.8 & 3.8 & 3.8 & 3.6 \\
\hline
\end{tabular}

* Группировка по областям науки представлена в соответствии с классификатором ОЭСР (OECD Fields of Science Classification) на основании переходной таблицы, разработанной специалистами Национального центра Греции по работе с научно-технической информацией (Greek National Documentation Centre). Сумма по столбцу не равна $100 \%$, т.к. одна публикация может относиться к двум и более областям науки. 


\section{8. СТРУКТУРА ПУБЛИКАЦИЙ РОССИЙСКИХ АВТОРОВ В НАУЧНЫХ ЖУРНАЛАХ, ИНДЕКСИРУЕМЫХ В WEВ ОF SCIENCE, ПО ОБЛАСТЯМ НАУКИ* \\ (проченты)}

\begin{tabular}{|c|c|c|c|c|c|c|c|c|c|c|c|c|}
\hline & 2000 & 2005 & 2006 & 2007 & 2008 & 2009 & 2010 & 2011 & 2012 & 2013 & 2014 & 2015 \\
\hline \multicolumn{13}{|c|}{ Россия } \\
\hline \multicolumn{13}{|l|}{ Естественные и точные } \\
\hline Технические науки & 27.6 & 27.4 & 25.7 & 26.6 & 26.6 & 25.9 & 23.5 & 23.8 & 25.8 & 26.0 & 30.2 & 28.6 \\
\hline Медицинские науки & 6.4 & 7.2 & 7.2 & 7.8 & 7.6 & 7.7 & 7.9 & 8.1 & 8.5 & 8.6 & 7.1 & 7.4 \\
\hline \multicolumn{13}{|l|}{ Сельскохозяйственные } \\
\hline науки & 1.1 & 1.0 & 1.1 & 1.1 & 1.0 & 1.0 & 0.9 & 0.9 & 0.9 & 0.9 & 0.9 & 0.9 \\
\hline Общественные науки & 2.5 & 2.5 & 1.9 & 2.0 & 1.8 & 2.1 & 2.3 & 2.7 & 3.1 & 3.3 & 3.9 & 4.2 \\
\hline Гуманитарные науки & 0.6 & 0.6 & 0.7 & 0.8 & 0.7 & 1.3 & 1.4 & 1.1 & 1.5 & 1.4 & 1.9 & 2.2 \\
\hline \multicolumn{13}{|c|}{ Мир в целом } \\
\hline \multicolumn{13}{|l|}{ Естественные и точные } \\
\hline науки & 52.2 & 54.2 & 54.4 & 54.0 & 52.9 & 52.3 & 50.7 & 50.5 & 49.6 & 50.0 & 50.5 & 51.8 \\
\hline Технические науки & 26.4 & 28.3 & 29.1 & 31.7 & 31.5 & 31.4 & 28.8 & 29.3 & 31.4 & 31.9 & 31.2 & 28.3 \\
\hline Медицинские науки & 27.8 & 26.2 & 25.9 & 25.7 & 25.8 & 25.5 & 26.9 & 26.6 & 25.9 & 25.7 & 25.7 & 27.3 \\
\hline \multicolumn{13}{|l|}{ Сельскохозяйственные } \\
\hline науки & 4.5 & 4.3 & 4.2 & 4.4 & 4.4 & 4.3 & 4.4 & 4.4 & 4.2 & 4.0 & 4.0 & 4.2 \\
\hline Общественные науки & 8.5 & 7.9 & 8.0 & 8.6 & 9.5 & 9.8 & 10.4 & 10.3 & 9.6 & 9.9 & 10.0 & 9.9 \\
\hline Гуманитарные науки & 4.7 & 3.9 & 4.0 & 4.1 & 5.0 & 4.5 & 3.9 & 3.8 & 3.8 & 3.9 & 3.9 & 3.4 \\
\hline
\end{tabular}

* Группировка по областям науки представлена в соответствии с классификатором ОЭСР (OECD Fields of Science Classification) на основании переходной таблицы, разработанной специалистами компании Thomson Reuters. Сумма по столбцу не равна 100\%, т.к. одна публикация может относиться к двум и более областям науки. 


\section{9. ИНДЕКСЫ НАУЧНОЙ СПЕЦИАЛИЗАЦИИ РОССИИ ПО ПУБЛИКАЦИЯМ В НАУЧНЫХ ЖУРНАЛАХ, ИНДЕКСИРУЕМЫХ В SCOPUS, ПО ОБЛАСТЯМ НАУКИ*}

\section{Естественные и точные, технические, медицинские науки}

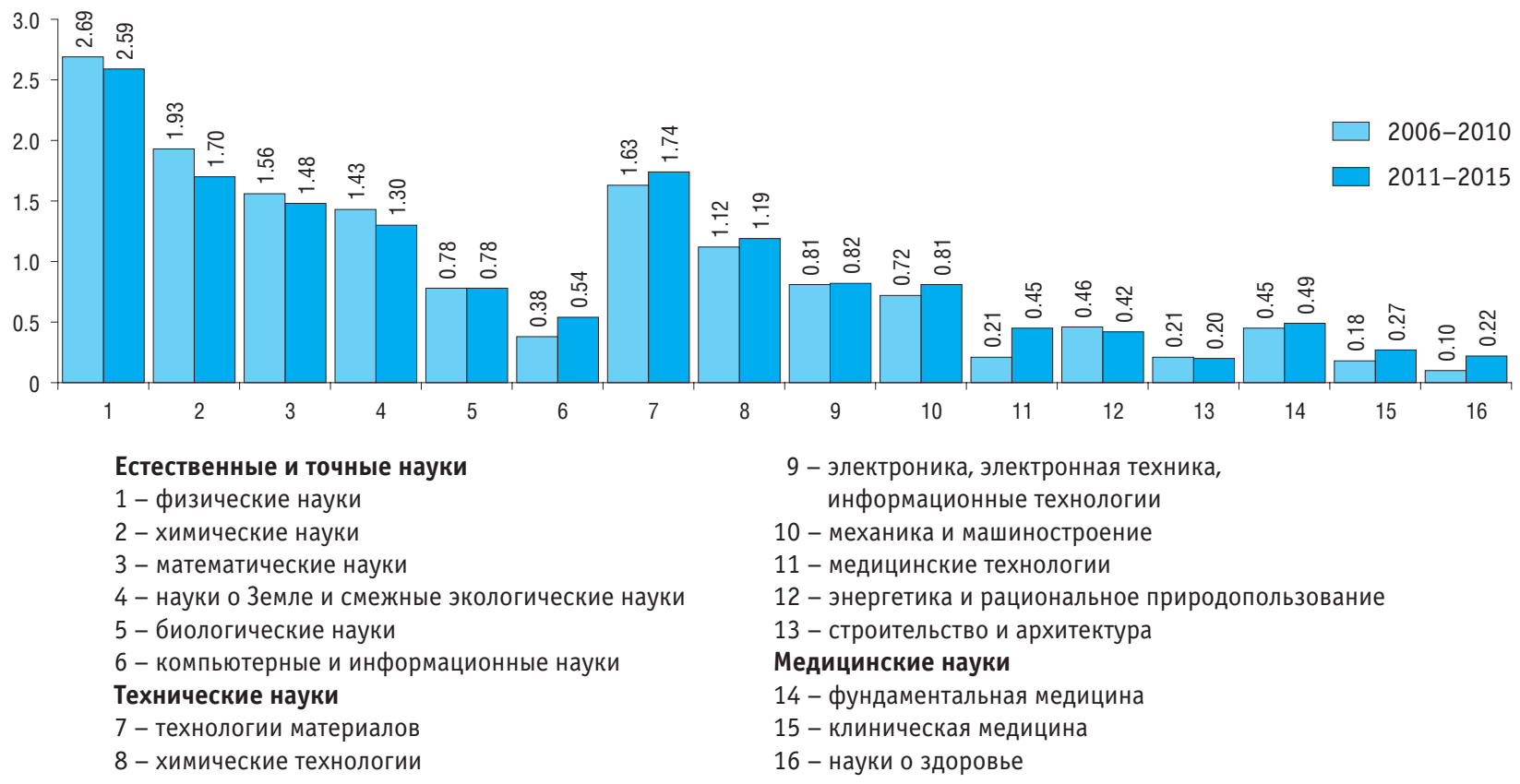


(окончание)

\section{Сельскохозяйственные, общественные, гуманитарные науки}

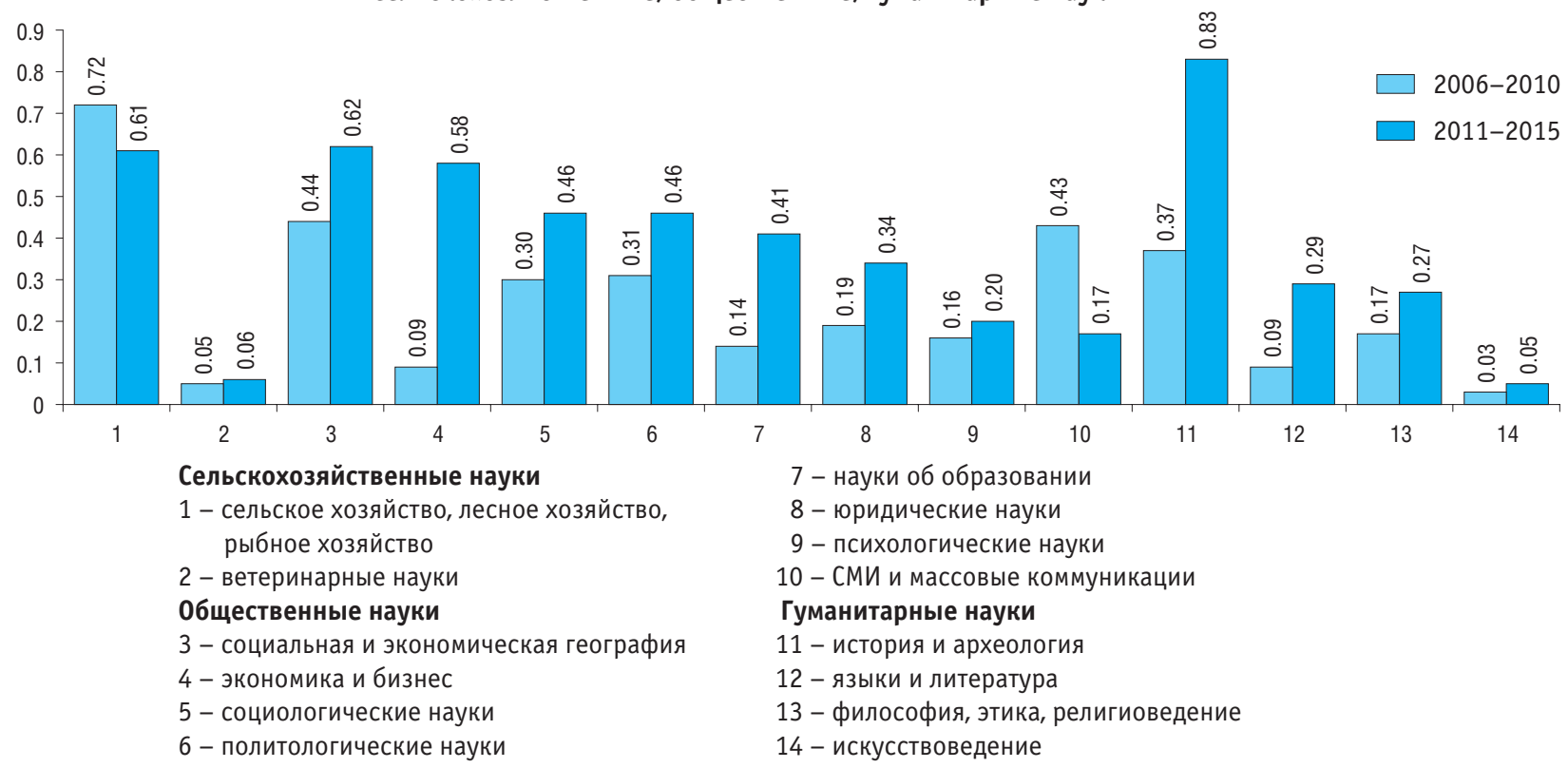

* Группировка по областям науки представлена в соответствии с классификатором ОЭСР (OECD Fields of Science Classification) на основании переходной таблицы, разработанной специалистами Национального центра Греции по работе с научно-технической информацией (Greek National Documentation Centre). Поскольку в данной таблице отсутствуют такие направления, как междисциплинарные исследования, экологические биотехнологии, нанотехнологии, животноводство и молочное хозяйство, на графике они не представлены. 


\subsection{0. ИНДЕКСЫ НАУЧНОЙ СПЕЦИАЛИЗАЦИИ РОССИИ ПО ПУБЛИКАЦИЯМ В НАУЧНЫХ ЖУРНАЛАХ, ИНДЕКСИРУЕМЫХ В WЕВ ОF SCIENCE, ПО ОБЛАСТЯМ НАУКИ*}

\section{Естественные и точные, технические, медицинские науки}
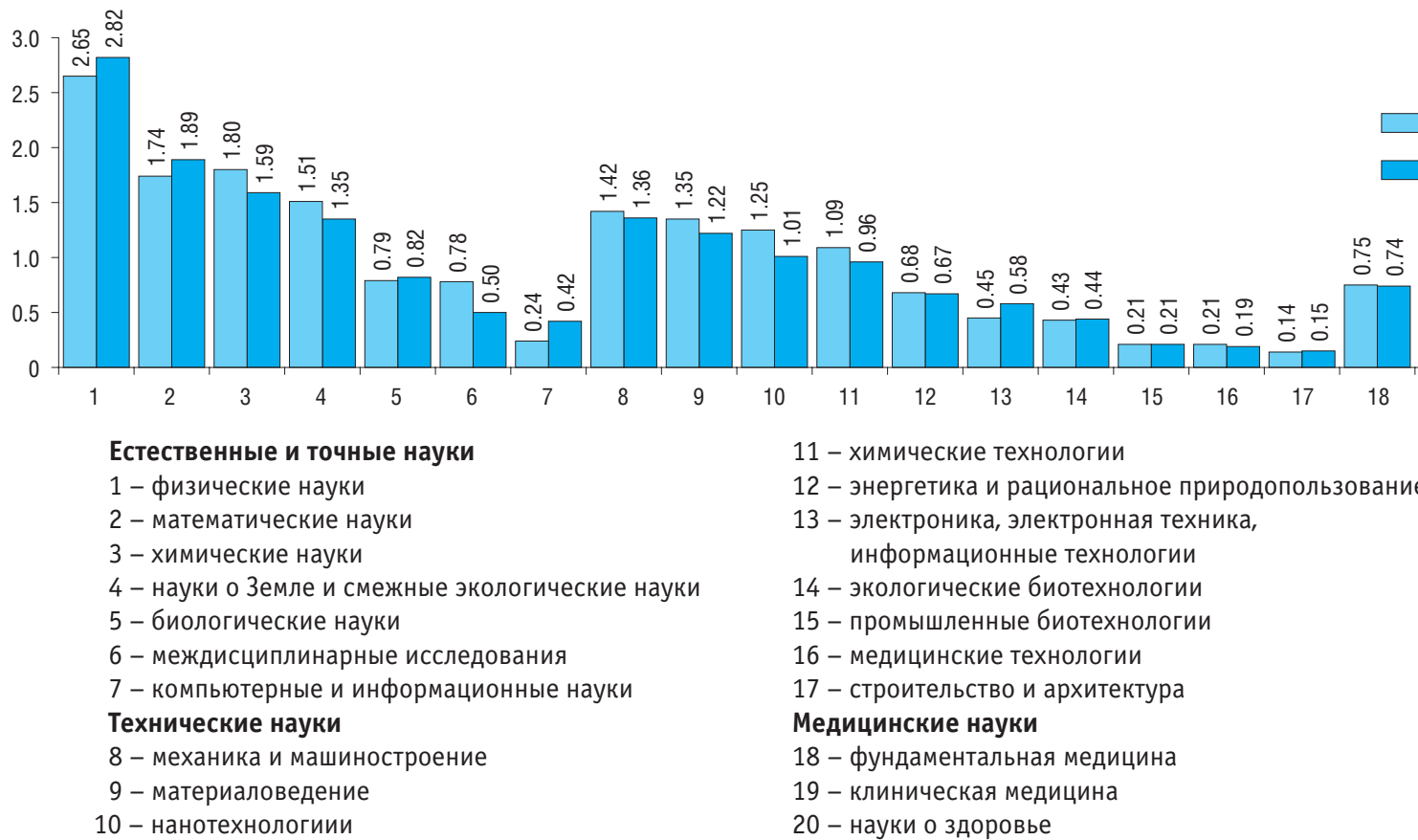

10

11

13

14

15

16

17

18

$19 \quad 20$

11 - химические технологии

12 - энергетика и рациональное природопользование

13 - электроника, электронная техника,

информационные технологии

14 - экологические биотехнологии

15 - промышленные биотехнологии

16 - медицинские технологии

17 - строительство и архитектура

\section{Медицинские науки}

18 - фундаментальная медицина

19 - клиническая медицина

20 - науки о здоровье 
(окончание)

\section{Сельскохозяйственные, общественные, гуманитарные науки}

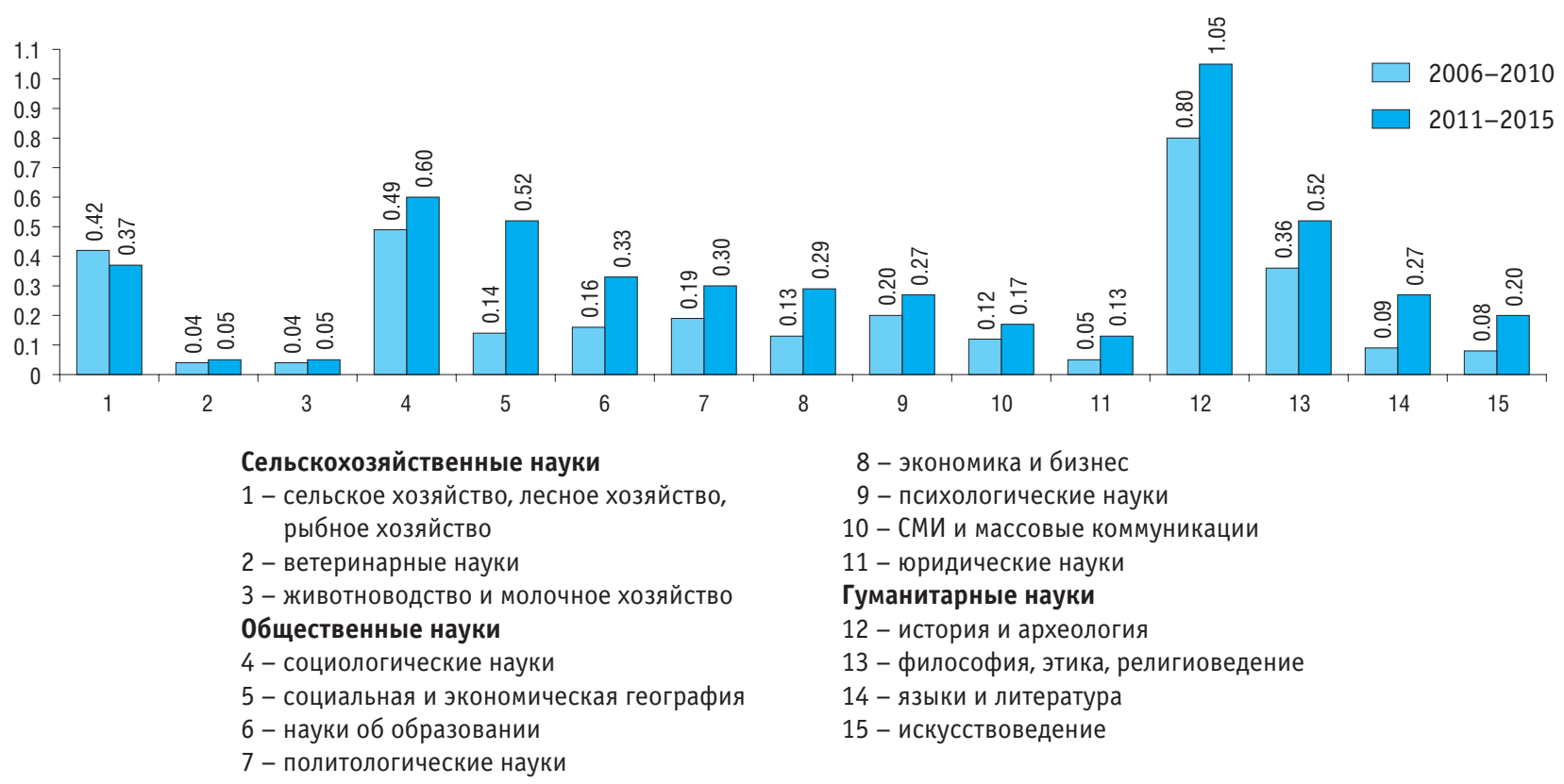

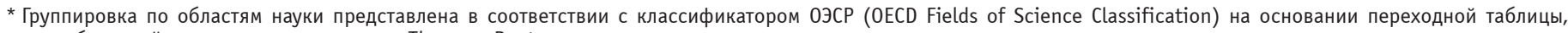
разработанной специалистами компании Thomson Reuters. 
6.11. ПОСТУПЛЕНИЕ ПАТЕНТНЫХ ЗАЯВОК И ВЫДАЧА ПАТЕНТОВ НА ИЗОБРЕТЕНИЯ

\begin{tabular}{|c|c|c|c|c|c|c|c|c|c|}
\hline & 1995 & 2000 & 2005 & 2010 & 2011 & 2012 & 2013 & 2014 & 2015 \\
\hline Подано патентных заявок в России & 22202 & 28688 & 32254 & 42500 & 41414 & 44211 & 44914 & 40308 & 45517 \\
\hline \multicolumn{10}{|l|}{ В том числе заявителями: } \\
\hline отечественными & 17551 & 23377 & 23644 & 28722 & 26495 & 28701 & 28765 & 24072 & 29269 \\
\hline иностранными & 4651 & 5311 & 8610 & 13778 & 14919 & 15510 & 16149 & 16236 & 16248 \\
\hline Выдано патентов Российской Федерации & 31556 & 17592 & 23390 & 30322 & 29999 & 32880 & 31638 & 33950 & 34706 \\
\hline \multicolumn{10}{|l|}{ В том числе заявителям: } \\
\hline отечественным & 20861 & 14444 & 19447 & 21627 & 20339 & 22481 & 21378 & 23065 & 22560 \\
\hline иностранным & 4772 & 3148 & 3943 & 8695 & 9660 & 10399 & 10260 & 10885 & 12146 \\
\hline Действует патентов Российской Федерации & 76186 & 144325 & 123089 & 181904 & 168558 & 181515 & 194248 & 208320 & 218974 \\
\hline
\end{tabular}




\subsection{2. ПОКАЗАТЕЛИ ПАТЕНТНОЙ АКТИВНОСТИ}

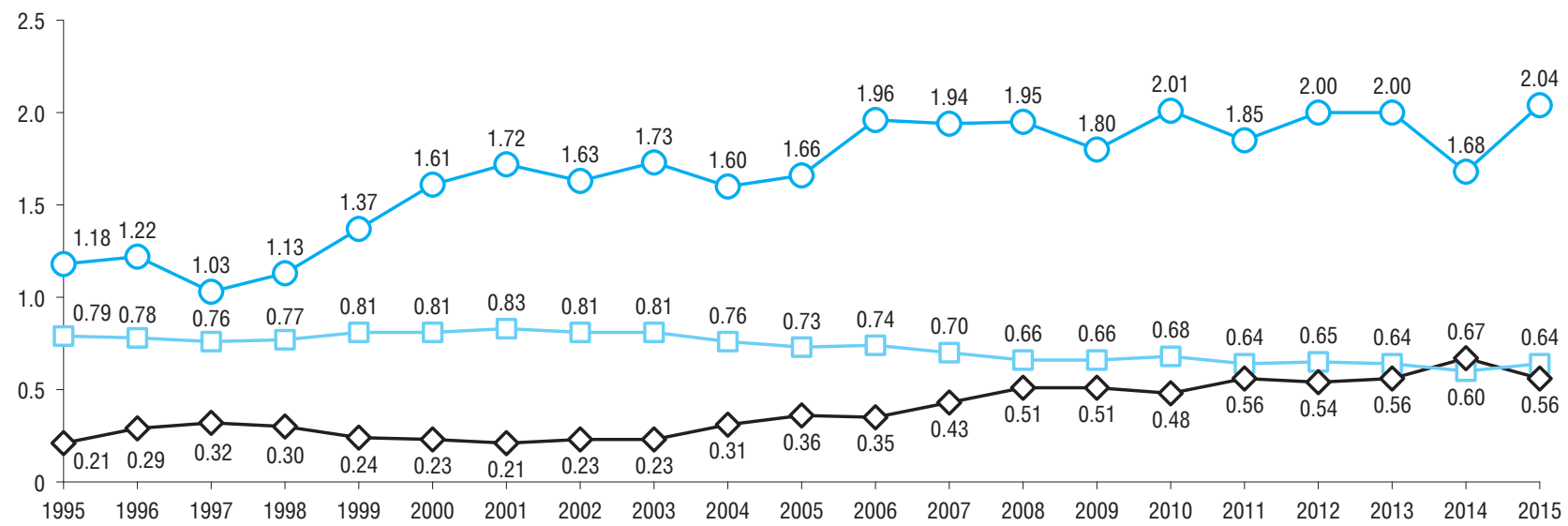

- - Коэффициент изобретательской активности - число отечественных патентных заявок на изобретения, поданных в России, в расчете на 10000 чел. населения

$-\square-$ Коэффициент самообеспеченности - соотношение числа отечественных и всех поданных в России патентных заявок на изобретения

$\checkmark$ Коэффициент технологической зависимости - соотношение числа иностранных и отечественных патентных заявок на изобретения, поданных в России 
6.13. ПАТЕНТЫ РОССИЙСКОЙ ФЕДЕРАЦИИ НА ИЗОБРЕТЕНИЯ ПО РАЗДЕЛАМ МЕЖДУНАРОДНОЙ ПАТЕНТНОЙ КЛАССИФИКАЦИИ *

\begin{tabular}{|c|c|c|c|c|c|c|c|c|c|}
\hline & 1995 & 2000 & 2005 & 2010 & 2011 & 2012 & 2013 & 2014 & 2015 \\
\hline Всего & 25633 & 17592 & 23390 & 30322 & 29999 & 32880 & 31638 & 33950 & 34706 \\
\hline \multicolumn{10}{|l|}{ А. Удовлетворение жизненных потребностей } \\
\hline человека & 4207 & 4347 & 6703 & 8468 & 8907 & 9506 & 8042 & 9890 & 8283 \\
\hline В. Различные технологические процессы; транспортирование & 6129 & 2905 & 3669 & 4711 & 4412 & 4969 & 4965 & 5331 & 5618 \\
\hline С. Химия; металлургия & 4529 & 3332 & 3645 & 5167 & 5512 & 5524 & 5779 & 5154 & 5910 \\
\hline D. Текстиль; бумага & 437 & 197 & 216 & 320 & 301 & 274 & 271 & 305 & 266 \\
\hline Е. Строительство; горное дело & 2042 & 1156 & 1659 & 1977 & 1603 & 1898 & 1807 & 2033 & 2068 \\
\hline \multicolumn{10}{|l|}{$\begin{array}{l}\text { F. Машиностроение; освещение; отопление; } \\
\text { двигатели и насосы; оружие и боеприпасы; }\end{array}$} \\
\hline взрывные работы & 3033 & 2144 & 2634 & 3062 & 2761 & 3246 & 3453 & 3459 & 3824 \\
\hline G. Физика & 3083 & 2172 & 3068 & 3734 & 3881 & 4381 & 4285 & 4484 & 5231 \\
\hline Н. Электричество & 2173 & 1339 & 1796 & 2883 & 2622 & 3082 & 3036 & 3294 & 3506 \\
\hline
\end{tabular}

* Патенты, выданные отечественным и иностранным заявителям. 
6.14. РАСПРЕДЕЛЕНИЕ ВЫДАННЫХ ПАТЕНТОВ РОССИЙСКОЙ ФЕДЕРАЦИИ НА ИЗОБРЕТЕНИЯ

ПО ПРИНАДЛЕЖНОСТИ ЗАЯВИТЕЛЕЙ И РАЗДЕЛАМ МЕЖДУНАРОДНОЙ ПАТЕНТНОЙ КЛАССИФИКАЦИИ: 2015

Проценты

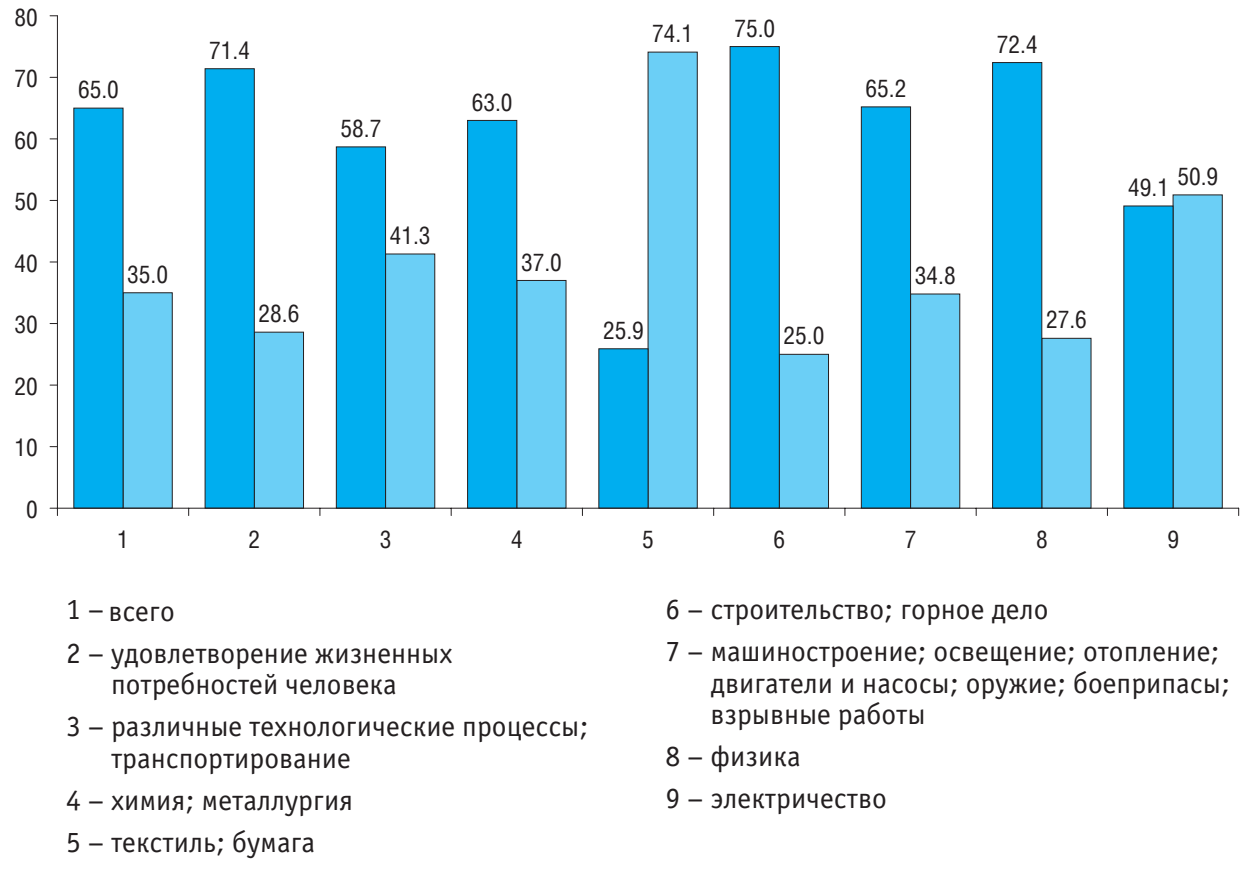

Патенты, выданные отечественным заявителям

$\square$ Патенты, выданные иностранным заявителям 


\subsection{5. ПОСТУПЛЕНИЕ ПАТЕНТНЫХ ЗАЯВОК И ВЫДАЧА ПАТЕНТОВ НА ПОЛЕЗНЫЕ МОДЕЛИ}

\begin{tabular}{|c|c|c|c|c|c|c|c|c|c|}
\hline & 1995 & 2000 & 2005 & 2010 & 2011 & 2012 & 2013 & 2014 & 2015 \\
\hline Подано патентных заявок в России & 2039 & 4631 & 9473 & 12262 & 13241 & 14069 & 14358 & 13952 & 11906 \\
\hline \multicolumn{10}{|l|}{ В том числе заявителями: } \\
\hline отечественными & 1997 & 4549 & 9082 & 11757 & 12584 & 13479 & 13589 & 13000 & 11403 \\
\hline иностранными & 42 & 82 & 391 & 505 & 657 & 590 & 769 & 952 & 503 \\
\hline Выдано патентов Российской Федерации & 1207 & 4098 & 7242 & 10581 & 11079 & 11671 & 12653 & 13080 & 9008 \\
\hline \multicolumn{10}{|l|}{ В том числе заявителям: } \\
\hline отечественным & 1195 & 4041 & 6958 & 10187 & 10571 & 11152 & 12154 & 12267 & 8390 \\
\hline иностранным & 12 & 57 & 284 & 394 & 508 & 519 & 499 & 813 & 618 \\
\hline Действует патентов Российской Федерации & 2971 & 15498 & 28364 & 54848 & 46876 & 50746 & 54420 & 58238 & 57448 \\
\hline
\end{tabular}


6.16. ПАТЕНТЫ РОССИЙСКОЙ ФЕДЕРАЦИИ НА ПОЛЕЗНЫЕ МОДЕЛИ

ПО РАЗДЕЛАМ МЕЖДУНАРОДНОЙ ПАТЕНТНОЙ КЛАССИФИКАЦИИ *

\begin{tabular}{|c|c|c|c|c|c|c|c|c|c|}
\hline & 1995 & 2000 & 2005 & 2010 & 2011 & 2012 & 2013 & 2014 & 2015 \\
\hline Всего & 1207 & 4098 & 7242 & 10581 & 11079 & 11671 & 12653 & 13080 & 9008 \\
\hline \multicolumn{10}{|l|}{ А. Удовлетворение жизненных потребностей } \\
\hline человека & 190 & 835 & 1344 & 1914 & 1833 & 1933 & 2091 & 2240 & 1579 \\
\hline В. Различные технологические процессы; транспортирование & 311 & 1004 & 1741 & 2411 & 2518 & 2678 & 2917 & 2935 & 2021 \\
\hline С. Химия; металлургия & 30 & 145 & 289 & 398 & 340 & 370 & 398 & 383 & 269 \\
\hline D. Текстиль; бумага & 37 & 73 & 73 & 57 & 68 & 55 & 52 & 45 & 42 \\
\hline Е. Строительство; горное дело & 115 & 465 & 1022 & 1503 & 1459 & 1466 & 1611 & 1684 & 1192 \\
\hline \multicolumn{10}{|l|}{$\begin{array}{l}\text { F. Машиностроение; освещение; отопление; } \\
\text { двигатели и насосы; оружие и боеприпасы; }\end{array}$} \\
\hline взрывные работы & 235 & 679 & 1111 & 1701 & 1815 & 1957 & 2112 & 2459 & 1557 \\
\hline G. Физика & 150 & 490 & 949 & 1580 & 1842 & 1912 & 2017 & 2011 & 1376 \\
\hline Н. Электричество & 139 & 407 & 713 & 1017 & 1204 & 1300 & 1455 & 1323 & 972 \\
\hline
\end{tabular}

* Патенты, выданные отечественным и иностранным заявителям. 
6.17. РЕГИСТРАЦИЯ ОБЪЕКТОВ ИНТЕЛЛЕКТУАЛЬНОЙ СОБСТВЕННОСТИ В СФЕРЕ ИНФОРМАТИЗАЦИИ

Программы для ЭВМ

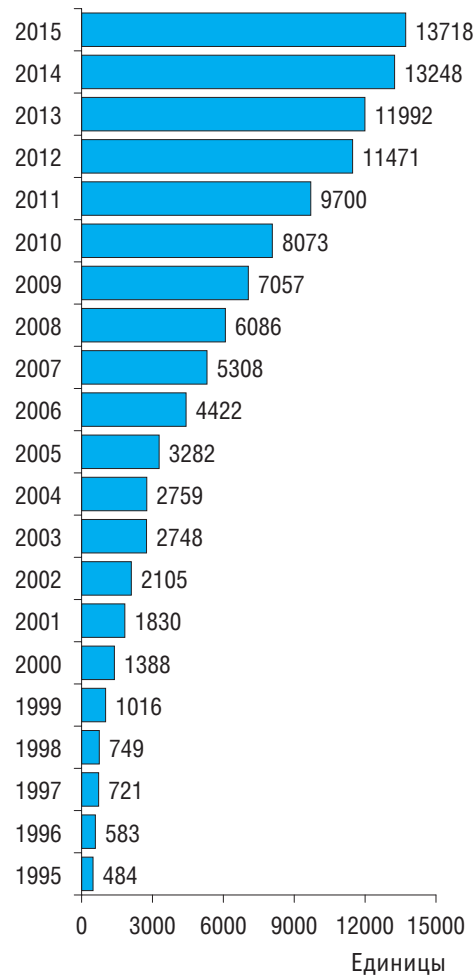

\section{Базы данных}

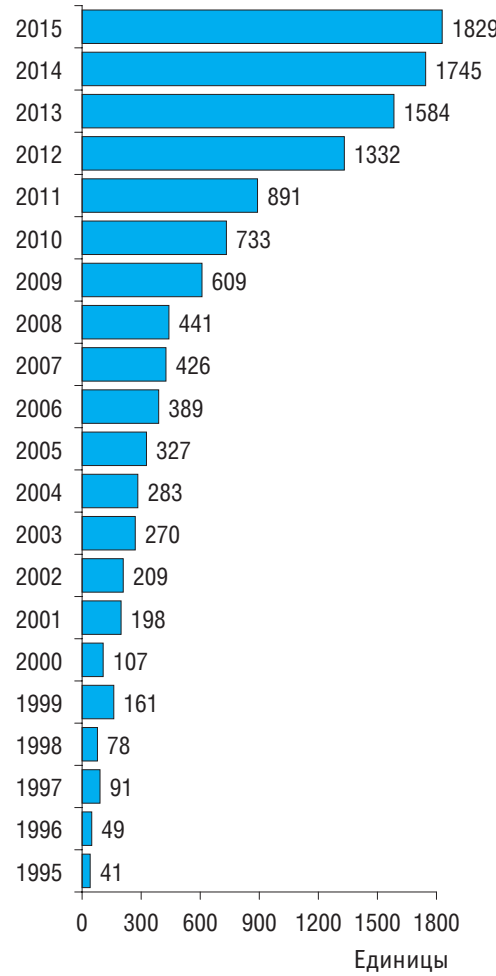

\section{Топологии интегральных микросхем}

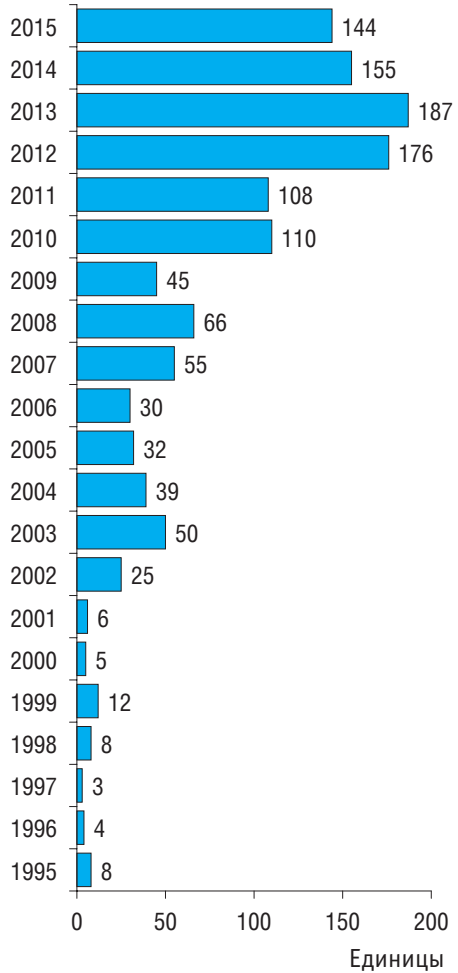




\subsection{8. РЕГИСТРАЦИЯ ВНУТРЕННИХ ДОГОВОРОВ О ТОРГОВЛЕ ЛИЦЕНЗИЯМИ И ОТЧУЖДЕНИИ ПРАВ НА ПАТЕНТЫ*}

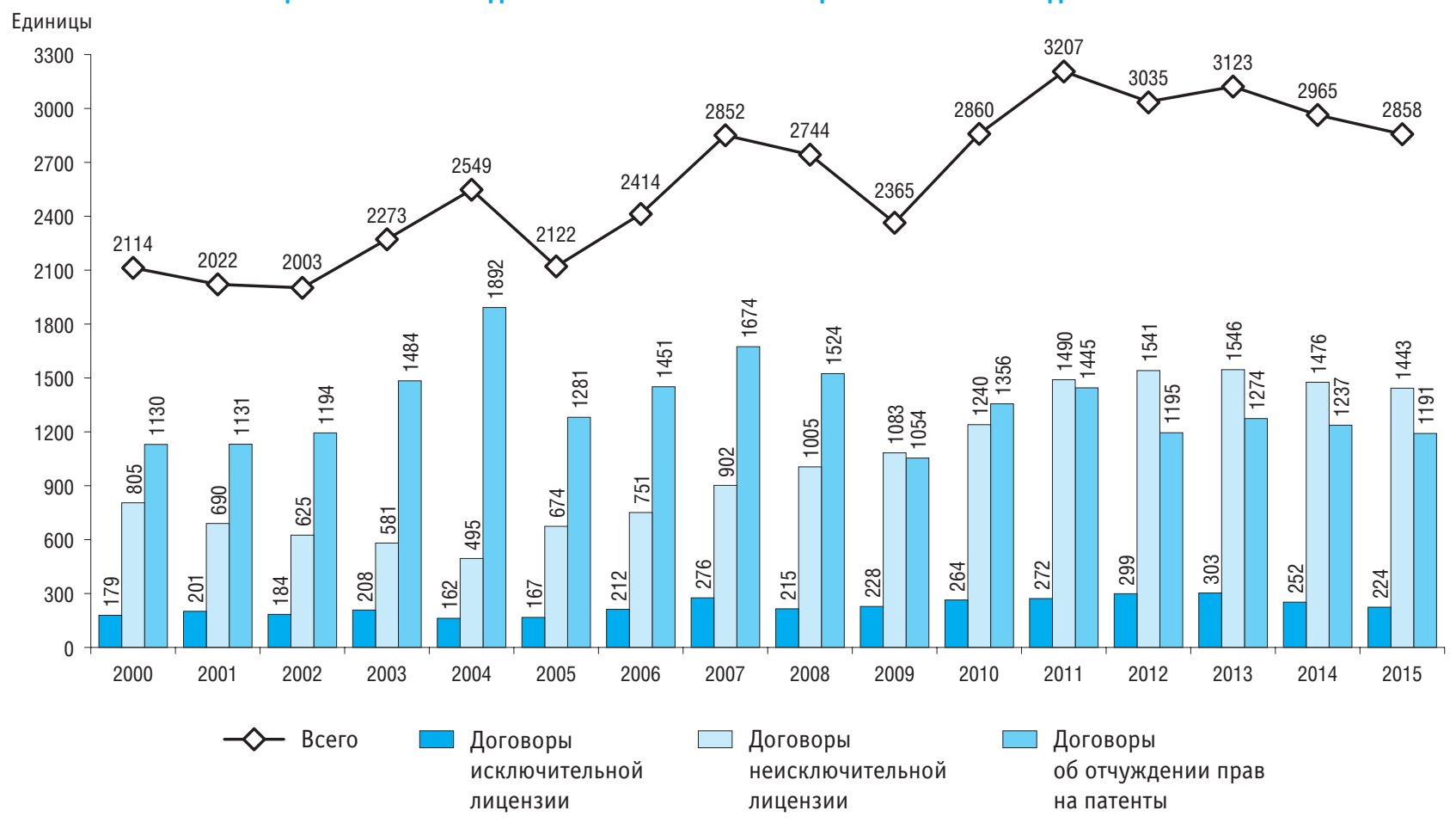

* Включены патенты на изобретения, полезные модели и промышленные образцы. До 2008 г. - договоры об уступке прав на патенты. 


\subsection{9. РЕГИСТРАЦИЯ ВНУТРЕННИХ ДОГОВОРОВ О ТОРГОВЛЕ ЛИЦЕНЗИЯМИ \\ И ОТЧУЖДЕНИИ ПРАВ НА ПАТЕНТЫ ПО ОБЛАСТЯМ ТЕХНИКИ}

\begin{tabular}{|c|c|c|c|c|c|c|c|c|c|c|c|c|}
\hline & 2000 & 2005 & 2006 & 2007 & 2008 & 2009 & 2010 & 2011 & 2012 & 2013 & 2014 & 2015 \\
\hline Всего & 2114 & 2122 & 2414 & 2852 & 2744 & 2365 & 2860 & 3207 & 3035 & 3123 & 2965 & 2858 \\
\hline I. Строительство, строительные материалы & 89 & 108 & 160 & 423 & 272 & 266 & 135 & 207 & 246 & 252 & 245 & 226 \\
\hline $\begin{array}{l}\text { II. Машиностроение, станкостроение, производство } \\
\text { инструмента }\end{array}$ & 345 & 417 & 414 & 366 & 250 & 373 & 118 & 285 & 264 & 248 & 211 & 205 \\
\hline III. Химия, нефтехимия & 203 & 268 & 500 & 120 & 94 & 94 & 286 & 454 & 438 & 382 & 407 & 406 \\
\hline IV. Металлургия & 85 & 69 & 181 & 245 & 133 & 186 & 86 & 113 & 103 & 108 & 100 & 62 \\
\hline $\begin{array}{l}\text { V. Электроника, вычислительная техника, } \\
\text { приборостроение }\end{array}$ & 78 & 165 & 157 & 137 & 73 & 101 & 311 & 257 & 260 & 216 & 209 & 222 \\
\hline VI. Легкая, пищевая промышленность & 323 & 105 & 160 & 211 & 173 & 186 & 163 & 194 & 215 & 276 & 200 & 257 \\
\hline VII. Энергетика, электротехника & 150 & 223 & 220 & 390 & 247 & 364 & 421 & 567 & 499 & 490 & 470 & 511 \\
\hline VIII. Медицина & 264 & 249 & 295 & 120 & 76 & 140 & 294 & 414 & 388 & 473 & 439 & 396 \\
\hline IX. Нефтегазодобывающая промышленность & 224 & 136 & 100 & 434 & 338 & 449 & 162 & 158 & 152 & 168 & 135 & 142 \\
\hline Х. Прочие & 353 & 382 & 227 & 406 & 709 & 585 & 884 & 558 & 470 & 510 & 549 & 431 \\
\hline
\end{tabular}


6.20. РАСПРЕДЕЛЕНИЕ ВНУТРЕННИХ ДОГОВОРОВ О ТОРГОВЛЕ ЛИЦЕНЗИЯМИ И ОТЧУЖДЕНИИ ПРАВ НА ПАТЕНТЫ ПО ОБЛАСТЯМ ТЕХНИКИ

(проценты)

2014

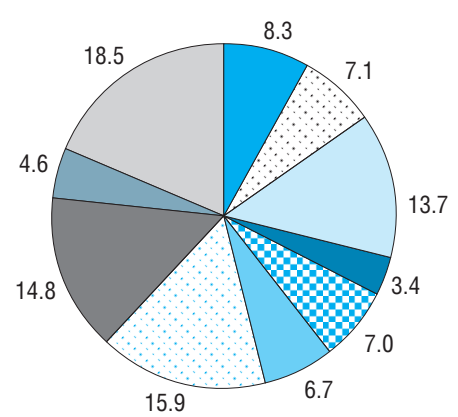

2015

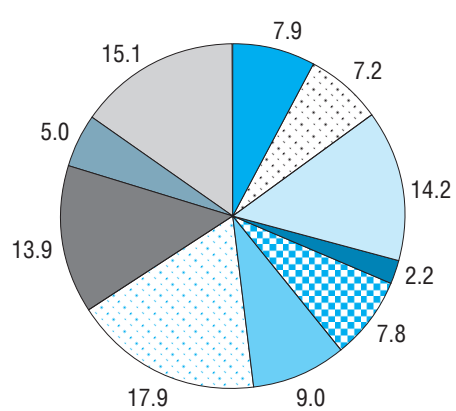

$\square$ Строительство, строительные материалы

$\because \because$ Машиностроение, станкостроение, производство инструмента

$\square$ Химия, нефтехимия

$\square$ Металлургия

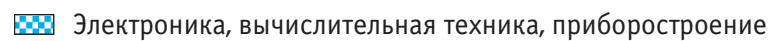

$\square$ Легкая, пищевая промышленность

$\because$ Энергетика, электротехника

$\square$ Медицина

$\square$ Нефтегазодобывающая промышленность

Прочие 


\subsection{1. РАСПРЕДЕЛЕНИЕ ВНУТРЕННИХ ДОГОВОРОВ О ТОРГОВЛЕ ЛИЦЕНЗИЯМИ И ОТЧУЖДЕНИИ ПРАВ НА ПАТЕНТЫ ПО КАТЕГОРИЯМ ХОЗЯЙСТВУЮЩИХ СУБЪЕКТОВ}

Лицензиары (продавцы)

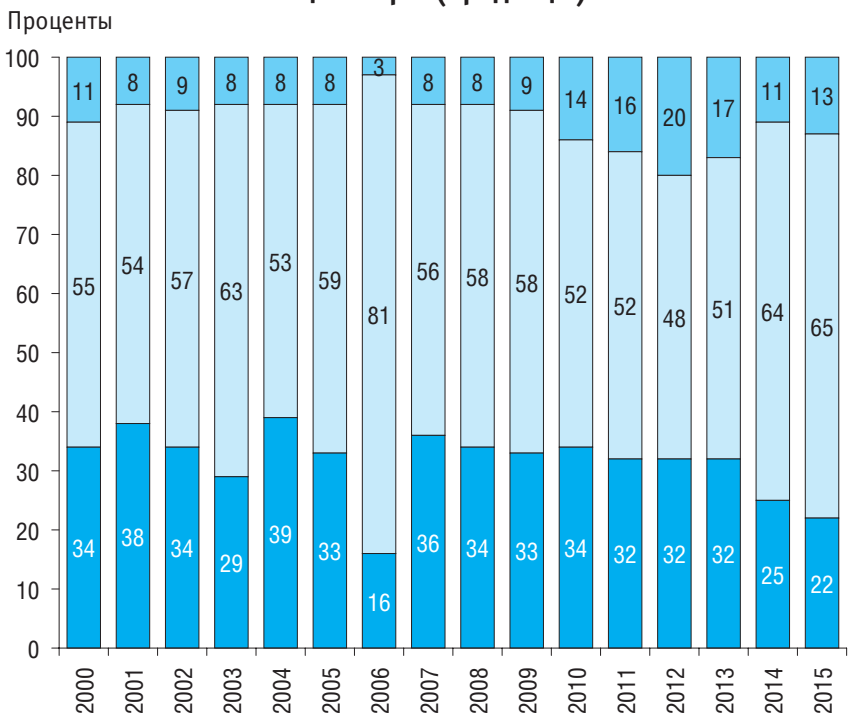

Лицензиаты (покупатели)

\section{Проценты}

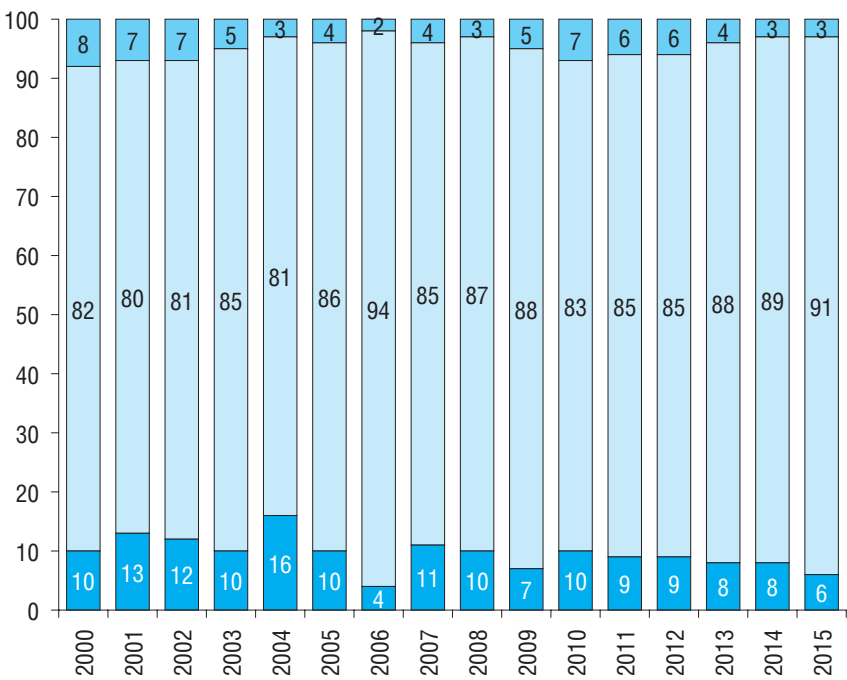




\subsection{2. БАЛАНС ПЛАТЕЖЕЙ ЗА ТЕХНОЛОГИИ ПО КАТЕГОРИЯМ СОГЛАШЕНИЙ} (тысячи долларов (ША)

\begin{tabular}{|c|c|c|c|c|c|c|c|c|c|c|c|}
\hline & Всего & $\begin{array}{c}\text { Патенты } \\
\text { на изобре- } \\
\text { тения }\end{array}$ & $\begin{array}{l}\text { Беспатент- } \\
\text { ные изо- } \\
\text { бретения }\end{array}$ & $\begin{array}{l}\text { Патентные } \\
\text { лицензии }\end{array}$ & $\begin{array}{l}\text { Полезные } \\
\text { модели }\end{array}$ & Hoy-xay & $\begin{array}{c}\text { Товарные } \\
\text { знаки }\end{array}$ & $\begin{array}{l}\text { Промыш- } \\
\text { ленные } \\
\text { образцы }\end{array}$ & $\begin{array}{c}\text { Инжини- } \\
\text { ринговые } \\
\text { услуги }\end{array}$ & $\begin{array}{c}\text { Научные } \\
\text { исследова- } \\
\text { ния и раз- } \\
\text { работки }\end{array}$ & Прочее \\
\hline \multicolumn{12}{|c|}{ Поступления от экспорта технологий } \\
\hline 2002 & 211478.4 & 214.5 & - & 210.0 & $\ldots$ & 1909.3 & 1446.9 & 84.9 & 143764.1 & 20812.0 & 43036.7 \\
\hline 2003 & 237403.9 & 147.3 & 0.9 & 4000.6 & $\ldots$ & 1292.0 & 1185.5 & 2.0 & 166376.7 & 25974.2 & 38424.7 \\
\hline 2004 & 383985.2 & 767.3 & 370.0 & 980.6 & $\ldots$ & 2933.9 & 1539.3 & 2.0 & 177335.0 & 63671.3 & 136385.8 \\
\hline 2005 & 389396.4 & 926.3 & 467.0 & 1788.0 & $\ldots$ & 517.9 & 5583.5 & 1017.3 & 150858.8 & 83214.4 & 145023.2 \\
\hline 2006 & 533385.9 & 100.8 & 4284.7 & 2576.1 & $\ldots$ & 398.0 & 6191.6 & 219.8 & 166911.1 & 89260.1 & 263443.7 \\
\hline 2007 & 630391.6 & 347.2 & - & 5215.8 & 0.5 & 1985.1 & 7550.3 & 2457.0 & 267561.2 & 101170.3 & 244104.2 \\
\hline 2008 & 833164.4 & 112.8 & - & 5183.8 & 3765.0 & 9709.5 & 17685.4 & 3752.3 & 491665.1 & 151463.4 & 149827.1 \\
\hline 2009 & 618184.5 & 191.8 & 10.8 & 12825.7 & 936.2 & 10980.9 & 431.9 & 3554 & 410907.2 & 120877.9 & 57468.1 \\
\hline 2010 & 627887.5 & 582.6 & 1987.0 & 11821.3 & 1718.9 & 13778.5 & 759.1 & 2531.0 & 368971.3 & 138356.8 & 87381.0 \\
\hline 2011 & 584656.9 & 98.9 & 212.0 & 20334.7 & 688.0 & 4886.2 & 1251.7 & 2304.0 & 382161.5 & 111499.3 & 61220.6 \\
\hline 2012 & 688469.9 & 21.0 & - & 21850.1 & 898.7 & 15653.4 & 999.4 & 2291.0 & 376428.2 & 170752.9 & 99575.2 \\
\hline 2013 & 770584.8 & 81.0 & 110.0 & 25409.6 & 75.4 & 11798.9 & 388.2 & 2452.2 & 364000.7 & 235654.9 & 130613.9 \\
\hline 2014 & 1279213.1 & 72.7 & - & 26610.9 & 35.9 & 11526.7 & 2765.3 & 2000.8 & 707674.2 & 356496.9 & 172029.7 \\
\hline 2015 & 1654732.1 & 63.2 & - & 79062.3 & 4113.6 & 2474.5 & 3990.3 & 2492.1 & 1112557.2 & 164939.8 & 285039.1 \\
\hline \multicolumn{12}{|c|}{ Выплаты по импорту технологий } \\
\hline 2002 & 572488.8 & 403.2 & - & 3873.6 & $\ldots$ & 16042.0 & 83127.7 & 508.0 & 180620.6 & 182662.7 & 105251.0 \\
\hline 2003 & 666114.1 & 675.9 & 1095.3 & 18375.9 & $\ldots$ & 20265.2 & 141515.7 & 533.5 & 413643.7 & 17953.6 & 52055.3 \\
\hline 2004 & 823030.1 & 1164.3 & 531.6 & 19910.5 & $\ldots$ & 28024.4 & 215034.5 & 644.7 & 497121.0 & 9612.8 & 50986.3 \\
\hline 2005 & 954199.2 & 8730.3 & 2983.5 & 19315.4 & $\ldots$ & 9489.7 & 191045.0 & 1519.5 & 582813.8 & 16512.8 & 121789.2 \\
\hline 2006 & 1128425.8 & 3201.3 & - & 21402.1 & 101.2 & 49705.7 & 160720.2 & 217.9 & 658016.9 & 38631.3 & 196429.2 \\
\hline 2007 & 1426387.6 & 14408.5 & - & 68538.3 & 959.1 & 70461.1 & 222142.6 & 559.3 & 754249.4 & 32476.3 & 262593.0 \\
\hline
\end{tabular}


(окончание)

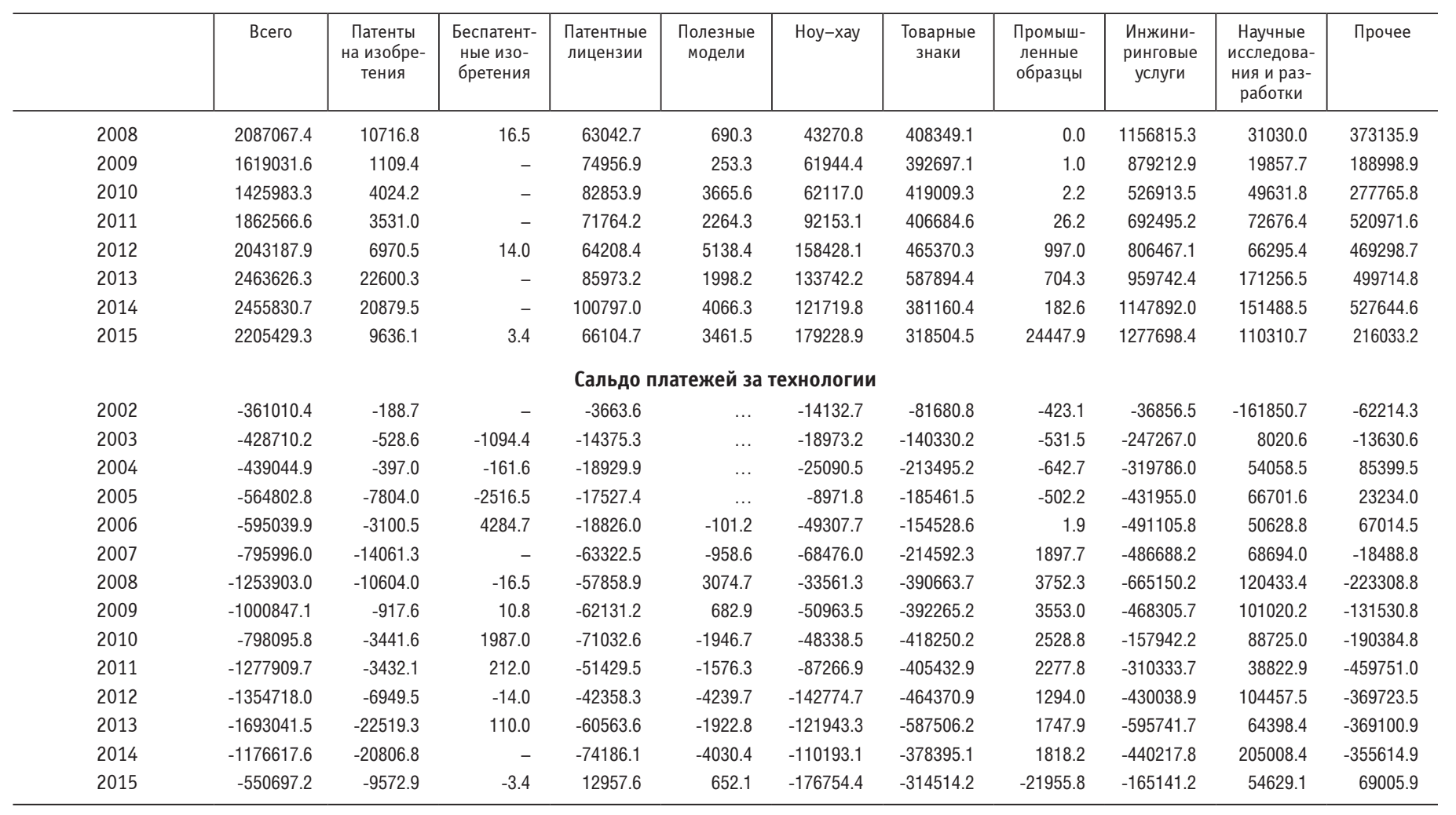




\subsection{3. СТРУКТУРА ЭКСПОРТА И ИМПОРТА ТЕХНОЛОГИЙ ПО КАТЕГОРИЯМ СОГЛАШЕНИЙ}

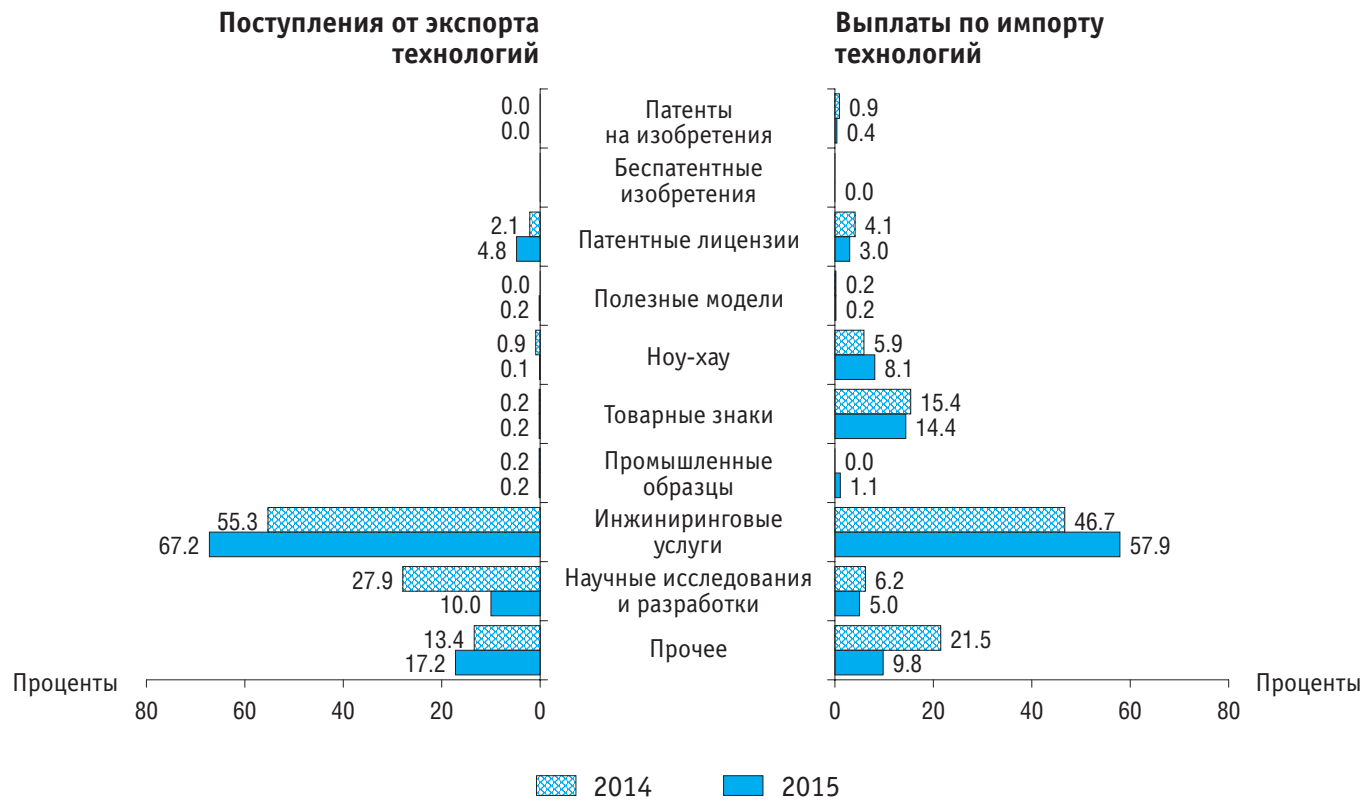




\subsection{4. БАЛАНС ПЛАТЕЖЕЙ ЗА ТЕХНОЛОГИИ ПО СТРАНАМ}

(тысячи долларов США)

\begin{tabular}{|c|c|c|c|c|c|c|c|c|c|}
\hline & \multicolumn{3}{|c|}{ Поступления от экспорта технологий } & \multicolumn{3}{|c|}{ Выплаты по импорту технологий } & \multicolumn{3}{|c|}{ Сальдо платежей за технологии } \\
\hline & 2013 & 2014 & 2015 & 2013 & 2014 & 2015 & 2013 & 2014 & 2015 \\
\hline Всего & 770584.8 & 1279213.1 & 1654732.1 & 2463626.3 & 2455830.7 & 2205429.3 & -1693041.5 & -1176617.6 & -550697.2 \\
\hline Страны СНГ & 75303.4 & 198398.0 & 134126.3 & 88131.0 & 71229.1 & 36156.9 & -12827.6 & 127168.9 & 97969.4 \\
\hline Азербайджан & 5599.7 & 5263.8 & 1116.3 & 836.5 & 12.0 & 103.2 & 4763.2 & 5251.8 & 1013.1 \\
\hline Армения & 18.0 & 151.5 & 164.8 & 296.0 & 17.8 & 77.0 & -278.0 & 133.7 & 87.8 \\
\hline Беларусь & 27224.3 & 87698.8 & 79447.4 & 11221.3 & 15805.9 & 8330.2 & 16003.0 & 71892.9 & 71117.2 \\
\hline Казахстан & 19849.1 & 57558.1 & 27409.6 & 6815.1 & 7235.2 & 10882.4 & 13034.0 & 50322.9 & 16527.2 \\
\hline Киргизия & 1359.6 & 1752.8 & 4824.5 & 37.9 & 60.1 & 44.2 & 1321.7 & 1692.7 & 4780.3 \\
\hline Республика Молдова & 644.6 & 794.3 & 537.1 & 123.0 & 370.4 & 176.1 & 521.6 & 423.9 & 361.0 \\
\hline Таджикистан & 5248.6 & 6746.8 & 7360.3 & 17.6 & 116.3 & 12.6 & 5231.0 & 6630.5 & 7347.7 \\
\hline Туркмения & 113.5 & 3095.8 & 3043.9 & - & 13.6 & 60.0 & 113.5 & 3082.2 & 2983.9 \\
\hline Узбекистан & 1243.7 & 4885.6 & 2154.7 & 186.6 & 124.4 & 736.9 & 1057.1 & 4761.2 & 1417.8 \\
\hline Украина & 14002.3 & 30450.5 & 8067.7 & 68597.0 & 47473.4 & 15734.3 & -54594.7 & -17022.9 & -7666.6 \\
\hline Страны ОЭСР & 409978.9 & 908085.0 & 620086.4 & 2275154.4 & 2298971.0 & 1862817.6 & -1865175.5 & -1390886.0 & -1242731.2 \\
\hline Австралия & 116.6 & 168.6 & 64.2 & 568.7 & 661.8 & 3614.8 & -452.1 & -493.2 & -3550.6 \\
\hline Австрия & 5113.6 & 3748.6 & 21974.7 & 35294.4 & 53621.8 & 84060.9 & -40860.1 & -49873.2 & -62086.2 \\
\hline Бельгия & 4824.6 & 5012.3 & 8346.1 & 29924.5 & 38765.1 & 35310.6 & -25099.9 & -33752.8 & -26964.5 \\
\hline Великобритания & 29474.7 & 31858.5 & 19546.9 & 200226.5 & 155378.6 & 138564.1 & -170751.8 & -123520.1 & -119017.2 \\
\hline Венгрия & 1469.3 & 1150.8 & 272.7 & 1791.0 & 4476.9 & 1518.6 & 321.7 & -3326.1 & -1245.9 \\
\hline Германия & 37631.0 & 42102.8 & 47236.1 & 223429.3 & 271533.0 & 392597.9 & -185798.3 & -229430.2 & -345361.9 \\
\hline Греция & 3.3 & 383.2 & 297.6 & 4058.4 & 3068.6 & 1406.6 & -4055.1 & -2685.4 & -1109.0 \\
\hline Дания & 6598.2 & 4823.4 & 6638.2 & 31823.8 & 87177.2 & 24054.3 & -25225.6 & -82353.8 & -17416.1 \\
\hline Израиль & 5351.9 & 1340.6 & 1574.8 & 542.1 & 1238.1 & 505.8 & 4809.8 & 102.5 & 1069.0 \\
\hline Ирландия & 1637.5 & 1146.1 & 1916.4 & 5556.6 & 8362.4 & 5442.5 & -3919.1 & -7216.3 & -3526.1 \\
\hline
\end{tabular}


(продолжение)

\begin{tabular}{|c|c|c|c|c|c|c|c|c|c|}
\hline & \multicolumn{3}{|c|}{ Поступления от экспорта технологий } & \multicolumn{3}{|c|}{ Выплаты по импорту технологий } & \multicolumn{3}{|c|}{ Сальдо платежей за технологии } \\
\hline & 2013 & 2014 & 2015 & 2013 & 2014 & 2015 & 2013 & 2014 & 2015 \\
\hline Исландия & - & - & - & - & 0.8 & - & - & -0.8 & - \\
\hline Испания & 6702.0 & 7984.6 & 1808.1 & 121445.8 & 36527.1 & 28977.5 & -114743.8 & -28542.5 & -27169.4 \\
\hline Италия & 5833.1 & 108753.1 & 7204.6 & 166347.5 & 94195.6 & 53949.9 & -160514.4 & 14557.5 & -46745.3 \\
\hline Канада & 3460.2 & 3222.4 & 3884.8 & 121197.8 & 10294.6 & 21350.3 & -117737.6 & -7072.2 & -17465.5 \\
\hline Люксембург & 157.8 & 23500.4 & 2953.0 & 7293.4 & 36351.9 & 29899.2 & -7135.6 & -12851.5 & -26946.2 \\
\hline Мексика & 218.5 & 4286.6 & 21.6 & 4.4 & 2.6 & 53.6 & 214.1 & 4284.0 & -32.0 \\
\hline Нидерланды & 44681.2 & 50449.0 & 32305.2 & 140125.3 & 104249.4 & 81365.1 & -95444.1 & -53800.4 & -49059.9 \\
\hline Новая Зеландия & 5.0 & 44.6 & - & 215.7 & 603.0 & - & -210.7 & -558.4 & - \\
\hline Норвегия & 14001.2 & 10649.6 & 4663.2 & 14690.3 & 2611.7 & 3089.3 & -689.1 & 8037.9 & -1573.9 \\
\hline Польша & 353.5 & 964.6 & 392.9 & 28667.3 & 10675.6 & 7187.4 & -28313.8 & -9711.0 & -6794.5 \\
\hline Португалия & 286.1 & 592.6 & 1.9 & 72.8 & 253.5 & 414.3 & 213.3 & 339.1 & -412.4 \\
\hline Республика Корея & 20555.9 & 9944.3 & 10024.7 & 57535.6 & 44174.4 & 44388.2 & -36979.7 & -34230.1 & -34363.5 \\
\hline Словакия & 421.4 & 50.4 & 414.3 & 886.4 & 1177.8 & 479.0 & -465.0 & -1127.4 & -64.7 \\
\hline Словения & 915.0 & 932.2 & 384.4 & 1592.3 & 336.3 & 1075.9 & -677.3 & 595.9 & -691.5 \\
\hline США & 134433.2 & 162299.2 & 319102.5 & 522093.1 & 617260.4 & 254056.7 & -387659.9 & -454961.2 & 65045.8 \\
\hline Турция & 798.2 & 363367.3 & 70293.4 & 24584.6 & 163367.3 & 11871.4 & -23786.4 & 200000.0 & 58422.0 \\
\hline Финляндия & 19074.8 & 5895.6 & 4837.6 & 42057 & 62808.4 & 196087.1 & -22982.2 & -56912.8 & -191249.5 \\
\hline Франция & 31118.4 & 20381.3 & 20646.8 & 184481.0 & 181465.9 & 174907.1 & -153362.8 & -161084.6 & -154260.3 \\
\hline Чешская Республика & 1551.6 & 2111.0 & 4702.3 & 31940.7 & 84109.6 & 16266.8 & -30389.1 & -81998.6 & -11564.5 \\
\hline Чили & - & - & 31.7 & - & - & - & - & - & 31.7 \\
\hline Швейцария & 18658.2 & 15857.8 & 16940.2 & 169351.5 & 124912.1 & 166535.0 & -150693.3 & -109054.3 & -149594.8 \\
\hline Швеция & 7912.1 & 9898.2 & 4996.2 & 36267.2 & 39116.4 & 42724.1 & -28355.1 & -29218.2 & -37727.9 \\
\hline Эстония & 214.2 & 349.9 & 416.5 & 4598.6 & 601.4 & 1925.3 & -4384.4 & -251.5 & -1508.8 \\
\hline Япония & 6406.3 & 14815.4 & 6553.5 & 66490.6 & 59592.1 & 39138.3 & -60084.3 & -44776.7 & -32584.8 \\
\hline
\end{tabular}


(окончание)

\begin{tabular}{|c|c|c|c|c|c|c|c|c|c|}
\hline & \multicolumn{3}{|c|}{ Поступления от экспорта технологий } & \multicolumn{3}{|c|}{ Выплаты по импорту технологий } & \multicolumn{3}{|c|}{ Сальдо платежей за технологии } \\
\hline & 2013 & 2014 & 2015 & 2013 & 2014 & 2015 & 2013 & 2014 & 2015 \\
\hline Другие страны & 285302.5 & 172730.1 & 900519.4 & 100340.9 & 85630.6 & 306454.8 & 184961.6 & 87099.5 & 594064.6 \\
\hline Болгария & 20097.4 & 19605.9 & 14242.1 & 1087.8 & 274.1 & 418.9 & 19009.6 & 19331.8 & 13823.2 \\
\hline Бразилия & 1299.7 & 428.4 & 926.5 & - & 397.6 & 111.8 & 1299.7 & 30.8 & 814.7 \\
\hline Гонконг & 5899.4 & 4902.4 & 7035.6 & 2186.3 & 394.2 & 1948.8 & 3713.1 & 4508.2 & 5086.8 \\
\hline Грузия & 421.8 & 201.7 & 210.3 & - & - & 18.9 & 421.8 & 201.7 & 191.4 \\
\hline Индия & 49675.2 & 26872.8 & 85910.6 & 3329.6 & 1058.6 & 1735.9 & 46345.6 & 25814.2 & 84174.7 \\
\hline Иран & 54242.7 & 8762.1 & 17011.2 & 313.0 & - & - & 53929.7 & 8762.1 & 17011.2 \\
\hline Кипр & 7826.2 & 11649.3 & 9084.1 & 36803.2 & 41810.6 & 28103.0 & -28977.0 & -30161.3 & -19018.9 \\
\hline Китай & 75034.8 & 60362.2 & 460338.5 & 7265.1 & 15644.3 & 5899.7 & 67769.7 & 44717.9 & 454438.8 \\
\hline Румыния & 211.4 & 286.7 & 4480.9 & 908.6 & 468.7 & 427.6 & -697.2 & -182.0 & 4053.3 \\
\hline Сингапур & 5430.8 & 585.4 & 1118.0 & 6289.0 & 14587.4 & 4525.2 & -858.2 & -14002.0 & -3407.2 \\
\hline Тайвань & 34.2 & 1150.9 & 838.9 & 116.5 & 10.8 & 677.3 & -82.3 & 1140.1 & 161.6 \\
\hline ЮАР & 3607.9 & 823.7 & 991.7 & 1061.8 & 51.5 & 63.2 & 2546.1 & 772.2 & 928.5 \\
\hline Прочие & 61431.0 & 37098.6 & 298331.0 & 40980.0 & 10932.8 & 262524.5 & 20451.0 & 26165.8 & 35806.5 \\
\hline
\end{tabular}


6.25. СТРУКТУРА ЭКСПОРТА И ИМПОРТА ТЕХНОЛОГИЙ ПО ГРУППАМ СТРАН (проценты)

Поступления от экспорта

технологий

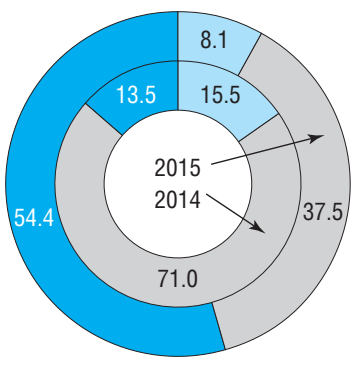

$\square$ Страны СНГ
Выплаты по импорту

технологий

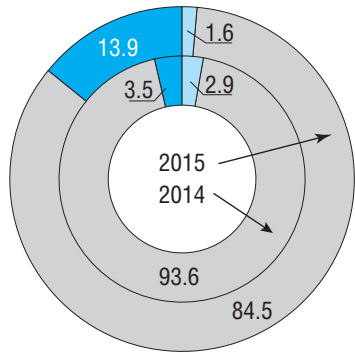

Другие страны 


\subsection{6. БАЛАНС ПЛАТЕЖЕЙ ЗА ТЕХНОЛОГИИ ПО СЕКТОРАМ ДЕЯТЕЛЬНОСТИ}

(тысячи долларов США)

\begin{tabular}{|c|c|c|c|c|c|c|c|c|c|}
\hline & \multicolumn{3}{|c|}{ Поступления от экспорта технологий } & \multicolumn{3}{|c|}{ Выплаты по импорту технологий } & \multicolumn{3}{|c|}{ Сальдо платежей за технологии } \\
\hline & 2013 & 2014 & 2015 & 2013 & 2014 & 2015 & 2013 & 2014 & 2015 \\
\hline Всего & 770584.8 & 1279213.1 & 1654732.1 & 2463626.3 & 2455830.7 & 2205429.3 & -1693041.5 & -1176617.6 & -550697.2 \\
\hline \multicolumn{10}{|l|}{ Секторы деятельности: } \\
\hline государственный & 144036.8 & 96353.5 & 56382.3 & 53088.6 & 92443.1 & 72446.0 & 90948.2 & 3910.4 & -16063.7 \\
\hline предпринимательский & 622104.9 & 1176888.9 & 1591990.1 & 2410406.5 & 2362556.1 & 2132098.0 & -1788301.6 & -1185667.2 & -540107.9 \\
\hline высшего образования & 4443.1 & 5970.7 & 6359.7 & 130.0 & 830.3 & 884.1 & 4313.1 & 5140.4 & 5475.6 \\
\hline некоммерческих организаций & - & - & - & 1.2 & 1.2 & 1.2 & -1.2 & -1.2 & -1.2 \\
\hline
\end{tabular}




\subsection{7. БАЛАНС ПЛАТЕЖЕЙ ЗА ТЕХНОЛОГИИ ПО ВИДАМ ЭКОНОМИЧЕСКОЙ ДЕЯТЕЛЬНОСТИ}

(тысячи долларов США)

\begin{tabular}{|c|c|c|c|c|c|c|c|c|c|}
\hline & \multicolumn{3}{|c|}{ Поступления от экспорта технологий } & \multicolumn{3}{|c|}{ Выплаты по импорту технологий } & \multicolumn{3}{|c|}{ Сальдо платежей за технологии } \\
\hline & 2013 & 2014 & 2015 & 2013 & 2014 & 2015 & 2013 & 2014 & 2015 \\
\hline Всего & 770584.8 & 1279213.1 & 1654732.1 & 2463626.3 & 2455830.7 & 2205429.3 & -1693041.5 & -1176617.6 & -550697.2 \\
\hline Сельское хозяйство, охота и лесное хозяйство & - & 1478.0 & 2932.0 & 180.4 & 1956.4 & 3683.7 & -180.4 & -478.4 & -751.7 \\
\hline $\begin{array}{l}\text { Рыбоводство, рыболовство и предоставление } \\
\text { услуг в этих областях }\end{array}$ & 75.4 & - & - & 29.5 & - & - & 45.9 & - & - \\
\hline Добыча полезных ископаемых & 1407.2 & 2057.1 & 11210.7 & 134826.8 & 208401.9 & 264897.9 & -133419.6 & -206344.8 & -253687.2 \\
\hline Обрабатывающие производства & 57440.7 & 143521.3 & 152094.1 & 1967032.1 & 1506157.5 & 1435667.2 & -1909591.4 & -1362636.2 & -1283573.1 \\
\hline $\begin{array}{l}\text { Производство и распределение электроэнергии, } \\
\text { газа и воды }\end{array}$ & 2070.0 & 5519.7 & 1983.3 & 1769.8 & 1643.2 & 9842.2 & 300.2 & 3876.5 & -7858.9 \\
\hline Строительство & 563.6 & 24.0 & 25.1 & 9733.6 & 2221.5 & 953.2 & -9170.0 & -2197.5 & -928.1 \\
\hline $\begin{array}{l}\text { Оптовая и розничная торговля, ремонт автотранс- } \\
\text { портных средств, мотоциклов, бытовых изделий }\end{array}$ & & & & & & & & & \\
\hline и предметов личного пользования & 127933.6 & 388882.5 & 857611.8 & 35216.7 & 71575.8 & 222180.1 & 92716.9 & 317306.7 & 635431.7 \\
\hline Деятельность гостиниц и ресторанов & - & - & - & 100129.2 & 17047.0 & 16583.9 & -100129.2 & -17047.0 & -16583.9 \\
\hline Транспорт и связь & 38513.8 & 43002.3 & 27777.0 & 114174.2 & 196969.4 & 89845.7 & -75660.4 & -153967.1 & -62068.7 \\
\hline $\begin{array}{l}\text { Операции с недвижимым имуществом, аренда } \\
\text { и предоставление услуг }\end{array}$ & 538917.6 & 691226.2 & 598591.9 & 95201.7 & 441677.9 & 159022.4 & 443715.9 & 249548.3 & 439569.5 \\
\hline $\begin{array}{l}\text { Из них: } \\
\text { деятельность, связанная с использованием } \\
\text { вычислительной техники и информационных }\end{array}$ & & & & & & & & & \\
\hline технологий & 145268.3 & 191511.8 & 184732.6 & 9110.5 & 7705.1 & 8451.2 & 136157.8 & 183806.7 & 176281.4 \\
\hline $\begin{array}{l}\text { из нее разработка программного обеспече- } \\
\text { ния и консультирование в этой области }\end{array}$ & 112810.8 & 154491.2 & 155364.8 & 8162.8 & 6565.1 & 7585.5 & 104648.0 & 147926.1 & 147779.3 \\
\hline научные исследования и разработки & 197102.9 & 315586.9 & 157917.7 & 35354.5 & 301861.6 & 108754.4 & 161748.4 & 13725.3 & 49163.3 \\
\hline $\begin{array}{l}\text { Государственное управление и обеспечение } \\
\text { военной безопасности, обязательное социаль- } \\
\text { ное обеспечение }\end{array}$ & 4.4 & 441.5 & - & - & 157.5 & - & 4.4 & 284.0 & - \\
\hline
\end{tabular}


(окончание)

\begin{tabular}{|c|c|c|c|c|c|c|c|c|c|}
\hline & \multicolumn{3}{|c|}{ Поступления от экспорта технологий } & \multicolumn{3}{|c|}{ Выплаты по импорту технологий } & \multicolumn{3}{|c|}{ Сальдо платежей за технологии } \\
\hline & 2013 & 2014 & 2015 & 2013 & 2014 & 2015 & 2013 & 2014 & 2015 \\
\hline Образование & 3577.7 & 3060.5 & 2351.4 & 376.1 & 1362.5 & 624.1 & 3201.6 & 1698.0 & 1727.3 \\
\hline $\begin{array}{l}\text { Здравоохранение и предоставление социальных } \\
\text { услуг }\end{array}$ & 80.8 & - & 154.8 & 198.0 & 168.0 & 259.5 & -117.2 & -168.0 & -104.7 \\
\hline $\begin{array}{l}\text { Предоставление коммунальных, социальных } \\
\text { и персональных услуг }\end{array}$ & - & - & - & 4758.2 & 6492.1 & 1869.4 & -4758.2 & -6492.1 & -1869.4 \\
\hline $\begin{array}{l}\text { Из них деятельность по организации отдыха } \\
\text { и развлечений, культуры и спорта }\end{array}$ & - & - & - & 4758.2 & 6492.1 & 1869.4 & -4758.2 & -6492.1 & -1869.4 \\
\hline
\end{tabular}




\subsection{8. РАЗРАБОТКА ПЕРЕДОВЫХ ПРОИЗВОДСТВЕННЫХ ТЕХНОЛОГИЙ ПО ВИДАМ}

\begin{tabular}{|c|c|c|c|c|c|c|c|c|c|c|c|c|c|}
\hline & 1997 & 2000 & 2005 & 2006 & 2007 & 2008 & 2009 & 2010 & 2011 & 2012 & 2013 & 2014 & 2015 \\
\hline \multicolumn{14}{|l|}{ Передовые производственные } \\
\hline технологии & 996 & 688 & 637 & 735 & 780 & 854 & 897 & 864 & 1138 & 1323 & 1429 & 1409 & 1398 \\
\hline \multicolumn{14}{|l|}{ Из них: } \\
\hline проектирование и инжиниринг & 223 & 165 & 138 & 148 & 177 & 173 & 196 & 216 & 316 & 305 & 426 & 445 & 359 \\
\hline производство, обработка и сборка & 390 & 281 & 291 & 362 & 365 & 369 & 328 & 383 & 405 & 548 & 517 & 506 & 548 \\
\hline \multicolumn{14}{|l|}{$\begin{array}{l}\text { автоматизированные погрузочно- } \\
\text { разгрузочные операции; } \\
\text { транспортировка материалов }\end{array}$} \\
\hline и деталей & 20 & 20 & 9 & 13 & 8 & 14 & 21 & 18 & 24 & 23 & 22 & 22 & 12 \\
\hline $\begin{array}{l}\text { аппаратура автоматизированного } \\
\text { наблюдения (контроля) }\end{array}$ & 141 & 76 & 91 & 97 & 110 & 99 & 102 & 116 & 128 & 121 & 137 & 110 & 117 \\
\hline связь и управление & 131 & 90 & 57 & 56 & 67 & 68 & 67 & 70 & 154 & 204 & 206 & 202 & 232 \\
\hline $\begin{array}{l}\text { производственные } \\
\text { информационные системы }\end{array}$ & 39 & 18 & 21 & 24 & 14 & 23 & 26 & 20 & 51 & 60 & 68 & 65 & 84 \\
\hline $\begin{array}{l}\text { интегрированное управление } \\
\text { и контроль }\end{array}$ & 52 & 38 & 30 & 35 & 39 & 41 & 49 & 41 & 60 & 62 & 53 & 59 & 46 \\
\hline
\end{tabular}




\subsection{9. РАЗРАБОТКА ПЕРЕДОВЫХ ПРОИЗВОДСТВЕННЫХ ТЕХНОЛОГИЙ ПО СТЕПЕНИ НОВИЗНЫ И ВИДАМ}

\begin{tabular}{|c|c|c|c|c|c|c|c|c|c|c|c|c|c|}
\hline & 1997 & 2000 & 2005 & 2006 & 2007 & 2008 & 2009 & 2010 & 2011 & 2012 & 2013 & 2014 & 2015 \\
\hline Технологии, новые в стране & 830 & 569 & 538 & 642 & 653 & 738 & 757 & 762 & 1028 & 1188 & 1276 & 1245 & 1223 \\
\hline \multicolumn{14}{|l|}{ Из них: } \\
\hline проектирование и инжиниринг & 195 & 136 & 125 & 138 & 140 & 150 & 169 & 191 & 272 & 269 & 367 & 390 & 323 \\
\hline производство, обработка и сборка & 315 & 231 & 239 & 308 & 314 & 316 & 283 & 336 & 371 & 491 & 469 & 450 & 471 \\
\hline \multicolumn{14}{|l|}{$\begin{array}{l}\text { автоматизированные погрузочно- } \\
\text { разгрузочные операции; транспортировка }\end{array}$} \\
\hline материалов и деталей & 17 & 19 & 8 & 11 & 8 & 12 & 17 & 16 & 23 & 21 & 21 & 20 & 10 \\
\hline \multicolumn{14}{|l|}{ аппаратура автоматизированного } \\
\hline наблюдения (контроля) & 101 & 66 & 72 & 79 & 91 & 87 & 92 & 98 & 117 & 101 & 108 & 84 & 82 \\
\hline связь и управление & 118 & 74 & 52 & 52 & 52 & 65 & 61 & 67 & 147 & 194 & 195 & 187 & 218 \\
\hline \multicolumn{14}{|l|}{ производственные информационные } \\
\hline системы & 38 & 14 & 20 & 24 & 13 & 20 & 22 & 17 & 41 & 55 & 66 & 59 & 78 \\
\hline \multicolumn{14}{|l|}{ интегрированное управление } \\
\hline и контроль & 46 & 29 & 22 & 30 & 35 & 37 & 40 & 37 & 57 & 57 & 50 & 55 & 41 \\
\hline \multicolumn{14}{|l|}{ Из них: } \\
\hline проектирование и инжиниринг & 18 & 12 & 12 & 7 & 17 & 7 & 27 & 25 & 44 & 36 & 59 & 55 & 36 \\
\hline производство, обработка и сборка & 41 & 32 & 30 & 25 & 30 & 24 & 45 & 47 & 34 & 57 & 48 & 56 & 77 \\
\hline \multicolumn{14}{|l|}{ автоматизированные погрузочно- } \\
\hline материалов и деталей & - & 1 & - & 1 & - & 1 & 4 & 2 & 1 & 2 & 1 & 2 & 2 \\
\hline \multicolumn{13}{|l|}{ аппаратура автоматизированного } & 35 \\
\hline связь и управление & 7 & 9 & 4 & 3 & 12 & 1 & 6 & 3 & 7 & 10 & 11 & 15 & 14 \\
\hline \multicolumn{14}{|l|}{ производственные информационные } \\
\hline системы & - & 4 & 1 & - & 1 & 1 & 4 & 3 & 10 & 5 & 2 & 6 & 6 \\
\hline интегрированное управление и контроль & 4 & 8 & 1 & 2 & 1 & 3 & 9 & 4 & 3 & 5 & 3 & 4 & 5 \\
\hline
\end{tabular}


6.30. РАЗРАБОТКА ПЕРЕДОВЫХ ПРОИЗВОДСТВЕННЫХ ТЕХНОЛОГИЙ ПО СТЕПЕНИ НОВИЗНЫ И ВИДАМ ЭКОНОМИЧЕСКОЙ ДЕЯТЕЛЬНОСТИ

\begin{tabular}{|c|c|c|c|c|c|c|}
\hline & \multicolumn{2}{|c|}{ Bсего } & \multicolumn{4}{|c|}{ Из них технологии } \\
\hline & \multirow[t]{2}{*}{2014} & \multirow[t]{2}{*}{2015} & \multicolumn{2}{|c|}{ новые в стране } & \multicolumn{2}{|c|}{ принципиально новые } \\
\hline & & & 2014 & 2015 & 2014 & 2015 \\
\hline Передовые производственные технологии & 1409 & 1398 & 1245 & 1223 & 164 & 175 \\
\hline Добыча полезных ископаемых & 25 & 18 & 23 & 17 & 2 & 1 \\
\hline Обрабатывающие производства & 414 & 442 & 382 & 416 & 32 & 26 \\
\hline \multicolumn{7}{|l|}{ Производство и распределение электроэнергии, } \\
\hline газа и воды & 33 & 28 & 32 & 28 & 1 & - \\
\hline Транспорт и связь & 39 & 54 & 5 & 50 & 5 & 4 \\
\hline $\begin{array}{l}\text { Операции с недвижимым имуществом, аренда } \\
\text { и предоставление услуг }\end{array}$ & \multicolumn{5}{|c|}{ Операции с недвижимым имуществом, аренда } & 102 \\
\hline \multicolumn{7}{|l|}{ Из них: } \\
\hline научные исследования и разработки & 546 & 529 & 461 & 429 & 85 & 100 \\
\hline предоставление прочих видов услуг & 40 & 31 & 37 & 29 & 3 & 2 \\
\hline Образование & 312 & 296 & 276 & 254 & 36 & 42 \\
\hline Из него высшее образование & 312 & 296 & 276 & 254 & 36 & 42 \\
\hline
\end{tabular}




\subsection{1. ИСПОЛЬЗОВАНИЕ ПЕРЕДОВЫХ ПРОИЗВОДСТВЕННЫХ ТЕХНОЛОГИЙ ПО ВИДАМ}

\begin{tabular}{|c|c|c|c|c|c|c|c|c|c|c|c|c|c|}
\hline & 1997 & 2000 & 2005 & 2006 & 2007 & 2008 & 2009 & 2010 & 2011 & 2012 & 2013 & 2014 & 2015 \\
\hline \multicolumn{14}{|l|}{ Передовые производственные } \\
\hline технологии & 55452 & 70069 & 140983 & 168311 & 180324 & 184568 & 201850 & 203330 & 191650 & 191372 & 193830 & 204546 & 218018 \\
\hline \multicolumn{14}{|l|}{ Из них: } \\
\hline проектирование и инжиниринг & 7109 & 14385 & 43273 & 50653 & 54044 & 47116 & 54539 & 56130 & 41422 & 39664 & 38735 & 38598 & 39831 \\
\hline производство, обработка и сборка & 36538 & 35408 & 42976 & 50290 & 48956 & 47235 & 52460 & 55438 & 53563 & 55579 & 55424 & 58111 & 63379 \\
\hline \multicolumn{14}{|l|}{$\begin{array}{l}\text { автоматизированные погрузочно- } \\
\text { разгрузочные операции; }\end{array}$} \\
\hline транспортировка материалов и деталей & 707 & 685 & 970 & 1270 & 1420 & 1469 & 1668 & 1853 & 1649 & 1570 & 1823 & 1983 & 2129 \\
\hline \multicolumn{14}{|l|}{ аппаратура автоматизированного } \\
\hline наблюдения (контроля) & 2644 & 2409 & 4525 & 5941 & 6758 & 7531 & 8075 & 9106 & 9395 & 9519 & 11314 & 12263 & 12876 \\
\hline связь и управление & 6650 & 13713 & 44135 & 53971 & 62102 & 74468 & 77457 & 72798 & 77662 & 76479 & 78028 & 84730 & 89967 \\
\hline \multicolumn{14}{|l|}{ производственные информационные } \\
\hline системы & 790 & 1823 & 3177 & 4092 & 4602 & 4175 & 4510 & 4848 & 4853 & 5171 & 5293 & 5555 & 6300 \\
\hline \multicolumn{14}{|l|}{ интегрированное управление } \\
\hline и контроль & 1014 & 1646 & 1927 & 2094 & 2442 & 2380 & 2877 & 3157 & 3106 & 3390 & 3213 & 3306 & 3536 \\
\hline
\end{tabular}




\subsection{2. ИСПОЛЬЗОВАНИЕ ПЕРЕДОВЫХ ПРОИЗВОДСТВЕННЫХ ТЕХНОЛОГИЙ ПО ВИДАМ И ПРОДОЛЖИТЕЛЬНОСТИ}

\begin{tabular}{|c|c|c|c|c|c|c|c|c|}
\hline & \multirow{2}{*}{\multicolumn{2}{|c|}{ Всего }} & \multicolumn{6}{|c|}{ Из них технологии, использовавшиеся в течение, лет } \\
\hline & & & \multicolumn{2}{|c|}{ до одного года } & \multicolumn{2}{|c|}{ одного-пяти } & \multicolumn{2}{|c|}{ шести и более } \\
\hline & 2014 & 2015 & 2014 & 2015 & 2014 & 2015 & 2014 & 2015 \\
\hline $\begin{array}{l}\text { Передовые производственные технологии } \\
\text { Из них: }\end{array}$ & 204546 & 218018 & 16179 & 16844 & 84182 & 87543 & 104185 & 113631 \\
\hline проектирование и инжиниринг & 38598 & 39831 & 3712 & 3498 & 16461 & 17869 & 18425 & 18464 \\
\hline производство, обработка и сборка & 58111 & 63379 & 4893 & 5323 & 20635 & 21624 & 32583 & 36432 \\
\hline $\begin{array}{l}\text { автоматизированные погрузочно-разгрузочные } \\
\text { операции; транспортировка материалов } \\
\text { и деталей }\end{array}$ & 1983 & 2129 & 192 & 157 & 757 & 882 & 1034 & 1090 \\
\hline $\begin{array}{l}\text { аппаратура автоматизированного наблюдения } \\
\text { (контроля) }\end{array}$ & 12263 & 12876 & 1234 & 1109 & 6294 & 6368 & 4735 & 5399 \\
\hline связь и управление & 84730 & 89967 & 5539 & 6067 & 36411 & 37103 & 42780 & 46797 \\
\hline производственные информационные системы & 5555 & 6300 & 379 & 460 & 2425 & 2500 & 2751 & 3340 \\
\hline интегрированное управление и контроль & 3306 & 3536 & 230 & 230 & 1199 & 1197 & 1877 & 2109 \\
\hline
\end{tabular}




\subsection{3. ИСПОЛЬЗОВАНИЕ ПЕРЕДОВЫХ ПРОИЗВОДСТВЕННЫХ ТЕХНОЛОГИЙ}

ПО ВИДАМ ЭКОНОМИЧЕСКОЙ ДЕЯТЕЛЬНОСТИ И ПРОДОЛЖИТЕЛЬНОСТИ

\begin{tabular}{|c|c|c|c|c|c|c|c|c|}
\hline & \multirow{2}{*}{\multicolumn{2}{|c|}{ Всего }} & \multicolumn{6}{|c|}{ Из них технологии, использовавшиеся в течение, лет } \\
\hline & & & \multicolumn{2}{|c|}{ до одного года } & \multicolumn{2}{|c|}{ одного-пяти } & \multicolumn{2}{|c|}{ шести и более } \\
\hline & 2014 & 2015 & 2014 & 2015 & 2014 & 2015 & 2014 & 2015 \\
\hline Передовые производственные технологии & 204546 & 218018 & 16179 & 16844 & 84182 & 87543 & 104185 & 113631 \\
\hline Добыча полезных ископаемых & 8892 & 9222 & 715 & 382 & 4760 & 5126 & 3417 & 3714 \\
\hline Обрабатывающие производства & 127492 & 146700 & 9518 & 10815 & 47746 & 54736 & 70228 & 81149 \\
\hline $\begin{array}{l}\text { Производство и распределение электроэнергии, } \\
\text { газа и воды }\end{array}$ & 16971 & 18443 & 1677 & 1762 & 7651 & 8359 & 7643 & 8322 \\
\hline $\begin{array}{l}\text { Оптовая и розничная торговля, ремонт автотранс } \\
\text { портных средств, мотоциклов, бытовых изделий } \\
\text { и предметов личного пользования }\end{array}$ & 353 & 357 & 21 & 7 & 158 & 168 & 174 & 182 \\
\hline Транспорт и связь & 7625 & 8766 & 591 & 608 & 3530 & 4091 & 3504 & 4067 \\
\hline $\begin{array}{l}\text { Операции с недвижимым имуществом, аренда } \\
\text { и предоставление услуг }\end{array}$ & 37416 & 29038 & 3085 & 2757 & 17844 & 12871 & 16487 & 13410 \\
\hline Из них научные исследования и разработки & 29969 & 22195 & 2579 & 2331 & 13892 & 9424 & 13498 & 10440 \\
\hline Образование & 5681 & 5492 & 562 & 513 & 2449 & 2192 & 2670 & 2787 \\
\hline Из него высшее образование & 5681 & 5492 & 562 & 513 & 2449 & 2192 & 2670 & 2787 \\
\hline $\begin{array}{l}\text { Предоставление коммунальных, социальных } \\
\text { и персональных услуг }\end{array}$ & 116 & - & 10 & - & 44 & - & 62 & - \\
\hline
\end{tabular}


6.34. ИСПОЛЬЗОВАНИЕ ПЕРЕДОВЫХ ПРОИЗВОДСТВЕННЫХ ТЕХНОЛОГИЙ ПО ВИДАМ И ИСТОЧНИКУ ПРИОБРЕТЕНИЯ: 2015

\begin{tabular}{|c|c|c|c|c|}
\hline & \multirow[t]{3}{*}{ Bсего } & \multicolumn{3}{|c|}{ Из них технологии } \\
\hline & & \multirow{2}{*}{$\begin{array}{c}\text { разработанные } \\
\text { в отчитывающейся } \\
\text { организации }\end{array}$} & \multicolumn{2}{|c|}{ приобретенные } \\
\hline & & & в России & за рубежом \\
\hline Передовые производственные технологии & 218018 & 32182 & 122583 & 63253 \\
\hline \multicolumn{5}{|l|}{ Из них: } \\
\hline проектирование и инжиниринг & 39831 & 9166 & 24293 & 6372 \\
\hline производство, обработка и сборка & 63379 & 13335 & 25545 & 24499 \\
\hline автоматизированные погрузочно-разгрузочные & & & & \\
\hline операции; транспортировка материалов и деталей & 2129 & 253 & 917 & 959 \\
\hline $\begin{array}{l}\text { аппаратура автоматизированного наблюдения } \\
\text { (контроля) }\end{array}$ & 12876 & 1478 & 7390 & 4008 \\
\hline связь и управление & 89967 & 6023 & 58609 & 25335 \\
\hline производственные информационные системы & 6300 & 1457 & 3660 & 1183 \\
\hline интегрированное управление и контроль & 3536 & 470 & 2169 & 897 \\
\hline
\end{tabular}


6.35. ИСПОЛЬЗОВАНИЕ ПЕРЕДОВЫХ ПРОИЗВОДСТВЕННЫХ ТЕХНОЛОГИЙ

ПО ВИДАМ ЭКОНОМИЧЕСКОЙ ДЕЯТЕЛЬНОСТИ И ИСТОЧНИКУ ПРИОБРЕТЕНИЯ: 2015

\begin{tabular}{|c|c|c|c|c|}
\hline & \multirow[t]{3}{*}{ Bсего } & \multicolumn{3}{|c|}{ Из них технологии } \\
\hline & & \multirow{2}{*}{$\begin{array}{c}\text { разработанные } \\
\text { в отчитывающейся } \\
\text { организации }\end{array}$} & \multicolumn{2}{|c|}{ приобретенные } \\
\hline & & & в России & за рубежом \\
\hline Передовые производственные технологии & 218018 & 32182 & 122583 & 63253 \\
\hline Добыча полезных ископаемых & 9222 & 361 & 6336 & 2525 \\
\hline Обрабатывающие производства & 146700 & 21458 & 76499 & 48743 \\
\hline $\begin{array}{l}\text { Производство и распределение электроэнергии, } \\
\text { газа и воды }\end{array}$ & 18443 & 1145 & 14482 & 2816 \\
\hline $\begin{array}{l}\text { Оптовая и розничная торговля, ремонт автотранс } \\
\text { средств, мотоциклов, бытовых изделий и предме }\end{array}$ & & & & \\
\hline пользования & 357 & 13 & 307 & 37 \\
\hline Транспорт и связь & 8766 & 603 & 5923 & 2240 \\
\hline $\begin{array}{l}\text { Операции с недвижимым имуществом, аренда } \\
\text { и предоставление услуг }\end{array}$ & 29038 & 7150 & 15890 & 5998 \\
\hline Из них научные исследования и разработки & 22195 & 6819 & 10235 & 5141 \\
\hline Образование & 5492 & 1452 & 3146 & 894 \\
\hline Из него высшее образование & 5492 & 1452 & 3146 & 894 \\
\hline
\end{tabular}




\subsection{6. ИСПОЛЬЗОВАНИЕ ПЕРЕДОВЫХ ПРОИЗВОДСТВЕННЫХ ТЕХНОЛОГИЙ, РАЗРАБОТАННЫХ} НА ОСНОВЕ ЗАПАТЕНТОВАННЫХ ИЗОБРЕТЕНИЙ, ПО ВИДАМ*

\begin{tabular}{|c|c|c|c|c|c|c|c|c|c|c|c|c|c|}
\hline & 1997 & 2000 & 2005 & 2006 & 2007 & 2008 & 2009 & 2010 & $2011^{*}$ & 2012 & 2013 & 2014 & 2015 \\
\hline $\begin{array}{l}\text { Передовые производственные технологии } \\
\text { Из них: }\end{array}$ & 3247 & 2804 & 3072 & 2168 & 1373 & 2463 & 1344 & 1012 & 6566 & 6032 & 9099 & 9519 & 9249 \\
\hline проектирование и инжиниринг & 829 & 1115 & 1055 & 814 & 499 & 223 & 244 & 274 & 1574 & 1582 & 2193 & 2129 & 1819 \\
\hline производство, обработка и сборка & 1756 & 1231 & 1411 & 914 & 442 & 506 & 415 & 337 & 2523 & 2236 & 2670 & 3203 & 3274 \\
\hline $\begin{array}{l}\text { автоматизированные погрузочно- } \\
\text { разгрузочные операции; транспортировка }\end{array}$ & & & & & & & & & & & & & \\
\hline материалов и деталей & 26 & 45 & 16 & 5 & 4 & 13 & 24 & 18 & 76 & 69 & 218 & 131 & 121 \\
\hline $\begin{array}{l}\text { аппаратура автоматизированного } \\
\text { наблюдения (контроля) }\end{array}$ & 328 & 171 & 262 & 142 & 115 & 725 & 114 & 116 & 661 & 739 & 726 & 715 & 704 \\
\hline связь и управление & 197 & 182 & 258 & 213 & 238 & 885 & 426 & 209 & 1418 & 1138 & 2844 & 2870 & 2775 \\
\hline производственные информационные & & & & & & & & & & & & & \\
\hline системы & 29 & 9 & 44 & 53 & 51 & 52 & 47 & 31 & 193 & 172 & 321 & 316 & 395 \\
\hline интегрированное управление и контроль & 82 & 51 & 26 & 27 & 24 & 25 & 42 & 27 & 121 & 96 & 127 & 155 & 161 \\
\hline
\end{tabular}

* В связи с изменением методологии начиная с 2011 г. данные не сопоставимы с данными 2001-2010 гг. 


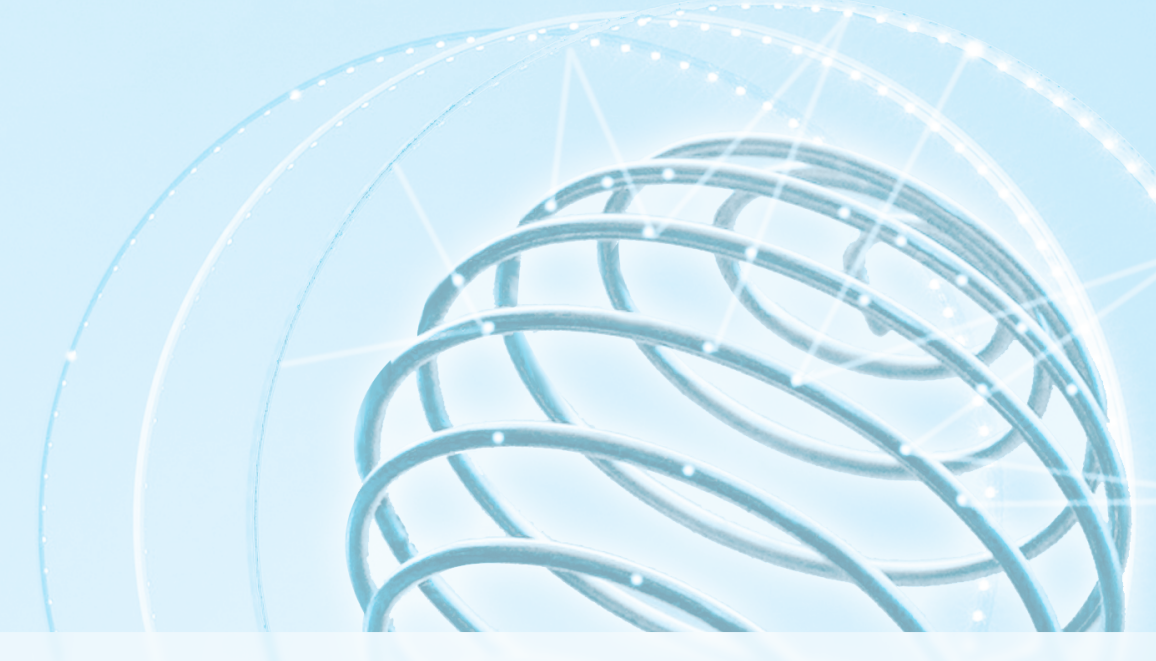

7. Общественное мнение о науке 


\section{1. ОБЕСПОКОЕННОСТЬ НАСЕЛЕНИЯ РОССИИ РАЗЛИЧНЫМИ СОЦИАЛЬНЫМИ ПРОБЛЕМАМИ: 2015* (в процентах от численности опрошенных)}

\section{Насколько Вас волнуют следующие проблемы?}

Высокие цены на ресурсы (электричество, бензин и др.)

Перебои в работе электричества дома или на дачном участке

Нерациональное использование воды, электричества, тепла в домохозяйствах

Нехватка времени и/или сил для работы по дому

Низкая доступность получения консультаций высококвалифицированных врачей

Рождение детей с генетическими и/или неизлечимыми заболеваниями

Отравление, загрязнение почвы и воды отходами

Образование слишком большого количества свалок бытовых отходов

Загрязнение воздуха

Низкое качество продуктов питания

Наличие токсинов и других вредных веществ в продуктах питания

Низкое содержание полезных веществ в пищевых продуктах

Пробки на дорогах, слишком большое количество машин на дорогах

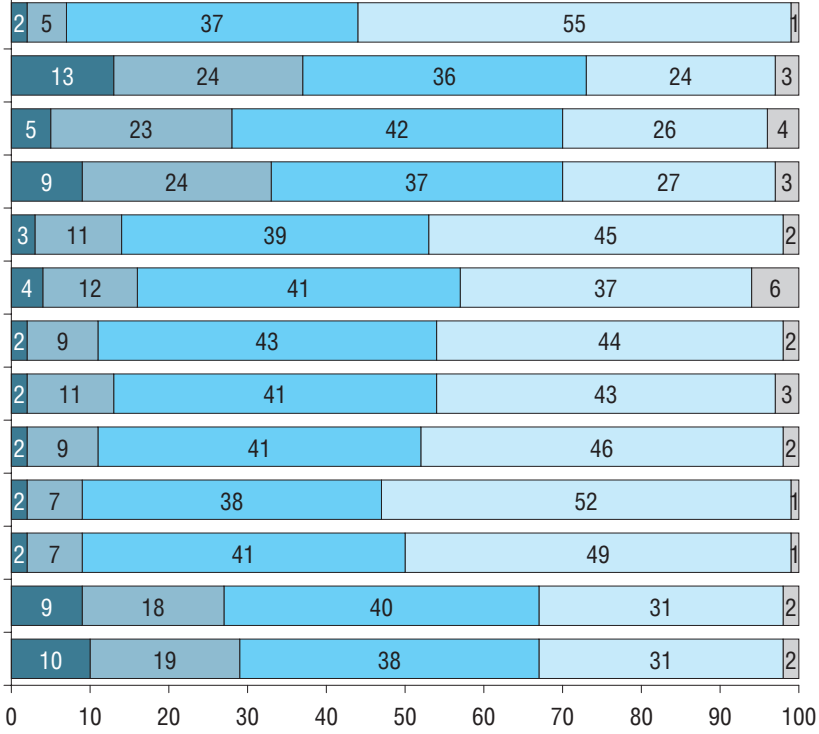

Совсем не волнует

$\square$ Скорее волнует

$\square$ Затруднились ответить

$\square$ Скорее не волнует

$\square$ Очень волнует

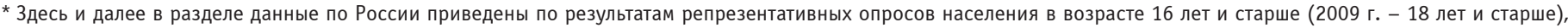
организованных Институтом статистических исследований и экономики знаний НИУ ВШЭ в рамках Программы фундаментальных исследований НИУ ВШЭ. 


\section{2. ОЦЕНКА НАСЕЛЕНИЕМ РОЛИ НАУКИ, ТЕХНОЛОГИЙ И ТЕХНИКИ В ОБЩЕСТВЕ \\ (в процентах от численности опрошенных)}

\section{Россия: Как Вы считаете, от науки, технологий и техники в целом больше пользы или вреда?}

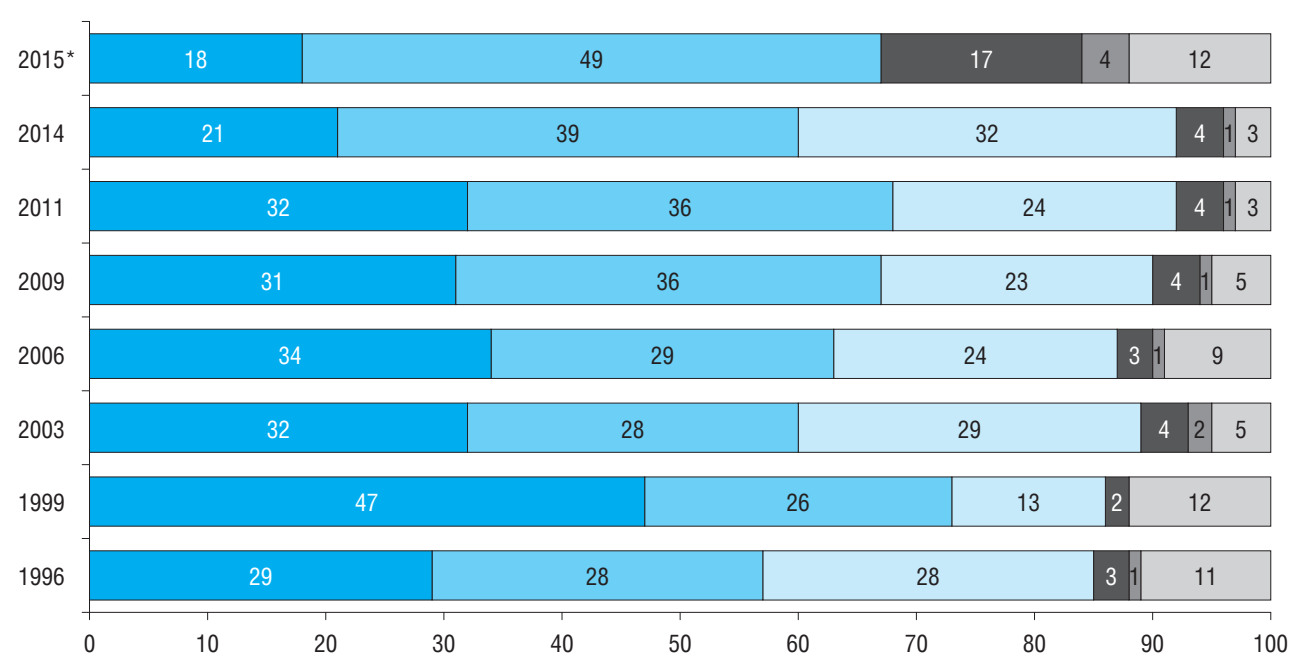

$\square$ Безусловно, больше пользы

$\square$ Скорее больше пользы

$\square$ Примерно одинаково

Скорее больше вреда

$\square$ Безусловно, больше вреда

$\square$ Затруднились ответить

* В 2015 г. вариант «Примерно одинаково и пользы, и вреда» был исключен из списка возможных ответов. 
(окончание)

\section{Как Вы считаете, от науки, технологий и техники в целом больше пользы или вреда? **}

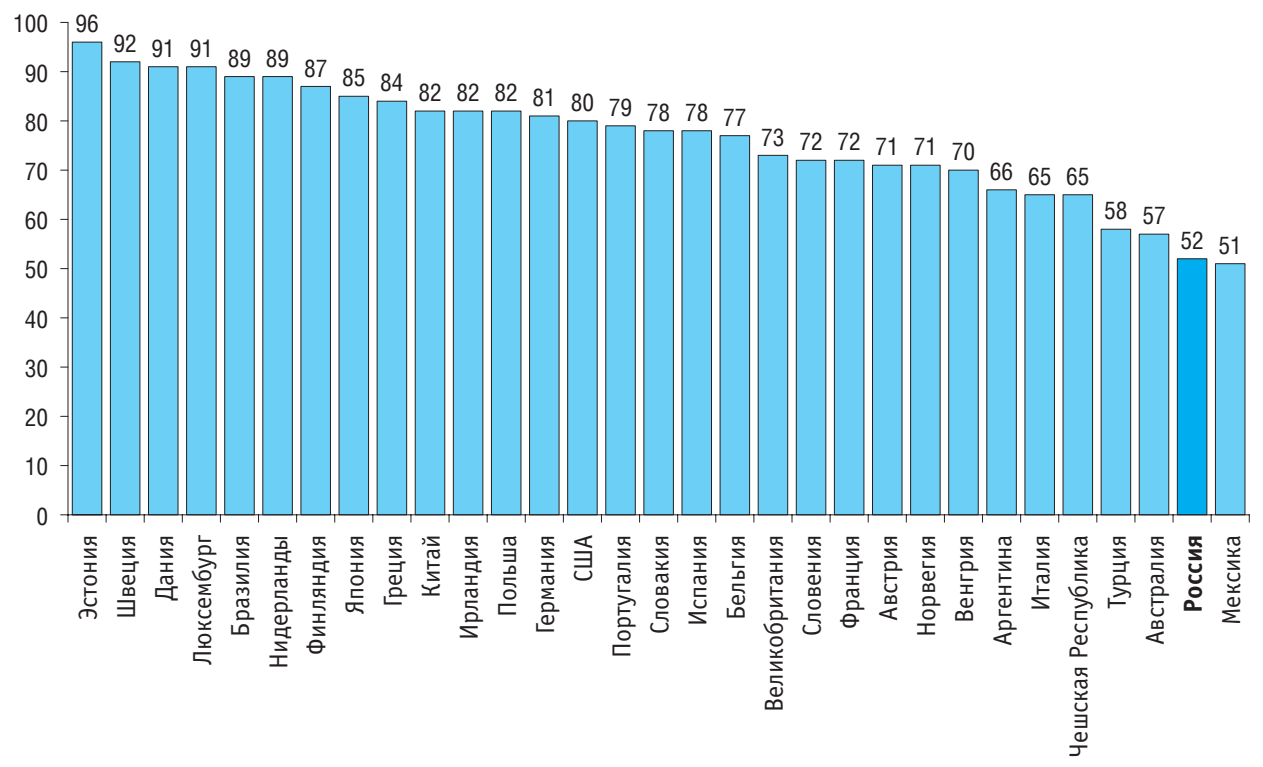

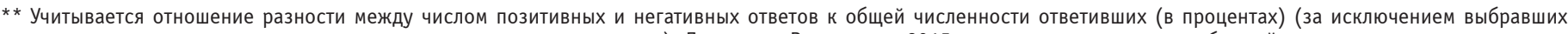

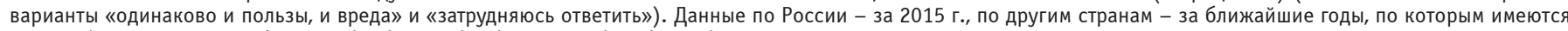
данные (источник: OECD Science, Technology and Industry Scoreboard, 2015). 


\section{3. ОЦЕНКИ НАСЕЛЕНИЕМ РОССИИ ВЛИЯНИЯ РАЗВИТИЯ НАУКИ, ТЕХНОЛОГИЙ, ТЕХНИКИ \\ НА УРОВЕНЬ ЖИЗНИ, ЗДОРОВЬЕ ЛЮДЕЙ И СОСТОЯНИЕ ОКРУЖАЮЩЕЙ СРЕДЫ \\ (в процентах от численности опрошенных)}

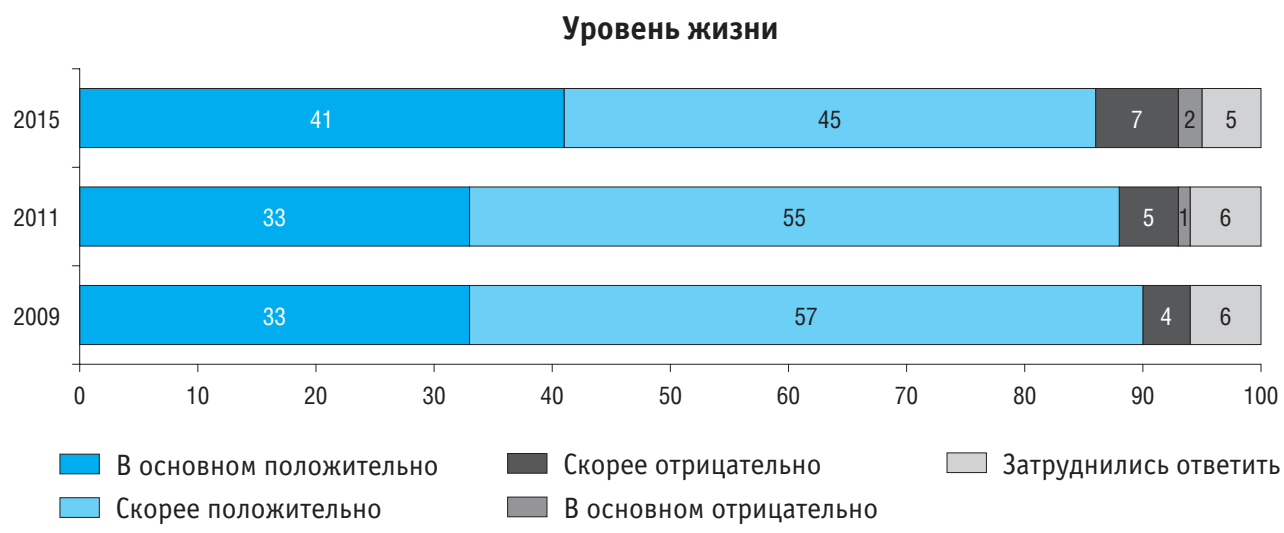




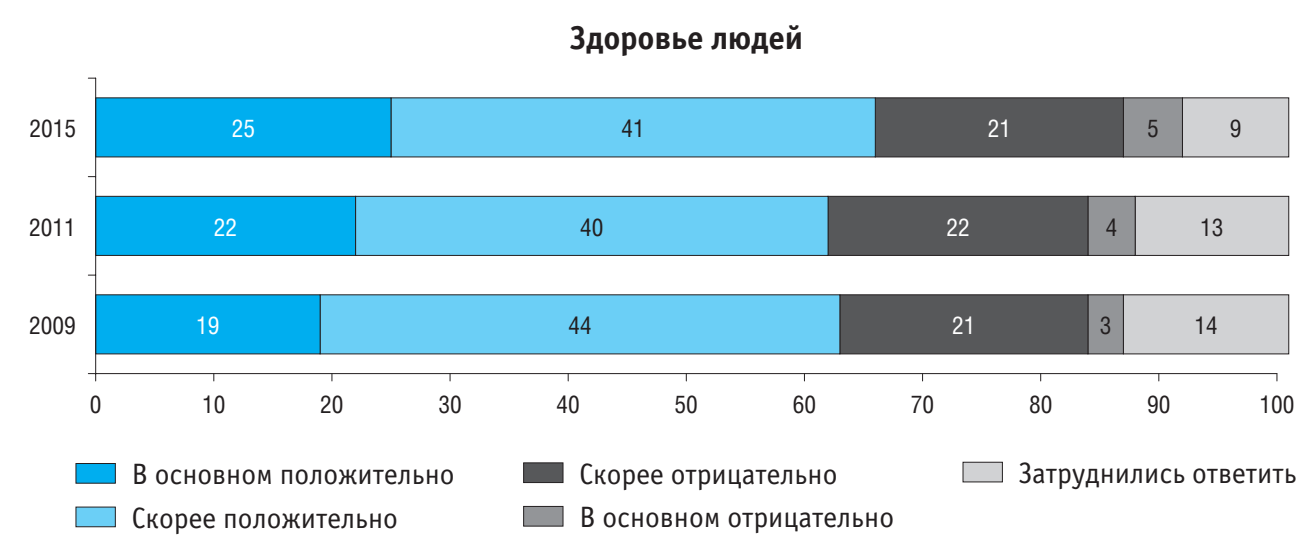




\section{Состояние окружающей среды}

\begin{tabular}{|c|c|c|c|c|c|c|c|c|c|}
\hline 2015 & 14 & & 30 & & \multicolumn{3}{|c|}{34} & 9 & 13 \\
\hline 2011 & 15 & & \multicolumn{2}{|l|}{30} & \multicolumn{3}{|c|}{33} & 8 & 14 \\
\hline \multirow[t]{2}{*}{2009} & 12 & \multicolumn{2}{|c|}{28} & & \multicolumn{2}{|r|}{37} & & 7 & 16 \\
\hline & 10 & 20 & 30 & 40 & 50 & 60 & 70 & 80 & 100 \\
\hline & \multicolumn{3}{|c|}{ В основном положительно } & \multicolumn{4}{|c|}{ Скорее отрицательно } & \multicolumn{2}{|c|}{ Затруднились ответить } \\
\hline | & \multicolumn{3}{|c|}{ Скорее положительно } & & HOM & ате & & & \\
\hline
\end{tabular}




\section{4. ОЦЕНКИ НАСЕЛЕНИЕМ ВЛИЯНИЯ РАЗВИТИЯ НАУКИ, ТЕХНОЛОГИЙ, ТЕХНИКИ НА РАЗЛИЧНЫЕ СТОРОНЫ ЖИЗНИ: 2015* (в процентах от численности опрошенных)}

\section{Россия: Согласны ли Вы со следующими утверждениями?}

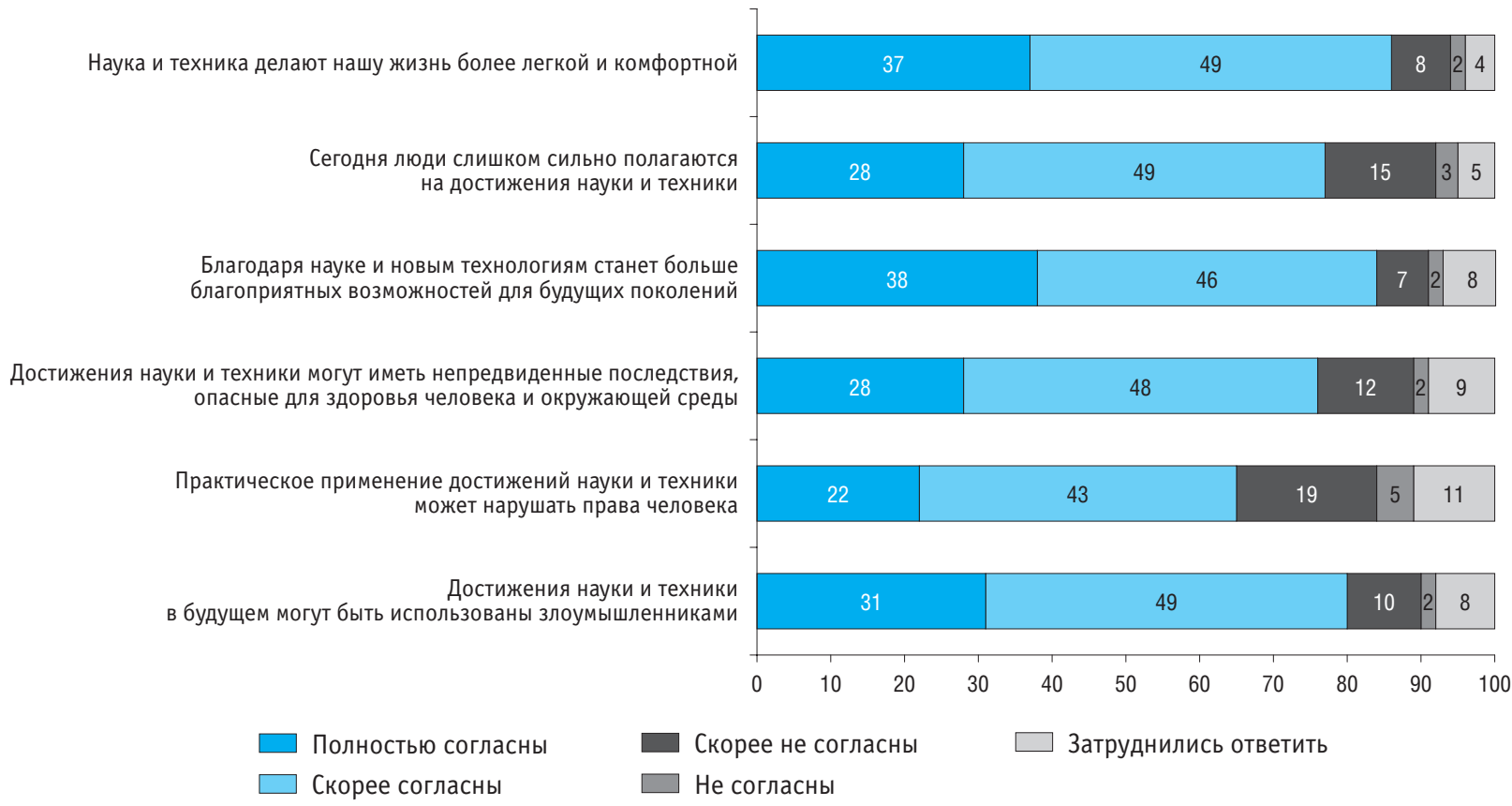

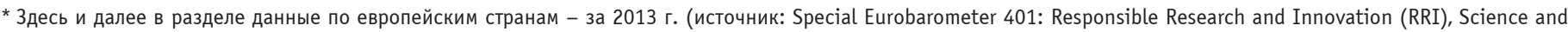
Technology. European Commission, 2013). 
(продолжение)
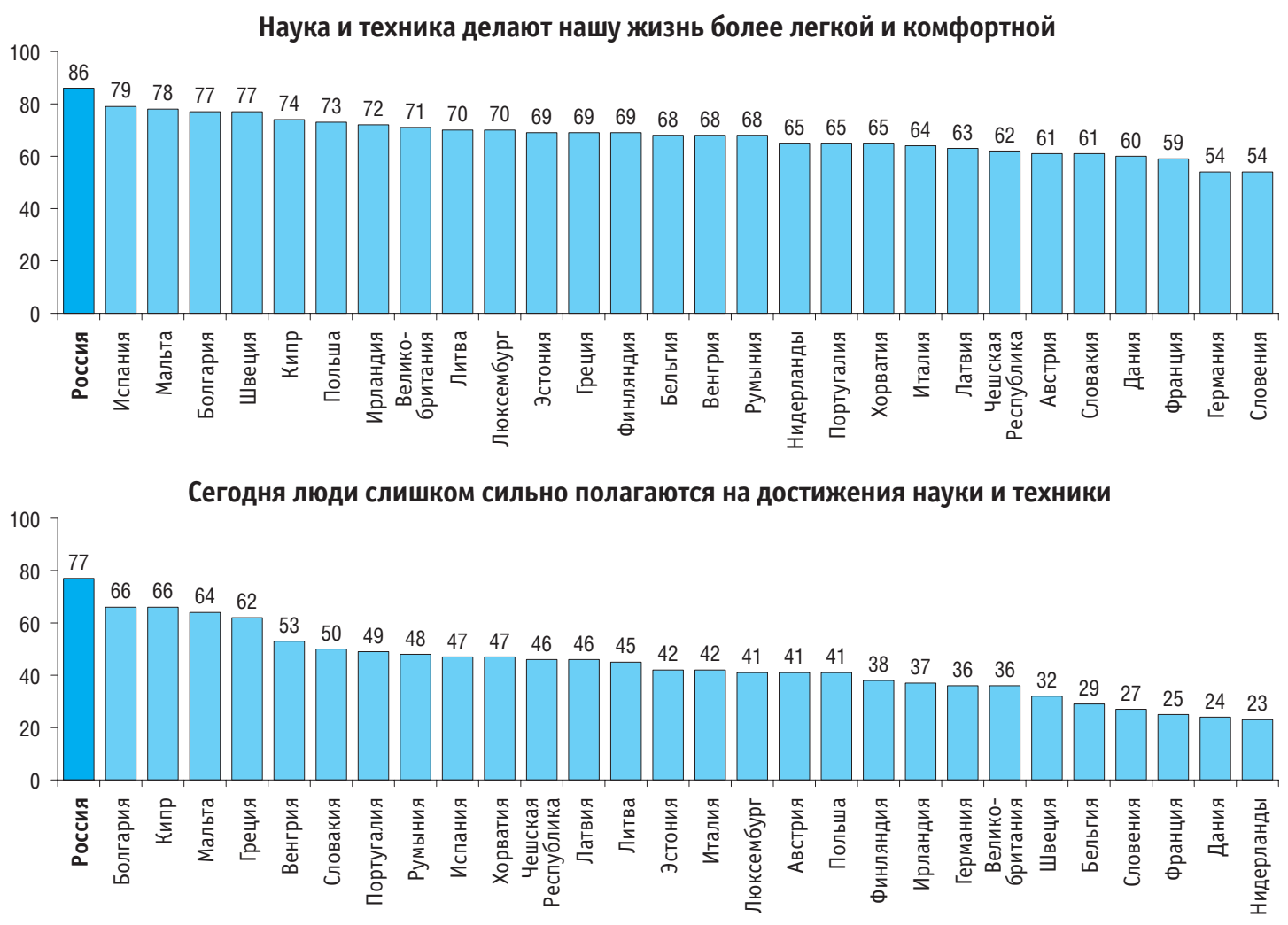
(продолжение)

Благодаря науке и новым технологиям станет больше благоприятных возможностей для будущих поколений

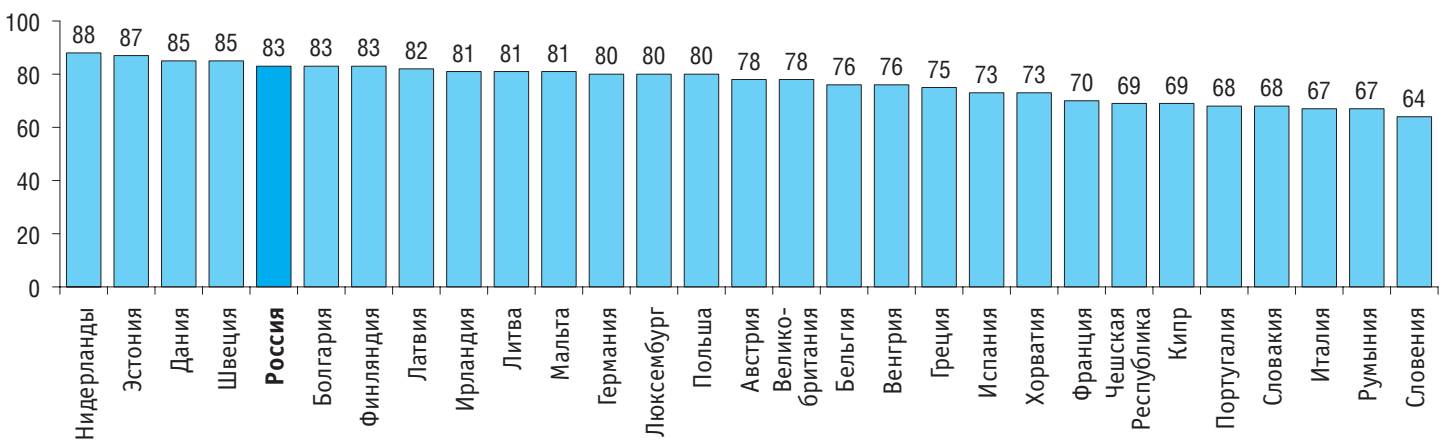

Достижения науки и техники могут иметь непредвиденные последствия, опасные для здоровья человека и и окружающей среды

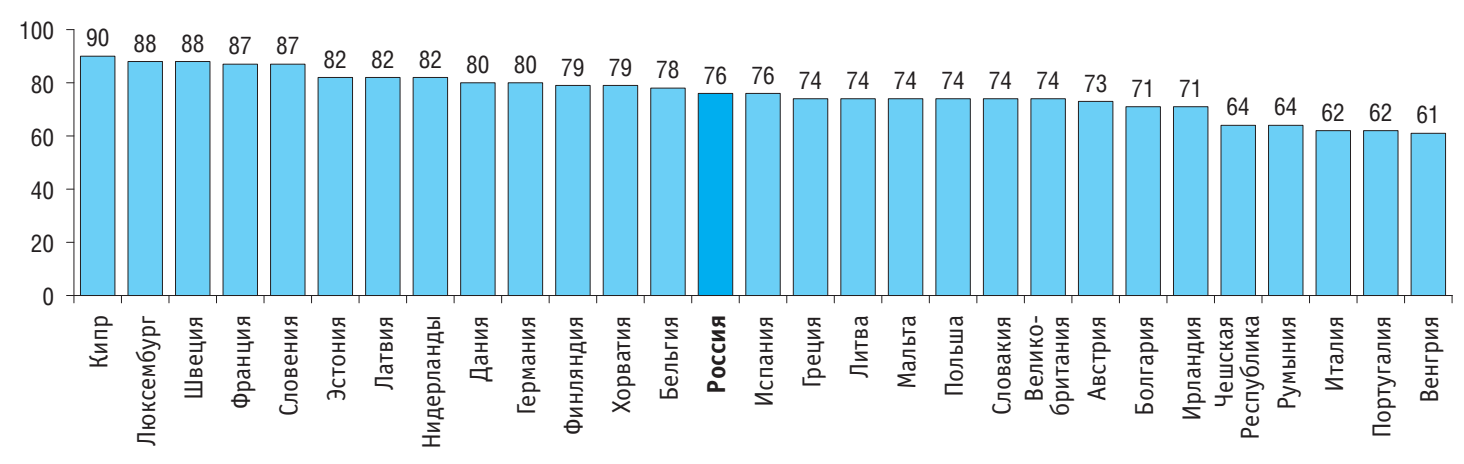




\section{Практическое применение достижений науки и техники может нарушать права человека}

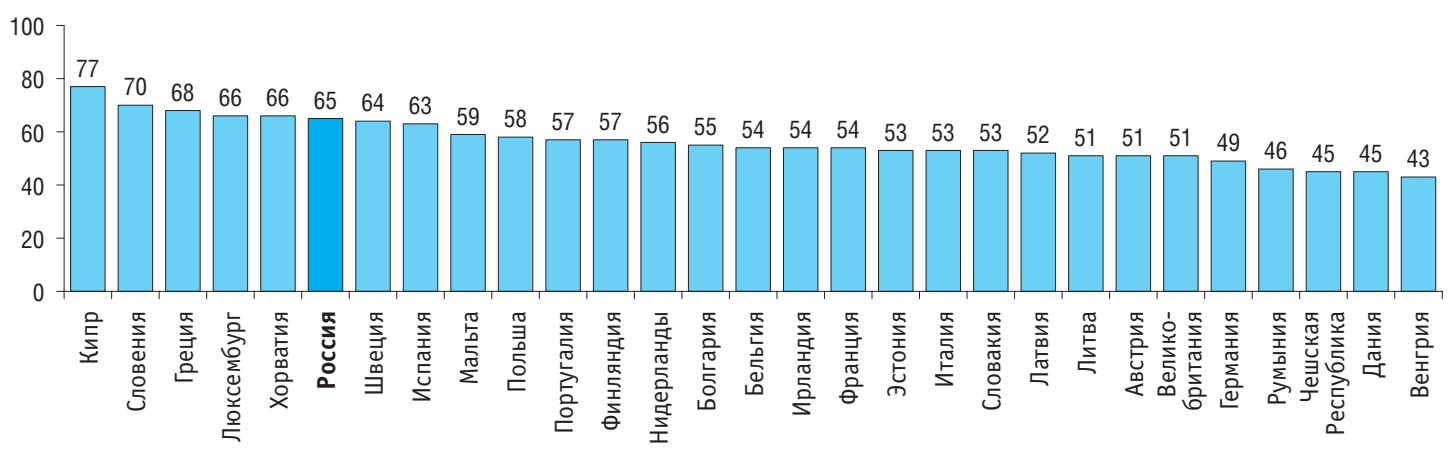

\section{Достижения науки и техники в будущем могут быть использованы злоумышленниками}

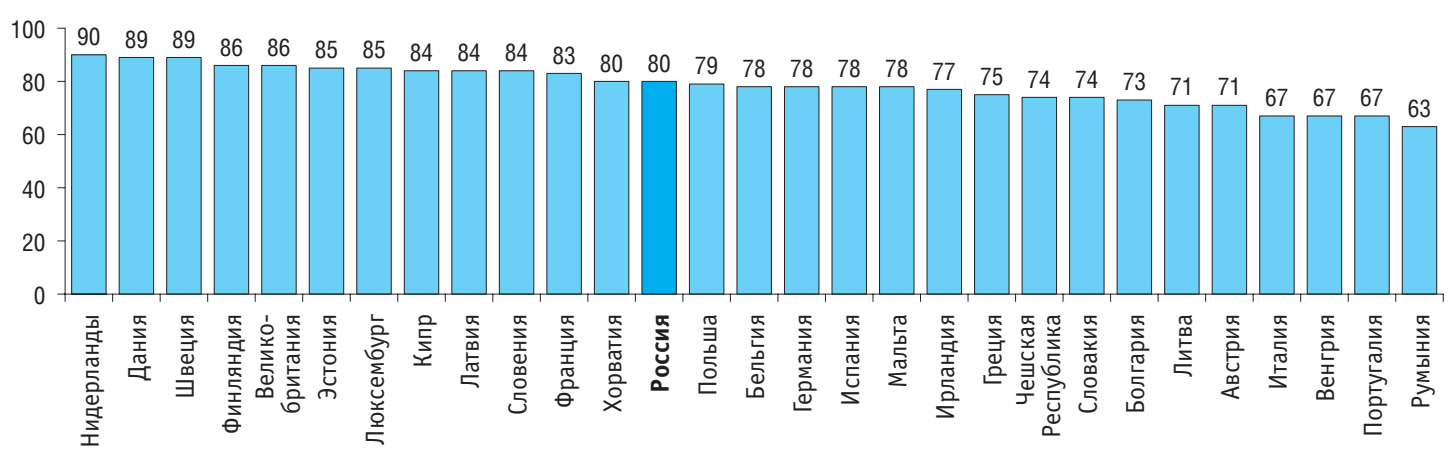




\section{5. ОТНОШЕНИЕ НАСЕЛЕНИЯ РОССИИ К ПРИОБРЕТЕНИЮ И ИСПОЛЬЗОВАНИЮ ТЕХНИЧЕСКИХ НОВИНОК В ПОВСЕДНЕВНОЙ ЖИЗНИ: 2015* \\ (в процентах от численности опрощенных)}

\section{Какие из следующих высказываний наиболее точно отражают Ваше отношение к новинкам?}

Без некоторых видов техники в современной жизни не обойтись

Я покупаю новую технику, только если оценил(а) все «за» и «против» Я приобретаю современную технику, Я не использую те товары и услуги, надежность и безопасность которых вызывает у меня сомнения

Меня восхищают различные технические новинки, и я стараюсь использовать их при любой возможности

Я приобретаю и использую современную технику, чтобы «быть в тренде», не отстать от жизни

Мои дети побуждают нашу семью пользоваться техническими новинками

Мои друзья, родственники или знакомые часто подталкивают меня к покупке технических новинок

Я практически не сталкиваюсь с современной техникой в повседневной жизни

Мне приходится пользоваться некоторыми техническими новинками, поскольку это необходимо мне по работе

Если появляются новые товары или услуги, которые мне интересны, то я покупаю/осваиваю их одним из первых

Современная техника меня пугает

Ни одно из них

Затрудняюсь ответить

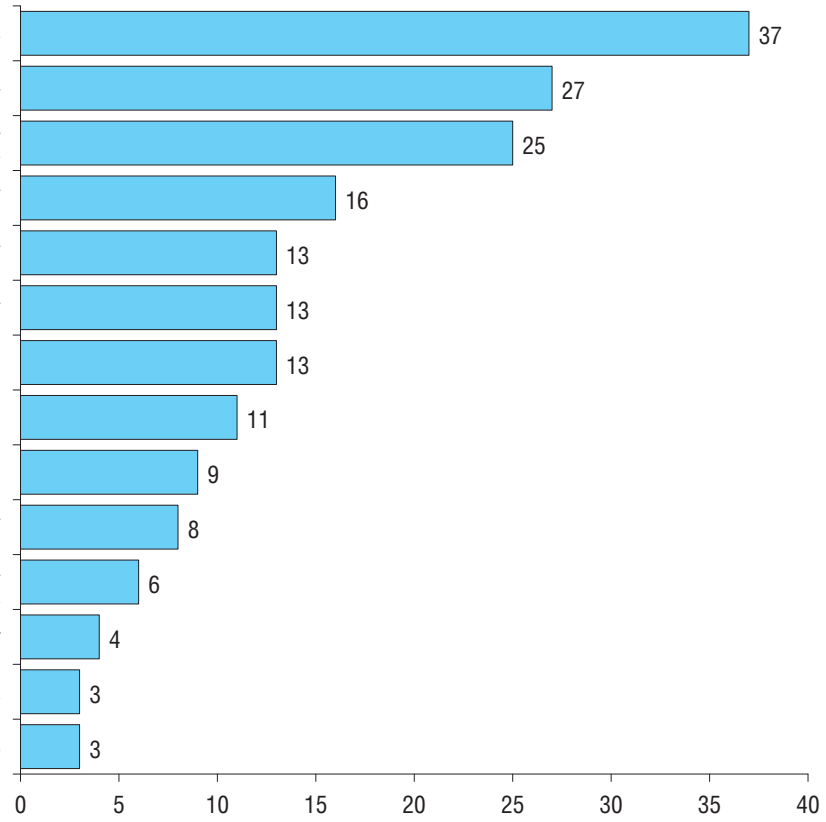

* Сумма превышает 100\%, т.к. респонденты могли выбрать несколько вариантов ответов. 


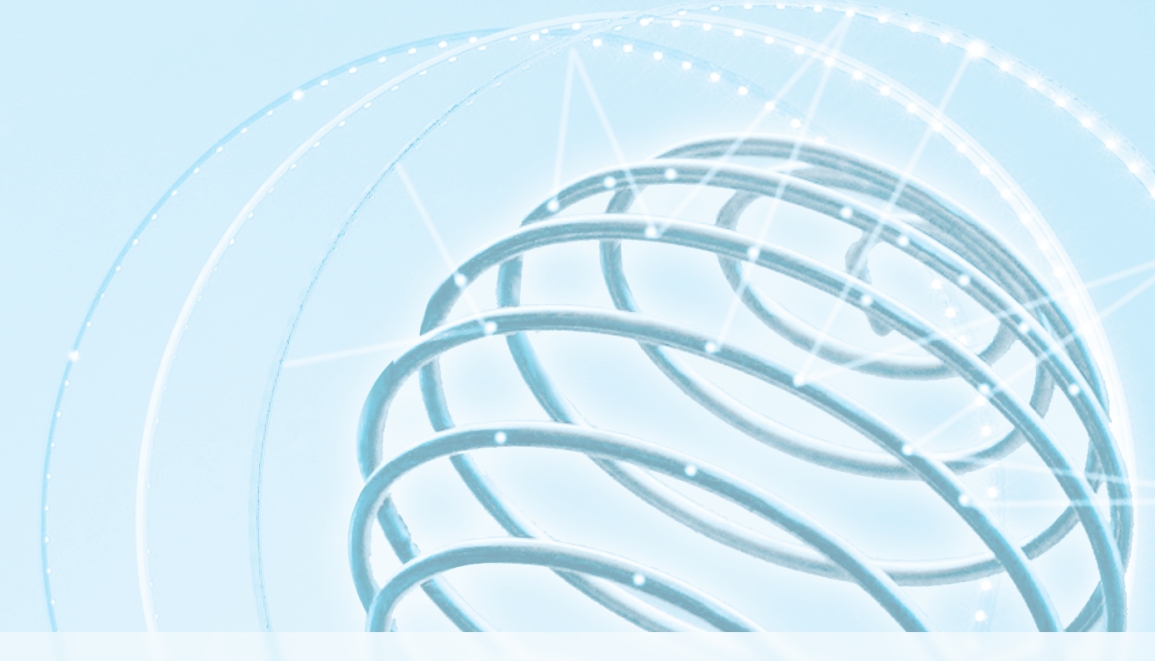

\section{8. Международные сопоставления}




\section{1. ВНУТРЕННИЕ ЗАТРАТЫ НА ИССЛЕДОВАНИЯ И РАЗРАБОТКИ}

(миллионы долларов США; в расчете по паритету покупательной способности национальных валют)

\begin{tabular}{|c|c|c|c|c|c|c|c|c|c|c|c|c|}
\hline & 1995 & 2000 & 2005 & 2007 & 2008 & 2009 & 2010 & 2011 & 2012 & 2013 & 2014 & 2015 \\
\hline Россия & 8122.3 & 10726.9 & 18115.0 & 26543.7 & 30060.9 & 34628.2 & 33062.4 & 35183.1 & 38795.4 & 40683.5 & 39864.9 & 40525.9 \\
\hline \multicolumn{13}{|c|}{ Страны СНГ } \\
\hline Азербайджан & $\ldots$ & 95.6 & 132.3 & 182.1 & 200.2 & 333.0 & 309.1 & 304.7 & 326.6 & 341.3 & 350.7 & $\ldots$ \\
\hline Армения & $\ldots$ & 13.1 & 36.6 & 40.9 & 47.4 & 53.1 & 45.6 & 54.5 & 52.6 & 51.3 & 58.4 & $\ldots$ \\
\hline Беларусь & $\ldots$ & 418.0 & 633.5 & 1135.4 & 983.3 & 860.5 & 1012.6 & 1101.9 & 1086.5 & 1125.4 & $\ldots$ & .. \\
\hline Казахстан & $\ldots$ & 207.3 & 597.4 & 561.2 & 612.9 & 661.6 & 480.9 & 540.7 & 620.8 & 691.4 & $\ldots$ & ... \\
\hline Киргизия & $\ldots$ & 12.6 & 21.6 & 30.2 & 27.1 & 23.6 & 23.2 & 25.2 & 27.2 & 27.5 & 24.5 & $\ldots$ \\
\hline Республика Молдова & $\ldots$ & $\ldots$ & 42.3 & 66.2 & 71.3 & 66.4 & 60.3 & 60.3 & 62.8 & 59.1 & 65.8 & $\ldots$ \\
\hline Таджикистан & $\ldots$ & $\ldots$ & 10.0 & 8.6 & 9.8 & 12.5 & 14.1 & 21.0 & 21.6 & 24.3 & $\ldots$ & $\ldots$ \\
\hline Узбекистан & $\ldots$ & $\ldots$ & $\ldots$ & $\ldots$ & $\ldots$ & $\ldots$ & $\ldots$ & $\ldots$ & $\ldots$ & $\ldots$ & 339.0 & $\ldots$ \\
\hline Украина & $\ldots$ & 1803.7 & 3561.8 & 3184.8 & 3295.7 & 2862.6 & 2929.5 & 2792.8 & 2902.2 & 2984.9 & 2440.8 & .. \\
\hline \multicolumn{13}{|c|}{ Страны 0ЭСР } \\
\hline Австралия & $\ldots$ & 7964.1 & $\ldots$ & $\ldots$ & 19133.0 & $\cdots$ & 20572.2 & 20955.6 & $\ldots$ & 23084.0 & $\ldots$ & $\ldots$ \\
\hline Австрия & 2889.3 & 4476.1 & 6802.5 & 7916.7 & 8854.1 & 8857.6 & 9592.5 & 9906.5 & 11324.6 & 11918.5 & 12498.0 & 12865.4 \\
\hline Бельгия & 3798.7 & 5572.7 & 6171.1 & 7167.8 & 7799.3 & 8065.9 & 8772.0 & 9729.1 & 11023.9 & 11705.0 & 12023.3 & $\ldots$ \\
\hline Великобритания & 21887.3 & 27865.3 & 34080.7 & 38731.0 & 39396.9 & 39420.2 & 38165.6 & 39132.6 & 38811.9 & 41743.4 & 44174.1 & $\ldots$ \\
\hline Венгрия & 667.6 & 977.1 & 1615.7 & 1870.7 & 2058.2 & 2382.0 & 2474.3 & 2696.2 & 2861.0 & 3322.8 & 3389.2 & $\ldots$ \\
\hline Германия & 40190.9 & 52361.4 & 64298.8 & 74015.7 & 81970.7 & 82873.8 & 87966.1 & 96369.6 & 100697.1 & 102573.0 & 108827.2 & ... \\
\hline Греция & 677.1 & $\ldots$ & 1615.5 & 1866.8 & 2284.7 & 2129.8 & 1928.6 & 1986.9 & 2007.4 & 2383.5 & 2447.1 & $\ldots$ \\
\hline Дания & 2186.3 & $\ldots$ & 4418.9 & 5311.2 & 6235.8 & 6715.0 & 6816.5 & 7157.1 & 7424.3 & 7841.6 & 7920.9 & $\ldots$ \\
\hline Израиль & 2663.6 & 6162.8 & 6966.3 & 8728.4 & 8706.4 & 8501.2 & 8658.7 & 9523.4 & 10448.8 & 10998.9 & 11376.5 & $\ldots$ \\
\hline
\end{tabular}


(продолжение)

\begin{tabular}{|c|c|c|c|c|c|c|c|c|c|c|c|c|}
\hline & 1995 & 2000 & 2005 & 2007 & 2008 & 2009 & 2010 & 2011 & 2012 & 2013 & 2014 & 2015 \\
\hline Ирландия & 814.5 & 1222.8 & 2009.4 & 2537.3 & 2738.3 & 3065.7 & 3168.6 & 3203.8 & 3303.7 & 3361.9 & 3402.4 & ... \\
\hline Исландия & 95.1 & 216.5 & 287.1 & 310.6 & 333.6 & 337.8 & $\ldots$ & 314.8 & & 259.0 & 272.3 & \\
\hline Испания & 4997.7 & 7792.3 & 13330.8 & 18314.7 & 20414.9 & 20548.2 & 20350.3 & 20149.1 & 19361.2 & 19318.4 & 19245.9 & $\ldots$ \\
\hline Италия & 11683.5 & 15252.3 & 17999.0 & 22315.0 & 24076.1 & 24640.9 & 25168.9 & 25769.3 & 27164.4 & 28128.1 & 27744.4 & $\ldots$ \\
\hline Канада & 11367.7 & 16746.6 & 23090.0 & 24742.0 & 24911.9 & 25046.8 & 25048.2 & 25674.6 & 26279.0 & 26303.8 & 25813.6 & $\ldots$ \\
\hline Люксембург & $\ldots$ & 387.3 & 495.3 & 639.9 & 682.8 & 683.7 & 655.0 & 705.9 & 621.0 & 678.4 & 688.0 & $\ldots$ \\
\hline Мексика & 1941.5 & 3362.8 & 5346.2 & 5717.1 & 6626.6 & 7009.8 & 7865.7 & 8058.5 & 8574.0 & 10053.4 & 11682.7 & $\ldots$ \\
\hline Нидерланды & 6554.1 & 9065.7 & 10904.4 & 12060.9 & 12467.8 & 12366.2 & 12831.0 & 14736.6 & 15093.7 & 15781.3 & 16291.1 & $\ldots$ \\
\hline Новая Зеландия & 607.3 & $\ldots$ & 1189.3 & 1435.1 & $\ldots$ & 1655.2 & $\ldots$ & 1766.6 & $\ldots$ & 1902.8 & $\ldots$ & $\ldots$ \\
\hline Норвегия & 1733.4 & $\ldots$ & 3315.9 & 4189.7 & 4630.5 & 4675.4 & 4747.1 & 5057.4 & 5317.9 & 5608.4 & 5764.4 & $\ldots$ \\
\hline Польша & 1810.8 & 2605.6 & 2982.4 & 3620.4 & 4150.9 & 4863.1 & 5726.5 & 6394.7 & 7914.3 & 8113.9 & 9031.1 & $\ldots$ \\
\hline Португалия & 708.2 & 1324.6 & 1755.2 & 2989.5 & 3981.9 & 4375.5 & 4365.9 & 4142.4 & 3929.6 & 3874.1 & 3849.9 & $\ldots$ \\
\hline Республика Корея & 13195.6 & 18533.1 & 30618.3 & 40640.3 & 43906.4 & 45987.3 & 52172.8 & 58379.7 & 64862.5 & 68051.5 & 72266.8 & $\ldots$ \\
\hline Словакия & 411.5 & 384.4 & 440.1 & 517.9 & 594.1 & 592.6 & 816.7 & 903.5 & 1140.2 & 1227.8 & 1360.3 & $\ldots$ \\
\hline Словения & 393.0 & 482.3 & 674.9 & 795.3 & 972.6 & 1019.0 & 1163.7 & 1418.6 & 1511.3 & 1560.8 & 1496.1 & $\ldots$ \\
\hline США & 184077.0 & 269513.0 & 328128.0 & 380316.0 & 407238.0 & 406405.0 & 410093.0 & 428745.0 & 436078.0 & 456977.0 & $\ldots$ & $\ldots$ \\
\hline Турция & 1203.9 & 2824.0 & 4617.5 & 7048.0 & 7744.5 & 8864.3 & 9859.3 & 11245.5 & 12731.4 & 13713.5 & 15132.3 & $\ldots$ \\
\hline Финляндия & 2171.2 & 4446.3 & 5601.2 & 6636.5 & 7487.9 & 7512.4 & 7658.3 & 7892.0 & 7486.2 & 7321.7 & 7050.8 & $\ldots$ \\
\hline Франция & 27451.9 & 32969.4 & 39235.7 & 44011.4 & 46547.8 & 49741.1 & 50765.0 & 53428.4 & 54829.9 & 57986.8 & 58750.3 & $\ldots$ \\
\hline Чешская Республика & 1261.7 & 1864.1 & 2664.5 & 3586.1 & 3496.9 & 3659.2 & 3799.0 & 4683.8 & 5406.1 & 6031.9 & 6556.1 & $\ldots$ \\
\hline Чили & $\ldots$ & $\ldots$ & $\ldots$ & 860.9 & 1026.1 & 963.7 & 1027.8 & 1232.1 & 1355.5 & 1471.9 & 1486.9 & $\ldots$ \\
\hline Швейцария & $\ldots$ & 5767.2 & $\ldots$ & $\ldots$ & 10525.2 & $\ldots$ & $\ldots$ & $\ldots$ & 13571.2 & $\ldots$ & $\ldots$ & $\ldots$ \\
\hline Швеция & 6293.1 & $\ldots$ & 10499.9 & 12083.8 & 13496.1 & 12720.7 & 12594.1 & 13419.7 & 13879.5 & 14304.1 & 13882.8 & $\ldots$ \\
\hline Эстония & $\ldots$ & 81.4 & 207.2 & 312.9 & 379.1 & 376.3 & 444.6 & 733.4 & 724.9 & 614.0 & 531.3 & $\ldots$ \\
\hline Япония & 76617.3 & 98758.0 & 128694.6 & 147602.2 & 148719.2 & 136954.0 & 140607.4 & 148389.2 & 152325.6 & 162347.2 & 166861.3 & $\ldots$ \\
\hline
\end{tabular}


(окончание)

\begin{tabular}{|c|c|c|c|c|c|c|c|c|c|c|c|c|}
\hline & 1995 & 2000 & 2005 & 2007 & 2008 & 2009 & 2010 & 2011 & 2012 & 2013 & 2014 & 2015 \\
\hline \multicolumn{13}{|c|}{ Страны ЕС, не входящие в ОЭСР } \\
\hline Болгария & $\ldots$ & 258.6 & 347.4 & 429.0 & 498.8 & 548.9 & 637.0 & 614.9 & 709.7 & 742.7 & 954.5 & $\ldots$ \\
\hline Кипр & $\ldots$ & 32.8 & 74.8 & 98.5 & 107.1 & 124.1 & 127.3 & 128.0 & 120.7 & 124.4 & 124.6 & $\ldots$ \\
\hline Латвия & $\ldots$ & 84.3 & 167.6 & 232.2 & 252.0 & 165.4 & 223.1 & 279.9 & 281.9 & 271.9 & 314.3 & $\ldots$ \\
\hline Литва & $\ldots$ & 178.0 & 364.6 & 498.9 & 524.4 & 479.8 & 487.1 & 617.2 & 644.5 & 723.3 & 794.9 & $\ldots$ \\
\hline Мальта & $\ldots$ & & 48.0 & 55.6 & 58.3 & 58.1 & 75.7 & 83.7 & 105.9 & 109.1 & 111.2 & $\ldots$ \\
\hline Румыния & 974.6 & 468.8 & 831.8 & 1438.4 & 1866.7 & 1493.2 & 1516.6 & 1726.2 & 1738.4 & 1452.9 & 1505.4 & $\ldots$ \\
\hline Хорватия & & 511.0 & 590.4 & 665.1 & 802.3 & 725.4 & 624.1 & 662.5 & 676.8 & 739.8 & 710.2 & $\ldots$ \\
\hline \multicolumn{13}{|c|}{ Другие страны } \\
\hline Аргентина & & 1592.8 & 2037.4 & 2676.2 & 2951.2 & 3410.0 & 4038.3 & 4655.2 & 5454.1 & 5785.0 & 5700.9 & $\ldots$ \\
\hline Бразилия & $\ldots$ & 15834.0 & 20547.2 & 25891.6 & 28943.7 & 28848.3 & 32514.7 & 33904.4 & 35462.2 & 39704.5 & $\ldots$ & $\ldots$ \\
\hline Грузия & $\ldots$ & 24.6 & 32.3 & $\ldots$ & $\ldots$ & $\ldots$ & $\ldots$ & $\ldots$ & $\ldots$ & 26.9 & 33.6 & $\ldots$ \\
\hline Индия & $\ldots$ & 15662.8 & 26532.1 & 32866.2 & 37028.5 & 39401.9 & 42813.4 & 48063.0 & $\ldots$ & $\ldots$ & $\ldots$ & $\ldots$ \\
\hline Индонезия & $\ldots$ & 659.0 & $\ldots$ & $\ldots$ & $\ldots$ & 1553.0 & $\ldots$ & $\ldots$ & $\ldots$ & 2131.9 & $\ldots$ & $\ldots$ \\
\hline Иран & $\ldots$ & $\ldots$ & 5853.6 & $\ldots$ & 7690.5 & 3360.6 & 3537.7 & $\ldots$ & 4170.4 & $\ldots$ & $\ldots$ & $\ldots$ \\
\hline Китай & 12781.9 & 33044.5 & 86827.6 & 124187.1 & 146126.6 & 185266.7 & 213460.1 & 247808.3 & 292062.9 & 333521.6 & 368731.6 & $\ldots$ \\
\hline Малайзия & $\ldots$ & 1405.8 & $\ldots$ & $\ldots$ & 4248.1 & 5400.0 & 6023.5 & 6456.6 & 7329.9 & $\ldots$ & 9679.6 & $\ldots$ \\
\hline Сингапур & 1265.3 & 3003.5 & 5080.1 & 6905.3 & 8036.2 & 6633.2 & 7218.1 & 8359.7 & 8204.7 & 8726.4 & 10054.8 & $\ldots$ \\
\hline Тайвань & 5608.5 & 9182.7 & 15298.9 & 19396.5 & 21536.8 & 22651.1 & 25060.8 & 27422.7 & 29055.1 & 30722.4 & 32440.4 & $\ldots$ \\
\hline ЮAP & $\ldots$ & $\ldots$ & 4051.2 & 4877.7 & 5162.9 & 4819.1 & 4433.3 & 4652.2 & 4824.2 & $\ldots$ & $\ldots$ & $\ldots$ \\
\hline
\end{tabular}




\section{2. ВНУТРЕННИЕ ЗАТРАТЫ НА ИССЛЕДОВАНИЯ И РАЗРАБОТКИ В ПРОЦЕНТАХ \\ К ВАЛОВОМУ ВНУТРЕННЕМУ ПРОДУКТУ: 2015*}

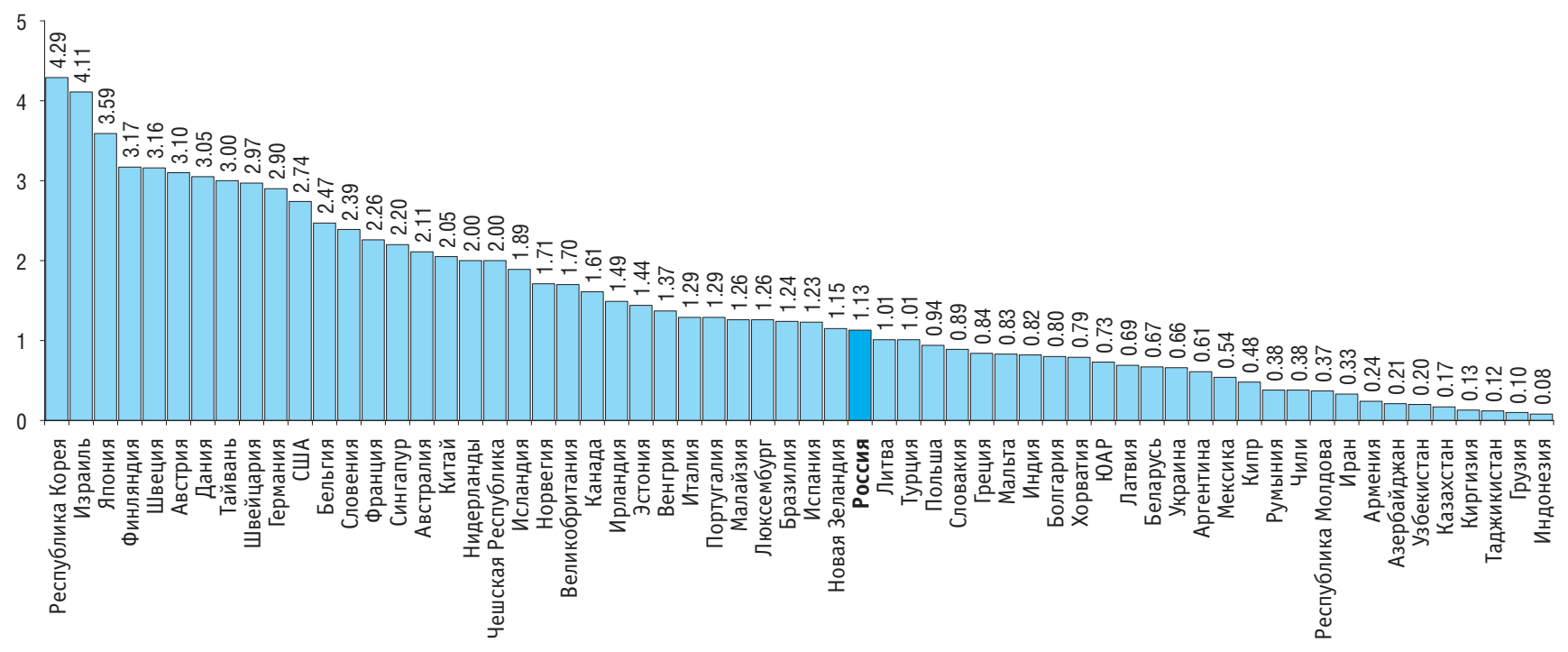

* Или ближайшие годы, по которым имеются данные. 


\section{3. СТРУКТУРА ВНУТРЕННИХ ЗАТРАТ НА ИССЛЕДОВАНИЯ И РАЗРАБОТКИ ПО СЕКТОРАМ НАУКИ: 2015* (проценты)}

\begin{tabular}{|c|c|c|c|c|c|}
\hline & $\begin{array}{c}\text { Внутренние затраты } \\
\text { на исследования } \\
\text { и разработки }\end{array}$ & $\begin{array}{l}\text { Государственный } \\
\text { сектор }\end{array}$ & $\begin{array}{c}\text { Предпринимательский } \\
\text { сектор }\end{array}$ & $\begin{array}{c}\text { Сектор } \\
\text { высшего образования }\end{array}$ & $\begin{array}{c}\text { Сектор } \\
\text { некоммерческих } \\
\text { организаций }\end{array}$ \\
\hline Россия & 100 & 31.1 & 59.2 & 9.6 & 0.1 \\
\hline \multicolumn{6}{|c|}{ Страны СНГ } \\
\hline Азербайджан & 100 & 86.1 & 9.9 & 4.0 & $\ldots$ \\
\hline Армения & 100 & 83.1 & $\ldots$ & 16.9 & $\ldots$ \\
\hline Беларусь & 100 & 23.8 & 65.3 & 10.8 & 0.0 \\
\hline Казахстан & 100 & 29.7 & 29.4 & 30.7 & 10.2 \\
\hline Киргизия & 100 & 64.2 & 14.3 & 14.2 & $\ldots$ \\
\hline Республика Молдова & 100 & 69.6 & 18.4 & 12.0 & $\ldots$ \\
\hline Таджикистан & 100 & 88.3 & $\ldots$ & 11.7 & $\ldots$ \\
\hline Узбекистан & 100 & 48.7 & 31.7 & 18.7 & 0.8 \\
\hline Украина & 100 & 37.8 & 56.4 & 5.8 & $\ldots$ \\
\hline \multicolumn{6}{|c|}{ Страны ОЭСР } \\
\hline Австралия & 100 & 11.2 & 56.3 & 29.6 & 2.8 \\
\hline Австрия & 100 & 4.4 & 70.8 & 24.3 & 0.4 \\
\hline Бельгия & 100 & 8.2 & 71.2 & 20.2 & 0.3 \\
\hline Великобритания & 100 & 7.8 & 64.4 & 26.1 & 1.7 \\
\hline Венгрия & 100 & 13.7 & 71.5 & 13.5 & $\ldots$ \\
\hline Германия & 100 & 14.8 & 67.5 & 17.7 & $\ldots$ \\
\hline Греция & 100 & 27.7 & 33.9 & 37.2 & 1.2 \\
\hline Дания & 100 & 2.3 & 64.0 & 33.2 & 0.4 \\
\hline
\end{tabular}

* Или ближайшие годы, по которым имеются данные. 
(продолжение)

\begin{tabular}{|c|c|c|c|c|c|}
\hline & $\begin{array}{c}\text { Внутренние затраты } \\
\text { на исследования } \\
\text { и разработки }\end{array}$ & $\begin{array}{l}\text { Государственный } \\
\text { сектор }\end{array}$ & $\begin{array}{c}\text { Предпринимательский } \\
\text { сектор }\end{array}$ & $\begin{array}{c}\text { Сектор } \\
\text { высшего образования }\end{array}$ & $\begin{array}{c}\text { Сектор } \\
\text { некоммерческих } \\
\text { организаций }\end{array}$ \\
\hline Израиль & 100 & 1.9 & 84.5 & 12.5 & 1.1 \\
\hline Ирландия & 100 & 4.6 & 74.7 & 20.7 & $\ldots$ \\
\hline Исландия & 100 & 6.5 & 56.8 & 35.3 & 1.4 \\
\hline Испания & 100 & 18.8 & 52.9 & 28.1 & 0.2 \\
\hline Италия & 100 & 14.5 & 55.7 & 26.9 & 2.9 \\
\hline Канада & 100 & 9.2 & 49.9 & 40.4 & 0.5 \\
\hline Люксембург & 100 & 28.9 & 52.6 & 18.5 & $\ldots$ \\
\hline Мексика & 100 & 30.5 & 39.0 & 28.9 & 1.6 \\
\hline Нидерланды & 100 & 11.9 & 56.0 & 32.1 & $\ldots$ \\
\hline Новая Зеландия & 100 & 23.2 & 46.4 & 30.4 & $\ldots$ \\
\hline Норвегия & 100 & 15.2 & 53.7 & 31.0 & $\ldots$ \\
\hline Польша & 100 & 24.0 & 46.6 & 29.2 & 0.3 \\
\hline Португалия & 100 & 6.3 & 46.4 & 45.6 & 1.7 \\
\hline Республика Корея & 100 & 11.2 & 78.2 & 9.0 & 1.5 \\
\hline Словакия & 100 & 28.3 & 36.8 & 34.4 & 0.4 \\
\hline Словения & 100 & 12.2 & 77.3 & 10.5 & 0.0 \\
\hline США & 100 & 11.2 & 70.6 & 14.2 & 4.1 \\
\hline Турция & 100 & 9.7 & 49.8 & 40.5 & $\ldots$ \\
\hline Финляндия & 100 & 8.6 & 67.7 & 22.9 & 0.8 \\
\hline Франция & 100 & 13.1 & 64.8 & 20.6 & 1.5 \\
\hline Чешская Республика & 100 & 18.2 & 56.0 & 25.4 & 0.4 \\
\hline Чили & 100 & 8.1 & 33.5 & 38.9 & 19.5 \\
\hline Швейцария & 100 & 0.8 & 69.3 & 28.1 & 1.8 \\
\hline Швеция & 100 & 3.7 & 67.0 & 29.0 & 0.2 \\
\hline Эстония & 100 & 11.0 & 43.5 & 44.3 & 1.2 \\
\hline Япония & 100 & 8.3 & 77.8 & 12.6 & 1.3 \\
\hline
\end{tabular}


(окончание)

\begin{tabular}{|c|c|c|c|c|c|}
\hline & $\begin{array}{c}\text { Внутренние затраты } \\
\text { на исследования } \\
\text { и разработки }\end{array}$ & $\begin{array}{c}\text { Государственный } \\
\text { сектор }\end{array}$ & $\begin{array}{c}\text { Предпринимательский } \\
\text { сектор }\end{array}$ & $\begin{array}{c}\text { Сектор } \\
\text { высшего образования }\end{array}$ & $\begin{array}{c}\text { Сектор } \\
\text { некоммерческих } \\
\text { организаций }\end{array}$ \\
\hline
\end{tabular}

\section{Страны ЕС, не входящие в ОЭСР}

$\begin{array}{lc}\text { Болгария } & 100 \\ \text { Кипр } & 100 \\ \text { Латвия } & 100 \\ \text { Литва } & 100 \\ \text { Мальта } & 100 \\ \text { Румыния } & 100 \\ \text { Хорватия } & 100\end{array}$

\section{0}

100

100

100

100

100

100

\section{Аргентина \\ Грузия \\ Индия \\ Индонезия \\ Иран \\ Китай \\ Малайзия \\ Сингапур \\ Тайвань \\ ЮАР}

$$
\begin{array}{r}
24.7 \\
13.7 \\
24.0 \\
17.3 \\
9.0 \\
43.0 \\
26.1
\end{array}
$$$$
24.0
$$$$
17.3
$$$$
9.0
$$

\section{Другие страны}

47.7

60.5

39.4

56.1

15.8

8.2

11.4

12.6

22.9

\section{7}

17.3

35.5

29.6

59.8

41.5

48.3

$\begin{array}{rr}8.8 & 0.8 \\ 52.7 & 16.3 \\ 40.5 & \ldots \\ 53.1 & \ldots \\ 31.2 & \ldots \\ 15.2 & 0.4 \\ 25.7 & \ldots\end{array}$

30.5

100.0

4.1

34.9

33.3

6.9

46.1

27.4

10.0

30.7
0.8

6.3

... 


\section{4. СТРУКТУРА ВНУТРЕННИХ ЗАТРАТ НА ИССЛЕДОВАНИЯ И РАЗРАБОТКИ ПО ИСТОЧНИКАМ ФИНАНСИРОВАНИЯ: 2015*}

(проценты)

\begin{tabular}{|c|c|c|c|c|c|}
\hline & $\begin{array}{c}\text { Внутренние затраты } \\
\text { на исследования } \\
\text { и разработки }\end{array}$ & $\begin{array}{c}\text { Средства } \\
\text { государства }\end{array}$ & $\begin{array}{c}\text { Средства } \\
\text { предпринимательского } \\
\text { сектора }\end{array}$ & $\begin{array}{c}\text { Другие } \\
\text { национальные } \\
\text { источники }\end{array}$ & $\begin{array}{c}\text { Иностранные } \\
\text { источники }\end{array}$ \\
\hline Россия & 100 & $69.5^{\star *}$ & 26.5 & 1.4 & 2.6 \\
\hline \multicolumn{6}{|c|}{ Страны СНГ } \\
\hline Азербайджан & 100 & 67.6 & 30.5 & 1.7 & 0.2 \\
\hline Армения & 100 & 71.0 & $\ldots$ & $\ldots$ & 5.1 \\
\hline Беларусь & 100 & 48.3 & 43.8 & $\ldots$ & 7.9 \\
\hline Казахстан & 100 & 63.7 & 28.9 & $\ldots$ & 0.8 \\
\hline Киргизия & 100 & 90.4 & 7.4 & 0.2 & 1.0 \\
\hline Республика Молдова & 100 & $\ldots$ & $\ldots$ & $\ldots$ & 12.8 \\
\hline Таджикистан & 100 & 92.5 & $\ldots$ & 0.2 & 0.2 \\
\hline Узбекистан & 100 & 58.9 & 35.9 & $\ldots$ & 0.8 \\
\hline Украина & 100 & 43.8 & 35.2 & 0.2 & 19.8 \\
\hline \multicolumn{6}{|c|}{ Страны ОЭСР } \\
\hline Австралия & 100 & 34.6 & 61.9 & 1.9 & 1.6 \\
\hline Австрия & 100 & 36.6 & 47.0 & 0.5 & 15.9 \\
\hline Бельгия & 100 & 28.5 & 56.9 & 1.4 & 13.2 \\
\hline Великобритания & 100 & 28.8 & 46.5 & 5.8 & 18.9 \\
\hline Венгрия & 100 & 33.5 & 48.3 & 0.7 & 17.5 \\
\hline Германия & 100 & 28.8 & 65.8 & 0.3 & 5.0 \\
\hline Греция & 100 & 53.3 & 29.8 & 3.7 & 13.2 \\
\hline Дания & 100 & 30.4 & 57.9 & 4.3 & 7.4 \\
\hline
\end{tabular}

* Или ближайшие годы, по которым имеются данные.

** Включая средства бюджета, бюджетные ассигнования на содержание образовательных организаций высшего образования, средства организаций государственного сектора (в том числе собственные). 
(продолжение)

\begin{tabular}{|c|c|c|c|c|c|}
\hline & $\begin{array}{c}\text { Внутренние затраты } \\
\text { на исследования } \\
\text { и разработки }\end{array}$ & $\begin{array}{c}\text { Средства } \\
\text { государства }\end{array}$ & $\begin{array}{c}\text { Средства } \\
\text { предпринимательского } \\
\text { сектора }\end{array}$ & $\begin{array}{c}\text { Другие } \\
\text { национальные } \\
\text { источники }\end{array}$ & $\begin{array}{c}\text { Иностранные } \\
\text { источники }\end{array}$ \\
\hline Израиль & 100 & 12.7 & 36.5 & 2.0 & 48.8 \\
\hline Ирландия & 100 & 24.6 & 54.5 & 1.1 & 19.8 \\
\hline Исландия & 100 & 35.0 & 39.2 & 5.8 & 20.1 \\
\hline Испания & 100 & 41.4 & 46.4 & 4.8 & 7.4 \\
\hline Италия & 100 & 41.4 & 45.2 & 3.7 & 9.7 \\
\hline Канада & 100 & 34.6 & 45.4 & 14.0 & 6.0 \\
\hline Люксембург & 100 & 48.4 & 16.5 & 2.8 & 32.3 \\
\hline Мексика & 100 & 73.6 & 23.8 & 2.2 & 0.5 \\
\hline Нидерланды & 100 & 33.2 & 51.1 & 3.1 & 12.7 \\
\hline Новая Зеландия & 100 & 39.8 & 39.8 & 13.2 & 7.2 \\
\hline Норвегия & 100 & 45.8 & 43.1 & 1.6 & 9.5 \\
\hline Польша & 100 & 45.2 & 39.0 & 2.4 & 13.4 \\
\hline Португалия & 100 & 46.4 & 42.3 & 5.2 & 6.1 \\
\hline Республика Корея & 100 & 23.0 & 75.3 & 1.0 & 0.7 \\
\hline Словакия & 100 & 41.4 & 32.2 & 2.7 & 23.7 \\
\hline Словения & 100 & 21.8 & 68.4 & 0.6 & 9.3 \\
\hline США & 100 & 27.7 & 60.9 & 6.9 & 4.5 \\
\hline Турция & 100 & 26.3 & 50.9 & 21.8 & 1.1 \\
\hline Финляндия & 100 & 27.5 & 53.5 & 1.7 & 17.3 \\
\hline Франция & 100 & 35.2 & 55.0 & 1.7 & 8.0 \\
\hline Чешская Республика & 100 & 32.9 & 35.9 & 0.7 & 30.5 \\
\hline Чили & 100 & 44.1 & 32.0 & 10.2 & 13.8 \\
\hline Швейцария & 100 & 25.4 & 60.8 & 1.7 & 12.1 \\
\hline Швеция & 100 & 28.3 & 61.0 & 4.1 & 6.7 \\
\hline Эстония & 100 & 49.5 & 37.1 & 1.0 & 12.5 \\
\hline Япония & 100 & 16.0 & 77.3 & 6.3 & 0.4 \\
\hline
\end{tabular}




\section{(окончание)}

\begin{tabular}{|c|c|c|c|c|c|}
\hline & $\begin{array}{c}\text { Внутренние затраты } \\
\text { на исследования } \\
\text { и разработки }\end{array}$ & $\begin{array}{l}\text { Средства } \\
\text { государства }\end{array}$ & $\begin{array}{c}\text { Средства } \\
\text { предпринимательского } \\
\text { сектора }\end{array}$ & $\begin{array}{c}\text { Другие } \\
\text { национальные } \\
\text { источники }\end{array}$ & $\begin{array}{c}\text { Иностранные } \\
\text { источники }\end{array}$ \\
\hline \multicolumn{6}{|c|}{ Страны ЕС, не входящие в ОЭСР } \\
\hline Болгария & 100 & 31.6 & 19.5 & 0.6 & 48.3 \\
\hline Кипр & 100 & 62.1 & 12.1 & 6.2 & 19.6 \\
\hline Латвия & 100 & 25.6 & 27.8 & 2.3 & 44.2 \\
\hline Литва & 100 & 33.7 & 31.7 & 0.4 & 34.3 \\
\hline Мальта & 100 & 27.2 & 50.0 & 1.3 & 21.5 \\
\hline Румыния & 100 & 48.5 & 32.9 & 1.5 & 17.0 \\
\hline Хорватия & 100 & 41.7 & 42.9 & 2.6 & 12.8 \\
\hline \multicolumn{6}{|c|}{ Другие страны } \\
\hline Аргентина & 100 & 75.4 & 21.4 & 2.5 & 0.7 \\
\hline Бразилия & 100 & 57.7 & 40.3 & 1.9 & $\ldots$ \\
\hline Грузия & 100 & 42.1 & $\ldots$ & 43.9 & 14.0 \\
\hline Индонезия & 100 & 84.5 & 14.7 & 0.2 & $\ldots$ \\
\hline Иран & 100 & 61.6 & 30.9 & 7.4 & $\ldots$ \\
\hline Китай & 100 & 20.3 & 75.4 & $\ldots$ & 0.8 \\
\hline Малайзия & 100 & 29.7 & 60.2 & 2.5 & 4.6 \\
\hline Сингапур & 100 & 37.1 & 54.1 & 2.0 & 6.8 \\
\hline Тайвань & 100 & 21.7 & 77.2 & 1.0 & 0.1 \\
\hline ЮАР & 100 & 45.4 & 38.3 & 3.2 & 13.1 \\
\hline
\end{tabular}




\section{5. СТРУКТУРА ВНУТРЕННИХ ЗАТРАТ НА ИССЛЕДОВАНИЯ И РАЗРАБОТКИ ПО ОБЛАСТЯМ НАУКИ: 2015*} (проченты)

\begin{tabular}{|c|c|c|c|c|c|c|c|}
\hline & Всего & $\begin{array}{c}\text { Естественные } \\
\text { науки }\end{array}$ & $\begin{array}{l}\text { Технические } \\
\text { науки }\end{array}$ & $\begin{array}{l}\text { Медицинские } \\
\text { науки }\end{array}$ & $\begin{array}{c}\text { Сельскохозяйствен- } \\
\text { ные науки }\end{array}$ & $\begin{array}{c}\text { 0бщественные } \\
\text { науки }\end{array}$ & $\begin{array}{l}\text { Гуманитарныє } \\
\text { науки }\end{array}$ \\
\hline Россия & 100 & 17.4 & 73.4 & 3.5 & 1.6 & 2.6 & 1.5 \\
\hline \multicolumn{8}{|c|}{ Страны СНГ } \\
\hline Азербайджан & 100 & 24.2 & 48.4 & 6.4 & 5.7 & 6.9 & 8.4 \\
\hline Армения & 100 & 45.9 & 23.4 & 2.9 & 0.7 & 6.6 & 12.1 \\
\hline Беларусь & 100 & 17.0 & 68.2 & 4.3 & 5.6 & 3.8 & 1.1 \\
\hline Казахстан & 100 & 36.3 & 38.8 & 5.6 & 9.1 & 4.6 & 5.6 \\
\hline Киргизия & 100 & 49.8 & 19.2 & 10.8 & 9.9 & 2.0 & 8.2 \\
\hline Республика Молдова & 100 & 39.8 & 18.7 & 10.4 & 15.4 & 9.4 & 6.3 \\
\hline Таджикистан & 100 & 24.5 & 10.9 & 6.7 & 26.6 & 10.3 & 21.0 \\
\hline Узбекистан & 100 & 31.1 & 36.2 & 7.4 & 7.5 & 11.0 & 6.7 \\
\hline Украина & 100 & 19.6 & 57.7 & 5.5 & 6.2 & 4.7 & 1.9 \\
\hline \multicolumn{8}{|c|}{ Страны ОЭСР } \\
\hline Австралия & 100 & 30.8 & 41.8 & 15.2 & 4.8 & 6.0 & 1.5 \\
\hline Великобритания & 100 & 7.2 & 5.2 & 8.0 & 1.4 & 6.7 & 6.2 \\
\hline Венгрия & 100 & 25.2 & 53.9 & 7.2 & 5.9 & 3.7 & 2.8 \\
\hline Греция & 100 & 15.1 & 39.9 & 20.5 & 4.7 & 8.4 & 11.3 \\
\hline Исландия & 100 & 15.9 & 47.5 & 4.8 & 8.7 & 19.3 & 3.8 \\
\hline Испания & 100 & 19.1 & 53.1 & 14.2 & 5.9 & 5.1 & 2.5 \\
\hline Мексика & 100 & 20.8 & 44.2 & 10.5 & 6.4 & 12.2 & 5.9 \\
\hline Нидерланды & 100 & 20.3 & 41.5 & 16.4 & 9.0 & 9.6 & 3.2 \\
\hline Польша & 100 & 21.3 & 52.9 & 10.5 & 5.1 & 6.4 & 3.8 \\
\hline Португалия & 100 & 24.0 & 41.6 & 12.3 & 3.6 & 11.7 & 7.0 \\
\hline Республика Корея & 100 & 13.8 & 68.6 & 11.8 & 2.2 & 2.2 & 1.4 \\
\hline Словакия & 100 & 17.8 & 48.8 & 10.0 & 6.9 & 10.3 & 6.2 \\
\hline
\end{tabular}

* Или ближайшие годы, по которым имеются данные. 
(окончание)

\begin{tabular}{|c|c|c|c|c|c|c|c|}
\hline & Всего & $\begin{array}{c}\text { Естественные } \\
\text { науки }\end{array}$ & $\begin{array}{l}\text { Технические } \\
\text { науки }\end{array}$ & $\begin{array}{c}\text { Медицинские } \\
\text { науки }\end{array}$ & $\begin{array}{c}\text { Сельскохозяйствен- } \\
\text { ные науки }\end{array}$ & $\begin{array}{c}\text { Общественные } \\
\text { науки }\end{array}$ & $\begin{array}{c}\text { Гуманитарные } \\
\text { науки }\end{array}$ \\
\hline Словения & 100 & 34.9 & 53.7 & 2.8 & 2.1 & 3.9 & 2.7 \\
\hline Турция & 100 & 10.6 & 54.6 & 15.0 & 4.4 & 10.1 & 5.2 \\
\hline Чешская Республика & 100 & 33.2 & 50.2 & 7.9 & 2.2 & 3.5 & 3.1 \\
\hline Чили & 100 & 32.0 & 32.5 & 11.6 & 14.1 & 7.7 & 2.0 \\
\hline \multicolumn{8}{|c|}{ Страны EС, не входящие в ОЭСР } \\
\hline Болгария & 100 & 18.1 & 23.7 & 43.3 & 6.9 & 3.6 & 4.3 \\
\hline Кипр & 100 & 36.6 & 25.4 & 3.7 & 9.2 & 16.7 & 8.4 \\
\hline Латвия & 100 & 31.9 & 34.0 & 11.1 & 9.1 & 10.7 & 3.3 \\
\hline Литва & 100 & 24.2 & 15.2 & 10.0 & 4.7 & 11.6 & 8.9 \\
\hline Мальта & 100 & 26.4 & 29.6 & 22.4 & 3.0 & 11.2 & 5.8 \\
\hline Румыния & 100 & 28.3 & 42.3 & 12.3 & $\ldots$ & 4.2 & 4.6 \\
\hline Хорватия & 100 & 21.4 & 41.1 & 16.0 & 7.9 & 8.7 & 4.8 \\
\hline \multicolumn{8}{|c|}{ Другие страны } \\
\hline Аргентина & 100 & 23.1 & 36.5 & 9.8 & 11.3 & 12.4 & 6.0 \\
\hline Грузия & 100 & 13.6 & 21.9 & 15.7 & $\ldots$ & 15.3 & 17.4 \\
\hline Индия & 100 & 22.6 & 47.6 & 6.8 & 14.5 & 2.9 & $\ldots$ \\
\hline Китай & 100 & 16.6 & 70.8 & 3.4 & 7.1 & $2.1^{* *}$ & $\ldots$ \\
\hline Малайзия & 100 & 47.2 & 31.1 & 5.9 & 7.6 & 7.0 & 1.2 \\
\hline Сингапур & 100 & 11.6 & 61.0 & 18.1 & 2.8 & $\ldots$ & $\ldots$ \\
\hline Тайвань & 100 & 10.5 & 76.9 & 7.0 & 2.2 & 2.4 & 1.0 \\
\hline ЮАР & 100 & 33.0 & 27.3 & 17.2 & 7.7 & 12.6 & 2.2 \\
\hline
\end{tabular}

* Или ближайшие годы, по которым имеются данные.

** Включая гуманитарные науки. 
8.6. СТРУКТУРА ВНУТРЕННИХ ТЕКУЩИХ ЗАТРАТ НА ИССЛЕДОВАНИЯ И РАЗРАБОТКИ ПО ВИДАМ РАБОТ: 2015* (проценты)

\begin{tabular}{|c|c|c|c|c|}
\hline & $\begin{array}{c}\text { Внутренние текущие затраты } \\
\text { на исследования } \\
\text { и разработки }\end{array}$ & $\begin{array}{c}\text { Фундаментальные } \\
\text { исследования }\end{array}$ & $\begin{array}{c}\text { Прикладные } \\
\text { исследования }\end{array}$ & Разработки \\
\hline Россия & 100 & 15.5 & 19.9 & 64.7 \\
\hline \multicolumn{5}{|c|}{ Страны СНГ } \\
\hline Азербайджан & 100 & 52.2 & 21.2 & 2.6 \\
\hline Армения & 100 & 34.3 & 9.6 & 56.1 \\
\hline Беларусь & 100 & 14.2 & 26.1 & 59.7 \\
\hline Казахстан ** & 100 & 29.5 & 54.1 & 16.4 \\
\hline Киргизия & 100 & 53.1 & 10.2 & 36.7 \\
\hline Республика Молдова & 100 & 26.4 & 56.2 & 17.4 \\
\hline Таджикистан & 100 & 62.7 & 21.6 & 15.7 \\
\hline Узбекистан & 100 & 22.6 & 41.8 & 28.8 \\
\hline Украина & 100 & 24.6 & 16.5 & 47.8 \\
\hline \multicolumn{5}{|c|}{ Страны ОЭСР } \\
\hline Австралия * * & 100 & 20.1 & 38.7 & 41.2 \\
\hline Австрия** & 100 & 18.9 & 35.6 & 43.9 \\
\hline Бельгия** & 100 & 19.9 & 38.7 & 41.4 \\
\hline Великобритания & 100 & 13.1 & 46.2 & 40.7 \\
\hline Венгрия & 100 & 19.9 & 31.1 & 48.9 \\
\hline Греция** & 100 & 34.6 & 38.9 & 26.5 \\
\hline Дания & 100 & 19.1 & 36.9 & 44.1 \\
\hline Израиль & 100 & 10.2 & 11.1 & 78.6 \\
\hline Ирландия** & 100 & 18.3 & 33.0 & 48.7 \\
\hline Исландия & 100 & 36.7 & 28.9 & 30.2 \\
\hline Испания & 100 & 22.9 & 41.3 & 35.8 \\
\hline
\end{tabular}


(продолжение)

\begin{tabular}{|c|c|c|c|c|}
\hline & $\begin{array}{c}\text { Внутренние текущие затраты } \\
\text { на исследования } \\
\text { и разработки }\end{array}$ & $\begin{array}{c}\text { Фундаментальные } \\
\text { исследования }\end{array}$ & $\begin{array}{c}\text { Прикладные } \\
\text { исследования }\end{array}$ & Разработки \\
\hline Италия** & 100 & 25.4 & 48.0 & 26.7 \\
\hline Мексика** & 100 & 24.4 & 30.8 & 44.8 \\
\hline Нидерланды** & 100 & 28.7 & 45.5 & 25.8 \\
\hline Новая Зеландия** & 100 & 25.2 & 39.1 & 35.8 \\
\hline Норвегия & 100 & 18.8 & 39.5 & 41.6 \\
\hline Польша & 100 & 34.3 & 21.6 & 44.1 \\
\hline Португалия & 100 & 24.8 & 41.1 & 34.1 \\
\hline Республика Корея** & 100 & 17.6 & 18.9 & 63.4 \\
\hline Словакия & 100 & 44.1 & 25.4 & 30.6 \\
\hline Словения & 100 & 13.9 & 50.5 & 35.6 \\
\hline США & 100 & 17.6 & 19.9 & 62.5 \\
\hline Франция** & 100 & 24.2 & 37.9 & 34.5 \\
\hline Чешская Республика* * & 100 & 32.9 & 32.4 & 34.7 \\
\hline Чили & 100 & 35.2 & 32.9 & 31.9 \\
\hline Швейцария * * & 100 & 30.4 & 40.7 & 28.9 \\
\hline Эстония & 100 & 28.7 & 32.5 & 38.8 \\
\hline Япония ** & 100 & 12.3 & 19.9 & 63.4 \\
\hline \multicolumn{5}{|c|}{ Страны ЕС, не входящие в ОЭСР } \\
\hline Болгария** & 100 & 12.5 & 73.8 & 13.7 \\
\hline Кипр** & 100 & 20.8 & 62.6 & 16.6 \\
\hline Латвия** & 100 & 24.4 & 56.5 & 19.1 \\
\hline Литва** & 100 & 30.9 & 45.6 & 23.5 \\
\hline Мальта** & 100 & 54.7 & 20.8 & 9.8 \\
\hline Румыния & 100 & 38.4 & 41.9 & 19.7 \\
\hline Хорватия** & 100 & 33.2 & 33.9 & 32.9 \\
\hline
\end{tabular}


(окончание)

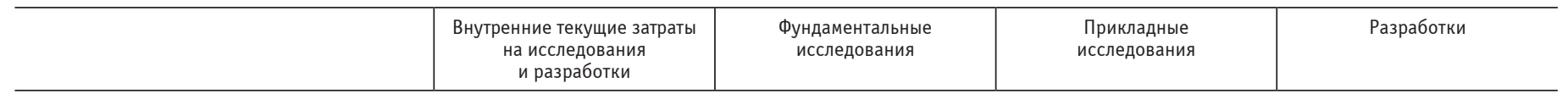

\begin{tabular}{|c|c|c|c|c|}
\hline \\
\hline Аргентина** & 100 & 33.5 & 45.7 & 20.8 \\
\hline Грузия** & 100 & 23.7 & 8.7 & 0.3 \\
\hline Индия** & 100 & 16.0 & 22.3 & 23.5 \\
\hline Китай ${ }^{* *}$ & 100 & 4.7 & 10.7 & 84.5 \\
\hline Малайзия & 100 & 16.9 & 75.5 & 7.5 \\
\hline Сингапур** & 100 & 20.5 & 33.2 & 46.4 \\
\hline Тайвань** & 100 & 9.0 & 23.0 & 68.1 \\
\hline ЮА $* *$ & 100 & 25.3 & 46.3 & 28.4 \\
\hline
\end{tabular}

* Или ближайшие годы, по которым имеются данные.

** В процентах к внутренним затратам на исследования и разработки. 
8.7. АССИГНОВАНИЯ НА ИССЛЕДОВАНИЯ И РАЗРАБОТКИ ИЗ СРЕДСТВ ГОСУДАРСТВЕННОГО БЮДЖЕТА

(миллионы долларов (ША; в расчете по паритету покупательной способности национальных валют)

\begin{tabular}{|c|c|c|c|c|c|c|c|c|c|c|c|c|}
\hline & 1995 & 2000 & 2005 & 2007 & 2008 & 2009 & 2010 & 2011 & 2012 & 2013 & 2014 & 2015 \\
\hline Россия & 5977.1 & 4784.6 & 13254.0 & 18502.4 & 20829.0 & 27813.7 & 26060.3 & 28259.5 & 30546.1 & 35903.1 & 33932.8 & 34988.7 \\
\hline \multicolumn{13}{|c|}{ Страны 0ЭСР } \\
\hline Австралия & 2324.6 & 2859.3 & 3729.1 & 3835.7 & 3895.0 & 4639.5 & 4677.2 & 4742.0 & 4496.0 & 4958.2 & 4804.2 & 4716.7 \\
\hline Австрия & 1230.3 & 1430.3 & 1827.3 & 2040.5 & 2330.5 & 2545.8 & 2699.4 & 2906.4 & 2990.9 & 3222.2 & 3276.1 & 3397.5 \\
\hline Бельгия & 1164.9 & 1597.8 & 1987.2 & 2283.1 & 2684.0 & 2666.7 & 2782.5 & 2852.4 & 2998.2 & 3093.2 & 3320.4 & $\ldots$ \\
\hline Великобритания & 8799.5 & 10517.4 & 13476.8 & 14478.3 & 14188.8 & 14370.4 & 13538.9 & 13020.0 & 13083.0 & 14435.9 & 14553.2 & $\ldots$ \\
\hline Венгрия & $\ldots$ & $\ldots$ & 708.7 & 747.7 & 881.2 & 952.1 & 767.5 & 662.9 & 767.9 & 1556.2 & 698.5 & 796.8 \\
\hline Германия & 16069.2 & 16812.5 & 19865.0 & 22513.6 & 24261.3 & 26822.9 & 28916.9 & 30279.0 & 30638.2 & 32640.1 & 32683.3 & 33029.6 \\
\hline Греция & 400.6 & 619.8 & 889.5 & 918.5 & 1466.4 & 1217.7 & 975.3 & 926.2 & 1098.5 & 1396.3 & 1284.7 & 1303.2 \\
\hline Дания & 792.3 & 1171.2 & 1326.1 & 1672.7 & 1930.4 & 2163.1 & 2302.1 & 2440.3 & 2496.7 & 2649.6 & 2651.3 & 2676.9 \\
\hline Израиль & 883.5 & 1292.4 & 1044.9 & 1026.9 & 1156.6 & 1254.5 & 1355.2 & 1479.7 & 1568.8 & 1652.1 & 1753.2 & $\ldots$ \\
\hline Ирландия & 209.6 & 314.1 & 711.7 & 932.8 & 977.8 & 997.9 & 979.0 & 945.6 & 909.2 & 880.2 & 876.5 & 866.3 \\
\hline Исландия & 44.9 & 76.2 & 91.0 & 98.9 & 116.6 & 130.4 & 120.3 & 122.9 & 130.3 & 146.8 & 140.6 & $\ldots$ \\
\hline Испания & 3011.2 & 5175.9 & 6479.5 & 10963.6 & 11684.6 & 12259.6 & 11589.5 & 10302.1 & 8942.4 & 8436.3 & 8671.7 & $\ldots$ \\
\hline Италия & 6731.0 & 9372.3 & 11050.6 & 12165.1 & 12602.6 & 12543.5 & 12245.3 & 11917.0 & 11688.9 & 11319.7 & 11287.8 & $\ldots$ \\
\hline Канада & 3833.3 & 4589.9 & 6777.1 & 7534.1 & 7933.5 & 8413.0 & 8489.6 & 7736.9 & 7746.2 & 7943.3 & $\ldots$ & $\ldots$ \\
\hline Люксембург & $\ldots$ & 25.1 & 81.0 & 147.9 & 185.2 & 217.8 & 244.3 & 282.7 & 335.8 & 389.9 & 394.1 & $\ldots$ \\
\hline Мексика & 1263.3 & 2119.1 & 2599.5 & 2873.6 & 3597.0 & 3727.0 & 4698.4 & 4735.8 & $\ldots$ & $\ldots$ & $\ldots$ & $\ldots$ \\
\hline Нидерланды & 2830.8 & 3793.3 & 4529.7 & 5194.9 & 5438.9 & 5764.1 & 5721.9 & 5992.1 & 5641.5 & 5936.0 & 5984.4 & 6206.2 \\
\hline Новая Зеландия & 307.7 & $\ldots$ & $\ldots$ & 542.7 & 657.7 & 685.7 & 681.5 & 729.2 & 735.4 & 775.1 & 895.8 & 991.2 \\
\hline Норвегия & 823.2 & 1057.5 & 1554.6 & 1979.8 & 2113.8 & 2302.8 & 2418.4 & 2501.0 & 2564.8 & 2753.8 & 2882.8 & 3111.6 \\
\hline Польша & 1141.0 & 1539.9 & 1547.5 & 2011.4 & 2079.3 & 2440.3 & 2884.9 & 2649.6 & 3161.5 & 3396.4 & 4131.7 & $\ldots$ \\
\hline Португалия & 560.3 & 1019.8 & 1581.1 & 1927.7 & 2420.9 & 2766.8 & 2799.1 & 2830.5 & 2634.3 & 2708.5 & 2804.3 & 3016.6 \\
\hline Республика Корея & $\ldots$ & 5017.9 & 9886.5 & 12675.7 & 14099.7 & 15405.6 & 16300.1 & 17423.9 & 18744.5 & 19677.4 & 20159.5 & $\ldots$ \\
\hline
\end{tabular}


(окончание)

\begin{tabular}{|c|c|c|c|c|c|c|c|c|c|c|c|c|}
\hline & 1995 & 2000 & 2005 & 2007 & 2008 & 2009 & 2010 & 2011 & 2012 & 2013 & 2014 & 2015 \\
\hline Словакия & 171.7 & 213.0 & 244.1 & 238.4 & 348.2 & 447.8 & 496.0 & 624.1 & 574.2 & 581.3 & 587.6 & 580.7 \\
\hline Словения & $\ldots$ & 174.0 & 272.7 & 286.3 & 298.9 & 380.0 & 339.9 & 348.1 & 309.3 & 291.3 & 271.1 & 267.3 \\
\hline США & 68791.0 & 83612.5 & 131259.0 & 141890.3 & 144391.0 & 164292.0 & 148962.0 & 144379.0 & 143737.0 & 132477.0 & 136159.0 & 137172.0 \\
\hline Турция & $\ldots$ & $\ldots$ & $\ldots$ & $\ldots$ & 2726.5 & 3958.6 & 4027.7 & 4462.2 & 4408.7 & 5397.8 & 4824.9 & 4732.8 \\
\hline Финляндия & 929.9 & 1302.9 & 1651.7 & 1849.3 & 1976.6 & 2134.7 & 2272.8 & 2282.3 & 2261.9 & 2210.4 & 2167.2 & 2185.0 \\
\hline Франция & 13264.7 & 14743.5 & 18084.5 & 15798.5 & 19214.2 & 20336.7 & 19106.4 & 19913.4 & 17838.8 & 18295.5 & 18096.3 & 17290.4 \\
\hline Чешская Республика & $\ldots$ & 834.7 & 1148.4 & 1468.3 & 1436.7 & 1654.7 & 1620.9 & 1928.2 & 1953.8 & 2069.1 & 2101.9 & 2071.8 \\
\hline Чили & $\ldots$ & $\ldots$ & $\ldots$ & $\ldots$ & $\ldots$ & $\ldots$ & $\ldots$ & 691.5 & 821.9 & 881.4 & 985.4 & 994.6 \\
\hline Швейцария & $\ldots$ & 1474.8 & $\ldots$ & $\ldots$ & 2689.8 & $\ldots$ & 3076.0 & $\ldots$ & 3993.5 & $\ldots$ & 4331.3 & $\ldots$ \\
\hline Швеция & 2087.4 & 1731.5 & 2535.0 & 2780.1 & 2917.3 & 3169.5 & 3282.6 & 3272.8 & 3578.6 & 3613.9 & 3684.7 & 3670.3 \\
\hline Эстония & $\ldots$ & 44.9 & 90.1 & 139.7 & 189.6 & 183.7 & 196.3 & 240.2 & 277.7 & 289.9 & 262.9 & $\ldots$ \\
\hline Япония & 14324.8 & 21193.4 & 27617.8 & 29188.0 & 30559.9 & 30857.4 & 32150.0 & 34105.2 & 35413.2 & 35133.9 & 34869.1 & 32794.6 \\
\hline \multicolumn{13}{|c|}{ Другие страны } \\
\hline Аргентина & $\ldots$ & 898.3 & 1092.1 & 1533.3 & 1724.9 & 2136.6 & 2258.4 & 2477.1 & 2808.2 & $\ldots$ & $\ldots$ & $\ldots$ \\
\hline Румыния & 554.6 & 178.2 & 441.7 & 1018.4 & 1283.6 & 968.2 & 935.1 & 926.4 & 777.0 & 774.7 & 837.0 & 1061.4 \\
\hline Тайвань & $\ldots$ & 2967.0 & 4886.4 & 5910.0 & 6262.8 & 6667.9 & 7044.2 & 7362.6 & 7350.6 & 7303.9 & 7359.0 & 7569.5 \\
\hline
\end{tabular}


8.8. ПЕРСОНАЛ, ЗАНЯТЫЙ ИССЛЕДОВАНИЯМИ И РАЗРАБОТКАМИ: 2015*

(человеко-лет; в эквиваленте полной занятости)

\begin{tabular}{|c|c|c|}
\hline & Персонал, занятый исследованиями и разработками & Исследователи \\
\hline Россия & 833654 & 449180 \\
\hline \multicolumn{3}{|c|}{ Страны СНГ } \\
\hline Азербайджан & 23329 & 16337 \\
\hline Армения & 5627 & 4144 \\
\hline Беларусь & 28937 & 18353 \\
\hline Казахстан & 17586 & 12552 \\
\hline Киргизия & 4242 & 3013 \\
\hline Республика Молдова & 4149 & 2655 \\
\hline Таджикистан & 3389 & 2152 \\
\hline Узбекистан & 35836 & 30785 \\
\hline Украина & 87390 & 46191 \\
\hline \multicolumn{3}{|c|}{ Страны ОЭСР } \\
\hline Австралия & 147809 & 100414 \\
\hline Австрия & 68101 & 41595 \\
\hline Бельгия & 68701 & 46880 \\
\hline Великобритания & 387934 & 273560 \\
\hline Венгрия & 37329 & 26213 \\
\hline Германия & 603911 & 351130 \\
\hline Греция & 43316 & 29877 \\
\hline Дания & 58745 & 40647 \\
\hline
\end{tabular}

* Или ближайшие годы, по которым имеются данные. По некоторым странам СНГ (Азербайджан, Армения, Беларусь, Киргизия и Таджикистан), Ирану и Индонезии численность указана в физических лицах (человек). Данные по Мексике и Индонезии приведены за разные годы. 
(продолжение)

\begin{tabular}{|c|c|c|}
\hline & Персонал, занятый исследованиями и разработками & Исследователи \\
\hline Израиль & 77143 & 63521 \\
\hline Ирландия & 24742 & 17243 \\
\hline Исландия & 2766 & 1950 \\
\hline Испания & 200233 & 122235 \\
\hline Италия & 246423 & 119977 \\
\hline Канада & 226620 & 159190 \\
\hline Люксембург & 5061 & 2548 \\
\hline Мексика & 70293 & 38823 \\
\hline Нидерланды & 124066 & 76229 \\
\hline Новая Зеландия & 24900 & 17900 \\
\hline Норвегия & 40297 & 29237 \\
\hline Польша & 104359 & 78622 \\
\hline Португалия & 46878 & 38155 \\
\hline Республика Корея & 430868 & 345463 \\
\hline Словакия & 17594 & 14742 \\
\hline Словения & 14866 & 8574 \\
\hline США & $\ldots$ & 1307973 \\
\hline Турция & 115444 & 89657 \\
\hline Финляндия & 52130 & 38281 \\
\hline Франция & 422452 & 269377 \\
\hline Чешская Республика & 64444 & 36040 \\
\hline Чили & 15910 & 7602 \\
\hline Швейцария & 75476 & 35950 \\
\hline Швеция & 83473 & 66643 \\
\hline Эстония & 5796 & 4323 \\
\hline Япония & 895285 & 682935 \\
\hline
\end{tabular}


(окончание)

\begin{tabular}{|c|c|c|}
\hline & Персонал, занятый исследованиями и разработками & Исследователи \\
\hline \multicolumn{3}{|c|}{ Страны ЕС, не входящие в ОЭСР } \\
\hline Болгария & 19335 & 13201 \\
\hline Кипр & 1260 & 865 \\
\hline Латвия & 5739 & 3748 \\
\hline Литва & 11283 & 8638 \\
\hline Мальта & 1586 & 891 \\
\hline Румыния & 31391 & 18109 \\
\hline Хорватия & 10027 & 6117 \\
\hline \multicolumn{3}{|c|}{ Другие страны } \\
\hline Аргентина & 76904 & 51665 \\
\hline Бразилия & 266709 & 138653 \\
\hline Грузия & 3726 & 2362 \\
\hline Индия & 441126 & 192819 \\
\hline Индонезия & 55118 & 41143 \\
\hline Иран & 128009 & 95200 \\
\hline Китай & 3710580 & 1524280 \\
\hline Малайзия & 75062 & 61351 \\
\hline Сингапур & 42543 & 36666 \\
\hline Тайвань & 240528 & 142983 \\
\hline ЮАР & 35050 & 21383 \\
\hline
\end{tabular}




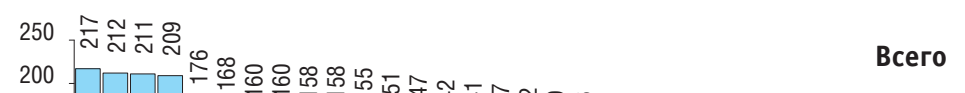

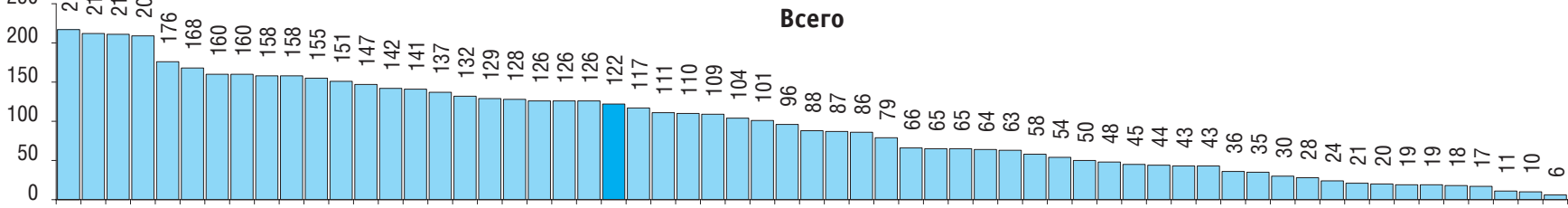
D.
s.

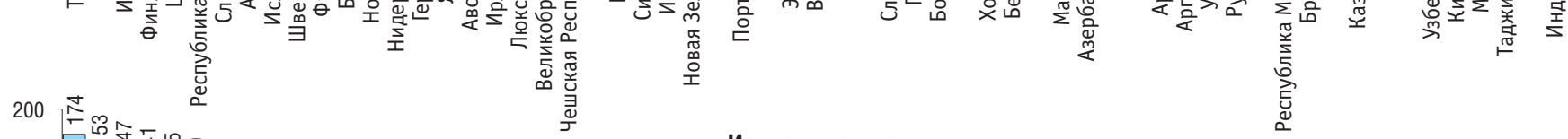

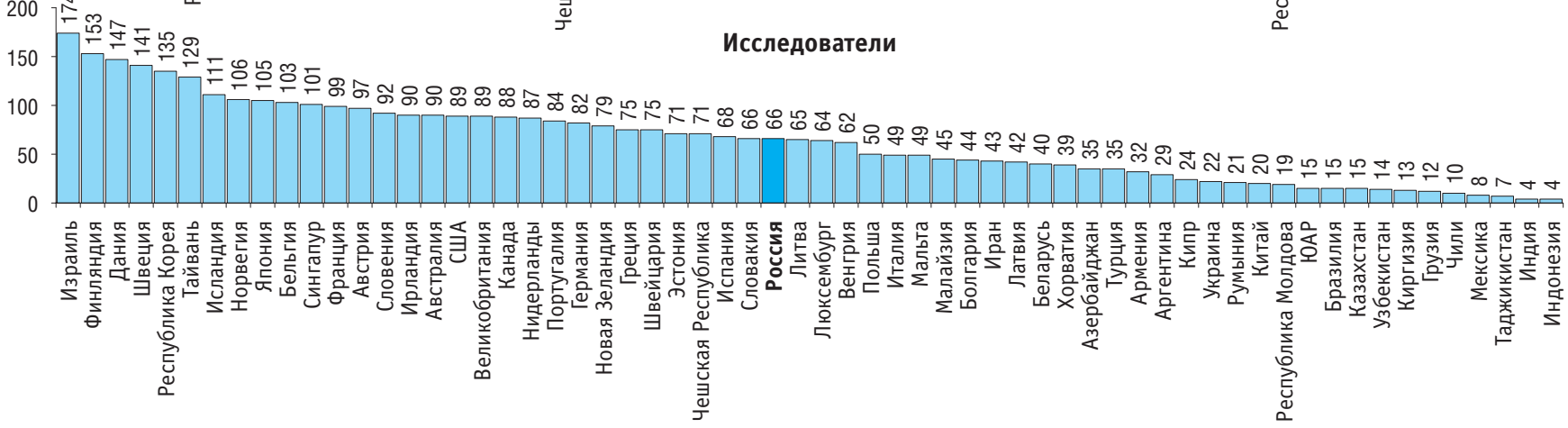

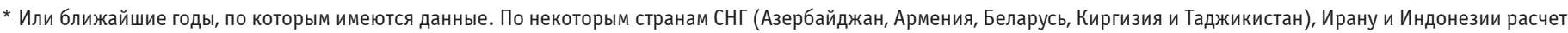
произведен по численности физических лиц, по остальным странам - в эквиваленте полной занятости. 


\subsection{0. РАСПРЕДЕЛЕНИЕ ЧИСЛЕННОСТИ ИССЛЕДОВАТЕЛЕЙ ПО СЕКТОРАМ НАУКИ: 2015*}

(проценты)

\begin{tabular}{|c|c|c|c|}
\hline & Государственный сектор & Предпринимательский сектор & Сектор высшего образования \\
\hline Россия & 32.7 & 46.4 & 20.6 \\
\hline \multicolumn{4}{|c|}{ Страны СНГ } \\
\hline Азербайджан & 72.5 & 5.3 & 22.0 \\
\hline Армения & 70.6 & $\ldots$ & 29.4 \\
\hline Беларусь & 29.7 & 60.3 & 10.0 \\
\hline Казахстан & 22.4 & 18.3 & 53.6 \\
\hline Киргизия & 55.7 & 2.9 & 41.5 \\
\hline Республика Молдова & 72.0 & 6.6 & 21.4 \\
\hline Таджикистан & 69.9 & $\ldots$ & 30.1 \\
\hline Узбекистан & 15.4 & 5.0 & 79.3 \\
\hline Украина & 57.1 & 32.8 & 10.1 \\
\hline \multicolumn{4}{|c|}{ Страны ОЭСР } \\
\hline Австралия & $\ldots$ & 27.9 & 60.6 \\
\hline Австрия & 3.9 & 63.7 & 31.8 \\
\hline Бельгия & 7.9 & 50.8 & 40.8 \\
\hline Великобритания & 2.8 & 38.2 & 57.9 \\
\hline Венгрия & 18.2 & 59.4 & 22.4 \\
\hline Германия & 15.1 & 56.4 & 28.5 \\
\hline Греция & 19.6 & 16.5 & 62.9 \\
\hline Дания & 3.1 & 59.5 & 36.9 \\
\hline
\end{tabular}

* Или ближайшие годы, по которым имеются данные. По некоторым странам СНг (Азербайджан, Армения, Беларусь, Казахстан, Киргизия, Таджикистан и Узбекистан) расчет произведен по численности физических лиц, по остальным странам - в эквиваленте полной занятости. 
(продолжение)

\begin{tabular}{|c|c|c|c|}
\hline & Государственный сектор & Предпринимательский сектор & Сектор высшего образования \\
\hline Израиль & 0.8 & 83.7 & 14.9 \\
\hline Ирландия & 2.7 & 65.2 & 32.1 \\
\hline Исландия & 9.1 & 37.7 & 51.9 \\
\hline Испания & 16.5 & 36.6 & 46.8 \\
\hline Италия & 18.0 & 38.3 & 40.2 \\
\hline Канада & 5.7 & 56.0 & 37.9 \\
\hline Люксембург & 29.1 & 40.3 & 30.5 \\
\hline Мексика & 23.6 & 30.0 & 43.0 \\
\hline Нидерланды & 11.3 & 59.9 & 28.8 \\
\hline Новая Зеландия & 11.2 & 34.1 & 54.7 \\
\hline Норвегия & 15.8 & 49.0 & 35.2 \\
\hline Польша & 17.6 & 31.7 & 50.5 \\
\hline Португалия & 3.8 & 29.4 & 65.5 \\
\hline Республика Корея & 7.2 & 79.5 & 12.1 \\
\hline Словакия & 21.2 & 17.9 & 60.8 \\
\hline Словения & 20.3 & 54.1 & 25.4 \\
\hline США & $\ldots$ & 69.9 & $\ldots$ \\
\hline Турция & 7.3 & 46.7 & 46.0 \\
\hline Финляндия & 10.7 & 55.8 & 32.3 \\
\hline Франция & 10.9 & 60.4 & 27.2 \\
\hline Чешская Республика & 18.3 & 50.7 & 30.4 \\
\hline Чили & 10.1 & 29.8 & 47.4 \\
\hline Швейцария & 1.2 & 46.2 & 52.2 \\
\hline Швеция & 3.5 & 66.7 & 29.4 \\
\hline Эстония & 12.3 & 29.3 & 56.5 \\
\hline Япония & 4.4 & 74.1 & 20.1 \\
\hline
\end{tabular}


(окончание)

\begin{tabular}{|c|c|c|c|}
\hline & Государственный сектор & Предпринимательский сектор & Сектор высшего образования \\
\hline \multicolumn{4}{|c|}{ Страны ЕС, не входящие в ОЭСР } \\
\hline Болгария & 38.2 & 27.0 & 34.1 \\
\hline Кипр & 9.2 & 20.8 & 60.1 \\
\hline Латвия & 18.2 & 20.7 & 61.1 \\
\hline Литва & 16.2 & 23.1 & 60.7 \\
\hline Мальта & 1.8 & 59.8 & 38.4 \\
\hline Румыния & 35.4 & 29.0 & 35.2 \\
\hline Хорватия & 30.4 & 15.1 & 54.6 \\
\hline \multicolumn{4}{|c|}{ Другие страны } \\
\hline Аргентина & 48.0 & 6.2 & 44.8 \\
\hline Бразилия & 5.5 & 25.9 & 67.8 \\
\hline Грузия & $\ldots$ & $\ldots$ & 100.0 \\
\hline Индия & 45.6 & 38.7 & 11.5 \\
\hline Индонезия & 29.5 & 35.5 & 35.0 \\
\hline Иран & 33.6 & 15.0 & 51.5 \\
\hline Китай & 19.4 & 62.1 & 18.5 \\
\hline Малайзия & 6.8 & 10.8 & 82.5 \\
\hline Сингапур & 5.3 & 50.5 & 44.2 \\
\hline Тайвань & 10.3 & 67.9 & 21.4 \\
\hline ЮАР & 13.0 & 21.3 & 64.3 \\
\hline
\end{tabular}




\subsection{1. УДЕЛЬНЫЙ ВЕС ЖЕНЩИН В ЧИСЛЕННОСТИ ИССЛЕДОВАТЕЛЕЙ: 2015*}

Проценты

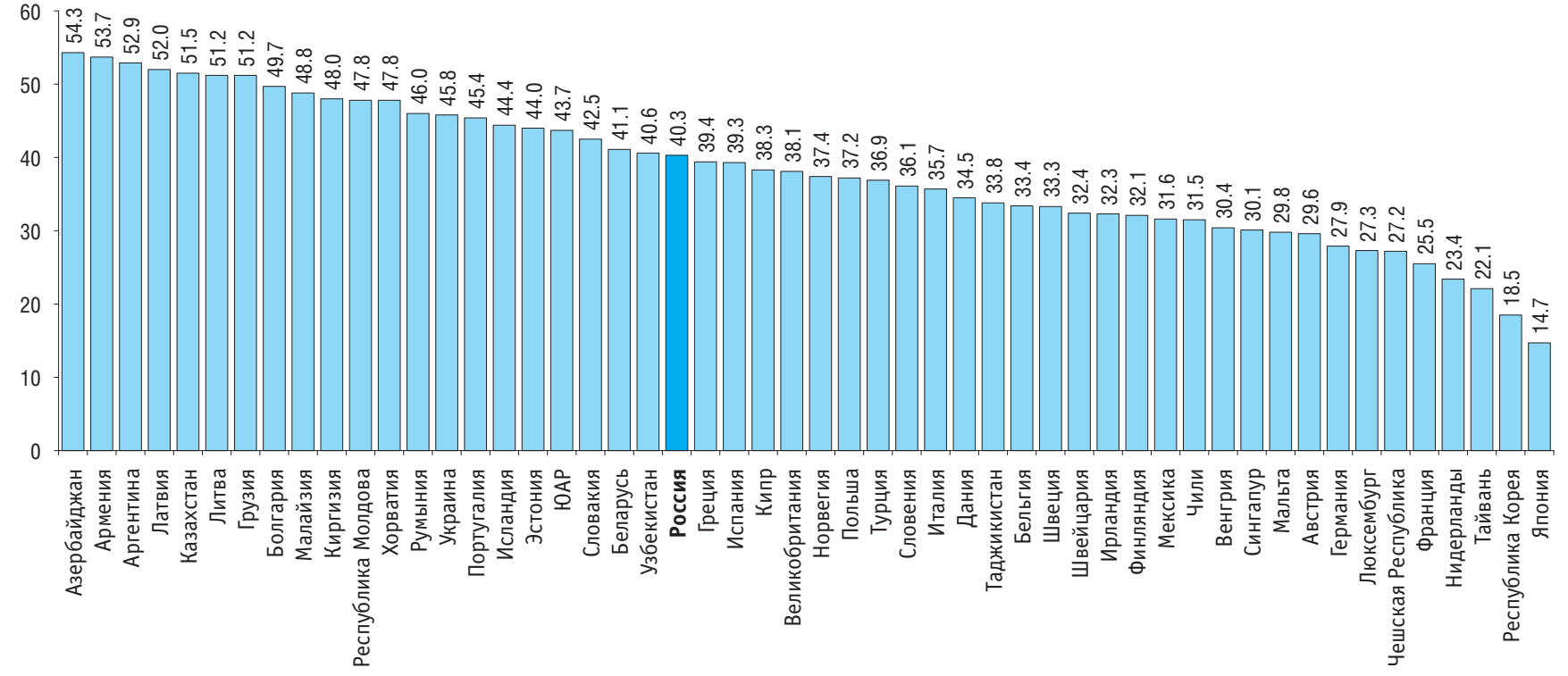

* Или ближайшие годы, по которым имеются данные. Расчет произведен по численности физических лиц. 
8.12. ЧИСЛО ПУБЛИКАЦИЙ И ЧИСЛО ЦИТИРОВАНИЙ В НАУЧНЫХ ЖУРНАЛАХ, ИНДЕКСИРУЕМЫХ В WЕВ OF SCIENCE: 2011-2015*

\begin{tabular}{|c|c|c|c|c|}
\hline & $\begin{array}{c}\text { Число } \\
\text { публикаций }\end{array}$ & $\begin{array}{c}\text { Число } \\
\text { цитирований ** }\end{array}$ & $\begin{array}{c}\text { Число цитирований } \\
\text { в расчете } \\
\text { на одну публикацию }\end{array}$ & $\begin{array}{c}\text { Средняя } \\
\text { нормализованная } \\
\text { цитируемость }\end{array}$ \\
\hline Россия & 180878 & 695175 & 3.84 & 0.70 \\
\hline \multicolumn{5}{|c|}{ Страны СНГ } \\
\hline Азербайджан & 2690 & 19801 & 7.36 & 1.15 \\
\hline Армения & 4001 & 27422 & 6.85 & 1.34 \\
\hline Беларусь & 5046 & 45317 & 8.98 & 1.52 \\
\hline Казахстан & 3971 & 29400 & 7.40 & 1.37 \\
\hline Киргизия & 466 & 5063 & 10.86 & 2.36 \\
\hline Республика Молдова & 1226 & 3985 & 3.25 & 0.84 \\
\hline Таджикистан & 252 & 1105 & 4.38 & 0.76 \\
\hline Туркмения & 54 & 305 & 5.65 & 1.00 \\
\hline Узбекистан & 1230 & 2414 & 1.96 & 0.54 \\
\hline Украина & 14311 & 128895 & 9.01 & 1.34 \\
\hline \multicolumn{5}{|c|}{ Страны ОЭСР } \\
\hline Австралия & 84289 & 896232 & 10.63 & 1.50 \\
\hline Австрия & 51341 & 408547 & 7.96 & 1.29 \\
\hline Бельгия & 64404 & 410795 & 6.38 & 1.06 \\
\hline Великобритания & 149025 & 587277 & 3.94 & 0.73 \\
\hline Венгрия & 13080 & 48736 & 3.73 & 0.70 \\
\hline Германия & 140615 & 1367600 & 9.73 & 1.43 \\
\hline Греция & 21255 & 74268 & 3.49 & 0.69 \\
\hline Дания & 42586 & 227758 & 5.35 & 0.90 \\
\hline
\end{tabular}


(продолжение)

\begin{tabular}{|c|c|c|c|c|}
\hline & $\begin{array}{c}\text { Число } \\
\text { публикаций }\end{array}$ & $\begin{array}{c}\text { Число } \\
\text { цитирований }\end{array}$ & $\begin{array}{c}\text { Число цитирований } \\
\text { в расчете } \\
\text { на одну публикацию }\end{array}$ & $\begin{array}{c}\text { Средняя } \\
\text { нормализованная } \\
\text { цитируемость*** }\end{array}$ \\
\hline Израиль & 26049 & 110459 & 4.24 & 1.14 \\
\hline Ирландия & 10684 & 98637 & 9.23 & 1.60 \\
\hline Исландия & 2148 & 12851 & 5.98 & 0.99 \\
\hline Испания & 66728 & 497807 & 7.46 & 1.19 \\
\hline Италия & 70002 & 624473 & 8.92 & 1.44 \\
\hline Канада & 70002 & 624473 & 8.92 & 1.44 \\
\hline Люксембург & 1949 & 19725 & 10.12 & 1.43 \\
\hline Мексика & 13080 & 48736 & 3.73 & 0.70 \\
\hline Нидерланды & 38829 & 279133 & 7.19 & 1.06 \\
\hline Новая Зеландия & 6822 & 50615 & 7.42 & 1.50 \\
\hline Норвегия & 8235 & 73162 & 8.88 & 1.47 \\
\hline Польша & 21387 & 129504 & 6.06 & 0.96 \\
\hline Португалия & 13080 & 48736 & 3.73 & 0.70 \\
\hline Республика Корея & 29764 & 127597 & 4.29 & 0.65 \\
\hline Словакия & 4019 & 18180 & 4.52 & 0.78 \\
\hline Словения & 3971 & 29400 & 7.40 & 1.37 \\
\hline США & 53959 & 372331 & 6.90 & 1.19 \\
\hline Турция & 14636 & 67683 & 4.62 & 0.89 \\
\hline Финляндия & 6793 & 35926 & 5.29 & 1.02 \\
\hline Франция & 29764 & 127597 & 4.29 & 0.65 \\
\hline Чешская Республика & 7269 & 29535 & 4.06 & 0.87 \\
\hline Чили & 3801 & 19814 & 5.21 & 0.94 \\
\hline
\end{tabular}


(продолжение)

\begin{tabular}{|c|c|c|c|c|}
\hline & $\begin{array}{c}\text { Число } \\
\text { публикаций }\end{array}$ & $\begin{array}{c}\text { Число } \\
\text { цитирований ** }\end{array}$ & $\begin{array}{c}\text { Число цитирований } \\
\text { в расчете } \\
\text { на одну публикацию }\end{array}$ & $\begin{array}{c}\text { Средняя } \\
\text { нормализованная } \\
\text { цитируемость *** }\end{array}$ \\
\hline Швейцария & 13080 & 48736 & 3.73 & 0.70 \\
\hline Швеция & 8235 & 73162 & 8.88 & 1.47 \\
\hline Эстония & 1435 & 8845 & 6.16 & 1.33 \\
\hline Япония & 21687 & 119730 & 5.52 & 0.85 \\
\hline \multicolumn{5}{|c|}{ Страны ЕС, не входящие в ОЭСР } \\
\hline Болгария & 1458 & 13381 & 9.18 & 1.70 \\
\hline Кипр & 1106 & 10315 & 9.33 & 1.54 \\
\hline Латвия & 1148 & 7299 & 6.36 & 1.01 \\
\hline Литва & 1435 & 8845 & 6.16 & 1.33 \\
\hline Мальта & 283 & 2933 & 10.36 & 2.43 \\
\hline Румыния & 3309 & 44242 & 13.37 & 1.89 \\
\hline Хорватия & 1614 & 7251 & 4.49 & 0.74 \\
\hline \multicolumn{5}{|c|}{ Другие страны } \\
\hline Аргентина & 2248 & 8094 & 3.60 & 1.20 \\
\hline Бразилия & 6653 & 38237 & 5.75 & 1.42 \\
\hline Грузия & 385 & 2393 & 6.22 & 1.09 \\
\hline Египет & 1949 & 19725 & 10.12 & 1.43 \\
\hline Индия & 6793 & 35926 & 5.29 & 1.02 \\
\hline Индонезия & 1148 & 7299 & 6.36 & 1.01 \\
\hline Иран & 4399 & 10741 & 2.44 & 0.58 \\
\hline Китай & 8235 & 73162 & 8.88 & 1.47 \\
\hline Малайзия & 2822 & 20010 & 7.09 & 1.01 \\
\hline Пакистан & 1289 & 4472 & 3.47 & 1.06 \\
\hline
\end{tabular}


(окончание)

\begin{tabular}{l|c|c|c}
\hline & $\begin{array}{c}\text { Число } \\
\text { публикаций }\end{array}$ & $\begin{array}{c}\text { Число } \\
\text { цитирований** }\end{array}$ & $\begin{array}{c}\text { Число цитирований } \\
\text { в расчете } \\
\text { на одну публикацию }\end{array}$ \\
\hline Саудовская Аравия & 1635 & 11513 & 7.04 \\
нормализовяанная \\
цитируемость***
\end{tabular}

* По данным аналитической системы InCites Thomson Reuters.

** В анализ включены цитирования, полученные публикациями с начала 2011 г. до 26 октября 2016 г.

*** Средняя цитируемость, нормализованная по предметной области относительно среднемирового уровня. 
8.13. ЧИСЛО ПУБЛИКАЦИЙ И ЧИСЛО ЦИТИРОВАНИЙ В НАУЧНЫХ ЖУРНАЛАХ,

ИНДЕКСИРУЕМЫХ В SCOPUS: 2011-2015*

\begin{tabular}{|c|c|c|c|c|}
\hline & $\begin{array}{c}\text { Число } \\
\text { публикаций }\end{array}$ & $\begin{array}{c}\text { Число } \\
\text { цитирований }\end{array}$ & $\begin{array}{c}\text { Число цитирований } \\
\text { в расчете } \\
\text { на одну публикацию }\end{array}$ & $\begin{array}{c}\text { Средняя } \\
\text { нормализованная } \\
\text { цитируемость }{ }^{* \star *}\end{array}$ \\
\hline Россия & 244500 & 865049 & 3.54 & 0.74 \\
\hline \multicolumn{5}{|c|}{ Страны СНГ } \\
\hline Азербайджан & 3766 & 21413 & 5.69 & 0.77 \\
\hline Армения & 5049 & 47385 & 9.39 & 1.16 \\
\hline Беларусь & 8233 & 51274 & 6.23 & 0.89 \\
\hline Казахстан & 7491 & 13084 & 1.75 & 0.47 \\
\hline Киргизия & 605 & 3027 & 5.00 & 0.96 \\
\hline Республика Молдова & 1942 & 8944 & 4.61 & 0.87 \\
\hline Таджикистан & 498 & 1359 & 2.73 & 0.44 \\
\hline Туркменистан & 128 & 493 & 3.85 & 1.25 \\
\hline Узбекистан & 2430 & 7051 & 2.90 & 0.48 \\
\hline Украина & 45771 & 159226 & 3.48 & 0.62 \\
\hline \multicolumn{5}{|c|}{ Страны ОЭСР } \\
\hline Австралия & 363304 & 3442923 & 9.48 & 1.55 \\
\hline Австрия & 100036 & 976148 & 9.76 & 1.54 \\
\hline Бельгия & 136680 & 1480277 & 10.83 & 1.69 \\
\hline Великобритания & 756224 & 7652116 & 10.12 & 1.57 \\
\hline Венгрия & 45838 & 338633 & 7.39 & 1.15 \\
\hline Германия & 719890 & 6700780 & 9.31 & 1.44 \\
\hline Греция & 82010 & 658918 & 8.03 & 1.33 \\
\hline Дания & 104162 & 1235375 & 11.86 & 1.83 \\
\hline
\end{tabular}


(продолжение)

\begin{tabular}{|c|c|c|c|c|}
\hline & $\begin{array}{c}\text { Число } \\
\text { публикаций }\end{array}$ & $\begin{array}{c}\text { Число } \\
\text { цитирований }\end{array}$ & $\begin{array}{c}\text { Число цитирований } \\
\text { в расчете } \\
\text { на одну публикацию }\end{array}$ & $\begin{array}{c}\text { Средняя } \\
\text { нормализованная } \\
\text { цитируемость*** }\end{array}$ \\
\hline Израиль & 85410 & 833187 & 9.76 & 1.48 \\
\hline Ирландия & 56152 & 562390 & 10.02 & 1.52 \\
\hline Исландия & 6002 & 88557 & 14.75 & 2.15 \\
\hline Испания & 378270 & 3205938 & 8.48 & 1.30 \\
\hline Италия & 441547 & 3926597 & 8.89 & 1.52 \\
\hline Канада & 428505 & 4169354 & 9.73 & 1.49 \\
\hline Люксембург & 6896 & 54834 & 7.95 & 1.65 \\
\hline Мексика & 88371 & 479283 & 5.42 & 0.86 \\
\hline Нидерланды & 242413 & 2932690 & 12.10 & 1.78 \\
\hline Новая Зеландия & 60176 & 531724 & 8.84 & 1.44 \\
\hline Норвегия & 80920 & 795085 & 9.83 & 1.59 \\
\hline Польша & 176797 & 925038 & 5.23 & 0.99 \\
\hline Португалия & 96940 & 721959 & 7.45 & 1.25 \\
\hline Республика Корея & 354581 & 2354509 & 6.64 & 1.07 \\
\hline Словакия & 30984 & 144201 & 4.65 & 1.05 \\
\hline Словения & 26754 & 179896 & 6.72 & 1.14 \\
\hline США & 2685021 & 26270411 & 9.78 & 1.48 \\
\hline Турция & 176049 & 781540 & 4.44 & 0.78 \\
\hline Финляндия & 83513 & 796753 & 9.54 & 1.59 \\
\hline Франция & 512014 & 4495100 & 8.78 & 1.36 \\
\hline Чешская Республика & 95263 & 556036 & 5.84 & 1.10 \\
\hline Чили & 44663 & 306988 & 6.87 & 1.09 \\
\hline
\end{tabular}


(продолжение)

\begin{tabular}{|c|c|c|c|c|}
\hline & $\begin{array}{c}\text { Число } \\
\text { публикаций }\end{array}$ & $\begin{array}{c}\text { Число } \\
\text { цитирований }\end{array}$ & $\begin{array}{c}\text { Число цитирований } \\
\text { в расчете } \\
\text { на одну публикацию }\end{array}$ & $\begin{array}{c}\text { Средняя } \\
\text { нормализованная } \\
\text { цитируемость*** }\end{array}$ \\
\hline Швейцария & 181646 & 2300039 & 12.66 & 1.84 \\
\hline Швеция & 161316 & 1739494 & 10.78 & 1.66 \\
\hline Эстония & 12369 & 121556 & 9.83 & 1.68 \\
\hline Япония & 610109 & 3786704 & 6.21 & 0.96 \\
\hline \multicolumn{5}{|c|}{ Страны ЕС, не входящие в ОЭСР } \\
\hline Болгария & 18694 & 101433 & 5.43 & 0.84 \\
\hline Кипр & 8188 & 66537 & 8.13 & 1.52 \\
\hline Латвия & 8045 & 31781 & 3.95 & 1.03 \\
\hline Литва & 15087 & 81425 & 5.40 & 0.97 \\
\hline Мальта & 2142 & 10835 & 5.06 & 1.07 \\
\hline Румыния & 68287 & 256213 & 3.75 & 0.77 \\
\hline Хорватия & 29088 & 150188 & 5.16 & 0.82 \\
\hline \multicolumn{5}{|c|}{ Другие страны } \\
\hline Аргентина & 56348 & 386761 & 6.86 & 1.01 \\
\hline Бразилия & 293121 & 1407144 & 4.80 & 0.81 \\
\hline Грузия & 4713 & 50406 & 10.70 & 1.54 \\
\hline Египет & 67129 & 331054 & 4.93 & 0.85 \\
\hline Индия & 532806 & 2294790 & 4.31 & 0.75 \\
\hline Индонезия & 24467 & 84973 & 3.47 & 0.81 \\
\hline Иран & 201544 & 944212 & 4.68 & 0.83 \\
\hline Китай & 2151673 & 10270290 & 4.77 & 0.82 \\
\hline Малайзия & 117292 & 463400 & 3.95 & 0.90 \\
\hline Пакистан & 51408 & 244477 & 4.76 & 0.85 \\
\hline
\end{tabular}


(окончание)

\begin{tabular}{|c|c|c|c|c|}
\hline & $\begin{array}{c}\text { Число } \\
\text { публикаций }\end{array}$ & $\begin{array}{c}\text { Число } \\
\text { цитирований }\end{array}$ & $\begin{array}{c}\text { Число цитирований } \\
\text { в расчете } \\
\text { на одну публикацию }\end{array}$ & $\begin{array}{c}\text { Средняя } \\
\text { нормализованная } \\
\text { цитируемость *** }\end{array}$ \\
\hline Саудовская Аравия & 68909 & 495779 & 7.19 & 1.28 \\
\hline Сербия & 34050 & 173469 & 5.09 & 0.86 \\
\hline Сингапур & 84018 & 945350 & 11.25 & 1.81 \\
\hline Тайвань & 199548 & 1210754 & 6.07 & 1.02 \\
\hline Таиланд & 57852 & 309344 & 5.35 & 0.94 \\
\hline ЮАР & 77001 & 520792 & 6.76 & 1.16 \\
\hline
\end{tabular}

* По данным аналитической системы Scopus SciVal.

** В анализ включены цитирования, полученные публикациями с начала 2011 г. до 24 октября 2016 г.

*** Средняя цитируемость, нормализованная по предметной области относительно среднемирового уровня. 


\subsection{4. УДЕЛЬНЫЙ ВЕС СТРАН В ОБЩЕМИРОВОМ ЧИСЛЕ ПУБЛИКАЦИЙ В НАУЧНЫХ ЖУРНАЛАХ, ИНДЕКСИРУЕМЫХ В WЕВ OF SCIENCE: 2015* \\ (проченты)}

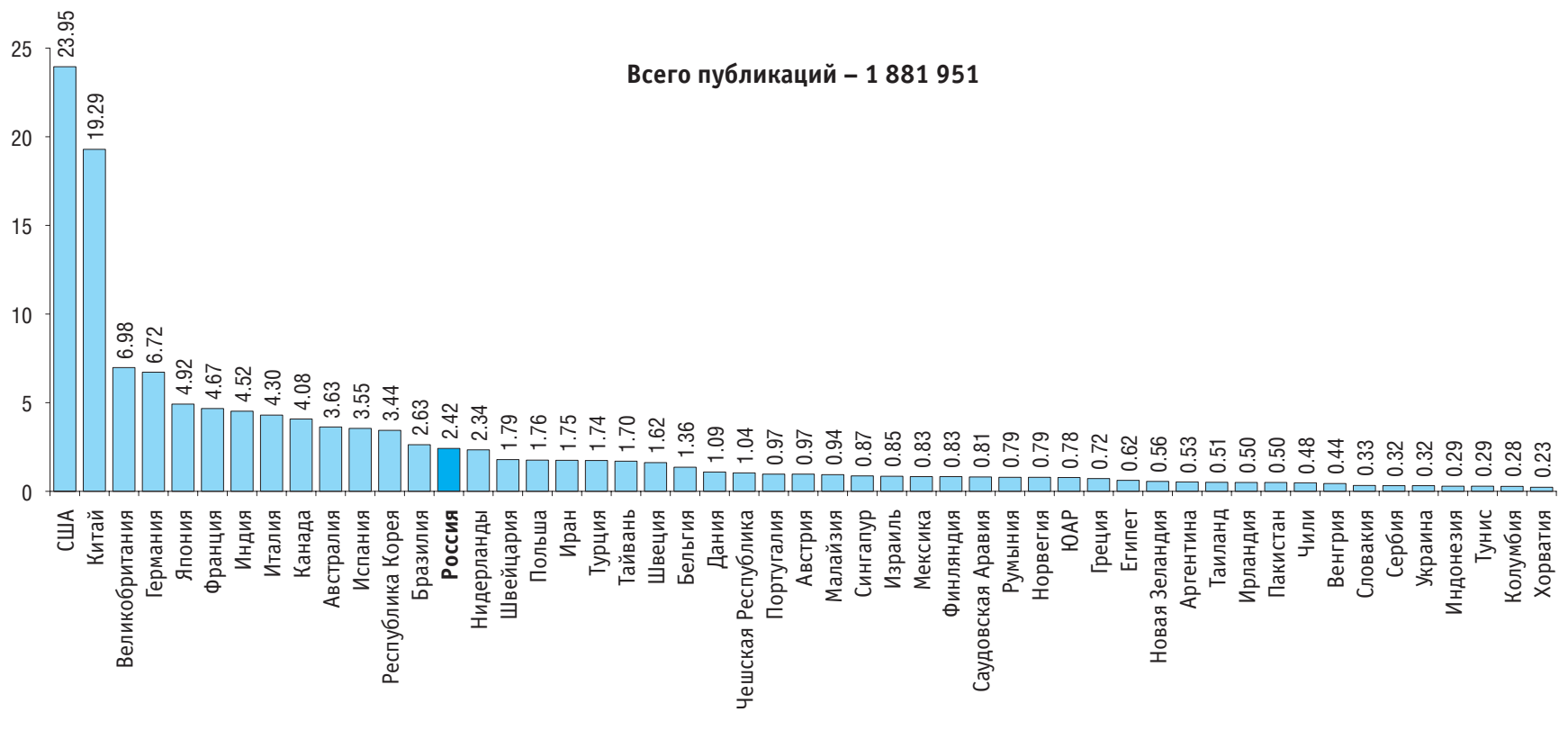

* Здесь и в разделе 8.15 под публикацией подразумеваются три типа документов (статья, обзор, доклад). 


\section{6}

\subsection{5. УДЕЛЬНЫЙ ВЕС СТРАН В ОБЩЕМИРОВОМ ЧИСЛЕ ПУБЛИКАЦИЙ \\ В НАУЧНЫХ ЖУРНАЛАХ, ИНДЕКСИ РУЕМЫХ В SCOPUS: 2015 \\ (проценты)}

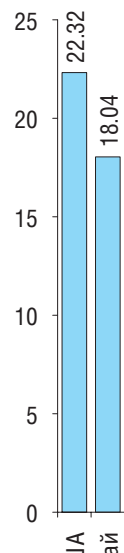

Всего публикаций - 2389051

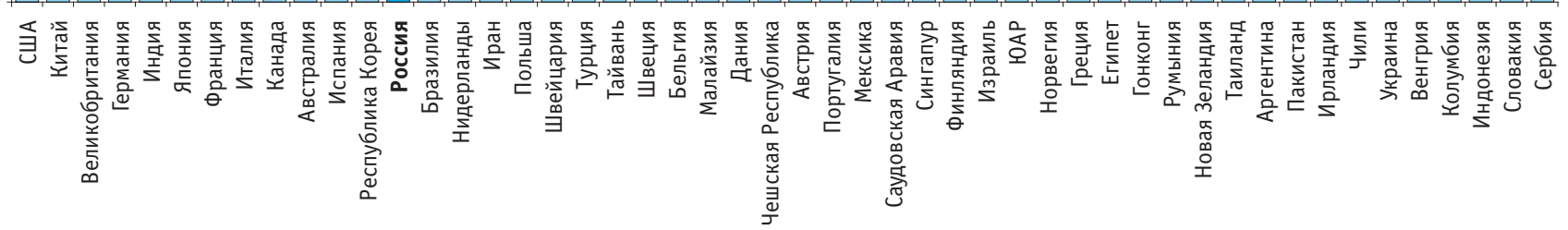


8.16. УДЕЛЬНЫЙ ВЕС ПУБЛИКАЦИЙ В СОАВТОРСТВЕ С ЗАРУБЕЖНЫМИ УЧЕНЫМИ В ОБЩЕМ ЧИСЛЕ ПУБЛИКАЦИЙ СТРАНЫ В НАУЧНЫХ ЖУРНАЛАХ, ИНДЕКСИРУЕМЫХ В WЕВ OF SCIENCE: 2015

(проченты)

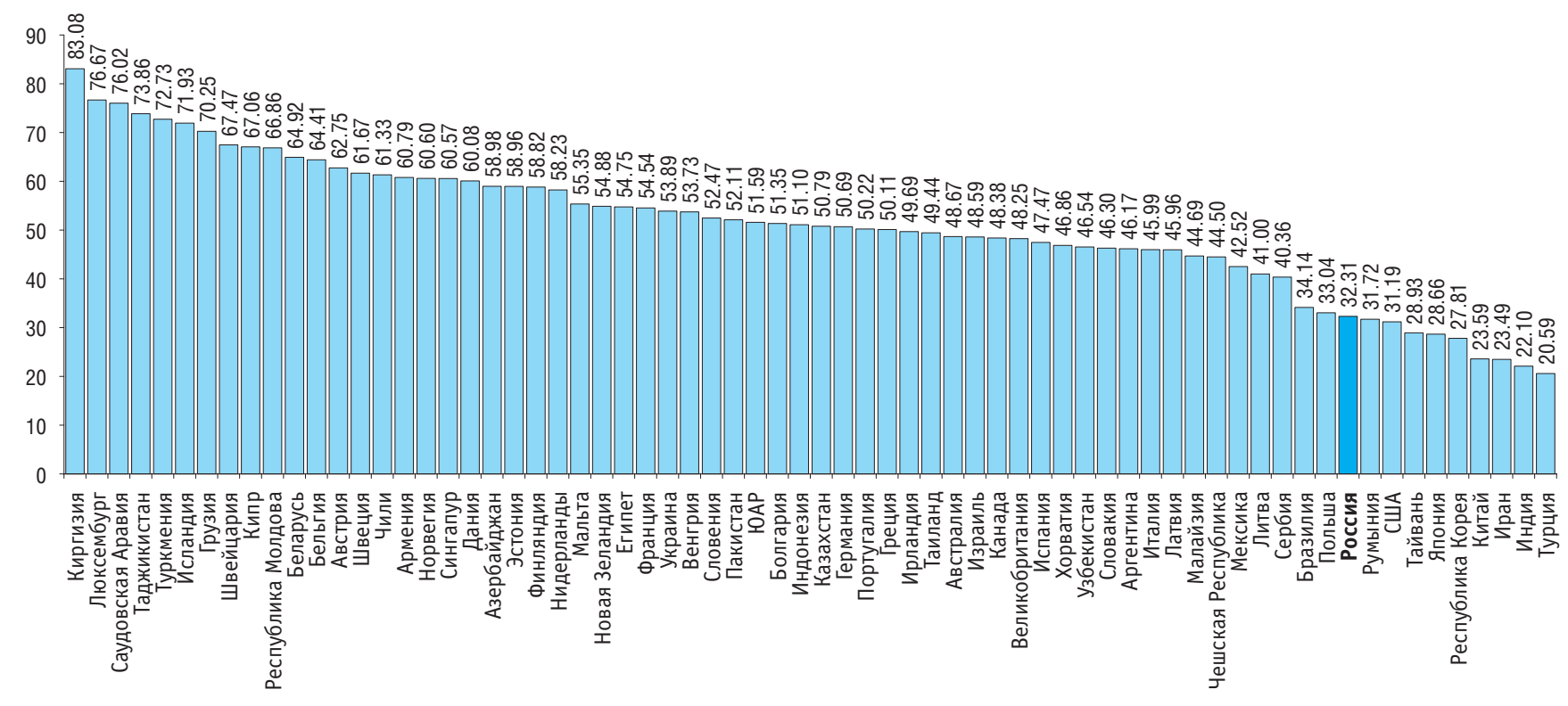


8.17. УДЕЛЬНЫЙ ВЕС ПУБЛИКАЦИЙ В СОАВТОРСТВЕ С ЗАРУБЕЖНЫМИ УЧЕНЫМИ В ОБЩЕМ ЧИСЛЕ ПУБЛИКАЦИЙ СТРАНЫ В НАУЧНЫХ ЖУРНАЛАХ, ИНДЕКСИРУЕМЫХ В SCOPUS: 2015* (проценты)

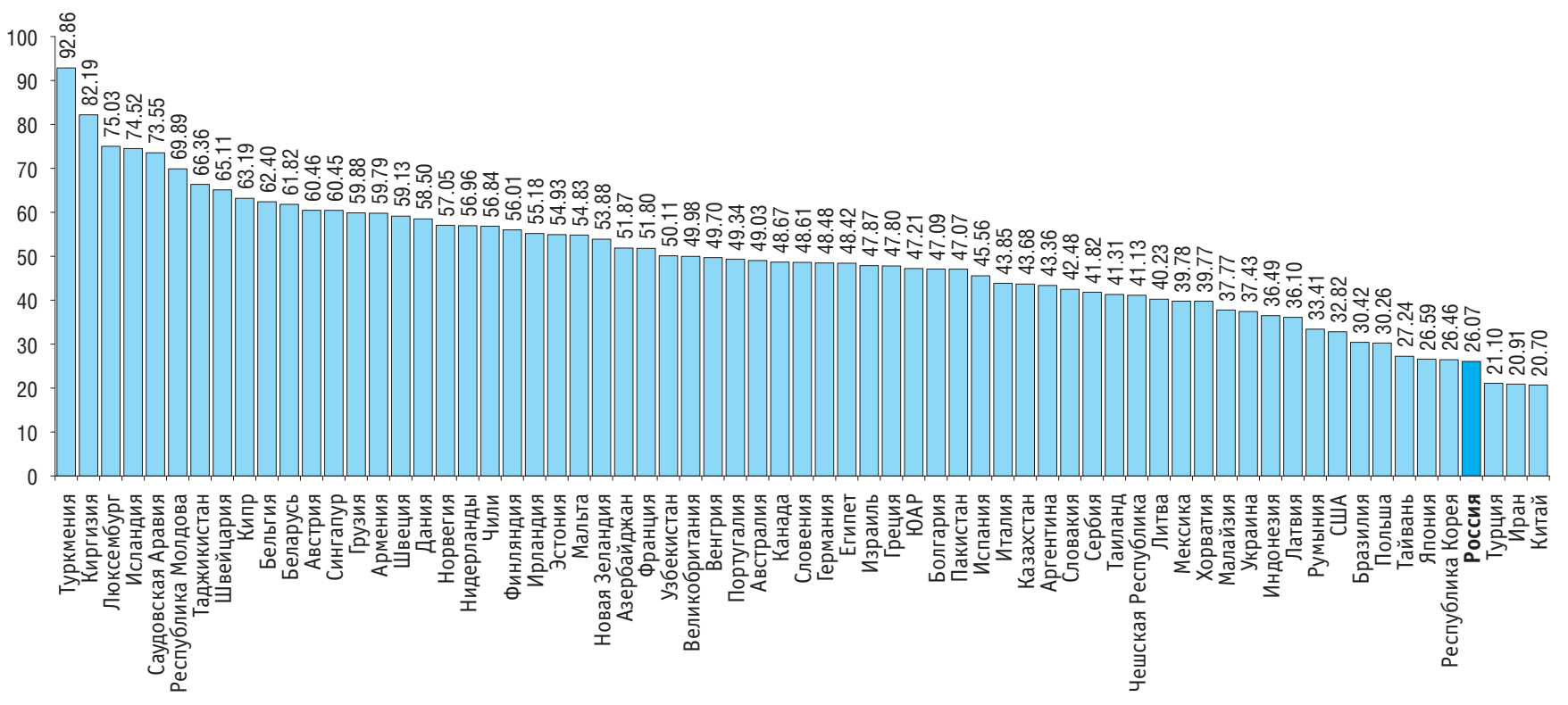

* По данным SCImago Journal \& Country Rank. 
8.18. ПАТЕНТНЫЕ ЗАЯВКИ НА ИЗОБРЕТЕНИЯ, ПОДАННЫЕ НАЦИОНАЛЬНЫМИ И ИНОСТРАННЫМИ ЗАЯВИТЕЛЯМИ

В ПАТЕНТНЫЕ ВЕДОМСТВА СТРАНЫ

\begin{tabular}{|c|c|c|c|c|c|c|c|c|c|c|c|c|c|}
\hline & 1995 & 2000 & 2005 & 2006 & 2007 & 2008 & 2009 & 2010 & 2011 & 2012 & 2013 & 2014 & 2015 \\
\hline Россия & 22202 & 28688 & 32254 & 37691 & 39439 & 41849 & 38564 & 42500 & 41414 & 44211 & 44914 & 40308 & 45517 \\
\hline \multicolumn{14}{|c|}{ Страны СНГ } \\
\hline Азербайджан & 251 & $\cdots$ & 287 & 259 & 295 & 233 & 281 & 271 & 205 & 144 & 156 & 168 & 184 \\
\hline Армения & 285 & 127 & 208 & 193 & 140 & 230 & 127 & 142 & 140 & 141 & 131 & 123 & 115 \\
\hline Беларусь & 1039 & 1198 & 1462 & 1525 & 1662 & 1730 & 1926 & 1933 & 1871 & 1871 & 1634 & 757 & 691 \\
\hline Казахстан & 1373 & 1515 & 1626 & 1557 & 1827 & 1672 & 1827 & 1964 & 1732 & $\ldots$ & 2202 & 2013 & 1503 \\
\hline Киргизия & 148 & 84 & 131 & 127 & 158 & 138 & 149 & 140 & 129 & 111 & 114 & 139 & 126 \\
\hline Республика Молдова & 309 & 250 & 388 & 312 & 347 & 295 & 139 & 150 & 108 & 115 & 96 & 139 & 124 \\
\hline Таджикистан & 65 & 52 & 36 & 26 & $\ldots$ & $\ldots$ & 12 & 10 & 5 & 6 & 4 & $\ldots$ & 1 \\
\hline Туркмения & $\ldots$ & $\ldots$ & $\ldots$ & $\ldots$ & 1 & $\ldots$ & 1 & $\ldots$ & $\ldots$ & $\ldots$ & $\ldots$ & $\ldots$ & $\ldots$ \\
\hline Узбекистан & 1058 & 968 & 444 & 509 & 522 & 448 & 412 & 632 & 556 & 510 & 557 & 568 & 507 \\
\hline Украина & 5960 & 7224 & 5592 & 5890 & 6163 & 5697 & 4814 & 5312 & 5253 & 4955 & 5412 & 4813 & 4497 \\
\hline \multicolumn{14}{|c|}{ Страны ОЭСР } \\
\hline Австралия & 14061 & 22001 & 23857 & 26003 & 26840 & 26346 & 23681 & 24887 & 25526 & 26358 & 29717 & 25956 & 28605 \\
\hline Австрия & 2186 & 2301 & 2505 & 2649 & 2672 & 2627 & 2555 & 2673 & 2430 & 2552 & 2406 & 2363 & 2441 \\
\hline Бельгия & 1087 & 820 & 622 & 651 & 617 & 708 & 817 & 760 & 763 & 882 & 876 & 1026 & 1097 \\
\hline Великобритания & 27521 & 32747 & 27988 & 25745 & 24999 & 23379 & 22465 & 21929 & 22259 & 23235 & 22938 & 23040 & 22801 \\
\hline Венгрия & 2889 & 4937 & 1202 & 924 & 791 & 772 & 787 & 696 & 698 & 758 & 708 & 619 & 633 \\
\hline Германия & 46158 & 62142 & 60222 & 60585 & 60992 & 62417 & 59583 & 59245 & 59444 & 61340 & 63167 & 65965 & 66893 \\
\hline Греция & 312 & 340 & 482 & 562 & 595 & 658 & 720 & 744 & $\ldots$ & 656 & 717 & 670 & 573 \\
\hline Дания & 1484 & 1870 & 1823 & 1691 & 1857 & 1829 & 1649 & 1768 & 1771 & 1635 & 1534 & 1583 & 1732 \\
\hline Израиль & 4425 & 6802 & 6826 & 7496 & 8009 & 7742 & 6774 & 7306 & 6886 & 6792 & 6185 & 6273 & 6908 \\
\hline
\end{tabular}


(продолжение)

\begin{tabular}{|c|c|c|c|c|c|c|c|c|c|c|c|c|c|}
\hline & 1995 & 2000 & 2005 & 2006 & 2007 & 2008 & 2009 & 2010 & 2011 & 2012 & 2013 & 2014 & 2015 \\
\hline Ирландия & 990 & 1080 & 864 & 935 & 925 & 1007 & 961 & 792 & 561 & 555 & 390 & 321 & 440 \\
\hline Исландия & 68 & 876 & 592 & 371 & 114 & 81 & 86 & 76 & 71 & 44 & 46 & 64 & 46 \\
\hline Испания & 2600 & 3194 & 3353 & 3427 & 3532 & 3884 & 3803 & 3779 & 3626 & 3475 & 3244 & 3178 & 3020 \\
\hline Италия & 8574 & 9273 & 9331 & 10903 & 10125 & 9449 & 9717 & 9723 & 9721 & 9310 & 9212 & 9382 & 9687 \\
\hline Канада & 26592 & 39622 & 39888 & 42038 & 40131 & 42089 & 37477 & 35449 & 35111 & 35242 & 34741 & 35481 & 36964 \\
\hline Люксембург & 104 & 176 & 88 & 52 & 40 & 71 & 84 & 100 & 128 & 161 & 169 & 218 & 247 \\
\hline Мексика & 5234 & 13061 & 14435 & 15505 & 16599 & 16581 & 14281 & 14576 & 14055 & 15314 & 15444 & 16135 & 18071 \\
\hline Нидерланды & 2692 & 2994 & 2850 & 2716 & 2446 & 2732 & 2854 & 2767 & 2895 & 2713 & 2764 & 2582 & 2494 \\
\hline Новая Зеландия & 4719 & 7048 & 7005 & 7365 & 7844 & 5724 & 6358 & 6636 & 6209 & 7099 & 6781 & 7728 & 6501 \\
\hline Норвегия & 5408 & 6700 & 5986 & 6076 & 6656 & 5430 & 3604 & 1813 & 1776 & 1564 & 1749 & 1563 & 1805 \\
\hline Польша & 3860 & 7303 & 6583 & 2812 & 2753 & 2778 & 3140 & 3430 & 4123 & 4657 & 4411 & 4096 & 4815 \\
\hline Португалия & 201 & 146 & 205 & 220 & 281 & 405 & 617 & 545 & 646 & 647 & 669 & 740 & 945 \\
\hline Республика Корея & 78499 & 102010 & 160921 & 166189 & 172469 & 170632 & 163523 & 170101 & 178924 & 188915 & 204589 & 210292 & 213694 \\
\hline Словакия & 1669 & 2040 & 250 & 283 & 345 & 242 & 239 & 282 & 257 & 203 & 210 & 234 & 256 \\
\hline Словения & 430 & 431 & 373 & 299 & 346 & 307 & 385 & 453 & 481 & $\ldots$ & $\ldots$ & $\ldots$ & $\ldots$ \\
\hline США & 228142 & 295895 & 390733 & 425966 & 456154 & 456321 & 456106 & 490226 & 503582 & 542815 & 571612 & 578802 & 589410 \\
\hline Турция & 1690 & 3433 & 1146 & 1232 & 2021 & 2397 & 2732 & 3357 & 4113 & 4666 & 4661 & 5097 & 5841 \\
\hline Финляндия & 3791 & 2903 & 2059 & 2018 & 2015 & 1946 & 1933 & 1833 & 1774 & 1827 & 1737 & 1545 & 1416 \\
\hline Франция & 15896 & 17353 & 17275 & 17249 & 17109 & 16419 & 15693 & 16580 & 16754 & 16632 & 16886 & 16533 & 16300 \\
\hline Чешская Республика & 3519 & 4939 & 830 & 836 & 908 & 854 & 881 & 982 & 880 & 1071 & 1081 & 972 & 952 \\
\hline Чили & 1706 & 3120 & 3007 & 3215 & 3806 & 3952 & 1717 & 1076 & 2792 & 3019 & 3072 & 3105 & 3274 \\
\hline Швейцария & 3720 & 2551 & 2098 & 2102 & 2034 & 2033 & 2078 & 2155 & 2043 & 2988 & 2156 & 2048 & 1923 \\
\hline Швеция & 4865 & 5068 & 2960 & 2859 & 2925 & 2855 & 2649 & 2549 & 2341 & 2436 & 2495 & 2425 & 2428 \\
\hline Эстония & 79 & 804 & 38 & 45 & 63 & 72 & 96 & 97 & 77 & 25 & 42 & 50 & 36 \\
\hline Япония & 368831 & 419543 & 427078 & 408674 & 396291 & 391002 & 348596 & 344598 & 342610 & 342796 & 328436 & 325989 & 318721 \\
\hline
\end{tabular}


(окончание)

\begin{tabular}{|c|c|c|c|c|c|c|c|c|c|c|c|c|c|}
\hline & 1995 & 2000 & 2005 & 2006 & 2007 & 2008 & 2009 & 2010 & 2011 & 2012 & 2013 & 2014 & 2015 \\
\hline \multicolumn{14}{|c|}{ Страны ЕС, не входящие в ОЭСР } \\
\hline Болгария & 731 & 940 & 313 & 291 & 239 & 271 & 266 & 260 & 283 & 259 & 297 & 234 & 291 \\
\hline Кипр & $\ldots$ & 70 & 64 & 34 & 19 & 21 & 12 & 8 & 8 & 12 & 3 & 4 & 7 \\
\hline Латвия & 300 & 179 & 169 & 151 & 147 & 215 & 243 & 185 & 183 & 205 & 233 & 107 & 137 \\
\hline Литва & 133 & 127 & 115 & 99 & 82 & 105 & 107 & 114 & 108 & 124 & 137 & 165 & 119 \\
\hline Мальта & 24 & 116 & $\ldots$ & 805 & 39 & 48 & 29 & 19 & 15 & 17 & 17 & 13 & 11 \\
\hline Румыния & 2232 & 1290 & 984 & 876 & 886 & 1031 & 1091 & 1418 & 1463 & 1077 & 1046 & 1036 & 1053 \\
\hline Хорватия & 600 & 875 & 1012 & 436 & 437 & 401 & 318 & 278 & 251 & 249 & 253 & 200 & 186 \\
\hline \multicolumn{14}{|c|}{ Другие страны } \\
\hline Аргентина & 4264 & 6636 & 5269 & 5617 & 5743 & 5582 & 4916 & 4717 & 4821 & 4813 & 4772 & 4682 & 4125 \\
\hline Бразилия & 7448 & 17376 & 20005 & 24074 & 21825 & 22917 & 21944 & 22686 & 28306 & 30116 & 30884 & 30342 & 30219 \\
\hline Грузия & 707 & 456 & 461 & 535 & 162 & 247 & 468 & 359 & 398 & 372 & 333 & 297 & 271 \\
\hline Индия & 6566 & 8538 & 24382 & 28928 & 35218 & 36812 & 34287 & 39762 & 42291 & 43955 & 43031 & 42854 & 45658 \\
\hline Индонезия & 2874 & 3890 & 4304 & 4612 & 5134 & 5133 & 4518 & 5630 & 5830 & $\ldots$ & 7450 & 8023 & 9153 \\
\hline Иран & 407 & 616 & 4494 & 6527 & 11150 & 15955 & 12700 & 11636 & 12018 & 11054 & 11643 & 13802 & 14279 \\
\hline Китай & 18699 & 51906 & 173327 & 210501 & 245161 & 289838 & 314604 & 391177 & 526412 & 652777 & 825136 & 928177 & 1101864 \\
\hline Малайзия & 4052 & 6227 & 6286 & 4800 & 2372 & 5303 & 5737 & 6383 & 6452 & 6940 & 7205 & 7620 & 7727 \\
\hline Сингапур & 2557 & 8236 & 8605 & 9163 & 9951 & 9692 & 8736 & 9773 & 9794 & 9685 & 9722 & 10312 & 10814 \\
\hline ЮАР & 6365 & 3295 & 7004 & 7605 & 8317 & 7941 & 6735 & 6383 & 7245 & 7444 & 7295 & 7552 & 7497 \\
\hline
\end{tabular}




\subsection{9. СТРУКТУРА ПАТЕНТНЫХ ЗАЯВОК НА ИЗОБРЕТЕНИЯ ПО ЗАЯВИТЕЛЯМ И СТРАНАМ: 2015*}

Проценты 으으 ๘

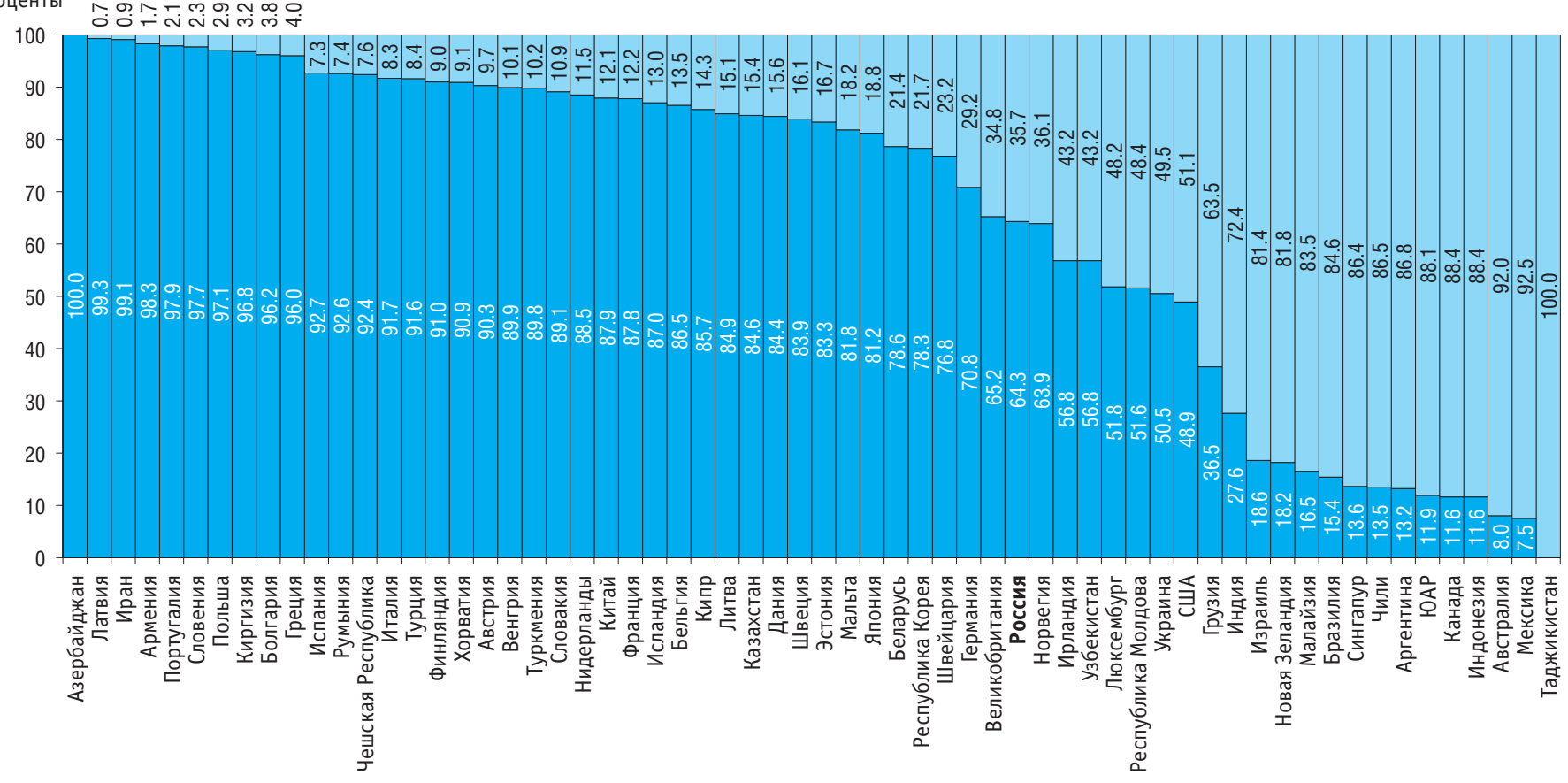

Заявители:

национальные

иностранные

* Или ближайшие годы, по которым имеются данные. 
8.20. ЧИСЛО ПАТЕНТНЫХ ЗАЯВОК, ПОДАННЫХ НАЦИОНАЛЬНЫМИ ЗАЯВИТЕЛЯМИ

В СТРАНЕ И ЗА РУБЕЖОМ

\begin{tabular}{|c|c|c|c|c|c|c|c|c|c|c|c|}
\hline & \multicolumn{4}{|c|}{ Число заявок } & \multicolumn{4}{|c|}{$\begin{array}{c}\text { Число заявок в расчете на } 1000000 \text { человек } \\
\text { населения }\end{array}$} & \multicolumn{3}{|c|}{$\begin{array}{c}\text { Число заявок в расчете } \\
\text { на } 1000000 \text { человек } \\
\text { экономически активного населения* }\end{array}$} \\
\hline & 2012 & 2013 & 2014 & 2015 & 2012 & 2013 & 2014 & 2015 & 2012 & 2013 & 2014 \\
\hline Россия & 34379 & 34067 & 28512 & 33786 & 240.1 & 237.4 & 198.2 & 230.9 & 447.1 & 443.1 & 371.5 \\
\hline \multicolumn{12}{|c|}{ Страны СНГ } \\
\hline Азербайджан & 331 & 448 & 542 & 493 & 35.6 & 47.6 & 56.8 & 50.8 & 69.7 & 92.4 & 109.5 \\
\hline Армения & 184 & 175 & 156 & 160 & 61.3 & 58.8 & 52.0 & 53.3 & 122.7 & 116.7 & 97.5 \\
\hline Беларусь & 2701 & 2323 & 1781 & 1967 & 284.3 & 245.3 & 187.5 & 207.1 & 600.2 & 516.2 & 395.8 \\
\hline Казахстан & 504 & 2386 & 2453 & 1797 & 30.0 & 140.0 & 141.8 & 102.7 & 55.4 & 259.3 & 263.8 \\
\hline Киргизия & 130 & 130 & 173 & 180 & 23.2 & 22.8 & 29.8 & 20.0 & 50.0 & 48.1 & 64.1 \\
\hline Республика Молдова & 144 & 144 & 79 & 98 & 40.0 & 40.0 & 21.9 & 27.2 & 120.0 & 120.0 & 65.8 \\
\hline Таджикистан & 19 & 11 & 8 & 16 & 2.4 & 1.4 & 1.0 & 1.9 & 5.4 & 3.1 & 2.2 \\
\hline Туркмения & 2 & 1 & 1 & $\ldots$ & 0.4 & 0.2 & 0.2 & $\ldots$ & 0.9 & 0.4 & 0.4 \\
\hline Узбекистан & 270 & 308 & 374 & 305 & 9.1 & 10.2 & 12.1 & 9.7 & 20.8 & 23.2 & 27.5 \\
\hline Украина & 3069 & 3499 & 2990 & 2878 & 67.3 & 76.9 & 65.9 & 63.7 & 132.8 & 151.2 & 129.5 \\
\hline \multicolumn{12}{|c|}{ Страны 0ЭСР } \\
\hline Австралия & 11719 & 12515 & 11743 & 11175 & 515.6 & 541.4 & 500.5 & 469.5 & 973.5 & 1022.4 & 945.7 \\
\hline Австрия & 12398 & 13352 & 13786 & 13925 & 1476.0 & 1570.8 & 1621.9 & 1619.2 & 2817.7 & 3034.5 & 3063.6 \\
\hline Бельгия & 12136 & 117260 & 12184 & 12090 & 1093.3 & 10469.6 & 1087.9 & 1069.9 & 2476.7 & 23452.0 & 2436.8 \\
\hline Великобритания & 51562 & 51300 & 52605 & 52648 & 809.4 & 800.0 & 814.2 & 808.7 & 1584.9 & 1565.4 & 1593.0 \\
\hline Венгрия & 1655 & 1560 & 1434 & 1487 & 167.2 & 157.6 & 144.8 & 151.7 & 376.1 & 354.5 & 325.9 \\
\hline Германия & 183048 & 184493 & 179506 & 174109 & 2276.0 & 2246.3 & 2216.6 & 2138.9 & 4386.3 & 4315.1 & 4252.3 \\
\hline Греция & 1107 & 1083 & 1251 & 1151 & 100.2 & 98.8 & 114.9 & 106.6 & 220.6 & 217.5 & 253.4 \\
\hline Дания & 10950 & 12207 & 12538 & 12123 & 1955.4 & 2179.8 & 2221.7 & 2126.8 & 3775.9 & 4209.3 & 4323.4 \\
\hline
\end{tabular}


(продолжение)

\begin{tabular}{|c|c|c|c|c|c|c|c|c|c|c|c|}
\hline & \multicolumn{4}{|c|}{ Число заявок } & \multicolumn{4}{|c|}{$\begin{array}{c}\text { Число заявок в расчете на } 1000000 \text { человек } \\
\text { населения }\end{array}$} & \multicolumn{3}{|c|}{$\begin{array}{c}\text { Число заявок в расчете } \\
\text { на } 1000000 \text { человек } \\
\text { экономически активного населения* }\end{array}$} \\
\hline & 2012 & 2013 & 2014 & 2015 & 2012 & 2013 & 2014 & 2015 & 2012 & 2013 & 2014 \\
\hline Израиль & 12384 & 12767 & 13437 & 14470 & 1567.6 & 1576.2 & 1638.7 & 1722.6 & 3347.0 & 3450.5 & 3631.6 \\
\hline Ирландия & 4278 & 4389 & 4779 & 5310 & 930.0 & 954.1 & 1035.0 & 1154.3 & 1944.5 & 1995.0 & 2172.3 \\
\hline Исландия & 320 & 233 & 302 & 263 & 1066.7 & 776.7 & 1006.7 & 876.7 & 1600.0 & 1226.3 & 1510.0 \\
\hline Испания & 11844 & 11012 & 10924 & 10777 & 253.2 & 236.2 & 235.0 & 232.3 & 500.4 & 470.2 & 467.9 \\
\hline Италия & 28523 & 28896 & 29288 & 21320 & 479.1 & 479.7 & 481.8 & 350.7 & 1136.0 & 1134.3 & 1135.8 \\
\hline Канада & 26828 & 26304 & 24705 & 24497 & 772.0 & 748.2 & 695.1 & 684.3 & 1390.7 & 1347.8 & 1252.4 \\
\hline Люксембург & 2449 & 2650 & 3137 & 2734 & 4898.0 & 5300.0 & 5228.3 & 4556.7 & 8163.3 & 10192.3 & 10456.7 \\
\hline Мексика & 2219 & 2139 & 2187 & 2508 & 18.2 & 17.3 & 17.4 & 19.7 & 41.6 & 39.3 & 39.4 \\
\hline Нидерланды & 31305 & 33589 & 37729 & 37017 & 1863.4 & 1999.3 & 2232.5 & 2190.4 & 3479.1 & 3732.8 & 4183.1 \\
\hline Новая Зеландия & 2894 & 3450 & 3429 & 3264 & 657.7 & 784.1 & 760.4 & 709.6 & 1205.8 & 1437.5 & 1428.8 \\
\hline Норвегия & 5970 & 5765 & 5872 & 5601 & 1194.0 & 1130.4 & 1151.4 & 1077.1 & 2211.1 & 2135.2 & 2174.8 \\
\hline Польша & 6043 & 6031 & 6171 & 7009 & 158.6 & 158.7 & 162.3 & 184.4 & 330.3 & 329.7 & 337.6 \\
\hline Португалия & 1128 & 1318 & 1332 & 1624 & 107.4 & 125.5 & 128.1 & 157.7 & 205.1 & 244.1 & 246.7 \\
\hline Республика Корея & 203836 & 223527 & 230553 & 238015 & 4076.7 & 4452.7 & 4572.3 & 4703.9 & 7910.7 & 8557.8 & 8747.6 \\
\hline Словакия & 368 & 401 & 454 & 495 & 68.1 & 74.3 & 84.1 & 91.7 & 136.3 & 148.5 & 168.1 \\
\hline Словения & 496 & 536 & 509 & 462 & 236.2 & 255.2 & 242.4 & 220.0 & 496.0 & 536.0 & 509.0 \\
\hline США & 473489 & 501162 & 509521 & 526296 & 1507.4 & 1583.8 & 1597.7 & 1637.5 & 3027.4 & 3136.2 & 3162.8 \\
\hline Турция & 5983 & 5793 & 6495 & 7269 & 79.9 & 76.0 & 83.8 & 92.4 & 220.0 & 208.4 & 228.7 \\
\hline Финляндия & 12940 & 12710 & 14070 & 13076 & 2396.3 & 2336.4 & 2558.2 & 2377.5 & 4792.6 & 4707.4 & 5211.1 \\
\hline Франция & 69985 & 71083 & 72310 & 71666 & 1065.9 & 1077.5 & 1087.4 & 1072.8 & 2332.8 & 2361.6 & 2394.4 \\
\hline Чешская Республика & 1886 & 2140 & 2180 & 2359 & 179.6 & 203.8 & 207.6 & 222.5 & 355.8 & 403.8 & 411.3 \\
\hline Чили & 784 & 805 & 998 & 850 & 45.1 & 45.7 & 56.2 & 47.2 & 92.2 & 93.6 & 113.4 \\
\hline
\end{tabular}


(окончание)

\begin{tabular}{|c|c|c|c|c|c|c|c|c|c|c|c|}
\hline & \multicolumn{4}{|c|}{ Число заявок } & \multicolumn{4}{|c|}{$\begin{array}{c}\text { Число заявок в расчете на } 1000000 \text { человек } \\
\text { населения }\end{array}$} & \multicolumn{3}{|c|}{$\begin{array}{c}\text { Число заявок в расчете } \\
\text { на } 1000000 \text { человек } \\
\text { экономически активного населения* }\end{array}$} \\
\hline & 2012 & 2013 & 2014 & 2015 & 2012 & 2013 & 2014 & 2015 & 2012 & 2013 & 2014 \\
\hline Швейцария & 42015 & 44997 & 44406 & 44458 & 5251.9 & 5555.2 & 5415.4 & 5356.4 & 9133.7 & 9573.8 & 9251.3 \\
\hline Швеция & 21725 & 22647 & 23854 & 24267 & 2286.8 & 2359.1 & 2460.2 & 2476.2 & 4259.8 & 4440.6 & 4587.3 \\
\hline Эстония & 291 & 273 & 278 & 236 & 223.8 & 210.0 & 213.8 & 181.5 & 415.7 & 390.0 & 397.1 \\
\hline Япония & 490271 & 473141 & 465971 & 454285 & 3843.4 & 3715.6 & 3665.3 & 3577.0 & 7508.0 & 7212.5 & 7135.8 \\
\hline \multicolumn{12}{|c|}{ Страны ЕС, не входящие в ОЭСР } \\
\hline Болгария & 371 & 500 & 467 & 512 & 50.8 & 68.5 & 64.9 & 71.1 & 112.4 & 151.5 & 141.5 \\
\hline Кипр & 439 & 353 & 492 & 350 & 399.1 & 320.9 & 410.0 & 291.7 & 731.7 & 588.3 & 820.0 \\
\hline Латвия & 359 & 480 & 193 & 287 & 179.5 & 240.0 & 96.8 & 143.5 & 326.4 & 480.0 & 193.0 \\
\hline Литва & 196 & 220 & 254 & 275 & 65.3 & 73.3 & 87.6 & 94.8 & 122.5 & 146.7 & 169.3 \\
\hline Мальта & 265 & 273 & 475 & 459 & 631.8 & 644.8 & 1111.5 & 1065.0 & 1325.0 & 1365.0 & 2375.0 \\
\hline Румыния & 1244 & 1241 & 1252 & 1229 & 61.9 & 62.1 & 62.9 & 62.1 & 130.9 & 130.6 & 130.4 \\
\hline Хорватия & 345 & 411 & 259 & 250 & 80.2 & 95.6 & 61.7 & 59.5 & 181.6 & 216.3 & 143.9 \\
\hline \multicolumn{12}{|c|}{ Другие страны } \\
\hline Аргентина & 1079 & 922 & 791 & 889 & 25.6 & 21.7 & 18.4 & 20.5 & 56.7 & 47.8 & 40.5 \\
\hline Бразилия & 6603 & 6848 & 6717 & 6554 & 32.6 & 33.5 & 32.6 & 31.5 & 61.7 & 63.2 & 61.2 \\
\hline Грузия & 153 & 119 & 131 & 124 & 40.3 & 31.3 & 35.4 & 33.5 & 74.6 & 58.5 & 64.9 \\
\hline Индия & 18202 & 20908 & 22445 & 23844 & 14.4 & 16.3 & 17.3 & 18.2 & 38.1 & 42.9 & 45.2 \\
\hline Индонезия & $\ldots$ & 755 & 771 & 1174 & $\ldots$ & 3.0 & 3.0 & 4.6 & $\ldots$ & 6.2 & 6.2 \\
\hline Иран & 10700 & 11343 & 13768 & $\ldots$ & 140.5 & 147.0 & 176.2 & $\ldots$ & 409.3 & 425.7 & 507.4 \\
\hline Китай & 561408 & 734096 & 837817 & 1010406 & 415.6 & 540.8 & 614.1 & 736.9 & 705.4 & 915.6 & 1038.8 \\
\hline Малайзия & 1975 & 2299 & 2661 & 2293 & 68.1 & 78.0 & 89.0 & 75.7 & 155.8 & 176.9 & 200.1 \\
\hline Сингапур & 4884 & 5471 & 5927 & 6137 & 921.5 & 1013.1 & 1077.6 & 1115.8 & 1618.4 & 1784.1 & 1905.6 \\
\hline ЮAP & 1688 & 2211 & 2317 & 2064 & 32.2 & 41.6 & 42.9 & 37.5 & 89.4 & 113.8 & 115.8 \\
\hline
\end{tabular}

* Данные о численности экономически активного населения за 2015 г. отсутствуют. 


\subsection{1. ЧИСЛО «ТРИАДНЫХ» ПАТЕНТНЫХ СЕМЕЙ *}

\begin{tabular}{|c|c|c|c|c|c|c|c|c|c|c|c|}
\hline & 1995 & 2000 & 2005 & 2006 & 2007 & 2008 & 2009 & 2010 & 2011 & 2012 & 2013 \\
\hline Россия & 63 & 85 & 91 & 74 & 78 & 57 & 88 & 88 & 100 & 109 & 111 \\
\hline \multicolumn{12}{|c|}{ Страны 0ЭСР } \\
\hline Австралия & 236 & 516 & 480 & 364 & 345 & 315 & 350 & 307 & 314 & 314 & 316 \\
\hline Австрия & 223 & 346 & 409 & 354 & 377 & 343 & 368 & 388 & 419 & 456 & 498 \\
\hline Бельгия & 375 & 455 & 541 & 477 & 430 & 458 & 478 & 460 & 477 & 472 & 467 \\
\hline Великобритания & 1586 & 2362 & 2163 & 2088 & 1798 & 1695 & 1722 & 1649 & 1654 & 1693 & 1726 \\
\hline Венгрия & 25 & 42 & 58 & 47 & 59 & 31 & 51 & 37 & 43 & 44 & 43 \\
\hline Германия & 4914 & 7637 & 7139 & 6529 & 5807 & 5471 & 5562 & 5474 & 5537 & 5561 & 5525 \\
\hline Греция & 2 & 11 & 24 & 22 & 14 & 16 & 15 & 5 & 11 & 10 & 10 \\
\hline Дания & 189 & 290 & 389 & 317 & 315 & 344 & 258 & 301 & 308 & 322 & 331 \\
\hline Израиль & 161 & 385 & 501 & 419 & 350 & 369 & 376 & 351 & 369 & 396 & 412 \\
\hline Ирландия & 31 & 51 & 97 & 76 & 91 & 84 & 86 & 64 & 70 & 72 & 73 \\
\hline Исландия & 6 & 13 & 7 & 8 & 10 & 5 & 2 & 3 & 3 & 3 & 3 \\
\hline Испания & 83 & 194 & 292 & 267 & 258 & 268 & 254 & 237 & 246 & 243 & 240 \\
\hline Италия & 621 & 832 & 965 & 821 & 729 & 760 & 736 & 682 & 672 & 679 & 685 \\
\hline Канада & 390 & 612 & 714 & 667 & 681 & 686 & 677 & 553 & 576 & 583 & 593 \\
\hline Люксембург & 14 & 22 & 21 & 24 & 15 & 20 & 20 & 19 & 23 & 21 & 20 \\
\hline Мексика & 12 & 9 & 19 & 27 & 19 & 17 & 15 & 16 & 17 & 18 & 20 \\
\hline Нидерланды & 769 & 1264 & 1759 & 1477 & 1065 & 1128 & 1047 & 823 & 958 & 955 & 947 \\
\hline Новая Зеландия & 21 & 72 & 73 & 71 & 57 & 72 & 55 & 44 & 51 & 56 & 61 \\
\hline Норвегия & 87 & 137 & 142 & 123 & 105 & 88 & 129 & 116 & 116 & 118 & 119 \\
\hline Польша & 5 & 9 & 18 & 18 & 25 & 37 & 32 & 61 & 62 & 71 & 78 \\
\hline Португалия & 3 & 5 & 16 & 21 & 42 & 30 & 17 & 16 & 25 & 27 & 28 \\
\hline Республика Корея & 331 & 908 & 2746 & 2348 & 1977 & 1826 & 2109 & 2459 & 2665 & 2866 & 3107 \\
\hline Словакия & 2 & 2 & 2 & 3 & 4 & 4 & 2 & 8 & 13 & 14 & 15 \\
\hline
\end{tabular}

* Патентные заявки, поданные одновременно в патентные ведомства ЕС, США и Японии. 
(окончание)

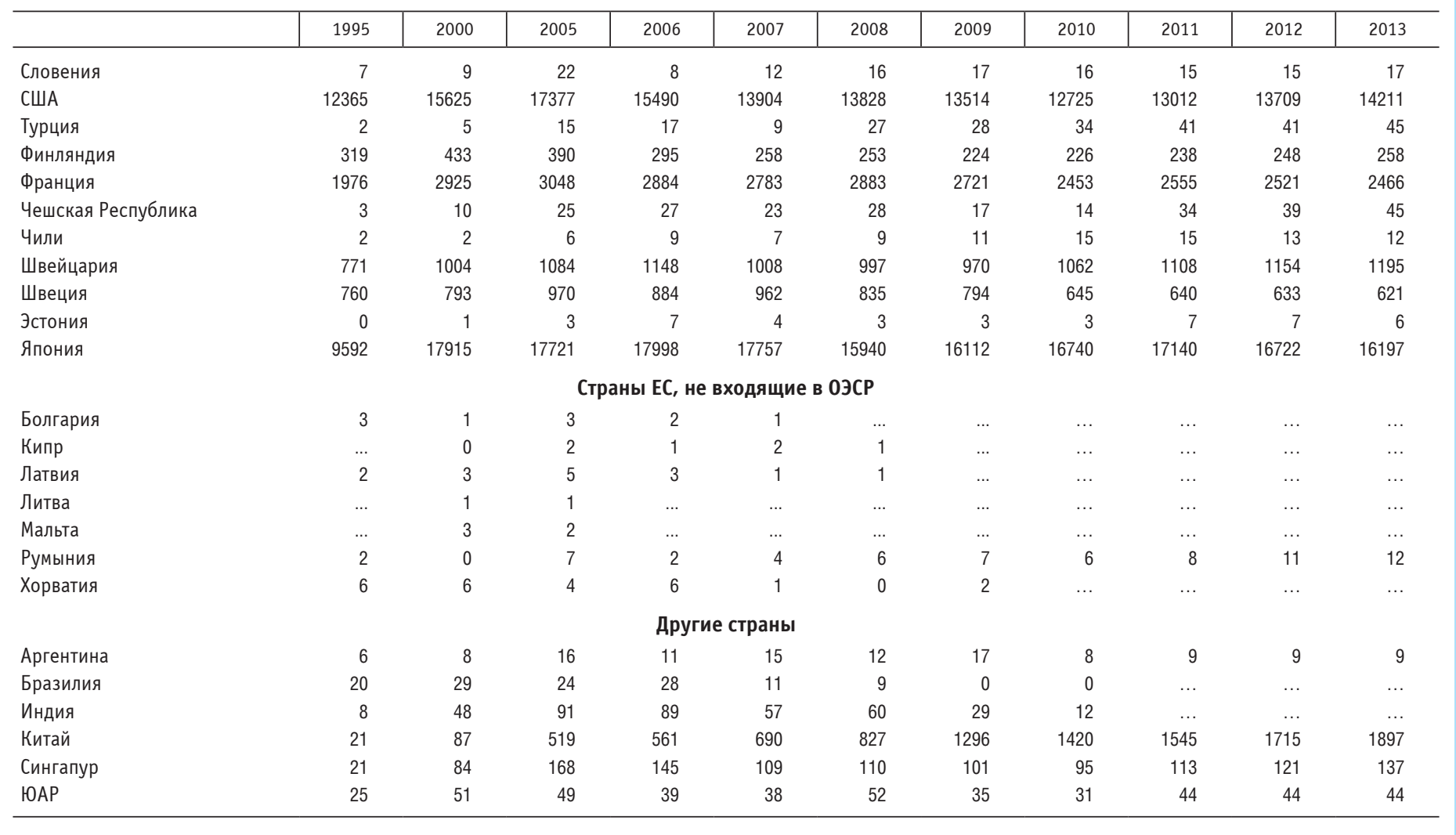




\subsection{2. ПОСТУПЛЕНИЯ ОТ ЭКСПОРТА ТЕХНОЛОГИЙ И ВЫПЛАТЫ ПО ИМПОРТУ ТЕХНОЛОГИЙ: 2015*}

(миллионы долларов США)

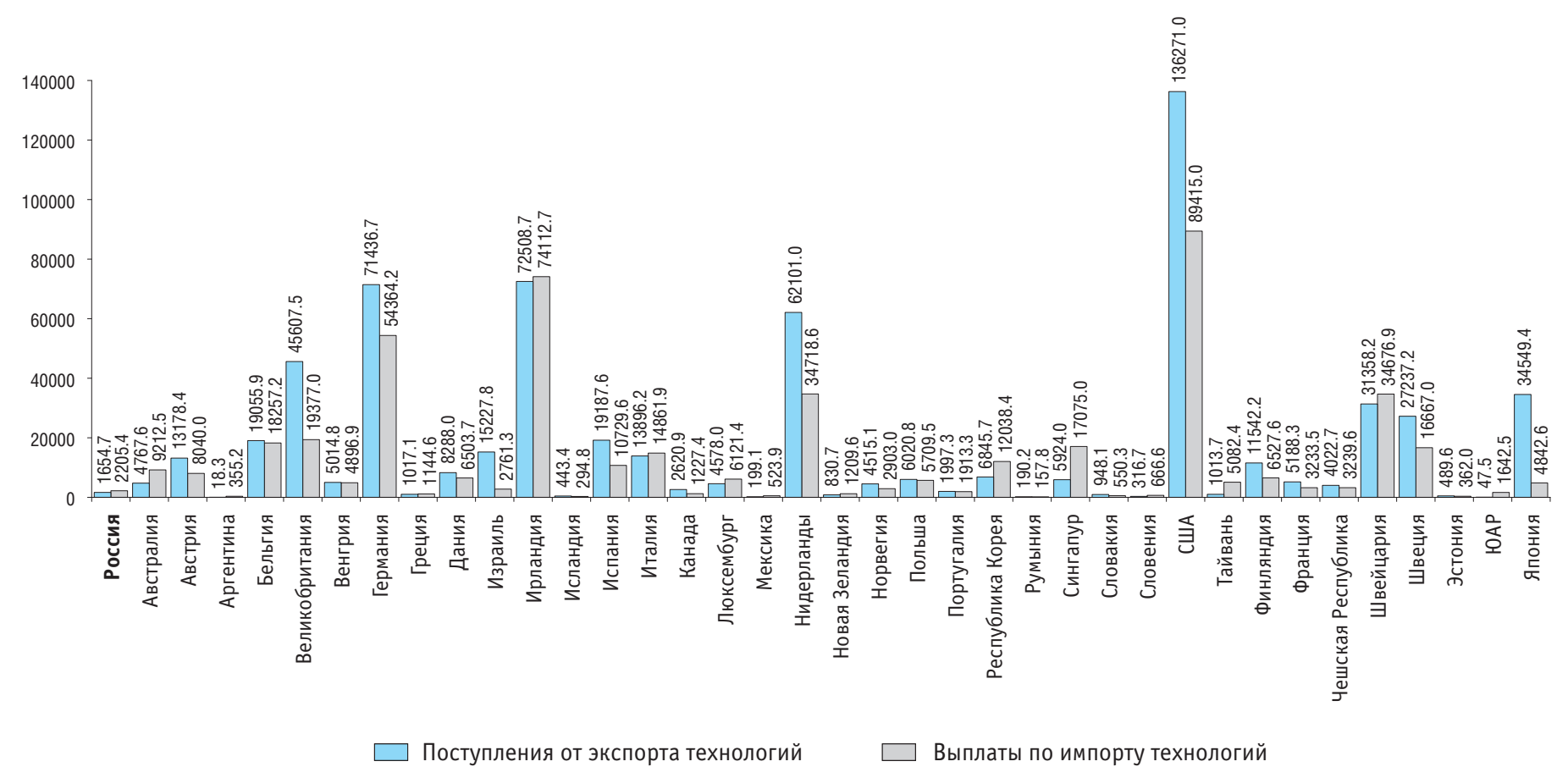

* Или ближайшие годы, по которым имеются данные. 


\section{МЕТОДОЛОГИЧЕСКИЕ КОММЕНТАРИИ}

Аспирантура - основная форма подготовки научных и научнопедагогических кадров в научно-исследовательских организациях, образовательных организациях высшего и дополнительного профессионального образования. К освоению программ подготовки научнопедагогических кадров в аспирантуре допускаются лица, имеющие образование не ниже высшего (специалитет или магистратура). С 1 января 2014 г. в соответствии с Федеральным законом от 29 декабря 2012 г. № 273-Ф3 «0б образовании в Российской Федерации» прием в аспирантуру осуществляется по направлениям подготовки, утвержденным приказом Министерства образования и науки Российской Федерации от 12 сентября 2013 г. № 1061 «0б утверждении перечней специальностей и направлений подготовки высшего образования». Данные о лицах, зачисленных в аспирантуру до 1 января 2014 г., приводятся в соответствии с Номенклатурой специальностей научных работников, утвержденной приказом Министерства образования и науки Российской Федерации от 25 февраля 2009 г. № 59 (в редакции приказов Минобрнауки России от 11 августа 2009 г. № 294, от 16 ноября 2009 г. № 603, от 10 января 2012 г. № 5, от 20 февраля 2015 г. № 114).

Ассигнования на гражданскую науку из средств федерального бюджета - средства федерального бюджета, выделенные на фундаментальные и прикладные научные исследования гражданского назначения. В связи с введением с 1 января 2005 г. новой бюджетной классификации ассигнования, ранее учитывавшиеся по подразделам 0601 «Фундаментальные исследования» и 0602 «Разработка перспективных технологий и приоритетных направлений научно-технического прогресса» раздела 06 «Фундаментальные исследования и содействие научно-техническому прогрессу» федерального бюджета, отнесены соответственно к фундаментальным и прикладным исследованиям.

Баланс платежей за технологии - совокупность перечислений денежных средств по всем нематериальным сделкам, связанным с экспортом и импортом технологий.

Библиометрические индикаторы в части показателей публикационной активности рассчитаны на основе баз данных Web of Science и Scopus, в части показателей цитируемости - с использованием ресурсов InCites компании Thomson Reuters и SciVal компании Elsevier (на базе материалов Scopus). Под публикацией, если не указано иное, подразумеваются три типа документов, индексируемых в базах данных Web of Science и Scopus: научная статья (article), обзор (review) и доклад на конференции (proseedings / conference paper). Публикация считается принадлежащей определенной стране, если та фигурирует в адресе места работы автора или одного из соавторов и была распознана системами Web of Science $и$ Scopus. Если у единственного автора указано несколько адресов, ассоциированных с более чем одной страной, подобная публикация считается подготовленной в международном соавторстве. Аналогичным образом, если у одного или нескольких соавторов в адресе указана дополнительная аффилиация, ассоциированная с другой страной, подобная публикация также считается подготовленной в международном соавторстве. Все данные, представленные в настоящем сборнике, отражают состояние баз данных на 1 ноября 2016 г. 
Внутренние затраты на исследования и разработки - выраженные в денежной форме фактические затраты на выполнение научных исследований и разработок на территории страны (включая финансируемые из-за рубежа, но исключая выплаты, сделанные за рубежом). Их оценка базируется на статистическом учете затрат на выполнение исследований и разработок собственными силами организаций в течение отчетного года независимо от источника финансирования.

Внутренние затраты на исследования и разработки включают:

- текущие затраты - затраты на оплату труда, отчисления на единый социальный налог, затраты на приобретение или изготовление специального оборудования (в том числе за счет себестоимости выполненных работ), другие материальные затраты (стоимость приобретаемых со стороны сырья, материалов, комплектующих изделий, полуфабрикатов, топлива, энергии, работ и услуг производственного характера и др.), прочие текущие затраты;

- капитальные затраты - затраты на приобретение земельных участков, строительство или покупку зданий, приобретение оборудования, включаемого в состав основных фондов, и пр.

Внутренние затраты на исследования и разработки оценены как в действующих, так и в постоянных ценах, рассчитанных по дефлятору валового внутреннего продукта.

Докторантура - форма подготовки научных кадров высшей квалификации. В докторантуру принимаются лица, имеющие ученую степень кандидата наук. Подготовка диссертаций докторантами осуществляется в образовательных организациях высшего образования, дополнительного профессионального образования и научных организациях. Докторант осуществляет подготовку диссертации на соискание ученой степени доктора наук по выбранной научной специ- альности в соответствии с Номенклатурой специальностей научных работников, утверждаемой Министерством образования и науки Российской Федерации.

Гранты - денежные и иные средства, передаваемые безвозмездно и безвозвратно гражданами и юридическими лицами, в том числе иностранными гражданами и иностранными юридическими лицами, а также международными организациями, получившими право на предоставление грантов Российской Федерации в установленном Правительством Российской Федерации порядке, на осуществление конкретных научных, научно-технических программ и проектов, инновационных проектов, проведение конкретных научных исследований на условиях, предусмотренных грантодателями (Федеральный закон от 26 августа 1996 г. № 127-Ф3 «0 науке и государственной научнотехнической политике» (с изменениями и дополнениями)).

Затраты на инновации - выраженные в денежной форме фактические расходы, связанные с осуществлением различных видов инновационной деятельности, выполняемой в масштабе организации (отрасли, региона, страны). В составе затрат на инновации учитываются текущие и капитальные затраты. Статистика изучает затраты на технологические, маркетинговые и организационные инновации.

Изобретение - техническое решение в любой области, относящееся к продукту (в частности устройству, веществу, штамму микроорганизма, культуре клеток растений и животных) или способу (процессу осуществления действий над материальным объектом с помощью материальных средств). Изобретение должно обладать новизной, изобретательским уровнем, быть промышленно применимо.

Индекс научной специализации страны (в определенной области науки) рассчитывается как отношение удельного веса публикаций по соответствующей области науки в совокупности научных 
публикаций авторов из данной страны в научных журналах, индексируемых в базах Web of Science или Scopus, к ее же удельному весу в общемировом числе индексируемых публикаций. Если значение индекса превышает 1.0, область науки входит в число направлений специализации данной страны.

Инновационная активность организации характеризует степень участия организации в осуществлении инновационной деятельности в целом или отдельных ее видов в течение определенного периода времени. Уровень инновационной активности организаций обычно определяется как отношение числа организаций, осуществлявших технологические, маркетинговые или организационные инновации, к общему числу обследованных за определенный период времени организаций в стране, отрасли, регионе и т. д.

Инновационная деятельность - вид деятельности, связанный с трансформацией идей (обычно результатов научных исследований и разработок либо иных научно-технических достижений) в технологически новые или усовершенствованные продукты или услуги, внедренные на рынке, в новые или усовершенствованные технологические процессы или способы производства (передачи) услуг, использованные в практической деятельности. Инновационная деятельность предполагает целый комплекс научных, технологических, организационных, финансовых и коммерческих мероприятий, и именно в своей совокупности они приводят к инновациям.

Инновационные товары, работы, услуги - товары, работы, услуги, новые или подвергавшиеся в течение последних трех лет разной степени технологическим изменениям. По уровню новизны выделяются два вида инновационных товаров, работ, услуг - вновь внедренные (или подвергавшиеся значительным технологическим изменениям) и подвергавшиеся усовершенствованию.
Источники финансирования исследований и разработок первичные источники денежных средств на исследования и разработки - определяются на основе факта прямой передачи средств от организации-заказчика организации-исполнителю.

В целом средства отчитывающейся организации на исследования и разработки разделяются на те, которые относятся к собственным средствам организации, и те, которые ею получены от других организаций, вне зависимости от их принадлежности к различным секторам деятельности.

В составе источников финансирования рассматриваются:

- средства бюджета (включая средства федерального бюджета, бюджетов субъектов РФ и местных бюджетов);

- бюджетные ассигнования на содержание образовательных организаций высшего образования;

- средства внебюджетных фондов;

- средства иностранных источников;

- средства организаций государственного сектора;

- средства организаций предпринимательского сектора;

- средства организаций сектора высшего образования;

- средства частных некоммерческих организаций;

- собственные средства организаций.

Конкурсное (программное) финансирование - средства, поступившие на счет организации, занявшей первое место по решению конкурсной комиссии в результате подведения итогов конкурса научных, научно-технических программ, инновационных и других проектов, связанных с выполнением научных исследований и разработок, на основании представленных этой организацией лучших условий реализации конкурсного проекта по сравнению с предложенными другими участниками. 
Лицензия подразумевает предоставление на определенных условиях и за обусловленное вознаграждение владельцем (лицензиаром) исключительного права на какой-либо объект промышленной собственности или ноу-хау заинтересованной стороне (лицензиату) либо прав на использование объекта соглашения, оформленное специальным договором (соглашением). Патентная лицензия предоставляет право на использование патента, определяет объем передаваемых прав, территорию и период его использования, а также форму платежа.

Маркетинговые инновации - реализованные новые или значительно улучшенные маркетинговые методы, охватывающие существенные изменения в дизайне и упаковке товаров, работ, услуг; использование новых методов продаж и презентации товаров, работ, услуг, их представления и продвижения на рынки сбыта; формирование новых ценовых стратегий. Маркетинговые инновации направлены на более полное удовлетворение потребностей и расширение состава потребителей продуктов и услуг, освоение новых рынков сбыта с целью повышения объемов продаж.

Научные исследования и разработки - творческая деятельность, осуществляемая на систематической основе с целью увеличения суммы научных знаний, в том числе о человеке, природе и обществе, а также поиска новых областей применения этих знаний.

Организации, осуществлявшие технологические инновации, организации, осуществлявшие разработку и внедрение новых или усовершенствованных товаров, работ, услуг, технологических процессов или способов производства (передачи) услуг и иные виды инновационной деятельности.

Организационные инновации - реализованные новые методы ведения бизнеса, организации рабочих мест, внешних связей. Направлены на повышение эффективности деятельности организации за счет снижения административных и трансакционных издержек, совершенствования организации рабочих мест (рабочего времени) и связанного с этим роста производительности труда, получения доступа к отсутствующим на рынке активам, снижения стоимости поставок.

\section{Основные фонды (средства) исследований и разработок} включают:

- здания и сооружения;

- машины и оборудование, в том числе опытно-экспериментальные установки, научные приборы, средства автоматизации и вычислительную технику и т. д.;

- транспортные средства;

- инструмент, инвентарь и прочие основные фонды, состоящие на балансе научных организаций и их опытных баз и используемые в их основной деятельности.

Патент на изобретение - охранный документ, выдаваемый на изобретение и удостоверяющий приоритет, авторство и исключительное право на использование в течение срока действия патента.

Передовые производственные технологии - технологические процессы, включающие машины, аппараты, оборудование и приборы, основанные на микроэлектронике или управляемые с помощью компьютера и используемые при проектировании, производстве или обработке продукции.

Персонал, занятый исследованиями и разработками, - совокупность лиц, чья творческая деятельность, осуществляемая на систематической основе, направлена на увеличение и поиск новых областей применения знаний, а также занятых оказанием прямых услуг, связанных с выполнением исследований и разработок.

Персонал, занятый исследованиями и разработками, подразделяется на следующие категории: 
- исследователи - работники, профессионально занимающиеся исследованиями и разработками и непосредственно осуществляющие создание новых знаний, продуктов, процессов, методов и систем, а также управление указанными видами деятельности. Исследователи обычно имеют законченное высшее образование;

- техники - работники, участвующие в исследованиях и разработках и выполняющие технические функции (эксплуатацию и обслуживание научных приборов, лабораторного оборудования, вычислительной техники, подготовку материалов, чертежей, проведение экспериментов, опытов и анализов и т. д.), как правило, под руководством исследователей. В эту категорию обычно включаются лица, имеющие среднее профессиональное образование и/или необходимый профессиональный опыт и знания;

- вспомогательный персонал - работники, выполняющие вспомогательные функции, связанные с проведением исследований и разработок: работники планово-экономических, финансовых подразделений, патентных служб, подразделений научно-технической информации, научно-технических библиотек; рабочие, осуществляющие монтаж, наладку, обслуживание и ремонт научного оборудования и приборов; рабочие опытных (экспериментальных) производств; лаборанты, не имеющие высшего и среднего профессионального образования;

- прочий персонал включает работников по хозяйственному обслуживанию, а также выполняющих функции общего характера, связанные с деятельностью организации в целом (работники бухгалтерии, кадровой службы, канцелярии, под- разделений материально-технического обеспечения, машинистки и т. д.).

Полезная модель - техническое решение, относящееся к устройству. Полезная модель должна обладать новизной, быть промышленно применимой.

Прикладные исследования представляют собой оригинальные работы, направленные на получение новых знаний с целью решения конкретных практических задач. Прикладные исследования определяют возможные пути использования результатов фундаментальных исследований, новые методы решения ранее сформулированных проблем.

Промышленный образец - художественно-конструкторское решение изделия промышленного или кустарно-ремесленного производства, определяющее его внешний вид.

Разработки - систематические работы, которые основаны на существующих знаниях, полученных в результате исследований и/или практического опыта, и направлены на создание новых материалов, продуктов, процессов, устройств, услуг, систем или методов. Эти работы могут также предполагать значительное усовершенствование уже имеющихся объектов.

\section{Секторы науки:}

- в состав государственного сектора входят: организации министерств и ведомств, обеспечивающие управление государством и удовлетворение потребностей общества в целом; некоммерческие организации, полностью или в основном финансируемые и контролируемые правительством;

- предпринимательский сектор включает: все организации и предприятия, чья основная деятельность связана с производством продукции или услуг в целях продажи, в том числе нахо- 
дящиеся в собственности государства; частные некоммерческие организации, обслуживающие вышеназванные организации;

- сектор высшего образования объединяет: образовательные организации высшего образования, независимо от источников финансирования и правового статуса, а также находящиеся под их контролем либо ассоциированные с ними научно-исследовательские институты, экспериментальные станции, клиники;

- сектор некоммерческих организаций состоит из частных организаций, не ставящих своей целью получение прибыли (профессиональные общества, общественные организации и т. д.), и частных индивидуальных организаций.

Технологические инновации представляют собой конечный результат инновационной деятельности, получивший воплощение в виде нового либо усовершенствованного продукта или услуги, внедренных на рынке, нового либо усовершенствованного процесса или способа производства (передачи) услуг, используемых в практической дея- тельности. Инновация считается осуществленной в том случае, если она внедрена на рынке или в производственном процессе.

Торговля технологиями с зарубежными странами охватывает все коммерческие сделки по экспорту и импорту технологий и услуг технологического характера, включая сделки между совместными и иностранными организациями, зарегистрированными в России, их филиалами (представительствами) и их зарубежными материнскими компаниями.

Фундаментальные исследования - экспериментальные или теоретические исследования, направленные на получение новых знаний без какой-либо конкретной цели, связанной с использованием этих знаний. Их результат - гипотезы, теории, методы и т. д. Фундаментальные исследования могут завершаться рекомендациями о проведении прикладных исследований для выявления возможностей практического использования полученных научных результатов, научными публикациями и т. д.

\section{ИНДИКАТОРЫ НАУКИ: 2017 \\ Статистический сборник}

Редактор М. Ю. Соколова. Художник П. А. Шелегеда. Компьютерный макет Т. Ю. Кольщова, В. Г. Паршина

Подписано в печать 26.12.2016. Формат $60 \times 90$ 1/16. Бумага офсетная. Печ. л. 19. Уч.-изд. л. 10.4. Тираж 350 экз. Заказ №2314. Национальный исследовательский университет «Высшая школа экономики»

Отпечатано в 000 «Типография ИРМ-1». 140000, Московская обл., г. Люберцы, Инициативная ул., 38

По вопросам приобретения сборника обращаться в Институт статистических исследований и экономики знаний НИУ ВШЭ: 101000, Москва, Мясницкая ул., 20. Тел.: +7 (495) 621-28-73, http://issek.hse.ru, e-mail: issek@hse.ru 